FERNANDO CINTRA MORTARA

UTILIZAÇÃO DE LEITOS DE DRENAGEM NO DESAGUAMENTO DE LODOS ANAERÓBIOS

São Paulo 
FERNANDO CINTRA MORTARA

\section{UTILIZAÇÃO DE LEITOS DE DRENAGEM NO DESAGUAMENTO DE LODOS ANAERÓBIOS}

Dissertação apresentada à Escola Politécnica da Universidade de São Paulo para obtenção do título de mestre em Engenharia.

São Paulo 
FERNANDO CINTRA MORTARA

\section{UTILIZAÇÃO DE LEITOS DE DRENAGEM NO DESAGUAMENTO DE LODOS ANAERÓBIOS}

Dissertação apresentada à Escola Politécnica da Universidade de São Paulo para obtenção do título de mestre em Engenharia.

Área de Concentração: Engenharia Hidráulica e Ambiental

Orientador: Professor Titular Pedro Alem Sobrinho

São Paulo 
Este exemplar foi revisado e alterado em relação à versão original, sob responsabilidade única do autor e com a anuência de seu orientador.

São Paulo, 17 de novembro de 2011.

Assinatura do autor

Assinatura do orientador

FICHA CATALOGRÁFICA

Mortara, Fernando Cintra

Utilização de leitos de drenagem no desaguamento de lodos anaeróbios / F.C. Mortara. -- ed.rev. -- São Paulo, 2011.

$241 \mathrm{p}$.

Dissertação (Mestrado) - Escola Politécnica da Universidade de São Paulo. Departamento de Engenharia Hidráulica e Sanitária.

1. Lodo de esgoto 2. Desaguamento 3. Leito de secagem 4. Condicionamento 5. Geotêxteis I. Universidade de São Paulo. Escola Politécnica. Departamento de Engenharia Hidráulica e Sanitária II. t. 


\section{DEDICATÓRIA}

Ao meu avô Carlos do Amaral Cintra, exemplo de caráter e de vida (in memoriam). 


\section{AGRADECIMENTOS}

Ao tempo, que a cada dia se encarrega de renovar o passado em infinitas possibilidades futuras.

Aos meus avós, pai, mãe e família. Em especial a Fabio Arruda Mortara, Patrícia Maria Galvão Cintra Mortara, Pedro Cintra Mortara, Fernanda Margarida Galvão Cintra.

Aos colegas, professores e mestres. Em especial a Pedro Alem Sobrinho, Roque Passos Pivelli, Dione Mari Morita, Miriam Cegalla, Maria Eugênia Boscov, Ricardo Franci Gonçalves, Antonio Osmar Fontana, Marcelo Miki, Luciano Matos Queiroz, Humberto Tamaki, Gisele Sanches da Silva, Fabio Campos, Laerte Carvalho, Fabio Fuji, Rafael Camargo, Nicolas Rodrigues, Carolina Yabroudi, Humberto Ruggeri Júnior, Mônica Scholz e Rodrigo Bueno.

A Vera Lúcia Aguiar, Celso Cardoso, Alexandre Castro, Ademar da ETE Jaraguá, Ronaldo da ETE Ribeirão Pires e demais colaboradores da SABESP.

A Clóvis, Wellinton, Eric, Plínio, Daniel, Zé Amaro, Célio, Zézinho, Pereira e demais colaboradores do CTH.

Agradeço ainda aos amigos, amigas, parceiros e sócios na Sharewater. Em especial a Maria Brígida Ramos, Diogo Fonseca Carbonari de Almeida, Pedro Henrique Yonenaga Valiati, Rodrigo Cassiari Martinho, Eleandro Ferronatto de Souza, Fábio Fukunaga, Jamerson Isaias de Santana, Mauricio Marcondes, Marcelo Castro, Fernando Tonetti, Jaqueline Marquez de Oliveira, Vladimir Novaes Paternostro, Felipe Aguiar Marcondes de Faria, Damiany da Fonseca, Tomaz Araújo Roberto e Bruno Galvão.

A SNF, KEMIRA, CIBA, ASHLAND, MACCAFERRI, HUESKER, PROPEX e Ramalho, pelo fornecimento de materiais e apoio técnico. 
Ela está no horizonte. Me aproximo dois passos, ela se afasta dois passos. Caminho dez passos e o horizonte corre dez passos. Por mais que eu caminhe, já mais a alcançarei. Para que serve a utopia? Serve para isso: para caminhar. (Eduardo Galeano, em: As palavras andantes, 1994). 


\section{RESUMO}

O método de desaguamento por leitos de drenagem foi desenvolvido por Cordeiro a partir do ano de 1993 (CORDEIRO, 2001) para o desaguamento de lodos de Estações de Tratamento de Água. A sua aplicação para lodos de lagoas de estabilização de esgotos foi feita por Fontana et al. (2007). Este trabalho teve por objetivo avaliar a utilização de leitos de drenagem no desaguamento de lodos produzidos em reatores UASB. Para tanto foram realizados ensaios em laboratório, utilizando testes do tempo de drenagem, para avaliar a influência de diferentes doses e tipos de polímeros no desaguamento do lodo. Alguns geotêxteis foram utilizados como meio filtrante nos funis de Buchner e também avaliados pelo teste do tempo de drenagem. Após escolhidas a manta e o polímero que apresentaram os melhores resultados em laboratório, foram desenvolvidos ensaios em escala piloto, com a utilização de três unidades cobertas de leitos de drenagem, cada um com dimensões de 1,58 m x 1,09 m por 0,5 m de altura. Para a avaliação do efeito das diferentes doses de polímero em escala piloto, foram utilizadas doses de polímero de 0 a $8 \mathrm{~g} / \mathrm{kg}$ de sólidos totais (peso seco) e mantida a taxa de aplicação de sólidos em $15 \mathrm{kgST} / \mathrm{m}^{2}$.ciclo (a concentração de sólidos no lodo foi de aproximadamente 27 $\mathrm{g} / \mathrm{L}$ ). Os resultados indicaram que com doses de polímero $\geq 2 \mathrm{~g} / \mathrm{kgST}$ (peso seco) obtinha-se teor de sólidos no lodo de cerca de 13\% após 1 dia e $20 \%$ após 10 a 15 dias. Para se atingir teor de sólidos de 25 a $30 \%$ o período de secagem necessário foi de cerca de 30 dias. Embora que mesmo sem a aplicação de polímeros o comportamento do lodo fosse semelhante ao de lodos condicionados com polímero, em relação à evolução do teor de sólidos em função dos períodos de secagem, observou-se certa dificuldade na remoção do lodo desaguado e principalmente na limpeza das mantas geotêxteis. Para avaliar diferentes taxas de aplicação superficial de sólidos, foram ensaiadas taxas entre 9 e $22 \mathrm{kgST} / \mathrm{m}^{2}$.ciclo. A evolução do teor de sólidos, ao longo do período de secagem dos 3 ensaios realizados, indicou que taxas mais altas de aplicação de sólidos não diminuem as velocidades de secagem, sugerindo que, inclusive, taxas mais altas poderiam ser ensaiadas.

Palavras-chave: Lodo de esgoto. Desaguamento. Leito de secagem. Leito de drenagem. Geotêxteis. Condicionamento. 


\section{ABSTRACT}

The method of dewatering sludge through Drainage Beds was originally developed in 1993 by Cordeiro (CORDEIRO, 2001) with sludge from Water Treatment Plants. Fontana et al. (2007) used sludge from wastewater stabilization ponds with positive results. The purpose of this research is the evaluation of the drainage bed method to dewater sludge from UASB reactors. Several laboratory trials were performed, measuring drainage times to assess the influence of different polymer types and doses on sludge dewatering. Few geotextiles were used as filter on the drainage time test to evaluate their performance. Once the polymer and the geotextile that best performed in the laboratory were chosen, several pilot experiments were performed with the use of three covered units of drainage beds, each measuring $1.58 \mathrm{~m} \times 1.09 \mathrm{~m}$ (width) $\times 0.5 \mathrm{~m}$ (height). For the evaluation of different polymer conditioning doses on a pilot scale, doses from 0 to $8 \mathrm{~g} / \mathrm{kg}$ of total solids (dry weight) were used and the applied rate of solids kept at $15 \mathrm{kgTS} / \mathrm{m}^{2}$.cycle (the concentration of solids in the sludge was of approximately $27 \mathrm{~g} / \mathrm{L}$ ). Results indicated that with the use of polymer doses $\geq 2 \mathrm{~g} / \mathrm{kgTS}$ (dry weight), approximately $13 \%$ of total solids in the sludge was observed after one day, which increased to approximately $20 \%$ after 15 days. To reach $25 \%$ to $30 \%$ of total solids in the sludge, the drying time required was circa 30 days. Even without the application of polymers, the behavior of sludge in terms of total solids during the drying period was similar to the sludge conditioned with polymers. Although, with the unconditioned sludge, some difficulty to remove the dewatered sludge cake was observed, mainly in cleaning of the geotextile sleeves. In order to evaluate different application rates of solids, the pilot experiments included rates between 9 and $22 \mathrm{kgTS} / \mathrm{m}^{2}$.cycle. The behavior of the total solids in the cake during the drying period of the three experiments suggested that the higher rates of application of solids does not reduce the drying speed, indicating that higher rates can be targeted in future research projects.

Keywords: Wastewater Sludge. Dewatering. Drying beds. Drainage beds, Conditioning. Geotextiles. 


\section{LISTA DE ILUSTRAÇÕES}

Figura 1 - Diagrama genérico dos processos de tratamento de esgotos sanitários.28 Figura 2 - Relação entre o volume do lodo e sua fração de sólidos para um lodo com teor de sólidos inicial de $10 \%(0,1)$ e outro com TS inicial de 5\% $(0,05)$ (van HAANDEL; LETTINGA, 1994)

Figura 3 - Reogramas de um mesmo lodo com tempos de armazenamento entre 0 e 65 dias (BAUDEZ e COUSSOT, 2001)

Figura 4 - Gráfico log-normal da distribuição granulométrica relativa (histograma) e relativa acumulada (linha vermelha) dos diâmetros das partículas de um lodo de ETA (Adaptado de WOLFF et al., 2005)

Figura 5 - Efeito da formação de arcos como pré-filtro do geotêxtil (Adaptado de

FREITAS, 2003). 45

Figura 6 - Diferentes frações de água no lodo (CHEN; YUE; MUJUMDAR, 2002) ..50

Figura 7 - Ilustração com os conceitos básicos da reologia (BRAGA, 2003) .53

Figura 8 - Reograma em triplicata de lodo sintético à base de celulose (ABU-ORF, 1999) .55

Figura 9 - Reogramas de fluidos com diferentes comportamentos (LEITE, 2009) ...55

Figura 10 - Modelo de OSTWALD (BRAGA, 2003) .56

Figura 11 - Aderência do reograma de lodo sintético (BAUDEZ; COUSSOT, 2001)56 Figura 12 - Efeito da tixotropia na mudança de comportamento do material entre a aplicação de tensões sucessivamente superiores e, após período de repouso, sucessivamente inferiores (BRAGA, 2003). .57

Figura 13 - "Slump Test" modificado (Baudez et al., 2004) ...................................59

Figura 14 - Equipamento utilizado em um teste de REF (BRAGA, 2003) ..... 61

Figura 15 - Gráfico de t/V x V gerado em um teste de REF e determinação da inclinação b no trecho linear (MIKI, 1998)

Figura 16 - Equipamentos do ensaio CST (ADAMMS JR et al., 1981 apud GONÇALVES et al., 2001). .64

Figura 17 - Equipamentos do ensaio de CST (BRAGA, 2003). .64

Figura 18 - Desenhos da estrutura física do leito de secagem (GONÇALVES, 2001) 
Figura 19 - Detalhe da soleira drenante (GONÇALVES, 1999)

Figura 20 - Detalhe da disposição dos tijolos que compõem a camada suporte (GONÇALVES, 1999)

Figura 21 - llustração dos leitos de secagem convencional (Tradicional) e modificados (CORDEIRO, 2001)

Figura 22 - llustração dos leitos de secagem modificados por mistura e aeração à esquerda e ao centro (YAMAOKA; HATA, 2003) e pela utilização de forças eletrocinéticas à direita (GLENDINNING et al., 2007)

Figura 23 - Fluxos de ar obtidos dentro de uma estufa de secagem de lodo (METCALF; EDDY, 1935) .73

Figura 24 - Profundidade da torta de lodo, precipitação e teor de sólidos (TS) ao longo de um ciclo de drenagem (Adaptado de COFIE et al., 2006)..................76

Figura 25 - Geotêxtil e a estrutura tecida e não-tecida (VIDAL, 2002) 85

Figura 26 - Esquema do ensaio para determinação da espessura nominal de geotêxteis e produtos correlatos (VIDAL, 2002)

Figura 27 - Distribuição de poros de um geotêxtil em função de sua compressão (ELSHARIEF, A.; LOVELL, C., 1996) ..... .89

Figura 28 - Ensaios de tração (VIDAL, 2002). 90

Figura 29 - Punção do ensaio CBR (à direita - recomendado pela ABNT NBR 13359, de 1995) e de outros testes padronizados pela ASTM (KOERNER, R.

M.; KOERNER, G. R., 2010). 91

Figura 30 - Ensaio de puncionamento estático (VIDAL, 2002). 91

Figura 31 - Arranjo do ensaio para determinação da permeabilidade normal (VERTEMATTI, 2004)

Figura 32 - Arranjo do ensaio para determinação da permeabilidade planar (VERTEMATTI, 2004) .93

Figura 33 - Determinação da abertura de filtração (VERTEMATTI, 2004) 95

Figura 34 - Adsorção inicial do polímero (MIKI, 1998) 103

Figura 35 - Formação do floco (MIKI, 1998). 104

Figura 36 - Adsorção secundária do polímero (MIKI, 1998). 104

Figura 37 - Adsorção inicial com excesso de polímero (MIKI, 1998) 105

Figura 38 - Quebra do floco (MIKI, 1998). 105

Figura 39 - Readsorção secundária (MIKI, 1998) 106

Figura 40 - Coleta de lodo na ETE de Ribeirão Pires 113 
Figura 41 - Galão de 20 litros com lodo coletado (esquerda) e lodo em agitação para análise do teor de sólidos no recipiente de 5 litros (direita).... 114

Figura 42 - Polímeros utilizados nos ensaios. 116

Figura 43 - Materiais utilizados na determinação da concentração de sólidos no lodo

Figura 44 - Lodo em mistura após a adição de polímero orgânico (esquerda) e funil de Buchner e proveta utilizados (direita).

Figura 45 - Materiais utilizados no Teste do Tempo de Drenagem.

Figura 46 - Amostras de lodo condicionado em processo de desaguamento no laboratório (esquerda) e aspecto da torta formada (direita)

Figura 47 - Leitos de drenagem sem cobertura e tanques de condicionamento elevados (à esquerda) e os 3 leitos com cobertura translúcida (à direita) .......123

Figura 48 - Vista do sistema em escala piloto. 123

Figura 49 - Tanque de condicionamento com o motor e as pás do misturador (esquerda) e recipiente de preparo de polímero e misturador (direita) 124

Figura 50 - Diagrama do sistema de desaguamento piloto 124

Figura 51 - Vista em corte (esquerda) e em planta (direita) sem escala de um dos

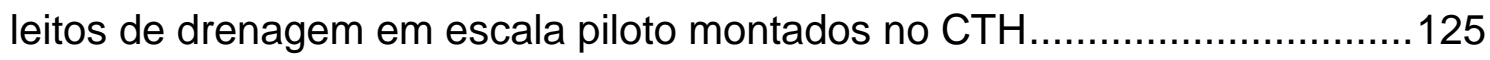

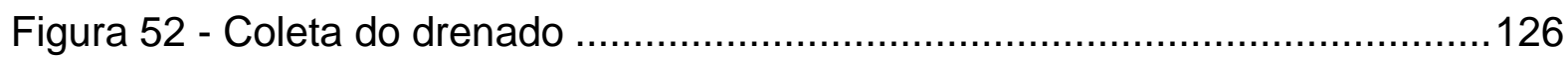

Figura 53 - Amostrador, recipientes de coleta e amostra retirada da torta............128

Figura 54 - Retirada da torta e limpeza da manta geotêxtil ................................128

Figura 55 - Resultados do ensaio em duplicata para o polímero SNF FLONEX $4190 \mathrm{SH}$, que validaram a nova metodologia .......................................131

Figura 56 - Resultados da segunda série de TTD ......................................... 132

Figura 57 - Resultados da segunda série de TTD com alteração na escala do eixo das ordenadas para evidenciar as melhores doses ..................................133

Figura 58 - Resultados dos polímeros sólidos da terceira série de TTD ................135 Figura 59 - Resultados dos polímeros sólidos da terceira série de TTD com alteração na escala do eixo das ordenadas para evidenciar as melhores doses 136

Figura 60 - Resultados dos polímeros em emulsão da terceira série de TTD.......137 Figura 61 - Resultados dos polímeros em emulsão da terceira série de TTD com alteração na escala do eixo das ordenadas para evidenciar as melhores doses 
Figura 62 - Resultados dos testes da quarta série de TTD 142

Figura 63 - Resultados dos testes da quinta série de TTD 144

Figura 64 - Aspecto do lodo condicionado com aumento significativo do porcentual de água livre e formação de flocos estruturados 145

Figura 65 - Altura e teor de sólidos da torta no leito de drenagem para o ensaio piloto $\mathrm{E} 1$ 149

Figura 66 - Altura e teor de sólidos da torta no leito de drenagem para o ensaio piloto E2 150

Figura 67 - Altura e teor de sólidos da torta no leito de drenagem para o ensaio piloto E3. 150

Figura 68 - Altura e teor de sólidos da torta no leito de drenagem para o ensaio piloto E4 150

Figura 69 - Altura e teor de sólidos da torta no leito de drenagem para o ensaio piloto E5. 151

Figura 70 - Altura e teor de sólidos da torta no leito de drenagem para o ensaio piloto E6. 151

Figura 71 - Altura e teor de sólidos da torta no leito de drenagem para o ensaio piloto $\mathrm{E7}$ 151

Figura 72 - Altura e teor de sólidos da torta no leito de drenagem para o ensaio piloto E8. 152

Figura 73 - Altura e teor de sólidos da torta no leito de drenagem para o ensaio piloto E9. 152

Figura 74 - Altura e teor de sólidos da torta no leito de drenagem para o ensaio piloto E10. 153

Figura 75 - Altura e teor de sólidos da torta no leito de drenagem para o ensaio piloto E11 153

Figura 76 - Aspecto da manta após a remoção manual da torta de ensaio sem condicionamento à esquerda (E9) e com condicionamento à direita (E10) ....156

Figura 77 - Altura e teor de sólidos da torta no leito de drenagem para o ensaio piloto E12. 159

Figura 78 - Altura e teor de sólidos da torta no leito de drenagem para o ensaio piloto E13. 159

Figura 79 - Altura e teor de sólidos da torta no leito de drenagem para o ensaio piloto E14 160 
Figura 80 - Resultados da altura da torta nos ensaios E12 a E14 161

Figura 81 - Resultados do teor de sólidos nos ensaios E12 a E14 162

Figura 82 - Sugestão construtiva para leitos de drenagem como forma de aumentar a exposição da manta geotêxtil ao ar (Fontana, 2008) 168

Figura 83 - Aspecto do leito de drenagem ao final do ciclo de secagem do E11 ...169

Figura 84 - Desenho em planta do sistema piloto de desaguamento 182

Figura 85 - Vista A do sistema piloto de desaguamento 183

Figura 86 - Vista B do sistema piloto de desaguamento 184

Figura 87 - TTD para o mesmo polímero e doses com erro na metodologia. 186

Figura 88 - Resultados do teste em duplicata para o polímero CIBA ZETAG 8160

Figura 89 - Resultados do teste em duplicata para o polímero ASHLAND K 144L 188 Figura 90 - Resultados do teste em duplicata para o polímero KEMIRA SUPERFLOC 494 189

Figura 91 - Resultados do teste em duplicata para o polímero KEMIRA SUPERFLOC 492

Figura 92 - Resultados do teste em duplicata para o polímero SNF FLONEX $4190 \mathrm{SH}$

Figura 93 - Resultados do teste em duplicata para o polímero CIBA ZETAG 8165 192

Figura 94 - Resultados do teste em duplicata para o polímero SNF FLONEX $5350 \mathrm{SH}$

Figura 95 - Resultados do teste em duplicata para o polímero SNF FLONEX $4490 \mathrm{SH}$. 194

Figura 96 - Resultado da altura da torta nos ensaios E1 a E8 215

Figura 97 - Resultado do teor de sólidos nos ensaios E1 a E8. .216

Figura 98 - Resultado da altura da torta nos ensaios E9 a E11 217

Figura 99 - Resultados do teor de sólidos nos ensaios E9 a E11. 218

Figura 100 - Ensaio $1-\mathrm{Dc}=1 \mathrm{~g} / \mathrm{kgST}$ e $\mathrm{Ca}=19,82 \mathrm{kgST} / \mathrm{m}^{2}$.ciclo - DQO, Condutividade, $\mathrm{pH}$ e turbidez do drenado. 219

Figura 101 - Ensaio $2-\mathrm{Dc}=2 \mathrm{~g} / \mathrm{kgST}$ e $\mathrm{Ca}=19,02 \mathrm{kgST} / \mathrm{m}^{2}$.ciclo - DQO,

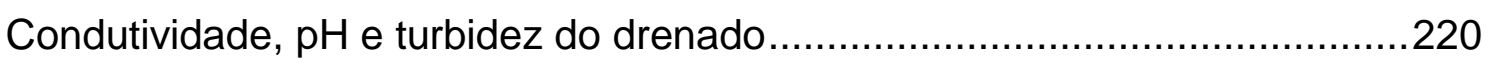

Figura 102 - Ensaio $3-\mathrm{Dc}=3 \mathrm{~g} / \mathrm{kgST}$ e $\mathrm{Ca}=14,7 \mathrm{kgST} / \mathrm{m}^{2}$.ciclo - DQO, Condutividade, $\mathrm{pH}$ e turbidez do drenado. .220 
Figura 103 - Ensaio $4-\mathrm{Dc}=4 \mathrm{~g} / \mathrm{kgST}$ e $\mathrm{Ca}=14,31 \mathrm{kgST} / \mathrm{m}^{2}$.ciclo $-\mathrm{DQO}$, Condutividade, $\mathrm{pH}$ e turbidez do drenado..................................................221

Figura 104 - Ensaio $5-\mathrm{Dc}=5 \mathrm{~g} / \mathrm{kgST}$ e $\mathrm{Ca}=15,5 \mathrm{kgST} / \mathrm{m}^{2}$.ciclo - DQO,

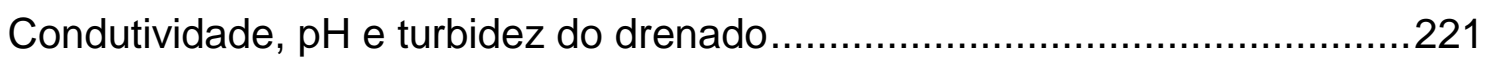

Figura 105 - Ensaio $6-\mathrm{Dc}=6 \mathrm{~g} / \mathrm{kgST}$ e $\mathrm{Ca}=15,06 \mathrm{kgST} / \mathrm{m}^{2}$.ciclo $-\mathrm{DQO}$, Condutividade, $\mathrm{pH}$ e turbidez do drenado .................................................222

Figura 106 - Ensaio $7-\mathrm{Dc}=0 \mathrm{~g} / \mathrm{kgST}$ e $\mathrm{Ca}=15,35 \mathrm{kgST} / \mathrm{m}^{2}$.ciclo $-\mathrm{DQO}$, Condutividade, $\mathrm{pH}$ e turbidez do drenado ..............................................222

Figura 107 - Ensaio $8-\mathrm{Dc}=8 \mathrm{~g} / \mathrm{kgST}$ e $\mathrm{Ca}=12,81 \mathrm{kgST} / \mathrm{m}^{2}$.ciclo - DQO, Condutividade, $\mathrm{pH}$ e turbidez do drenado................................................223

Figura 108 - Ensaio $9-\mathrm{Dc}=0 \mathrm{~g} / \mathrm{kgST}$ e $\mathrm{Ca}=13,59 \mathrm{kgST} / \mathrm{m}^{2}$.ciclo $-\mathrm{DQO}$, Condutividade, $\mathrm{pH}$ e turbidez do drenado................................................223

Figura 109 - Ensaio $10-\mathrm{Dc}=2 \mathrm{~g} / \mathrm{kgST}$ e $\mathrm{Ca}=14,57 \mathrm{kgST} / \mathrm{m}^{2}$.ciclo - DQO, Condutividade, $\mathrm{pH}$ e turbidez do drenado ..............................................224

Figura 110 - Ensaio $11-\mathrm{Dc}=4 \mathrm{~g} / \mathrm{kgST}$ e $\mathrm{Ca}=14,89 \mathrm{kgST} / \mathrm{m}^{2}$.ciclo - DQO, Condutividade, $\mathrm{pH}$ e turbidez do drenado .................................................224

Figura 111 - Ensaio $12-\mathrm{Dc}=2 \mathrm{~g} / \mathrm{kgST}$ e $\mathrm{Ca}=14,38 \mathrm{kgST} / \mathrm{m}^{2}$.ciclo - DQO,

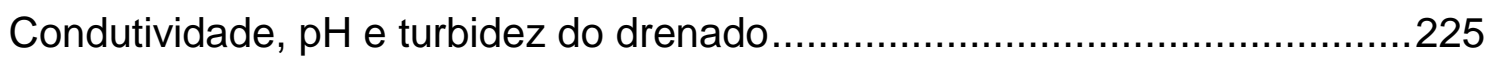

Figura 112 - Ensaio $13-\mathrm{Dc}=2 \mathrm{~g} / \mathrm{kgST}$ e $\mathrm{Ca}=21,24 \mathrm{kgST} / \mathrm{m}^{2}$.ciclo - DQO,

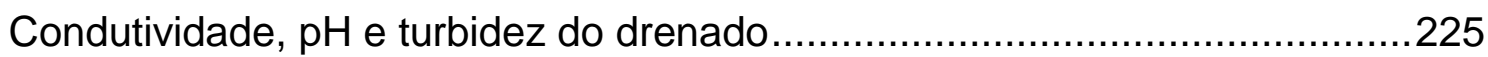

Figura 113 - Ensaio $14-\mathrm{Dc}=2 \mathrm{~g} / \mathrm{kgST}$ e $\mathrm{Ca}=9,77 \mathrm{kgST} / \mathrm{m}^{2}$.ciclo - DQO, Condutividade, $\mathrm{pH}$ e turbidez do drenado ..............................................226

Figura 114 - Alimentação do leito de drenagem com lodo condicionado (Dc = 2

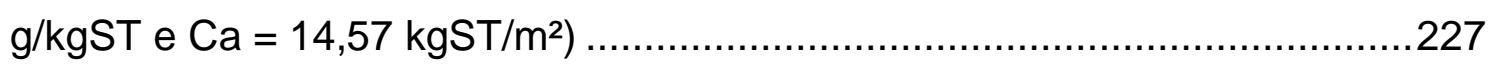

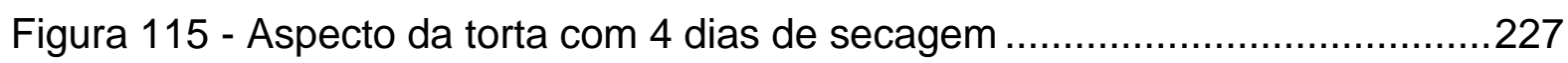

Figura 116 - Aspecto da torta com 8 (esquerda) e 13 (direita) dias de secagem ...228 Figura 117 - Aspecto da torta com 18 (esquerda) e 25 (direita) dias de secagem.228 Figura 118 - Remoção da torta no $31^{\circ}$ dia de secagem .228 


\section{LISTA DE TABELAS}

Tabela 1 - Origem e descrição básica dos diferentes tipos de lodo produzido em sistemas de tratamento de esgotos sanitários (Adaptado de ANDREOLLI, VON SPERLING e FERNANDES, 2007).

Tabela 2 - Características e quantidade de lodo produzido no tratamento de esgoto (Adaptado de ANDREOLLI, VON SPERLING e FERNANDES, 2007) 30

Tabela 3 - Avaliação dos aspectos ambientais de métodos de desaguamento (ANDREOLLI, VON SPERLING e FERNANDES, 2007) .33

Tabela 4 - Composição de nutrientes no lodo em \% de matéria seca (SANEPAR, 1997 apud ANDREOLLI; FERNANDES E VON SPERLING, 2007) 36

Tabela 5 - Micro e macropropriedades de lodos de ETA (Adaptado de DHARMAPPA, 1997)

Tabela 6 - Relações para verificação da auto estabilidade (CHEN, 1981 apud VERTEMATTI, 2004)

Tabela 7 - Parâmetros reológicos obtidos por Slatter (1997) para lodos anaeróbios digeridos com diferentes teores de sólidos .54

Tabela 8 - Alguns métodos para avaliação da capacidade de desaguamento 61

Tabela 9 - Vantagens e desvantagens do uso de leitos de secagem de lodo (Adaptado de SAMUDIO, 1993). 66

Tabela 10 - Recomendações para a camada de areia do leito de secagem. .69

Tabela 11 - Qualidade do drenado de leito de secagem desaguando lodo de tanque séptico (COFIE et al., 2006)

Tabela 12 - Aspectos ambientais de alguns processos de desaguamento (SAMUDIO, 1993)

Tabela 13 - Composição aproximada (\% de massa) dos principais polímeros utilizados em geossintéticos (Adaptado de KOERNER, 1994)

Tabela 14 - Efeito do polímero e da fabricação do geotêxtil em algumas propriedades dos geotêxteis (Adaptado de ABRAMENTO, 1995) 86

Tabela 15 - Métodos, equipamentos e procedimentos das determinações analíticas 
Tabela 16 - Doses "ideais", e respectivos tempos de desaguamento e turbidez, determinadas pelo TTD com os 18 polímeros cedidos pelos fabricantes 139

Tabela 17 - Relação dos polímeros ensaiados ordenados em função do custo estimado de condicionamento por tonelada de sólidos no lodo (considerando $\mathrm{R} \$ 1,6=$ US $\$ 1$ ) 140

Tabela 18 - Resultados dos ensaios com os geotêxteis 146

Tabela 19 - Resultados da altura e teor de sólidos da torta para os ensaios piloto E1 a E11 ao longo do período de secagem 149

Tabela 20 - Fluxo de água e médias dos resultados das análises de DQO, Condutividade, $\mathrm{pH}$ e Turbidez do drenado 155

Tabela 21 - Resultados da altura e teor de sólidos da torta para os ensaios piloto E12 a E14 ao longo do período de secagem 158

Tabela 22 - Fluxo de água inicial e média dos resultados das análises de DQO, Condutividade, $\mathrm{pH}$ e Turbidez do drenado 163

Tabela 23 - Planilha dos testes da terceira série com polímeros sólidos 195

Tabela 24 - Planilha dos testes da terceira série com polímeros sólidos 196

Tabela 25 - Planilha dos testes da terceira série com polímeros em emulsão.......197

Tabela 26 - Planilha com os dados dos testes da quarta série de ensaios............198

Tabela 27 - Planilha com os dados dos testes da quinta série de ensaios ............199

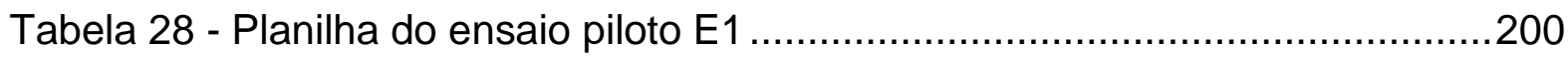

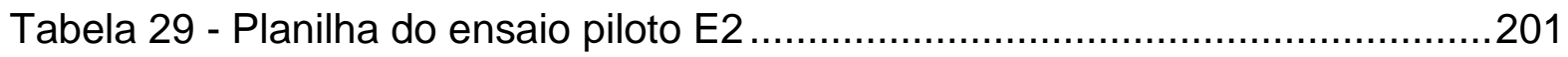

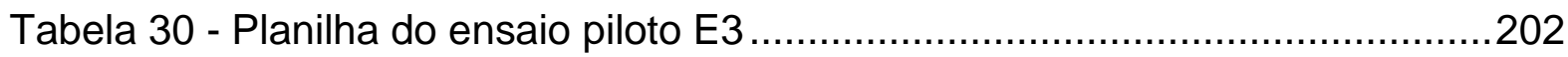

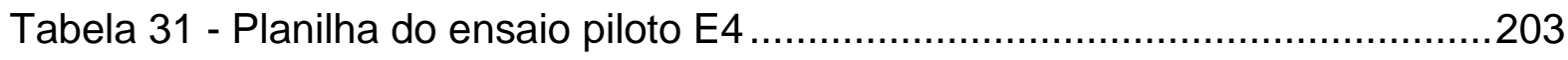

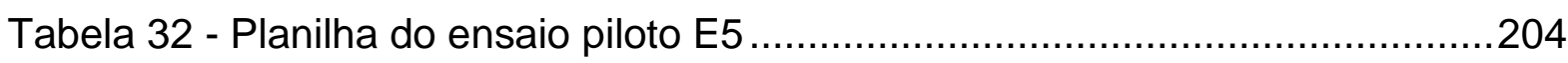

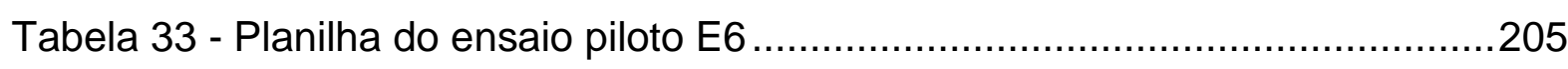

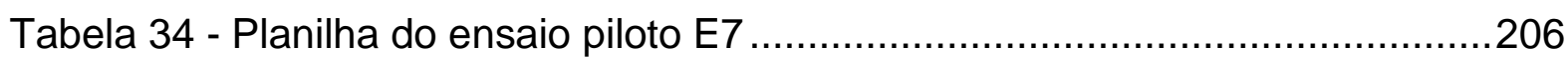

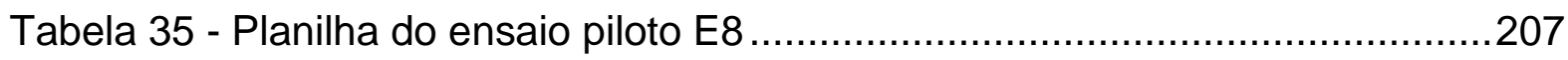

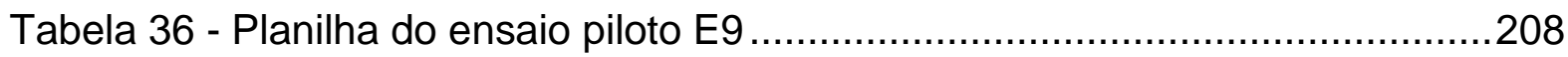

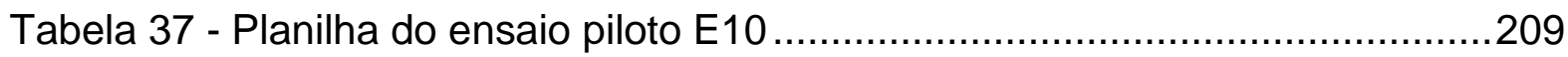

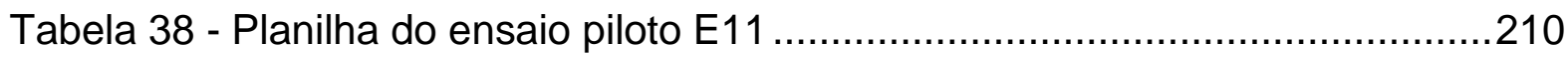

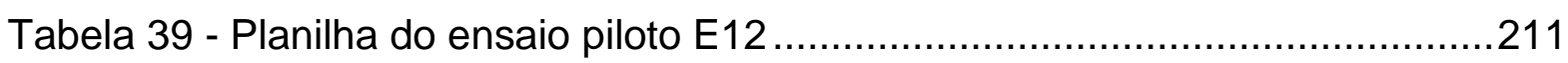

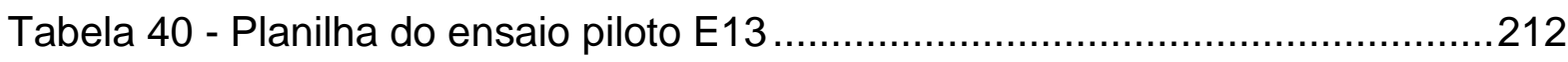

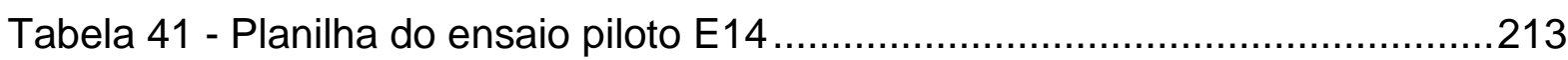


Tabela 42 - Planilha com as características dos polímeros utilizados nos ensaios

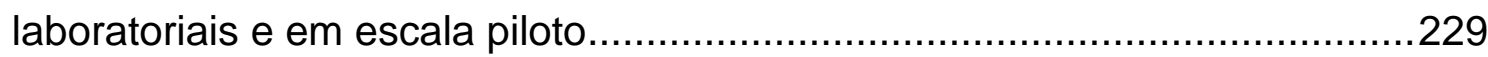

Tabela 43 - Planilha com as características de diversos geotêxteis do mercado ..230

Tabela 44 - Planilha com as características de diversos geotêxteis do mercado. .231

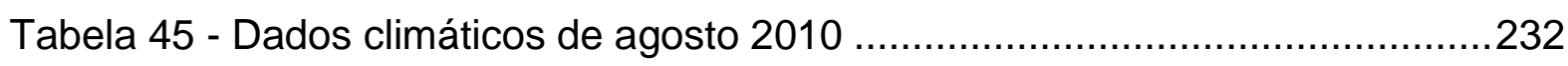

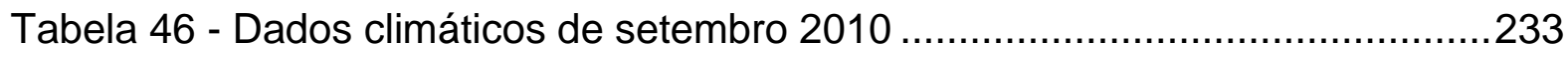

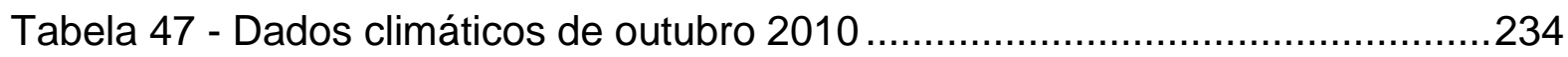

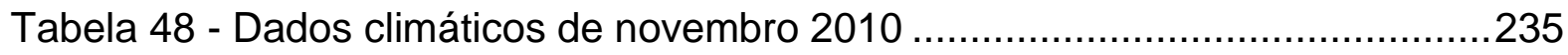

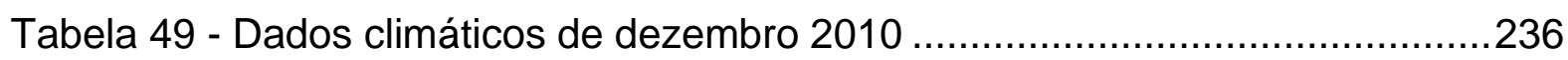

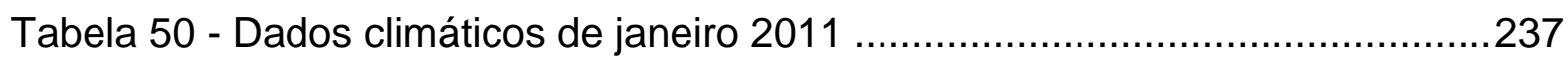

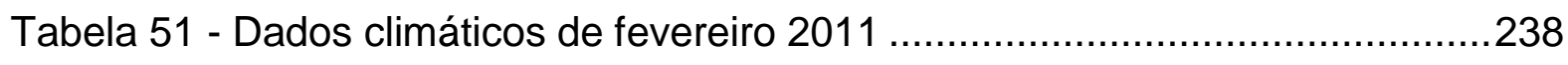

Tabela 52 - Dados climáticos de março 2011 ..................................................239

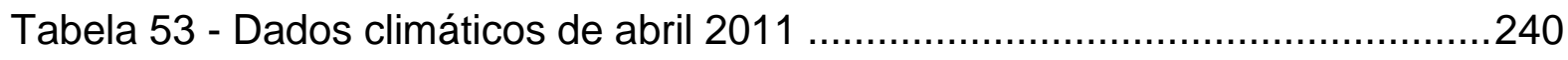

Tabela 54 - Dados climáticos de maio 2011 .....................................................241 


\section{LISTA DE ABREVIATURAS, SÍMBOLOS E SIGLAS}

[ ] - Concentração em mg/L de determinada substância química

${ }^{\circ} \mathrm{C}$ - Unidade de temperatura, graus Celsius

$\mu$ - Viscosidade absoluta

A - Área de filtração

ABNT - Associação Brasileira de Normas Técnicas

Ae - Área específica requerida

APHA - American Public Health Association

ASTM - American Society for Testing and Materials

AWWA - American Water Works Association

$b$ - Inclinação da parte linear da curva de $t / V \times V$ do teste de REF

BF - Biofiltro Aerado Submerso

c - Massa de sólidos secos na torta por volume filtrado

$\mathrm{Ca}$ - Taxa de aplicação de sólidos por unidade de área por ciclo de secagem

Cc - Coeficiente de curvatura

$\mathrm{cm}$ - centímetros $\left(10^{-2} \mathrm{~m}\right)$

CONAMA - Conselho Nacional de Meio Ambiente

COSEAS - Restaurante Central da USP

CRUSP - Conjunto Residencial da USP

CST - Tempo de sucção capilar ou "Capillary Suction Time"

$\mathrm{CTH}$ - Centro Tecnológico de Hidráulica

$\mathrm{Cu}$ - Coeficiente de uniformidade

d - Dia

$\mathrm{D}_{85}$ - Diâmetro equivalente do material granular tal que $85 \%$ (em peso) de todas as partículas são inferiores a ele (análogo para outros diâmetros)

DBO - Demanda Bioquímica de Oxigênio

Dc - Dose aplicada de condicionante ( $\mathrm{g} / \mathrm{kg}$ sólidos totais - peso seco)

de - Diâmetro equivalente

df - Diâmetro da fibra

Di - Espessura da camada de lodo

Dii - Espessura final da torta seca 
DQO - Demanda Química de Oxigênio

DSi - Teor de sólidos no lodo aplicado

DSii - Teor de sólidos que é desejado na torta seca

e - Espessura da camada de lodo aplicado em cada ciclo

ETA - Estação de Tratamento de Água

ETE - Estação de Tratamento de Esgoto

EUA - Estados Unidos da América (país)

G - Gradiente hidráulico

g - Gramas

$\gamma$ - Peso

$\gamma$ - Taxa de cisalhamento

ye - Peso específico do material

Gt - Gradiente aplicado durante certo período de tempo. Corresponde à intensidade de mistura que é aplicada a um líquido

Hab - Habitante (unidade populacional)

IA - Carga de lodo aplicado

Ic - Índice de consistência

$\mathrm{K}$ - Fator de forma da partícula

$\mathrm{k}, \mathrm{M}, \mathrm{m}$ e $\mu$ - indicam $10^{3}, 10^{6}, 10^{-3}$ e $10^{-6}$, respectivamente

$\mathrm{Kn}$ - Permeabilidade normal

$\mathrm{m}$ - Metros

MA - Gramatura (massa em gramas por unidade de área)

min - Minutos

MLT - Base dimensional

$\mathrm{N}$ - Newtons

nc - Número de ciclos de secagem por ano

nGT - Porosidade do material

$\varnothing$ - Diâmetro

$\mathrm{O}_{95}$ - Abertura de filtração do geotêxtil

P - Pressão do vácuo

$\mathrm{Pa}$ - Unidade Pascal de pressão

Pc - Porcentagem do volume total aplicado que é coletado pelo sistema de drenagem do leito $\mathrm{pH}-$ Potencial Hidrogeniônico $(=-\log [\mathrm{H}+])$ 
PNRS - Política Nacional de Resíduos Sólidos

PNSB - Plano Nacional de Saneamento Básico

PROSAB - Programa de Pesquisa em Saneamento Básico

$Q$ - Quantidade de lodo digerido produzido na ETE

$r$ - Resistência específica à filtração

RAFA - Reator Anaeróbio de Fluxo Ascendente e Manto de Lodo (UASB)

REF - Resistência Específica à Filtração

rpm - Rotações por minuto

$s$ - Segundos

$S$ - Siemens (unidade de condutividade elétrica)

SABESP - Companhia de Saneamento Básico do Estado de São Paulo

So - Área superficial

SST - Sólidos Suspensos Totais

ST - Sólidos Totais

$\mathrm{t}$ - Tempo de mistura

tGT - Espessura nominal do geotêxtil

TS - Teor de sólidos em \% de massa por massa

TSC - Tempo de Sucção Capilar (CST)

TTD - Teste do Tempo de Drenagem

UASB - Upflow anaerobic sludge blanket (RAFA)

UFES - Universidade Federal do Espírito Santo

UFMG - Universidade Federal de Minas Gerais

UFRJ - Universidade Federal do Rio de Janeiro

UFSC - Universidade Federal de São Carlos

USEPA - United States Environmental Protection Agency

USP - Universidade de São Paulo

$\mathrm{V}$ - Volts

WEF - Water Environmental Foundation

WPCF - Water Pollution Control Federation

y - um fator proposto pelos autores dos critérios

$\mathrm{Zn}, \mathrm{Mn}, \mathrm{Cu}, \mathrm{B}, \mathrm{Mo}$ e $\mathrm{Cl}, \mathrm{N}, \mathrm{P}, \mathrm{K}, \mathrm{C}, \mathrm{Ca}, \mathrm{Mg}$ - Elementos químicos da tabela periódica

$\theta$ - transmissividade

$\rho$ - Massa específica ou densidade do material

$\sigma$ - Tensão de cisalhamento 


\section{SUMÁRIO}

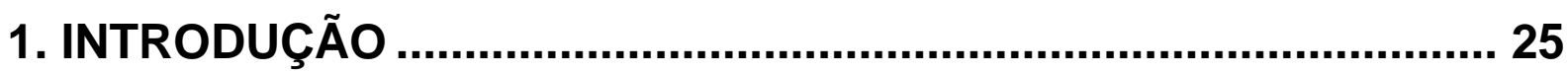

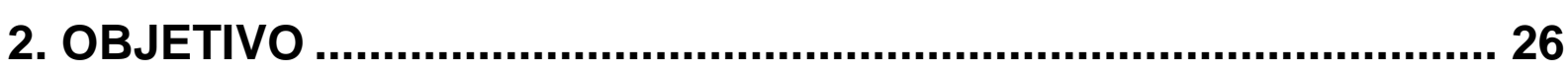

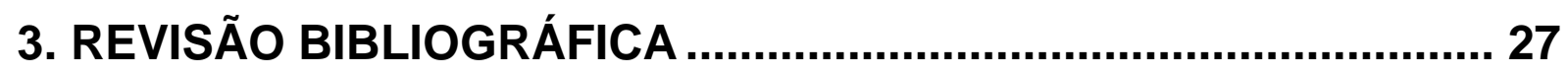

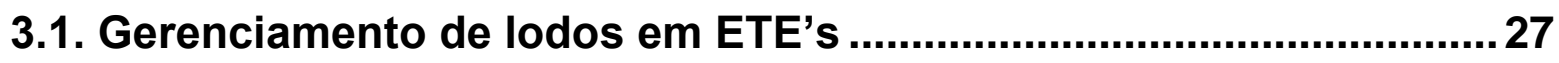

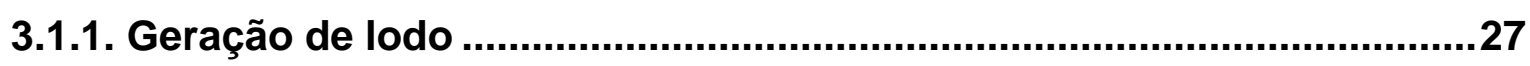

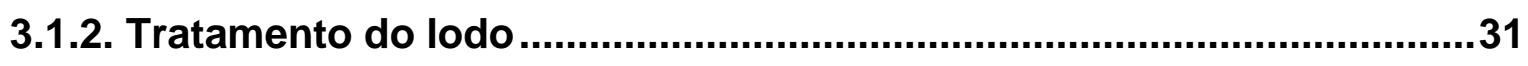

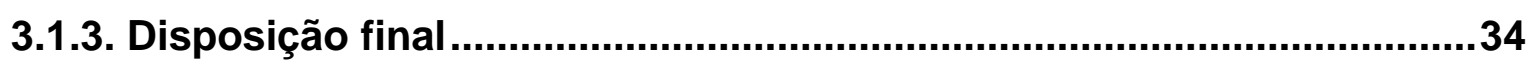

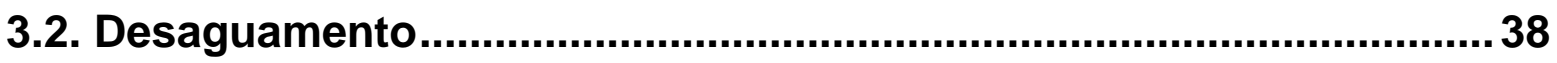

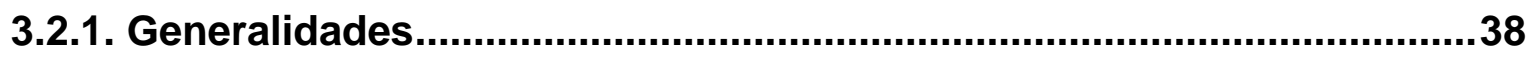

3.2.2. Fatores que interferem na remoção de água do lodo ..........................40

3.2.2.1. Distribuição e tamanho dos flocos ...................................................43

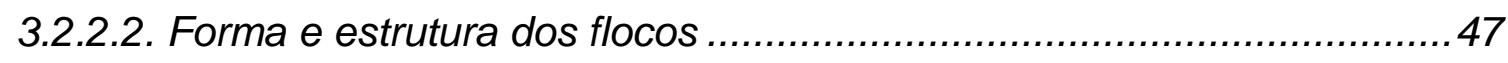

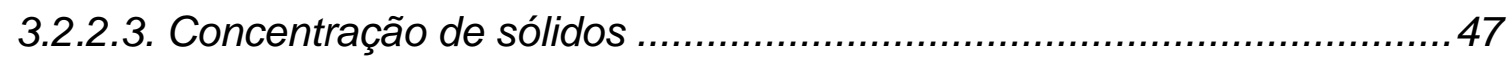

3.2.2.4. Temperatura, viscosidade e tensão superficial.................................. 48

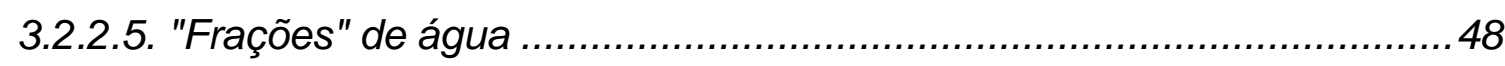

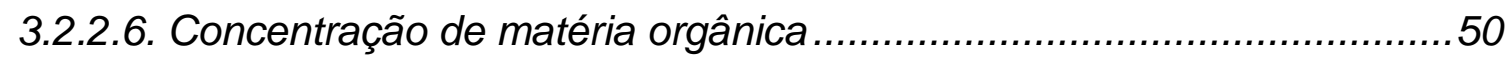

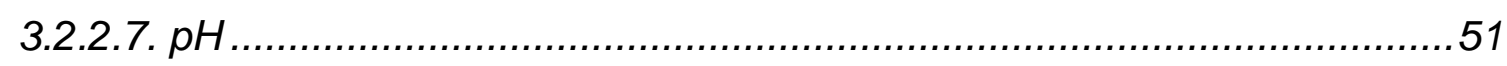

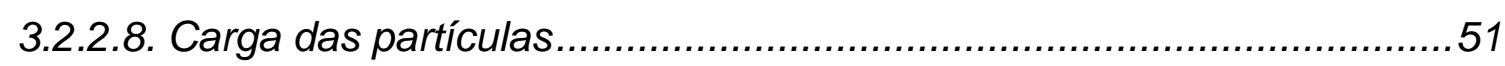

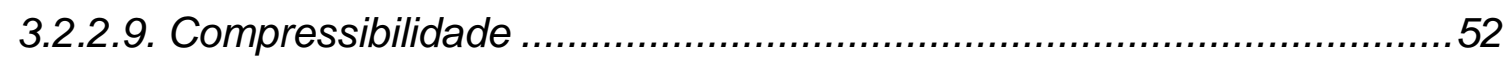

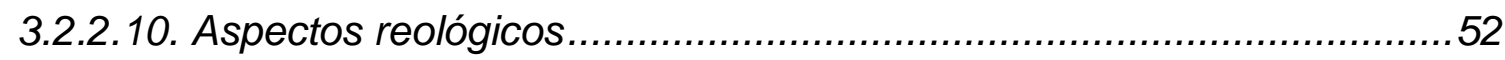

3.2.3. Métodos para avaliação da capacidade de desaguamento ...................60

3.2.3.1. Teste da resistência específica à filtração ...........................................61

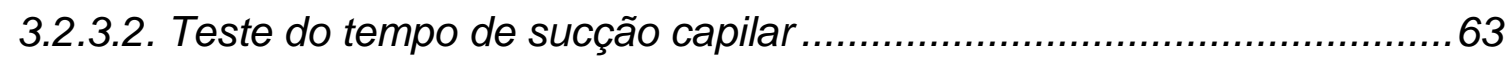

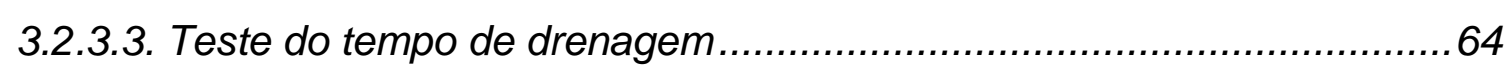

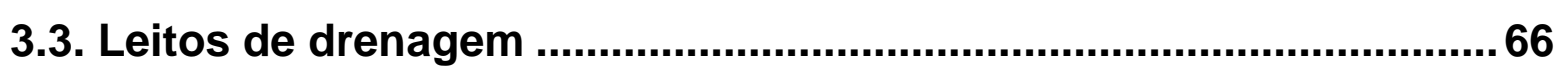

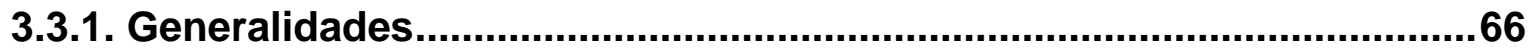

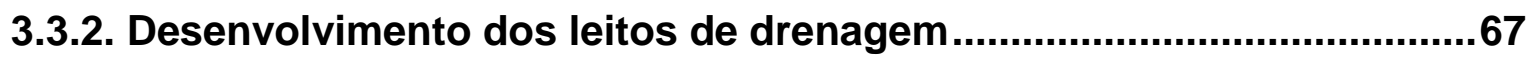

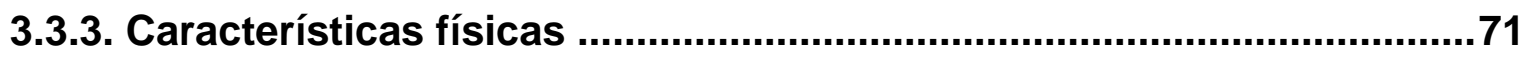

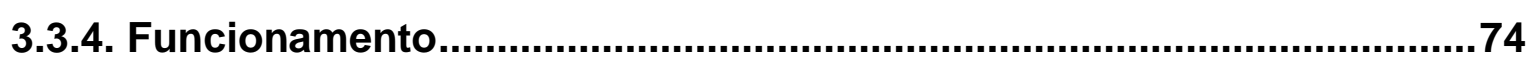

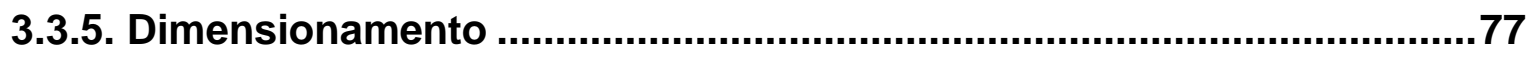


3.3.5.1. Dimensionamento empírico

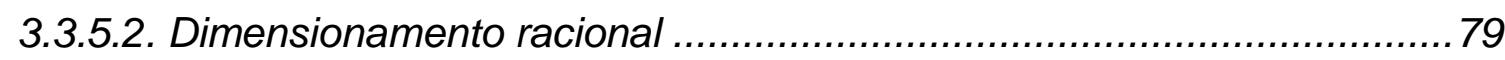

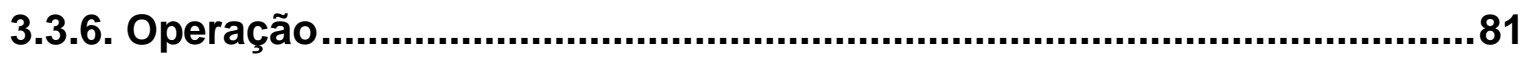

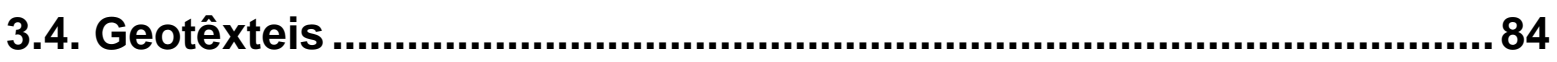

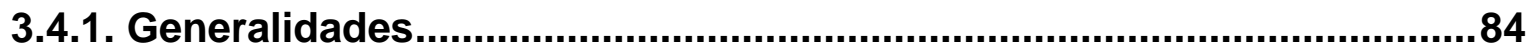

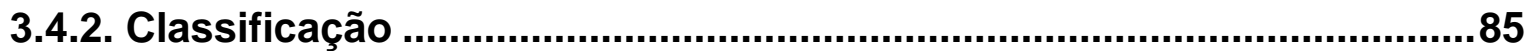

3.4.3. Composição........................................................................................... 86

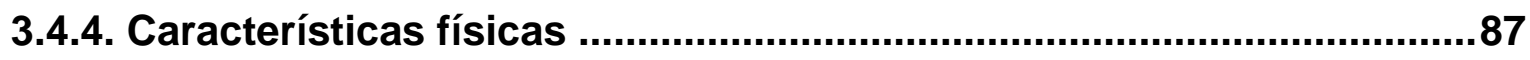

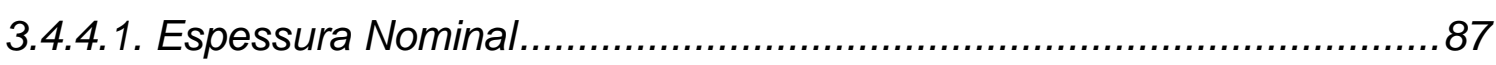

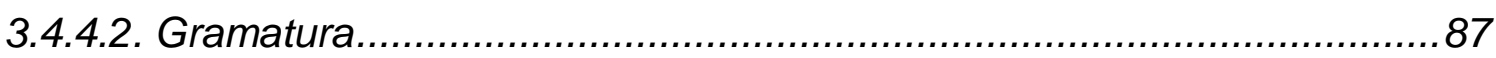

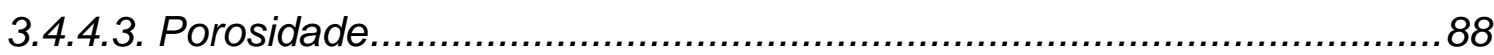

3.4.5. Propriedades mecânicas ...................................................................89

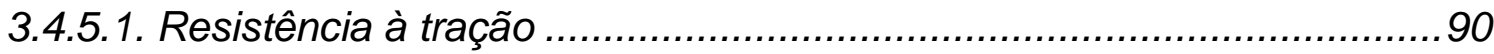

3.4.5.2. Resistência à penetração por puncionamento estático .......................90

3.4.6. Propriedades hidráulicas.................................................................91

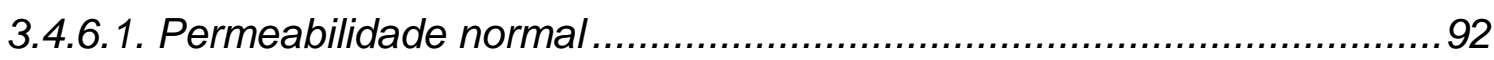

3.4.6.2. Permeabilidade planar ............................................................ 93

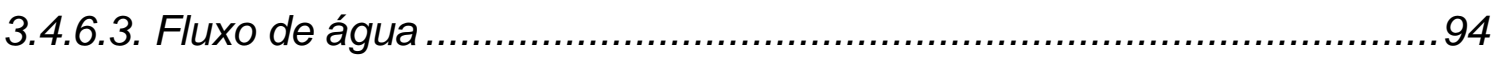

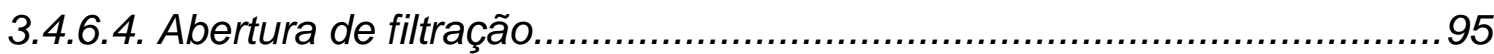

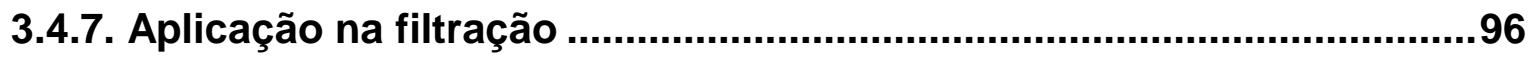

3.4.8. Dimensionamento de filtros têxteis .......................................................97

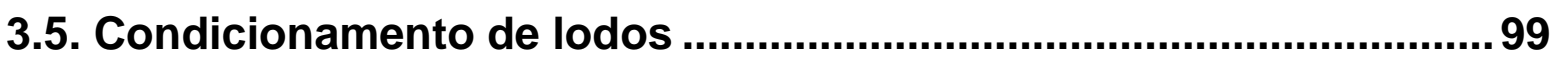

3.5.1. Condicionamento inorgânico ............................................................100

3.5.2. Condicionamento inorgânico + orgânico.............................................100

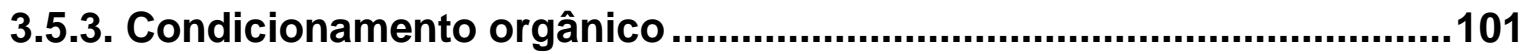

3.5.3.1. Mecanismo de floculação dos polímeros ........................................ 103

3.5.3.2. Efeito das condições de preparação e aplicação................................106

3.5.3.3. Determinação das melhores dosagens......................................... 108

3.5.3.4. Fatores que interferem na avaliação do efeito do condicionamento ... 109

3.5.3.5. Fatores que interferem na seleção dos polímeros .............................111

4. MATERIAL E MÉTODOS............................................................112

4.1. Ensaios laboratoriais .....................................................................112

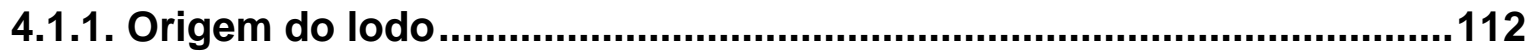


4.1.2. Coleta e preparação do lodo .113

4.1.3. Preparação do polímero 115

4.1.4. Teste do Tempo de Drenagem para avaliação dos polímeros .116

4.1.4.1. Materiais utilizados 116

4.1.4.2. Descrição dos testes. 118

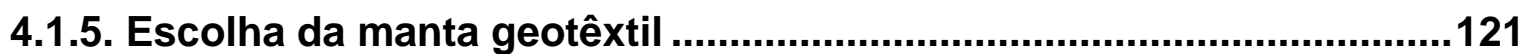

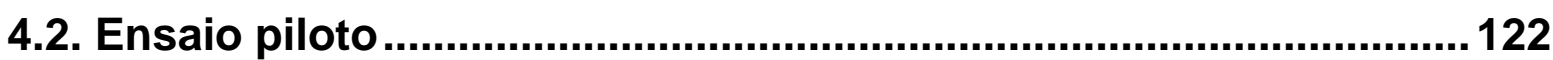

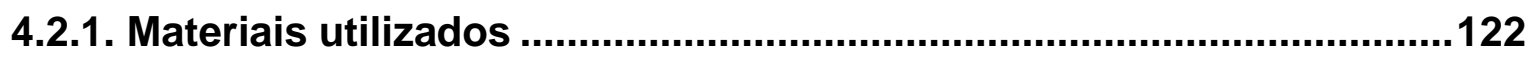

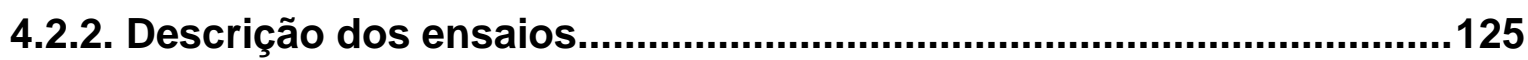

4.2.2.1. Ensaios para avaliar as dosagens em escala piloto .......................... 127

4.2.2.2. Ensaios para avaliar diferentes taxas de aplicação de sólidos ............128

4.3. Métodos analíticos .......................................................................129

5. RESULTADOS E DISCUSSÃO .................................................130

5.1. Teste do Tempo de Drenagem ......................................................130

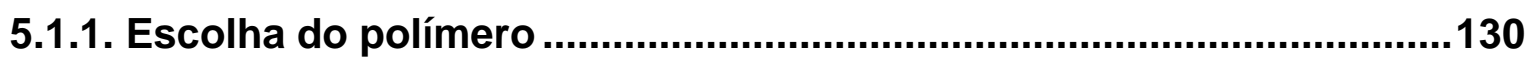

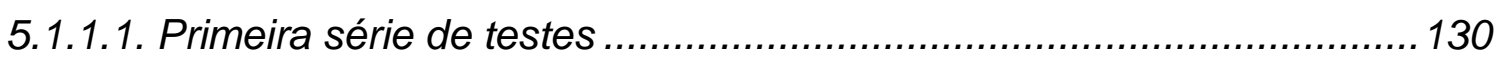

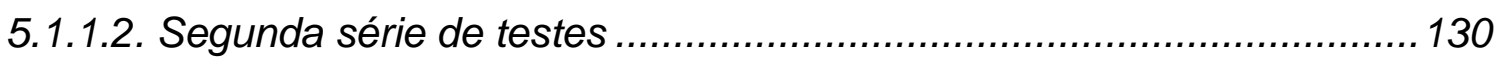

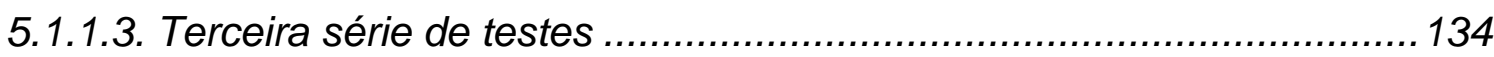

5.1.1.4. Dose "ideal" e estimativa de custo .................................................... 139

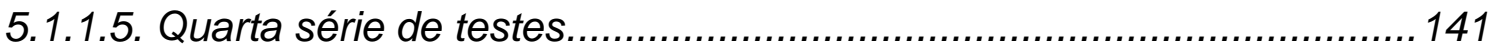

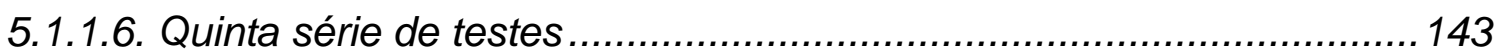

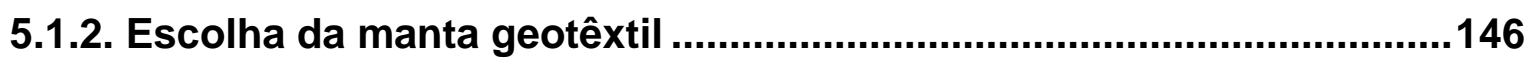

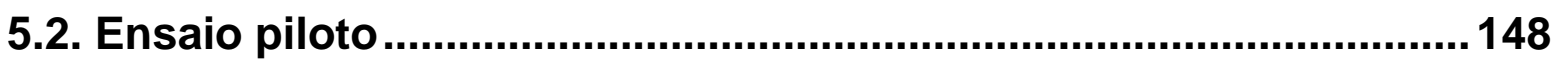

5.2.1. Ensaios para avaliar o efeito das diferentes dosagens de polímero.148

5.2.2. Ensaios para avaliar diferentes taxas de aplicação de sólidos ..........157

6. CONSIDERAÇÕES FINAIS .......................................................164

7. CONCLUSÕES E RECOMENDAÇÕES.....................................170

REFERÊNCIAS ...........................................................................171

APÊNDICE 1 - Desenhos do sistema piloto..................................182

APÊNDICE 2 - Resultados da primeira série de testes com o TTD 
APÊNDICE 3 - Dados e resultados da segunda série de testes com

O TTD 187

APÊNDICE 4 - Dados e resultados da terceira série de testes com o TTD

APÊNDICE 5 - Dados e resultados da quarta série de testes com o

TTD 198

APÊNDICE 6 - Dados e resultados da quinta série de testes com o

TTD 199

APÊNDICE 7 - Planilhas do ensaio piloto 200

APÊNDICE 8 - Resultados da altura e teor de sólidos da torta dos ensaios piloto E1 a E8. .214 APÊNDICE 9 - Resultados das análises do drenado dos ensaios piloto 219 APÊNDICE 10 - Sequência de fotos ilustrativa do aspecto da torta formada ao longo do ciclo de secagem do ensaio E10. .227

ANEXO A - Características dos polímeros 229

ANEXO B - Características dos geotêxteis. .230

ANEXO C - Dados climáticos da Estação Meteorológica do Instituto de Astronomia, Geofísica e Ciências Atmosféricas .232 


\section{INTRODUÇÃO}

O lodo gerado no tratamento de efluentes municipais corresponde a cerca de 1 a $2 \%$ do volume de esgoto tratado (ANDREOLLI, VON SPERLING e FERNANDES, 2007). Este resíduo necessita de tratamento e disposição adequada para evitar a proliferação de vetores e a contaminação de corpos d'água, sendo considerado um grave problema ambiental de médios e grandes centros urbanos (ALEM SOBRINHO, 2001). O desaguamento do lodo é um processo realizado em Estações de Tratamento de Esgoto (ETE's) imprescindível para reduzir o volume e os custos com sua disposição final.

Existem diversos métodos mecânicos e naturais para redução do volume de lodos com diferentes eficiências e custos. $O$ desaguamento em leito de secagem é um processo natural, normalmente utilizado em pequenas estações de tratamento. A quantidade de lodo que pode ser tratada em determinado período de tempo por este método de desaguamento depende da estrutura física do leito de secagem e de condições climáticas. Assim, diante da atual carência de ETE's no Brasil, em especial no Norte e Nordeste (regiões de altas temperaturas), o aperfeiçoamento deste processo tem papel relevante na busca pela universalização do saneamento.

Neste contexto, o Leito de Drenagem foi desenvolvido a partir de 1993 (CORDEIRO, 2001) para o desaguamento de lodos de Estações de Tratamento de Água. A sua aplicação para lodos de lagoas de estabilização de esgotos foi feita por Fontana et al. (2007). Em relação ao leito de secagem, o leito de drenagem possui uma menor soleira drenante e tem a areia substituída por uma manta geossintética. Este estudo contemplou a avaliação desta estrutura física de leito associada ao condicionamento químico com polímeros orgânicos sintéticos no desaguamento de lodo anaeróbio.

Desta forma, lodos de reatores anaeróbios tipo UASB, processo cada vez mais utilizado no tratamento de esgoto sanitário (ALEM SOBRINHO, 2001), foram utilizados para, em escala de laboratório, estimar o efeito de diferentes doses de polímeros orgânicos e, em escala piloto, observar o comportamento dos leitos de drenagem no desaguamento deste tipo de lodo. 


\section{OBJETIVO}

O objetivo deste trabalho é estudar o desaguamento de lodos anaeróbios de reatores UASB em leitos de drenagem e verificar a possibilidade de reduzir o tempo de cada ciclo de secagem ou aumentar a taxa de aplicação superficial de sólidos por ciclo. 


\section{REVISÃO BIBLIOGRÁFICA}

\subsection{Gerenciamento de lodos em ETE's}

\subsubsection{Geração de lodo}

No processo de tratamento do esgoto sanitário é gerado um material facilmente putrescível e que rapidamente gera odores desagradáveis, além de possuir grande número de patógenos (ANDREOLLI, VON SPERLING e FERNANDES, 2007). Portanto, o tratamento da fase sólida, composto pelas etapas de adensamento, digestão e desaguamento, deve receber a atenção necessária para que os objetivos ambientais e sociais das ETE's sejam atendidos.

Neste trabalho será abordado o tratamento de apenas uma parte dos resíduos sólidos gerados nas ETE's, que é o lodo biológico gerado em reatores anaeróbios do tipo UASB. Outros subprodutos como os sólidos grosseiros retidos nas grades, a areia do desarenador e a escuma formada em diversas etapas do tratamento não serão abordados neste trabalho.

A qualidade do lodo gerado depende dos processos utilizados para tratamento da fase líquida e fase sólida, da eficiência obtida em cada etapa e, ainda, da forma com que o lodo é removido do local de geração e transportado até o local do tratamento. Sua composição ainda é influenciada pelas características do esgoto afluente à ETE. As características do esgoto variam em função da época do ano (sofre variação sazonal), dos hábitos de consumo da população e da taxa de infiltração na rede.

Os lodos produzidos nos sistemas de tratamento são normalmente classificados de acordo com o processo de tratamento em que foram gerados, sendo denominados como primário, secundário, misto (primário + secundário), digerido, não digerido ou 
químico. Porém, mesmo sendo classificado de acordo com a etapa em que é gerado, o mesmo processo de uma ETE pode produzir lodo com uma qualidade diferente do lodo de outras ETE's.

O lodo primário é produzido numa etapa realizada antes do tratamento biológico, pela separação física dos sólidos sedimentáveis presentes nos esgoto municipal. O lodo secundário é produzido na etapa biológica aerada das ETE's. O lodo digerido é ainda classificado em anaerobiamente digerido ou aerobiamente digerido, sendo esta uma referência ao processo pelo qual o lodo, primário, secundário ou misto, foi biologicamente estabilizado. O lodo químico é formado a partir da ação de produtos químicos adicionados ao processo para a precipitação de sólidos.

Um diagrama genérico dos processos de tratamento das fases líquida e sólida do esgoto sanitário é apresentado na Figura 1:

\section{Tratamento da fase líquida}

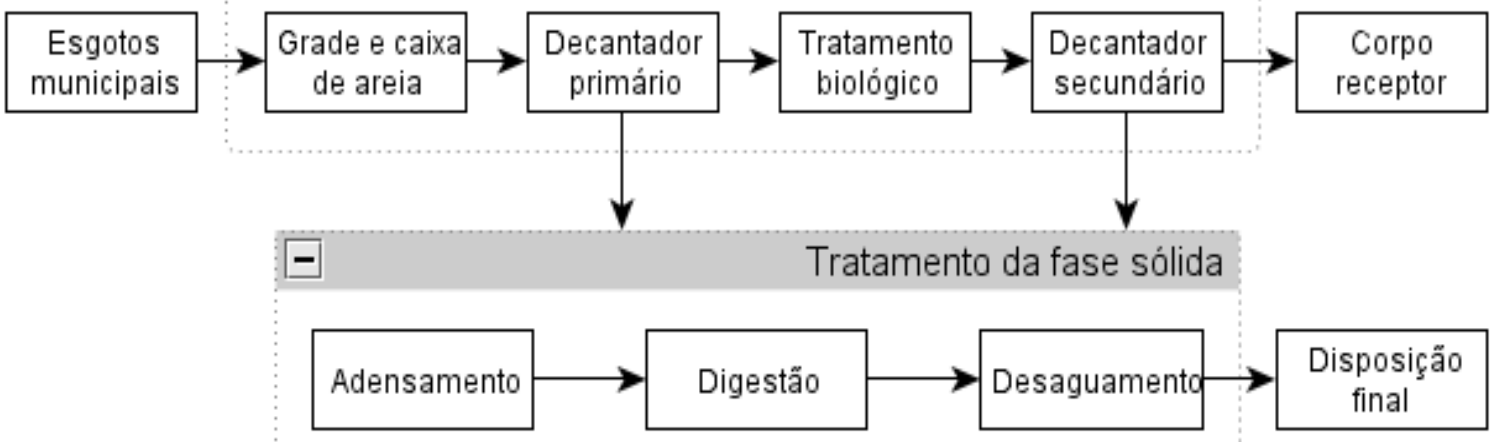

Figura 1 - Diagrama genérico dos processos de tratamento de esgotos sanitários

Uma breve descrição dos diferentes tipos de lodo gerados no tratamento de esgotos sanitários é apresentada na Tabela 1: 
Tabela 1 - Origem e descrição básica dos diferentes tipos de lodo produzido em sistemas de tratamento de esgotos sanitários (Adaptado de ANDREOLLI, VON SPERLING e FERNANDES, 2007)

\begin{tabular}{|c|c|c|}
\hline Subproduto sólido & Origem & Descrição \\
\hline Lodo primário & Decantador primário & $\begin{array}{l}\text { Sólidos sedimentados com baixa taxa } \\
\text { de mineralização }\end{array}$ \\
\hline $\begin{array}{l}\text { Lodo biológico aeróbio não } \\
\text { estabilizado }\end{array}$ & $\begin{array}{l}\text { Lodos ativados convencional e } \\
\text { reatores aeróbios com biofilme }\end{array}$ & $\begin{array}{l}\text { Biomassa retirada dos reatores com } \\
\text { baixa taxa de mineralização (lodo } \\
\text { secundário) }\end{array}$ \\
\hline $\begin{array}{l}\text { Lodo biológico aeróbio } \\
\text { estabilizado }\end{array}$ & $\begin{array}{l}\text { Lodos ativados (aeração } \\
\text { prolongada) e reatores aeróbios } \\
\text { com biofilme }\end{array}$ & $\begin{array}{c}\text { Biomassa formada em reator de baixa } \\
\text { carga com altas taxas de respiração } \\
\text { endógena }\end{array}$ \\
\hline $\begin{array}{l}\text { Lodo biológico anaeróbio } \\
\text { estabilizado }\end{array}$ & Lagoas e reatores anaeróbios & $\begin{array}{l}\text { Biomassa com alto tempo de residência } \\
\text { no reator e digerido sem a presença de } \\
\text { oxigênio }\end{array}$ \\
\hline Lodo químico & $\begin{array}{l}\text { Decantador primário e } \\
\text { precipitação química de fósforo }\end{array}$ & $\begin{array}{l}\text { Resultante da precipitação assistida } \\
\text { com cal ou sais metálicos }\end{array}$ \\
\hline
\end{tabular}

A configuração de sistemas de tratamento que possuem reatores tipo UASB dispensa o uso de decantador primário e as etapas da fase sólida de adensamento e digestão, sendo que todos estes processos são realizados dentro deste reator. Por outro lado, é comumente necessária uma etapa de tratamento biológico complementar para atender aos requisitos de qualidade do efluente tratado, sendo que o lodo gerado nesta etapa normalmente é encaminhado para o reator anaeróbio. Desta forma, sistemas de tratamento que utilizam o reator UASB possuem como único processo de tratamento da fase sólida o desaguamento, ao qual é encaminhado o lodo digerido anaerobiamente, já adensado e digerido no UASB.

A Tabela 2 mostra valores estimados de produção de lodo para diferentes tipos de tratamento e suas características físicas aproximadas. Os dados contidos na tabela são baseados numa densidade de lodo de $1000 \mathrm{~kg} / \mathrm{m}^{3}$ e em uma geração de 0,1 $\mathrm{k} / \mathrm{hab} . \mathrm{d}$ e $0,06 \mathrm{kgSS} / \mathrm{hab} . \mathrm{d}$. É ainda considerado que 1 litro de lodo/hab.d = 1 (gSS/hab.d) / (10.TS) e que o pós-tratamento aeróbio do Reator UASB é feito por lodos ativados, filtro biológico ou biofiltro aerado submerso e o lodo é digerido no próprio reator UASB antes de ser quantificado. 
Tabela 2 - Características e quantidade de lodo produzido no tratamento de esgoto (Adaptado de ANDREOLLI, VON SPERLING e FERNANDES, 2007)

\begin{tabular}{|c|c|c|c|c|}
\hline \multirow[b]{2}{*}{ Sistema de tratamento } & \multicolumn{4}{|c|}{$\begin{array}{l}\text { Características do lodo produzido e descartado da fase } \\
\text { líquida (dirigido ao tratamento da fase sólida) }\end{array}$} \\
\hline & $\begin{array}{c}\mathrm{KgSS} / \mathrm{KgDQO} \\
\text { aplicada }\end{array}$ & $\begin{array}{c}\text { Teor de } \\
\text { sólidos secos } \\
\text { (\%) }\end{array}$ & $\begin{array}{l}\text { Massa de } \\
\text { lodo } \\
\text { (gSS/hab.d) }\end{array}$ & $\begin{array}{l}\text { Volume de } \\
\text { lodo } \\
\text { (L/hab.d) }\end{array}$ \\
\hline Tratamento primário (convencional) & 0,35 a 0,45 & 2 a 6 & 35 a 45 & 0,6 a 2,2 \\
\hline Tratamento primário (tanques sépticos) & 0,20 a 0,30 & 3 a 6 & 20 a 30 & 0,3 a 1 \\
\hline Lagoa facultativa & 0,12 a 0,32 & 5 a 15 & 12 a 32 & 0,1 a 0,25 \\
\hline \multicolumn{5}{|l|}{ Lagoa anaeróbia - lagoa facultativa } \\
\hline Lagoa anaeróbia & 0,20 a 0,45 & 15 a 20 & 20 a 45 & 0,1 a 0,3 \\
\hline Lagoa facultativa & 0,06 a 0,10 & 7 a 12 & 6 a 10 & 0,05 a 0,15 \\
\hline Total & 0,26 a 0,55 & - & 26 a 55 & 0,15 a 0,45 \\
\hline Lagoa aerada facultativa & 0,08 a 0,13 & 6 a 10 & 8 a 13 & 0,08 a 0,22 \\
\hline $\begin{array}{l}\text { Lagoa aerada mistura completa - lagoa } \\
\text { sedimentação }\end{array}$ & 0,11 a 0,13 & 5 a 8 & 11 a 13 & 0,15 a 0,25 \\
\hline \multicolumn{5}{|l|}{ Tanque séptico + filtro anaeróbio } \\
\hline Tanque séptico & 0,20 a 0,30 & 3 a 6 & 20 a 30 & 0,3 a 1 \\
\hline Filtro anaeróbio & 0,07 a 0,09 & 0,5 a 4,0 & 7 a 9 & 0,2 a 1,8 \\
\hline Total & 0,27 a 0,39 & 1,4 a 5,4 & 27 a 39 & 0,5 a 2,8 \\
\hline \multicolumn{5}{|l|}{ Lodos ativados convencional } \\
\hline Lodo primário & 0,35 a 0,45 & 2 a 6 & 35 a 45 & 0,6 a 2,2 \\
\hline Lodo secundário & 0,25 a 0,35 & 0,6 a 1 & 25 a 35 & 2,5 a 6 \\
\hline Total & 0,60 a 0,80 & 1 a 2 & 60 a 80 & 3,1 a 8,2 \\
\hline Lodos ativados aeração prolongada & 0,50 a 0,55 & 0,8 a 1,2 & 40 a 45 & 3,3 a 5,6 \\
\hline \multicolumn{5}{|l|}{ Filtro biológico alta carga } \\
\hline Lodo primário & 0,35 a 0,45 & 2 a 6 & 35 a 45 & 0,6 a 2,2 \\
\hline Lodo secundário & 0,20 a 0,30 & 1 a 2,5 & 20 a 30 & 0,8 a 3,0 \\
\hline Total & 0,55 a 0,75 & 1,5 a 4 & 55 a 75 & 1,4 a 5,2 \\
\hline \multicolumn{5}{|l|}{ Biofiltro aerado submerso } \\
\hline Lodo primário & 0,35 a a 0,45 & 2 a 6 & 35 a 45 & 0,6 a 2,2 \\
\hline Lodo secundário & 0,25 a 0,35 & 0,6 a 1 & 25 a 35 & 2,5 a 6 \\
\hline Total & 0,60 a 0,80 & 1 a 2 & 60 a 80 & 3,1 a 8,2 \\
\hline Reator UASB & 0,12 a 0,18 & 3 a 6 & 12 a 18 & 0,2 a 0,6 \\
\hline \multicolumn{5}{|l|}{ UASB + pós-tratamento aeróbio } \\
\hline Lodo anaeróbio (UASB) & 0,12 a 0,18 & 3 a 4 & 12 a 18 & 0,3 a 0,6 \\
\hline Lodo aeróbio (lodos ativados) & 0,08 a 0,14 & 3 a 4 & 8 a 14 & 0,2 a 0,5 \\
\hline Total & 0,20 a 0,32 & 3 a 4 & 20 a 32 & 0,5 a 1,1 \\
\hline
\end{tabular}

Considerando a cobertura da rede coletora de esgotos no Brasil em 2001 e que todo o esgoto coletado recebesse tratamento adequado, a geração de lodo desaguado chegaria a cerca de 4 milhões de toneladas anuais (ANDREOLLI, VON SPERLING e FERNANDES, 2007). 


\subsubsection{Tratamento do lodo}

O adensamento é uma etapa de redução do volume de lodo a ser digerido, pois como o tempo de detenção em um digestor é longo, cada decréscimo no volume a ser digerido significa grande redução no tamanho deste reator. O tempo de digestão varia com a temperatura no reator e, no Brasil, este tempo fica em torno de 15 a 20 dias a uma temperatura média de $30^{\circ} \mathrm{C}(\mathrm{MIKI}, 1998)$. O adensamento do lodo pode ser realizado mecanicamente, mas o lodo primário é comumente adensado por gravidade e o lodo secundário, que também pode ser adensado por gravidade, por vezes é flotado, o que permite taxas de aplicação superficial superiores (ANDREOLLI, VON SPERLING e FERNANDES, 2007).

A digestão é um processo de tratamento da fase sólida realizado para redução do teor de sólidos voláteis no lodo, diminuindo assim, o material putrescível presente e permitindo a melhoria de suas características tanto para o desaguamento quanto para disposição final. Nesse processo, a matéria orgânica volátil é transformada em gases, em água e é mineralizada pela ação de agentes bioquímicos. Esta etapa de tratamento é realizada apenas em lodo primário e secundário gerado em processos aeróbios, onde a fração de sólidos voláteis é elevada. Nestes lodos, a digestão é muitas vezes realizada de forma anaeróbia, para evitar o alto consumo de energia de digestores aeróbios.

A quantidade de lodo a ser tratada no digestor depende das taxas de captura de sólidos de processos anteriores como o adensamento e a decantação primária e secundária, além da carga de sólidos em suspensão (SS) afluente à ETE. Conforme Metcalf e Eddy (2002), a concentração de sólidos totais em lodos digeridos tem o valor típico de $35 \mathrm{~g} / \mathrm{L}$ e a eficiência na redução de sólidos voláteis situa-se numa faixa de 45 a $60 \%$.

Depois de adensado e digerido, o lodo deve ser desaguado para que seu volume seja reduzido, assim como os custos com seu transporte e disposição final. A retirada da água presente no lodo digerido pode ser realizada de forma natural ou mecanizada. Os métodos naturais incluem lagoas de lodo, leitos de secagem, leitos 
de drenagem e disposição no solo e os processos mecanizados são aqueles que utilizam centrífugas, filtros prensa de placas, filtros prensa de esteira ou filtros a vácuo, entre outros.

De acordo com WEF (1998), os métodos mecanizados são mais caros operacionalmente e possuem maior dependência de condicionamento prévio. Porém, segundo Metcalf e Eddy (2003), por serem mais constantes, dispensam o uso de grandes tanques de equalização de lodo. Os métodos naturais necessitam de áreas de implantação maiores, demandam mais tempo para desaguar o lodo e necessitam de mão de obra menos especializada, mas mais intensiva, principalmente na retirada do lodo desaguado (METCALF; EDDY, 2003).

Segundo Vesilind (1980) apud Spellman (1997), o tratamento da fase sólida e a disposição final do lodo são responsáveis, aproximadamente, por $40 \%$ do investimento inicial, $50 \%$ do custo de operação e $90 \%$ dos problemas operacionais de uma ETE. Considerando que estas informações possuem mais de 30 anos, e que a legislação ambiental possui a tendência de ser cada vez mais restritiva, é provável que estes custos e quantidade de problemas sejam maiores atualmente e improvável que sejam reduzidos ao longo do tempo. Por isso, o processo de desaguamento, assim como as outras etapas do tratamento da fase sólida, deve ser concebido com a intenção de reduzir os custos e as dificuldades operacionais.

Para Spellman (1997), o método ideal de desaguamento é aquele que reduz o volume do lodo e captura a maior parte ou a totalidade de sólidos ao menor custo, além de gerar uma torta que pode ser manuseada com reduzidos riscos à saúde e ao meio ambiente. Ainda são citadas pelo autor como características importantes: a confiabilidade do sistema, a facilidade de operação e a compatibilidade com o local e com as outras unidades e sistemas da ETE.

Ainda em relação à escolha do processo de desaguamento, o WPCF (1983) enfatiza a necessidade de minimizar o custo total da ETE e não apenas focar nesta etapa do tratamento, pois, às vezes, a escolha errada de um método de desaguamento pode, por exemplo, aumentar a recirculação de sólidos para o início da ETE e elevar o custo total de operação. 
A escolha do processo de desaguamento deve também considerar o método de disposição final do lodo e todas as legislações pertinentes, pois a seleção de dado processo de tratamento é determinante das características do lodo a ser disposto. Além disso, o WPCF (1983) ressalta a necessidade de serem consideradas no dimensionamento do processo de desaguamento do lodo as vazões e fluxos de origens diversas como o lodo de ETE's ou até ETA's (municipais, particulares ou industriais) próximas que careçam de métodos eficientes ou ainda a contribuição da escuma produzida por processos anaeróbios de tratamento.

Além de utilizar um critério técnico com uma visão global do processo, a escolha do melhor método de tratamento a ser adotado no projeto de uma ETE deve contemplar: análises econômico-financeiras que considerem o custo de instalação e operação para o período de funcionamento do sistema, análises e levantamentos dos impactos sociais e ambientais, a flexibilidade para ampliação e a dependência de matéria prima e mão de obra qualificada (WPCF, 1983). O desempenho ambiental de alguns dos mais comuns métodos de desaguamento de lodo é comparado na Tabela 3:

Tabela 3 - Avaliação dos aspectos ambientais de métodos de desaguamento (ANDREOLLI, VON SPERLING e FERNANDES, 2007)

\begin{tabular}{|c|c|c|c|c|c|c|}
\hline \multirow[b]{2}{*}{ Características } & \multicolumn{2}{|c|}{ Processos naturais } & \multicolumn{4}{|c|}{ Processos mecanizados } \\
\hline & $\begin{array}{c}\text { Leito de } \\
\text { secagem }\end{array}$ & $\begin{array}{l}\text { Lagoas } \\
\text { de lodo }\end{array}$ & Centrífugas & $\begin{array}{c}\text { Filtros à } \\
\text { vácuo }\end{array}$ & $\begin{array}{c}\text { Prensas } \\
\text { desaguadoras }\end{array}$ & $\begin{array}{l}\text { Filtros } \\
\text { prensa }\end{array}$ \\
\hline Demanda de água & +++ & +++ & + & ++ & + & + \\
\hline Demanda de energia & - & - & ++ & +++ & ++ & +++ \\
\hline Custo de implantação & + & + & +++ & ++ & ++ & ++ \\
\hline Complexidade operacional & + & + & ++ & ++ & ++ & +++ \\
\hline Demanda de manutenção & + & + & ++ & ++ & +++ & +++ \\
\hline Complexidade de instalação & + & + & ++ & ++ & ++ & ++ \\
\hline Influência do clima & +++ & +++ & + & + & + & + \\
\hline Sensibilidade à qualidade do lodo & + & + & +++ & ++ & ++ & ++ \\
\hline Produtos químicos & + & - & +++ & +++ & +++ & +++ \\
\hline $\begin{array}{l}\text { Complexidade na remoção do } \\
\text { lodo }\end{array}$ & ++ & +++ & + & + & + & + \\
\hline Teor de ST na torta & +++ & ++ & ++ & + & ++ & +++ \\
\hline Odores e vetores & ++ & +++ & + & + & + & + \\
\hline Ruídos e vibrações & - & - & +++ & ++ & ++ & ++ \\
\hline Contaminação do lençol freático & ++ & +++ & + & + & + & + \\
\hline
\end{tabular}

+ pouco, reduzido; +++ grande, elevado, muito. ${ }^{*}$ - ciclo de secagem de 30 dias 


\subsubsection{Disposição final}

A destinação correta do lodo gerado nas ETE's é indispensável para manter a qualidade do meio ambiente e da saúde da população e sua disposição incorreta é considerada crime. A Lei Federal 9.605, de 1998 (BRASIL, 1998), chamada de "Lei da Vida" ou dos "Crimes Ambientais", prevê no artigo 54 da seção 3 que "causar poluição de qualquer natureza que resultem ou possam resultar danos à saúde humana, ou que provoque a morte de animais ou a destruição significativa da flora" é um crime contra o meio ambiente com pena prevista de um a quatro anos.

O Decreto Estadual de São Paulo 8.468, de 1976 (SÃO PAULO, 1976), também prevê no artigo 19-B que: "Os lodos provenientes do tratamento das fontes de poluição industrial, bem como o material proveniente de limpezas de fossas sépticas, poderão, a critério e mediante a autorização expressa da entidade responsável pela operação do sistema, ser recebidos pelo sistema público de esgotos, proibida sua disposição em galerias de águas pluviais ou em corpos de água". Por fim, a norma ABNT NBR 10.004 (2004) classifica os resíduos sólidos e regulamenta sua disposição final, estando o rejeito do tratamento da fase sólida sujeito aos procedimentos especificados.

Assim, a torta gerada pelo processo de desaguamento do lodo pode ser disposta no solo ou em aterros sanitários, mediante autorização dos órgãos competentes. A disposição em aterros é cara e possui restrições em relação ao teor de umidade, uma vez que tortas com teor de sólidos abaixo de 30\% podem causar deslizamentos e não podem ser destinadas a aterros sanitários, de acordo com Andreoli, Fernandes e Sperling (2007).

A disposição no solo pode ser realizada para uso benéfico (uso agrícola) ou apenas para descarte do material (disposição em aterros). O uso como condicionador de solo recicla a matéria orgânica e os nutrientes presentes na torta de lodo, também chamada de biossólido quando tem este tipo de uso benéfico como método de disposição final. Já o descarte em trincheiras utiliza o solo como substrato para decomposição sem fazer proveito das características físicas e químicas do lodo. 
A aplicação do lodo na agricultura depende do cumprimento das Normas e Legislações pertinentes, devendo assim seguir procedimentos controlados e um padrão de qualidade química, física e biológica para que possam ser utilizados. A geração de uma torta que contemple estes requisitos depende da qualidade do esgoto afluente à ETE e dos processos de tratamento das fases líquida e sólida. Assim, os efluentes industriais muitas vezes necessitam de pré-tratamento antes de serem lançados nas redes coletoras, para evitar a contaminação da torta e possibilitar o seu uso benéfico. Além disso, quando o biossólido é utilizado na agricultura, a estabilização do lodo por processos de digestão, compostagem ou estabilização alcalina diminui a geração de odores, os níveis de patógenos e a atratividade de vetores de doenças (ANDREOLI, SPERLING; FERNANDES, 2007).

Neste contexto, o desaguamento é um importante processo para adequação do material aos requisitos legais e para redução do volume do lodo e consequente redução dos custos com transporte até o local de disposição final. Porém, em regiões onde a água é escassa, a fertirrigação (aplicação direta de efluentes tratados na agricultura) pode ser usada nas proximidades da ETE.

A possibilidade de usar o biossólido como condicionador de solo depende da autorização das instituições competentes e deve estar em acordo com a Resolução $n^{0} 375$ do Conselho Nacional do Meio Ambiente (CONAMA, 2006). Os requisitos legais são a realização de análises físico-químicas e biológicas de metais pesados, de elementos patogênicos e de indicadores agronômicos, e o cadastro do gerador e do utilizador do biossólido, como forma de evitar irresponsabilidades que causem prejuízos à saúde pública e ao meio ambiente.

As diferenças na composição de nutrientes entre dois tipos de biossólidos, um proveniente de tratamento aeróbio e outro de tratamento anaeróbio, são apresentadas na Tabela 4: 
Tabela 4 - Composição de nutrientes no lodo em \% de matéria seca (SANEPAR, 1997 apud ANDREOLLI; FERNANDES E VON SPERLING, 2007)

\begin{tabular}{ccccccc}
\hline Tipo de lodo & $\mathbf{N}$ & $\mathbf{P}$ & $\mathbf{K}$ & $\mathbf{C}$ orgânico & $\mathbf{C a}$ & $\mathbf{M g}$ \\
\hline Lodo ativado & 4,19 & 3,7 & 0,36 & 32,1 & 1,59 & 0,6 \\
Anaeróbio & 2,22 & 0,67 & 0,95 & 20,1 & 0,83 & 0,3 \\
\hline
\end{tabular}

O Nitrogênio $(\mathrm{N})$ é um macronutriente e normalmente está presente em quantidades abundantes. Os micronutrientes $\mathrm{Zn}, \mathrm{Mn}, \mathrm{Cu}, \mathrm{B}$, Mo e $\mathrm{Cl}$ estão presentes em quantidades suficientes quando o biossólido é aplicado como única fonte de $\mathrm{N}$, não necessitando de complementação. Porém, a quantidade necessária destes microelementos é pequena e o uso exagerado de biossólido pode resultar em efeitos tóxicos. Dependendo da necessidade da cultura, pode ser necessária a complementação de P e K (ANDREOLI, SPERLING E FERNANDES, 2007).

O potencial de utilização agrícola do lodo de ETE's é grande e o benefício é evidente, considerando a redução da necessidade de utilização de fertilizantes químicos, a destinação controlada de um material potencialmente poluidor e a reciclagem de um composto orgânico e diversos minerais que seriam enterrados, manejados como resíduos com elevado custo de transporte e disposição e, portanto, subutilizados.

Dois instrumentos legais, de apoio ao gerenciamento dos resíduos sólidos do saneamento no Brasil, foram recentemente sancionados. Este fato gera uma expectativa de maior comprometimento das autoridades na fiscalização das atividades de manejo destes resíduos, o que pode aumentar da percentagem de lodo tratado e disposto de forma adequada.

O Plano Nacional de Saneamento Básico (PNSB) possui as diretrizes para sua elaboração descritas na Lei 11.445, de janeiro de 2007 (BRASIL, 2007), sendo que um de seus princípios fundamentais deve ser o abastecimento de água, esgotamento sanitário, limpeza urbana e manejo dos resíduos sólidos realizados de formas adequadas à saúde pública e à proteção do meio ambiente. 
A recém-aprovada Política Nacional de Resíduos Sólidos (PNRS), detalhada na Lei 12.305 de agosto de 2010 (BRASIL, 2010), possui princípios como o da prevenção da poluição, do poluidor-pagador, da coordenação entre as três esferas de governo e do reconhecimento do resíduo sólido reutilizável e reciclável como um bem econômico e de valor. A PNRS é um marco na busca pelo gerenciamento adequado de resíduos sólidos e corrobora com a utilização de lodos para fins benéficos como o uso agrícola.

Os objetivos da PNRS são inúmeros, mas podem ser condensados na busca pelo desenvolvimento sustentável com minimização de resíduos e manutenção da saúde pública através da destinação correta dos resíduos sólidos gerados pelas atividades humanas em sociedade. Vale destacar a mudança de paradigma para compras pelo Estado, em que a prioridade nas aquisições e contratações governamentais passa a ser para produtos reciclados e recicláveis e para bens, serviços e obras que possuam critérios compatíveis com padrões de consumo social e que sejam ambientalmente sustentáveis. 


\subsection{Desaguamento}

\subsubsection{Generalidades}

O tratamento da fase sólida tem de início o adensamento como processo utilizado para redução de volume e, depois, o processo de digestão para estabilização do material. $O$ desaguamento é utilizado na sequência do tratamento da fase sólida com o intuito de: elevar o teor de sólidos, reduzir os custos de transporte e possibilitar uma disposição final adequada, sem riscos ao meio ambiente e à saúde pública. Segundo Metcalf e Eddy (2003), os principais motivos para que seja realizado o desaguamento dos lodos são:

- Os custos com transporte para disposição final são reduzidos pela redução de volume causada pela retirada de água;

- O manejo de lodos desaguados é mais fácil;

- Lodos mais secos são mais bem incinerados;

- Se a compostagem for o processo escolhido para beneficiamento do lodo, existe uma redução no custo com produtos químicos;

- O desaguamento deixa o lodo menos ofensivo, podendo atender legislações mais restritivas;

- Na disposição final em solo, o desaguamento reduz a geração de lixiviado.

O processo de desaguamento é influenciado pelo (i) método de desaguamento e por (ii) características específicas do lodo. (i) Os métodos de desaguamento mecanizados sofrem interferências das características físicas do equipamento e de condições de operação. Já os métodos naturais são condicionados pela estrutura física do método e também por condições climáticas. Por outro lado, (ii) a facilidade com que a água passa por entre as partículas do lodo e é retirada da torta, também 
chamada de capacidade de desaguamento ou filtrabilidade (JACOMASSI, 2009), depende de algumas propriedades específicas do lodo (ver item 3.2.2).

No processo de desaguamento, à medida que a água é retirada do lodo, este sai de um estado aquoso primeiramente para uma pasta, depois para uma torta de lodo e, finalmente, para grãos de lodo (OUTWATER, 1994). Todavia, o processo de desaguamento possui maior viabilidade até cerca de $30 \%$ de teor de sólidos $(70 \%$ de umidade), geralmente não sendo utilizado até concentrações superiores e, portanto, finalizado na fase de torta. Isso ocorre, pois, a partir desta porcentagem de sólidos o lodo já adquiriu a consistência necessária ao seu manuseio por ferramentas e a redução de volume proporcionada pela retirada da água do lodo não é tão acentuada, como pode ser observado na Figura 2:

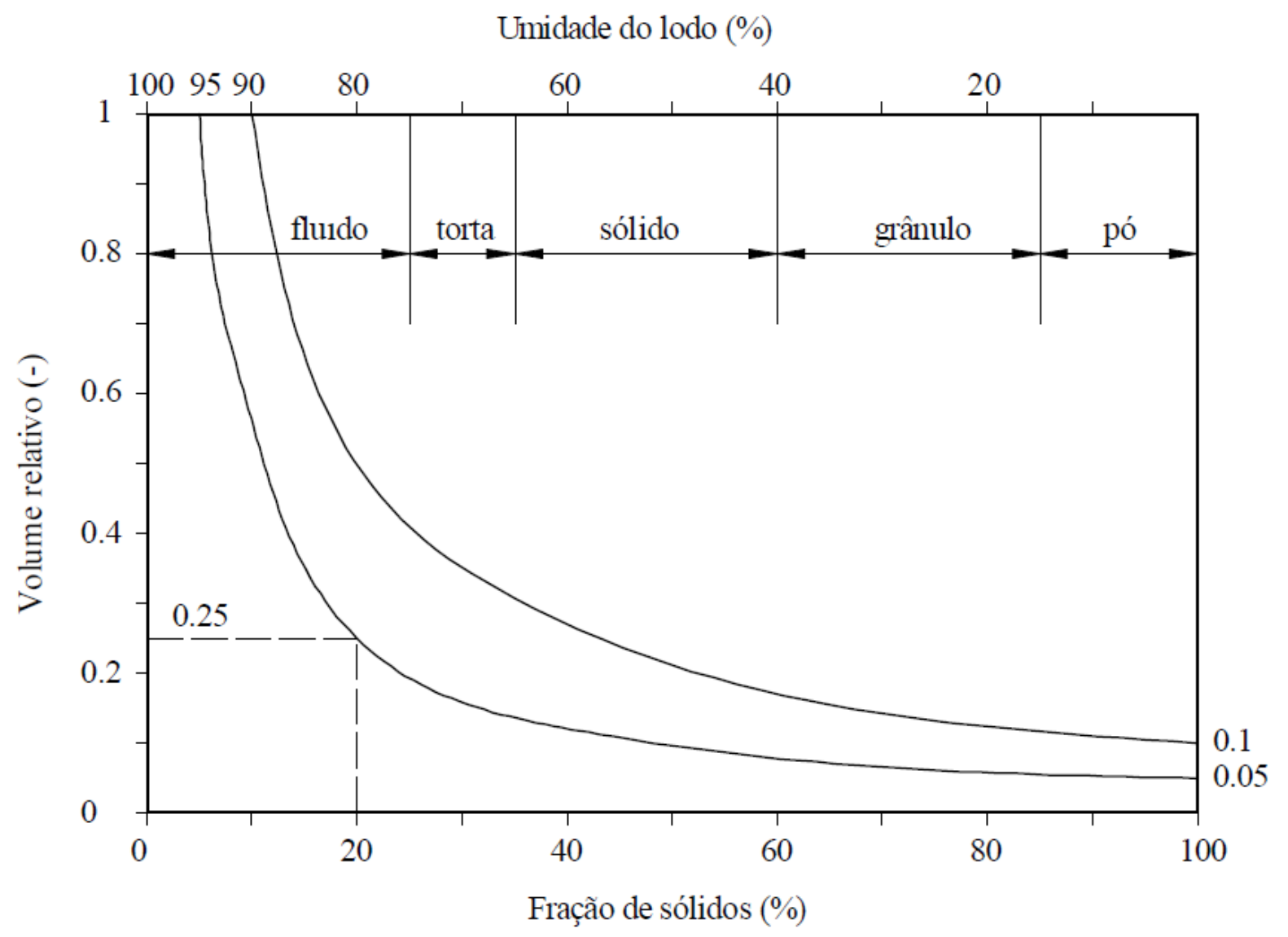

Figura 2 - Relação entre o volume do lodo e sua fração de sólidos para um lodo com teor de sólidos inicial de $10 \%(0,1)$ e outro com TS inicial de 5\% $(0,05)$ (van HAANDEL; LETTINGA, 1994) 


\subsubsection{Fatores que interferem na remoção de água do lodo}

O processo de tratamento em que o lodo é produzido é determinante das propriedades que influenciam em sua capacidade de desaguamento. Isso ocorre, pois os gradientes hidráulicos de mistura e as taxas e tipo de atividade biológica são características razoavelmente constantes de cada processo e, assim, os flocos formados em um mesmo processo de diferentes ETE's possuem características por vezes semelhantes.

Como exemplo de inferência sobre o comportamento de certo lodo em função do tipo de processo em que foi gerado, é possível afirmar que o lodo primário digerido possui facilidade de desaguamento, enquanto que o lodo de excesso, gerado em um reator de lodo ativado, possui grande dificuldade em ser concentrado. A maior dificuldade na retirada da água neste tipo de lodo é devida ao maior grau de agitação na etapa em que o lodo é gerado, mas também devida à forma com que a água esta ligada aos flocos, pois ela está ligada aos microrganismos do lodo ativado e presa em suas células (WPCF, 1983).

Contudo, é importante considerar que o método de tratamento não é o único fator determinante da qualidade do lodo e de sua capacidade de desaguamento. A USEPA (1982) apud Spellman (1997) lembra que a velocidade e tempo total para que seja retirada uma parte considerável da água presente no lodo depende de outros fatores como a qualidade do afluente à ETE, temperatura, grau de mineralização, pH, distribuição granulométrica e carga das partículas, compressibilidade, quantidade e forma de ligação da água presente com os sólidos e de outras características físicas e químicas específicas do lodo gerado.

Além disso, a origem do lodo e as variáveis operacionais dos processos de tratamento realizados na ETE também são determinantes de propriedades físicas e químicas que interferem no condicionamento do lodo. Miki (1998) cita estudos em que uma grande proporção de sólidos voláteis, de lodo secundário ou de lodo de origem industrial resultou na elevação da dose necessária de condicionante (LARSON, 1995; BOND; PESEK, 1996 apud MIKI, 1998). Dentre as variáveis que 
dependem da forma de operação da ETE e influenciam a nas características do lodo gerado, destacam-se a idade de lodo, o grau de mistura e a taxa de mineralização.

Dharmappa et al. (1997) classifica as propriedades de lodos de ETA's que influenciam 0 processo de desaguamento em micropropriedades e macropropriedades, sendo que as que são relativas às condições intrínsecas do material e da suspensão analisada são chamadas de micropropriedades e as características relativas à tratabilidade do material são chamadas de macropropriedades. Estas propriedades são apresentadas na Tabela 5:

\begin{tabular}{cc} 
Tabela 5 - Micro e macropropriedades de lodos de ETA (Adaptado de DHARMAPPA, \\
\hline Micropropriedades & Macropropriedades \\
\hline Distribuição e tamanho dos flocos & Velocidade de sedimentação \\
\hline Estrutura/forma dos flocos & Flotabilidade \\
\hline Tensão de cisalhamento dos flocos & Centrifugabilidade \\
\hline Densidade & Velocidade de drenagem em lagoas \\
\hline Concentração de sólidos & Resistência específica \\
\hline Viscosidade e temperatura & Tempo de filtração \\
\hline Tensão superficial & Velocidade de drenagem no solo \\
\hline "Fraçães" de água & Tempo de sucção por capilaridade \\
\hline Composição química & Compressibilidade \\
\hline Concentração de matéria orgânica & Lixiviação \\
\hline pH e alcalinidade & Força cisalhante \\
\hline Carga das partículas & \\
\hline
\end{tabular}

É importante considerar que as origens e processo de formação de lodos de ETA's e ETE's são distintos e, portanto, podem ser encontradas diferenças entre as propriedades de lodos de ETA's e ETE's que influenciam na capacidade de desaguamento de cada lodo.

As micropropriedades, por serem características químicas e físicas do material, possuem grande influência nas macropropriedades, que são características obtidas através de ensaios específicos para estimar a capacidade de desaguamento e conferem uma avaliação sobre o comportamento físico do material durante este processo de tratamento (BARROSO, 2007). Dessa forma, algumas micropropriedades e sua influência no desaguamento serão descritas a seguir. 
É importante considerar que o período de armazenamento, mesmo se mantidas as condições dos reatores em que foram gerados os lodos coletados, altera as características do material e, consequentemente, influencia sua capacidade de desaguamento. A Figura 3 mostra a alteração do comportamento reológico (ver item 3.2.2.10) do lodo submetido a diferentes períodos de armazenamento, indicando que outras propriedades também são alteradas. É possível observar um aumento da taxa de cisalhamento para as mesmas tensões aplicadas em uma mesma amostra de lodo submetida a tempos de armazenamento crescentes. Ou seja, os flocos tornamse mais frágeis com tempos de armazenamento crescentes, alterando a capacidade de desaguamento (ver item 3.2.2.10).

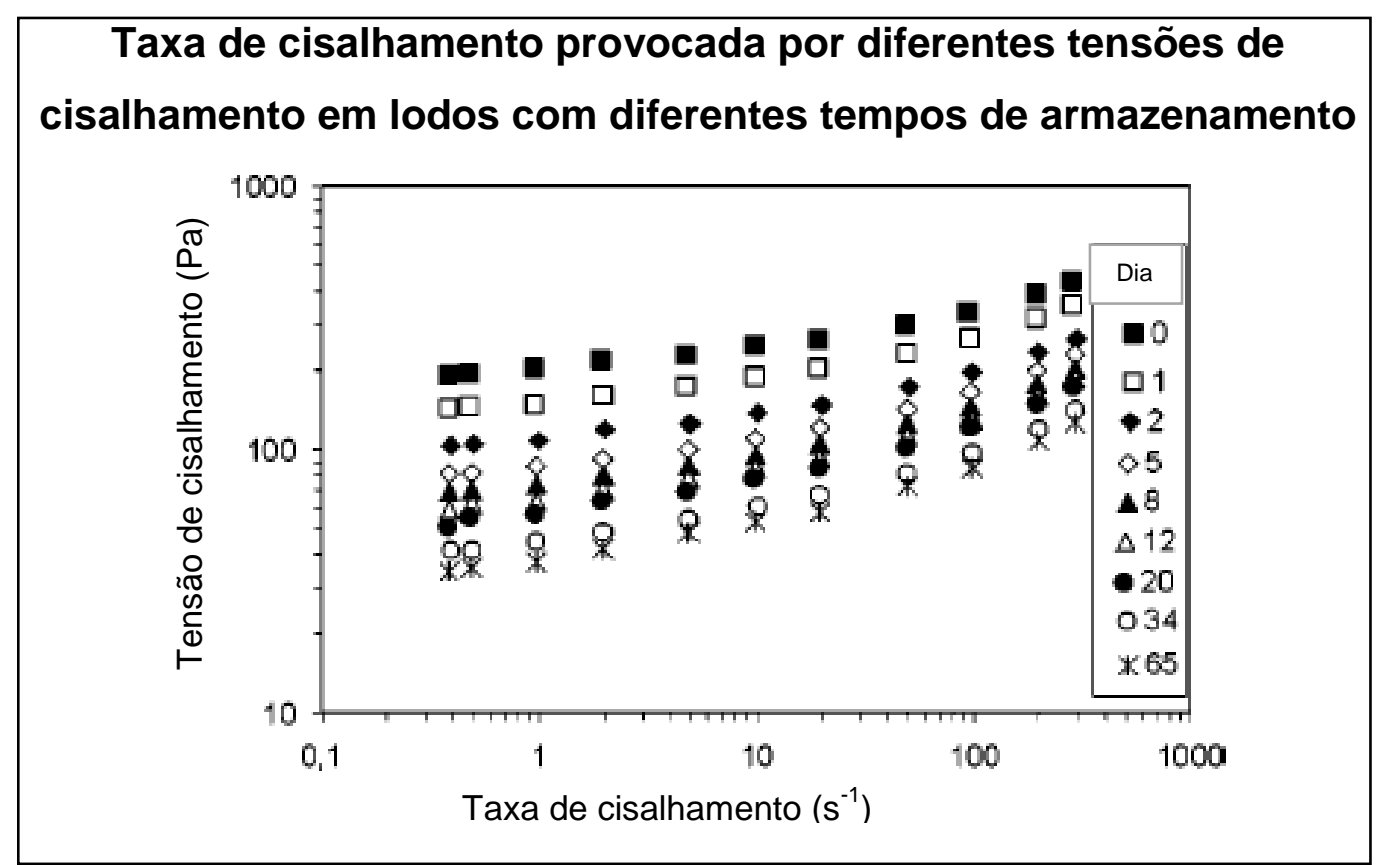

Figura 3 - Reogramas de um mesmo lodo com tempos de armazenamento entre 0 e 65 dias (BAUDEZ e COUSSOT, 2001) 
A distribuição e tamanho das partículas e flocos do lodo, também chamada de distribuição granulométrica, indica a porcentagem de sólidos do lodo que pertencem a um mesmo intervalo de diâmetros e possui grande influência sobre o processo de desaguamento. Estas porcentagens podem ser obtidas, entre outros métodos, por peneiramento seco, peneiramento úmido, sedimentação, fracionamento por filtração, Espectroscopia por dispersão de energia de raios- $X$ ou análise de imagem de Microscopia eletrônica de varredura.

A partir da distribuição ou frequência absoluta de partículas (histograma) que pertencem a determinado intervalo de diâmetros, pode ser determinada a frequência relativa e a frequência relativa acumulada de partículas (NAGHETTINI e PINTO, 2007). A frequência relativa (distribuição log-normal) e a frequência acumulada do diâmetro das partículas de um lodo de ETA, resultado de uma análise de imagem para determinação de sua granulometria, são apresentadas na Figura 4:

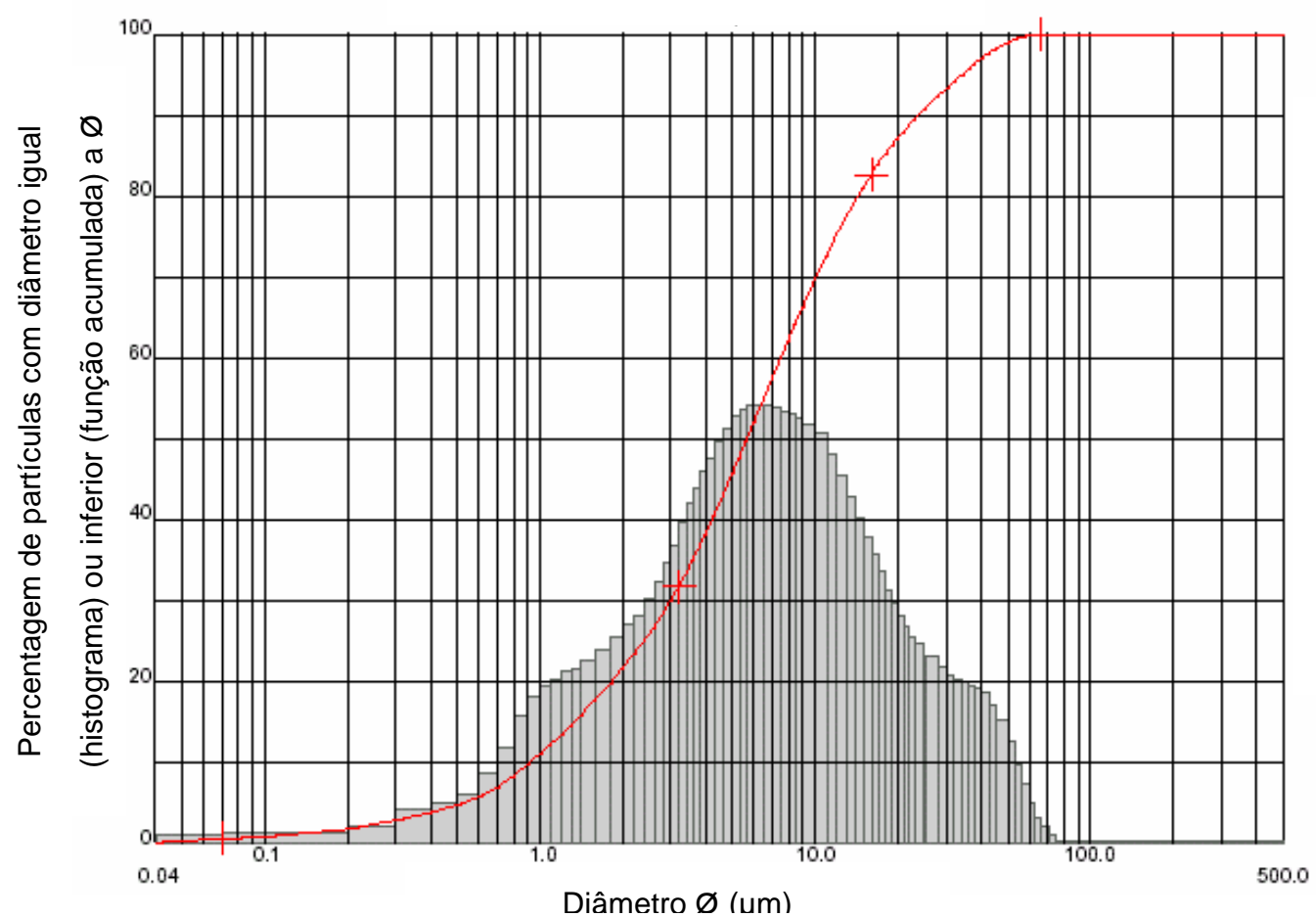

Figura 4 - Gráfico log-normal da distribuição granulométrica relativa (histograma) e relativa acumulada (linha vermelha) dos diâmetros das partículas de um lodo de ETA (Adaptado de WOLFF et al., 2005) 
A distribuição granulométrica dos flocos do lodo é influenciada, entre outros fatores, pelo grau de agitação no processo em que o lodo foi gerado ou, ainda, alterada pelo transporte do lodo até o local de tratamento. Esta característica também é utilizada para definir as dosagens de condicionantes (ver item 3.5.3.3) e a porosidade ideal dos meios filtrantes utilizados, sendo que sua determinação é requisito para alguns métodos racionais de dimensionamento de geossintéticos utilizados na filtração e separação de materiais (ver item 1.1.1.7).

\section{Influência da distribuição absoluta}

A distribuição dos diâmetros das partículas do lodo pode apresentar uma maior porcentagem de partículas próximas a um mesmo intervalo de diâmetros (material mal graduado) ou pode possuir uma distribuição mais homogênea (menos concentrada), com boa porcentagem de partículas mesmo em intervalos de diâmetro mais distantes do diâmetro médio (material bem graduado).

O Coeficiente de uniformidade $(\mathrm{Cu})$ e o Coeficiente de curvatura $(\mathrm{Cc})$ são utilizados para caracterizar a distribuição granulométrica de certa amostra de material particulado:

$$
\begin{aligned}
& C u=D_{60} / D_{10} \\
& C c=\left(D_{30}\right)^{2} /\left(D_{60} \cdot D_{10}\right)
\end{aligned}
$$

Onde:

$D_{10}, D_{30}$ e $D_{60}$ são, respectivamente, os diâmetros característicos que correspondem ao diâmetro maior que 10, 30 e 60\% das partículas presentes na amostra (PINTO, 2000).

As diferentes distribuições granulométricas interferem nas taxas de filtração e drenagem em meios porosos devido à interação das partículas com o filtro, que pode colmatar, fechando espaços vazios, ou formar um pré-filtro, que garante boas taxas 
de desaguamento. Uma ilustração da formação do pré-filtro em forma de arcos, acima do meio filtrante, pode ser observada na Figura 5:

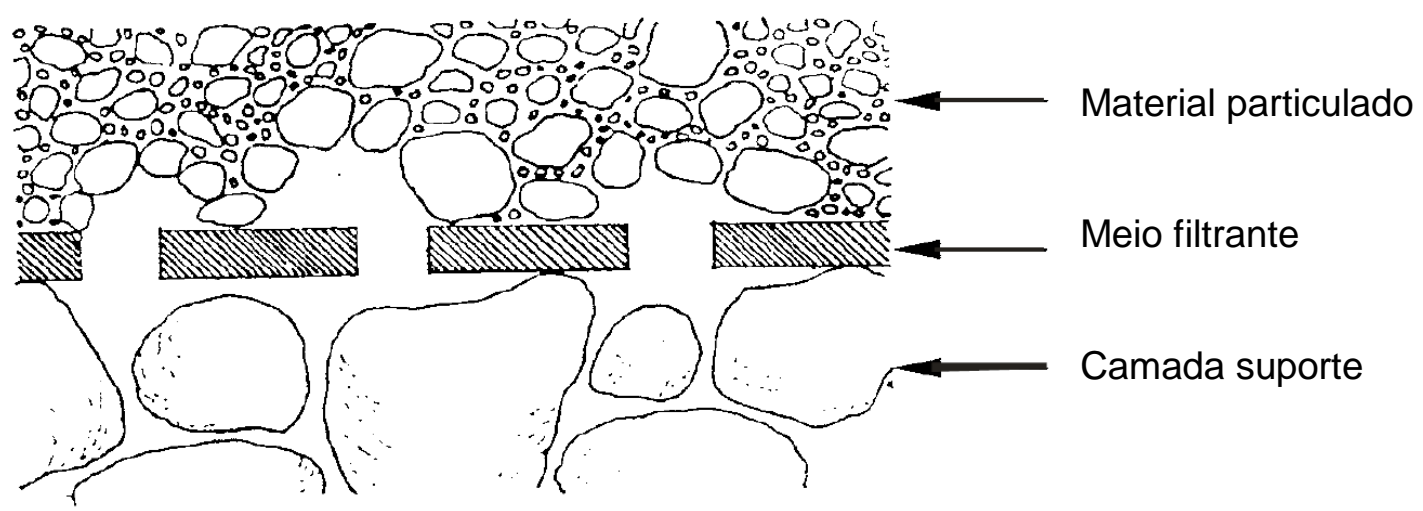

Figura 5 - Efeito da formação de arcos como pré-filtro do geotêxtil (Adaptado de FREITAS, 2003)

No caso de materiais bem graduados ( $\mathrm{Cu}>6$ e $1<\mathrm{Cc}<3)$, as partículas maiores, ao se chocarem contra a superfície do filtro, formam arcos de partículas que retém os sólidos mais finos. A formação deste tipo de estrutura faz com que a passagem de sólidos seja pequena para tamanhos de partículas não inferiores a 1/3 do diâmetro dos poros (VIDAL, 2002) e que a velocidade de filtração não seja alterada pela diminuição da permeabilidade do meio filtrante. Por outro lado, no caso de materiais mal graduados, com curva granulométrica com $\mathrm{Cc}<1$ ou $\mathrm{Cc}>3$, a perda de material é significativa (sufusão) pela passagem livre de partículas pequenas. A passagem de partículas para dentro do meio filtrante causa a colmatação do filtro e ocasiona uma queda nas taxas de filtração (VERTEMATTI, 2004).

O material que possui esta propriedade de formar um pré-filtro e não perder sólidos pelo meio filtrante é chamado de auto estável ou auto filtrante (VERTEMATTI, 2004). Para uma avaliação preliminar da estabilidade do material particulado a filtrar, Vertematti (2004) cita os critérios adotados por Chen (1981), sendo que o atendimento de duas das três condições da Tabela 6 atesta razoável estabilidade.

Tabela 6 - Relações para verificação da auto estabilidade (CHEN, 1981 apud VERTEMATTI, 2004) $\mathrm{D}_{50}>\mathrm{D}_{85} / 5$ $D_{35}>D_{50} / 5$ $D_{15}>D_{35} / 5$ 


\section{Influência do diâmetro médio}

Segundo Wang (1996), a resistência ao desaguamento é maior quanto menor o diâmetro médio das partículas ou maior a percentagem de finos no material. Este fenômeno ocorre, pois quanto menor o diâmetro dos flocos, maior sua área superficial e maior sua capacidade de hidratação, resultando numa maior parcela de água adsorvida ao floco (ver item 3.2.2.5), num aumento da fricção entre água e sólidos durante o escoamento e num aumento da possibilidade de colmatação do meio filtrante. A comprovação teórica em que a autora se baseia tem origem na equação de Kozeny para a resistência específica (GALE, 1967 apud WANG, 1996):

$$
r=K \cdot S o^{2} \cdot(1-e) /\left(e^{3} \cdot \rho\right)
$$

Onde:

$r$ - resistência específica $\left(\mathrm{L} \mathrm{M}^{-1}\right)$;

$\mathrm{K}$ - fator de forma da partícula;

e - porosidade da torta de lodo;

$\rho$ - densidade da torta de lodo $\left(\mathrm{M} \mathrm{L}^{-3}\right)$;

So - área superficial específica $\left(L^{2}\right)$.

Ainda segundo WANG (1996) a seguinte equação correlaciona a área superficial (So, em $\mathrm{m}^{2}$ ) com o diâmetro equivalente (de, em metros) da partícula média:

$$
\text { So }=6 / \text { de }
$$

Substituindo a equação (4) na equação (3), observa-se que a resistência específica é inversamente proporcional ao diâmetro equivalente numa relação quadrática. É importante frisar que Wang (1996) afirma que a comprovação teórica foi testada para tortas compressíveis e que se mantém a hipótese formulada. 


\subsubsection{Forma e estrutura dos flocos}

Além de serem determinantes da resistência específica à filtração, a forma e a estrutura dos flocos são determinantes da densidade e compressibilidade (ver item 3.2.2.9) do material e da capacidade do lodo de manter sua drenabilidade quando submetido a altas energias de mistura, que poderiam quebrar os flocos, aumentar o percentual de finos e diminuir a eficiência do processo.

Desta forma, lodos com flocos bem formados, de estrutura compacta e rígida, possuem facilidade de desaguamento e mantém esta característica mesmo quando submetidos à misturas com altos gradientes hidráulicos e grandes tensões de cisalhamento.

\subsubsection{Concentração de sólidos}

A concentração de sólidos no lodo pode interferir na capacidade de desaguamento, tanto nas taxas iniciais de drenagem quanto no teor final de sólidos na torta. Em uma pesquisa antiga, mas citada em bibliografias mais recentes (WEF 1998), Randall e Koch (1969) relatam tempos totais de drenagem duas vezes maiores para certo lodo com concentração de sólidos de $38 \mathrm{~g} / \mathrm{L}$ em relação a um com concentração de sólidos de 7,6 g/L.

Novak e Haugan (1980) verificaram que lodos com maiores concentrações de sólidos possuíam piores características de desaguamento. Porém, Wang (1996) analisou a influência do teor de sólidos na capacidade de drenagem e não encontrou diferenças significativas para lodos de ETA variando de 1 a $4 \%$.

Como o lodo de reatores UASB normalmente possui uma concentração de sólidos entre 15 e $40 \mathrm{~g} / \mathrm{L}$ (ALEM SOBRINHO, 2001), não se espera que este fator interfira nas análises. Porém, mesmo que seja pequena a variação da capacidade de drenagem nesta faixa de concentração de sólidos, recomenda-se que diferentes 
amostras de lodos sejam diluídas de forma a manterem concentrações de sólidos próximas, para que esta característica não interfira na avaliação da capacidade de desaguamento e comparação de desempenho entre lodos.

A concentração de sólidos também influencia na viscosidade do material, interferindo na capacidade de desaguamento (ver item 3.2.2.10).

\subsubsection{Temperatura, viscosidade e tensão superficial}

A capacidade de desaguamento também depende da temperatura, pois, além de influencias as condições do crescimento biológico, e, assim, as características do lodo secundário (WPCF, 1983), ela é determinante da viscosidade (ver item 3.2.2.10) e da tensão superficial da água.

\subsubsection{5. "Frações" de água}

O lodo bruto gerado em uma ETE é composto em grande parte por água, sendo que os teores de sólidos de lodos adensados quase nunca ultrapassam $10 \%$. A associação entre água e sólidos exerce grande influência na capacidade de desaguamento, pois, quanto menor for a fração de água ligada às partículas sólidas, maior será o volume percentual de água no estado livre e maior também será a velocidade de desaguamento.

Diversos são os estudos que caracterizam a água presente no lodo. Alguns autores dividem a porção de água em 3, outros em 4 ou 5 e outros em até 6 frações diferentes. No presente trabalho será adotada a divisão da água em 4 grupos que possuem clara distinção em relação à sua associação com os sólidos do lodo (OUTWATER, 1994; MIKI, 1998; COLIN; GAZBAR, 1995; SPELLMAN, 1997; ANDREOLI; Von SPERLING; FERNANDES, 2007; BARROSO, 2007; CHEN; YEU; MUJUMDAR, 2002). 


\section{$\underline{\text { Áqua livre }}$}

Esta fração da água não está associada às partículas do lodo e é facilmente retirada ou separada da fase sólida.

\section{Água intersticial}

A água presente entre os flocos e ligada a eles por efeito da capilaridade. Necessita de condicionamento químico ou forças mecânicas para que possa ser separada dos sólidos.

\section{Água coloidal}

Esta fração de água também é chamada de superficial, de união, vicinal ou adsorvida e está ligada aos flocos por pontes de hidrogênio. Dessa forma, necessita de condicionamento químico para que possa ser separada dos sólidos.

\section{$\underline{\text { Água intracelular }}$}

É a fração de água mais difícil de ser removida, pois está presente dentro das partículas (hidratação) e necessita que os flocos sejam quebrados através de tratamento térmico para ser liberada.

A forma de ligação da água com os flocos é ilustrada na Figura 6: 


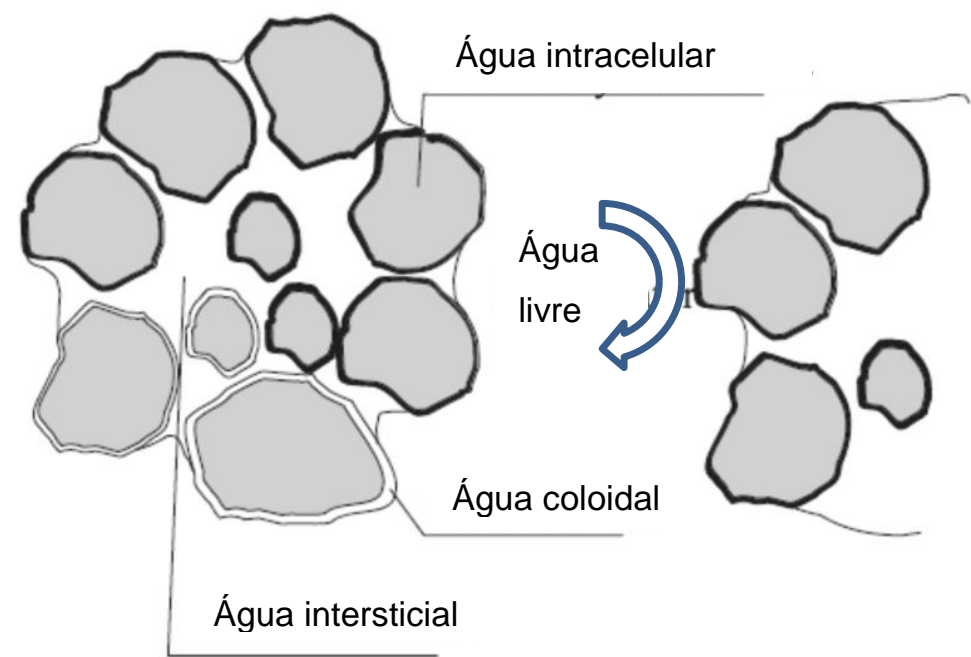

Figura 6 - Diferentes frações de água no lodo (CHEN; YUE; MUJUMDAR, 2002)

\subsubsection{Concentração de matéria orgânica}

O grau de mineralização do lodo é expresso pela relação entre sólidos totais voláteis e sólidos totais no lodo. Quanto menor esta relação, maior a presença de sólidos não voláteis no lodo, e, portanto maior o grau de mineralização da matéria orgânica presente no lodo. Como os sólidos não voláteis, que também são denominados de sólidos fixos, são estáveis e não putrescíveis, o grau de mineralização também pode ser denominado como grau de estabilização (METCALF; EDDY, 1991).

Segundo Spellman (1997), se o lodo tem maior grau de mineralização, assumindo que as outras características se mantenham constantes, a capacidade de desaguamento aumenta. Dessa forma, um lodo mal digerido e em estado de putrefação possui menores taxas de desaguamento que o mesmo lodo após este passar pela etapa de digestão.

Samudio (1993) explica que um lodo não digerido, quando em processo natural de desaguamento, não forma as fissuras responsáveis pelo aumento da área de exposição ao ambiente e, portanto, não se beneficia do consequente aumento da taxa de evaporação provocado por estas fissuras na torta. Este tipo de lodo, 
desaguado em leito de secagem convencional, pode chegar, no máximo, a 30\% de teor de sólidos e, para isso, demanda um grande período de tempo.

Todavia, o tipo de processo de digestão, anaeróbio ou aeróbio, também influencia na facilidade de desaguamento, sendo que os métodos de estabilização pela via aeróbia geram um lodo com maior facilidade de desaguamento (admitindo grau de mineralização equivalente) (SAMUDIO, 1993). Samudio (1993) ainda relata que, em leitos convencionais, a drenagem é responsável por $70 \%$ da água retirada do lodo digerido aerobiamente e apenas $20 \%$ de lodo anaeróbio. Desta forma, e considerando que a evaporação possua influência constante independente do tipo de digestão sofrida pelo lodo, a secagem de lodos anaeróbios tenderia a ser mais lenta. Isto ocorreria, pois, para se atingir os mesmos teores de sólidos na torta, a evaporação teria que agir por mais tempo neste tipo de lodo, o que diminuiria o número de ciclos anuais de secagem.

\subsubsection{7. $\mathrm{pH}$}

$\mathrm{O} \mathrm{pH}$ tem grande influência na etapa de condicionamento, mas é determinante também da capacidade de desaguamento do lodo. O lodo secundário do processo de lodo ativado, por exemplo, tem sua capacidade de perder água aumentada se o pH é reduzido de 8 para 3 (WPCF, 1983).

\subsubsection{Carga das partículas}

A carga elétrica superficial é a responsável pelas forças de repulsão entre as partículas coloidais e os flocos, impedindo que estas se aglomerem a eles e formem estruturas mais densas e pesadas. Uma das responsáveis por estas forças repulsivas é a própria água adsorvida na partícula, normalmente chamada de água coloidal, que forma uma camada na superfície dos sólidos e impede que eles se 
aproximem. As forças de repulsão podem ser medidas pelo potencial Zeta $(\mathrm{mV})$ da solução (KRISHNAMURTHY; VIRARAGHAVAN, 2005).

\subsubsection{Compressibilidade}

O processo de desaguamento também é influenciado pela compressibilidade do material, pois a deformação dos sólidos do lodo pode fechar espaços vazios que serviriam como caminho para o escoamento da água. Assim, materiais compressíveis possuem maior dificuldade para a retirada da água e resultam em menores taxas de desaguamento.

A influência da porosidade do lodo no seu desaguamento pode ser observada na equação 3 (ver item 3.2.2.1).

\subsubsection{Aspectos reológicos}

\section{Generalidades}

A reologia é a ciência que estuda a fluência e a deformação de soluções difusas e, portanto, o comportamento do lodo para diferentes concentrações de sólidos (BRAGA, 2003). Lodos com mais de $20 \%$ de sólidos podem, por exemplo, manter sua capacidade de escoamento quando depositados em superfícies inclinadas, enquanto que outros lodos perdem esta capacidade a partir de apenas $10 \%$ de sólidos. O mesmo vale para o ponto a partir do qual o lodo é manuseável com ferramentas, que varia de 20 a $40 \%$ de sólidos, dependendo do tipo de lodo (METCALF; EDDY, 1935).

Braga (2003) relacionou os parâmetros reológicos com as características de desaguamento de lodos anaeróbios combinados com aeróbios. O autor recomenda o uso dos parâmetros reológicos no controle dos processos de estabilização e 
desaguamento e na definição de critérios de dimensionamento para o transporte por tubulações e bombeamento de lodo. Os parâmetros reológicos também afetam os processos de mistura e transferência de massa e calor e, com isso, influenciam os processos e equilíbrios físico-químicos nos sistemas de tratamento.

A equação básica que relaciona os principais parâmetros reológicos é a Lei da Viscosidade de Newton (BRAGA, 2003):

$$
\sigma=\mu \cdot \gamma
$$

Onde:

$\sigma$ - tensão de cisalhamento $(\mathrm{Pa})$;

$\mu$ - viscosidade absoluta (Pa.s);

$\gamma$ - taxa de cisalhamento $\left(\mathrm{s}^{-1}\right)$.

Esta equação pode ser mais bem entendida a partir da Figura 7, onde a força $F$ aplicada por unidade de área $(\sigma)$ provoca movimento relativo entre dois planos paralelos $($ com distância $=d x)$ com um gradiente de velocidade $(d v / d x=\gamma)$ proporcional à viscosidade absoluta $(\mu)$.

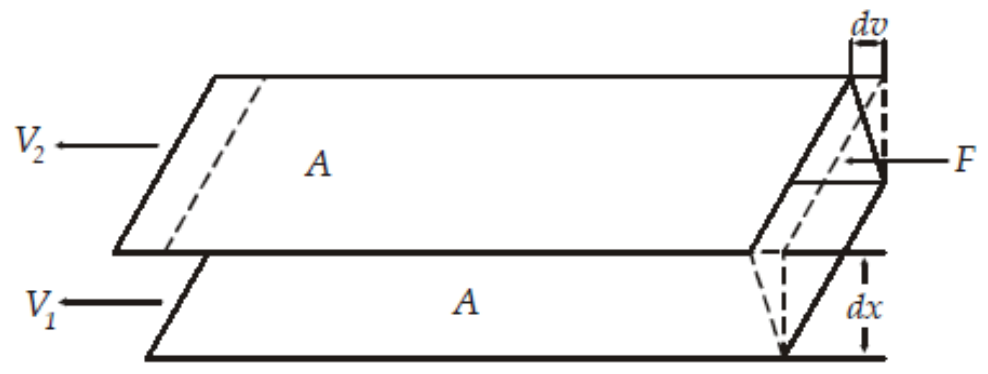

Figura 7 - Ilustração com os conceitos básicos da reologia (BRAGA, 2003)

Porém, para os materiais que apresentam viscoelasticidade (fluidos compressíveis), a viscosidade não é constante, sendo função da temperatura, concentração de sólidos, gradiente de velocidade e tempo, entre outros (BRAGA, 2003). Para estes materiais ou soluções a Lei da Potência correlaciona a viscosidade com a taxa de cisalhamento: 


$$
\mu=\mathrm{Ic} \cdot \gamma^{(\mathrm{n}-1)}
$$

Onde:

Ic - índice de consistência, numericamente igual à viscosidade para fluidos newtonianos ou não newtonianos $\operatorname{com} \gamma=1\left(\mathrm{~s}^{-1}\right)$;

$\mathrm{n}$ - expoente da lei da potência.

Os fluidos que não apresentam viscoelasticidade são considerados incompressíveis (Fluidos Newtonianos) e o valor de $\mathrm{n}$ para estes materiais é 1. Para um fluido com comportamento tipicamente plástico, por exemplo, o valor de $n$ é 0,5 (BRAGA, 2003).

Alguns valores para estas propriedades de lodos anaeróbios digeridos são apresentados na Tabela 7:

Tabela 7 - Parâmetros reológicos obtidos por Slatter (1997) para lodos anaeróbios digeridos com diferentes teores de sólidos

\begin{tabular}{ccccc}
\hline Amostra & TS $(\%)$ & $\sigma_{\text {o }}(\mathbf{P a})$ & $\boldsymbol{\mu}(\mathbf{P a} . \mathbf{s})$ & $\mathbf{n}$ \\
\hline Lodo 1 & 3,17 & 1,04 & 0,0239 & 0,827 \\
Lodo 2 & 4,64 & 3,13 & 0,240 & 0,632 \\
Lodo 3 & 6,62 & 12,0 & 0,366 & 0,664 \\
\hline
\end{tabular}

\section{Comportamento reológico}

Os reogramas são representações gráficas do comportamento de determinado material sob diferentes tensões de cisalhamento. Estes são normalmente obtidos com reômetros que determinam a tensão de cisalhamento para cada valor prédeterminado da taxa de cisalhamento ou vice-versa. Um exemplo de reograma de lodo pode ser observado Figura 8: 


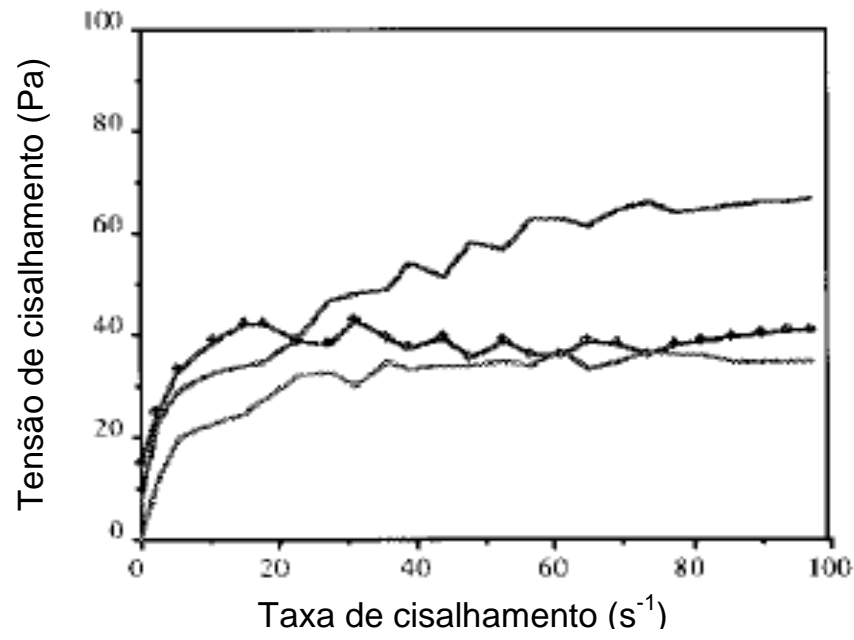

Figura 8 - Reograma em triplicata de lodo sintético à base de celulose (ABU-ORF, 1999)

O comportamento do lodo para diferentes tensões de cisalhamento pode ser comparado com materiais viscosos largamente estudados, como o gel e as soluções de produtos poliméricos (LEITE, 2009). Alguns comportamentos foram modelados por pesquisadores e deram origem a reogramas característicos, normalmente denominados pelo sobrenome do pesquisador que caracterizou tal comportamento, e apresentados na Figura 9:

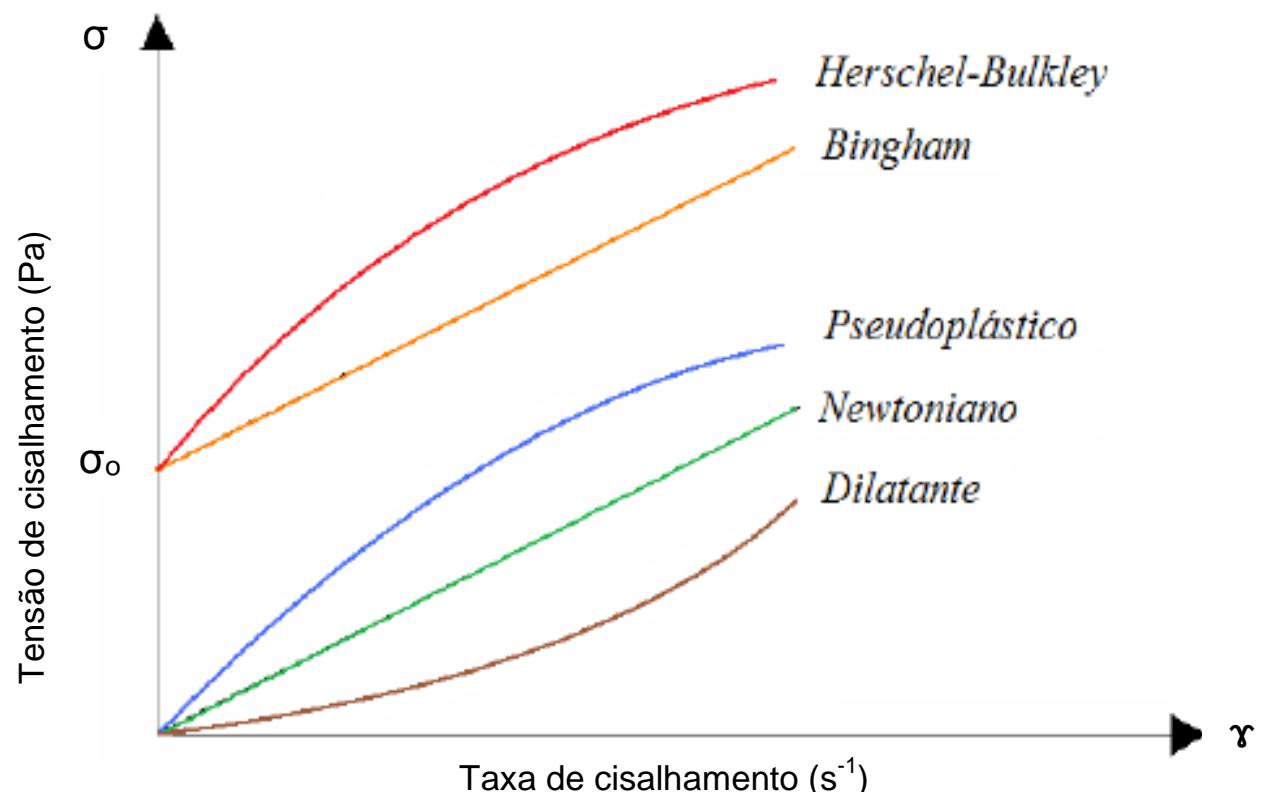

Figura 9 - Reogramas de fluidos com diferentes comportamentos (LEITE, 2009)

Braga (2003) observou uma maior aderência dos resultados de análises reológicas de lodos de reatores UASB, tratando esgoto sanitário e recebendo lodo de biofiltros 
aeróbios, com o modelo de OSTWALD. Neste modelo, a tensão mínima de cisalhamento $\left(\sigma_{0}\right)$ é zero e o primeiro ponto de inflexão da curva ( $\left.\sigma_{\text {máx }}\right)$ demonstra que após as ligações entre os flocos do lodo serem quebradas, o comportamento do material para tensões superiores muda drasticamente, conforme Figura 10:

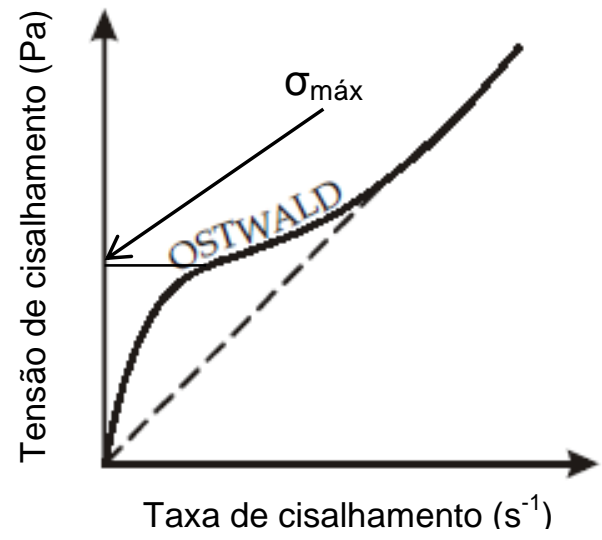

Figura 10 - Modelo de OSTWALD (BRAGA, 2003)

Por outro lado, Baudez et al. (2004) classificam o comportamento de lodos como não Newtoniano e em 3 diferentes domínios. Até o primeiro ponto crítico da tensão de cisalhamento $\left(\sigma_{0}\right)$ o lodo se comporta de forma viscoelástica e não sofre deformação. Até o segundo ponto crítico de tensão $\left(\sigma_{\text {máx }}\right)$ o lodo possui um comportamento intermediário e após este ponto um comportamento tipicamente viscoso. As observações do autor permitiram verificar uma maior aderência com o modelo de Herschel-Bulkley, conforme observado na Figura 11:

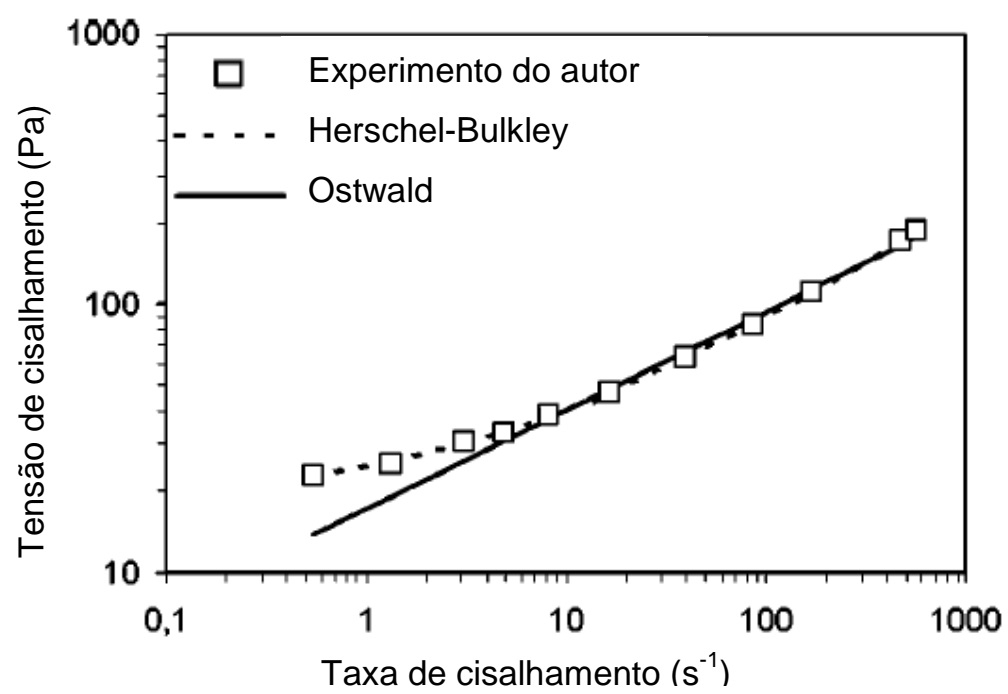

Figura 11 - Aderência do reograma de lodo sintético (BAUDEZ; COUSSOT, 2001) 
Outro aspecto importante do comportamento do lodo é que as características reológicas podem ser modificadas pela ação de forças e tensões de cisalhamento, sendo que após cessarem as forças aplicadas, o lodo não retorna às suas características originais. Ao estudo do comportamento do lodo ao longo de certo período sobre ação destas forças é dado o nome de Tixotropia e compreende o entendimento de como a viscosidade e outras características reológicas variam em função da aplicação de determinada tensão de cisalhamento ao longo do tempo (BRAGA, 2003; LEITE, 2009). A mudança de comportamento do lodo pode ser observada na Figura 12:

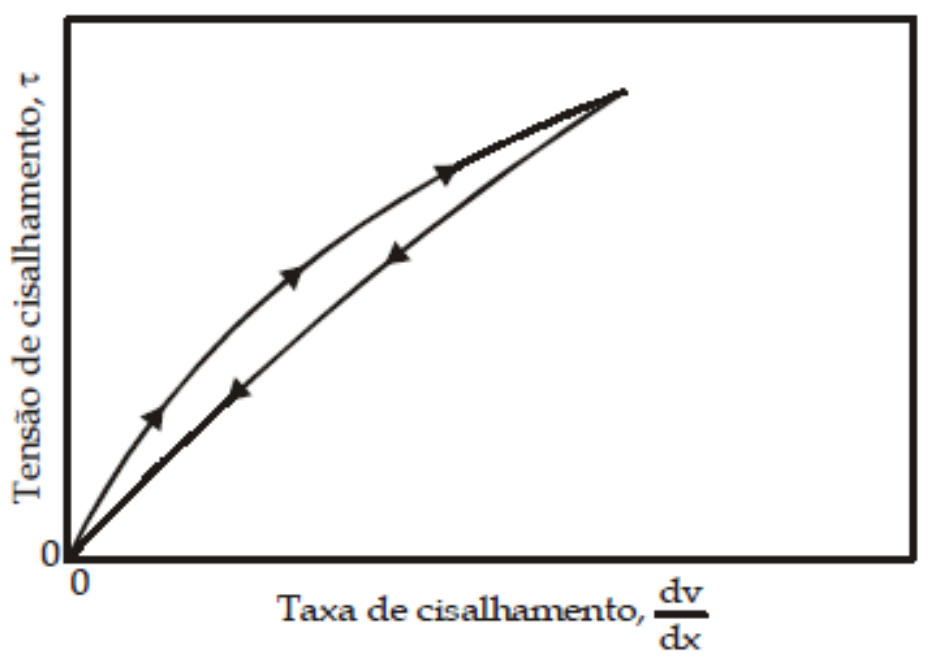

Figura 12 - Efeito da tixotropia na mudança de comportamento do material entre a aplicação de tensões sucessivamente superiores e, após período de repouso, sucessivamente inferiores (BRAGA, 2003)

Em relação à mudança de comportamento dos lodos por tensões aplicadas ao longo do tempo, estas são provavelmente causadas pela desfloculação e floculação das partículas presentes na solução e a consequente alteração da rede de forças do material (USUI et al., 2001 apud BRAGA, 2003). Essa alteração do comportamento do material indica que a quebra de flocos provocada por elevadas tensões de cisalhamento acarreta uma diminuição da capacidade de desaguamento (ver item 3.2.2.1) que não é revertida se o lodo é mantido em repouso. Dessa forma, o lodo se comporta como um material tixotrópico, cujas características reológicas são condicionadas pelo histórico de tensões a que foi submetido ao longo do tempo. 
Influência de alguns parâmetros reológicos no desaguamento de lodos

\section{- $\underline{\text { Viscosidade }}$}

A viscosidade de uma solução difusa é, entre outros aspectos, determinada pela interação entre as partículas sólidas, que cria uma rede de forças que aumenta a viscosidade. Além da quantidade de sólidos, as características da superfície das partículas (ABU-ORF; DENTEL, 1999) e a presença de polímeros extracelulares (CHRISTENSEN et al., 1993) também são determinantes da intensidade dessas forças de ligação.

A viscosidade do lodo exerce grande influência sobre métodos de desaguamento mecanizados, especialmente em centrífugas, onde a velocidade final de sedimentação, causada pela aceleração centrípeta, é inversamente proporcional à viscosidade da água drenada (SPELLMAN, 1997).

Com base nesta verificação de Spellman (1997) e na Lei de Darcy, que mostra que um aumento da viscosidade do líquido gera um aumento da força resistiva e a consequente queda da vazão de escoamento em meios porosos (PINTO, 2006), estima-se que a viscosidade também possua grande influência nas taxas de drenagem em leitos de drenagem. $O$ item 3.2.3.1 também relaciona a capacidade de drenagem com a viscosidade do fluido, mostrando a influencia deste parâmetro reológico no desaguamento de lodos.

A determinação da viscosidade em lodos de ETE's pode ser realizada com boa precisão através de viscosímetros rotacionais. Porém, estes equipamentos ainda têm limitações em função das partículas em suspensão e da não indicação da transição entre o regime laminar e turbulento (BRAGA, 2003). 


\section{- $\underline{\text { Tensão de cisalhamento mínima }\left(\sigma_{0}\right)}$}

A tensão a partir da qual o lodo inicia a quebra de flocos e o cisalhamento, resultado da quebra da estrutura de ligações entre os flocos, é identificada por tensão de cisalhamento mínima $\left(\sigma_{\circ}\right)$. A manutenção desta rede de forças ao longo do processo de desaguamento impede que a distribuição granulométrica seja modificada, o que aumentaria a percentagem de finos e diminuiria as taxas de desaguamento.

A determinação desta tensão mínima de cisalhamento pode ser realizada por diversos ensaios como a técnica de Vane, do Plano inclinado, de Kasumeter e o "Slump Test" (BAUDEZ et al., 2004). O "Slump Test" é um teste didático que mostra que o lodo, quando submetido a pequenas tensões de cisalhamento $\left(\sigma<\sigma_{0}\right)$, deforma, mas não sofre cisalhamento $(\gamma=0)$. A deformação de uma amostra de lodo durante um "Slump Test" para determinar a tensão cisalhante mínima $\left(\sigma_{\circ}\right)$ é ilustrada na Figura 13:
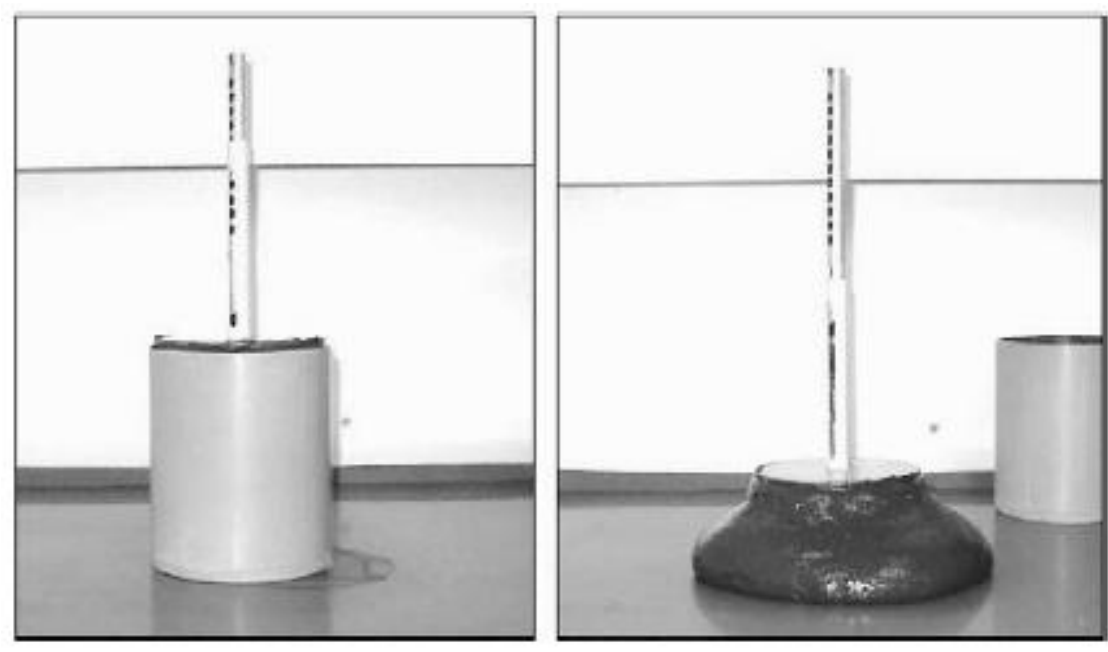

Figura 13 - "Slump Test" modificado (Baudez et al., 2004)

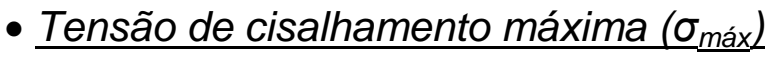

Assim como a tensão mínima de cisalhamento $\left(\sigma_{\circ}\right)$, a tensão de cisalhamento máxima $\left(\sigma_{\text {máx }}\right)$ indica uma mudança no comportamento reológico do material para tensões superiores a ela. Tensões intermediárias entre $\sigma$ e $\sigma_{\text {máx }}$ resultam em quebra 
parcial dos flocos e não eliminam as forças de atração entre os flocos presentes no lodo. Porém, para tensões de cisalhamento acima da máxima, o lodo perde por completo sua estrutura, provocando a quebra dos flocos.

A tensão de cisalhamento máxima é um bom indicador da capacidade do lodo em manter a estrutura de seus flocos (e a distribuição granulométrica correspondente) mesmo quando submetido a gradientes hidráulicos elevados, provocados por métodos de desaguamento mecanizado.

\subsubsection{Métodos para avaliação da capacidade de desaguamento}

A capacidade de desaguamento é avaliada através de testes laboratoriais específicos. Existem diversos testes descritos na bibliografia especializada, com diferentes materiais e procedimentos, que possibilitam determinar a facilidade com que a água é retirada do lodo. Porém, como a intensidade de mistura a que o lodo é submetido durante o teste de laboratório pode alterar as características do material, devem ser utilizados testes que imprimam intensidades de mistura semelhantes às verificadas nos métodos de desaguamento em escala real.

Estes testes são realizados principalmente para avaliar a necessidade de utilização de produtos químicos (ver item 3.5) que melhorem as características do lodo que interferem em sua capacidade de desaguamento (ver item 3.2.2). A seguir serão descritos os procedimentos para realização de alguns testes de determinação da capacidade de desaguamento e a aplicação destes testes para avaliar a influência do condicionamento será discutida no item 3.5.3.3.

A seguir serão descritos os testes da resistência específica à filtração e do tempo de sucção capilar, por serem recorrentes na bibliografia da área, e o teste do tempo de drenagem, por ter grande similaridade com o processo de desaguamento de leitos de drenagem. Outros métodos podem ser utilizados e alguns, assim como as referências bibliográficas que os descrevem, estão sintetizados na Tabela 8: 
Tabela 8 - Alguns métodos para avaliação da capacidade de desaguamento

\begin{tabular}{c|c}
\hline Método & Referências \\
\hline Desaguador estático vertical & Wanke (2005) \\
\hline Análise das diferentes frações de água & Spavier et al., 1997), Chen et al., (2002) \\
\hline Determinação de parâmetros reológicos & Abu-Orf (1999; 2003; 2005), Barroso (2007), \\
& Baudez (2001; 2004), Braga (2003), Dentel \\
& $(2009)$, Marinetti (2010), Mori (2006), Omerci \\
& $(2007 ; 2009)$, Seyssiecq (2003; 2008), Wang \\
(2010)
\end{tabular}

\subsubsection{Teste da resistência específica à filtração}

A Resistência Específica à Filtração (REF) é a força contrária ao desaguamento por unidade de massa seca por unidade de área. A resistência específica pode ser estimada a partir de características do lodo (ver item 3.2.2.1) ou determinada empiricamente. O teste que determina a resistência do lodo à filtração é também chamado de teste do funil de Buchner. Neste teste um funil de Buchner é revestido por um material permeável e preenchido pela amostra de lodo ensaiada. Em sua saída é acoplado um recipiente volumétrico (kitassato) para medição dos volumes filtrados e obtenção das respectivas taxas de filtração. No furo lateral do recipiente é acoplada uma bomba para promoção de vácuo. Normalmente é utilizado um papel filtro como meio filtrante do teste, porém, outros materiais podem ser utilizados. $O$ equipamento utilizado neste teste é apresentado na Figura 14:

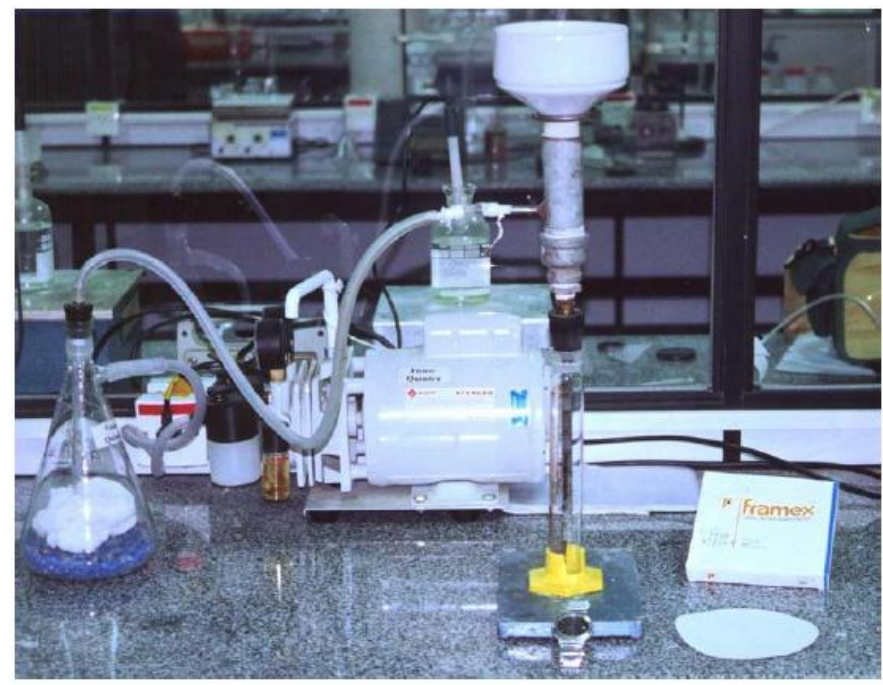

Figura 14 - Equipamento utilizado em um teste de REF (BRAGA, 2003) 
O volume filtrado e o tempo são medidos e anotados em intervalos pré-determinados e o gráfico da relação entre tempo sobre volume pelo volume (t/V x V) gerado, como observado na Figura 15:

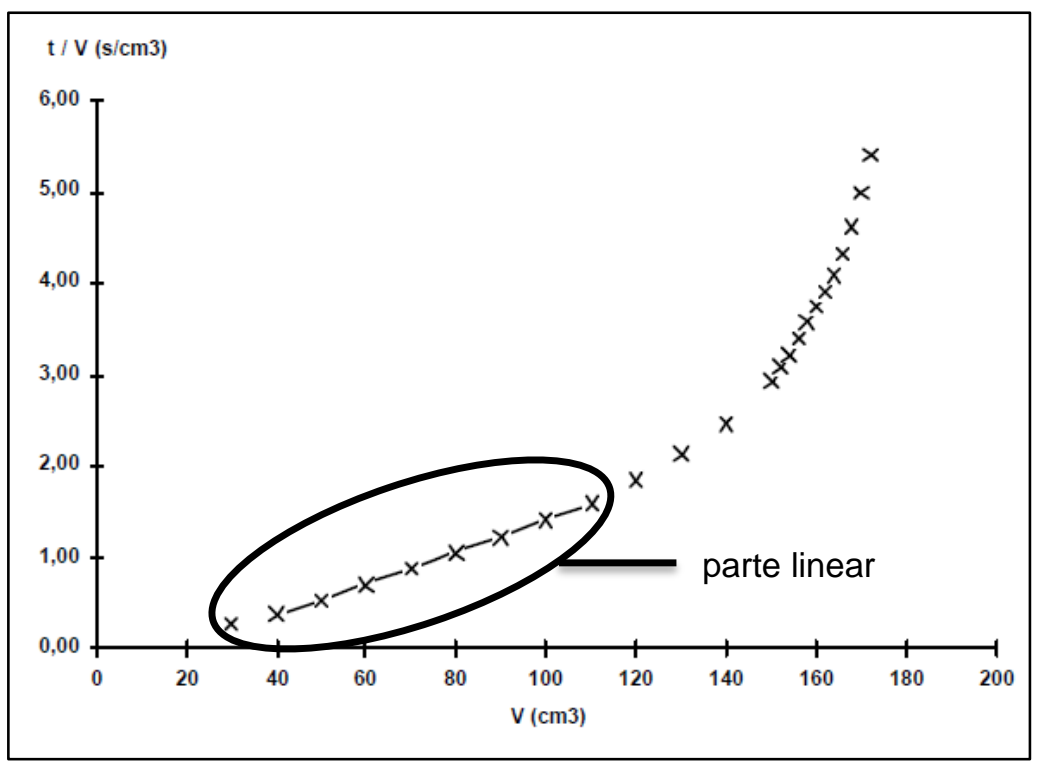

Figura 15 - Gráfico de t/V x V gerado em um teste de $R E F$ e determinação da inclinação $b$ no trecho linear (MIKI, 1998)

A parte reta da curva plotada tem inclinação b e a resistência específica à filtração pode ser determinada a partir de (WANG, 1996):

$$
r=\left(2 b \cdot P \cdot A^{2}\right) /(\mu . c)
$$

Onde:

$r$ - Resistência específica à filtração $(\mathrm{m} / \mathrm{kg})$;

$\mathrm{b}$ - inclinação da parte linear da curva de $\mathrm{t} / \mathrm{V} \times \mathrm{V}\left(\mathrm{s} / \mathrm{m}^{6}\right)$;

$\mathrm{P}$ - pressão do vácuo $\left(\mathrm{N} / \mathrm{m}^{2}\right)$;

A - área de filtração $\left(\mathrm{m}^{2}\right)$;

$\mu$ - viscosidade dinâmica do filtrado (N.s $\left./ \mathrm{m}^{2}\right)$;

$c$ - massa de sólidos secos na torta por volume filtrado $\left(\mathrm{kg} / \mathrm{m}^{3}\right)$.

Para avaliar a capacidade de drenagem de lodos, o menor valor de $r$ indica uma maior facilidade de desaguamento, pois corresponde a uma menor resistência encontrada pela água para drenar pela torta de lodo. Um valor de $10^{8} \mathrm{~m} / \mathrm{kg}$ pode ser 
considerado um valor baixo de resistência específica e está relacionado a uma boa condição de drenagem do lodo.

Este teste apresenta certa dificuldade em se determinar o exato momento em que a curva perde a linearidade, ocasionada pela quebra do vácuo quando surgem as fissuras na torta de lodo. Como para o cálculo da inclinação b do trecho linear da curva de t/ $\mathrm{V} \times \mathrm{V}$ os pontos da curva após a quebra do vácuo devem ser descartados, qualquer equivoco na delimitação destes pontos torna o método pouco confiável.

\subsubsection{Teste do tempo de sucção capilar}

O Teste do tempo de sucção capilar (CST), de acordo com Schwoyer (1981) apud Miki (1998), é definido como a medida do tempo em que a fração líquida do lodo leva para percorrer certa distância dentro de um meio poroso, normalmente, um papel de filtro. O aparelho é constituído de um reservatório cilíndrico, onde é colocado o lodo, sobreposto a um pedaço de papel filtro, onde são dispostos dois sensores circulares que determinam o tempo que a água leva para percolar de um ao outro.

A maior vantagem do ensaio do CST em contraposição a outros métodos de avaliação da capacidade de drenagem do lodo é a rapidez com que é realizado. Porém, esse teste tem 0 inconveniente limitar a utilização de amostras representativas, já que o despejo do lodo no recipiente do teste do CST acarreta na seleção de uma fase de efluente clarificado (sobrenadante decantado), de flocos menores ou, ainda, de pequenas partículas do lodo.

Os equipamentos utilizados neste teste são apresentados na Figura 16 e Figura 17: 


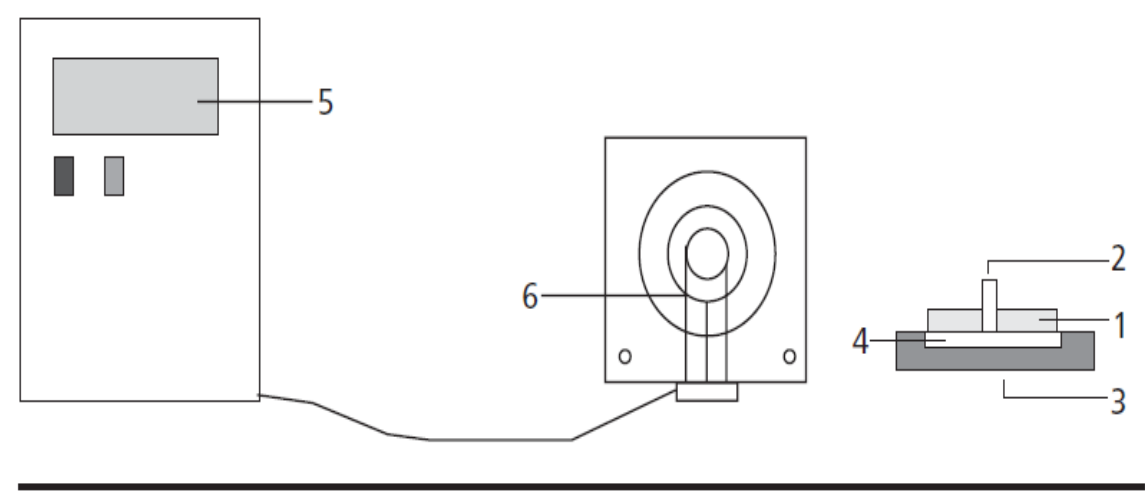

1 - Chapa superior quadrada em acrílico, de $11,1 \mathrm{~cm}$ de lado por $16 \mathrm{~mm}$ de espessura; 2 - reservatório de lodo constituído por um tubo de aço inox de 2,54 cm de comprimento e 1,91 cm de diâmetro; 3 - chapa inferior (de fundo) quadrada, acrílico, de $11,1 \mathrm{~cm}$ de lado por $16 \mathrm{~mm}$ de espessura; 4 - papel Whatman no 17; 5 - cronômetro automático; 6 - eletrodos de cunha de platina que devem ser assentados nas chapas inferiores a cada círculo inscrito na superfície inferior da chapa superior e repousando sobre o papel-filtro.

Figura 16 - Equipamentos do ensaio CST (ADAMMS JR et al., 1981 apud GONÇALVES et al., 2001)
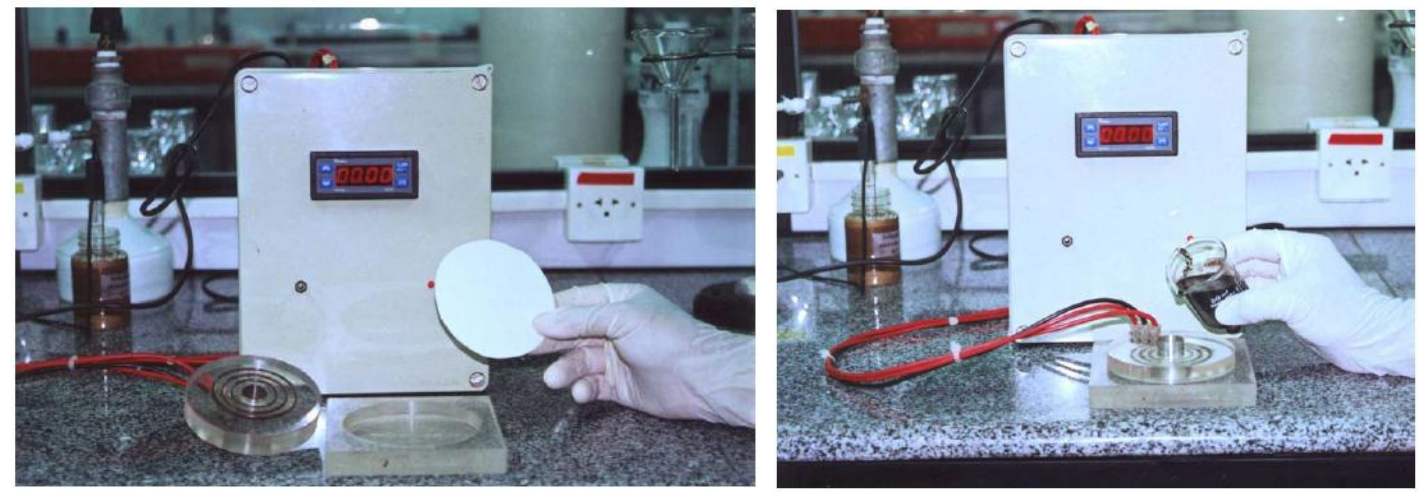

Figura 17 - Equipamentos do ensaio de CST (BRAGA, 2003)

Um valor de referência para o CST de lodos com boa capacidade de drenagem da água livre é de 20 segundos (SPAVIER, 1999).

\subsubsection{Teste do tempo de drenagem}

Este teste é uma variante do ensaio de resistência específica (MIKI, 1998), pois é constituído pelos mesmos equipamentos, com exceção da bomba, que não é utilizada e do kitassato, que pode ser substituído por qualquer recipiente volumétrico adequado. Além disso, a duração do teste não é limitada pela quebra do vácuo, pois 
tal força não é aplicada, mas é determinada pelo tempo que um volume predeterminado de filtrado demora para ser atingido. Como neste ensaio a retirada da água ocorre naturalmente, pela ação da gravidade, considera-se que a água é drenada e não filtrada, sendo assim chamado de teste do tempo de drenagem (TTD).

Seu princípio de funcionamento também é mais simples e apenas uma medida de tempo é realizada no instante em que um determinado volume de drenado for recolhido no recipiente volumétrico. Desta forma, a capacidade de desaguamento do lodo é determinada pelo tempo para se obter o volume especificado e, assim, é possível associar o menor tempo verificado à amostra de lodo com maior facilidade de desaguamento. 


\subsection{Leitos de drenagem}

\subsubsection{Generalidades}

Os leitos de drenagem foram desenvolvidos recentemente (CORDEIRO, 2001) e constituem um processo natural de desaguamento que, em relação aos métodos mecanizados, assim como os leitos de secagem, possuem simplicidade operacional e reduzidos custos de energia elétrica e manutenção (ver item 3.1.2). Por outro lado, ambos possuem grande suscetibilidade à variáveis climáticas, como a precipitação, a irradiação solar e a temperatura ambiente, sendo normalmente menos confiáveis e constantes que métodos mecanizados (WEF, 1998). Contudo, no Brasil, a utilização de métodos naturais de desaguamento de lodos é favorecida pelas condições vantajosas de espaço, existência de mão de obra barata e características climáticas favoráveis em diversas regiões (SAMUDIO, 1993; ANDREOLLI, 2000).

Dada a semelhança entre os leitos de drenagem e secagem, as vantagens e desvantagens dos leitos de secagem em relação a outros métodos de desaguamento são análogas aos leitos de drenagem e estão apresentadas na Tabela 9:

Tabela 9 - Vantagens e desvantagens do uso de leitos de secagem de lodo (Adaptado de SAMUDIO, 1993)

\begin{tabular}{c|c}
\hline Vantagens & Desvantagens \\
\hline $\begin{array}{c}\text { Baixo custo de capital se as áreas estiverem } \\
\text { disponíveis }\end{array}$ & $\begin{array}{c}\text { alta de critérios racionais de projeto para análise } \\
\text { econômica correta }\end{array}$ \\
\hline $\begin{array}{c}\text { Facilidade operacional e dispensa de operadores } \\
\text { especializados e exclusivos }\end{array}$ & $\begin{array}{c}\text { Demanda de mão-de-obra intensiva para } \\
\text { remoção de lodo }\end{array}$ \\
\hline Baixo consumo de energia & Necessidade de grandes áreas \\
\hline Flexibilidade para desidratar diversos tipos de lodo & Grande influência do clima \\
\hline Baixo consumo de produtos químicos & $\begin{array}{c}\text { Necessidade de estabilizar o lodo antes de sua } \\
\text { aplicação }\end{array}$ \\
\hline Alto teor de sólidos na torta seca & Prejuízo estético para a vizinhança
\end{tabular}




\subsubsection{Desenvolvimento dos leitos de drenagem}

$O$ desenvolvimento dos leitos de drenagem tem origem no leito de secagem, um processo de desaguamento utilizado desde o início do século XX para redução de volume de lodos em ETE's e ETA's e presente em cerca de 2/3 dos sistemas de tratamento de lodos de ETE's brasileiras (CORDEIRO, 2001).

O leito de secagem convencional é, basicamente, um tanque de fundo permeável utilizado para desaguar lodo adensado e digerido (ABNT, 1992). A estrutura do leito de secagem é composta de paredes laterais com borda livre (tamanho da parede acima da altura vertical máxima atingida pelo lodo no leito) de 10 a $25 \mathrm{~cm}$. As paredes laterais podem ser diques de terra coberta de grama, placas de madeira tratada, alvenaria ou ainda de placas ou blocos de concreto (SAMUDIO, 1993). Um desenho em planta e dois cortes de um leito de secagem tradicional são apresentados na Figura 18.

A soleira drenante, também chamada de meio filtrante (Figura 19) é composta por uma camada superior de areia com coeficiente de uniformidade e diâmetro efetivo padronizado, para evitar arraste e colmatação precoce (Tabela 10). Abaixo da areia existe uma camada de brita que cobre o sistema de drenagem e, assim como a camada de areia, possui um gradiente de granulometria para evitar a colmatação. A norma ABNT NBR 12.209 (1992) recomenda uma camada suporte de brita 4 ou pedra de mão, uma intermediária de 20 a $30 \mathrm{~cm}$ de brita 3 e 4 e uma superior de 10 a $15 \mathrm{~cm}$ de brita 1 e 2 . 


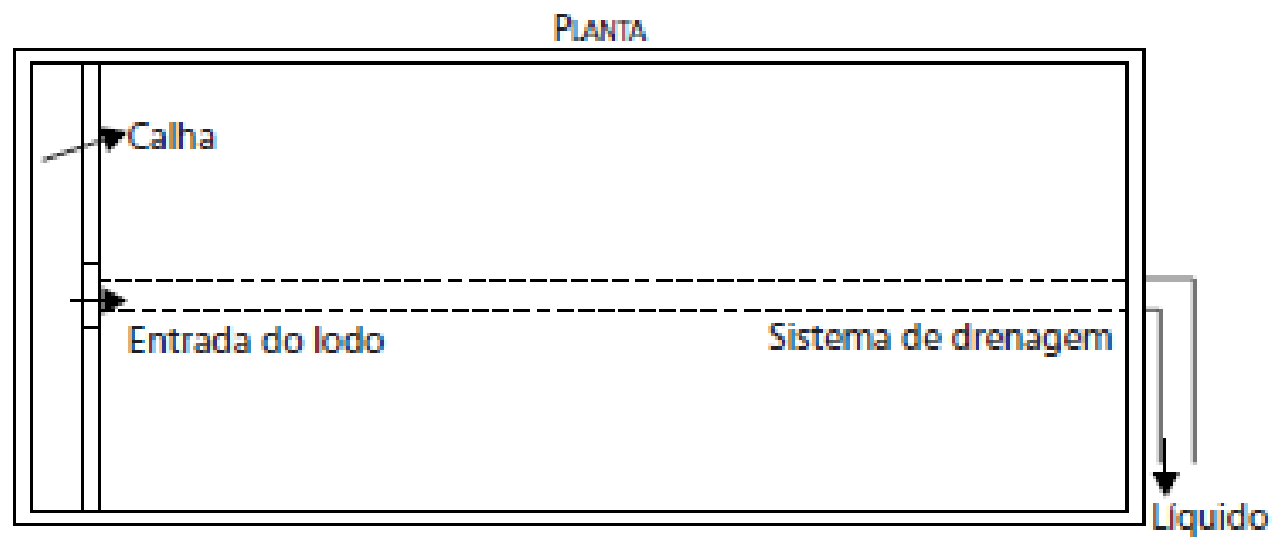

filtrado

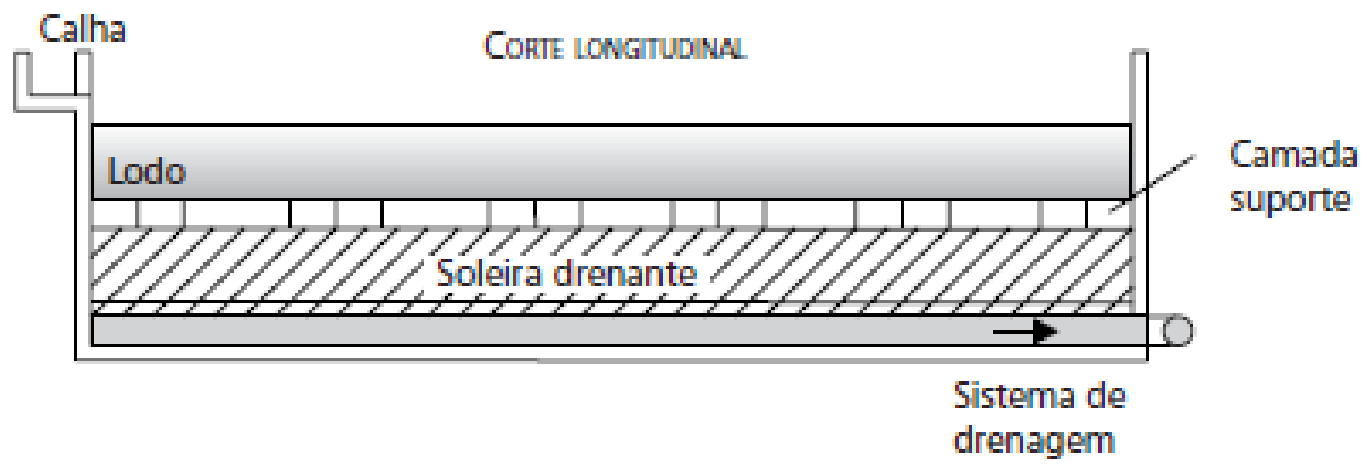

CORTE TRANSVERSAL

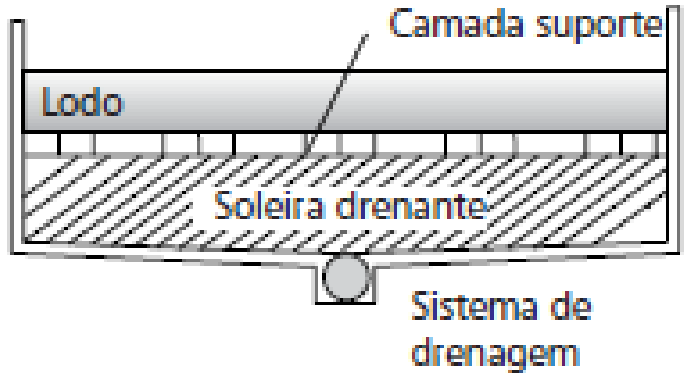

Figura 18 - Desenhos da estrutura física do leito de secagem (GONÇALVES, 2001)

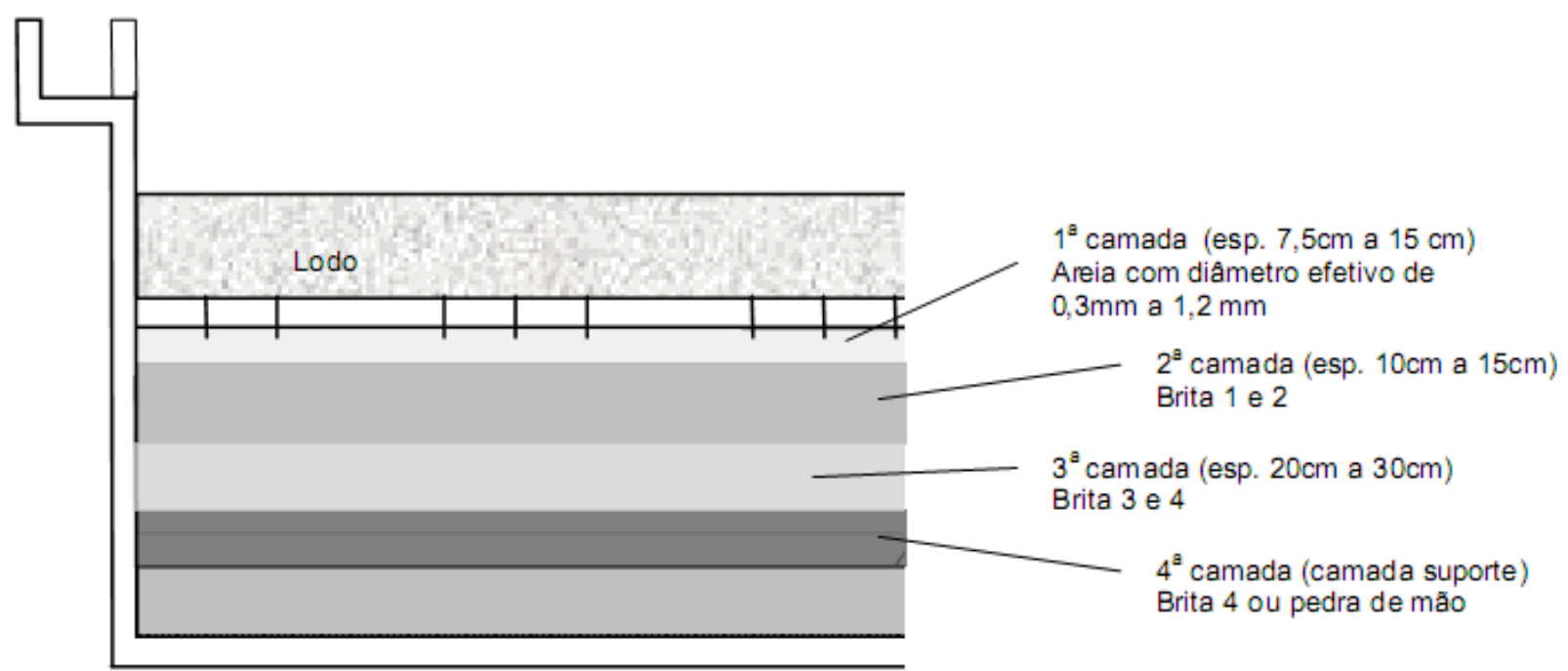

Figura 19 - Detalhe da soleira drenante (GONÇALVES, 1999) 
Tabela 10 - Recomendações para a camada de areia do leito de secagem

\begin{tabular}{c|c|c|c}
\hline & Metcalf e Eddy (1991) & WPCF (1983) & $\begin{array}{c}\text { ABNT NBR 12.209 } \\
(1992)\end{array}$ \\
\hline Altura (cm) & 23 a 30 & 30 & 7,5 a 15 \\
\hline $\begin{array}{c}\text { Coeficiente de } \\
\text { uniformidade (CU) }\end{array}$ & Inferior a 4 & $\begin{array}{c}<4 \text { (Preferivelmente } \\
\text { inferior a 3,5) }\end{array}$ & Inferior a 5 \\
\hline $\begin{array}{c}\text { Diâmetro efetivo } \\
(\mathbf{m m})\end{array}$ & 0,3 e 0,75 & 0,3 e 0,75 & 0,3 a 1,2 \\
\hline
\end{tabular}

Uma prática bastante difundida que evita a perda excessiva de areia, reduz os problemas de colmatação em leitos com remoção manual da torta e melhora a distribuição do lodo é a utilização, acima da soleira drenante, de uma camada suporte formada por tijolos recozidos (Figura 18). Este material deve ser disposto na superfície da areia de forma a deixar 2 a $3 \mathrm{~cm}$ de espaçamento entre os blocos e não ultrapassar 85\% da área total do leito (GONÇALVES, 1999; SAMUDIO, 1993). As configurações recomendadas por Gonçalves (1999) são apresentadas na Figura 20:
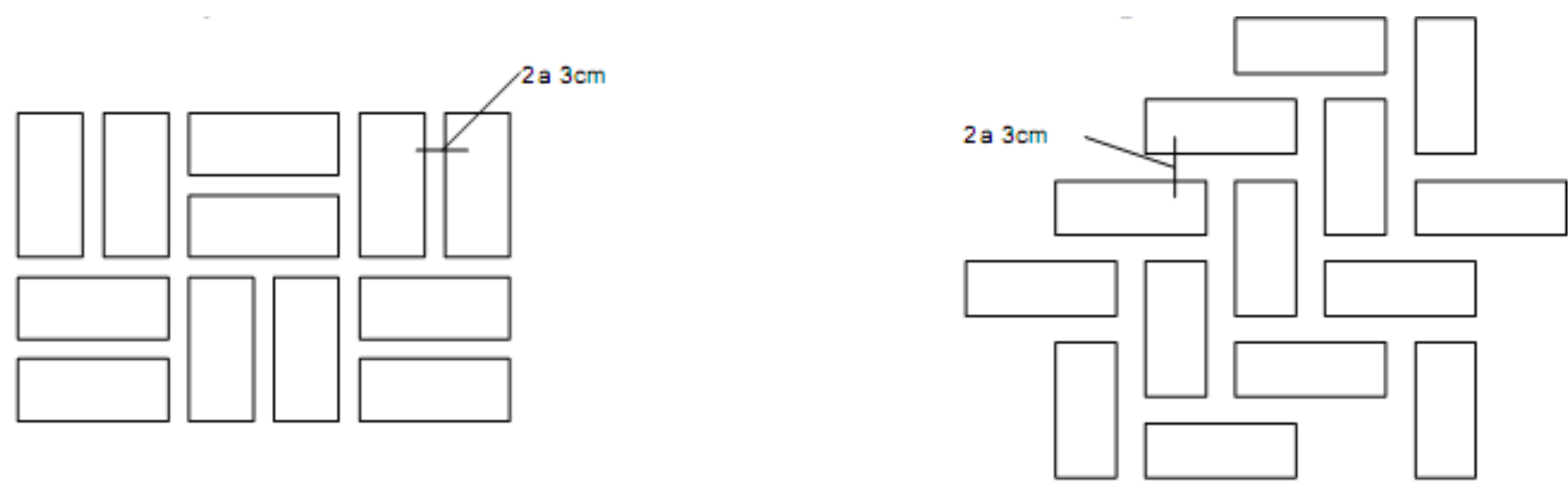

Figura 20 - Detalhe da disposição dos tijolos que compõem a camada suporte (GONÇALVES, 1999)

Os leitos de secagem foram modificados ao longo do tempo com o objetivo de aumentar sua eficiência. Algumas modificações, já desenvolvidas a mais de 30 anos, são citadas pelo WEF (1998):

- Leitos pavimentados com leito central de areia para drenagem, com ou sem tubos de aquecimento enterrados no pavimento e com ou sem cobertura;

- Leitos de arame em cunha septados e dotados de mecanização na entrada e limpeza de lodo e controle de decantação e formação da torta;

- Leitos de secagem assistidos a vácuo dotados de equipamentos para possibilitar a utilização de uma força extra para ajudar a gravidade. 
O leito de drenagem está sendo desenvolvido como uma alternativa de desaguamento natural de lodos desde os estudos de Cordeiro (2001). Sua proposta de alteração da estrutura física do leito de secagem convencional resultou num aumento da taxa de drenagem e melhoria da qualidade do drenado, conforme foi também confirmado por outros autores (FONTANA, 2004; BARROSO, 2007; FONTANA et al., 2007).

No estudo de Cordeiro (2001), a proposta final foi denominada de Leito Modificado 2, desenvolvida nos estudos do Projeto PROSAB 2, tema IV. A proposta de Leito Modificado 1 foi um passo intermediário entre a substituição total da areia do meio filtrante pelo geotêxtil (Figura 21). Observando uma grande redução do tempo de drenagem, resultado de um aumento na velocidade de retirada da água livre do lodo, esta nova configuração (Modificado 2) passou a ser denominada Leito de Drenagem.

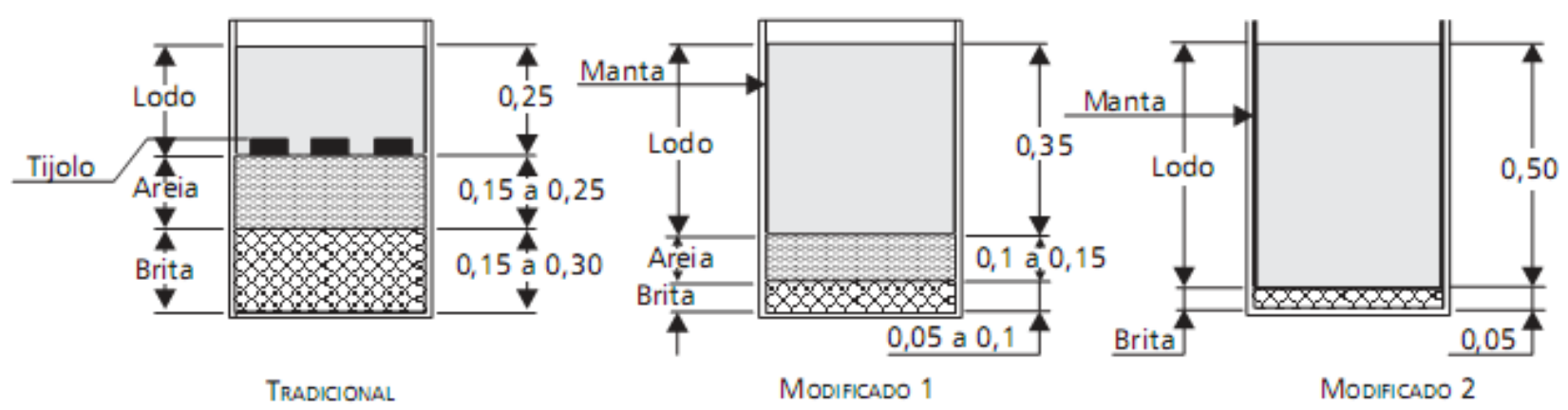

Figura 21 - llustração dos leitos de secagem convencional (Tradicional) e modificados (CORDEIRO, 2001)

Outras mudanças realizadas em leitos de secagem, e que merecem destaque, são as comentadas por Yamaoka e Hata (2003), onde os leitos foram modificados para que possam receber lodo primário e secundário não digerido através da utilização de aeração intermitente sob a camada de areia e de misturador no centro do leito. Já Glendinning, Lamont-Black e Jones (2007) sugerem a utilização de cátodos e ânodos para melhorar a separação de fases e gerar tortas com teores de sólidos maiores. Estas alterações no processo de desaguamento por leitos de secagem, que ainda são incipientes e pouco estudadas, são apresentadas na Figura 22: 

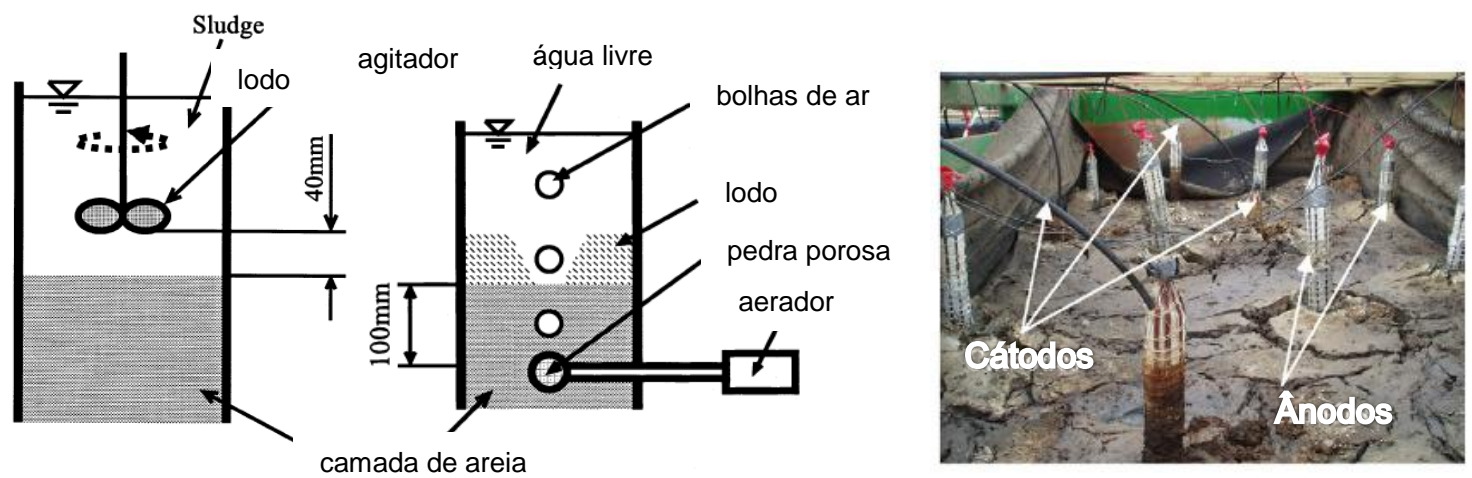

Figura 22 - llustração dos leitos de secagem modificados por mistura e aeração à esquerda e ao centro (YAMAOKA; HATA, 2003) e pela utilização de forças eletrocinéticas à direita (GLENDINNING et al., 2007)

\subsubsection{Características físicas}

Em comparação com o leito de secagem convencional, o leito de drenagem possui as principais diferenças físicas relacionadas ao meio filtrante, que tem a areia substituída por uma manta geossintética e a altura da camada de brita reduzida. Entre as propostas de Leito Modificado 1 e Modificado 2 de Cordeiro (2001), foi verificado que nem a areia nem a espessura do meio filtrante influenciavam na remoção de água livre e retenção de sólidos.

O meio filtrante de leitos de drenagem é, portanto, composto apenas por uma camada de 5 a $10 \mathrm{~cm}$ de brita no 1 ou 2 sobreposta por uma manta geossintética permeável e resistente aos esforços a que é submetida durante o ciclo de secagem e durante a remoção da torta gerada (CORDEIRO, 2001; FONTANA, 2007, 2008). Os materiais normalmente utilizados como meio filtrante em leitos de drenagem são os geotêxteis tecidos e não tecidos (FONTANA, 2007). O item 3.4 descreve as características e propriedades dos geotêxteis.

Com a redução do meio filtrante, as paredes laterais no leito de drenagem também podem ser reduzidas, sendo recomendado por Fontana (2004) o valor de $60 \mathrm{~cm}$.

A disposição ou divisão dos leitos deve ser otimizada para evitar o transporte da torta retirada a distâncias superiores a $10 \mathrm{~m}$, de acordo com a disponibilidade de espaço na Estação (ABNT NBR 12.209, 1992). As dimensões de um leito de 
secagem padrão, segundo Metcalf e Eddy (2002), são de 6 metros de largura por um comprimento que varia de 6 a 30 metros, porém, Samudio (1993) relata a construção de leitos com até 60 metros de comprimento. O mesmo autor, contudo, faz uma ressalva para leitos onde seja aplicado lodo condicionado com polímeros: o comprimento não deve ultrapassar $20 \mathrm{~m}$ para evitar má distribuição do material e manter uniforme a espessura da camada de lodo.

As linhas de distribuição de lodo podem ser de escoamento livre, em canais abertos ou fechados; ou escoamento forçado, por bombeamento, desde que mantidas as velocidades dentro da faixa de $1,0 \mathrm{~m} / \mathrm{s}$ a 2,4 m/s (MUNÕZ, 1994, apud CORDEIRO, 2001). As saídas que distribuem o lodo nos leitos de drenagem, assim como em leitos de secagem, devem ser dotadas de válvulas de fechamento, para possibilitar o manejo adequado dos leitos (WPCF, 1983), e posicionadas de forma a garantir a distribuição mais uniforme possível do lodo sobre os leitos (CORDEIRO, 2001).

O sistema de drenagem é essencial para o bom funcionamento do leito e deve ser capaz de drenar, de início, toda a água livre contida no lodo e, durante o ciclo de evaporação, toda a água pluvial que cair sobre o leito (WPCF, 1983).

De acordo com o tamanho e inclinação do fundo do leito de drenagem, tubos de drenagem podem ser utilizados de forma análoga aos de leitos de secagem. De acordo com Metcalf e Eddy (2002), estes devem ser de plástico ou de cerâmica e perfurados para possibilitar a entrada da água. Além disso, o WPCF (1983) recomenda que os tubos de drenagem sejam assentados sob a camada de brita, possuam ao menos 1\% de declividade e sejam espaçados em no máximo 6 metros. O diâmetro dos tubos de drenagem deve ser de 100 ou $150 \mathrm{~mm}$, dependendo da quantidade de lodo a ser desaguada (CORDEIRO, 2001), e após o assentamento destes, cargas pesadas não podem ser apoiadas no leito. O fundo dos leitos de drenagem deve ser de concreto (CORDEIRO, 2001) e possuir inclinação de 1 a 3\%, para possibilitar que toda a água escoe na direção dos condutores horizontais (FONTANA, 2004). 
As coberturas utilizadas em leitos de secagem ou estufas agrícolas também devem ser utilizadas em leitos de drenagem, pois, não retardam a evaporação durante a estiagem e reduzem a incorporação de água durante precipitações (MELO, 2006).

Estas estruturas podem ser feitas de vidro, fibra de vidro, acrílico e plástico translúcido, e sustentadas por estrutura adequada (WPCF, 1983; GONÇALVES, 2001; FONTANA, 2004). Estruturas metálicas ou em madeira devem ser tratadas ou pintadas de forma a prevenir a corrosão causada pela liberação de gases pelo lodo. O ambiente não deve ser totalmente vedado, mas sim dotado de entradas de ar para ventilação e troca do ar que se satura com a evaporação (WEF, 1998).

Em um estudo sobre a ventilação em leitos de secagem cobertos, Metcalf e Eddy (1935) verificaram que a melhor ventilação pode ser obtida a partir da configuração de aberturas apresentada na Figura 23. Caso o local seja muito úmido, a ventilação pode ser mecanizada. Estas e outras características do funcionamento de leitos de secagem e manejo de lodos de ETE's foram relatadas há muito tempo atrás por Metcalf e Eddy (1935), passando a serem ignoradas por bibliografias mais recentes. Dessa forma, esta referência será utilizada sempre que as informações relatadas não forem encontradas em referências mais recentes.

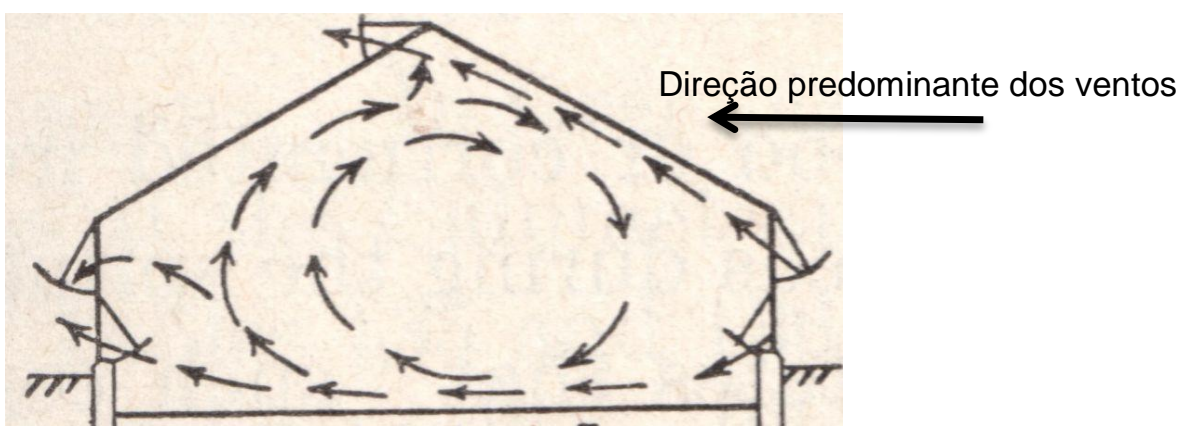

Figura 23 - Fluxos de ar obtidos dentro de uma estufa de secagem de lodo (METCALF; EDDY, 1935)

As coberturas têm o principal objetivo de aumentar o número de ciclos no ano e evitar interferências climáticas, mas às vezes não se justificam economicamente em clima tropical (SAMUDIO, 1993). 


\subsubsection{Funcionamento}

O processo de desaguamento em métodos naturais tem de início a gravidade como força principal na retirada de água, de modo que a água livre, sob ação desta força, escoa por entre os sólidos ainda em suspensão até atingir o meio filtrante (areia ou manta geotêxtil) e ser retirada do lodo em definitivo. A taxa de retirada de água vai caindo à medida que o percentual de água livre e a carga hidráulica sobre o filtro vão diminuindo e conforme as partículas do material vão se depositando sobre o filtro e colmatando seus poros (SAMUDIO, 1993; ANDREOLLI, VON SPERLING e FERNANDES, 2007).

O processo de drenagem retira a fração drenável da água livre, que pode ser maximizada através da utilização de polímero como condicionador. A manta geossintética permite um controle maior sobre a colmatação dos poros, possibilita taxas de drenagem maiores e, assim, diminui o tempo necessário para que a água livre tenha sido retirada. Ao fim da drenagem a evaporação passa a ser o principal processo responsável pela secagem do lodo (CORDEIRO, 2001).

A evaporação é a perda de água na forma de vapor, do lodo para o ar, e ocorre devido ao gradiente de umidade que existe na interface com o ar (SAMUDIO, 1993). A energia ou o calor responsável pelo processo é, inicialmente, o próprio calor da massa úmida e, depois de estabelecida uma relação de equilíbrio, o calor latente utilizado para a evaporação da água presente no lodo é proveniente do ar. Desta forma, a velocidade do processo de evaporação depende da temperatura, irradiação solar e umidade ambiente, do nível d'água no lodo e do tipo de ligação entre água e sólidos. Quanto maior a temperatura do ar, maior é a taxa de transferência de calor do ar para o lodo e maior a velocidade de secagem, consequentemente. Além disso, é importante considerar que a taxa de absorção de calor pelo lodo é muito mais alta que a da água, devido à presença de partículas escuras, o que possibilita uma maior velocidade de evaporação da água presente na massa úmida (SAMUDIO, 1993).

Como a evaporação é essencialmente determinada pelo clima, este processo sofre grande variação sazonal ao longo do ano em zonas temperadas. No Brasil, a 
variação ocorre principalmente na porção centro-sul e sudeste do país, sendo que no Norte e Nordeste os tempos dos ciclos são mais constantes.

A secagem natural de lodos foi descrita por Niebiker (1967) a mais de 40 anos, sendo ainda muito citada em referências atuais (SAMUDIO, 1993). Segundo Niebiker (1967), para uma determinada condição climática, a velocidade de evaporação não tem grande variação desde o momento em que se inicia, ainda com uma camada de sobrenadante até quando os efeitos de capilaridade não são suficientes para suprir todo o potencial de evaporação do ar. É neste ponto que ocorre o que o autor chama de primeiro ponto crítico de secagem. A partir deste ponto, o nível d'água vai se aprofundando dentro da camada de lodo até que o mesmo atinja a interface entre o lodo e a soleira drenante, de modo que quase a totalidade da água presente seja de natureza coloidal, necessitando de condições não proporcionadas pelo desaguamento natural do lodo para ser removida. Neste momento ocorre o que o autor chama de segundo ponto crítico do processo de evaporação.

Como comentado, a evaporação sofre influência da irradiação solar, temperatura, velocidade média dos ventos e umidade relativa do ar, além da dinâmica da água presente no lodo. Outra variável climática que provavelmente exerce grande influência nesta etapa da secagem do lodo é a precipitação, uma vez que Mayer (1998) verificou que $57 \%$ da água precipitada sobre o lodo ficou retida no leito. Assim, a chuva que cai sobre a torta de lodo pode fazer com que o processo volte à etapa anterior, onde a drenagem era a principal responsável pelo processo de desaguamento. Porém, se durante o evento de chuva o material possuir diversas e profundas fissuras ao longo do leito, a água da chuva escoará rapidamente pelo material e não atrasará ou prejudicará o processo (SAMUDIO, 1993). A influência climática no processo de secagem é ilustrada na Figura 24: 


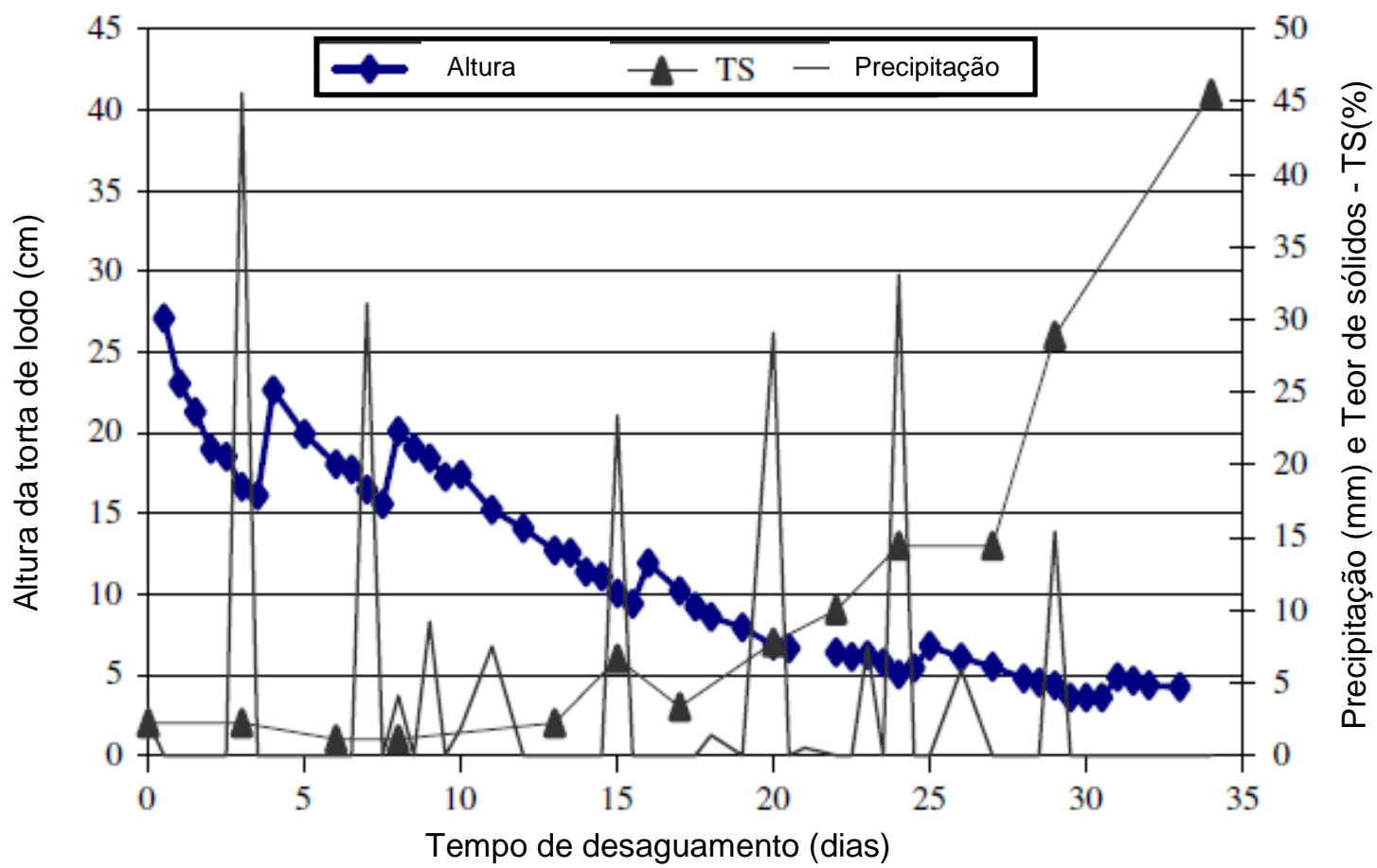

Figura 24 - Profundidade da torta de lodo, precipitação e teor de sólidos (TS) ao longo de um ciclo de drenagem (Adaptado de COFIE et al., 2006)

O fim do ciclo de secagem é determinado pelo momento em que o lodo atingiu as características necessárias para ser retirado do leito. A retirada do lodo do leito de drenagem é realizada manualmente, com o auxílio de ferramentas plásticas e vassoura para limpeza final, segundo Fontana (2004), ou através da retirada da própria manta com os sólidos dentro (o geotêxtil apresenta resistência suficiente para ser utilizado no transporte do material até local de disposição final ou intermediária) e subsequente lavagem com jateamento de água em local adequado, segundo Cordeiro (2001).

No ponto em que é retirado do leito, o volume de lodo já foi reduzido drasticamente, como foi apresentado na Figura 2, desta forma resultando numa massa proporcionalmente menor, num menor trabalho para retirada do material e menor estrutura para armazenar o material até ser encaminhado para disposição final. A Figura 2 indica que as reduções em volume são normalmente superiores a 70\%. 


\subsubsection{Dimensionamento}

O dimensionamento de leitos de drenagem inclui a determinação da área em planta necessária ao desaguamento do lodo produzido. A determinação da área dos leitos pode ser realizada de forma racional ou empírica. Os leitos de drenagem podem ser dimensionados com base nos mesmos métodos de dimensionamento de leitos de secagem, desde que os coeficientes e critérios utilizados sejam obtidos no desaguamento em leitos de drenagem.

Independente do método de dimensionamento, o principal parâmetro a ser determinado ou estimado para o projeto de um processo de desaguamento, é a produção de lodo no tratamento da fase líquida da ETE.

\subsubsection{Dimensionamento empírico}

Samudio (1993) sugere que a partir da produção de lodo por habitante por dia e da determinação empírica da melhor altura para camada de lodo aplicada em cada ciclo e do número de ciclos por ano no local, o dimensionamento pode ser realizado a partir da fórmula abaixo:

$$
A e=Q \times 365 / e \times n c
$$

Onde:

$\mathrm{Ae}=$ Área específica requerida $\left(\mathrm{m}^{2} / \mathrm{hab}\right) ;$

$\mathrm{Q}=$ Quantidade de lodo digerido produzido na ETE ( $\mathrm{m}^{3} / \mathrm{hab}$.dia);

$\mathrm{e}=$ espessura da camada de lodo aplicado em cada ciclo $(\mathrm{m})$;

$\mathrm{nc}=$ número de ciclos de secagem por ano.

Para o lodo do tratamento de esgotos tipicamente domésticos em leitos de secagem, alguns valores de "Ae" são sugeridos em bibliografias nacionais e internacionais, de acordo com o tipo de lodo a ser desaguado: primário, secundário ou misto; e 
digerido aeróbia ou anaerobiamente. Numa extensa pesquisa, Samudio (1993) encontrou valores para a área específica requerida $(\mathrm{Ae})$ de leitos de secagem convencionais entre 0,03 e $0,51 \mathrm{~m}^{2} / \mathrm{hab}$.

Outro parâmetro que também pode ser utilizado para determinar a área de leitos de drenagem de forma empírica, em substituição à espessura da camada de lodo, é a taxa de aplicação superficial de sólidos totais em $\mathrm{kgST} / \mathrm{m}^{2}$.ciclo, sendo que a norma ABNT NBR 12.209 (1992) sugere a aplicação de até 15 kg de sólidos suspensos totais por $\mathrm{m}^{2}$ de área do leito de secagem por ciclo.

Porém, Metcalf e Eddy (1935) mostram que o parâmetro mais constante em 9 ETE's que possuíam leitos de secagem nos EUA é a carga de sólidos por área aplicada no leito em um ano. A média anual entre as Estações em diferentes climas pode contornar as diferenças sazonais e indica que podem ser aplicados aproximadamente $146 \mathrm{kgST} / \mathrm{m}^{2}$.ano.

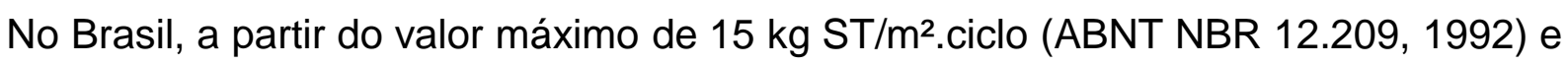
da estimativa de Samudio (1993) de até 15 ciclos por ano, chega-se ao valor máximo de $225 \mathrm{~kg} / \mathrm{m}^{2}$.ano.

A grande amplitude de valores utilizados no dimensionamento não racional de leitos de secagem para desaguamento de lodos de ETE's decorre da dependência de condições climáticas locais e características do lodo produzido, sendo que estes critérios são passíveis de interpretação e, portanto, devem ser utilizados de forma criteriosa.

Assim, é importante considerar o local de implantação durante o dimensionamento empírico tanto de leitos de secagem quanto de leitos de drenagem, dada a grande variedade climática de países com grande extensão territorial, como o Brasil, e também em países menores, pelas possíveis variações de altitude. 


\subsubsection{Dimensionamento racional}

Alguns métodos racionais de dimensionamento de leitos de secagem foram desenvolvidos baseados em modelos matemáticos que possuem um maior número de variáveis e parâmetros, sendo por este motivo, muitas vezes de difícil utilização. Samudio (1993) explica que, nestes modelos, variáveis como a taxa de evaporação local e o percentual de água drenada pelo meio filtrante são determinantes, mas a obtenção destes dados não é tarefa fácil em muitos casos.

Rolam (1979) apud Samudio (1993) desenvolveu um modelo matemático que é considerado o melhor método de dimensionamento racional que pode ser utilizado para projetos de leitos de secagem. Este método também é citado pela WEF (1998). Neste modelo é necessário calcular primeiramente a carga de lodo aplicada através da equação:

$$
\mathrm{IA}=\rho \mathrm{\rho} \times \mathrm{Di} \times \mathrm{Dsi} / 100
$$

Onde:

IA = carga de lodo aplicada em cada ciclo ( $\mathrm{kgST} / \mathrm{m}^{2}$.ciclo);

$\rho i$ = massa específica do lodo aplicado $\left(\mathrm{kg} / \mathrm{m}^{3}\right)$;

$\mathrm{Di}=$ espessura inicial da camada de lodo $(\mathrm{m})$;

DSi = teor de sólidos no lodo aplicado (\% peso seco);

100 = fator de conversão de porcentagem em unidades decimais.

A espessura final da camada de lodo, que depende do teor de sólidos que é desejado na torta final, e a diferença entre a espessura inicial e final são calculadas pelas seguintes equações:

$$
\begin{aligned}
& \text { Dii }=100 \times I A / \rho i i \times D S i i \\
& D D=D i-D i i
\end{aligned}
$$

Onde:

Dii = espessura final da torta seca $(m)$; 
DSii = teor de sólidos que é desejado na torta seca (\%);

pii = massa específica do lodo desaguado $\left(\mathrm{kg} / \mathrm{m}^{3}\right)$;

100 = fator de conversão de porcentagem em unidades decimais;

$\mathrm{DD}=$ Variação total de espessura da torta $(\mathrm{m})$.

A variação desta espessura que é resultante apenas da etapa de drenagem do processo de secagem é determinada por:

$$
\mathrm{DDu}=\mathrm{DD} \times \mathrm{Pc}
$$

Onde:

$\mathrm{Pc}=$ porcentagem do volume total aplicado que é coletado pelo sistema de drenagem do leito.

O valor de Pc é proporcional à facilidade com que a água presente no material passa pelos grãos da torta, atinge o meio filtrante e é coletada no sistema de drenagem. Rolam (1979) apud Samudio (1993) relata valores entre 20 e 30\% para leitos de secagem, mas técnicas como o condicionamento com polímeros associada à utilização de mantas geossintéticas (leitos de drenagem) devem possibilitar um aumento significativo do percentual de umidade perdida pela drenagem da água livre.

Assim, a espessura resultante após a etapa de drenagem e o tempo necessário para que a umidade desta torta seja evaporada são:

$$
\begin{aligned}
& \mathrm{DDe}=\mathrm{DD}-\mathrm{Ddu} \\
& \mathrm{T}=\mathrm{DDe} / \mathrm{E}
\end{aligned}
$$

Onde:

$\mathrm{DDe}=$ espessura da torta após a drenagem $(\mathrm{m})$;

$\mathrm{T}=$ tempo de secagem por evaporação (meses);

$E=$ taxa de evaporação média ( $m /$ mês). 
Por fim, o número de ciclos por ano (AA) e a taxa de aplicação anual de sólidos (IAa, em $\mathrm{kg} / \mathrm{m}^{2}$.ano) são determinados por:

$$
\begin{aligned}
& A A=12 \text { meses por ano } / T \\
& I A a=I A \times A A
\end{aligned}
$$

Neste equacionamento o teor de sólidos inicial e final, a espessura inicial da camada de lodo e o percentual de água drenada são determinantes no processo. $O$ valor utilizado em cada uma das equações deve ser definido baseado em uma análise da atividade de descarte de lodo, de coleta do drenado e de remoção da torta do leito, de forma a aperfeiçoar o processo como um todo. Neste contexto, o condicionamento químico para aumentar o valor de $\mathrm{Pc}$ tem papel fundamental, pois resulta no aumento das taxas de aplicação anual e, consequentemente, na diminuição das áreas necessárias para o desaguamento natural (dada uma produção de sólidos anual constante).

\subsubsection{Operação}

A operação de leitos de drenagem é simples, porém deve ser intensificada em certas etapas como as de enchimento do leito e de remoção da torta gerada. As variáveis operacionais no enchimento do leito são facilmente controláveis e se resumem ao teor de sólidos no lodo e à altura da camada aplicada, que determina a taxa de aplicação de sólidos no ciclo ( $\mathrm{kg} / \mathrm{m}^{2}$.ciclo).

Em relação à altura da camada de lodo, Nebiker (1967) aponta que o primeiro ponto crítico da secagem (ver item 3.3.4) é função da umidade média ao longo de toda a espessura do lodo e que, para alturas de camada menores, este ponto ocorre em uma umidade menor. Ou seja, para espessuras de lodo menores, a drenagem atua até um residual de umidade menor resultando em menor quantidade de água para ser evaporada na continuação do ciclo de secagem. 
Dessa forma, a realização do processo de desaguamento com um lodo com baixo teor de sólidos e aplicação no leito de finas camadas de lodo, que possibilitam maiores velocidades de drenagem, deve ser avaliada técnica e economicamente como opção à aplicação de espessas camadas de lodo bem concentrado, que resultaria na necessidade de um menor número de ciclos por ano.

Outro aspecto operacional, a remoção da torta gerada, pode ser facilitada controlando-se o tempo de secagem e o teor de sólidos final. A hora ideal para retirada da torta é aquela na qual o volume já foi significativamente reduzido e o teor de sólidos é compatível com o método manual ou mecanizado de remoção dos sólidos. A remoção da torta em leitos de drenagem piloto foi realizada retirando-se a manta com os sólidos (que eram descartados em local apropriado) e lavando-a com água pressurizada (CORDEIRO, 2001).

No estudo de Fontana (2004) com leitos de drenagem em escala real, a remoção da torta foi realizada manualmente, com auxílio de vassoura, pá e outras ferramentas plásticas, sem que as mantas geossintéticas fossem retiradas ou lavadas. Neste mesmo estudo, verificou-se que sem o procedimento de varrição a manta permanecia impregnada de sólidos, mas que tal fato não interferia nos tempos de drenagem ou na qualidade do drenado.

Durante a operação do leito são gerados efluentes líquidos provenientes da drenagem da água livre e da drenagem da água precipitada sobre o leito, que normalmente são encaminhadas ao início da estação para tratamento junto com o esgoto afluente. A qualidade do drenado melhora ao longo do desaguamento, como pode ser observado nos resultados do desaguamento de lodo de ETE, apresentados na Tabela 11: 
Tabela 11 - Qualidade do drenado de leito de secagem desaguando lodo de tanque séptico (COFIE et al., 2006)

\begin{tabular}{|c|c|c|c|c|c|c|c|c|}
\hline \multirow[b]{2}{*}{ Parâmetro } & \multicolumn{4}{|c|}{ Percolado do primeiro dia } & \multicolumn{4}{|c|}{ Percolado do último dia } \\
\hline & Mínimo & Máximo & Média & $\begin{array}{l}\text { Desvio } \\
\text { Padrão }\end{array}$ & Mínimo & Máximo & Média & $\begin{array}{l}\text { Desvio } \\
\text { Padrão }\end{array}$ \\
\hline $\mathrm{pH}$ & 7.9 & 8.8 & 8.2 & 0.3 & 6.9 & 9.2 & 7.9 & 0.9 \\
\hline $\begin{array}{l}\text { Condutividade } \\
(\mu \mathrm{S} / \mathrm{cm})\end{array}$ & 8600 & 41900 & 21900 & 12500 & 3000 & 31700 & 11400 & 11750 \\
\hline $\begin{array}{l}\text { SST (mg/l) } \\
\text { DQO (ma/l) }\end{array}$ & $\begin{array}{c}340 \\
1120\end{array}$ & $\begin{array}{c}850 \\
13200\end{array}$ & $\begin{array}{c}600 \\
5600\end{array}$ & $\begin{array}{c}230 \\
3870\end{array}$ & $\begin{array}{c}80 \\
770\end{array}$ & $\begin{array}{c}720 \\
8200\end{array}$ & $\begin{array}{c}290 \\
3600\end{array}$ & $\begin{array}{c}240 \\
2900\end{array}$ \\
\hline $\mathrm{DBO}(\mathrm{mg} / \mathrm{l})$ & 150 & 2600 & 1350 & 810 & 250 & 1650 & 870 & 620 \\
\hline $\mathrm{NH} 3(\mathrm{mgN} / \mathrm{l})$ & 210 & 1160 & 520 & 450 & 60 & 570 & 260 & 240 \\
\hline $\mathrm{NKT}\left(\mathrm{mg} / \mathrm{l}^{\prime}\right.$ & 210 & 1330 & 590 & 520 & 100 & 720 & 370 & 310 \\
\hline $\mathrm{NO3}(\mathrm{mgN} / \mathrm{l})$ & 20 & 80 & 50 & 20 & 20 & 610 & 170 & 210 \\
\hline O. Helmintos & 0 & 0 & 0 & 0 & 0 & 0 & 0 & 0 \\
\hline
\end{tabular}

O desaguamento por leitos de secagem é uma opção de tratamento com operação simples e que não depende de grandes gastos com energia elétrica e produtos químicos (ver item 3.1.2). Alguns métodos comumente utilizados no tratamento de lodo em ETE's são comparados na Tabela 12:

Tabela 12 - Aspectos ambientais de alguns processos de desaguamento (SAMUDIO, 1993)

\begin{tabular}{|c|c|c|c|c|c|}
\hline $\begin{array}{l}\text { Aspecto } \\
\text { Analisado }\end{array}$ & $\begin{array}{l}\text { Leitos e } \\
\text { Lagoas de } \\
\text { secagem }\end{array}$ & $\begin{array}{l}\text { Filtro } \\
\text { Prensa de } \\
\text { Esteira }\end{array}$ & $\begin{array}{l}\text { Filtro prensa } \\
\text { de placas }\end{array}$ & Centrifugas & $\begin{array}{l}\text { Filtro a } \\
\text { Vácuo }\end{array}$ \\
\hline Espaço ocupado & Alto & Baixo & Baixo & Baixo & Médio \\
\hline Manutenção & Baixa & Baixa & Media & Alta & Media \\
\hline $\begin{array}{c}\text { Facilidade } \\
\text { operacional }\end{array}$ & Baixa & Alto & Baixa & Alta & Media \\
\hline Tipo de operação & $\begin{array}{c}\text { Descontínua e } \\
\text { geralmente } \\
\text { manual }\end{array}$ & $\begin{array}{l}\text { Continua e } \\
\text { automática }\end{array}$ & $\begin{array}{c}\text { Descontinua e } \\
\text { manual ou } \\
\text { automática } \\
\end{array}$ & $\begin{array}{l}\text { Continua e } \\
\text { automática }\end{array}$ & $\begin{array}{l}\text { Continua e } \\
\text { automática }\end{array}$ \\
\hline $\begin{array}{l}\text { Consumo de } \\
\text { produtos } \\
\text { químicos }\end{array}$ & Nulo & Médio & Médio & Médio & Médio \\
\hline $\begin{array}{c}\text { Consumo de } \\
\text { energia }\end{array}$ & $\begin{array}{l}\text { Eventual, } \\
\text { baixo }\end{array}$ & Baixo & Baixo & Alto & Médio \\
\hline $\begin{array}{l}\text { Consumo de } \\
\text { utilidades (água, } \\
\text { ar, etc.) }\end{array}$ & Nulo & Baixo & Médio & Baixo & Médio \\
\hline Eficiência & $\begin{array}{c}\text { Variável, } \\
\text { depende do } \\
\text { clima }\end{array}$ & $\begin{array}{c}\text { Alta na } \\
\text { maioria das } \\
\text { aplicações }\end{array}$ & $\begin{array}{c}\text { Alta na } \\
\text { maioria das } \\
\text { aplicações } \\
\end{array}$ & $\begin{array}{c}\text { Media na } \\
\text { maioria das } \\
\text { aplicações }\end{array}$ & $\begin{array}{c}\text { Media na } \\
\text { maioria das } \\
\text { aplicações }\end{array}$ \\
\hline $\begin{array}{c}\text { Custo de } \\
\text { equipamentos }\end{array}$ & Baixo & Médio & $\begin{array}{c}\text { Alto na } \\
\text { maioria das } \\
\text { aplicações }\end{array}$ & Alto & Médio a alto \\
\hline $\begin{array}{l}\text { Custo de } \\
\text { construção civil }\end{array}$ & Variável* & Médio & Alto & Médio & Médio \\
\hline
\end{tabular}




\subsection{Geotêxteis}

\subsubsection{Generalidades}

Os geossintéticos foram desenvolvidos pela engenharia geotécnica para substituir materiais naturais, que não permitem uma fácil avaliação de seus parâmetros de comportamento, são praticamente artesanais, possuem baixa durabilidade (geralmente não podem sofrer ciclos de saturação e secagem) e têm sua qualidade difícil de controlar (VIDAL, 2002).

A norma ABNT NBR 12.553 - Geossintético - Terminologia, de 2003, define a terminologia utilizada na classificação dos materiais geossintéticos. Os produtos mais comuns são os geonets (georedes) e os geocompostos utilizados para drenagem, as geocélulas utilizadas para contenção e estabilização, o gabião tubular utilizado para proteção de encostas e controle de erosão, os geotubos utilizados pra drenagem em aterros sanitários entre outras aplicações, as geomembranas utilizadas em impermeabilizações e os geotêxteis utilizados em praticamente todas as aplicações da engenharia geotécnica e outros tipos de obras civis.

A utilização destes materiais poliméricos extrapola a área de aplicação da engenharia geotécnica, possuindo diversas utilidades em outros campos da engenharia, principalmente em obras hidráulicas e de drenagem. Segundo Vidal (2002), as principais funções desempenhadas por estes produtos, são:

- Filtração: Retenção do solo ou de outras partículas, permitindo a passagem livre do fluido em movimento;

- Drenagem: Coleta e condução de um fluido pelo corpo de um geossintético;

- Barreira de fluxo: Controle ou desvio de fluxo;

- Reforço: Utilização das propriedades mecânicas de um geossintético para a melhoria do comportamento mecânico de solos; 
- Proteção: Limitação ou prevenção de danos a elementos de obras geotécnicas;

- Separação: Ação de impedir a mistura ou interação de materiais adjacentes;

- Controle de erosão superficial: Prevenção da erosão superficial de partículas do solo devido às forças do vento ou escoamento superficial.

\subsubsection{Classificação}

Os geotêxteis podem ser classificados, de acordo com o processo de fabricação, em geotêxteis tecidos e não tecidos. Os geotêxteis tecidos apresentam uma estrutura organizada de tiras de material e os não tecidos se assemelham a um feltro, não apresentando uma organização das fibras, conforme a Figura 25:
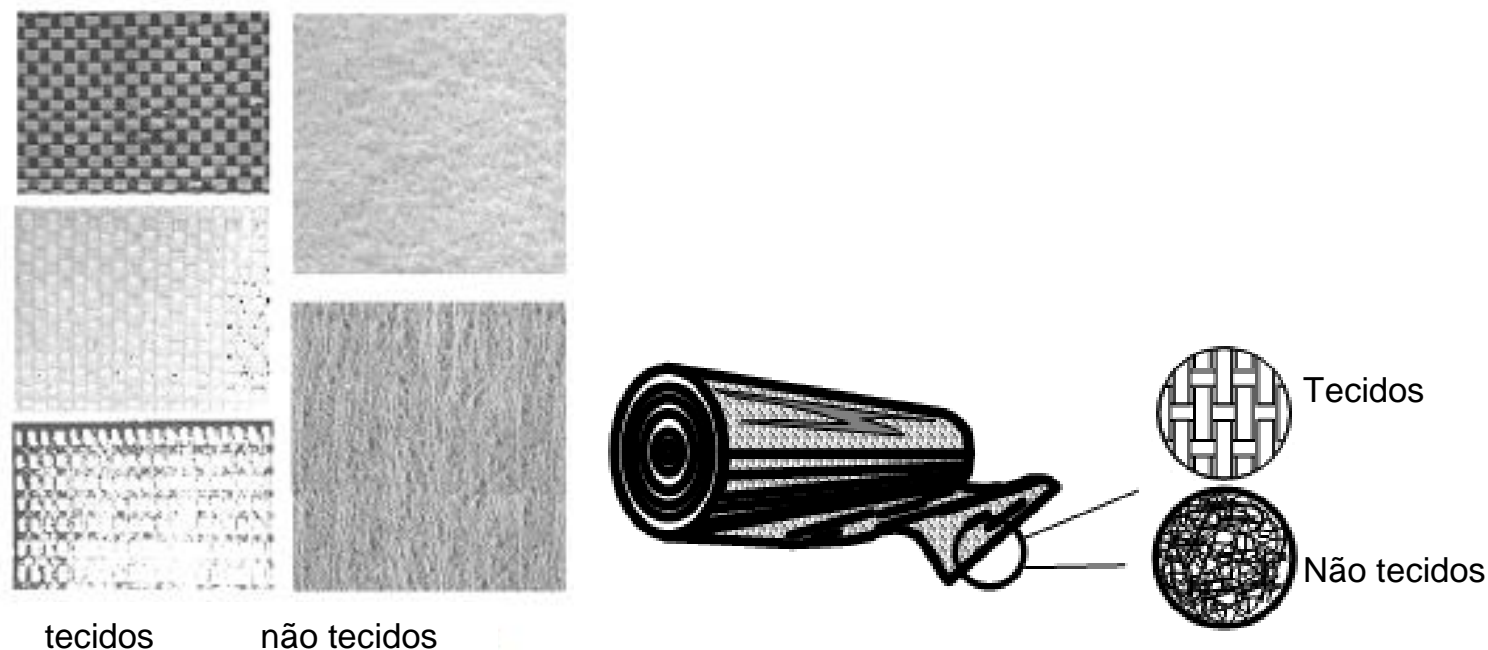

Figura 25 - Geotêxtil e a estrutura tecida e não-tecida (VIDAL, 2002)

O geotêxtil tecido é um material produzido em máquinas têxteis convencionais a partir do entrelaçamento de monofilamentos ou laminetes (fitas ou tiras), segundo direções preferenciais denominadas trama (sentido transversal) e urdume (sentido longitudinal). As mantas geotêxteis não tecidas são materiais compostos por fibras cortadas ou filamentos contínuos, distribuídos aleatoriamente, que são interligados por processos mecânicos, térmicos ou químicos. 


\subsubsection{Composição}

Os polímeros mais largamente empregados na fabricação de geotêxteis são, entre outros materiais, o polietileno, o poliéster e o polipropileno. Existe ainda uma série de aditivos que entram na composição de qualquer geossintético, cuja finalidade é melhorar as características mecânicas e aumentar sua durabilidade (ABRAMENTO, 1995). A composição aproximada dos principais polímeros utilizados em geossintéticos é apresentada na Tabela 13:

Tabela 13 - Composição aproximada (\% de massa) dos principais polímeros utilizados em geossintéticos (Adaptado de KOERNER, 1994)

\begin{tabular}{cccccc}
\hline Polímero & Resina & Preenchimento & $\begin{array}{c}\text { Negro de } \\
\text { fumo }\end{array}$ & Aditivos & Plastificantes \\
\hline Polietileno & 97 & 0 & $2-3$ & $0,5-1$ & 0 \\
Polipropileno & 96 & 0 & $2-3$ & $1-2$ & 0 \\
Poliéster & 97 & 0 & $2-3$ & $0,5-1$ & 0 \\
\hline
\end{tabular}

A composição de um geossintético influencia suas propriedades hidráulicas e mecânicas, principalmente ao longo do tempo. A durabilidade dos diversos polímeros usados na fabricação de geossintéticos afeta a resistência do material e deve ser considerada na seleção da manta geotêxtil.

Porém, o método de fabricação e a composição do produto influenciam as propriedades dos geotêxteis com diferentes intensidade, como pode ser observado na Tabela 14:

Tabela 14 - Efeito do polímero e da fabricação do geotêxtil em algumas propriedades dos geotêxteis (Adaptado de ABRAMENTO, 1995)

\begin{tabular}{c|lcc}
\hline \multicolumn{2}{c}{ Propriedades } & \multicolumn{2}{c}{ Fator } \\
\cline { 2 - 4 } Mecânicas & Polímero & Fabricação \\
\hline Hidráulicas & Fluência & 3 & 2 \\
& Abrasão & 1 & 3 \\
\hline \multirow{3}{*}{ De } & Térmatação & 0 & 3 \\
\hline Durabilidade & Biológica & 3 & 1 \\
& Hidrólise & 3 & 1 \\
& Química & 3 & 1 \\
& Ação UV & 3 & 1 \\
\hline
\end{tabular}

Nota: $0,1,2$ ou 3 é o grau de influência entre o fator (polímero ou processo de fabricação) e as propriedades do material 


\subsubsection{Características físicas}

As características físicas do geotêxtil são inerentes ao processo de fabricação e determinantes das propriedades mecânicas e hidráulicas destes materiais. A espessura e a gramatura do geotêxtil são responsáveis por garantir certa resistência mecânica, enquanto a porosidade do geotêxtil tem influência direta sobre suas propriedades hidráulicas.

\subsubsection{Espessura Nominal}

A Espessura Nominal (tGT, em metros), segundo ABNT NBR 12569 (1992), é a espessura do geotêxtil submetido a uma pressão confinante de $2 \mathrm{kPa}$, aplicada numa área de $2500 \mathrm{~mm}^{2}$, por placas rígidas paralelas, conforme esquematizado na Figura 26:

\section{$2 \mathrm{kPa}$}

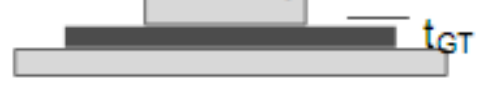

Figura 26 - Esquema do ensaio para determinação da espessura nominal de geotêxteis e produtos correlatos (VIDAL, 2002)

\subsubsection{Gramatura}

A gramatura (MA, normalmente expressa em $\mathrm{g} / \mathrm{m}^{2}$ ) é a medida da massa por unidade de área (ABNT NBR 12568, 2003), obtida em geral a partir de corpos de prova de $100 \times 100 \mathrm{~mm}$. Varia normalmente de 100 a $600 \mathrm{~g} / \mathrm{m}^{2}$ para as principais aplicações (ANEXO B). 


\subsubsection{Porosidade}

A estrutura porométrica dos geotêxteis é influenciada significativamente pelo processo de fabricação do geotêxtil, principalmente no caso dos não tecidos, onde o tipo de agulha que entrelaça os filamentos e a intensidade de agulhagem possuem grande influencia sobre esta característica (HWANG, 1998).

Esta característica física pode ser determinada, entre outros métodos, por sedimentação, medição ótica, microscopia eletrônica, análise de imagem, peneiramento à seco, peneiramento úmido ou peneiramento hidrodinâmico.

A porosidade dos geotêxteis não tecidos, por serem materiais tridimensionais, também pode ser estimada a partir da relação entre o volume de vazios e o volume total da amostra, em porcentagem. Esta porosidade não é medida diretamente, mas sim estimada através de outras propriedades do geotêxtil (FREITAS, 2003; VERTEMATTI, 2004):

$$
\eta G T=(V-V s) / V=1-\gamma / \gamma e f=[1-(M A / t G T . \gamma e f . \rho a)] .100
$$

Onde:

ПGT - porosidade do material (\%);

$\mathrm{V}$ - Volume do material $\left(\mathrm{m}^{3}\right)$;

Vs - Volume do sólido (Volume efetivo das fibras, em $\mathrm{m}^{3}$ );

$\gamma$ - peso $(\mathrm{kN})$;

yef - peso específico do material $\left(\mathrm{kN} / \mathrm{m}^{3}\right)$;

MA - gramatura do material $\left(\mathrm{kg} / \mathrm{m}^{2}\right)$;

tGT - Espessura do material (m);

of - densidade da fibra $\left(\mathrm{kg} / \mathrm{m}^{3}\right)$;

рa - densidade da água $\left(\mathrm{kg} / \mathrm{m}^{3}\right)$.

É importante ressaltar que a porosidade deixa de ser uma característica inerente ao material quando este é submetido a pressões confinantes, de modo que a determinação desta característica depende de ensaios de compressibilidade que 
permitam calcular a porosidade para cada nível de tensão confinante, conforme a Figura 27:

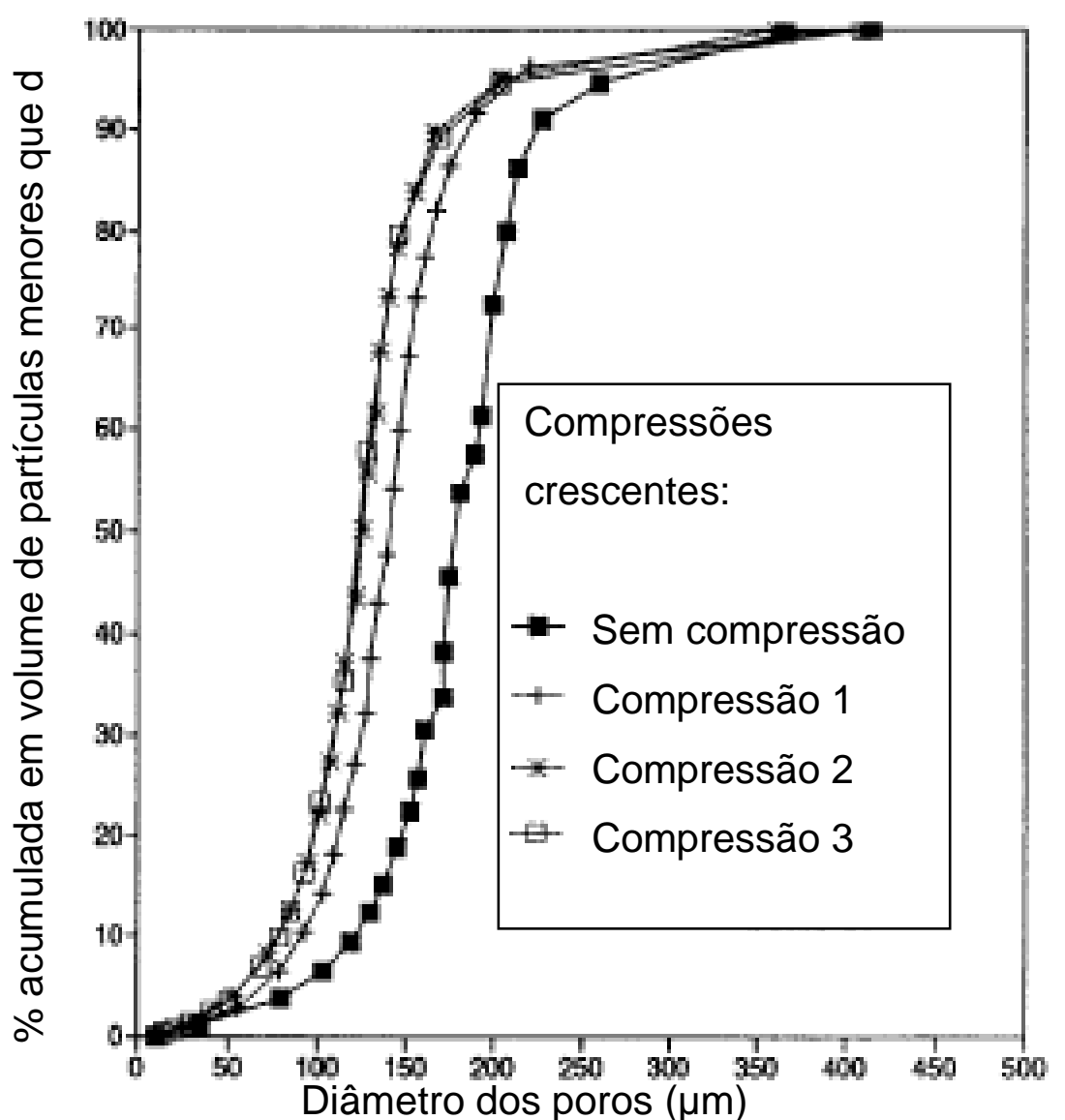

Figura 27 - Distribuição de poros de um geotêxtil em função de sua compressão (ELSHARIEF, A.; LOVELL, C., 1996)

\subsubsection{Propriedades mecânicas}

As solicitações impostas pelo processo de instalação dos geotêxteis e as solicitações impostas durante a vida útil do projeto implicam em requisitos mecânicos para a seleção e utilização de geotêxteis. As principais propriedades mecânicas de geotêxteis, segundo VIDAL (2002), são:

- Resistência à tração;

- Resistência à penetração e à perfuração; 
- Resistência aos danos de instalação (rasgos);

- Compressibilidade (ver item 3.4.4.3).

\subsubsection{Resistência à tração}

A resistência à tração unidirecional não confinada é determinada para geotêxteis e correlatos em ensaios descritos na norma ABNT NBR 12824 (1993), com corpos de prova de $20 \mathrm{~cm}$ de largura e $10 \mathrm{~cm}$ de altura livre. Esta propriedade dos geotêxteis, determinada pelo ensaio descrito nesta norma, varia normalmente entre 15 e 100 $\mathrm{kN} / \mathrm{m}$ (ANEXO B). Esquemas dos ensaios são apresentados Figura 28:

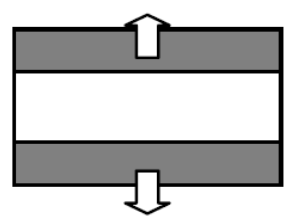

(a) unidirecional não confinado

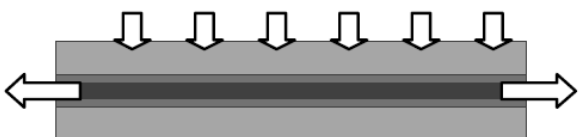

(b) unidirecional confinado

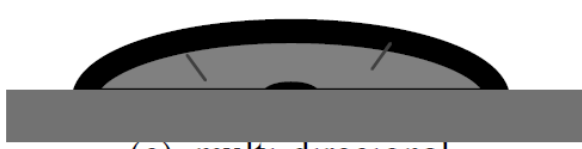

(c) mult1-direcional

Figura 28 - Ensaios de tração (VIDAL, 2002)

\subsubsection{Resistência à penetração por puncionamento estático}

A determinação da resistência à penetração por puncionamento é normatizada pela ABNT NBR 13359, de 1995. Os valores obtidos nestes ensaios com os geotêxteis mais comuns variam normalmente de 3 a $6 \mathrm{kN}$ (ANEXO B). Um detalhe importante deste ensaio é que, apesar do punção adotado ser o do ensaio CBR ("California 
Bearing Ratio" ou Índice de Suporte Califórnia - teste realizado para determinação da expansão de solos), ele deve ter as bordas arredondadas (Figura 29), conforme especifica a norma do ensaio, para evitar "cortar" o geossintético. Um esquema do ensaio é apresentado na Figura 30:

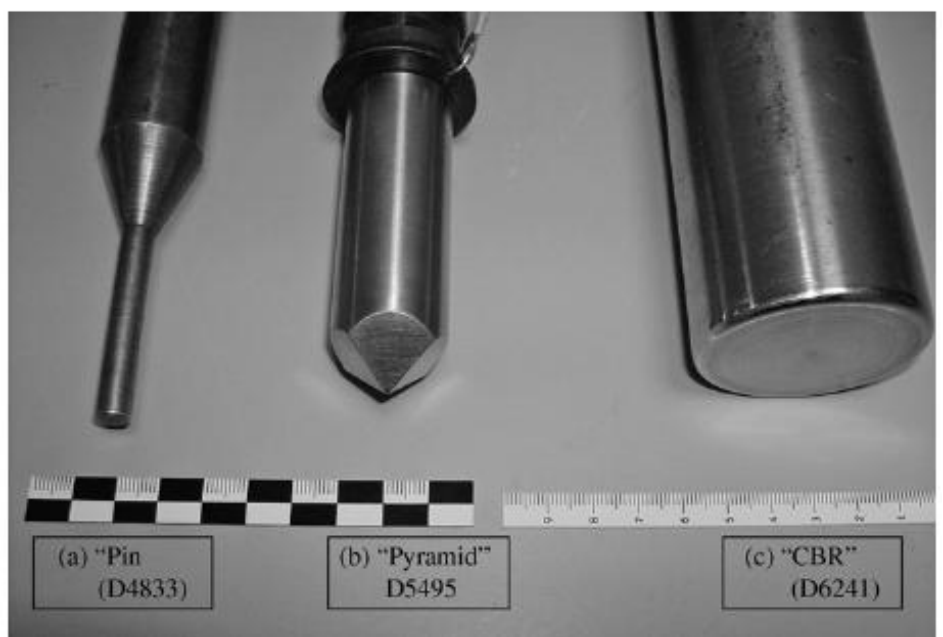

Figura 29 - Punção do ensaio CBR (à direita - recomendado pela ABNT NBR 13359, de 1995) e de outros testes padronizados pela ASTM (KOERNER, R. M.; KOERNER, G. R., 2010)

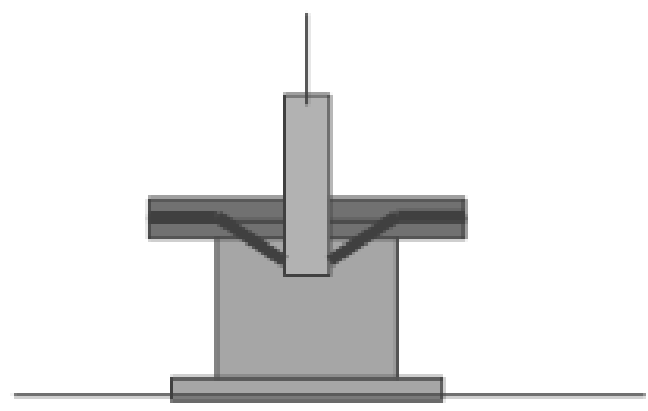

Figura 30 - Ensaio de puncionamento estático (VIDAL, 2002)

\subsubsection{Propriedades hidráulicas}

As principais propriedades hidráulicas a serem consideradas no dimensionamento de geotêxteis com aplicações de filtração, drenagem e controle de fluxo são (VIDAL, 2002):

- Permeabilidade normal à manta; 
- Permeabilidade no plano da manta;

- Fluxo de água;

- Abertura de filtração.

As propriedades hidráulicas sofrem grande influência da compressão a que estão submetidas às mantas geotêxteis, pois a porosidade e a abertura de filtração são afetadas. Desta forma, quando os geotêxteis são selecionados devido a suas propriedades hidráulicas, recomenda-se que seu comportamento seja estudado em ensaios preliminares.

\subsubsection{Permeabilidade normal}

A condutividade hidráulica transversalmente ao plano de um geotêxtil é expressa em termos do coeficiente de permeabilidade normal ao plano, $\mathrm{Kn}(\mathrm{cm} / \mathrm{s})$. A determinação desta propriedade de geotêxteis é realizada através de ensaio padronizado pela norma ASTM D 4491 de 2009 e pela norma ABNT NBR 15223 de 2005. Uma ilustração do ensaio é apresentada na Figura 31:

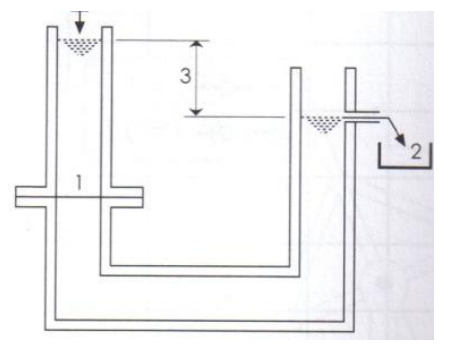

1 - Geotêxtil;

2 - Fluxo constante de água;

3 - Carga hidráulica.

Figura 31 - Arranjo do ensaio para determinação da permeabilidade normal (VERTEMATTI, 2004)

Geotêxteis não tecidos agulhados podem também ter sua permeabilidade estimada a partir de uma adaptação da equação de Kozeny-Carman, normalmente usada para areias. Esta equação considera a influência da porosidade, que por sua vez depende do nível de tensão confinante a que o material está submetido (ver item 3.4.4.3), conforme proposta de Gourc (1982) apud VIDAL (2002): 


$$
\mathrm{Kn} \sim(\rho / \mu) \cdot\left[0,006 \mathrm{df}^{2} \cdot \eta \mathrm{GT}^{3} /(1-\eta \mathrm{GT})^{2}\right]
$$

Sendo:

$\rho$ e $\mu$ - o massa específica $\left(\mathrm{kg} / \mathrm{m}^{3}\right)$ e a viscosidade do fluido $\left(\mathrm{N} . \mathrm{s} / \mathrm{m}^{2}\right)$;

df - o diâmetro da fibra $(\mathrm{m})$;

nGT - a porosidade do geotêxtil (\%).

Os valores da permeabilidade normal variam de 0,003 para alguns geotêxteis tecidos até 0,42 para alguns tecidos (ANEXO B). Costuma-se também definir para os geotêxteis não tecidos (tridimensionais) a permissividade hidráulica - $\Psi\left(\mathrm{s}^{-1}\right)$, dada pela razão entre a condutividade hidráulica normal ao plano e a espessura nominal, permitindo avaliar a facilidade com que o fluido passa através da estrutura do geotêxtil. Esta propriedade varia de 0,05 para geotêxteis tecidos, que podem ser considerados bidimensionais, até $1,5 \mathrm{~s}^{-1}$ geotêxteis tecidos de baixa gramatura (ANEXO B).

\subsubsection{Permeabilidade planar}

A permeabilidade planar é a capacidade de conduzir água pelo plano de um geotêxtil, sendo sua determinação padronizada através de ensaio apresentado pela norma ABNT ISO 12958 (2010). Esta característica é determinada para geotêxteis não tecidos, que são materiais tridimensionais, e normalmente expressa em $\mathrm{cm} / \mathrm{s}$. Uma ilustração do ensaio é apresentada na Figura 32:

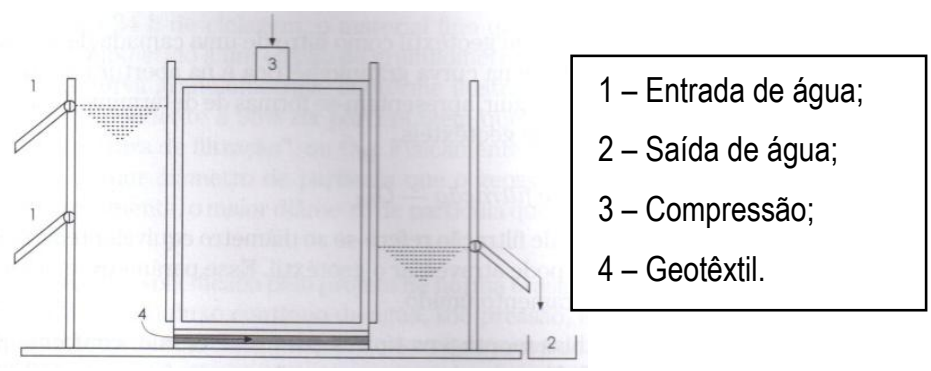

Figura 32 - Arranjo do ensaio para determinação da permeabilidade planar (VERTEMATTI, 2004) 
A influência da compressão na permeabilidade planar de geotêxteis não tecidos foi estudada por Gardoni et al. (1998) apud Vidal (2002). Os resultados apontaram para uma sensível variação desta propriedade para cargas normais de até $200 \mathrm{kPa}$, não apresentando a mesma influência para valores entre 200 kPa e 2000 kPa.

O produto da condutividade hidráulica no plano do geotêxtil por sua espessura é chamado de transmissividade $(\theta)$, expressa em $\mathrm{m}^{2} / \mathrm{s}$ (VERTEMATTI, 2004). Multiplicando-se a transmissividade pela largura do geotêxtil é possível estimar a vazão conduzida pelo material por seu plano.

\subsubsection{Fluxo de água}

O fluxo de água que pode ser drenado por determinado geotêxtil é determinado através de ensaio padronizado pela norma ABNT ISO 15225 (2005), com unidades convencionais de (L/s.m²). Varia entre 3 e 80 L/s.m², sendo que os geotêxteis tecidos possuem os maiores valores de fluxo de água no plano (ANEXO B).

O comportamento do geotêxtil em uma função de drenagem de uma solução de material particulado é diferente do observado durante o ensaio padronizado pela norma, onde se utiliza água. Para a estimativa da propriedade funcional de fluxo ao plano, é importante avaliar o comportamento do material sob as tensões confinantes a que este será submetido em sua aplicação e que a capacidade de fluxo seja estimada com a solução que será drenada, de modo a considerar a interação que ocorre na superfície do geotêxtil, onde os poros são preenchidos pelo material particulado. 
3.4.6.4. Abertura de filtração

Esta propriedade faz referência ao diâmetro da maior partícula que atravessa a superfície de um geotêxtil por seus poros (VERTEMATTI, 2004). A norma ABNT NBR 15229 (2005) padronizou um teste por peneiramento úmido para a determinação desta propriedade, porém, outras normas contemplam ensaios hidrodinâmicos e por peneiramento à seco, entre outros, para a determinação da abertura de filtração (VIDAL, 2002).

Nestes ensaios, uma amostra de material particulado é submetida à filtração pelo geotêxtil durante certo período de tempo, de forma a gerar um número infinito de confrontos entre as partículas e o filtro têxtil. O material particulado que passa pelo geotêxtil tem sua curva granulométrica determinada e o diâmetro maior que $95 \%$ das partículas que passaram pelo geotêxtil é chamado de abertura de filtração ou $\mathrm{O}_{95}$. Esta propriedade varia de 0,2 a 0,3 mm, mas podem ser encontrados geossintéticos com outros valores (ANEXO B). Uma curva granulométrica do material que passou pelo geotêxtil em um ensaio destes é apresentada na Figura 33:

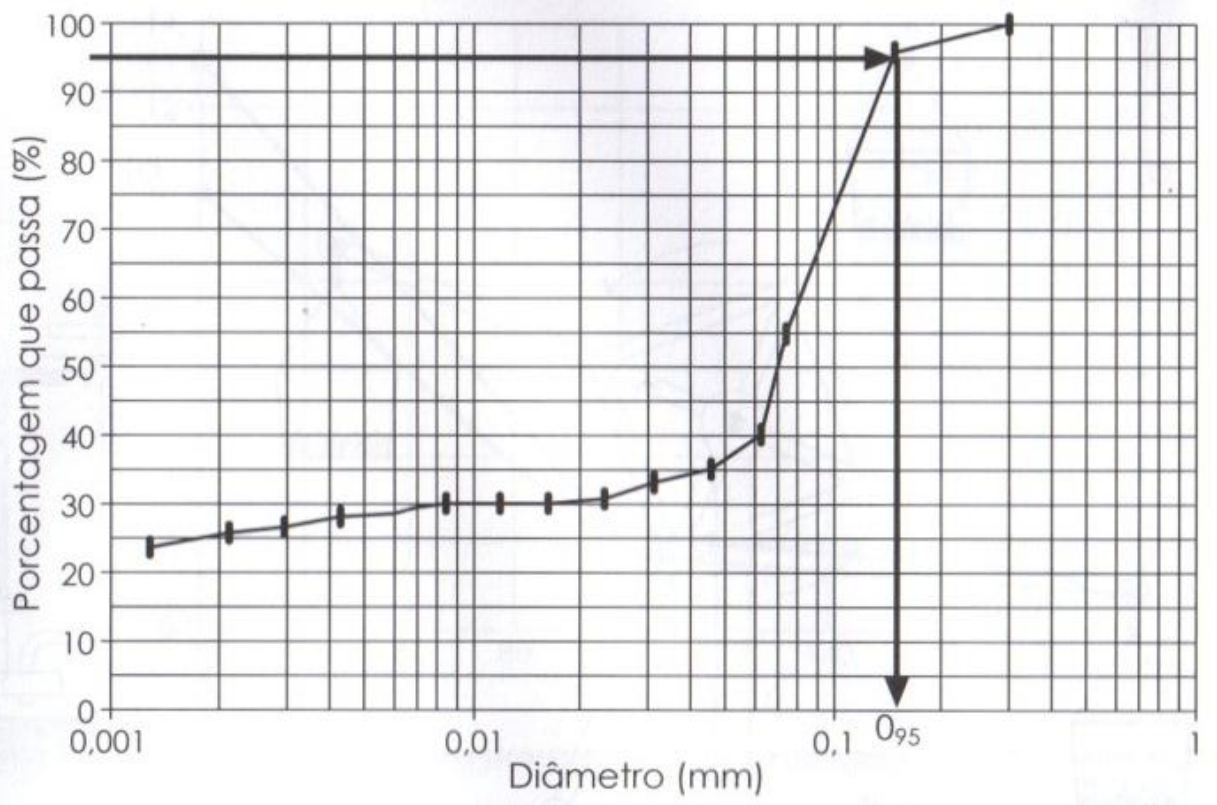

Figura 33 - Determinação da abertura de filtração (VERTEMATTI, 2004) 
Palmeira e Fanin (1998) apud VIDAL (2002) observaram a variação desta propriedade para carregamentos de até $25 \mathrm{kPa}$, com pequena redução dos valores, permanecendo constante para cargas normais superiores.

\subsubsection{Aplicação na filtração}

Os principais objetivos de um filtro são escoar o líquido o mais rápido possível e reter as partículas sólidas. A eficiência um geotêxtil como elemento filtrante entre solos ou outros materiais particulados depende do bom dimensionamento do material e de uma análise crítica das situações impostas pelo ambiente. Dessa forma, o filtro têxtil selecionado para determinada aplicação deve possuir propriedades mecânicas e hidráulicas compatíveis com os requisitos do projeto e ser capaz de manter estas propriedades ao longo do tempo.

A solução em filtração, no caso o lodo, também influencia diretamente o processo. Como visto no item 3.2.2.1, a capacidade de filtração depende da interação dos sólidos da solução em filtração com o meio filtrante. Assim, considerando a formação de arcos de partículas ao redor dos poros do material, a seleção do geotêxtil não deve se basear na seleção de um geotêxtil que possua uma abertura de filtração menor que as menores partículas do lodo. Este procedimento implicaria na seleção de um material que restringisse demasiadamente a permeabilidade do filtro.

Outro mecanismo importante do processo de filtração é a colmatação, que pode ser caracterizada por 3 diferentes processos: bloqueamento, cegamento e colmatação. O bloqueamento ocorre quando partículas de material com diâmetros maiores que os poros fecham a passagem, bloqueando o poro. O cegamento consiste no acúmulo de material em uma camada paralela ao filtro, impedindo o fluxo e a filtração. A colmatação propriamente dita ocorre quando partículas de diâmetro inferior ao dos poros penetram no filtro e ficam retidas ao longo da espessura do material. Normalmente a colmatação é causada pela precipitação de sais no interior do filtro têxtil, diferenciando-se assim dos outros processos citados (Barroso, 2007). 
É importante considerar que, diferentemente de solos, o lodo em filtração é constituído por flocos de estrutura física variável e que se modifica ao longo do tempo. Além disso, a determinação da distribuição granulométrica de lodos é complexa pela alta interferência do método na estimativa dos diâmetros equivalentes dos flocos (BARROSO, 2007). Assim, considera-se que o lodo é um material sem uma distribuição granulométrica definida e que se pode alterar esta característica a partir de técnicas de condicionamento químico (ver item 3.5).

Outro tipo de aplicação de geotêxteis na secagem de lodos é através dos chamados geotubos ou "bags", onde as mantas são costuradas e enchidas de lodo através de bombeamento, possibilitando a drenagem da água livre (MUTHUKUMARAN, 2006; KOERNER, 2006; CANTRÉ, 2010; WORLEY, 2008). Uma diferença essencial entre este método de desaguamento e os leitos de drenagem, que impacta no custo de utilização dos "bags", é que para disposição final do lodo desaguado a manta deve ser cortada e não pode ser reutilizada.

Segundo Fontana (2007), as mantas geotêxteis tecidas e não tecidas apresentam características semelhantes de drenagem da água livre, porém, para a condição de manejo dos sólidos residuais a manta geotêxtil tecida de polipropileno se apresenta mais adequada por não apresentar impregnação de materiais graxos e oleosos presentes nos lodos. Além disso, as mantas tecidas apresentam menor desgaste em operações seguidas de limpeza (Fontana, 2008).

\subsubsection{Dimensionamento de filtros têxteis}

O dimensionamento de um geotêxtil para filtração compreende a seleção de um material que resista às solicitações mecânicas da implantação e operação do sistema e atenda aos critérios de retenção e de permeabilidade ao longo de sua vida útil. Estes critérios foram desenvolvidos e são aplicados para a utilização de geotêxteis na filtração de solos, devendo ser avaliados se podem ser utilizados para o desaguamento de lodos. 
Os critérios baseados na retenção de sólidos são divididos em empíricos e racionais. Um dos critérios empíricos mais citados, baseado na retenção de sólidos, é o do Comitê Francês de Geotêxteis e Geomembranas (VIDAL, 2002). Para o dimensionamento racional de geotêxteis aplicados na retenção de sólidos, a teoria probabilística é bastante citada. Neste método, a partir da distribuição granulométrica do lodo e da distribuição de diâmetros de poros do geotêxtil, é determinada a probabilidade de uma partícula de tamanho definido ficar retida no material. Assim, definindo a menor partícula que deve ficar retida, determina-se a porosidade do geotêxtil que vai reter a quantidade desejada de sólidos (URASHIMA; VIDAL, 1995; SILVEIRA, 1993; VIDAL, 2002; URASHIMA, 1996).

Outro critério empírico utilizado no dimensionamento de geotêxteis aplicados na filtração de solos é com base na permeabilidade do geotêxtil e do solo. Este critério recomenda que o geotêxtil selecionado possua permeabilidade maior que a do solo, multiplicada por um coeficiente definido pelos autores e que deve ser reavaliado para a utilização deste critério no desaguamento de lodos (VERTEMATTI, 2004; VIDAL, 2002):

$$
\mathrm{Kn} \mathrm{GT}>y \cdot \mathrm{Kn}
$$

\section{Sendo:}

Kn GT - condutividade hidráulica normal ao plano do geotêxtil;

$y$ - um fator proposto pelos autores dos critérios;

$\mathrm{Kn}$ - condutividade hidráulica do material em filtração, em m/s. 


\subsection{Condicionamento de lodos}

O condicionamento é uma técnica utilizada para acelerar o processo de retirada da água presente no lodo. Esta técnica melhora a separação das fases sólido-líquido do lodo pela formação de flocos maiores e mais densos e, portanto, com menos água e maior velocidade de sedimentação.

O condicionamento é normalmente realizado por métodos químicos, já que os métodos físicos de congelamento ou aquecimento requerem grandes quantidades de energia em locais menos apropriados (USEPA, 1978). Os métodos de condicionamento podem ser divididos em inorgânicos e orgânicos, dependendo do tipo de produto utilizado, e normalmente possuem boa eficiência, independentemente da localidade.

Os principais condicionantes inorgânicos utilizados para o desaguamento de lodos são a cal, na forma de hidróxido, e sais de íons metálicos, como o ferro e o alumínio. Os outros condicionantes amplamente utilizados são polieletrólitos orgânicos sintéticos, comumente chamados de polímeros (MIKI, 1998).

A aplicação de condicionantes antes do desaguamento do lodo tem como objetivos principais formar flocos que se separem bem da água, formar uma torta porosa e permeável para rapidamente perder água por filtração, e formar um material com elevado teor de sólidos (MARINETTI, 2010). Segundo Novak e O'Brien (1975), o condicionamento de lodos pode diminuir o tempo de desaguamento, os custos com equipamentos e os custos operacionais.

A eficácia de um determinado condicionante depende da iteração entre as partículas do produto e a superfície dos sólidos presentes. Assim, a escolha de um produto, orgânico ou inorgânico, que proporcione um bom condicionamento para determinado lodo é feita utilizando-se os ensaios descritos no item 3.2.3. 


\subsubsection{Condicionamento inorgânico}

De acordo com Miki (1998), o condicionamento inorgânico é normalmente realizado através da adição de sais férricos, ferrosos e de alumínio ou óxidos e hidróxidos de cálcio ao lodo. Os produtos mais utilizados são a cal e o cloreto férrico, pois são eficazes no condicionamento de diversos tipos de lodos e amplamente disponíveis no mercado.

O mecanismo de ação dos condicionantes inorgânicos é a coagulação, resultante da adsorção do material na superfície do lodo, neutralização de cargas e compressão da dupla camada. Ainda segundo Miki (1998), os condicionantes inorgânicos têm sua ação baseada nos conceitos químicos da reação entre ácidos e bases, da solubilidade e da precipitação química. O mesmo autor ainda destaca que o cátion exerce importância fundamental no condicionamento por sais inorgânicos, mas que o ânion também tem seu papel no processo de coagulação.

A escolha e utilização de um condicionante orgânico ou inorgânico devem ser realizadas com base em estudos técnicos e econômicos. Um dos fatores que tem levado à rejeição da tradicional utilização de sais metálicos é a grande incorporação de massa ao lodo a ser desaguado, que pode aumentar em até $40 \%$. Os produtos inorgânicos são utilizados há décadas com sucesso no condicionamento de lodos antes do desaguamento, porém o uso de polieletrólitos orgânicos aumentou muito nas últimas décadas.

\subsubsection{Condicionamento inorgânico + orgânico}

O condicionamento inorgânico pode ser realizado em conjunto com o orgânico e Novak (1979) mostrou o benefício dessa prática que utiliza pequenas doses de sais metálicos, evitando o grande aumento da massa do material que vai para disposição final. 
Novak e Haugan (1979) avaliaram a eficiência do condicionamento de lodos oriundos de processos de lodos ativados e compararam as melhores dosagens de alguns polímeros orgânicos, com e sem a adição de condicionantes inorgânicos. Segundo o autor, a utilização de sais inorgânicos ou lodos de ETA's que utilizam o alumínio como coagulante possui influência benéfica na redução da dose necessária de condicionante orgânico e do tempo de drenagem, mesmo que inicialmente diminuindo levemente as taxas de filtração.

A teoria que embasa os resultados deste estudo é que os biopolímeros aniônicos naturalmente presentes no lodo são os grandes responsáveis pela presença de cargas superficiais e consumo de condicionantes (NOVAK; HAUGAN, 1979). Assim, os sais metálicos adicionados em conjunto com os polímeros orgânicos possuiriam grande capacidade de se adsorver a estes produtos e desestabilizar as partículas coloidais, diminuindo as doses "ideais" e melhorando as características de desaguamento do lodo. Outras descrições teóricas e explicações sobre esta prática não foram encontradas em estudos mais recentes, porém, Miki (1998) verificou em testes práticos algumas vantagens proporcionadas pelo condicionamento inorgânico somado com orgânico, em relação ao desprendimento da torta em filtros prensa de placas.

\subsubsection{Condicionamento orgânico}

Polieletrólitos orgânicos são comumente chamados de polímeros, por serem constituídos de monômeros ionizáveis que se repetem ao longo de uma cadeia linear ou ramificada do produto. Normalmente são descritos como polímeros sintéticos, para diferenciá-los de polímeros orgânicos naturais.

Os polieletrólitos podem ser encontrados em diversas formas físicas, entre elas as mais comuns são em emulsão, em pó (sólida) e líquida, mas podem também ser encontrados na forma de gel e solução do tipo "mannich" (WPCF, 1991 apud MIKI, 1998). Normalmente são compostos por moléculas grandes, de peso molecular que varia de baixo $\left(10^{3} \mathrm{~g} / \mathrm{mol}\right)$ até alto $\left(10^{6} \mathrm{~g} / \mathrm{mol}\right)$, com cargas iônicas devido à presença 
de grupos ionizáveis distribuídos ao longo da molécula, também chamados de sítios ativos, que lhe conferem a característica de aniônico, não iônico ou catiônico.

A matéria prima para a produção de polieletrólitos é, normalmente, a monoacrilamida, que carregada de cargas elétricas é ligada uma a outra formando um polímero de cadeia longa.

As principais vantagens de condicionantes orgânicos em relação a inorgânicos são (WPCF, 1988 apud MIKI, 1998):

- Proporcionar redução de custos com o condicionamento;

- Menor produção de lodo devido à menor quantidade de sólidos acrescentados;

- Constituem um incremento de energia quando o lodo é incinerado;

- Eliminam problemas de manuseio e estocagem de grandes volumes, associados ao uso de Cal, e de corrosão, associada aos sais de ferro.

Os polímeros normalmente usados no condicionamento de lodos de ETE's são catiônicos e na maioria dos casos têm bom desempenho e melhoram a capacidade de drenagem do material. Devido à presença natural de biopolímeros aniônicos no lodo, os polímeros catiônicos possuem uma maior eficiência, pois neutralizam a carga destas moléculas e criam pontes de ligação que diminuem a capacidade de retenção da água livre e adsorvida. Já os polímeros aniônicos e não-iônicos se combinam com estes biopolímeros e se tornam ineficazes ou por vezes pioram a capacidade de desaguamento do lodo (WPCF, 1983).

O peso molecular dos polímeros também exerce influência significativa na eficácia do condicionamento, sendo que há bastante tempo os polímeros de alto peso molecular são conhecidos por conferirem ao lodo melhores características de desaguamento (GRANDIN, 1992; NOVAK, O'BRIEN, 1975; WANG, 1996). 


\subsubsection{Mecanismo de floculação dos polímeros}

Segundo Grandin (1992), os polieletrólitos aderem às superfícies das partículas do lodo causando a dessorção de água livre e intersticial, a neutralização da carga e a aglomeração de pequenas partículas. O resultado é a formação de uma torta permeável que libera água mais facilmente. Miki (1998) descreve a interação física entre o polímero e o lodo a ser condicionado como resultante de 6 reações, explicadas e ilustradas a seguir:

\section{Adsorção inicial do polímero}

O contato entre as partículas do lodo e o polímero resulta na neutralização das cargas superficiais e na desestabilização da partícula, conforme Figura 34:

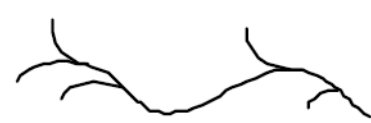

Polímero

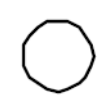

Partícula

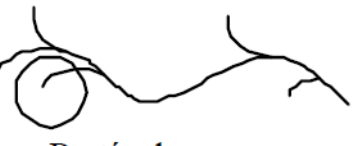

Partícula desestabilizada

Figura 34 - Adsorção inicial do polímero (MIKI, 1998)

\section{Formação do floco}

O floco é constituído de partículas desestabilizadas que se chocaram e suas superfícies ficaram aderidas com ajuda da cadeia polimérica do condicionante. As partículas se chocam quanto maior a mistura no reator, desde que a quebra de flocos não ocorra em grande escala. Esta reação é ilustrada na Figura 35: 


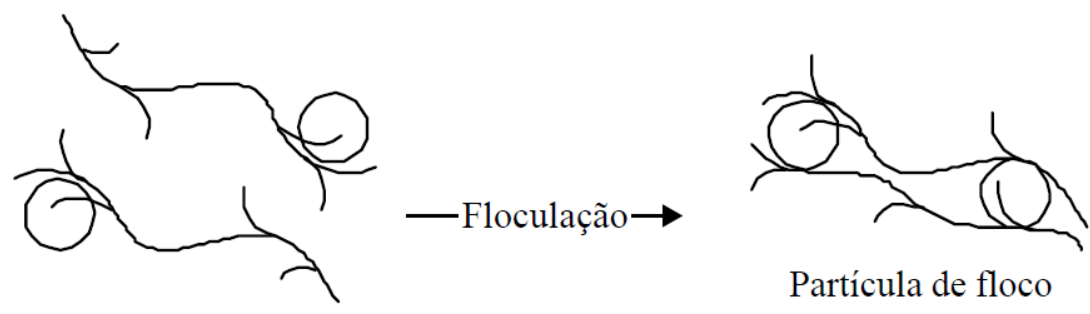

Partículas

Desestabilizadas

Figura 35 - Formação do floco (MIKI, 1998)

\section{Adsorção secundária do polímero}

Essa reação depende da presença de um excesso de polímero, de modo que sítios ativos que não se chocam com partículas acabam por aderirem em excesso a uma mesma superfície, conforme ilustrado na Figura 36:

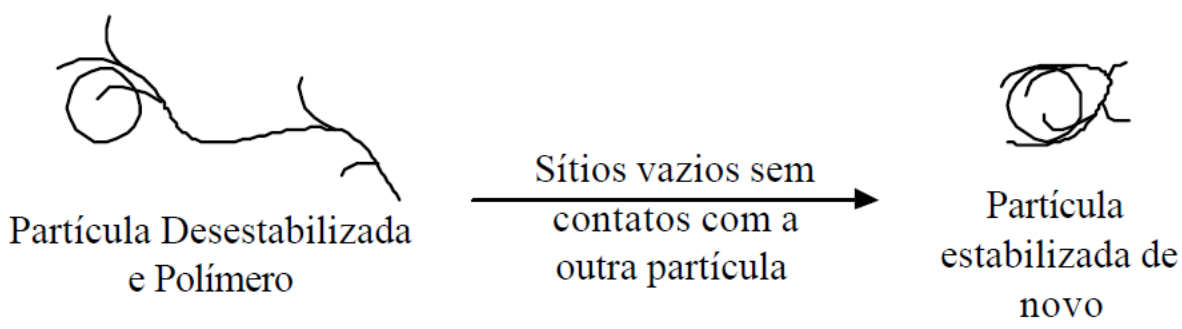

Figura 36 - Adsorção secundária do polímero (MIKI, 1998)

\section{Adsorção inicial com excesso de polímero}

A dosagem excessiva de polímeros é um desperdício de matéria prima e recursos e, ainda, pode causar efeitos adversos como a diminuição da taxa de filtração (CHRISTENSEN et al.,1993). A causa do encontro de poucas partículas com muito polímero pode ser a aplicação de polímero em excesso, sem prévia diluição adequada ou sem mistura suficiente após adição do condicionante. O mecanismo desta reação é apresentado na Figura 37: 


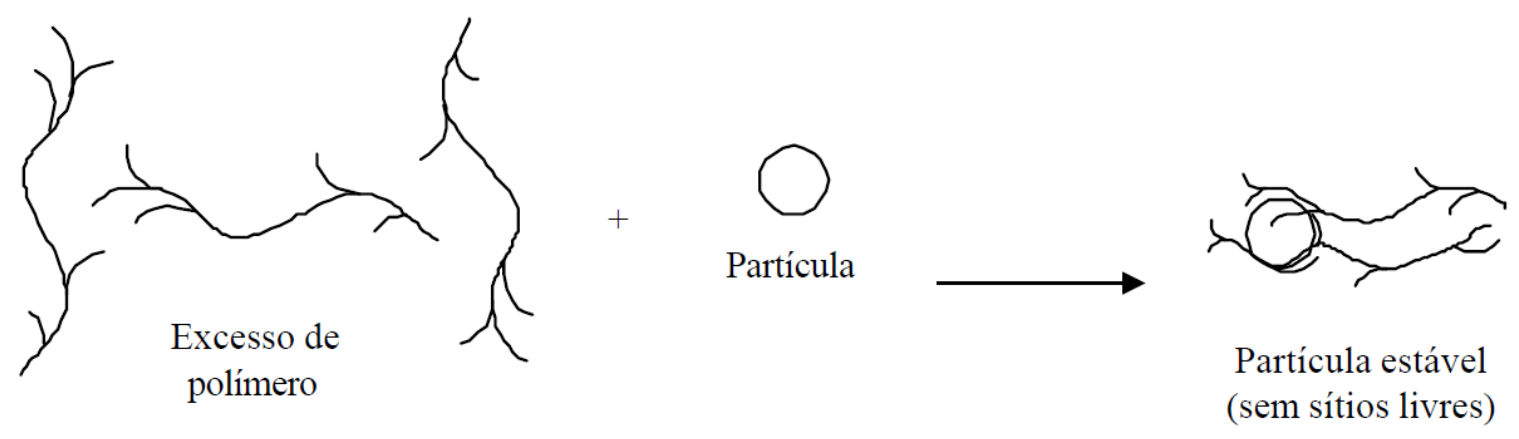

Figura 37 - Adsorção inicial com excesso de polímero (MIKI, 1998)

\section{Quebra do floco}

A quebra de flocos em partículas menores e de difícil sedimentação é resultado de condições de mistura excessivas, ou por tempo ou por gradiente hidráulico acima do ideal. O mecanismo da quebra de flocos é apresentado na Figura 38:

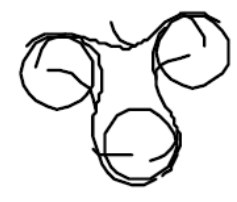

Floco de partícula estabilizado

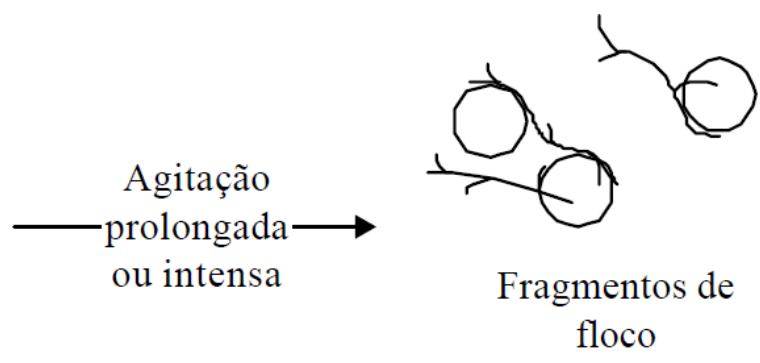

Figura 38 - Quebra do floco (MIKI, 1998)

\section{Readsorção secundária}

Este processo é normalmente decorrente de condições de alta energia de mistura, onde os flocos foram quebrados e passam a serem readsorvidos pelos sítios ativos remanescentes do polímero. Segundo Miki (1998), esta reação é frequente em equipamentos mecanizados de desaguamento de lodos, como filtros prensas de esteiras e centrífugas, e é ilustrada na Figura 39: 


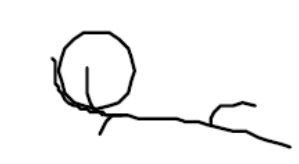

Fragmento de floco

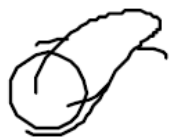

Fragmento de floco estabilizado de novo

Figura 39 - Readsorção secundária (MIKI, 1998)

\subsubsection{Efeito das condições de preparação e aplicação}

As principais variáveis operacionais do processo de condicionamento são a energia e o tempo de mistura aplicada ao polímero, em sua preparação, e ao lodo, durante e após a adição do condicionante.

\section{Preparação do polímero}

O condicionante orgânico é normalmente comercializado em formas concentradas e deve ser diluído para aplicação no lodo. A diluição do polímero pode ser feita em água potável e é comumente referida como abertura da cadeia, assim como a solução diluída é chamada de solução de aplicação (CIBA, 2006). A concentração em que deve ser diluído o polímero é determinada pelo fabricante, porém, devem ser evitadas razões de dosagem volumétricas de solução estoque ao lodo muito altas (MIKI, 1998).

A diluição do polímero na água deve levar em conta que valores de gradiente hidráulico elevados provocam a quebra das cadeias poliméricas e valores reduzidos não provocam a diluição total e homogênea do polímero no solvente. A duração deste processo de abertura da cadeia do polímero também interfere na sua boa diluição e tempos de mistura baixos provocam uma má diluição e a deposição de uma parcela do produto nas paredes da unidade de preparação.

A intensidade e o tempo de mistura necessários à preparação de cada polímero são especificados pelo fabricante. Porém, algumas observações devem ser realizadas 
durante o procedimento de diluição para verificar se a preparação do polímero foi adequada. A formação de olhos de peixe, como descrito por Miki (1998), e a formação de uma camada mais densa de polímero aderida às paredes da unidade de mistura demonstram uma baixa diluição do produto e que a solução deve ser descartada, pois pode não possuir a mesma eficiência de uma solução bem preparada.

\section{Aplicação do polímero}

Durante a adição do condicionante, o lodo deve ser mantido em agitação para que o polímero não fique aderido às paredes e ao fundo do dispositivo de mistura. $A$ mistura entre o polímero e o lodo tem o objetivo de dispersar de forma homogênea o produto químico. Segundo Miki (1998), em ensaios em laboratório que utilizam o Teste de Jarros, a agitação deve ser mantida por um período de tempo de cerca de 1 minuto e as razões de dosagem devem ficar entre 0,1 e 0,01 (MIKI, 2010).

A aplicação do polímero, segundo Grandin (1992), pode ser realizada por dispersão em linha ou em tanques de reação. A aplicação do polímero na linha que alimenta o tanque de condicionamento requer a utilização de um misturador estático, que promova a turbulência necessária à homogeneização. A utilização de tanques de contato deve prever a necessidade de acumulação de certo volume lodo antes do condicionamento, para garantir a dosagem especificada. Assim, o sistema funciona em bateladas e tanques de equalização devem ser previstos.

A mistura imposta durante a dispersão do polímero no lodo deve considerar os métodos de transporte e desaguamento que compõem o tratamento da fase sólida em cada ETE, de modo que a mistura imposta não seja muito inferior às condições de agitação a que o lodo será submetido na sequência do tratamento. Isso ocorre, pois o excesso de agitação posterior ao condicionamento pode quebrar os flocos formados, piorando as características de desaguamento do lodo. Por outro lado, aplicar gradientes hidráulicos acima dos impostos pelos métodos de desaguamento pode aumentar a necessidade de condicionante (ver item 3.5.3.4). 


\subsubsection{Determinação das melhores dosagens}

Devido ao mecanismo de ação dos polímeros (ver item 3.5.3.1), o consumo de produtos químicos depende essencialmente da quantidade de sólidos presentes num certo volume de lodo. Assim, as dosagens de condicionantes são normalmente estabelecidas em gramas $(\mathrm{g})$ de condicionante por quilograma $(\mathrm{kg})$ de sólidos secos no lodo.

Diversos pesquisadores realizaram ensaios para determinação das melhores doses de polímeros em lodos a serem tratados em diferentes métodos de desaguamento, entre eles podem ser citados os trabalhos de Wanke (2005) e Miki (1998). Nestes estudos, as melhores dosagens foram estimadas em laboratório e validadas em testes em escala real ou piloto. Para a estimativa inicial, em laboratório, são selecionados alguns produtos do mercado (ver item 3.5.3.5) e diferentes doses de cada polímero são aplicadas em diferentes amostras de lodo. Os efeitos na melhoria da capacidade de desaguamento de cada amostra de lodo condicionado são verificados através dos ensaios descritos no item 3.2.3. Assim, a dose que resulta na melhor característica de drenagem pode será, neste estudo, designada como a "dose ideal".

As dosagens "ideias" de polímeros orgânicos são menores que de condicionantes inorgânicos, variando normalmente de 1 a $10 \mathrm{~g} / \mathrm{kg}$ (ANDREOLLI, VON SPERLING e FERNANDES, 2007; ANDREOLI, 2001) e podendo chegar até $21 \mathrm{~g} / \mathrm{kg}$ para lodos com piores características iniciais de desaguamento (ABU-ORF; OMERCI, 2005).

A dose de polímero necessária para que uma amostra de lodo atinja sua maior capacidade de desaguamento é tão maior quanto pior for a capacidade de perder água do lodo antes de seu condicionamento. Assim, considerando duas amostras de lodo de origem distintas com o mesmo teor de sólidos, o consumo de produto químico, para que ambas atinjam as mesmas velocidades de retirada da água do lodo, será maior na amostra com pior capacidade de desaguamento inicial. 
Os ensaios para determinação da "dose ideal" devem ser realizados com o próprio lodo da ETE, pois cada lodo possui características específicas. No caso do projeto de novas ETE's, pode ser utilizado um lodo semelhante em termos de processo de tratamento biológico e de tipo de digestão (aeróbio ou anaeróbio).

Os ensaios laboratoriais têm normalmente o equipamento de Teste de Jarros como gerador do gradiente hidráulico de mistura do polímero ao lodo, sendo que a rotação e o tempo de mistura são controlados pelo responsável pelo teste, de acordo com a intensidade de mistura (Gt) que se pretende avaliar.

Além disso, deve-se considerar a utilização de um método de avaliação da capacidade de drenagem que possua certa similaridade com o processo de desaguamento da ETE cujo lodo está sendo ensaiado.

\subsubsection{Fatores que interferem na avaliação do efeito do condicionamento}

\section{Condição de mistura}

Diversas contribuições acadêmicas descreveram a influência de diferentes condições de mistura na determinação das melhores dosagens e na facilidade de filtração do lodo (NOVAK, 1980; 1984; 1988; MARINETTI, 2010; DENTEL, 2009; WANG, 2010; OMERCI, 2007; 2009; SEYSSIECQ, 2003). Muitos destes já foram realizados há algum tempo, mas permanecem como referências de pesquisas mais atuais sobre 0 assunto.

Segundo Werle et al (1984) e Novak e Haugan, (1980), o excesso de agitação na dispersão do polímero eleva a necessidade de condicionante e aumenta os custos com o processo. Em outro estudo, Novak e Bandak (1989) mostram que existe um gradiente hidráulico máximo acima do qual os flocos se quebram e a taxa de filtração para a mesma dosagem diminui. Os autores mostram também que doses elevadas de polímero podem atenuar este efeito, dando maior estabilidade ao lodo submetido a forte agitação. 


\section{Variação sazonal da qualidade do lodo}

O lodo gerado em uma mesma ETE possui características diferentes em cada descarte que é realizado da fase líquida para a fase sólida. Considerando que a qualidade do lodo gerado depende da qualidade do esgoto afluente à ETE, a qualidade do lodo sofre variações que seguem ciclos anuais, mas também podem sofrer variação semanal e até diária, dependendo das condições operacionais da ETE.

Assim, mesmo se os teores de sólidos permanecerem constantes a cada novo descarte de sólidos, as doses "ideais" podem variar pela variação de outras características do lodo. Dessa forma, recomenda-se que novas campanhas de avaliação do efeito da dosagem sejam realizadas periodicamente.

Como alternativa às campanhas periódicas de avaliação das diferentes doses, os parâmetros que possuam grande correlação com a capacidade de drenagem do lodo podem ser monitorados e as dosagens serem automatizadas em função deste monitoramento (ver item 3.2.2.10). Neste caso, as campanhas de avaliação da "dose ideal" devem ser utilizadas para calibração do sistema de dosagem automática.

\section{Presença de sais inorgânicos}

A presença de sais é indispensável para um bom condicionamento e a variabilidade da eficiência deste processo ao sazonalmente pode ser atribuída, entre outros fatores, à variação da concentração destes sais ao longo do dia e do ano (WPCF, 1983). Porém, apesar de presença obrigatória, o excesso de sais pode aumentar o valor das melhores doses e o consumo de polímero que é adicionado para melhorar as características de desaguamento. Isso ocorre, pois, o excesso de sais faz com que os polímeros adicionados ao lodo se tornem ineficazes e não formem ligações com as partículas. Neste caso, seria necessário estudar métodos para precipitação e remoção do excesso de sais antes do condicionamento do lodo (WPCF, 1983). 


\subsubsection{Fatores que interferem na seleção dos polímeros}

Algumas características do lodo influenciam na aptidão que cada polímero possui no seu condicionamento. Assim, cada produto de cada fabricante de polímeros possui uma eficácia diferente e, portanto, uma "dose ideal" diferente.

Segundo Metcalf e Eddy (1991), os processos de tratamento que deram origem ao lodo são os primeiros indicadores do tipo de condicionante que possui maior eficácia no condicionamento do lodo (ver item 3.2.2), assim como da faixa em que se pode encontrar as melhores dosagens de condicionante. Assim, a origem do lodo pode ser um indicativo de qual a carga dos polímeros que devem ser testados em determinado lodo e também, com base na literatura sobre doses ótimas, podem ser estimados os custos e a viabilidade de implantação do processo de condicionamento.

Além disso, $\mathrm{o} \mathrm{pH}$ e alcalinidade são importantes parâmetros químicos no condicionamento de lodos e exercem papel fundamental na cinética de floculação, por serem responsáveis pelas cargas superficiais das partículas presentes no lodo (WPCF, 1988, apud Miki, 1998).

Segundo Spellman (1997), se o pH do lodo é elevado, naturalmente ou por motivos de condicionamento com Cal, um polímero aniônico é mais aconselhável e se um lodo apresenta $\mathrm{pH}$ um pouco acima ou abaixo do neutro, a utilização de um polímero catiônico deve produzir melhores resultados.

A alcalinidade, diferentemente do $\mathrm{pH}$, não influencia diretamente na seleção do polímero, mas, como no condicionamento químico os produtos utilizados se comportam como ácidos em meio aquoso, a alcalinidade exerce um efeito tampão e impede que o pH se altere e as doses de condicionante se modifiquem (MIKI, 1998). 


\section{MATERIAL E MÉTODOS}

\subsection{Ensaios laboratoriais}

Os ensaios laboratoriais foram conduzidos com o objetivo determinar o polímero e o geotêxtil que seriam utilizados nos testes em escala piloto. Para isso, foram selecionados 18 polímeros das marcas CIBA, ASHLAND, SNF e KEMIRA para condicionamento do lodo e 5 mantas geotêxteis, 3 tecidas e 2 não tecidas, de 4 fabricantes diferentes (MACCAFERRI, HUESKER, BIDIM e PROPEX).

\subsubsection{Origem do lodo}

O lodo anaeróbio de reatores UASB utilizado nos ensaios de laboratório foi coletado em duas ETE's distintas. Inicialmente, foi utilizado lodo proveniente da ETE de Ribeirão Pires, operada pela SABESP. Com a desativação desta ETE, no fim de 2009, passou-se a utilizar lodo da ETE de Jaraguá, também operada pela SABESP.

A Estação de Tratamento de Esgotos de Ribeirão Pires se localiza na Rua Ada Mortari, sem número, em Ribeirão Pires, cidade da Região Metropolitana da Cidade de São Paulo. Esta ETE é composta por grade, caixa de areia, 4 reatores anaeróbios tipo UASB e 4 leitos de secagem de lodo. A capacidade desta ETE era de $70 \mathrm{~L} / \mathrm{s}$, porém, durante os estudos, a vazão afluente foi sendo reduzida pelo bombeamento dos esgotos da região para a ETE ABC (Estação de Tratamento de Esgotos ABC, também operada pela SABESP) até que no final de 2009 a Estação passou a não receber mais efluentes e foi desativada.

A ETE de Jaraguá está localizada na Estrada Turística do Jaraguá, número 8, no bairro de mesmo nome da Zona Oeste da Cidade de São Paulo. A ETE é composta por grade, caixa de areia, 4 reatores UASB, 2 reatores aerados com biodisco rotativo 
e um sistema de cloração para desinfecção antes do lançamento no corpo d'água. Como a ETE não possui estruturas de tratamento da fase sólida, o lodo gerado é encaminhado por caminhão tanque para a ETE Barueri.

\subsubsection{Coleta e preparação do lodo}

O lodo foi coletado em recipientes de 20 litros na canalização de distribuição de lodo para os leitos de secagem ou em tomadas de lodo dos reatores anaeróbios. Para manter a concentração de sólidos das diferentes amostras de lodo próximas, o lodo coletado foi descartado quando possuía menos que $15 \mathrm{~g} / \mathrm{L}$, ou, quando a aparência do lodo se apresentava excessivamente espessa, uma porção de efluente tratado foi coletada para utilização na diluição. As concentrações de sólidos utilizadas variaram entre 17 e $30 \mathrm{~g} / \mathrm{L}$. Fotos das coletas em Ribeirão Pires são apresentadas na Figura 40:
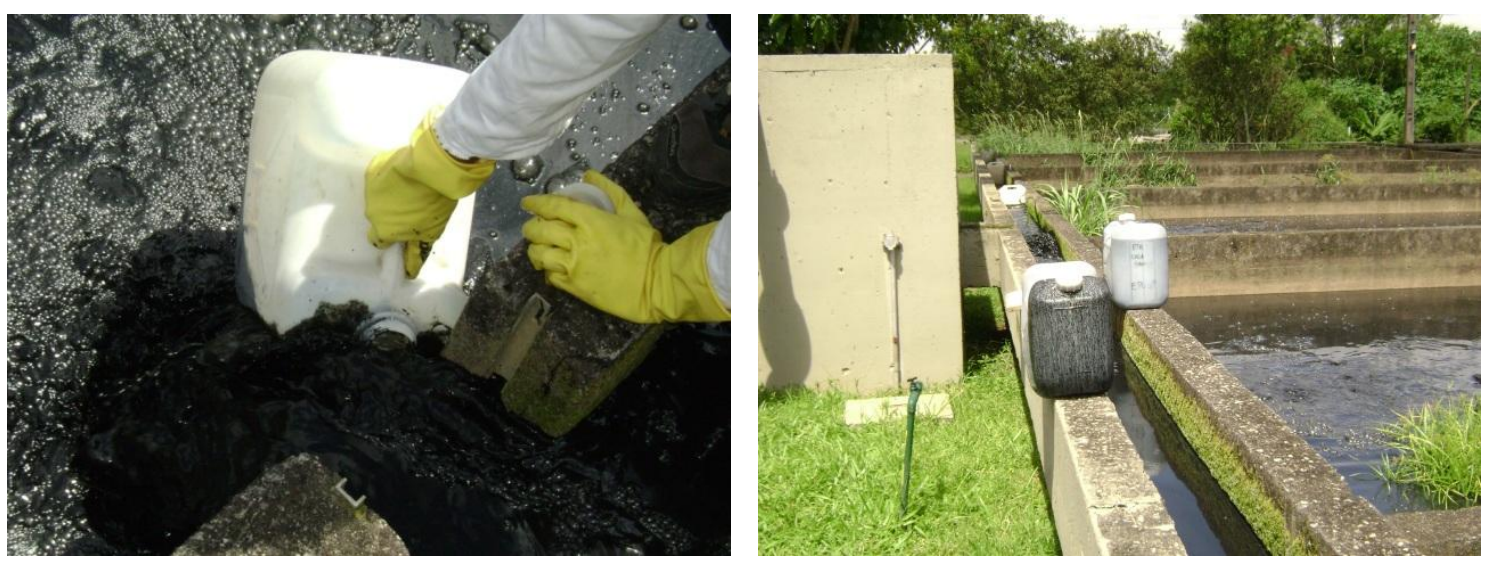

Figura 40 - Coleta de lodo na ETE de Ribeirão Pires

Os recipientes com 20 litros de lodo ou efluente tratado, assim que trazidos das ETE's, eram agitados para homogeneizar a mistura e tinham a concentração de sólidos totais $(\mathrm{g} / \mathrm{L})$ determinada em triplicata. Se um dos resultados fosse muito disperso, este era descartado, usando-se os outros dois dados para o cálculo da média da concentração de sólidos no lodo coletado. O lodo foi utilizado nos testes laboratoriais em no máximo 40 dias após a coleta. 
Determinadas as concentrações de sólidos nos galões de coleta, cerca de 4 litros de lodo eram adicionados, ou de uma mistura proporcional de lodo e efluente tratado, à recipientes de 5 litros. Nestes recipientes, o lodo era mantido em agitação, através de agitador magnético, e eram retiradas (com auxílio de béquer, proveta e cápsulas de porcelana) três amostras para colocar na estufa de secagem para nova determinação do teor de sólidos. Este novo valor de teor de sólidos é que foi utilizado nos cálculos dos volumes de lodo e de solução de polímero a serem utilizados nos ensaios laboratoriais.

Este procedimento teve o objetivo de evitar os erros metodológicos verificados nos testes preliminares com o TTD pela alteração da concentração de sólidos ao longo de retiradas sucessivas de lodo do recipiente de 20 litros (APÊNDICE 1). Os recipientes de 20 litros utilizados na coleta de lodo e os de 5 litros utilizados na homogeneização do lodo estão apresentados na Figura 41:
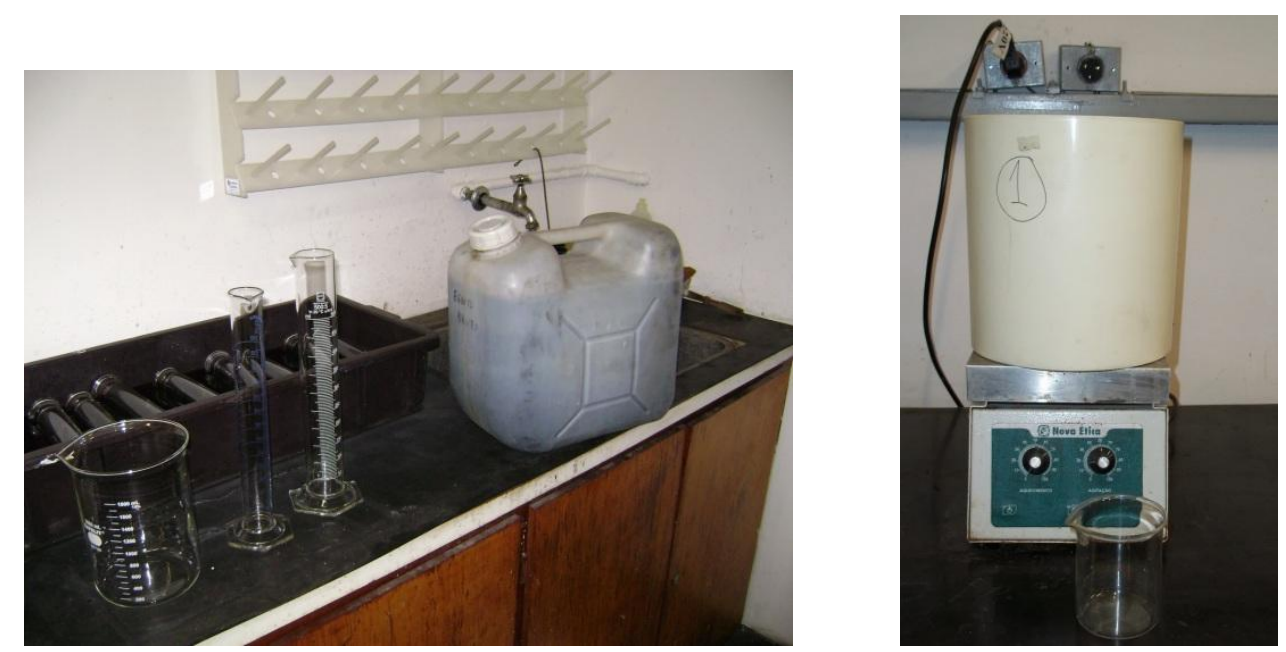

Figura 41 - Galão de 20 litros com lodo coletado (esquerda) e lodo em agitação para análise do teor de sólidos no recipiente de 5 litros (direita)

Para os ensaios com o Teste do Tempo de Drenagem, o lodo do recipiente de 5 litros foi homogeneizado através de mistura com auxílio de um béquer de 2 litros de volume. Este mesmo béquer foi utilizado para encher uma proveta de $500 \mathrm{~mL}$ até o volume que seria utilizado em cada jarro de 1 litro do equipamento de Teste de Jarros, de acordo com as diferentes dosagens que foram testadas (ver item 4.1.4). 


\subsubsection{Preparação do polímero}

Os polímeros eram preparados no equipamento de Teste de Jarros em diluições que variaram de 1 a $4 \mathrm{~g}$ do produto por litro, para manter a razão volumétrica de dosagem entre 0,004 e 0,2. Os fabricantes dos polímeros que indicavam faixa de diluição diferente da utilizada foram consultados, não fazendo qualquer objeção.

A quantidade desejada de polímero era adicionada, de forma cuidadosa, a $500 \mathrm{~mL}$ de água já em mistura no equipamento de Teste de Jarros, evitando-se que o polímero entrasse em contato com as paredes ou eixo e hélice do equipamento. Os polímeros em emulsão eram adicionados da mesma forma, mas antes era retirado o mesmo volume acrescentado.

A rotação da hélice de mistura do Teste de Jarros na diluição de todos os polímeros foi fixada em $250 \mathrm{rpm}$. Essa rotação de mistura gera um gradiente hidráulico de cerca de $1500 \mathrm{~s}^{-1}$, se desconsiderada a mudança de viscosidade resultante da adição de polímeros. Os tempos de mistura para abertura da cadeia foram orientados pela observação visual do polímero em diluição, sendo que polímeros sólidos precisam de tempos relativamente superiores aos polímeros em emulsão. Os polímeros em emulsão já adquiriam a aparência homogênea, o que denotava que estavam completamente diluídos, em cerca de 30 minutos, enquanto que os polímeros sólidos necessitavam de tempos entre 60 e 120 minutos. Isto seguiu em parte as recomendações dos fabricantes (Anexo A).

As soluções diluídas de polímero foram analisadas visualmente para verificar a formação de parcelas excessivamente concentradas tanto nas paredes dos recipientes de preparação quanto em suspensão, pela presença de "olhos de peixe" (ver item 3.5.3.2), e as que os possuíam eram descartadas.

As soluções utilizadas eram armazenadas brevemente em béquer de 1 litro e dosadas ao lodo com o auxílio de seringas de $3 \mathrm{~mL}$ e provetas de 100 e $250 \mathrm{~mL}$. O Anexo A contém as principais características dos polímeros testados, que estão apresentados na Figura 42: 


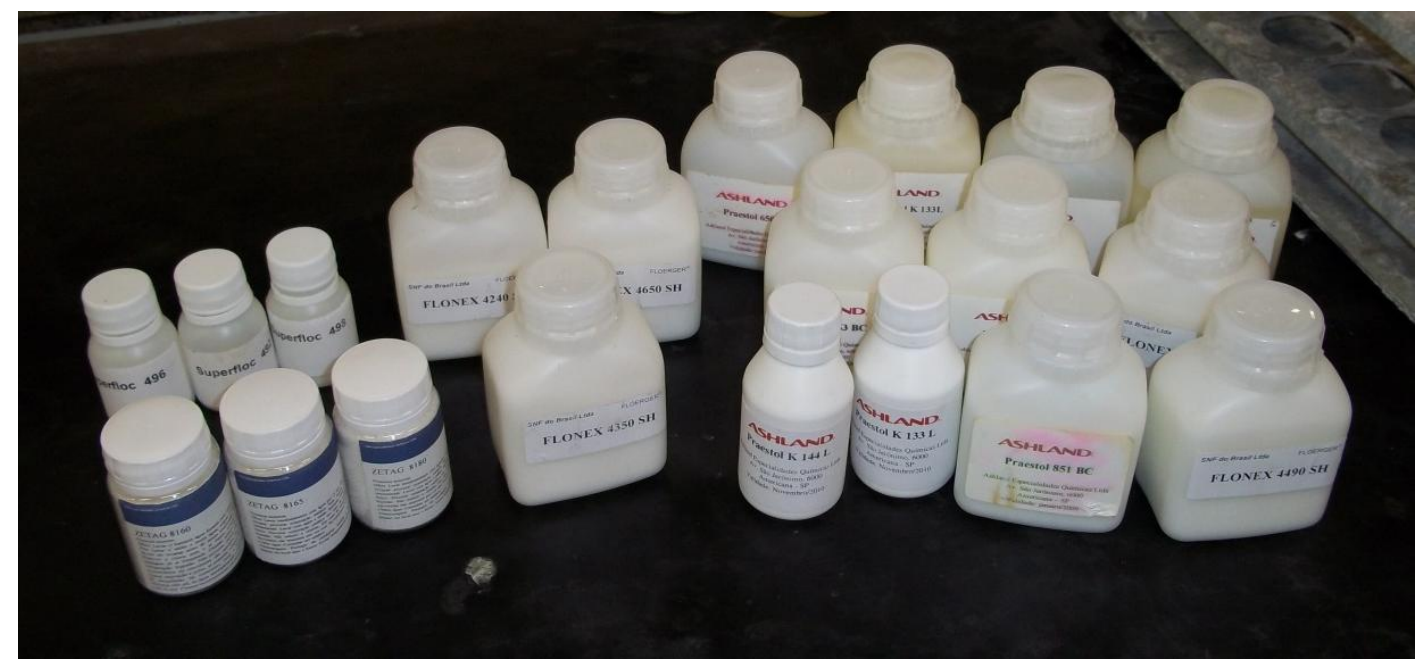

Figura 42 - Polímeros utilizados nos ensaios

\subsubsection{Teste do Tempo de Drenagem para avaliação dos polímeros}

\subsubsection{Materiais utilizados}

A determinação da concentração de sólidos no lodo foi realizada em cápsulas de porcelana, com o auxílio de agitador magnético, béqueres e provetas, conforme Figura 43:

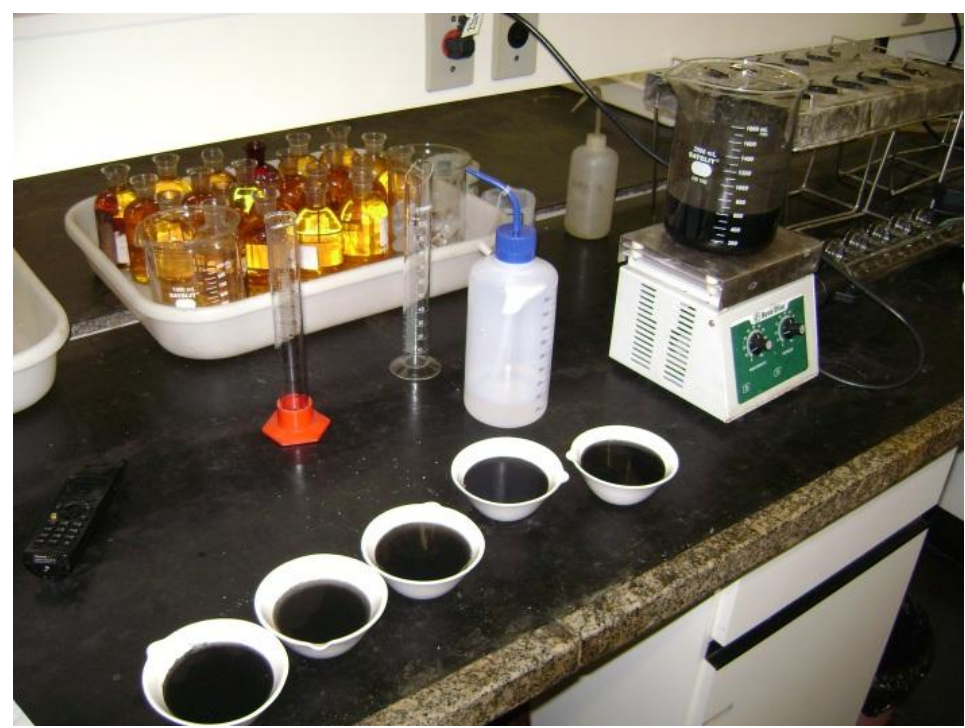

Figura 43 - Materiais utilizados na determinação da concentração de sólidos no lodo 
Os polímeros foram diluídos e adicionados ao lodo no equipamento Teste de Jarros em jarros de 1 litro de volume (foi utilizada uma base de isopor para manter a hélice do equipamento submersa no fluido).

O funil de Buchner era preparado para receber o lodo através da utilização de uma manta geotêxtil recobrindo seus orifícios, esticada pelas paredes laterais internas e presa por elástico na parede externa do funil. Três funis foram preparados, mas apenas dois foram utilizados, pois possuíam tempos de drenagem com água da torneira semelhantes (entre 8 e 9 segundos para drenar os $200 \mathrm{~mL}$ de capacidade). O geotêxtil escolhido para os TTD foi o utilizado com sucesso por Fontana et al. (2007) em estudos de leitos de drenagem para desaguamento de lodos de lagoas de estabilização, da marca Propex, de $140 \mathrm{~g} / \mathrm{m}^{2}$. Os jarros com lodo bruto em mistura e o funil de Buchner pronto para receber o lodo condicionado são apresentados na Figura 44:
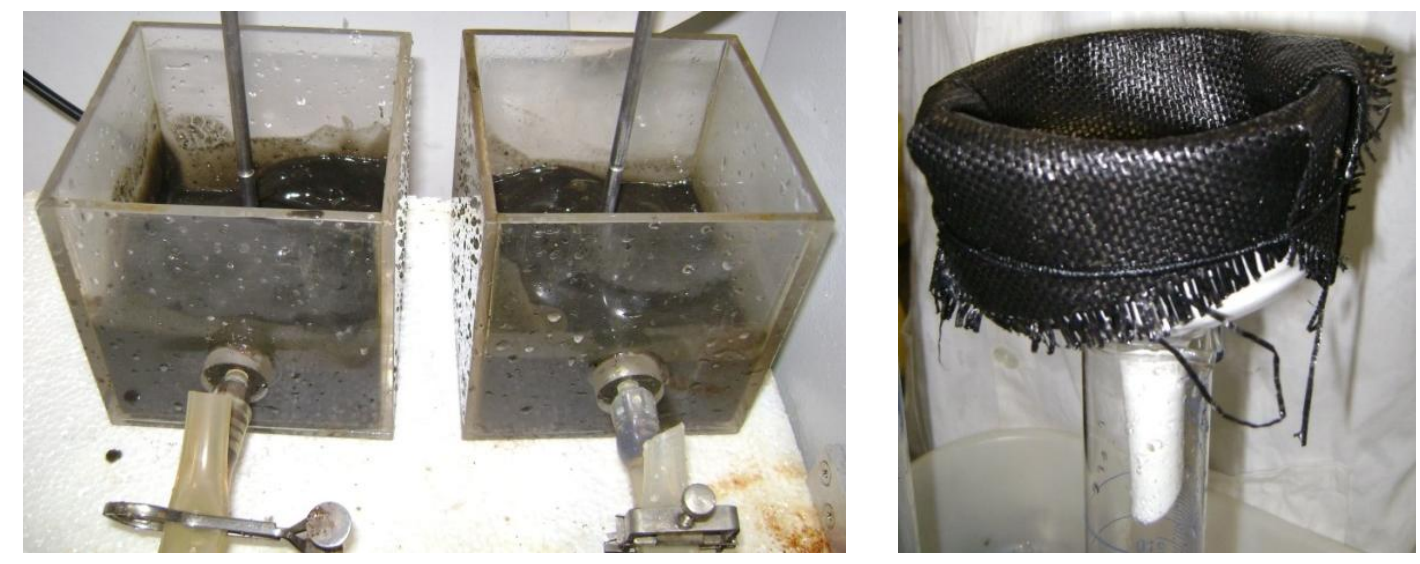

Figura 44 - Lodo em mistura após a adição de polímero orgânico (esquerda) e funil de Buchner e proveta utilizados (direita)

$\mathrm{O}$ drenado foi coletado em proveta de $250 \mathrm{~mL}$ e transposto para béqueres de $50 \mathrm{~mL}$ e erlenmeyers de $100 \mathrm{~mL}$, antes de ter a turbidez medida. Os recipientes utilizados para coletar o drenado e armazenar a solução de polímero diluído são apresentados na Figura 45: 


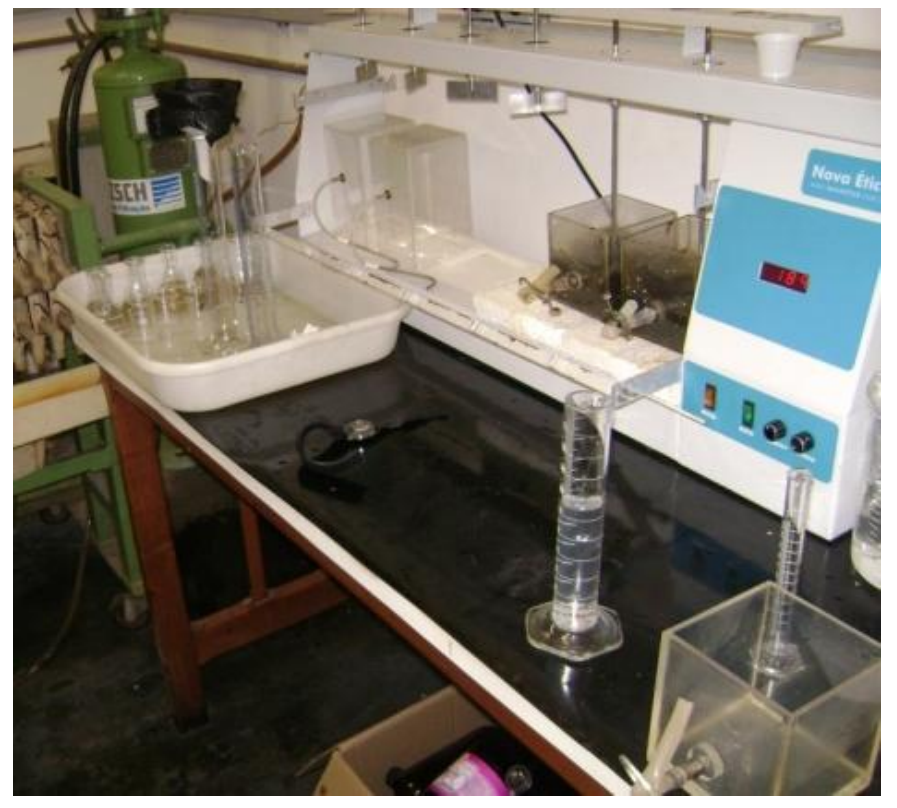

Figura 45 - Materiais utilizados no Teste do Tempo de Drenagem

\subsubsection{Descrição dos testes}

Foram realizadas 5 séries de TTD para verificar o comportamento do lodo para diferentes doses de condicionantes (Dc). A primeira série de testes (APÊNDICE 1) indicou que mesmo com doses relativamente baixas, os tempos de drenagem eram significativamente reduzidos. Assim, considerando que:

- Os erros indeterminados cometidos na obtenção dos dados são representativos para tempos inferiores a 5 segundos;

- Tempos de drenagem abaixo de 5 segundos já são muito inferiores aos tempos observados para lodo sem condicionamento, por vezes superiores a 40 minutos (item 5.1.1.6);

- Os custos com o condicionamento são superiores a cada elevação da dosagem de polímero, sendo que a dose é duplicada ou triplicada de $1 \mathrm{~g} / \mathrm{kg}$ para $2 \mathrm{~g} / \mathrm{kg}$ e $3 \mathrm{~g} / \mathrm{kg}$, respectivamente, e o tempo de drenagem não é reduzido proporcionalmente. 
Admitiu-se que a melhor dose de cada polímero seria a menor dose que proporcionasse a coleta dos $50 \mathrm{~mL}$ no TTD em um tempo inferior a 5 segundos. Essa dose foi considerada a melhor ou a "ideal" de cada polímero, por melhorar consideravelmente a capacidade de desaguamento com os menores custos operacionais.

Dessa forma, para validar a metodologia e determinar as melhores doses de cada polímero, foi realizada uma segunda série de testes com 7 polímeros sólidos, com doses de 0,5 a $8 \mathrm{~g} / \mathrm{kg}$, e 1 em emulsão, com doses de 1 a $10 \mathrm{~g} / \mathrm{kg}$ (segunda série de testes). Os ensaios foram realizados com lodo de Ribeirão Pires e cada dose foi testada em duplicata.

Os outros 2 polímeros em emulsão também foram testados com doses que variaram de 1 a $10 \mathrm{~g} / \mathrm{kg}$. O restante dos polímeros sólidos foi testado nas dosagens de 0,5; 1 e $2 \mathrm{~g} / \mathrm{kg}$, apenas para determinar as melhores dosagens de cada (terceira série de testes).

As quantidades da solução de polímero diluído que deveriam ser adicionadas ao lodo, para testar cada dosagem pré-determinada, foram estimadas com base na massa de sólidos contida em $500 \mathrm{~mL}$ de lodo e na concentração de polímero na solução diluída.

Porém, para manter o gradiente de mistura constante em cada jarro durante a aplicação de condicionante, a quantidade de lodo realmente utilizada foi a de 500 $\mathrm{mL}$ menos o volume determinado de solução de polímero diluído. Assim, cada TTD realizado teve sua dose recalculada a partir da quantidade de sólidos presentes no volume de lodo utilizado e da quantidade de polímero dosada.

O tempo de mistura foi fixado em 1 minuto e o lodo condicionado teve $200 \mathrm{~mL}$ utilizados para medição da capacidade de drenagem pelo TTD. Antes do TTD a manta geotêxtil foi umedecida para evitar que o preenchimento dos poros alterasse os tempos dos testes. Após a adição dos $200 \mathrm{~mL}$ de lodo condicionado ao funil de Buchner, o tempo necessário para que $50 \mathrm{~mL}$ fossem drenados foi anotado para 
cada dose de cada polímero testada e o drenado recolhido para posterior análise de turbidez. O lodo em desaguamento no TTD é apresentado na Figura 46:
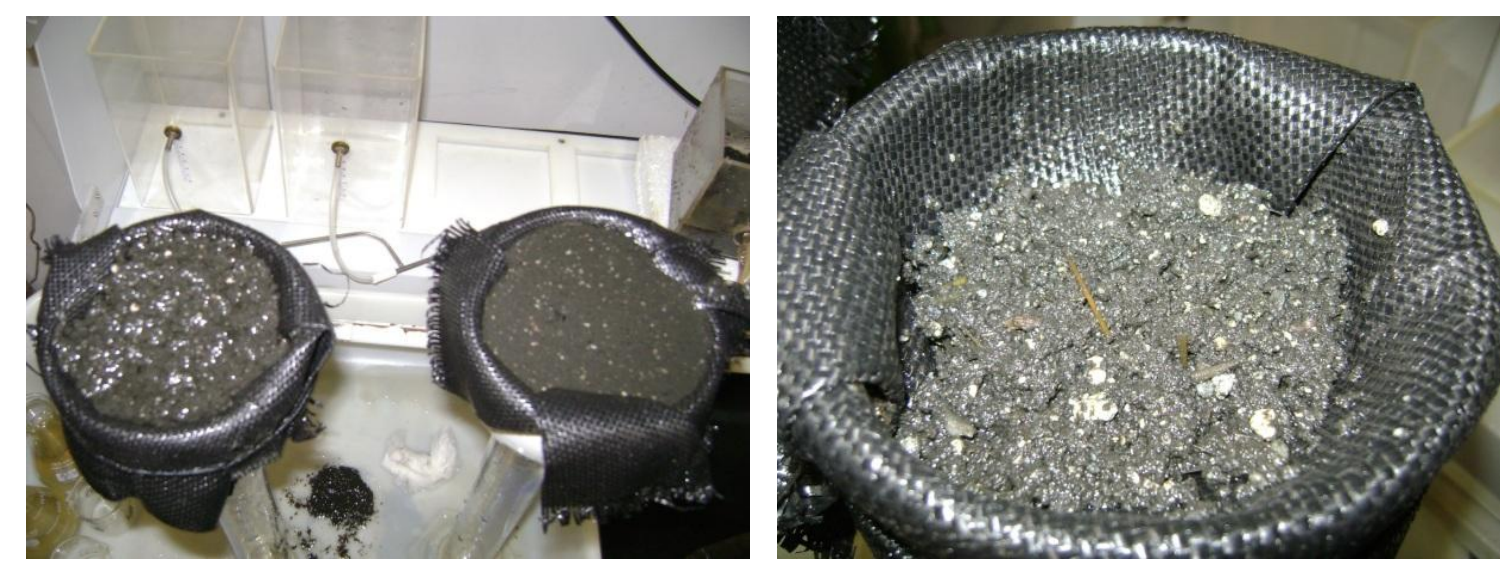

Figura 46 - Amostras de lodo condicionado em processo de desaguamento no laboratório (esquerda) e aspecto da torta formada (direita)

A turbidez foi medida para servir como parâmetro secundário de análise, pois fornece um indicativo, embora impreciso, da quantidade de sólidos presentes no drenado. Dessa forma, o comparativo entre polímeros para seleção e utilização nos ensaios em escala piloto foi realizado com base nos tempos medidos nos TTD.

Assim, as doses "ideais" dos 18 polímeros fornecidos pelos fabricantes foram determinadas com o lodo da ETE de Ribeirão Pires durante a segunda e terceira série de testes. Com a desativação desta ETE, foi necessário continuar os testes com o lodo da ETE de Jaraguá. Para estes testes, apenas o melhor polímero de cada fabricante, de acordo com os resultados obtidos, foi utilizado (quarta série de testes).

Os dois melhores polímeros ainda foram testados com doses de 0,5 a $8 \mathrm{~g} / \mathrm{kg}(0,5<$ Dc $<8 \mathrm{~g} / \mathrm{kgST}$ ) e em duplicata para enfim definir qual o polímero com a menor "dose ideal" para o lodo da ETE de Jaraguá e que seria utilizado nos ensaios em escala piloto (quinta série de testes).

As mantas utilizadas nos funis de Buchner foram mantidas ao longo de todos os testes, recebendo apenas uma lavagem superficial entre cada procedimento. 


\subsubsection{Escolha da manta geotêxtil}

A escolha de uma manta geotêxtil para a utilização na filtração de materiais particulados pode ser feita por métodos de dimensionamento racionais ou empíricos, como relatado na revisão bibliográfica deste documento. Porém, os métodos de determinação da distribuição de tamanhos de flocos no lodo são complexos e os resultados sofrem interferência dos métodos de análise. Além disso, a distribuição de poros dos geotêxteis não é fornecida pelos fabricantes. Dessa forma, optou-se pelo procedimento empírico através do TTD, utilizando-se os diferentes geotêxteis do mercado.

Estes testes tiveram o objetivo de selecionar a manta para ser utilizada nos ensaios piloto. Através do TTD foi avaliado o tempo de drenagem com água potável da torneira, lodo bruto e lodo condicionado na melhor dose do melhor polímero, de acordo com ensaios anteriores. Admitiu-se que, independente da manta, a dosagem "ideal" se manteria e que com o TTD seria possível comparar as taxas de drenagem de cada manta e selecionar a melhor para utilização no sistema piloto.

No Brasil os dois principais geotêxteis não tecidos encontrados são os agulhados e os termoligados, sendo que, os agulhados podem ser fabricados em poliéster, polietileno e polipropileno e os termoligados apenas em poliéster, com gramatura normalmente variando de 200 a $600 \mathrm{~g} / \mathrm{m}^{2}$. Os geotêxteis tecidos são encontrados em polipropileno com gramaturas que variam de 129 a quase $500 \mathrm{~g} / \mathrm{m}^{2}$.

Os geossintéticos escolhidos para este teste foram as mantas não tecidas RT21 da BIDIM, de $400 \mathrm{~g} / \mathrm{m}^{2}$, e a MacTex $\mathrm{N}$ - 350P da MACAFERRI, em polipropileno de 271 $\mathrm{g} / \mathrm{m}^{2}$; e as tecidas foram as HUESKER Hate $55 / 55$ e $80 / 80$, de 289 e $390 \mathrm{~g} / \mathrm{m}^{2}$ respectivamente, e Propex $14000 \mathrm{de} 140 \mathrm{~g} / \mathrm{m}^{2}$. Com isso foi testada uma ampla faixa de gramaturas dentre cada tipo de geotêxtil (não tecidos de 271 a $400 \mathrm{~g} / \mathrm{m}^{2}$ e tecidos de 140 a $390 \mathrm{~g} / \mathrm{m}^{2}$ ). O custo do geotêxtil não foi considerado na seleção destes geotêxteis, uma vez que possuem alta durabilidade. O Anexo B apresenta as principais características e preços destes e de outros geotêxteis tecidos e não tecidos. 


\subsection{Ensaio piloto}

\subsubsection{Materiais utilizados}

Para a realização dos ensaios em escala piloto foi utilizado lodo de um reator UASB de $23 \mathrm{~m}^{3}$, instalado no (Centro Tecnológico de Hidráulica da USP - CTH). Este reator é alimentado com esgotos provenientes do Conjunto Residencial da USP (CRUSP) e do Restaurante Central (COSEAS), da Cidade Universitária Armando Sales de Oliveira (USP). O reator UASB é precedido de uma peneira mecanizada de abertura de $5 \mathrm{~mm}$, caixa de areia e elevatória para alimentação do reator.

Como no início dos ensaios o manto de lodo do reator ainda não apresentava a concentração de sólidos desejada, foi necessário utilizar um inóculo de $6 \mathrm{~m}^{3}$ proveniente dos reatores UASB da ETE de Jaraguá. O lodo com concentração de sólidos de cerca de $60 \mathrm{~g} / \mathrm{L}$ foi transportado em caminhão tanque e despejado dentro do reator UASB do CTH.

Para realizar os ensaios de desaguamento de lodo anaeróbio em leitos de drenagem, foram montados dois tanques em fibrocimento, de 700 litros de volume útil, para condicionamento do lodo e 3 leitos de drenagem com dimensões de 1,58 $\mathrm{m}$ x 1,09 m por 0,5 m de altura, totalizando cerca de 1,26 $\mathrm{m}^{2}$ cada um. Os testes foram iniciados com 2 leitos de drenagem piloto e sem cobertura (Figura 47). Após o inicio das chuvas em meados de setembro, um novo leito foi implantado e os 3 leitos foram cobertos com plástico translúcido (Figura 47). Os ensaios em escala piloto com os leitos de drenagem foram realizados com a utilização de manta geotêxtil tecida, de gramatura igual a $289 \mathrm{~g} / \mathrm{m}^{2}$, da HUESKER (Hate $55 \mathrm{kN} / 55 \mathrm{kN}$ ).

Para garantir o transporte por gravidade do lodo, dos tanques de condicionamento até os leitos de drenagem, foi construída uma estrutura elevada em madeira para os tanques de condicionamento, conforme Figura 47: 

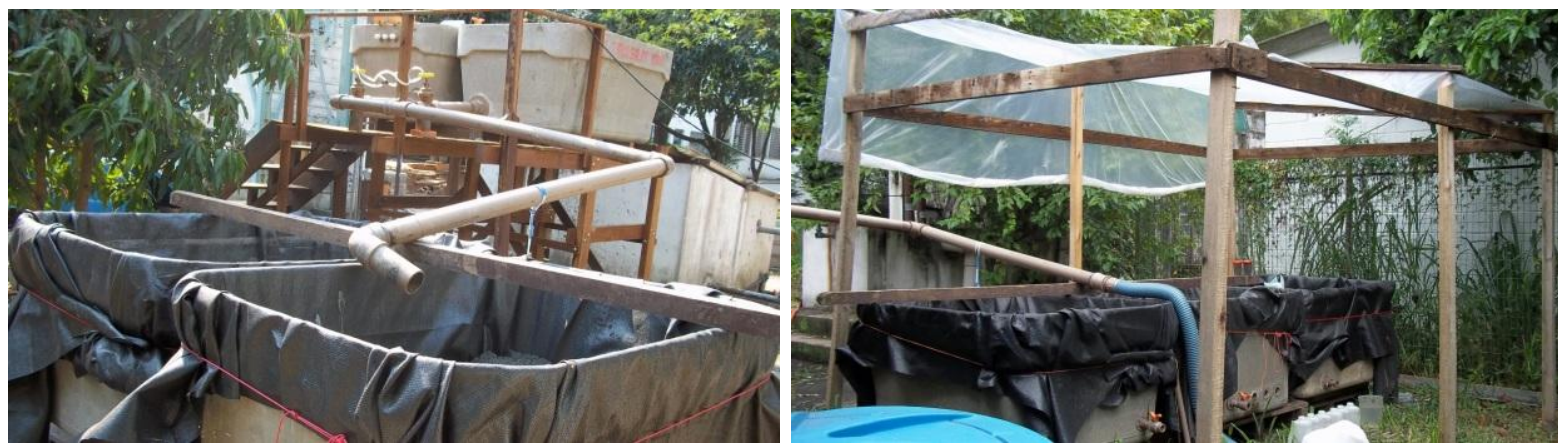

Figura 47 - Leitos de drenagem sem cobertura e tanques de condicionamento elevados (à esquerda) e os 3 leitos com cobertura translúcida (à direita)

Uma vista do sistema de pré-tratamento e do reator UASB é apresentada na Figura 48:

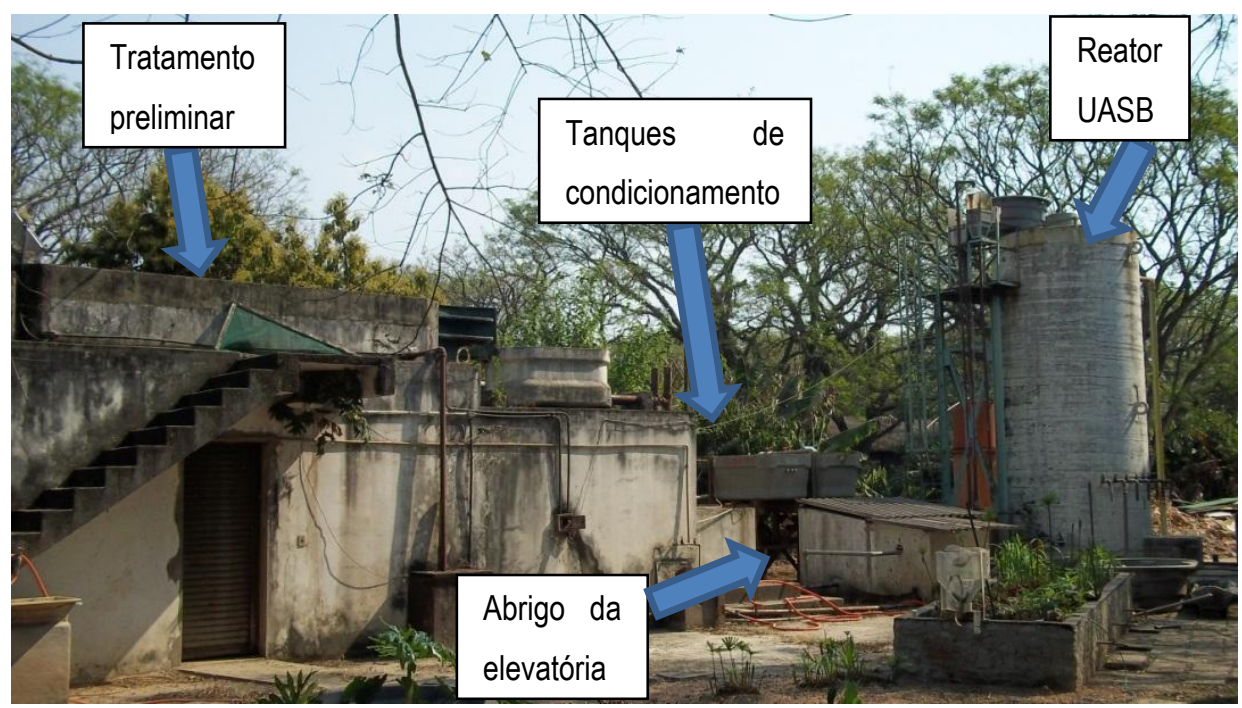

Figura 48 - Vista do sistema em escala piloto

O polímero foi diluído em recipiente de 50 litros com o auxílio de agitador mecânico de bancada, da marca Nova Ética. A adição do polímero diluído ao lodo foi realizada nos tanques de condicionamento com agitação proporcionada por misturador de fluxo radial de $1 / 6 \mathrm{cv}$, da marca Eberle. Estes equipamentos estão apresentados na Figura 49: 

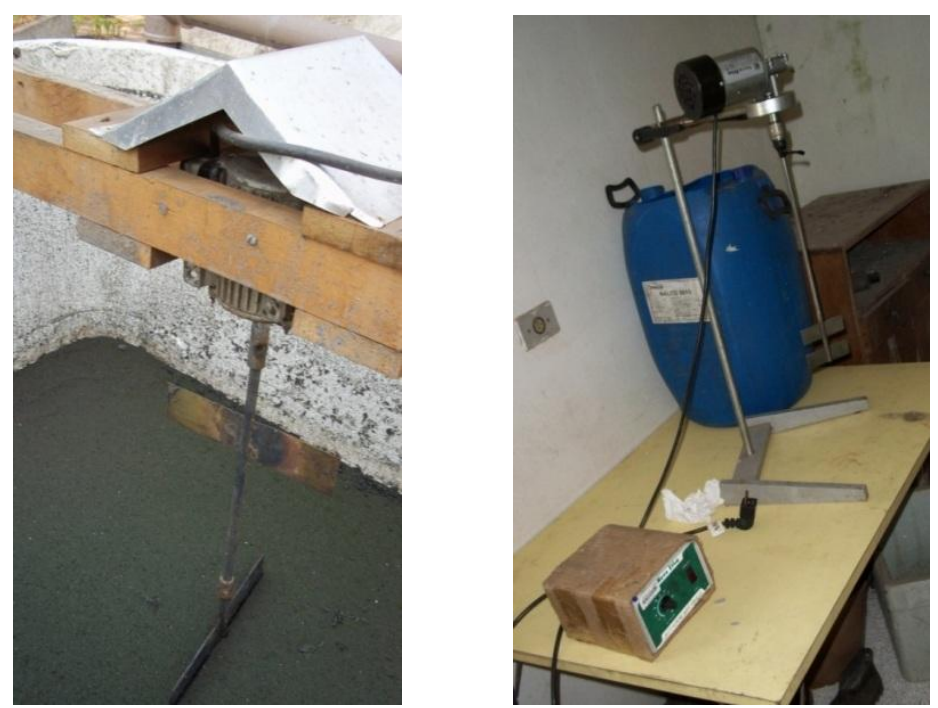

Figura 49 - Tanque de condicionamento com o motor e as pás do misturador (esquerda) e recipiente de preparo de polímero e misturador (direita)

Um diagrama esquemático, com os materiais e equipamentos utilizados para realizar os ensaios em escala piloto, é apresentado na Figura 50:

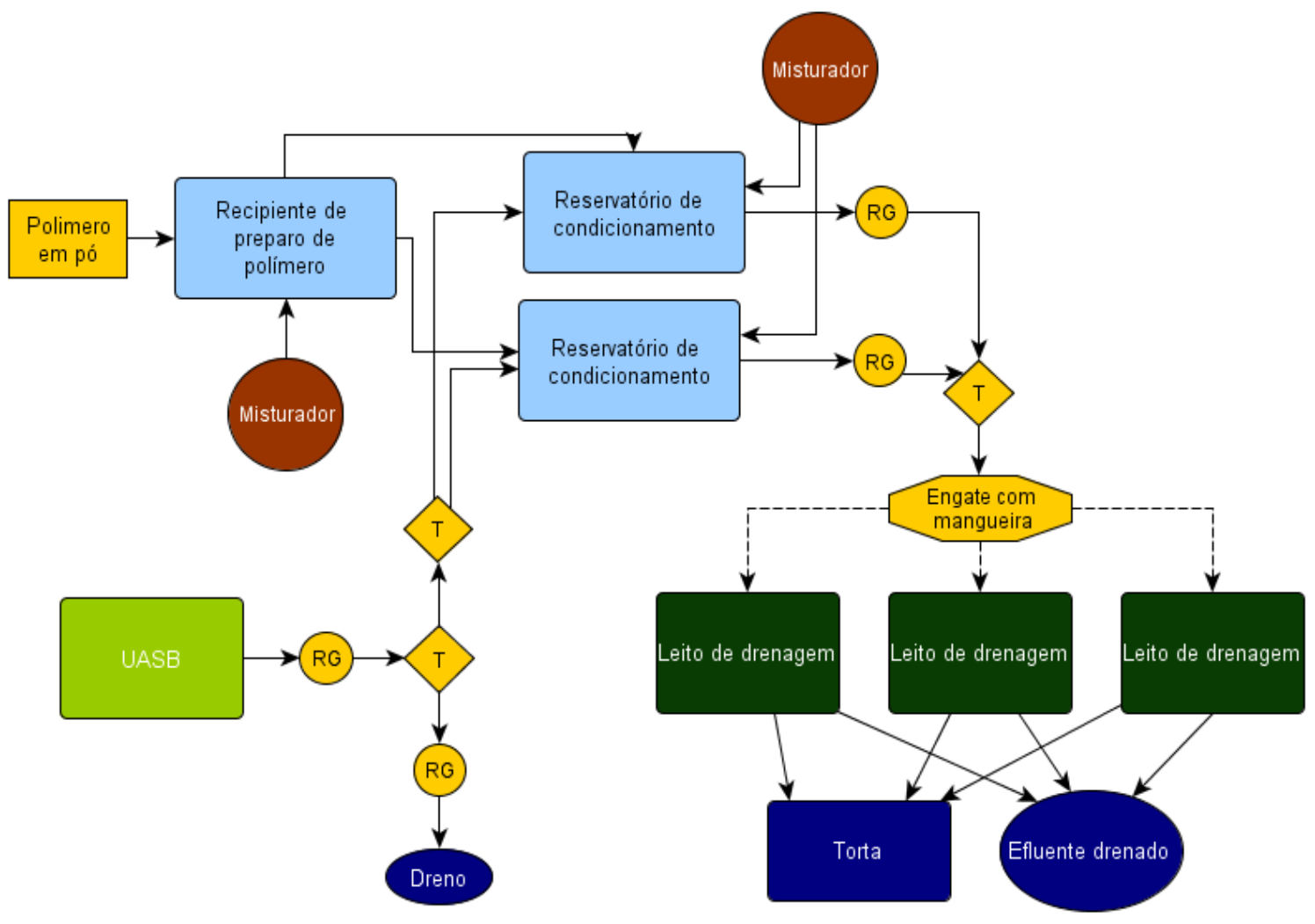

Figura 50 - Diagrama do sistema de desaguamento piloto 
Os desenhos técnicos ilustrativos de todo o sistema montado nas dependências do CTH se encontram no APÊNDICE 1. O leito de drenagem e suas características físicas são também apresentadas na Figura 51:
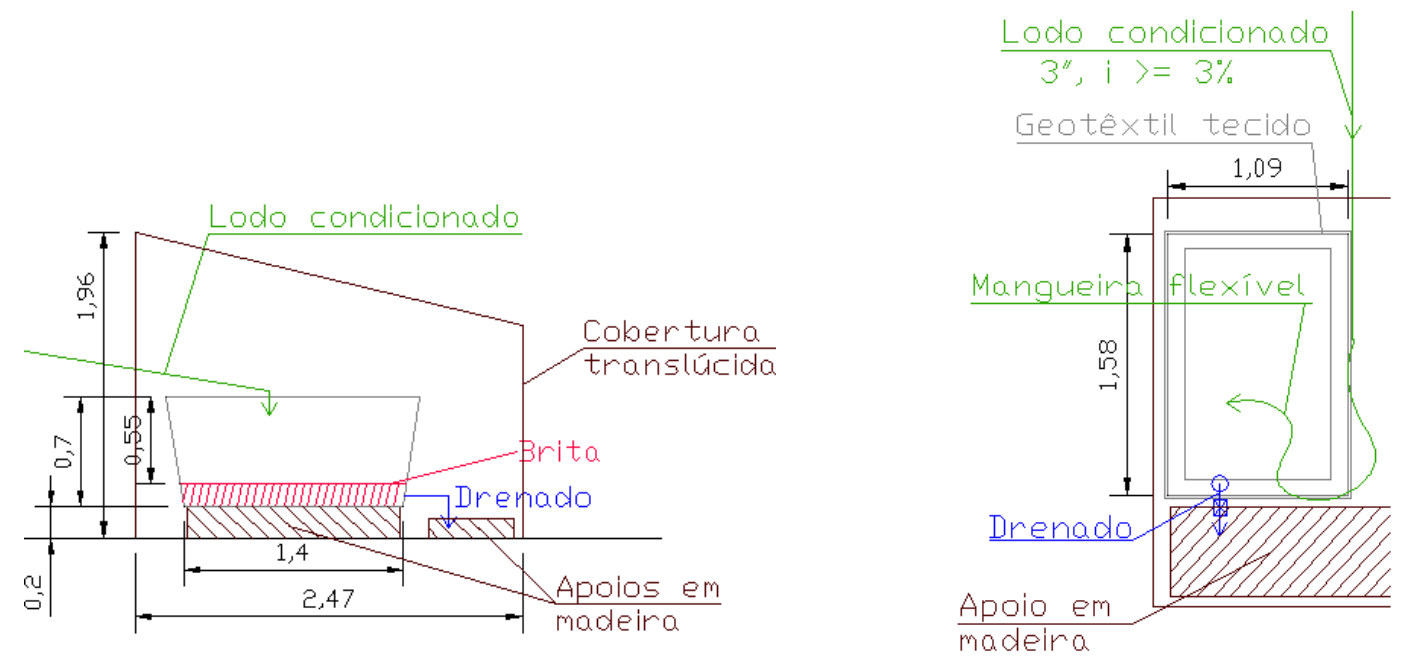

Figura 51 - Vista em corte (esquerda) e em planta (direita) sem escala de um dos leitos de drenagem em escala piloto montados no CTH

\subsubsection{Descrição dos ensaios}

Os ensaios em escala piloto tiveram o objetivo de avaliar a influência de diferentes doses de polímero e taxas de aplicação de sólidos no desaguamento em leitos de drenagem. Para isso, o lodo do UASB foi retirado de uma tomada localizada a 1 metro do fundo do reator e despejado nos tanques de condicionamento. Em todos os procedimentos de condicionamento o volume de lodo foi mantido em cerca de 700 litros, de forma a uniformizar o gradiente hidráulico aplicado. Assim, para se obter as taxas de aplicação de sólidos previstas, a concentração de sólidos foi ajustada antes da adição do polímero (ver página 127). Antes de adicionar o lodo aos leitos de drenagem, as mantas foram umedecidas. Ao fim de cada ensaio, a torta foi retirada manualmente e a manta geossintética limpa com o auxílio de uma pá de plástico e uma vassoura.

A concentração de diluição de polímero foi mantida em cerca de $2 \mathrm{~g} / \mathrm{L}$, exceto para os ensaios E6 e E8, em que para não exceder a capacidade do tanque de abertura 
da cadeia de polímero, as concentrações de diluição de polímeros foram de 2,4 e $3,6 \mathrm{~g} / \mathrm{L}$, respectivamente.

O lodo condicionado foi desaguado nos leitos de drenagem e teve a altura da torta e teor de sólidos monitorados. O drenado foi recolhido (Figura 52) durante a primeira hora após a alimentação do leito de drenagem, com uma amostra coletada para cada cerca de $50 \mathrm{~L}$ de volume drenado, nos ensaios com condicionamento, e a cada cerca de $25 \mathrm{~L}$ de volume drenado para os ensaios sem aplicação de polímero. As taxas de drenagem foram anotadas e as amostras foram analisadas em relação à DQO, turbidez, $\mathrm{pH}$ e condutividade.

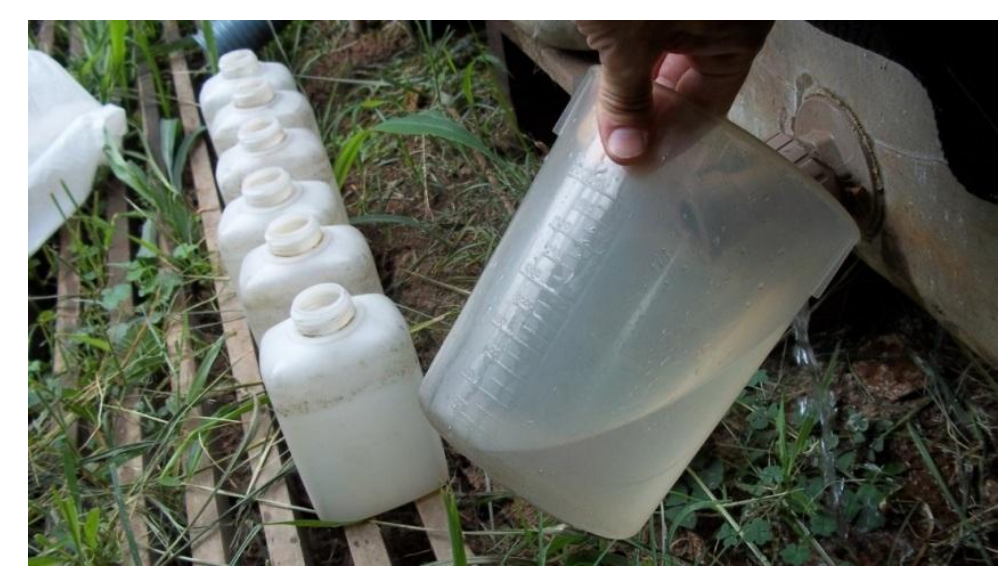

Figura 52 - Coleta do drenado

A intensidade de mistura para abertura da cadeia do polímero e para condicionamento do lodo foram padronizadas em $250 \mathrm{rpm}$ e $120 \mathrm{rpm}$, respectivamente. $O$ condicionamento não pode seguir a mesma rotação utilizada em laboratório devido a limitações do equipamento. Os tempos de mistura utilizados na diluição do polímero e na dispersão do polímero no lodo foram, respectivamente, de 2 a 4 horas e de 8 a 12 minutos.

As condições climáticas no $\mathrm{CTH}$ foram monitoradas e as precipitações diárias e as médias diárias da temperatura, velocidade dos ventos, irradiação solar, evaporação e umidade relativa do ar, em cada dia do ciclo de secagem, compiladas (ANEXO C). 


\subsubsection{Ensaios para avaliar as dosagens em escala piloto}

Inicialmente foram realizados ensaios com dosagens de polímero entre 0 e $8 \mathrm{~g} / \mathrm{kgST}$ (E1 a E8). Em seguida foram realizados três ensaios simultaneamente, como forma de reduzir a influência das variáveis climáticas, sendo um deles sem a utilização de polímero (E9) e os outros com as doses de 2 e $4 \mathrm{~g} / \mathrm{kgST}$ (E10 e E11).

Para manter taxa de aplicação superficial em cerca de $15 \mathrm{kgST} / \mathrm{m}^{2}$.ciclo, valor máximo recomendado pela norma ABNT 12.209 (1992) para leitos de secagem convencionais, a concentração de sólidos no lodo bruto deveria estar próxima a 27 g/L. Assim, a concentração de sólidos foi determinada em duplicata e, caso o valor observado não estivesse próximo ao desejado, o lodo era diluído com efluente tratado do próprio reator ou concentrado através da retirada de sobrenadante e adição de mais lodo. Apenas nos ensaios E1, E2 e E8 esta taxa de aplicação não foi utilizada, pois o procedimento não estava padronizado nos dois primeiros ensaios e o lodo se tornou pouco concentrado no início das férias escolares, ocasião do E8. Os ensaios E1 e E2 foram realizados com cerca de $19 \mathrm{kgST} / \mathrm{m}^{2}$.ciclo e o E8 foi realizado com uma taxa de aplicação de sólidos de 12,8 kgST/m².ciclo.

As amostras de torta de lodo do leito de drenagem foram coletadas a cada 2 ou 3 dias. A retirada de amostras foi realizada através de amostrador por sucção, abrangia o perfil vertical total da torta e era feita evitando-se as grandes fissuras formadas na superfície da torta (Figura 53). Foram coletadas duas amostras desse perfil vertical em cada coleta.

Ao final dos ensaios E9, E10 e E11, cerca de $30 \%$ do conteúdo total da torta resultante foi homogeneizado. Desta torta homogeneizada, foram preparadas duas amostras, que foram coletadas e analisadas para avaliar se o procedimento de amostragem utilizado (perfis verticais) foi representativo. 

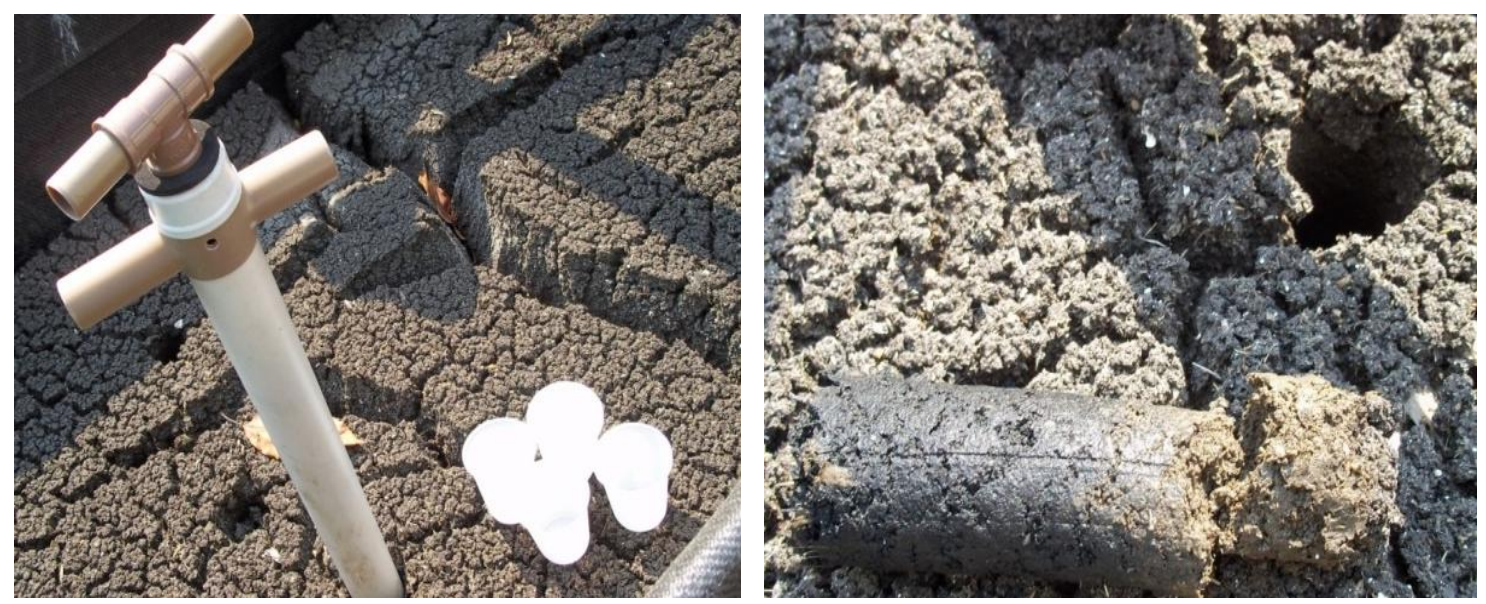

Figura 53 - Amostrador, recipientes de coleta e amostra retirada da torta

A retirada da torta gerada foi realizada de forma manual. Na limpeza do geotêxtil, foram utilizadas uma vassoura e uma pá plástica, conforme Figura 54:
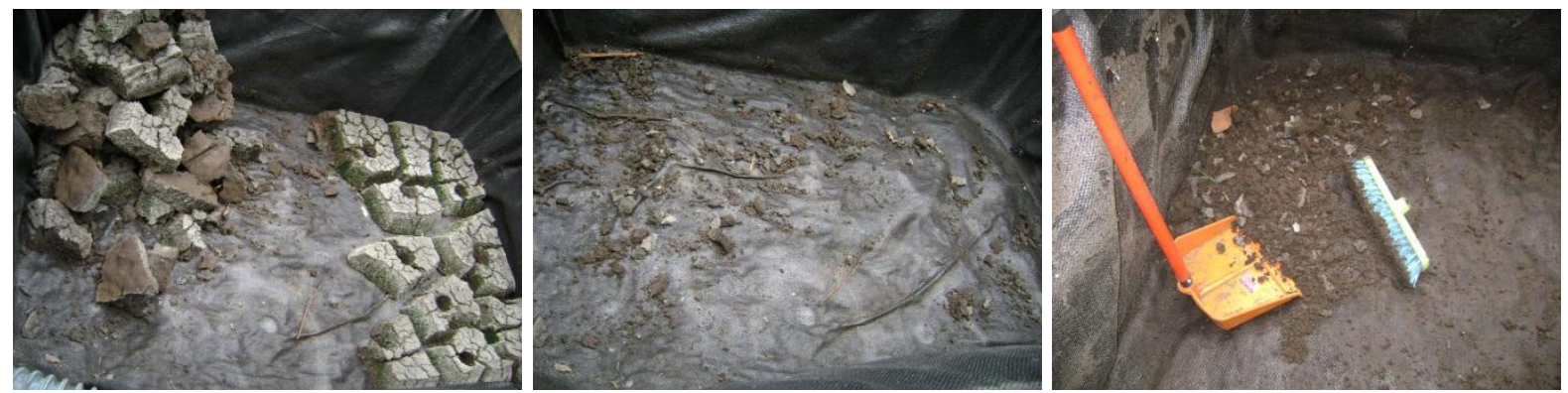

Figura 54 - Retirada da torta e limpeza da manta geotêxtil

\subsubsection{Ensaios para avaliar diferentes taxas de aplicação de sólidos}

Para avaliar a influência de diferentes taxas de aplicação de sólidos no aumento do teor de sólidos ao longo do ciclo de secagem, foram realizados 3 ensaios com a dosagem de polímero fixada em $2 \mathrm{~g} / \mathrm{kgST}$ e taxas de aplicação de sólidos variando de 9 a $22 \mathrm{kgST} / \mathrm{m}^{2}$. ciclo (E12 a E14).

Para possibilitar estas variações na taxa de aplicação superficial, a concentração de sólidos no lodo bruto foi de 17 a $38 \mathrm{~g} / \mathrm{L}$. Da mesma forma que nos ensaios para determinação da melhor dose em escala piloto, a concentração de sólidos foi determinada em duplicata e, caso o valor observado não estivesse próximo ao 
desejado, o lodo era diluído com efluente tratado do próprio reator ou concentrado através da retirada de sobrenadante e adição de mais lodo.

Para tentar conseguir uma amostra mais representativa do teor de sólidos na torta, evitou-se as regiões próximas às paredes do leito, que devido à escala reduzida do ensaio, exercem maior influência sobre a secagem do material. Assim, foram retiradas 2 amostras de cada ensaio a cada coleta, sendo uma mais próxima a uma fissura e a outra ao lado da primeira amostragem, porém mais longe da fissura. As amostras de torta de lodo do leito de drenagem foram coletadas a cada 3 ou 4 dias utilizando o mesmo amostrador por sucção da Figura 53.

O período de secagem se estendeu por cerca de 35 dias e ao longo do ciclo tiveram a altura e o teor de sólidos determinados a cada 3 ou 4 dias.

\subsection{Métodos analíticos}

As determinações analíticas foram realizadas conforme os métodos e procedimentos descritos no Standard Methods for the Examination of Water and Wastewater (APHA; AWWA; WEF, 2005) e estão apresentadas na Tabela 15:

Tabela 15 - Métodos, equipamentos e procedimentos das determinações analíticas

\begin{tabular}{|c|c|c|c|c|}
\hline $\begin{array}{c}\text { Parâmetro } \\
\text { (unidade usual) }\end{array}$ & $\begin{array}{l}\text { Material } \\
\text { analisado }\end{array}$ & Método & Equipamento & $\begin{array}{c}\text { Procedimento } \\
\text { (APHA, AWWA, } \\
\text { WEF) }\end{array}$ \\
\hline Turbidez (UNT) & $\begin{array}{c}\text { Drenado do } \\
\text { TTD }\end{array}$ & Nefelométrico & $\mathrm{HACH} 2100 \mathrm{~N}$ & $2130 \mathrm{~B}$ \\
\hline $\mathrm{DQO}(\mathrm{mg} / \mathrm{L})$ & $\begin{array}{c}\text { Drenado do } \\
\text { TTD }\end{array}$ & Refluxo aberto & & $5220 \mathrm{~B}$ \\
\hline $\begin{array}{c}\text { Concentração de } \\
\text { Sólidos Totais } \\
\text { (mg/L) }\end{array}$ & $\begin{array}{l}\text { Lodo bruto e } \\
\text { efluente do } \\
\text { UASB }\end{array}$ & $\begin{array}{c}\text { Peso constante a } \\
103-105^{\circ} \mathrm{C}\end{array}$ & & $2540 \mathrm{~B}$ \\
\hline $\begin{array}{l}\text { Teor de Sólidos (\% } \\
\text { de massa/massa) }\end{array}$ & $\begin{array}{l}\text { Torta de } \\
\text { lodo }\end{array}$ & $\begin{array}{c}\text { Secagem da amostra } \\
\text { semi-sólida ou sólida } \\
\text { até peso constante a } \\
103-105^{\circ} \mathrm{C}\end{array}$ & & $2540 G$ \\
\hline $\begin{array}{c}\begin{array}{c}\text { Condutividade } \\
(\mu \mathrm{S} / \mathrm{cm})\end{array} \\
\end{array}$ & $\begin{array}{c}\text { Drenado do } \\
\text { TTD } \\
\end{array}$ & $\begin{array}{c}\text { Condutivímetro de } \\
\text { bancada }\end{array}$ & $\begin{array}{c}\text { ORION modelo } \\
150 \\
\end{array}$ & $2510 B$ \\
\hline $\begin{array}{c}\mathrm{pH} \text { (escala de } 0 \mathrm{a} \\
14)\end{array}$ & $\begin{array}{c}\text { Drenado do } \\
\text { TTD }\end{array}$ & $\begin{array}{l}\text { Potenciométrico com } \\
\text { pHmetro de bancada }\end{array}$ & HEXIS 720A & $4500 \mathrm{H}^{+} \mathrm{B}$ \\
\hline
\end{tabular}




\section{RESULTADOS E DISCUSSÃO}

\subsection{Teste do Tempo de Drenagem}

\subsubsection{Escolha do polímero}

\subsubsection{Primeira série de testes}

A primeira série de testes foi realizada com um procedimento que se mostrou metodologicamente errado, gerando resultados imprecisos (APÊNDICE 2). Foram realizados mais de 180 TTD com tal metodologia e os resultados observados permitiram, apenas, aperfeiçoar os procedimentos utilizados, mas não serão apresentados neste trabalho. Os procedimentos utilizados na sequência do trabalho seguiu a metodologia descrita no item 4.1.4.2.

\subsubsection{Segunda série de testes}

A segunda série de testes foi realizada em duplicata com os polímeros CIBA ZETAG 8160 e 8165, KEMIRA SUPERFLOC 492 e 494, SNF FLONEX 4190SH, 4490SH e 4350SH e ASHLAND K144L. As dosagens de polímero utilizadas variaram entre 0,5 e $8 \mathrm{~g} / \mathrm{kg}$ de sólidos secos. As duas curvas geradas para cada um dos polímeros tiveram uma aderência muito alta, como pode ser observado no APÊNDICE 3 e na Figura 55: 


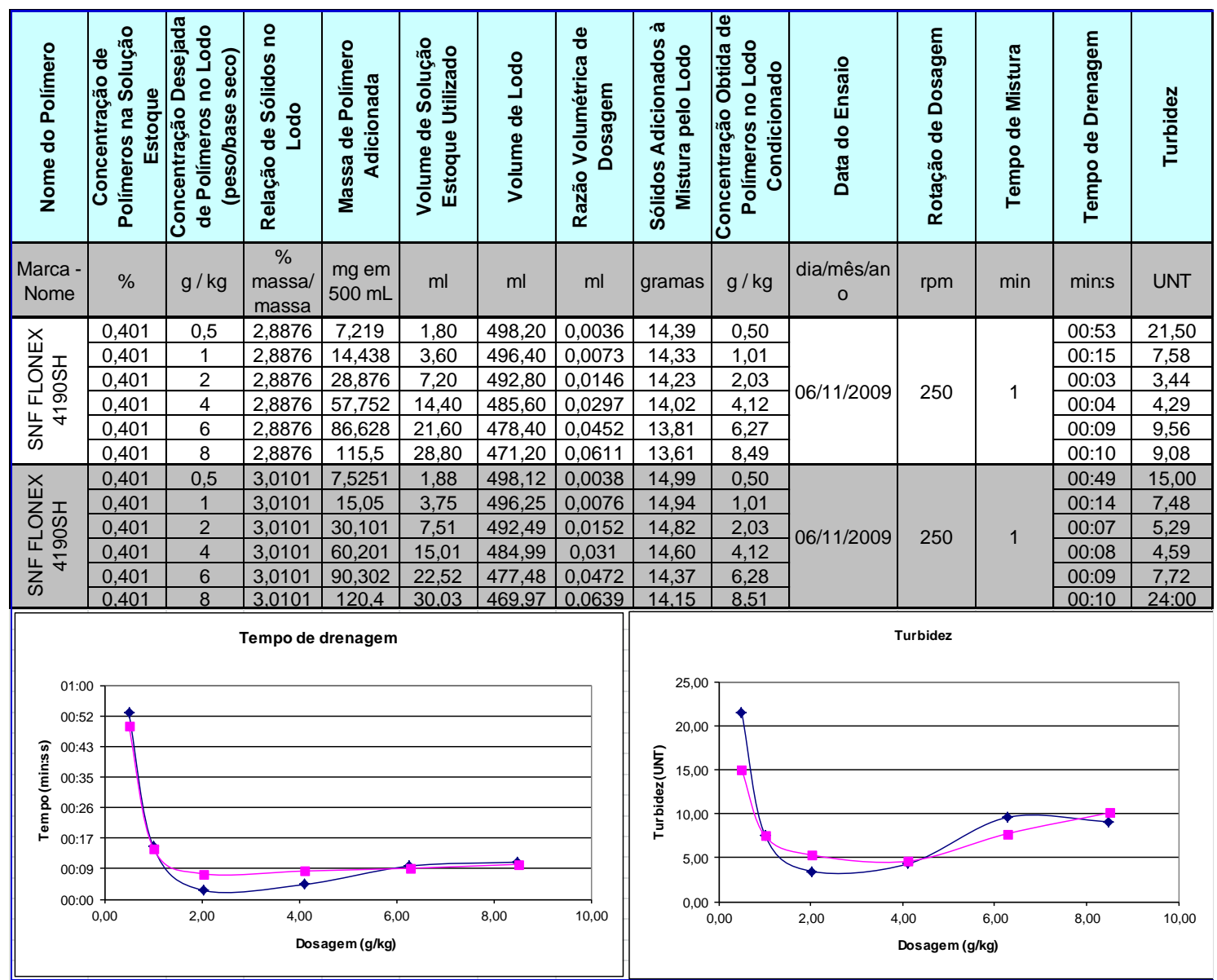

Figura 55 - Resultados do ensaio em duplicata para o polímero SNF FLONEX 4190SH, que validaram a nova metodologia

A boa aderência das duas curvas geradas para cada polímero indicou que a metodologia estava adequada.

Os resultados dos tempos de drenagem medidos nestes ensaios também estão apresentados em 2 gráficos, que contém as médias dos resultados das duas repetições do ensaio (Figura 56 e Figura 57). Os gráficos gerados para ilustrar esta segunda série de TTD são idênticos em relação aos dados de origem das curvas, porém um deles teve a escala do eixo das ordenadas alterada para evidenciar as melhores doses de cada polímero.

A turbidez para as melhores doses de cada polímero ficaram entre 3 e 10 UNT. 


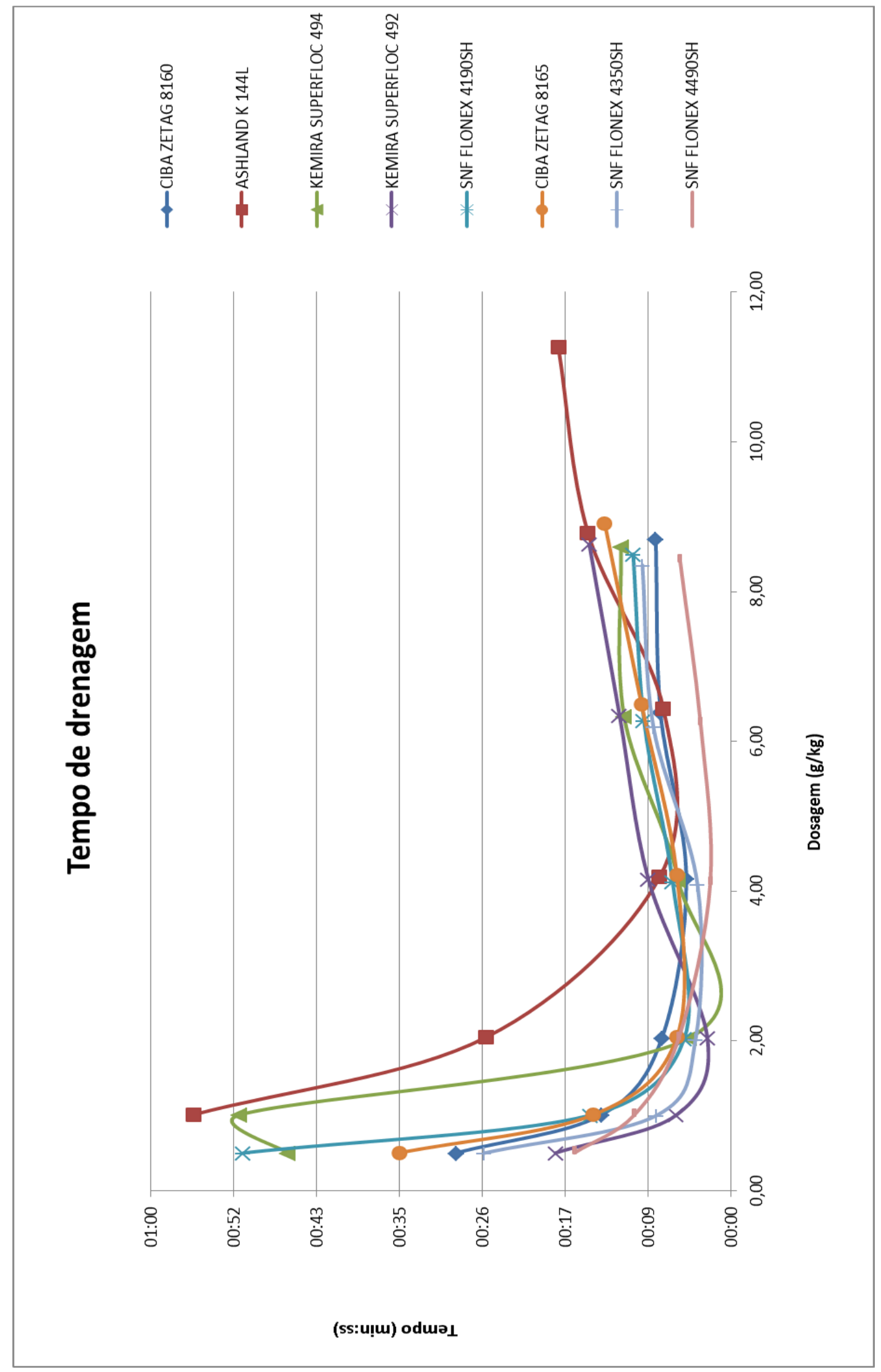

Figura 56 - Resultados da segunda série de TTD 


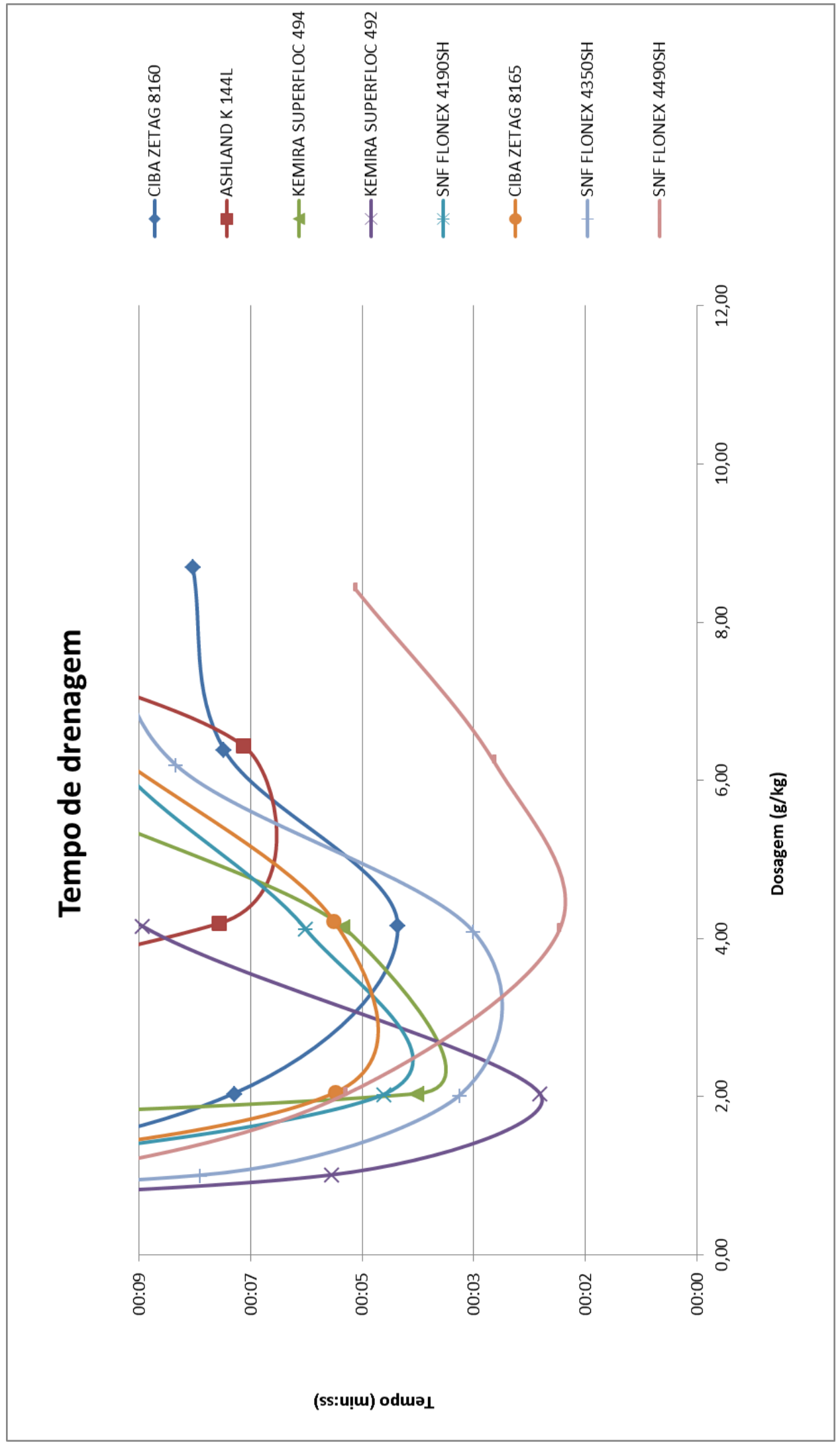

Figura 57 - Resultados da segunda série de TTD com alteração na escala do eixo das ordenadas para evidenciar as melhores doses 


\subsubsection{Terceira série de testes}

A terceira série de testes foi realizada com lodo da ETE Jaraguá e com os polímeros em emulsão ASHLAND K 111L, 133L e 144L. Estes produtos foram dosados em concentrações entre 1 e $10 \mathrm{~g} / \mathrm{kg}$. A terceira série também compreendeu a aplicação do TTD nos 8 polímeros sólidos restantes (ASHLAND 650TR, 851BC, 853BC e 857BS; KEMIRA SUPERFLOC 496 e 498; e SNF FLONEX 4240SH e 4650SH), que foram dosados apenas nas concentrações de 0,5; 1 e $2 \mathrm{~g} / \mathrm{kgST}$ como forma de verificar polímeros com doses "ideias" próximas ou melhores que as verificadas na segunda série de testes.

Os resultados mostraram que quase todos os polímeros sólidos testados produzem lodos facilmente desaguáveis com relativa baixa dosagem (cerca de $2 \mathrm{~g} / \mathrm{kg}$ de sólidos totais). Os polímeros em emulsão possuem doses "ideias" de produto comercial maiores, chegando a cerca de $6 \mathrm{~g} / \mathrm{kg}$.

A turbidez para as melhores doses de cada polímero ficou entre 2 e 10 UNT, com exceção do polímero ASHLAND K 111L, que teve para a melhor dose uma turbidez de cerca de 20 UNT.

As planilhas digitais da terceira série de ensaios estão no APÊNDICE 4 e os gráficos plotados para comparação visual dos produtos seguem nas Figura 58 a Figura 61: 


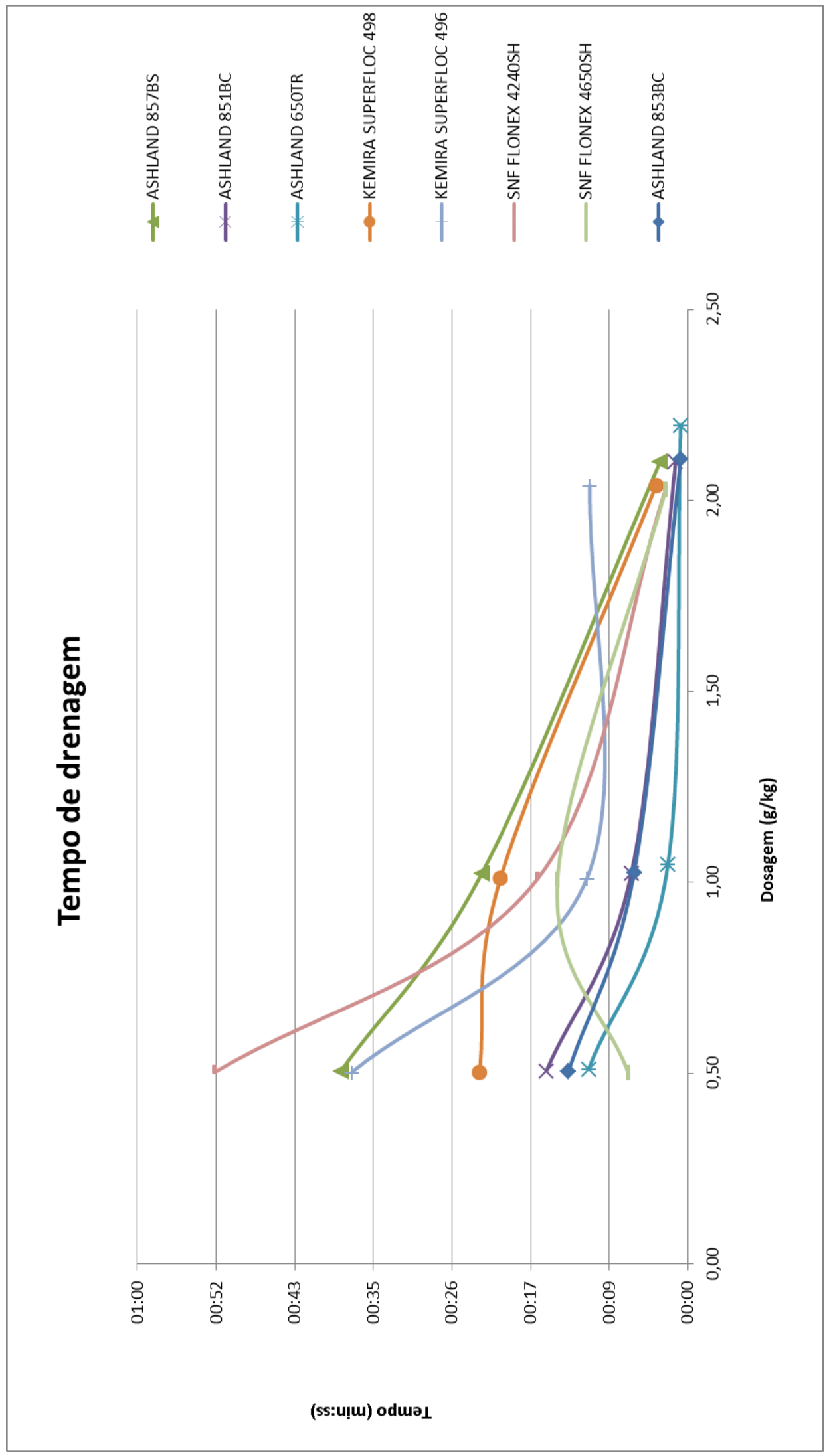

Figura 58 - Resultados dos polímeros sólidos da terceira série de TTD 


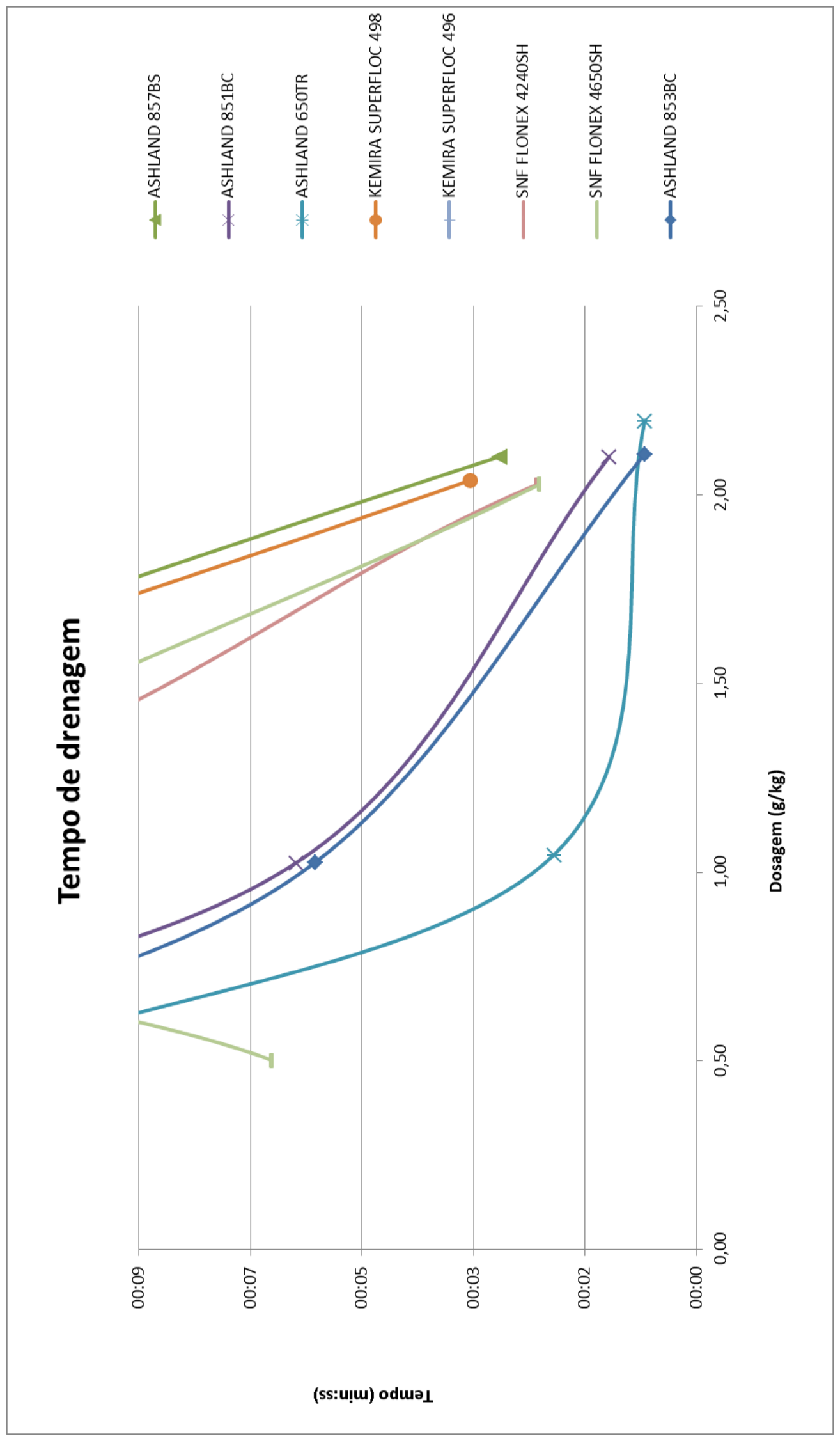

Figura 59 - Resultados dos polímeros sólidos da terceira série de TTD com alteração na escala do eixo das ordenadas para evidenciar as melhores doses 


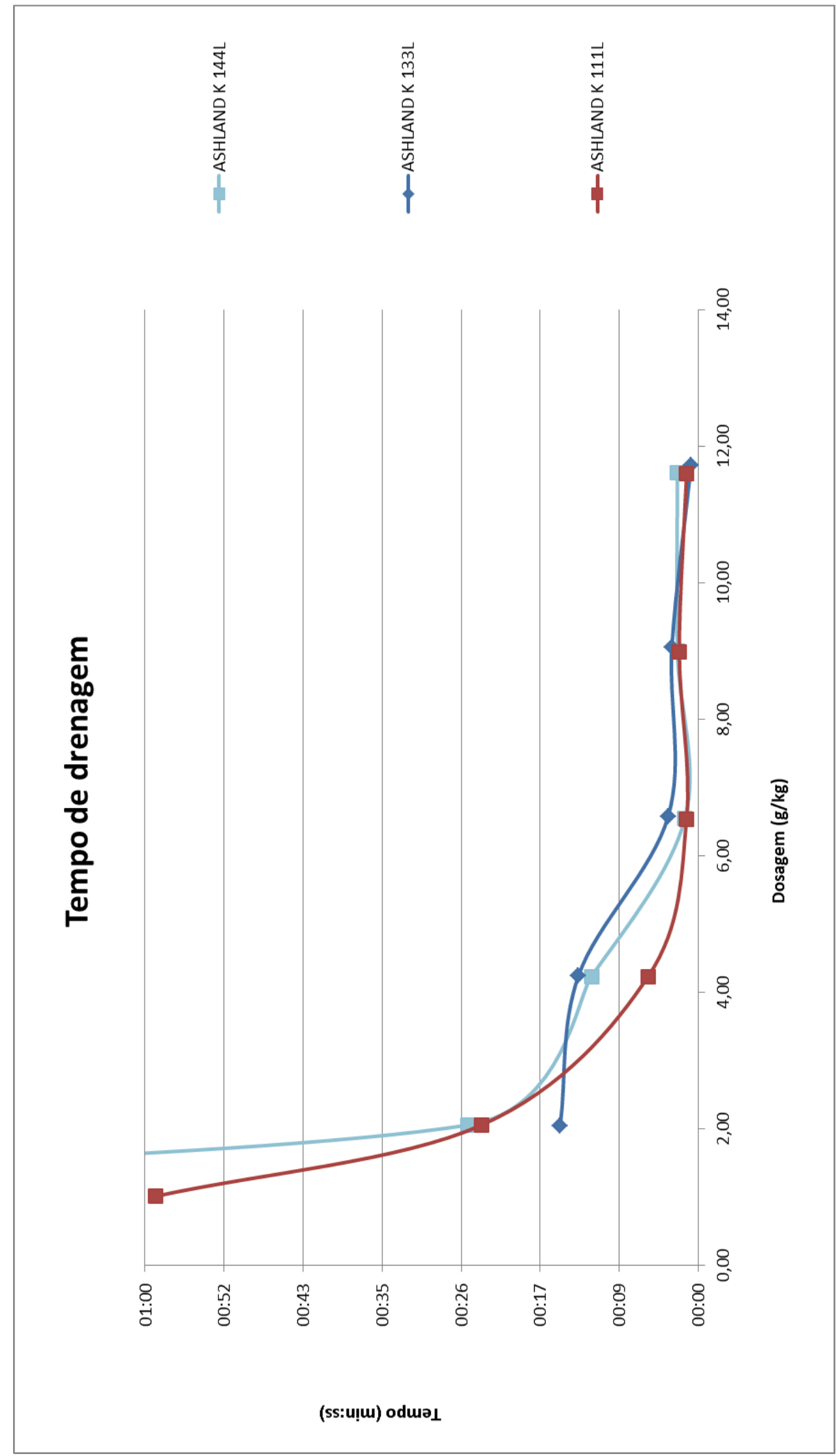

Figura 60 - Resultados dos polímeros em emulsão da terceira série de TTD 


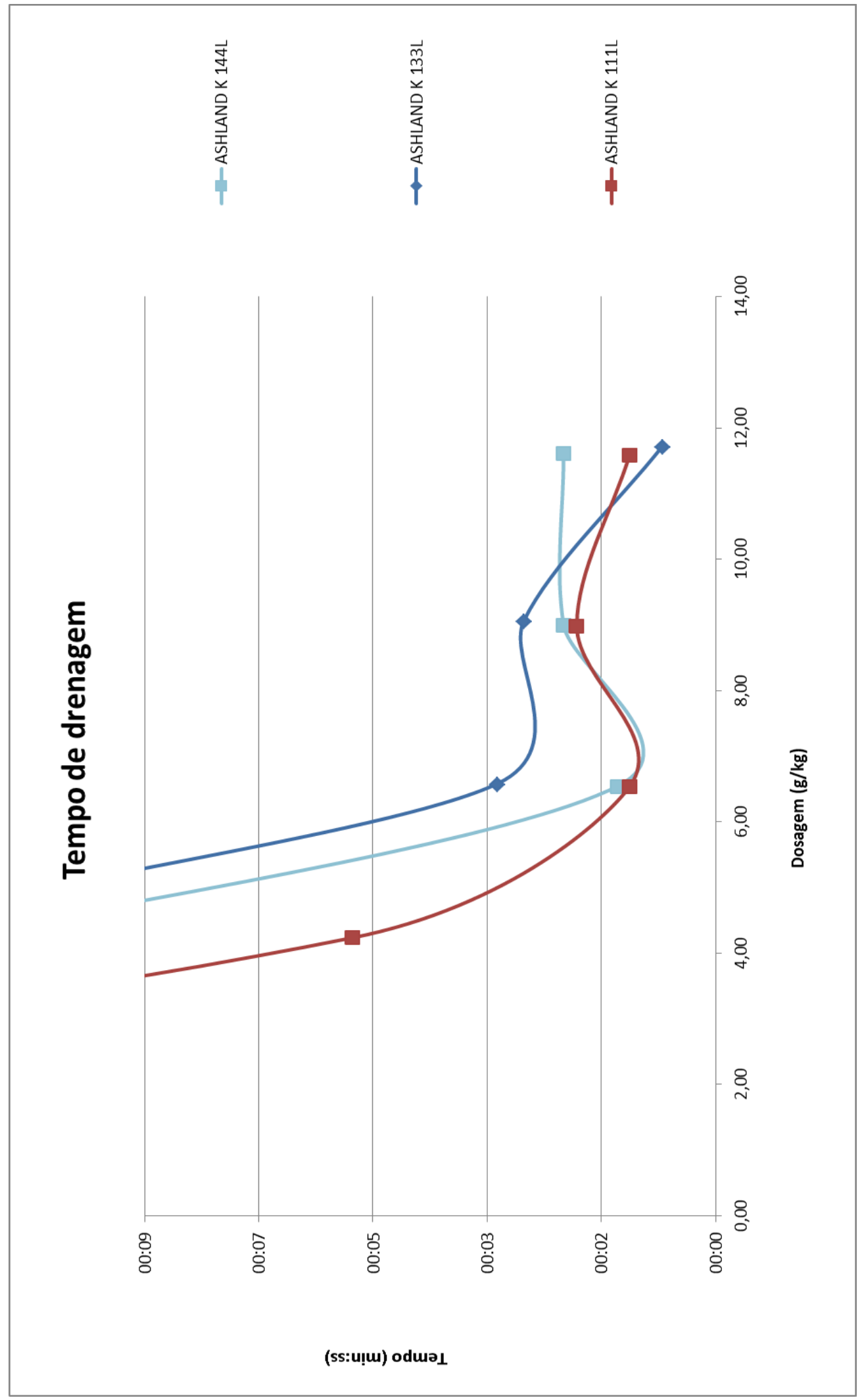

Figura 61 - Resultados dos polímeros em emulsão da terceira série de TTD com alteração na escala do eixo das ordenadas para evidenciar as melhores doses 
5.1.1.4. Dose "ideal" e estimativa de custo

As doses necessárias, de cada polímero, para proporcionar o desaguamento de 50 $\mathrm{mL}$ no TTD em um tempo inferior a 5 segundos (doses "ideais"), são apresentadas na Tabela 16:

Tabela 16 - Doses "ideais", e respectivos tempos de desaguamento e turbidez, determinadas pelo TTD com os 18 polímeros cedidos pelos fabricantes

\begin{tabular}{|c|c|c|c|c|c|c|c|c|c|c|c|c|c|c|c|c|c|c|}
\hline 옹 & 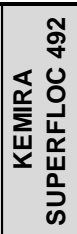 & 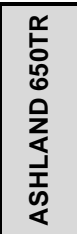 & 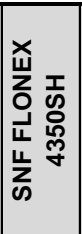 & 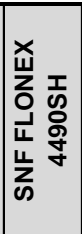 & 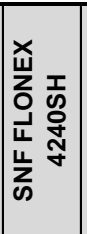 & 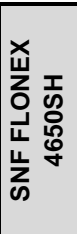 & 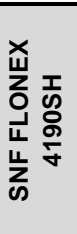 & 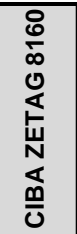 & 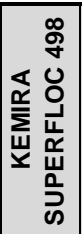 & 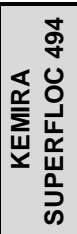 & 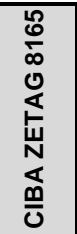 & 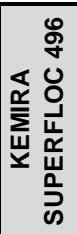 & 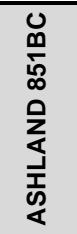 & 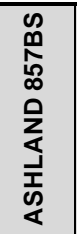 & 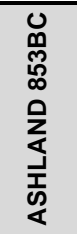 & 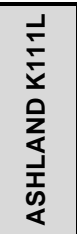 & 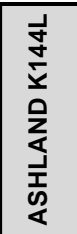 & 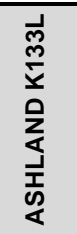 \\
\hline $\begin{array}{c}\text { Dose "ideal" } \\
\text { (g/KgST) }\end{array}$ & 1,01 & 1,05 & 2,02 & 2,03 & 2,03 & 2,03 & 2,03 & 2,03 & 2,04 & 2,04 & 2,04 & 2,04 & 2,10 & 2,10 & 2,11 & 4,23 & 6,54 & 6,58 \\
\hline $\begin{array}{c}\text { Tempo de } \\
\text { desaguamento } \\
\text { (min:s) }\end{array}$ & $00: 03$ & 00:02 & $00: 03$ & $00: 03$ & 00:02 & 00:02 & 00:03 & 00:04 & $00: 04$ & $00: 03$ & 00:02 & $00: 05$ & 00:01 & 00:03 & 00:01 & 00:05 & 00:01 & 00:03 \\
\hline Turbidez (UNT) & 5,29 & 6,69 & 4,86 & 3,03 & 9,91 & 8,71 & 3,44 & 7,30 & 8,68 & 5,38 & 0,22 & 4,72 & 6,83 & 6,02 & 9,61 & 20,80 & 5,26 & 9,58 \\
\hline
\end{tabular}

Os polímeros em emulsão (ASHLAND 111L, 133L e 144L) apresentaram doses "ideais" de produto comercial maiores, entre 4 e $6 \mathrm{~g} / \mathrm{kgST}$. Já os 15 polímeros sólidos testados na segunda e terceira série de testes apresentaram dosagens "ideais" de aproximadamente 1 a 2 g/kgST.

Além disso, foi realizada uma estimativa de custo em reais para o condicionamento de uma tonelada de sólidos secos no lodo, utilizando a melhor dose de cada polímero em $\mathrm{g} / \mathrm{kg}$ e o custo do produto (em dez/2010), e apresentada na Tabela 17: 
Tabela 17 - Relação dos polímeros ensaiados ordenados em função do custo estimado de condicionamento por tonelada de sólidos no lodo (considerando R $\$ 1,6=$ US $\$ 1$ )

\begin{tabular}{|c|c|c|c|c|c|c|c|}
\hline Polímero & $\begin{array}{l}\text { Dosagem } \\
\text { "ideal" (g/Kg) }\end{array}$ & $\begin{array}{l}\text { Tempo de } \\
\text { drenagem }\end{array}$ & $\begin{array}{l}\text { Turbidez } \\
\text { (UNT) }\end{array}$ & Preço & Un. & $\begin{array}{c}\text { Preço em } \\
\mathrm{R} \$ / \mathrm{Kg}\end{array}$ & $\begin{array}{l}\text { Custo de polímero } \\
\mathrm{R} \$ / 1000 \mathrm{KgST} \text { de lodo }\end{array}$ \\
\hline $\begin{array}{c}\text { KEMIRA } \\
\text { SUPERFLOC } 492\end{array}$ & 1,01 & 00:03 & 5,29 & 7 & US $\$ / \mathrm{Kg}$ & 11,2 & 11,30 \\
\hline ASHLAND 650TR & 1,05 & 00:02 & 6,69 & 9,45 & US $\$ / \mathrm{Kg}$ & 15,12 & 15,83 \\
\hline CIBA ZETAG 8165 & 2,04 & 00:02 & 0,22 & 7,38 & US $\$ / \mathrm{Kg}$ & 11,808 & 24,13 \\
\hline $\begin{array}{c}\text { KEMIRA } \\
\text { SUPERFLOC } 494\end{array}$ & 2,04 & 00:03 & 5,38 & 7,6 & US\$/Kg & 12,16 & 24,82 \\
\hline $\begin{array}{c}\text { KEMIRA } \\
\text { SUPERFLOC } 496 \\
\end{array}$ & 2,04 & 00:05 & 4,72 & 8,8 & US $\$ / \mathrm{Kg}$ & 14,08 & 28,72 \\
\hline ASHLAND 851BC & 2,10 & 00:01 & 3,59 & 8,7 & US\$/Kg & 13,92 & 29,23 \\
\hline $\begin{array}{c}\text { KEMIRA } \\
\text { SUPERFLOC } 498 \\
\end{array}$ & 2,04 & 00:04 & 8,68 & 9,25 & US $\$ / \mathrm{Kg}$ & 14,8 & 30,18 \\
\hline ASHLAND 853BC & 2,11 & 00:01 & 2,52 & 9 & US\$/Kg & 14,4 & 30,38 \\
\hline ASHLAND 857BS & 2,10 & 00:03 & 6,02 & 10,6 & US\$/Kg & 16,96 & 35,65 \\
\hline $\begin{array}{c}\text { SNF FLONEX } \\
4190 \mathrm{SH}\end{array}$ & 2,03 & 00:03 & 3,44 & 20 & $\mathrm{R} \$ / \mathrm{Kg}$ & 20 & 40,58 \\
\hline $\begin{array}{c}\text { SNF FLONEX } \\
4240 \mathrm{SH} \\
\end{array}$ & 2,03 & 00:02 & 9,91 & 20 & $\mathrm{R} \$ / \mathrm{Kg}$ & 21 & 42,58 \\
\hline $\begin{array}{c}\text { SNF FLONEX } \\
4350 \mathrm{SH}\end{array}$ & 2,02 & 00:03 & 5,72 & 23 & $\mathrm{R} \$ / \mathrm{Kg}$ & 23 & 46,55 \\
\hline ASHLAND K111L & 4,23 & 00:05 & 20,80 & 11 & $\mathrm{R} \$ / \mathrm{Kg}$ & 11 & 46,56 \\
\hline $\begin{array}{c}\text { SNF FLONEX } \\
4490 \mathrm{SH}\end{array}$ & 2,03 & 00:03 & 3,03 & 23 & $\mathrm{R} \$ / \mathrm{Kg}$ & 23 & 46,59 \\
\hline $\begin{array}{c}\text { SNF FLONEX } \\
4650 \mathrm{SH}\end{array}$ & 2,03 & 00:02 & 8,71 & 23 & $\mathrm{R} \$ / \mathrm{Kg}$ & 23 & 46,64 \\
\hline CIBA ZETAG 8160 & 2,03 & 00:04 & 7,30 & 23 & $\mathrm{R} \$ / \mathrm{Kg}$ & 23 & 46,80 \\
\hline ASHLAND K144L & 6,54 & 00:01 & 5,26 & 13,2 & $\mathrm{R} \$ / \mathrm{Kg}$ & 13,2 & 86,38 \\
\hline ASHLAND K133L & 6,58 & $00: 03$ & 9,58 & 14,15 & $\mathrm{R} \$ / \mathrm{Kg}$ & 14,15 & 93,13 \\
\hline
\end{tabular}

A partir da estimativa das doses "ideias" de cada polímero e respectivos custos de dosagem por tonelada de sólidos secos no lodo foi possível selecionar os produtos mais adequados ao condicionamento dos lodos anaeróbios utilizados. Estes polímeros foram submetidos a outros ensaios para garantir a escolha do melhor polímero para utilização nos ensaios em escala piloto. 
5.1.1.5. Quarta série de testes

A quarta série de TTD foi realizada com o melhor produto de cada fabricante, selecionados a partir dos resultados da segunda e terceira série de testes. Os seguintes produtos foram utilizados: ASHLAND 650 TR, KEMIRA SUPERFLOC 492, SNF FLONEX 4190SH e CIBA ZETAG 8165.

Os ensaios da quarta série foram realizados com as dosagens de 0,5 a $4 \mathrm{~g} / \mathrm{kg}$ de sólidos secos. O lodo que foi condicionado era de origem da ETE de Jaraguá, origem também do inóculo utilizado no reator do CTH.

Os resultados indicaram que os polímeros ASHLAND 650TR e KEMIRA SUPERFLOC 492 possuem as menores doses de polímero para drenar $50 \mathrm{~mL}$ no TTD e, também, os dois menores custos de condicionamento (ver item 5.1.1.4). Além disso, produzem os drenados com os menores valores de turbidez.

A planilha com os dados e resultados da quarta série de testes está no APÊNDICE 5. Os resultados dos tempos de drenagem da quarta série de testes estão apresentados na Figura 62: 


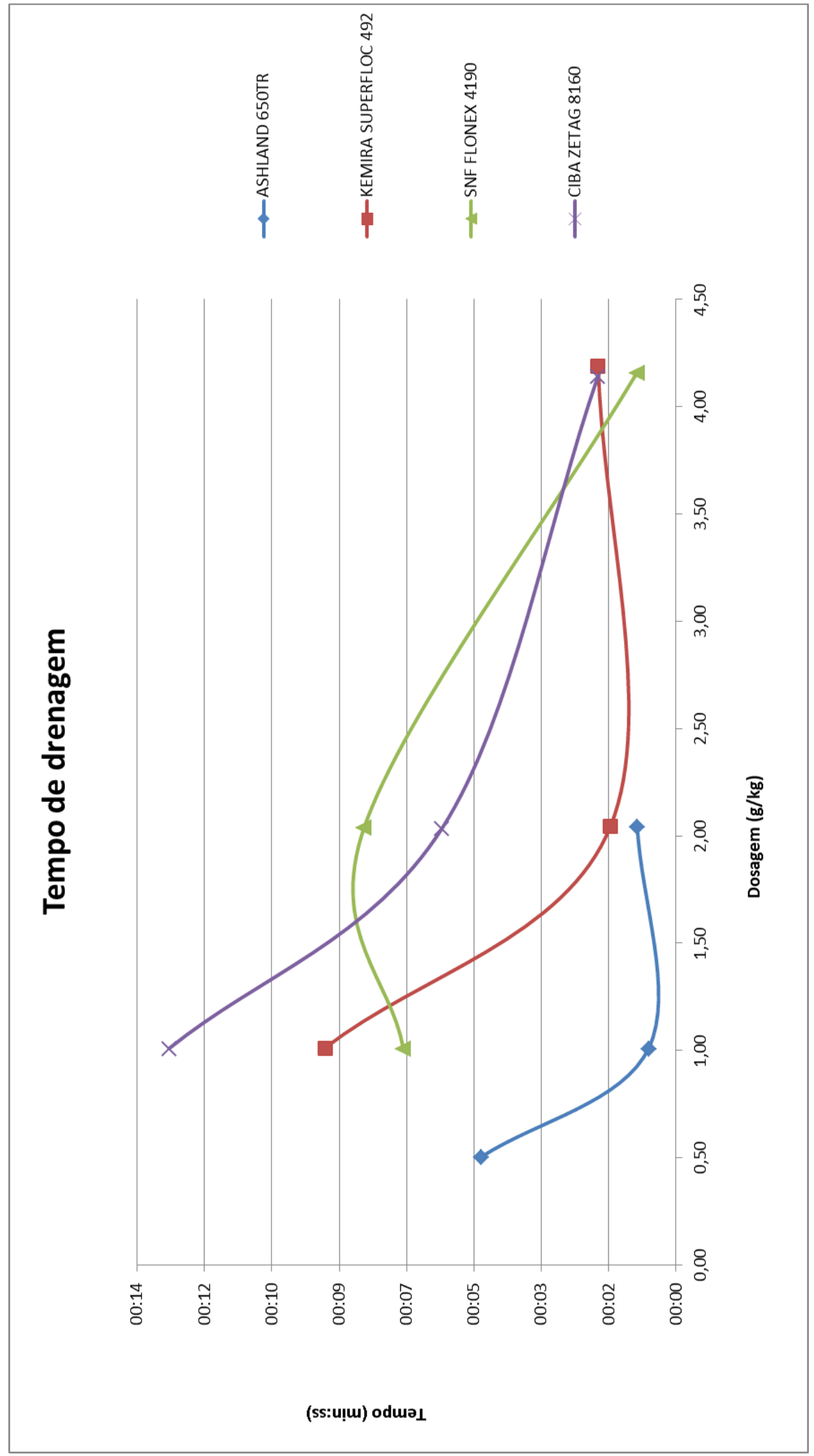

Figura 62 - Resultados dos testes da quarta série de TTD 
5.1.1.6. Quinta série de testes

Os dois melhores polímeros da quarta série de testes foram submetidos a um teste completo (dosagens entre 0,5 e $8 \mathrm{~g} / \mathrm{kg}$ ) e em duplicata, compondo a quinta e última série de ensaios com o TTD para determinação do polímero que foi utilizado nos ensaios em escala piloto.

A planilha com os dados e resultados da quarta série de testes estão no APÊNDICE 6. A partir da média dos tempos de drenagem para as mesmas doses, foi plotado o gráfico apresentado na Figura 63: 


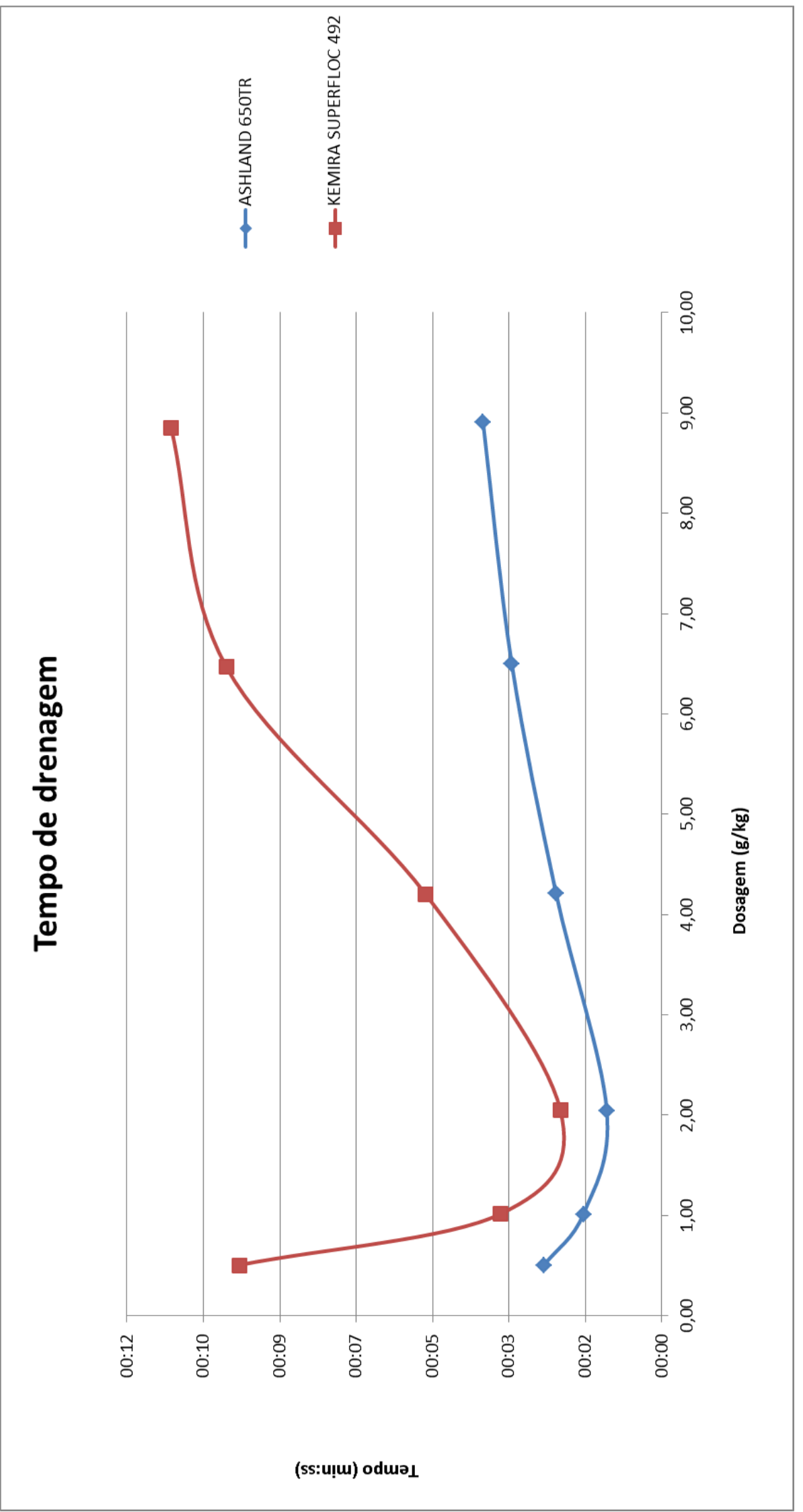

Figura 63 - Resultados dos testes da quinta série de TTD 
Os resultados da quinta série de TTD indicaram que o polieletrólito ASHLAND 650TR é o produto dentre todos que foram testados que possui maior aptidão com o lodo anaeróbio ensaiado, possibilitando as maiores velocidades para retirada de água com as menores doses. Este polímero foi utilizado no teste comparativo entre mantas geotêxteis e nos ensaios em escala piloto.

Porém, é importante ressaltar que todos os polímeros testados proporcionaram melhorias ao desaguamento natural através do aumento significativo das taxas de drenagem de água livre. Ensaios realizados (mas não apresentados neste trabalho) com lodo não condicionado resultaram em tempos de drenagem superiores a 40 minutos, enquanto que com pequenas doses de polímero é possível atingir tempos de drenagem inferiores a 2 segundos. $O$ aspecto do lodo após seu condicionamento é apresentado na Figura 64:

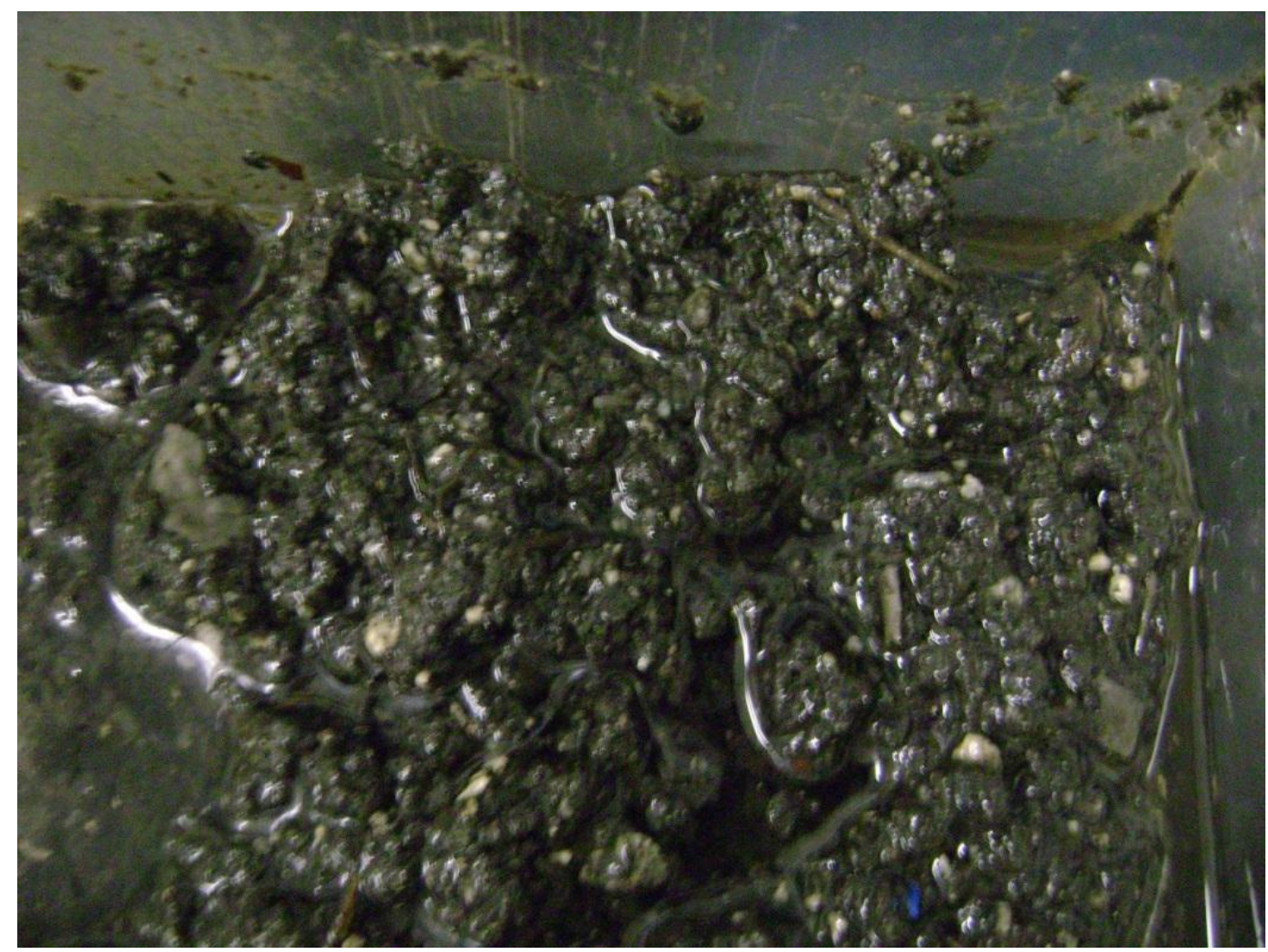

Figura 64 - Aspecto do lodo condicionado com aumento significativo do porcentual de água livre e formação de flocos estruturados 


\subsubsection{Escolha da manta geotêxtil}

Após os ensaios para avaliar o efeito das dosagens de cada polímero, o produto ASHLAND 650TR foi utilizado para comparar as mantas geotêxteis quanto a sua capacidade de desaguamento. Foram testados 5 materiais com o TTD para a filtração de água da torneira, lodo não condicionado e lodo condicionado na "dose ideal" de $1 \mathrm{~g} / \mathrm{kg}$ (determinada anteriormente de acordo com item 5.1.1). No TTD com água limpa foi medido o tempo para drenagem de $200 \mathrm{~mL}$ e, para o desaguamento de lodo não condicionado e condicionado, os $50 \mathrm{~mL}$ normalmente medidos no TTD. O lodo utilizado em todos os testes foi o mesmo, com cerca de $23 \mathrm{~g} / \mathrm{L}$ de concentração de sólidos, e o polímero possuía cerca de $2 \mathrm{~g} / \mathrm{L}$ de concentração de diluição. A rotação e o tempo de mistura foram mantidos em 250 rpm e 1 minuto, respectivamente, e os resultados são apresentados na Tabela 18:

Tabela 18 - Resultados dos ensaios com os geotêxteis

\begin{tabular}{|c|c|c|c|}
\hline Geossintético & Fluido & Tempo (min:s) & Turbidez (UNT) \\
\hline \multirow{6}{*}{$\begin{array}{c}\text { Propex } 14000- \\
140 \mathrm{~g} / \mathrm{m}^{2}\end{array}$} & $\mathrm{~A}$ & $00: 17$ & - \\
\hline & A & $00: 17$ & - \\
\hline & $\mathrm{LN}$ & $04: 12$ & 79,8 \\
\hline & LN & $05: 55$ & 87,2 \\
\hline & LC & $00: 02$ & 7,98 \\
\hline & LC & 00:04 & 8,54 \\
\hline \multirow{6}{*}{$\begin{array}{c}\text { Huesker } 80 / 80 \text { - } \\
390 \mathrm{~g} / \mathrm{m}^{2}\end{array}$} & A & $00: 20$ & - \\
\hline & $\mathrm{A}$ & $00: 25$ & - \\
\hline & LN & 04:01 & 67,8 \\
\hline & LN & $04: 36$ & 56,9 \\
\hline & LC & $00: 05$ & 4,9 \\
\hline & LC & 00:04 & 7,12 \\
\hline \multirow{6}{*}{$\begin{array}{c}\text { Huesker 55/55 - } \\
289 \mathrm{~g} / \mathrm{m}^{2}\end{array}$} & $A$ & $00: 15$ & - \\
\hline & $\mathrm{A}$ & $00: 15$ & - \\
\hline & LN & $02: 30$ & 98,1 \\
\hline & LN & $02: 48$ & 73,2 \\
\hline & LC & $00: 03$ & 10,2 \\
\hline & LC & $00: 06$ & 11,4 \\
\hline \multirow{6}{*}{$\begin{array}{c}\text { Bidim RT } 21 \text { - } \\
\quad 400 \mathrm{~g} / \mathrm{m}^{2}\end{array}$} & $\mathrm{~A}$ & 00:09 & - \\
\hline & $\mathrm{A}$ & 00:08 & - \\
\hline & LN & $06: 57$ & 90,3 \\
\hline & $\mathrm{LN}$ & $07: 46$ & 92,2 \\
\hline & LC & $00: 05$ & 9,89 \\
\hline & LC & $00: 06$ & 7,15 \\
\hline \multirow{6}{*}{$\begin{array}{c}\text { Macaferri } \\
\text { MacTex N - } \\
\text { 350P }\end{array}$} & $\mathrm{A}$ & $00: 04$ & - \\
\hline & $\mathrm{A}$ & 00:05 & - \\
\hline & $\mathrm{LN}$ & $08: 17$ & 85,4 \\
\hline & LN & $07: 46$ & 86,3 \\
\hline & LC & $00: 04$ & 9,43 \\
\hline & LC & $00: 05$ & 15,9 \\
\hline
\end{tabular}

A - Água; LN - Lodo não condicionado; e LC - Lodo condicionado 
Os geotêxteis ensaiados apresentam características de drenagem semelhantes, porém algumas observações feitas durante os ensaios foram determinantes para a seleção da manta geotêxtil para os ensaios em escala piloto. Foi observado que, mesmo depois de apenas um TTD, as mantas não tecidas já se encontravam levemente impregnadas e, a cada novo TTD que era realizado, apresentaram um desgaste considerável. Esse desgaste foi observado pela perda de compactação e aumento da espessura e mobilidade das fibras do material a cada nova limpeza, realizada com água corrente e leve atrito com os dedos para garantir a retirada do material preso nas dobras laterais da manta.

Conforme relatado na revisão bibliográfica deste documento, as mantas tecidas com filamentos em polipropileno seriam mais adequadas para a condição de manejo dos sólidos residuais, por não apresentarem, ao final de cada ciclo de secagem, impregnação de materiais graxos e oleosos presentes nos lodos (FONTANA, 2007).

Assim, com base na revisão bibliográfica e nos ensaios realizados, as mantas não tecidas foram descartadas por apresentarem desgaste excessivo nas operações de descarga de lodo no leito de drenagem e limpeza manual.

A HUESKER possui um material de excelente qualidade e com gramaturas diversas, além de que a empresa possui facilidade de comunicação e pronto atendimento, de modo que foi o fabricante selecionado para fornecer as mantas geotêxteis para os ensaios em escala piloto.

Mesmo com pouca diferença de custo, o geotêxtil de $289 \mathrm{~g} / \mathrm{m}^{2}$ da HUESKER é um pouco mais barato que o de $390 \mathrm{~g} / \mathrm{m}^{2}$, sendo assim o escolhido para sequência dos ensaios. Os custos de diversos geotêxteis foram levantados e todos se encontraram entre 2 e $11 \mathrm{R} \$ / \mathrm{m}^{2}$ para compra em bobinas padronizadas por cada fabricante, sendo que os materiais considerados adequados (geotêxteis tecidos uniformes e de boa qualidade com gramatura entre 200 e $400 \mathrm{~g} / \mathrm{m}^{2}$ ) custam cerca de 4 a $6 \mathrm{R} \$ / \mathrm{m}^{2}$.

As mantas geotêxteis devem sempre ser avaliadas no ato de seu recebimento, pois podem variar de qualidade entre diferentes lotes de fabricação. 


\subsection{Ensaio piloto}

Os ensaios piloto com os leitos de drenagem foram realizados no Centro Tecnológico de Hidráulica da USP, com a utilização da manta geotêxtil de gramatura igual a $289 \mathrm{~g} / \mathrm{m}^{2}$, da HUESKER (Hate $55 \mathrm{kN} / 55 \mathrm{kN}$ ), e com dosagem do polímero ASHLAND 650TR entre 0 e $8 \mathrm{~g} / \mathrm{kg}$ de sólidos secos. O drenado foi recolhido e teve sua $\mathrm{DQO}$, condutividade, $\mathrm{pH}$ e turbidez medidos. A torta teve sua altura e teor de sólidos monitorados.

As variáveis climáticas foram monitoradas diariamente ao longo dos ensaios. Porém, como nenhuma delas exerce influência predominante em leitos cobertos, não foram relacionadas diretamente com os resultados e nenhuma variável foi plotada junto com as curvas de secagem dos ensaios. Os dados foram obtidos junto ao Instituto de Astronomia, Geofísica e Ciências Atmosféricas da USP (IAG) e encontram-se no ANEXO C.

\subsubsection{Ensaios para avaliar o efeito das diferentes dosagens de polímero}

Os ensaios em escala piloto com os leitos de drenagem foram realizados com a utilização da manta geotêxtil tecida de gramatura igual a $289 \mathrm{~g} / \mathrm{m}^{2}$ da HUESKER (Hate $55 \mathrm{kN} / 55 \mathrm{kN}$ ). Foram inicialmente realizados ensaios com dosagens de polímero entre 0 e $8 \mathrm{~g} / \mathrm{kgST}$ (E1 a E8). Posteriormente foram realizados três ensaios simultaneamente, como forma de reduzir a influência das variáveis climáticas, sendo um deles sem a utilização de polímero (E9) e os outros com as doses de 2 e 4 $\mathrm{g} / \mathrm{kgST}$ (E10 e E11). Os resultados obtidos nos ensaios piloto, relativos à altura da torta no leito de drenagem e à evolução do teor de sólidos ao longo do período de secagem, são apresentados na Tabela 19 e nas Figura 65 a Figura 75. Uma sequência de fotos do aspecto da torta ao longo do ensaio E10 é apresentada no APÊNDICE 10. 
Tabela 19 - Resultados da altura e teor de sólidos da torta para os ensaios piloto E1 a E11 ao longo do período de secagem

\begin{tabular}{|c|c|c|c|c|c|c|c|c|c|c|c|c|c|c|c|c|c|c|c|c|c|c|}
\hline \multirow{2}{*}{$\begin{array}{l}\text { Período } \\
\text { de } \\
\text { secagem } \\
\text { (dias) }\end{array}$} & \multicolumn{2}{|c|}{$\begin{array}{l}E 1-D c=1 \mathrm{~g} / \mathrm{Kg} \\
\mathrm{Ca}=19,8 \mathrm{Kg} / \mathrm{m}^{2}\end{array}$} & \multicolumn{2}{|c|}{$\begin{array}{c}E 2-D c=2 g / K g \\
C a=19 K g / m^{2}\end{array}$} & \multicolumn{2}{|c|}{$\begin{array}{l}E 3-D c=3 \mathrm{~g} / \mathrm{Kg} \\
\mathrm{Ca}=14,7 \mathrm{Kg} / \mathrm{m}^{2}\end{array}$} & \multicolumn{2}{|c|}{$\begin{array}{l}E 4-D c=4 \mathrm{~g} / \mathrm{Kg} \\
\mathrm{Ca}=14,9 \mathrm{Kg} / \mathrm{m}^{2}\end{array}$} & \multicolumn{2}{|c|}{$\begin{array}{l}E 5-D c=5 \mathrm{~g} / \mathrm{Kg} \\
\mathrm{Ca}=15,5 \mathrm{Kg} / \mathrm{m}^{2}\end{array}$} & \multicolumn{2}{|c|}{$\begin{array}{l}E 6-D c=6 \mathrm{~g} / \mathrm{Kg} \\
\mathrm{Ca}=15,6 \mathrm{Kg} / \mathrm{m}^{2}\end{array}$} & \multicolumn{2}{|c|}{$\begin{array}{l}E 7-D c=0 \mathrm{~g} / \mathrm{Kg} \\
\mathrm{Ca}=15,4 \mathrm{Kg} / \mathrm{m}^{2}\end{array}$} & \multicolumn{2}{|c|}{$\begin{array}{l}E 8-D c=8 \mathrm{~g} / \mathrm{Kg} \\
\mathrm{Ca}=12,8 \mathrm{Kg} / \mathrm{m}^{2}\end{array}$} & \multicolumn{2}{|c|}{$\begin{array}{l}E 9-D c=0 \mathrm{~g} / \mathrm{Kg} \\
\mathrm{Ca}=15,6 \mathrm{Kg} / \mathrm{m}^{2}\end{array}$} & \multicolumn{2}{|c|}{$\begin{array}{c}E 10-D c=2 g / K g \\
C a=14,6 \mathrm{Kg} / \mathrm{m}^{2}\end{array}$} & \multicolumn{2}{|c|}{$\begin{array}{l}E 11-D c=4 \mathrm{~g} / \mathrm{Kg} \\
\mathrm{Ca}=14,9 \mathrm{Kg} / \mathrm{m}^{2}\end{array}$} \\
\hline & \begin{tabular}{|c|} 
Altura \\
da \\
torta \\
(m) \\
\end{tabular} & \begin{tabular}{|c|}
$\begin{array}{c}\text { Teor de } \\
\text { sólidos } \\
(\%)\end{array}$ \\
\end{tabular} & \begin{tabular}{|l} 
Altura \\
da \\
torta \\
(m) \\
\end{tabular} & \begin{tabular}{|c|}
$\begin{array}{c}\text { Teor de } \\
\text { sólidos } \\
(\%)\end{array}$ \\
\end{tabular} & \begin{tabular}{|c} 
Altura \\
da \\
torta \\
(m)
\end{tabular} & \begin{tabular}{|c} 
Teor de \\
sólidos \\
$(\%)$
\end{tabular} & \begin{tabular}{|c|} 
Altura \\
da \\
torta \\
(m) \\
\end{tabular} & \begin{tabular}{|c|}
$\begin{array}{c}\text { Teor de } \\
\text { sólidos } \\
(\%)\end{array}$ \\
\end{tabular} & \begin{tabular}{|c} 
Altura \\
da \\
torta \\
(m) \\
\end{tabular} & \begin{tabular}{|c|}
$\begin{array}{c}\text { Teor de } \\
\text { sólidos } \\
(\%)\end{array}$ \\
\end{tabular} & \begin{tabular}{|c|} 
Altura \\
da \\
torta \\
(m) \\
\end{tabular} & \begin{tabular}{|c|}
$\begin{array}{c}\text { Teor de } \\
\text { sólidos } \\
(\%)\end{array}$ \\
\end{tabular} & \begin{tabular}{|c} 
Altura \\
da \\
torta \\
(m)
\end{tabular} & \begin{tabular}{|c|c}
$\begin{array}{c}\text { Teor de } \\
\text { sólidos } \\
(\%)\end{array}$ \\
\end{tabular} & \begin{tabular}{|c|} 
Altura \\
da \\
torta \\
(m) \\
\end{tabular} & \begin{tabular}{|c} 
Teor de \\
sólidos \\
$(\%)$
\end{tabular} & \begin{tabular}{|c|} 
Altura \\
da \\
torta \\
(m) \\
\end{tabular} & \begin{tabular}{|c|c}
$\begin{array}{c}\text { Teor de } \\
\text { sólidos } \\
(\%)\end{array}$ \\
\end{tabular} & \begin{tabular}{|c}
$\begin{array}{c}\text { Altura } \\
\text { da } \\
\text { torta } \\
\text { (m) }\end{array}$ \\
\end{tabular} & \begin{tabular}{|c|}
$\begin{array}{c}\text { Teor de } \\
\text { sólidos } \\
(\%)\end{array}$ \\
\end{tabular} & \begin{tabular}{|c|} 
Altura \\
da \\
torta \\
(m) \\
\end{tabular} & \begin{tabular}{|c|}
$\begin{array}{c}\text { Teor de } \\
\text { sólidos } \\
(\%)\end{array}$ \\
\end{tabular} \\
\hline 0 & \begin{tabular}{|l|}
45 \\
\end{tabular} & 3,57 & 45 & 3,42 & 45 & 2,65 & 45 & 2,68 & 45 & 2,79 & 45 & 2,71 & 45 & 2,76 & 45 & 2,31 & 50 & 2,45 & 45 & 2,62 & 45 & 2,68 \\
\hline 1 & 25 & 12,49 & 17 & 15,26 & 11 & 14,14 & 11 & 14,56 & 15 & 14,00 & & & 15 & 15,97 & 9 & 13,14 & 20 & 11,85 & 12 & 13,69 & 12 & 13,79 \\
\hline 2 & & & 15 & 15,41 & & & & & & & 15 & 16,13 & & & & & & & & & & \\
\hline 3 & & & & & 11 & 14,67 & 10,5 & 14,76 & & & & & & & 8 & 15,95 & 12,5 & 13,99 & & & 11 & 15,86 \\
\hline 4 & & & 15 & 17,36 & & & & & 15 & 16,21 & & & 14 & 16,09 & & & & & 11 & 15,86 & & \\
\hline 5 & & & & & 11 & 15,72 & 10 & 15,69 & & & 14 & 16,59 & & & & & & & & & & \\
\hline 6 & 15 & 13,32 & & & & & & & 14 & 17,16 & & & 14 & 17,18 & 7 & 17,45 & 11 & 16,19 & 11 & 16,65 & 11 & 17,56 \\
\hline 7 & & & 14 & 23,68 & 11 & 16,66 & 10 & 16,43 & & & 14 & 17,43 & & & & & & & & & & \\
\hline 8 & & & & & & & & & 12 & 18,40 & & & 14 & 17,69 & & & 10 & 18,86 & 10 & 17,29 & 11 & 18,68 \\
\hline 9 & 14 & 13,85 & 14 & 18,15 & & & & & & & 12 & 17,73 & & & 6 & 20,59 & & & & & & \\
\hline 10 & & & & & 11 & 15,72 & 10 & 18,00 & 12 & 18,67 & & & & & & & 10 & 17,76 & & & 11 & 20,44 \\
\hline 11 & 13 & 16,13 & 14 & 19,12 & & & & & & & 11 & 18,65 & & & 6 & 21,88 & & & 10 & 19,78 & & \\
\hline 12 & & & & & 11 & 16,05 & 10 & 21,10 & 12 & 20,91 & & & 13 & 18,25 & & & & & & & & \\
\hline 13 & 13 & 15,76 & 14 & 21,51 & & & & & & & 10 & 18,90 & & & 5 & 22,38 & 10 & 27,43 & 10 & 19,91 & 11 & 20,18 \\
\hline 14 & & & & & 10,5 & 16,04 & 10 & 18,72 & & & & & 12 & 20,84 & & & & & & & & \\
\hline 15 & 13 & 18,21 & 13,5 & 20,05 & 10,5 & 16,01 & & & 11 & 19,54 & & & & & 5 & 23,76 & 10 & 21,28 & 10 & 20,49 & 11 & 20,81 \\
\hline \multicolumn{23}{|l|}{16} \\
\hline 17 & & & 13,5 & 18,27 & 10,5 & 16,28 & 10 & 20,06 & 11 & 21,72 & & & 12 & 22,77 & 5 & 24,67 & 10 & 23,32 & & & 11 & 20,91 \\
\hline 18 & 13 & 19,44 & & & & & & & & & 9 & 18,92 & & & & & & & 10 & 22,75 & & \\
\hline 19 & & & 13,5 & 18,88 & 10,5 & 16,56 & 10 & 20,19 & & & & & & & & & & & & & & \\
\hline 20 & 12 & 19,25 & & & & & & & 11 & 21,87 & 9 & 21,47 & 11 & 22,55 & 5 & 28,63 & 10 & 23,75 & 10 & 24,33 & & \\
\hline 21 & & & & & 10 & 15,77 & & & & & & & & & & & & & & & & \\
\hline 22 & 12 & 20,69 & 13,5 & 20,87 & & & 9 & 23,42 & 10 & 22,82 & & & 10 & 25,15 & 5 & 26,55 & 10 & 25,34 & 10 & 23,62 & 10 & 21,72 \\
\hline 23 & & & & & & & & & & & 9 & 23,56 & & & & & & & & & & \\
\hline 24 & 12 & 24,26 & 13,5 & 20,89 & 10 & 17,34 & 9 & 23,70 & 10 & 23,94 & & & & & 5 & 24,31 & 9 & 26,56 & & & & \\
\hline 25 & & & & & & & & & & & & & 10 & 22,03 & & & & & 9 & 30,05 & & \\
\hline 26 & 12 & 21,17 & & & 10 & 18,36 & 9 & 27,43 & & & 9 & 23,67 & & & & & & & & & & \\
\hline 27 & & & 13,5 & 21,56 & & & & & & & & & & & & & 9 & 28,63 & 9 & 28,14 & 10 & 23,90 \\
\hline 28 & 12 & 19,33 & & & 10 & 19,19 & 9 & 28,89 & 9 & 24,04 & 9 & 24,53 & 10 & 27,92 & 5 & 31,28 & & & & & & \\
\hline 29 & & & 13,5 & 25,04 & & & & & & & & & & & & & 8 & 25,70 & 9 & 28,29 & 10 & 25,52 \\
\hline 30 & 12 & 20,08 & & & & & 9 & 37,77 & 9 & 22,11 & & & 10 & 26,55 & 5 & 34,80 & & & & & & \\
\hline 31 & & & 13 & 23,32 & 10 & 21,85 & & & & & 9 & 27,03 & & & & & 8 & 25,39 & 9 & $37,68^{*}$ & 10 & $37,42^{*}$ \\
\hline 32 & & & & & & & & & & & & & 10 & 31,17 & & & 8 & $36,78^{*}$ & & & & \\
\hline 33 & 11 & 21,99 & & & & & & & 9 & 27,41 & & & & & & & & & & & & \\
\hline 34 & & & & & & & & & & & & & 10 & 34,65 & & & & & & & & \\
\hline
\end{tabular}

* - amostras homogeneizadas; Dc - dose de condicionante em g/kgST peso seco; e Ca - taxa de aplicação de sólidos em $\mathrm{kgST} / \mathrm{m}^{2}$.ciclo

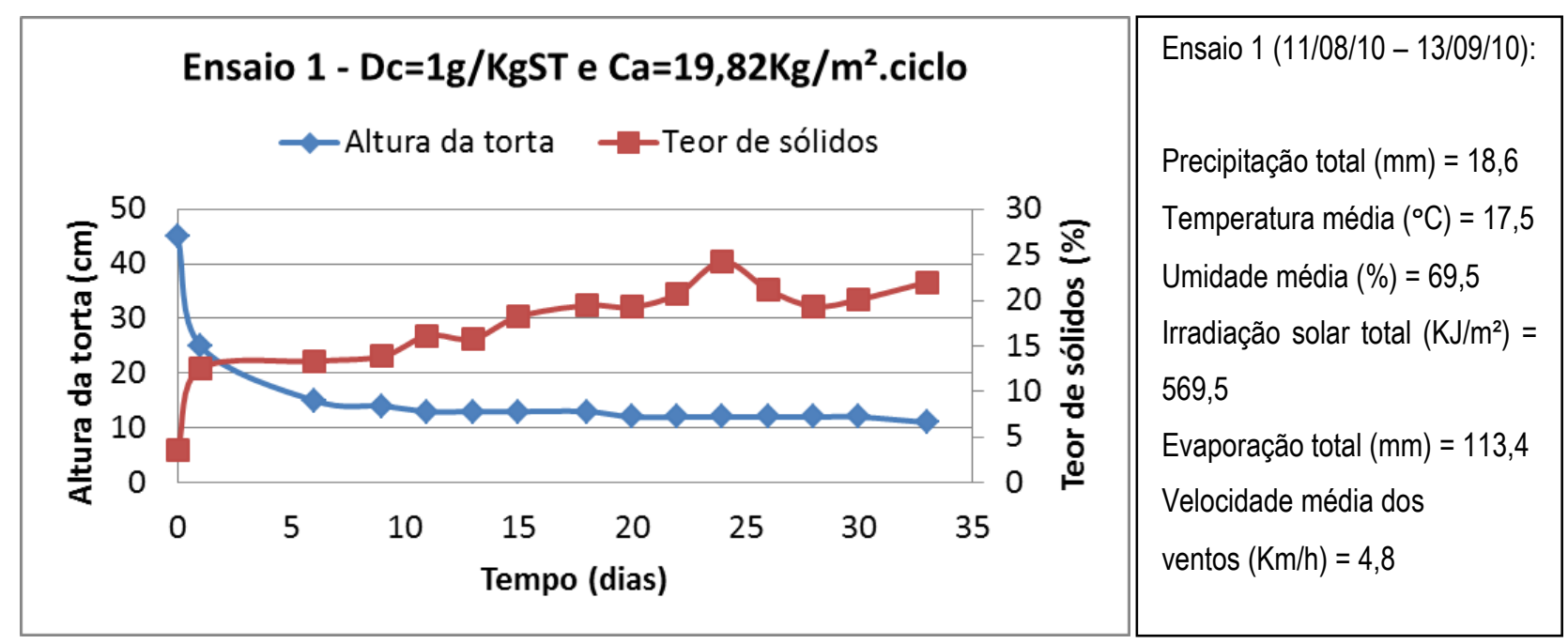

Figura 65 - Altura e teor de sólidos da torta no leito de drenagem para o ensaio piloto E1 


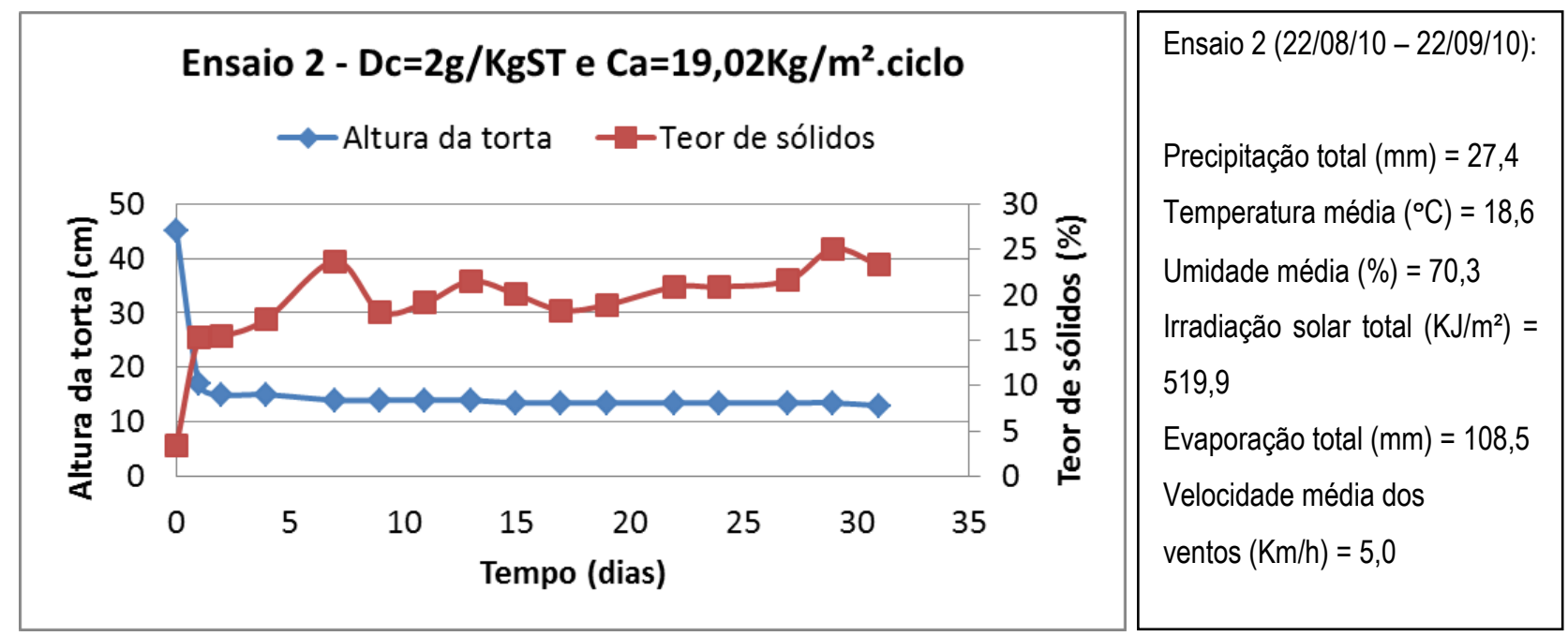

Figura 66 - Altura e teor de sólidos da torta no leito de drenagem para o ensaio piloto E2

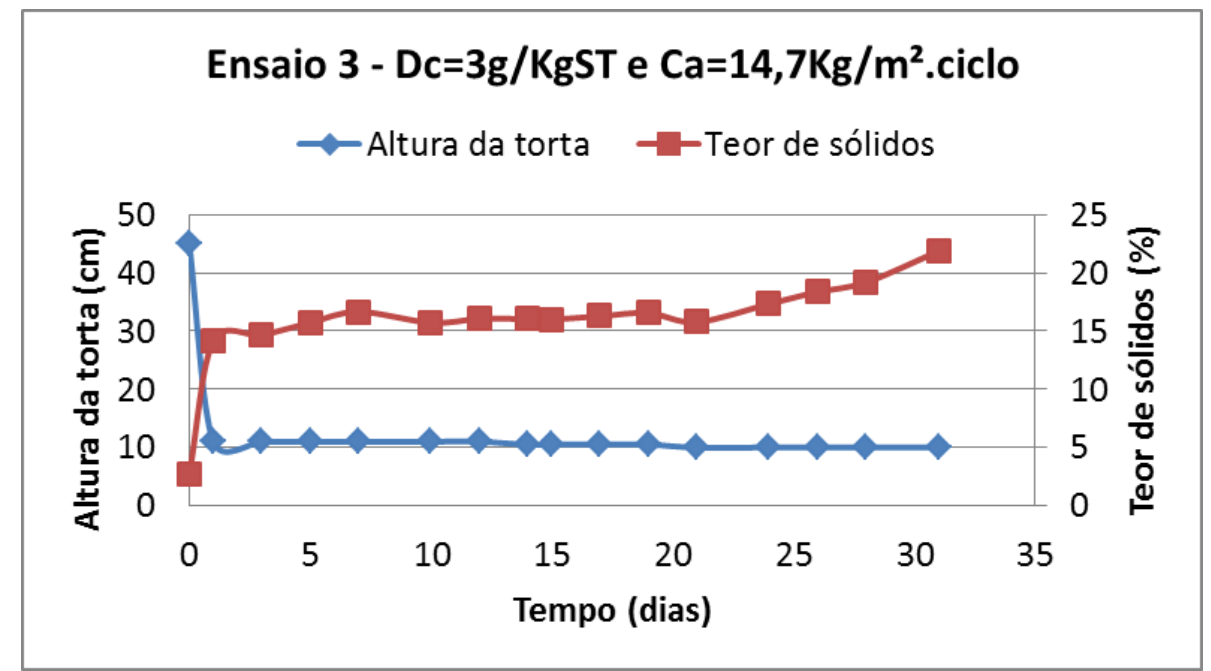

Ensaio $3(17 / 09 / 10-18 / 10 / 10)$ :
Precipitação total $(\mathrm{mm})=121,4$
Temperatura média $\left({ }^{\circ} \mathrm{C}\right)=17,7$
Umidade média $(\%)=84,7$
Irradiação solar total $\left(\mathrm{KJ} / \mathrm{m}^{2}\right)=$
430,2
Evaporação total $(\mathrm{mm})=77,5$
Velocidade média dos
ventos $(\mathrm{Km} / \mathrm{h})=5,9$

Figura 67 - Altura e teor de sólidos da torta no leito de drenagem para o ensaio piloto E3

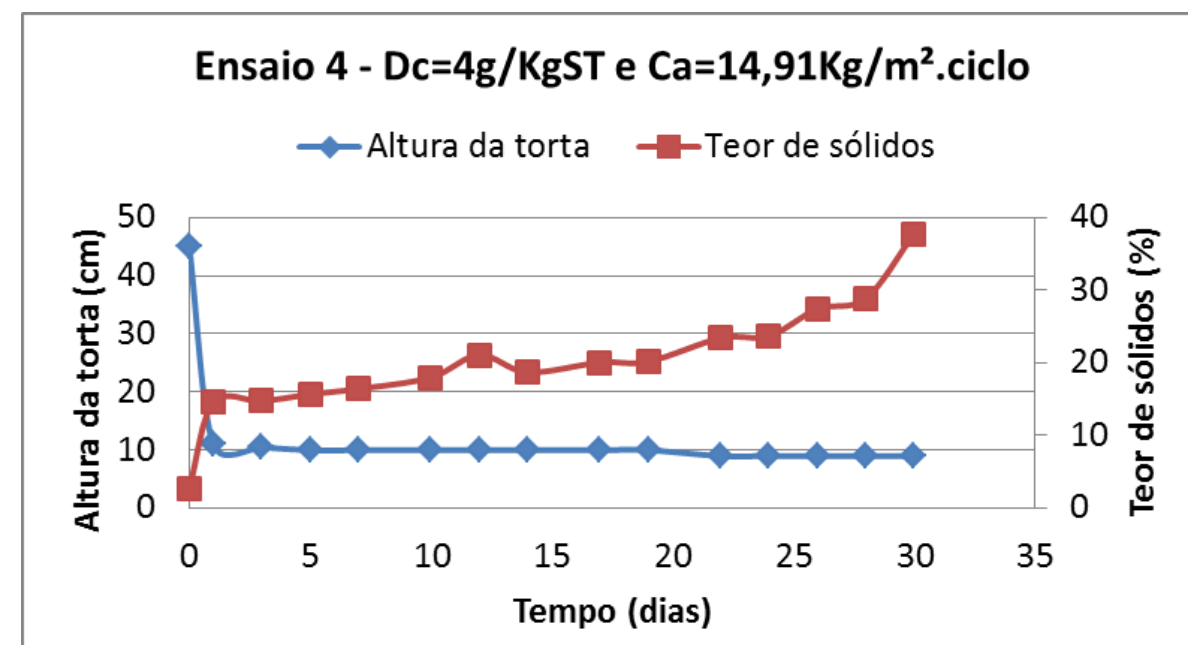

Ensaio $4(1 / 10 / 10-31 / 10 / 10)$ :

Precipitação total $(\mathrm{mm})=76,6$

Temperatura média $\left({ }^{\circ} \mathrm{C}\right)=17,7$

Umidade média $(\%)=82,5$

Irradiação solar total $\left(\mathrm{KJ} / \mathrm{m}^{2}\right)=$ 531,5

Evaporação total $(\mathrm{mm})=107,5$

Velocidade média dos

ventos $(\mathrm{Km} / \mathrm{h})=6,0$

Figura 68 - Altura e teor de sólidos da torta no leito de drenagem para o ensaio piloto E4 


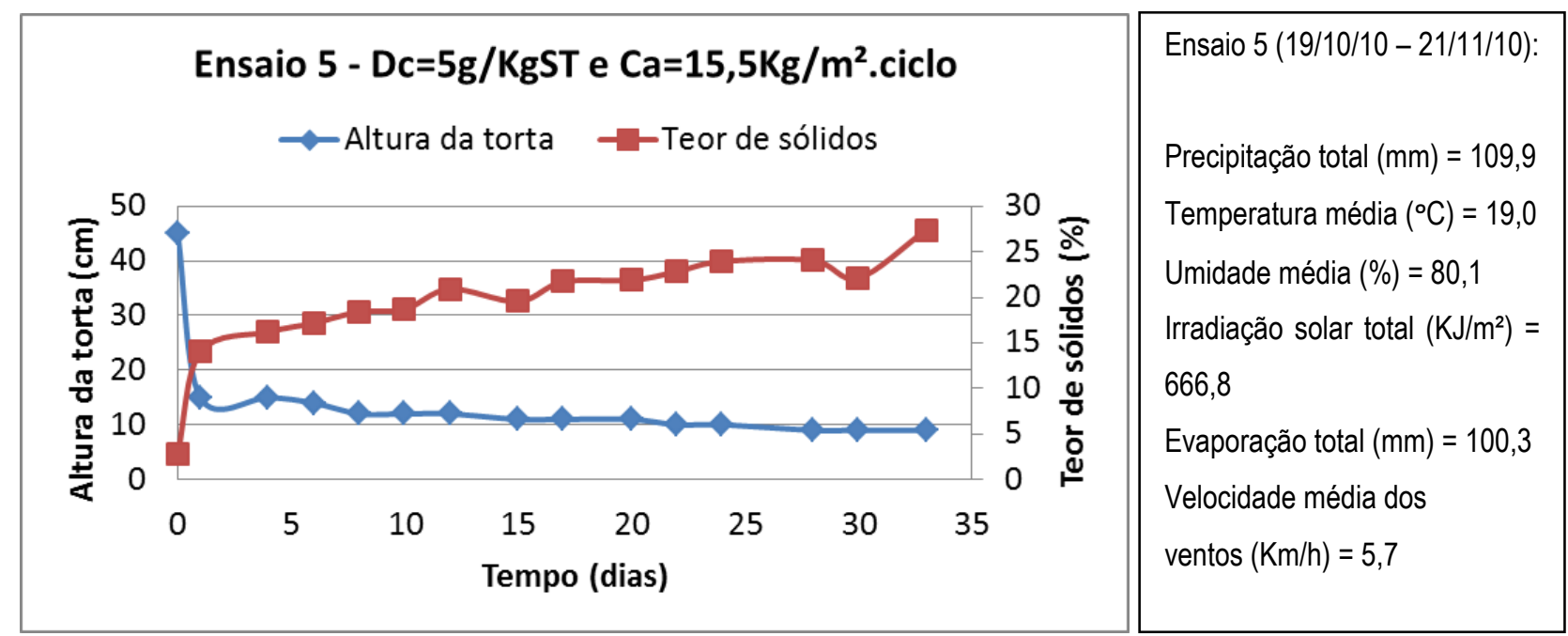

Figura 69 - Altura e teor de sólidos da torta no leito de drenagem para o ensaio piloto E5

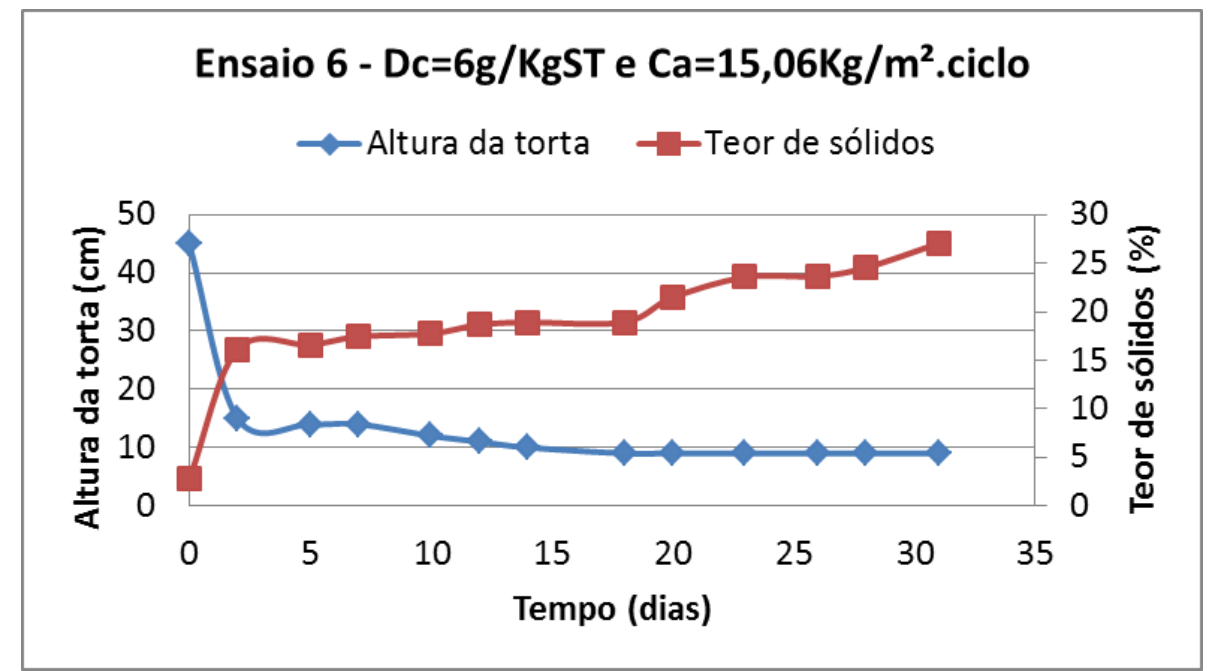

Ensaio $6(29 / 10 / 10-29 / 11 / 10)$ :
Precipitação total $(\mathrm{mm})=119,5$
Temperatura média $\left({ }^{\circ} \mathrm{C}\right)=20,0$
Umidade média $(\%)=80,1$
Irradiação solar total $\left(\mathrm{KJ} / \mathrm{m}^{2}\right)=$
601,8
Evaporação total $(\mathrm{mm})=78,6$
Velocidade média dos
ventos $(\mathrm{Km} / \mathrm{h})=5,8$

Figura 70 - Altura e teor de sólidos da torta no leito de drenagem para o ensaio piloto E6

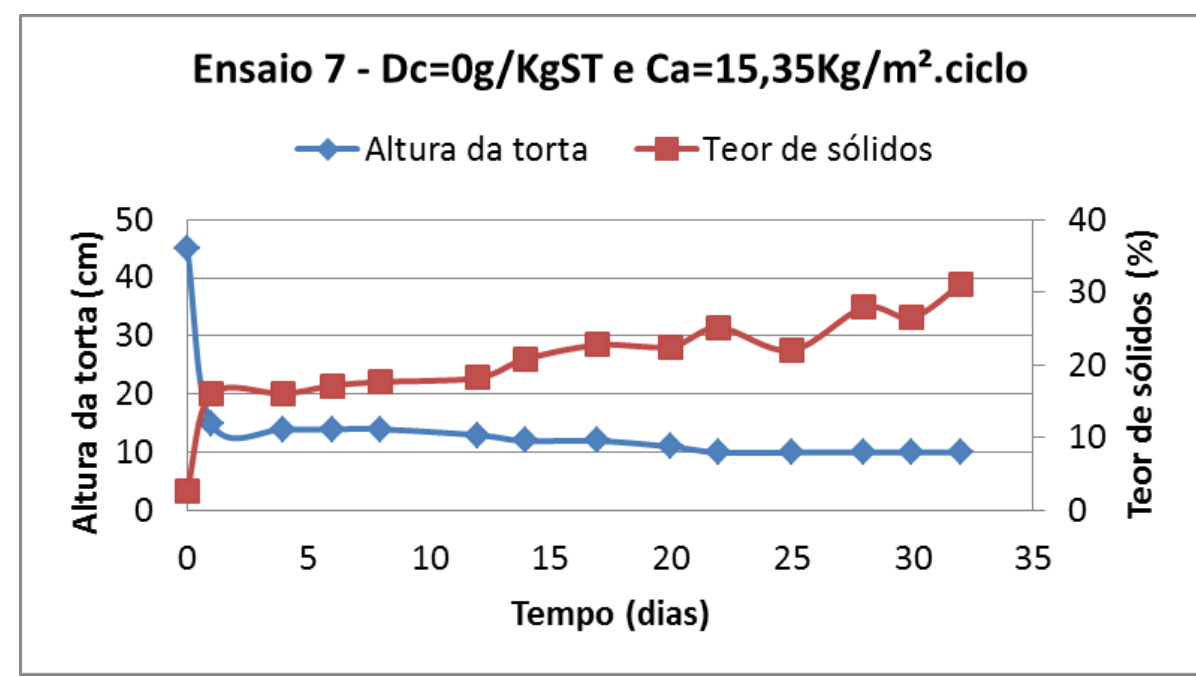

Ensaio 7 (4/11/10 - 6/12/10):

Precipitação total $(\mathrm{mm})=186,2$

Temperatura média $\left({ }^{\circ} \mathrm{C}\right)=20,7$

Umidade média $(\%)=81,0$

Irradiação solar total $\left(\mathrm{KJ} / \mathrm{m}^{2}\right)=$ 600,1

Evaporação total $(\mathrm{mm})=74,7$

Velocidade média dos

ventos $(\mathrm{Km} / \mathrm{h})=5,9$

Figura 71 - Altura e teor de sólidos da torta no leito de drenagem para o ensaio piloto E7 


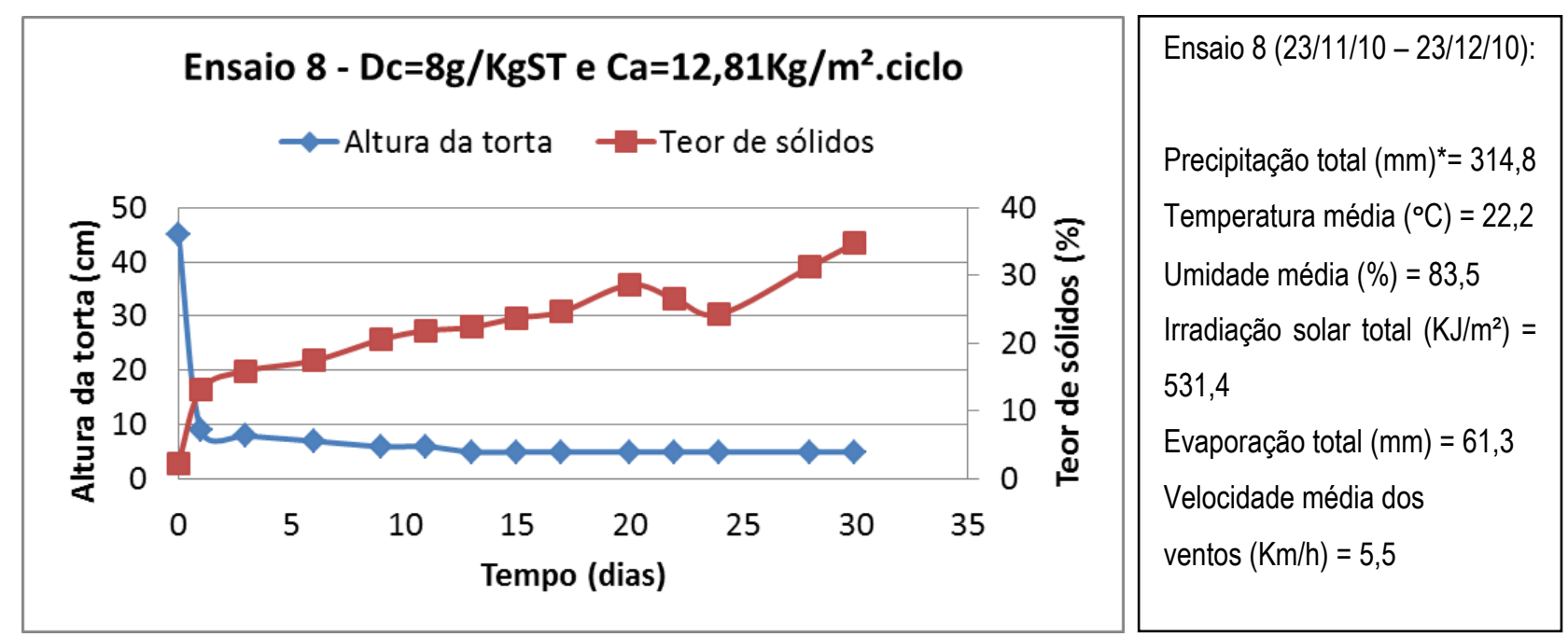

Nota: entre 20 e 25 dias de secagem choveu $150,3 \mathrm{~mm}$.

Figura 72 - Altura e teor de sólidos da torta no leito de drenagem para o ensaio piloto E8

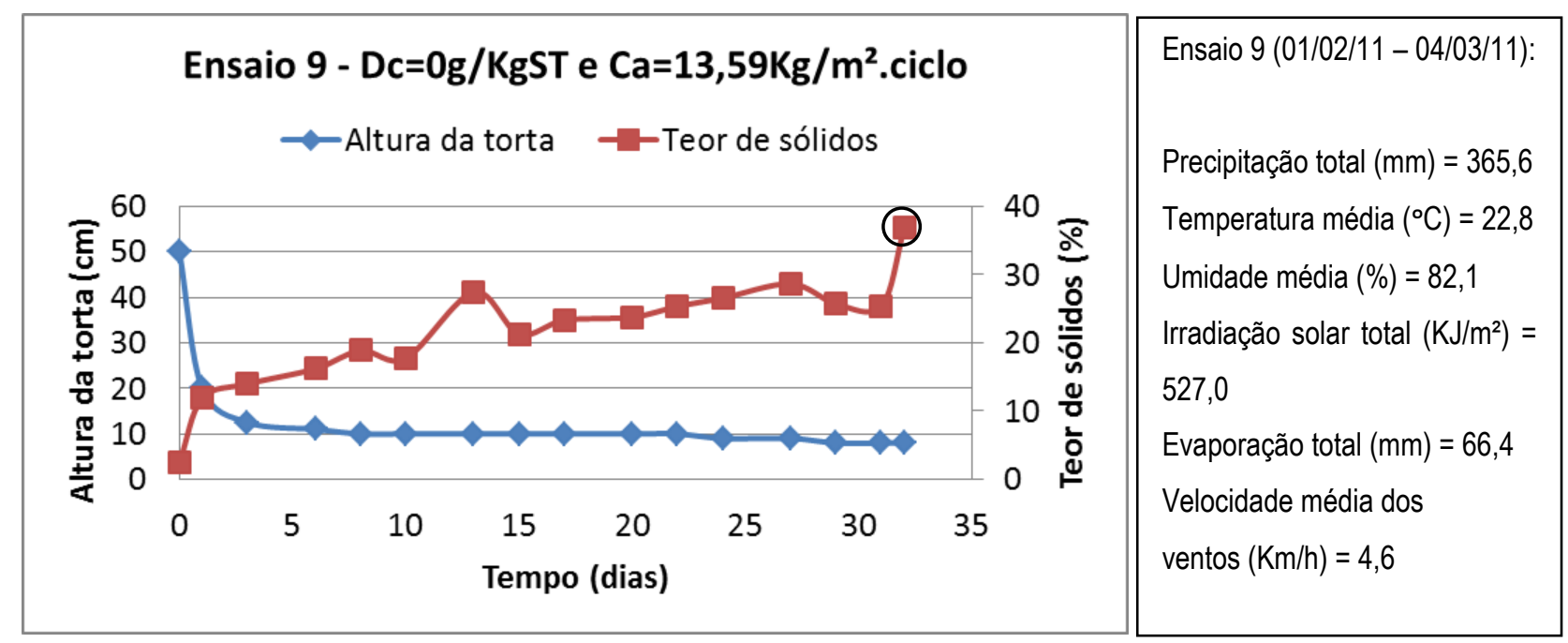

- amostra homogeneizada da torta

Figura 73 - Altura e teor de sólidos da torta no leito de drenagem para o ensaio piloto E9 


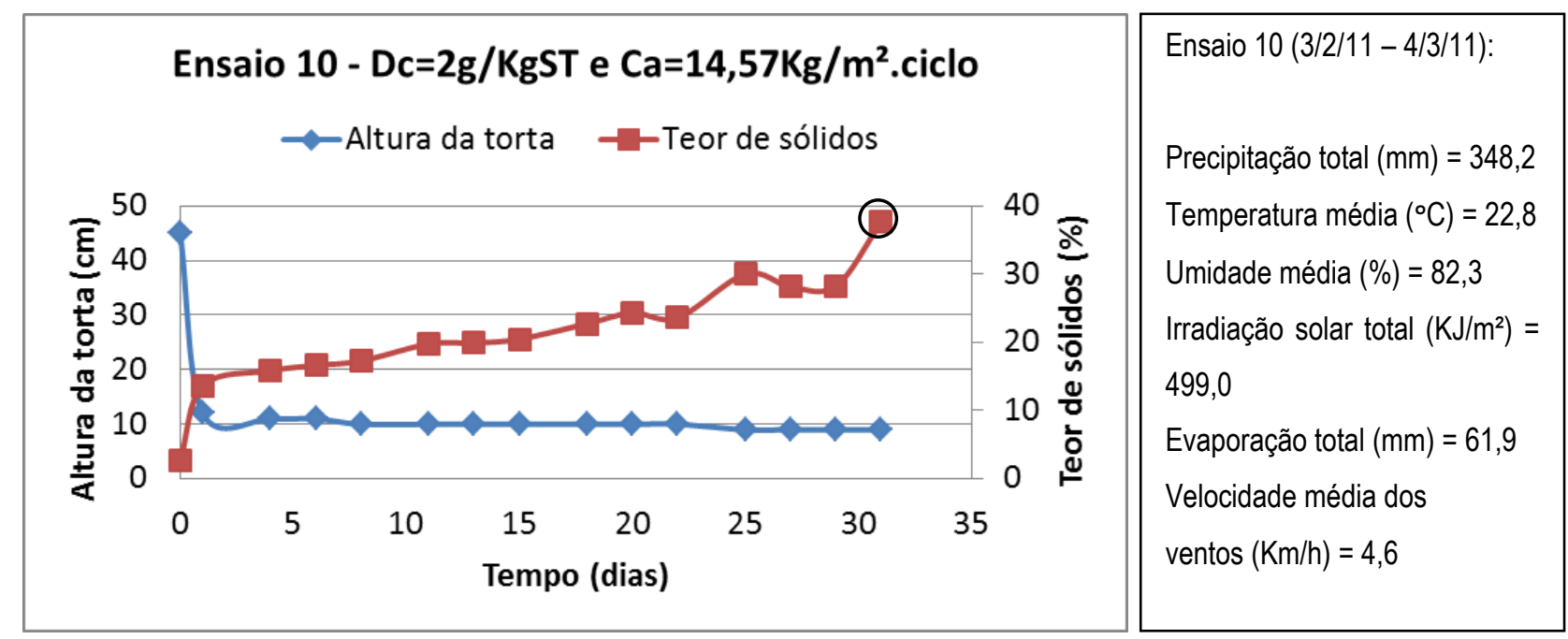

- amostra homogeneizada da torta

Figura 74 - Altura e teor de sólidos da torta no leito de drenagem para o ensaio piloto E10

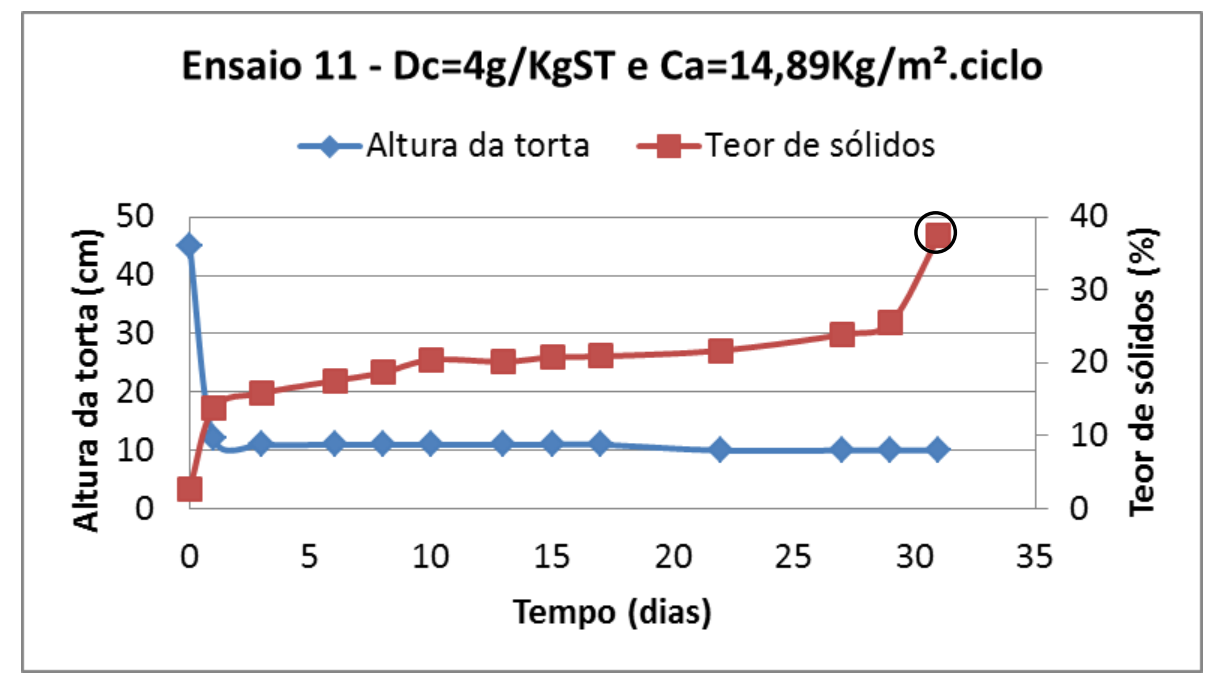

Ensaio $11(15 / 2 / 11$ - 16/3/11):

Precipitação total $(\mathrm{mm})=288,0$

Temperatura média $\left({ }^{\circ} \mathrm{C}\right)=21,4$

Umidade média $(\%)=86,5$ Irradiação solar total $\left(\mathrm{KJ} / \mathrm{m}^{2}\right)=$ 435,1

Evaporação total $(\mathrm{mm})=44,1$ Velocidade média dos ventos $(\mathrm{Km} / \mathrm{h})=5,0$

- amostra homogeneizada da torta

Figura 75 - Altura e teor de sólidos da torta no leito de drenagem para o ensaio piloto E11

A altura inicial da torta foi considerada como aquela máxima atingida pelo lodo no leito após a operação de alimentação do leito de drenagem. O teor de sólidos inicial é o que foi medido para o lodo descartado do UASB, antes de seu condicionamento.

A altura da torta apresentou um comportamento praticamente constante entre os ensaios, sofrendo grande redução, principalmente, no primeiro dia do período de secagem e reduzindo aos poucos nos dias seguintes. A menor altura final foi do E8, que foi realizado com a menor taxa de aplicação de sólidos, e maior foi do E1, realizado com a maior taxa de aplicação de sólidos. Assim, considerando que a altura final da torta no leito possui grande influência da taxa de aplicação de sólidos, 
os resultados indicam que a densidade da torta formada não varia com a dose de polímero aplicada.

Em relação à evolução do teor de sólidos no lodo, após 1 dia da aplicação do lodo ao leito de drenagem, tanto para lodo não condicionado como para todos os lodos condicionados com polímero já se alcançava aproximadamente 13\% de teor de sólidos. Entre 10 e 15 dias de secagem, os ensaios com melhores evoluções do teor de sólidos já chegavam à cerca de $20 \%$, inclusive o E7, em que não foi utilizado condicionamento. Todavia, apenas após 30 dias de secagem é que se chegava a valores entre 25 e $30 \%$ de teor de sólidos, aparentemente também de forma independente das dosagens de polímero.

Ainda com relação ao teor de sólidos da torta, conforme já descrito no item 4.2.2.2, a retirada de amostras de lodo dos leitos de drenagem abrangia o perfil vertical total de lodo, mas era realizada evitando-se as fissuras formadas na torta, o que pode ter resultado na obtenção de teores de sólidos na torta inferiores aos valores reais de amostras homogeneizadas de todo o lodo do leito de drenagem. Para verificar se realmente o procedimento de amostragem do lodo ao longo do período de secagem dos ensaios E1 a E11 estava subavaliando o teor de sólidos das amostras, ao final dos ensaios E9, E10 e E11, o conteúdo da torta resultante de cada ensaio foi homogeneizado e uma amostra mais representativa da torta final foi preparada para determinar o teor de sólidos.

Os resultados, também apresentados na Tabela 19 e nas Figura 73, Figura 74 e Figura 75, mostram que o teor de sólidos das tortas com a amostragem que evitou as fissuras foi de a cerca de $26 \%$ e nas amostras homogeneizadas das tortas o teor de sólidos obtido foi de aproximadamente 37\%, mostrando que realmente 0 procedimento de amostragem utilizado subavaliou os teores de sólidos nas tortas de lodo.

O fluxo de água inicial do leito de drenagem para lodos condicionados com dosagem $\geq 2 \mathrm{~g} / \mathrm{kgST}$ foi de cerca de $48 \mathrm{~L} / \mathrm{min} . \mathrm{m}^{2}$ e para lodo não condicionado ficou abaixo de $6,3 \mathrm{~L} / \mathrm{min} \cdot \mathrm{m}^{2}$. A qualidade do drenado apresentou pouca variação entre amostragens sucessivas (APÊNDICE 9). Os valores médios da Turbidez, DQO, Condutividade e 
$\mathrm{pH}$ das 6 amostras de drenado coletadas em cada ensaio piloto, são os apresentados na Tabela 20:

Tabela 20 - Fluxo de água e médias dos resultados das análises de DQO, Condutividade, pH e Turbidez do drenado

\begin{tabular}{|c|c|c|c|c|c|c|c|c|c|c|c|}
\hline & E1 & E2 & E3 & E4 & E5 & E6 & E7 & E8 & E9 & E10 & E11 \\
\hline Dosagem de polímero (g/KgST) & 1 & 2 & 3 & 4 & 5 & 6 & 0 & 8 & 0 & 2 & 4 \\
\hline Taxa de aplicação (KgST/m².ciclo) & 19,82 & 19,02 & 14,70 & 14,91 & 15,50 & 15,06 & 15,35 & 12,81 & 13,59 & 14,57 & 14,89 \\
\hline Fluxo de água inicial (L/min.m²) & 5 & 20 & 40 & 48 & 48 & 48 & 5 & 48 & 6 & 48 & 48 \\
\hline $\mathrm{DQO}(\mathrm{mg} / \mathrm{L})$ & 174,8 & 53,0 & 86,8 & 40,6 & 125,3 & 185,0 & 311,1 & 194,8 & 180,9 & 116,2 & 195,6 \\
\hline Condutividade $(\mu \mathrm{S})$ & 888 & 1154 & 1161 & 1140 & 973 & 1195 & 1111 & 1095 & 773 & 626 & 799 \\
\hline $\mathrm{pH}$ & 6,29 & 6,61 & 6,64 & 6,62 & 6,74 & 6,20 & 6,85 & 6,78 & 6,90 & 6,68 & 6,62 \\
\hline Turbidez (UNT) & 81,0 & 9,9 & 4,5 & 3,5 & 7,0 & 18,0 & 142,2 & 12,0 & 63,8 & 9,7 & 29,6 \\
\hline
\end{tabular}

Os resultados indicam que o fluxo inicial de água (taxas de drenagem) é sensivelmente alterado pela utilização de condicionante. Foi também possível observar que, para os lodos condicionados, estas taxas não foram influenciadas pelas dosagens de polímero adicionadas ao lodo. Este fato se deve, provavelmente, a influência do bocal de drenagem dos leitos, que limitou a vazão drenada.

A turbidez e a DQO apresentaram alguma influência das doses de polímero, sendo que a turbidez do drenado dos ensaios com lodo condicionado com dosagens $\geq 2$ $\mathrm{g} / \mathrm{kgST}$ apresentaram valores inferiores a 30 UNT e lodos condicionados com 1 $\mathrm{g} / \mathrm{kgST}$ ou sem adição de polímero apresentaram valores de turbidez para seus drenados superior a 60 UNT. A DQO apresentou valores menores que $100 \mathrm{mg} / \mathrm{L}$ para as dosagens de 2, 3 e $4 \mathrm{~g} / \mathrm{kgST}$ dos ensaios E2, E3 e E4. Nos ensaios E10 e E11, com dosagens de 2 e $4 \mathrm{~g} / \mathrm{kgST}$, a DQO média das 6 amostras foi superior a esta, não se tendo explicação para isso. Estes resultados de DQO e turbidez, a despeito das variações verificadas, podem indicar para uma melhor retenção de sólidos nas dosagens de condicionante de 2 a $4 \mathrm{~g} / \mathrm{kgST}$.

A Condutividade e o pH não apresentaram grandes influências do condicionamento. $\mathrm{O} \mathrm{pH}$ se manteve entre 6 e 7,5 para quase todas as amostras de drenado de todos os ensaios. A condutividade sofreu maiores variações entre os ensaios e a média das 6 amostras de cada ensaio apresentou valores entre 500 e $1300 \mu \mathrm{S} / \mathrm{cm}$. Como relatado na revisão bibliográfica, a superdosagem poderia ser verificada por alterações de alguns parâmetros químicos do drenado, porém, nem o pH e nem a condutividade apresentaram alguma correlação com as doses de polímeros, 
impossibilitando que pudesse ser verificada qualquer a influência das doses de polímeros nestes parâmetros.

Com relação à operação do leito de drenagem, a remoção da torta de lodo do leito de drenagem se mostrou bem mais fácil para os lodos condicionados com doses de polímero $\geq 2 \mathrm{~g} / \mathrm{kgST}$. Para os lodos não condicionados e com dose de $1 \mathrm{~g} / \mathrm{kgST}$, a remoção da torta se mostrou mais trabalhosa e a manta apresentou impregnação por material sólido úmido, que impedia a varrição da manta, como pode ser observado na Figura 76:
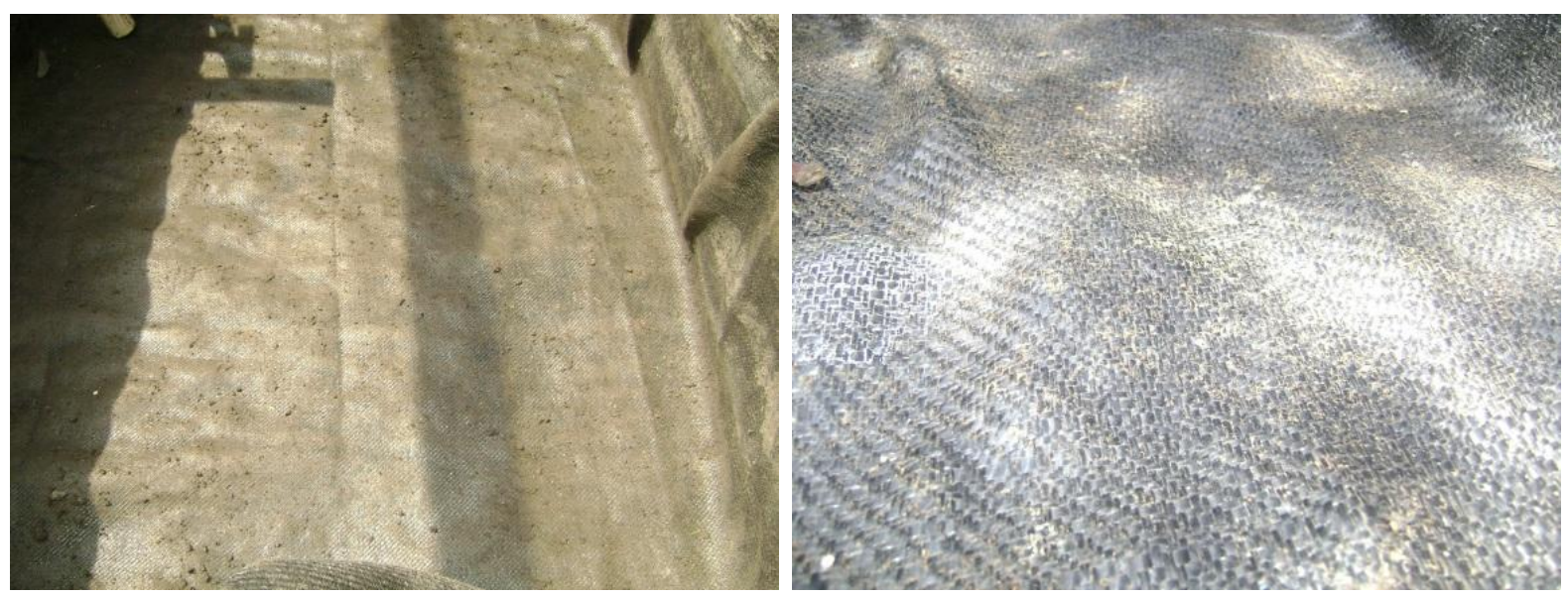

Figura 76 - Aspecto da manta após a remoção manual da torta de ensaio sem condicionamento à esquerda (E9) e com condicionamento à direita (E10)

Todos estes fatores indicam que a dose de $2 \mathrm{~g} / \mathrm{kgST}$, com base nos ensaios piloto, pode ser considerada a mais interessante.

As planilhas com os dados e resultados dos testes em escala piloto encontram-se no APÊNDICE 7. Os gráficos gerados para comparar o comportamento da altura da torta e teor de sólidos entre os ensaios encontram-se no APÊNDICE 8. 


\subsubsection{Ensaios para avaliar diferentes taxas de aplicação de sólidos}

Foram realizados 3 ensaios com taxas de aplicação superficial de sólidos (Ca) de $14,4 \mathrm{kgST} / \mathrm{m}^{2}$.ciclo (E12), 21,2 $\mathrm{kgST} / \mathrm{m}^{2}$.ciclo (E13) e $9,8 \mathrm{kgST} / \mathrm{m}^{2}$.ciclo (E14). A dosagem de polímeros (Dc) foi mantida em $2 \mathrm{~g} / \mathrm{kgST}$. Os 3 ensaios foram realizados em um mesmo intervalo de 40 dias, para reduzir a influência das variáveis climáticas nos resultados.

Em vista dos erros de amostragem descritos no item 5.2.1, as amostragens nos ensaios E12, E13 e E14 foram realizadas evitando-se regiões da torta próximas à parede. Assim, delimitou-se uma região central do leito, com distância mínima de 20 $\mathrm{cm}$ das paredes laterais, que foi dividida em 8 sub-regiões. A partir do momento em que as fissuras apareceram nos leitos de drenagem, cada sub-região foi amostrada em sua parte central, evitando-se que os furos pudessem provocar o aumento da velocidade de secagem nas sub-regiões adjacentes.

Os resultados obtidos nos ensaios piloto E12, E13 e E14, relativos à altura da torta no leito de drenagem e à evolução do teor de sólidos ao longo do período de secagem, são apresentados na Tabela 21 e em gráfico individuais na Figura 77, Figura 78 e Figura 79: 
Tabela 21 - Resultados da altura e teor de sólidos da torta para os ensaios piloto E12 a E14 ao longo do período de secagem

\begin{tabular}{|c|c|c|c|c|c|c|}
\hline \multirow{2}{*}{$\begin{array}{c}\text { Período de } \\
\text { secagem (dias) }\end{array}$} & \multicolumn{2}{|c|}{$\begin{array}{l}E 12-D c=2 g / K g S T \\
C a=14,4 \mathrm{KgST} / \mathrm{m}^{2}\end{array}$} & \multicolumn{2}{|c|}{$\begin{array}{c}\mathrm{E} 13-\mathrm{Dc}=2 \mathrm{~g} / \mathrm{KgST} \\
\mathrm{Ca}=21,2 \mathrm{KgST} / \mathrm{m}^{2}\end{array}$} & \multicolumn{2}{|c|}{$\begin{array}{c}\mathrm{E} 14-\mathrm{Dc}=2 \mathrm{~g} / \mathrm{KgST} \\
\mathrm{Ca}=9,8 \mathrm{KgST} / \mathrm{m}^{2}\end{array}$} \\
\hline & $\begin{array}{l}\text { Altura da } \\
\text { torta }(m)\end{array}$ & $\begin{array}{c}\text { Teor de } \\
\text { sólidos (\%) }\end{array}$ & $\begin{array}{l}\text { Altura da } \\
\text { torta }(m)\end{array}$ & $\mid \begin{array}{c}\text { Teor de } \\
\text { sólidos (\%) }\end{array}$ & $\begin{array}{l}\text { Altura da } \\
\text { torta }(\mathrm{m})\end{array}$ & $\begin{array}{c}\text { Teor de } \\
\text { sólidos (\%) }\end{array}$ \\
\hline 0 & 45 & 2,59 & 45 & 3,82 & 47 & 1,76 \\
\hline 1 & 12 & 13,65 & 17 & 15,65 & 8 & 13,75 \\
\hline \multicolumn{7}{|l|}{2} \\
\hline 3 & 11 & 14,62 & & & & \\
\hline \multicolumn{7}{|l|}{4} \\
\hline 5 & & & & & 7 & 14,59 \\
\hline 6 & 10 & 15,92 & 15 & 17,49 & & \\
\hline \multicolumn{7}{|l|}{7} \\
\hline 8 & & & & & 7 & 14,81 \\
\hline 9 & & & 14 & 17,19 & & \\
\hline \multicolumn{7}{|l|}{10} \\
\hline 11 & 10 & 15,73 & & & & \\
\hline 12 & & & & & 7 & 16,14 \\
\hline 13 & & & 14 & 18,63 & & \\
\hline 14 & 10 & 18,17 & & & & \\
\hline 15 & & & & & 7 & 15,67 \\
\hline 16 & & & 14 & 19,23 & & \\
\hline \multicolumn{7}{|l|}{17} \\
\hline 18 & 10 & 17,33 & & & 7 & 18,02 \\
\hline 19 & & & 14 & 20,33 & & \\
\hline \multicolumn{7}{|l|}{20} \\
\hline 21 & 10 & 18,73 & & & & \\
\hline 22 & & & & & 7 & 18,15 \\
\hline 23 & & & 14 & 21,19 & & \\
\hline 24 & 10 & 19,76 & & & & \\
\hline 25 & & & & & 7 & 20,21 \\
\hline 26 & & & 14 & 20,15 & & \\
\hline \multicolumn{7}{|l|}{27} \\
\hline 28 & 9,5 & 20,99 & & & & \\
\hline 29 & & & & & 7 & 20,37 \\
\hline 30 & & & 13 & 22,05 & & \\
\hline 31 & 9 & 20,97 & & & & \\
\hline 32 & & & & & 7 & 22,34 \\
\hline 33 & & & 13 & 22,11 & & \\
\hline \multicolumn{7}{|l|}{34} \\
\hline 35 & 9 & 23,54 & & & 7 & 24,85 \\
\hline 36 & & & 13 & 22,09 & & \\
\hline
\end{tabular}

Dc - dose de condicionante em g/kgST peso seco e Ca - taxa de aplicação de sólidos em $\mathrm{kgST} / \mathrm{m}^{2}$.ciclo 


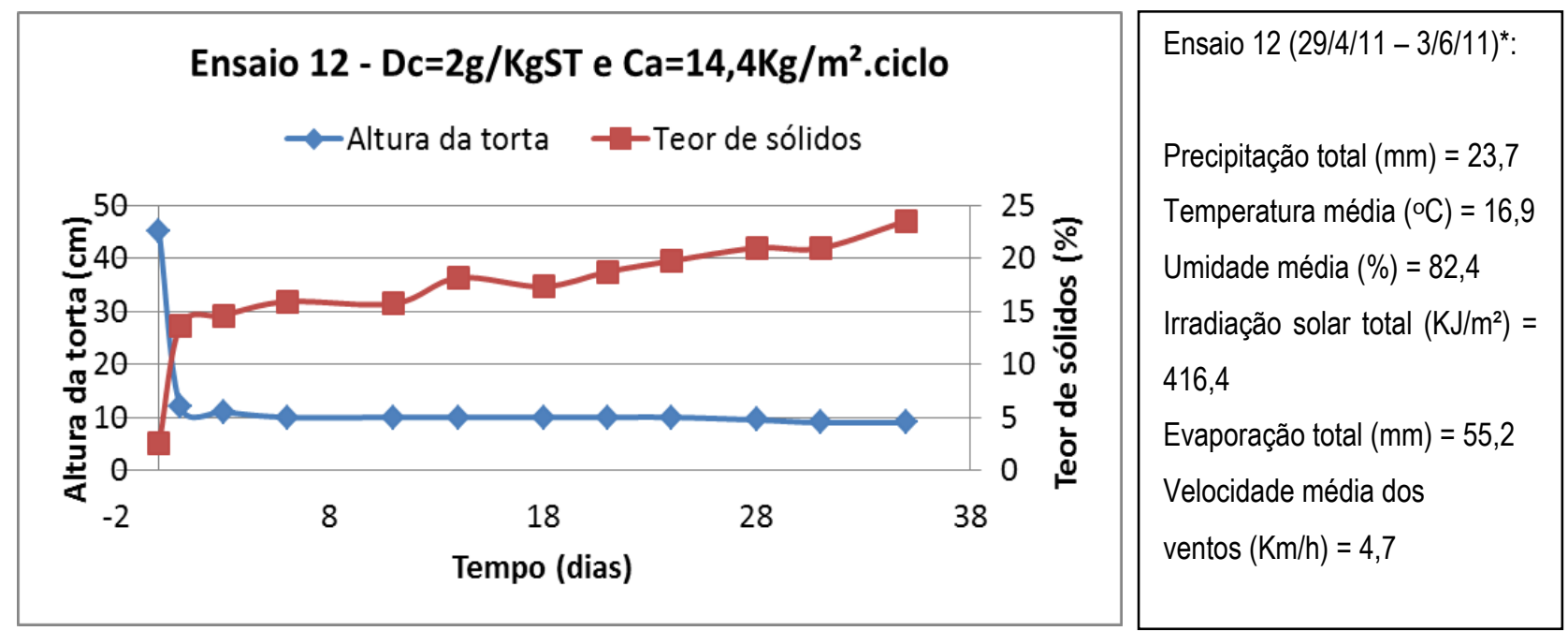

* - para o resumo dos dados climáticos foram considerados os dados disponíveis até 31/5

Figura 77 - Altura e teor de sólidos da torta no leito de drenagem para o ensaio piloto E12

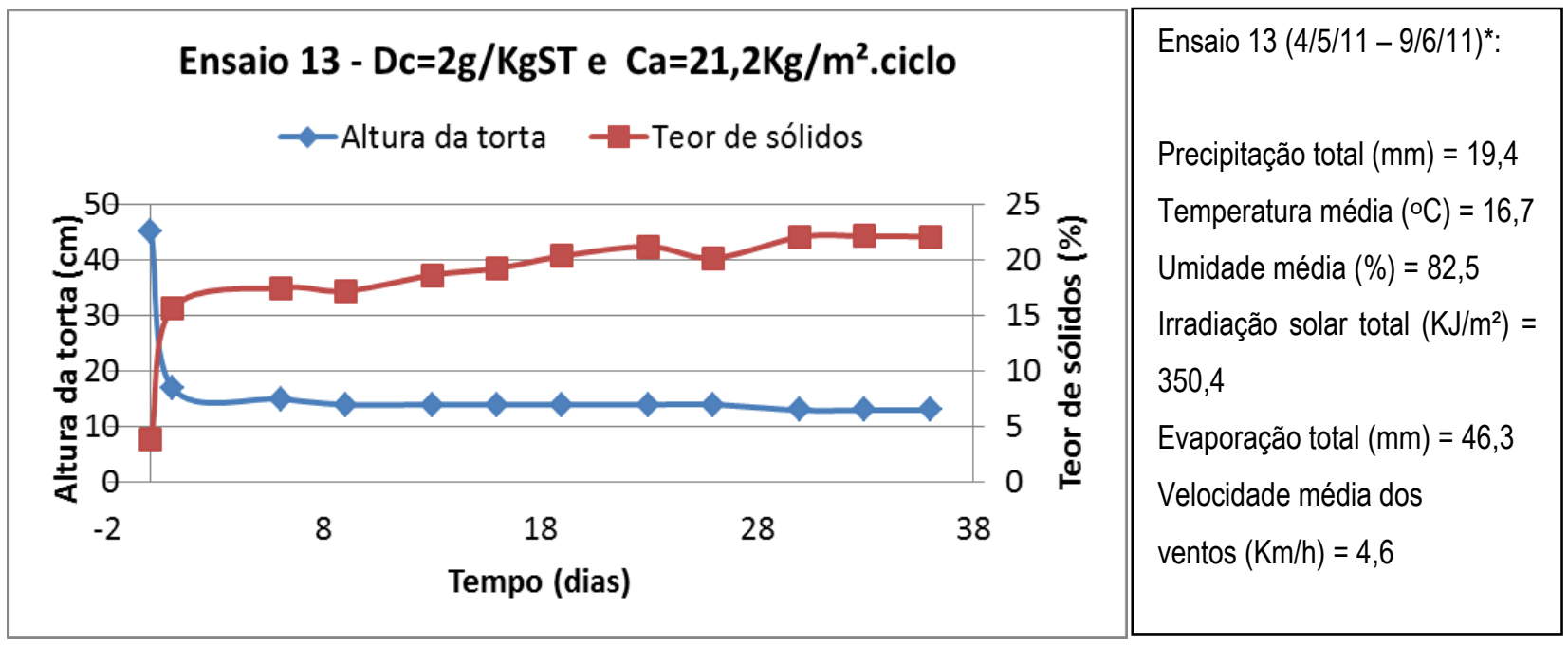

* - para o resumo dos dados climáticos foram considerados os dados disponíveis até 31/5

Figura 78 - Altura e teor de sólidos da torta no leito de drenagem para o ensaio piloto E13 


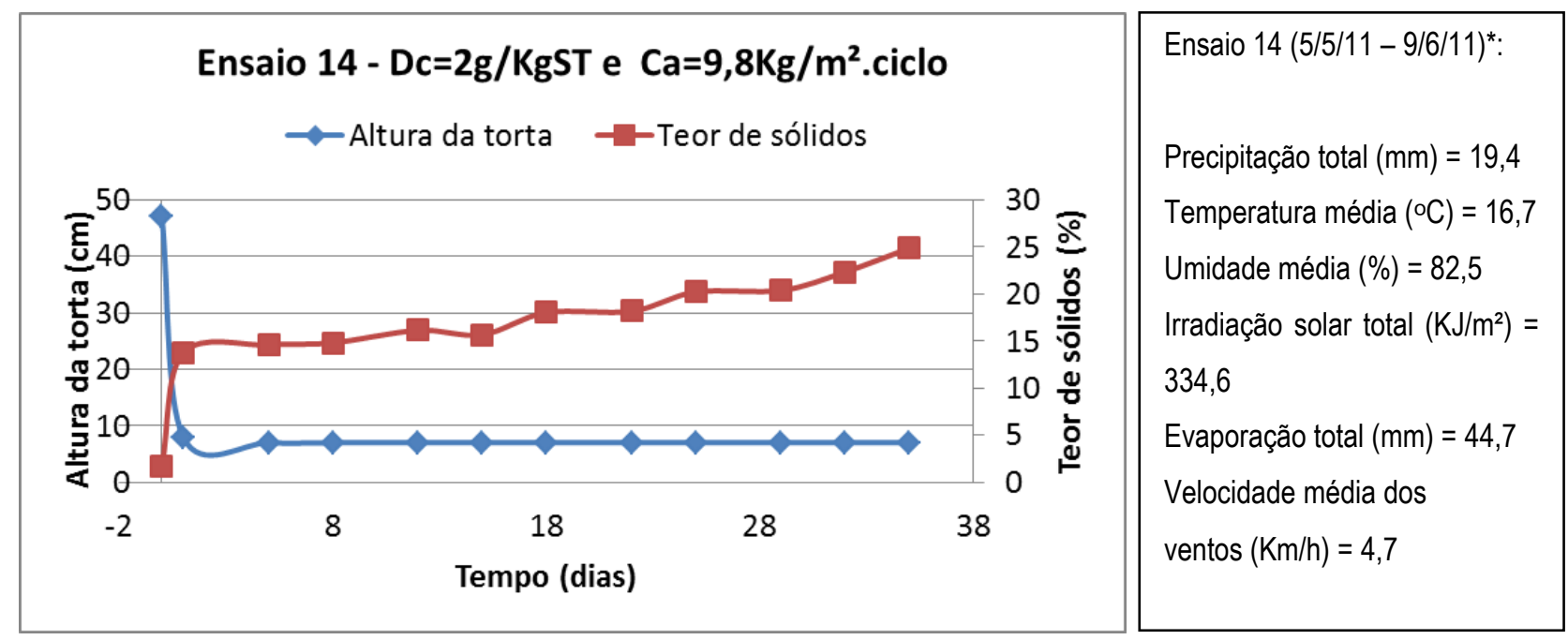

* - para o resumo dos dados climáticos foram considerados os dados disponíveis até 31/5

Figura 79 - Altura e teor de sólidos da torta no leito de drenagem para o ensaio piloto E14

Para a comparação visual entre os ensaios E12 a E14 foram plotados 4 gráficos com todos os ensaios, 2 apresentando a variação da altura da torta gerada e 2 a evolução do teor de sólidos. Assim como nos gráficos para comparação de polímeros e das tortas dos ensaios E1 a E11 (APÊNDICE 8), 2 gráficos são apenas uma repetição do anterior com alteração da escala do eixo das ordenadas para facilitar as análises (Figura 80 e Figura 81).

A altura da torta formada teve grande influência da taxa de aplicação de sólidos, corroborando com a análise dos ensaios E1 a E11. Observou-se que a altura final da torta foi maior para a maior taxa de aplicação superficial e menor para a menor taxa, sugerindo que a densidade da torta formada é praticamente constante. Por outro lado, as variações nas taxas de aplicação superficial de lodo no leito não influenciaram na evolução do teor de sólidos, que variou pouco entre os testes para os mesmos períodos de secagem. 

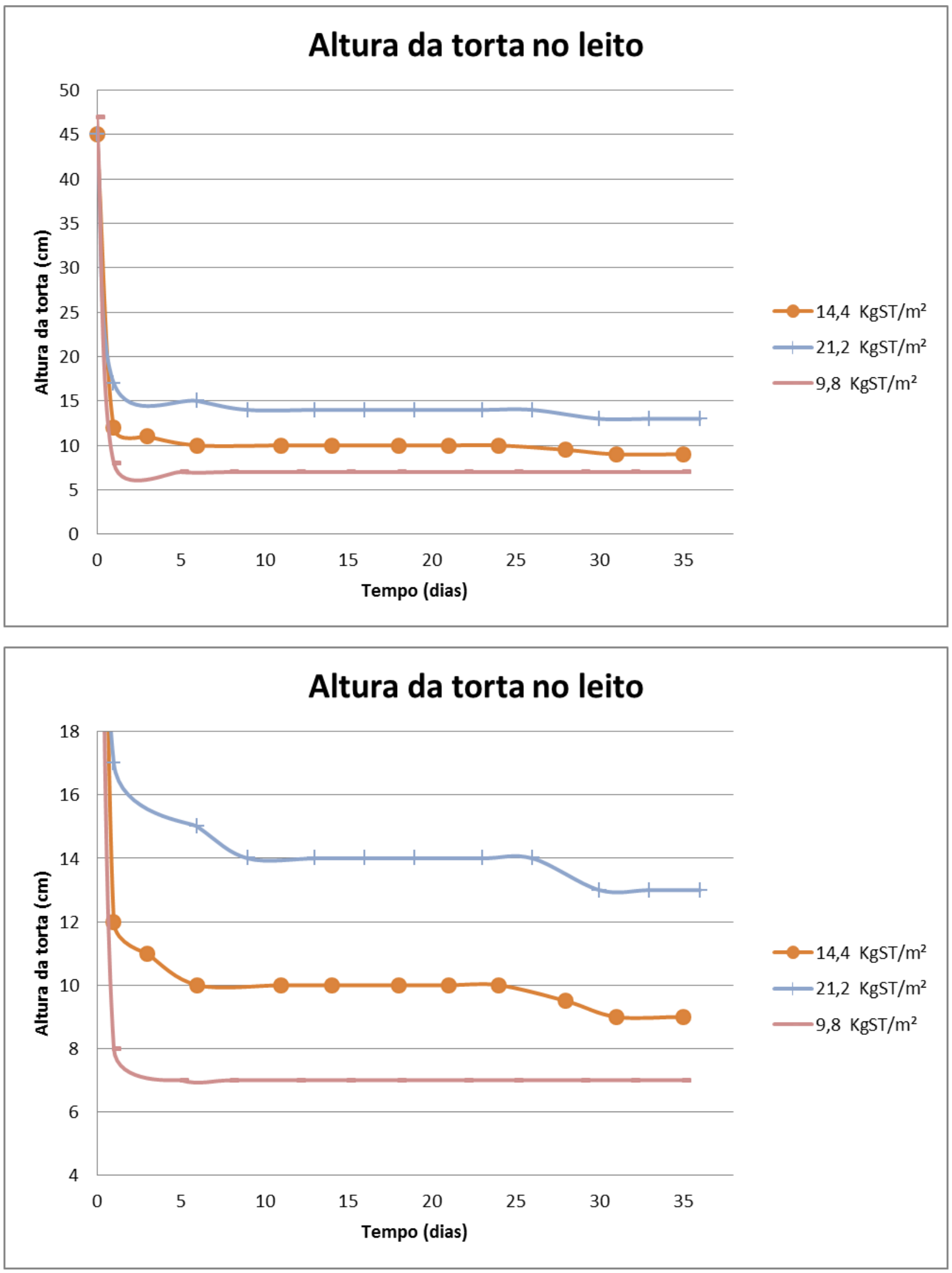

Figura 80 - Resultados da altura da torta nos ensaios E12 a E14 

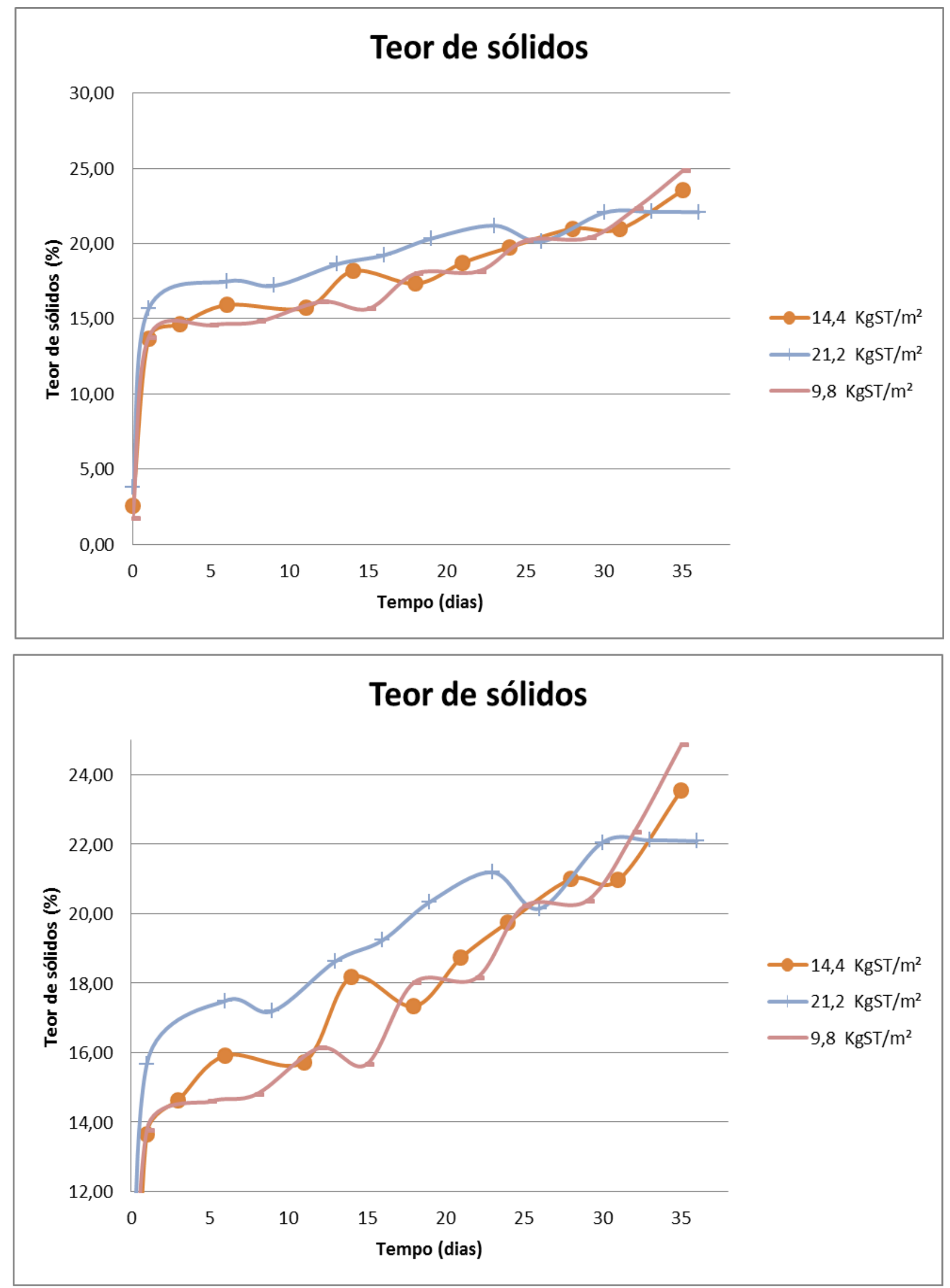

Figura 81 - Resultados do teor de sólidos nos ensaios E12 a E14 
O fluxo de água inicial do leito de drenagem para lodos condicionados com a dosagem $2 \mathrm{~g} / \mathrm{kgST}$ se manteve em $48 \mathrm{~L} / \mathrm{min}^{\mathrm{m}} \mathrm{m}^{2}$ para qualquer taxa de aplicação de sólidos ensaiada. A qualidade do drenado apresentou pouca variação entre amostragens sucessivas (APÊNDICE 9). Os valores médios da Turbidez, DQO, Condutividade e $\mathrm{pH}$ das 6 amostras de drenado coletadas em cada ensaio piloto, são os apresentados na Tabela 22:

Tabela 22 - Fluxo de água inicial e média dos resultados das análises de DQO, Condutividade, pH e Turbidez do drenado

\begin{tabular}{l|r|r|r}
\hline & \multicolumn{1}{|c|}{ E12 } & \multicolumn{1}{c|}{ E13 } & \multicolumn{1}{c}{ E14 } \\
\hline Dosagem de polímero (g/KgST) & 2 & 2 & 2 \\
\hline Taxa de aplicação (KgST/m²) & 14,40 & 21,20 & 9,80 \\
\hline Fluxo de água inicial (L/min.m $\left.\mathbf{m}^{2}\right)$ & 48 & 48 & 48 \\
\hline DQO (mg/L) & 85,7 & 29,4 & 100 \\
\hline Condutividade ( $\mu$ S) & 700,5 & 514 & 623,5 \\
\hline pH & 6,94 & 6,50 & 7,37 \\
\hline Turbidez (UNT) & 7,48 & 8,18 & 3,46 \\
\hline
\end{tabular}

A DQO dos três ensaios foi baixa, porém o ensaio com a maior taxa de aplicação de sólidos (E13) teve a menor DQO e não se tem uma justificativa para isso. A turbidez, o $\mathrm{pH}$ e a condutividade do drenado variaram pouco. Estes resultados indicam que existe baixa influência da taxa de aplicação de sólidos no leito na qualidade do drenado.

Os resultados dos ensaios para avaliação da influência das taxas de aplicação de sólidos ainda são pouco conclusivos, mas a análise realizada indica que a taxa de aplicação de sólidos pode não reduzir a velocidade em que a torta perde umidade e eleva seu teor de sólidos. Uma verificação visual que corrobora com esta hipótese é que as fissuras formadas na torta são tão maiores quanto maior a taxa de aplicação de sólidos. Isto ocorre, pois, maiores taxas de aplicação de sólidos, resultam em alturas de torta maiores e, portanto, maior peso se deslocando para formar as fissuras. Tal fato aumenta a área superficial de torta exposta ao ar por unidade de volume da torta. Porém, este indicativo deve ser mais estudado e confirmado em ensaios que repitam as taxas de aplicação de sólidos utilizadas e, inclusive, aumentem estas para testar a capacidade de desaguamento em leitos de drenagem de taxas de $30 \mathrm{kgST} / \mathrm{m}^{2}$.ciclo ou até superiores. 


\section{CONSIDERAÇÕES FINAIS}

O trabalho realizado e apresentado neste documento revisou detalhadamente 0 processo de desaguamento de lodos de ETE's e sua importância para a redução dos volumes destinados a disposição final. Em relação ao desaguamento em leitos de drenagem foram estudados os materiais geotêxteis e o condicionamento de lodos com polieletrólitos.

As mantas geotêxteis têm sido desenvolvidas e aperfeiçoadas pela engenharia de materiais e possuem diversas aplicações em filtração e drenagem. Porém, este trabalho foi desenvolvido com material floculento, como são os lodos de ETE's, e o dimensionamento racional utilizado para aplicação na filtração de solos não pode ser utilizado. É preciso desenvolver novos métodos de dimensionamento utilizando ferramentas de análise de imagem para determinação de tamanhos de flocos e porosidade dos geotêxteis.

O condicionamento com polímeros orgânicos sintéticos é utilizado há vários anos com resultados extremamente satisfatórios, tanto em questões técnicas de melhoria das características de desaguamento de lodos como em questões financeiras pelas reduzidas dosagens e menor incorporação de massa ao lodo gerado. Estudos para a utilização de micropropriedades do material no controle e automação do processo tem evoluído e parâmetros reológicos aparentam possuir uma boa correlação com a facilidade do lodo em perder água. Porém, uma maior quantidade de pesquisas é necessária para que este procedimento seja implementado em escala real.

Como forma de avaliar a aptidão de cada manta geotêxtil e cada polímero catiônico ao lodo anaeróbio, foi utilizado o Teste do Tempo de Drenagem. Este método de avaliação da capacidade de drenagem possui características de mistura e agitação semelhantes ao desaguamento natural em leitos de drenagem. Este teste, assim como no desaguamento natural, utiliza a própria gravidade como força que provoca a filtração do lodo e a consequente separação da água dos sólidos. Além disso, este teste possibilita trabalhar com amostras representativas, enquanto que o CST utiliza 
amostras de volume extremamente reduzido. Outro teste muito citado na bibliografia, o da Resistência Específica a Filtração, utiliza sucção por vácuo, que difere do princípio de funcionamento do processo de desaguamento por leitos de drenagem.

Com relação à observação visual de flocos, procedimento por vezes utilizado na determinação da dose "ideal" de condicionantes durante a operação de ETE's, este se mostrou equivocado para o desaguamento no TTD. Durante os testes em laboratório, os lodos condicionados com doses acima da determinada como ideal possuíam flocos maiores e mais bem formados. O que ocorre é que nas amostras com sobredosagem os flocos ficaram mais agregados, mas a sobra de polímeros provavelmente aumentou a viscosidade da água livre e aumentou o tempo de drenagem no teste. Dessa forma, o teste visual não é recomendado.

Os testes em laboratório foram importantes para evidenciar um erro que poderia ser recorrente em trabalhos futuros, ajudando pesquisadores a evitar retrabalho e incoerências derivadas de metodologias equivocadas. Além disso, os resultados gerados, a partir da metodologia descrita neste trabalho, foram validados de forma conclusiva e não deixaram dúvidas acerca do potencial de melhoria das características de drenagem do lodo com a adição de doses realmente reduzidas de condicionante.

Foram testados 18 polímeros catiônicos, de alto peso molecular, sendo 15 sólidos e 3 em emulsão, de 4 diferentes fabricantes. Os polímeros foram testados e classificados conforme as doses necessárias para reduzir para valores abaixo de 5 segundos os tempos necessários para drenar $50 \mathrm{~mL}$ no TTD, utilizando manta geotêxtil para drenagem no funil de Buchner. Tanto na avaliação técnica quanto econômica os polímeros sólidos foram superiores aos em emulsão.

A escolha do meio filtrante não foi baseada nos ensaios realizados com o TTD, mas sim oriunda de observações realizadas durante o manuseio do material e verificação de perda de resistência durante os testes com algumas mantas geotêxteis não tecidas. Desta forma, recomenda-se a utilização de geotêxteis tecidos no desaguamento de lodos em leitos de drenagem. Sobre o recebimento e aceitação destes produtos, é importante sempre avaliar a qualidade dos mesmos, uma vez que 
existe grande variação de características entre materiais de diferentes lotes de fabricação.

Os ensaios em escala piloto foram essenciais para validar as observações feitas em laboratório acerca do potencial de melhoria das propriedades do lodo e aumento significativo de sua capacidade de perder água pela adição de polímeros, mesmo com doses reduzidas. Porém, além de acompanhar a etapa de drenagem do processo de desaguamento, as taxas de secagem foram acompanhadas ao longo de cada ensaio e os resultados foram de certa forma inesperados. Acreditava-se que o aumento da fração de água livre proporcionada pelo condicionamento químico influenciaria também no aumento das taxas de evaporação e na consequente redução dos tempos dos ciclos de secagem.

Porém, a observação dos resultados possibilitou verificar que a drenagem foi melhorada, mas que praticamente nenhuma alteração na velocidade de secagem foi proporcionada pelo condicionamento químico, uma vez que o lodo sem condicionamento apresentou uma evolução do teor de sólidos semelhante a dos lodos condicionados ao longo do período de secagem.

Verificou-se também nos ensaios em escala piloto que o lodo a partir de $20 \%$ de sólidos apresentou uma consistência rígida e bem agregada. Em relação a este aspecto, é importante considerar que o lodo condicionado apresentou estrutura mais compacta que lodo não condicionado, que por sua vez apresentou uma estrutura mais quebradiça (os "torrões" de torta de lodo se esfarelavam mais facilmente).

Em relação à variação das taxas de aplicação de sólidos, os resultados mostraram que taxas de aplicação de sólidos, inclusive superiores à máxima recomendada pela norma ABNT 12.209 (1992) para leitos de secagem convencionais, aparentemente não resultam em menores teores de sólidos ao longo do período de secagem. Esta hipótese necessita de mais ensaios, mas, se confirmada, pode resultar numa menor necessidade de área de implantação de leitos de drenagem em relação a leitos de secagem convencionais. 
De forma geral, os leitos de drenagem se demonstraram capazes de proporcionar um bom desaguamento de lodos anaeróbios condicionados, permitindo altas taxas de drenagem no início do ciclo e teores de sólidos próximos a 20\% com cerca de 15 a 20 dias de secagem. Porém, comparando esta evolução do teor de sólidos ao longo do período de secagem com referências sobre a operação de leitos de secagem convencionais, não é possível considerar que há um aumento de eficiência do processo, já que valores inclusive superiores podem ser encontrados.

Porém, uma ressalva deve ser feita: O procedimento de amostragem deste estudo subavaliou o teor de sólidos do lodo, como relatado no item 5.2.1. Assim, os resultados obtidos neste trabalho não podem ser considerados como conclusivos.

Por outro lado, o procedimento de remoção da torta mostrou um aspecto que sem dúvida é uma melhoria proporcionada pelos leitos de drenagem em comparação com leitos de secagem convencional. Em leitos de drenagem existe uma grande facilidade de remoção do material ao fim de cada ciclo de desaguamento, sendo que a camada de areia de leitos de secagem necessita de reposição. Além disso, o condicionamento do lodo proporciona, ao fim do ciclo, a formação de uma torta que facilmente se solta da superfície do geotêxtil e é retirada sem dificuldades e a própria manta pode ser manuseada e utilizada para ajudar na remoção do lodo, pois apresenta alta resistência mecânica à tração.

Além disso, as mantas foram utilizadas em cerca de 5 ensaios sucessivos e não se verificou desgaste do material. Contudo, é importante considerar que os maiores "torrões" da torta de lodo eram removidos com as mãos (usando-se luvas) e o "farelo" que sobrava era varrido, com cuidado, e removido com uma pá de plástico.

Deve-se ainda considerar que os leitos de drenagem montados no CTH foram construídos em local com algumas limitações em relação à circulação de vento e incidência solar pela existência de edificações e diversas árvores em seu entorno. A incidência solar foi realmente direta entre 10 horas da manhã e 3 horas da tarde. Assim, os resultados obtidos neste trabalho devem ser avaliados de acordo com estas limitações. 
Em relação ao processo de secagem da torta, notou-se grande interferência das paredes no processo. Por vezes foi possível notar que a secagem foi facilitada perto das paredes laterais do leito e próximo às fissuras que apareceram no lodo, resultando em teores de sólidos mais elevados quando da retirada de amostras destes locais. Esta verificação indica que a forma construtiva dos leitos de drenagem poderia ser alterada para potencializar ainda mais este efeito. Como as mantas geossintéticas possuem grande resistência mecânica, poderiam ser construídos leitos sem as paredes, com vigas segurando as mantas, conforme proposto por Fontana e já utilizado no desaguamento de lodo de lagoa de estabilização na Regional da SABESP de Lins-SP (Figura 82).
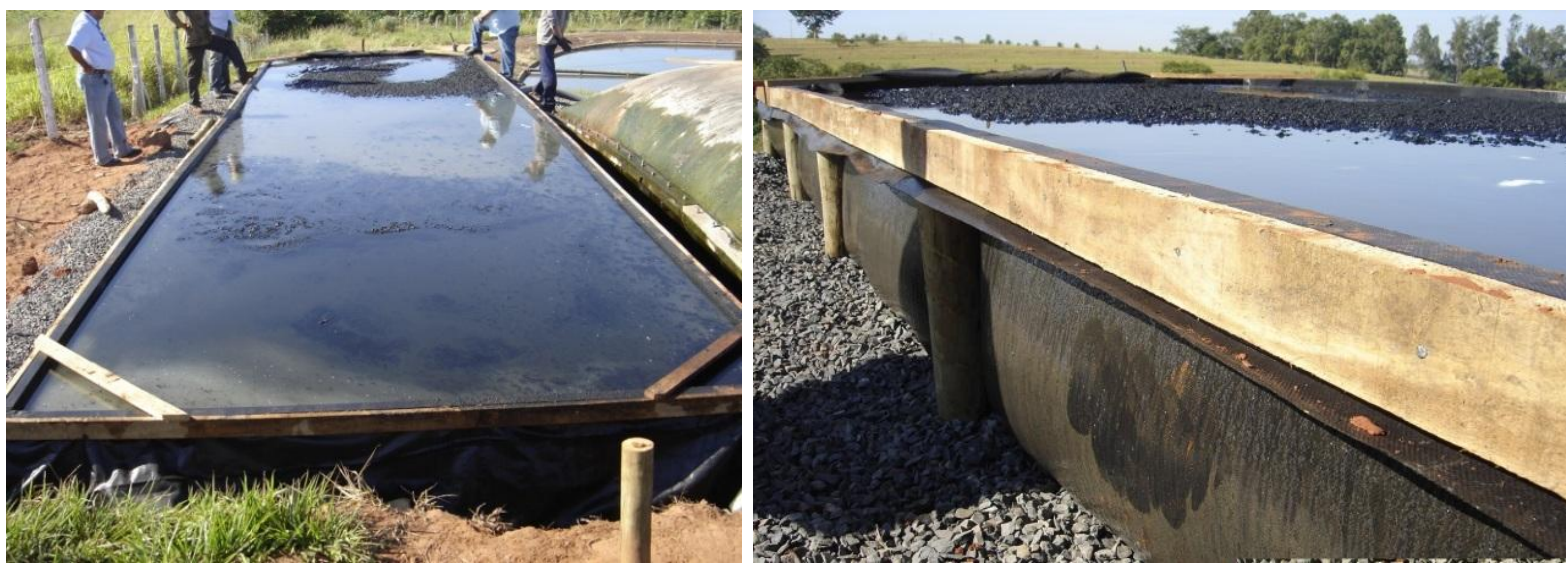

Figura 82 - Sugestão construtiva para leitos de drenagem como forma de aumentar a exposição da manta geotêxtil ao ar (Fontana, 2008)

A partir destas considerações, o processo de evaporação aparenta ser o fator determinante do tempo do ciclo. Este processo, como relatado na revisão bibliográfica, é potencializado pelo aparecimento de fissuras profundas na torta, que aumentam a área de exposição e facilitam a perda de água. O padrão das fissuras formadas é outro aspecto bastante influenciado pelas dosagens de condicionante $\mathrm{e}$ taxas de aplicação de sólidos, onde fissuras mais profundas e maiores foram observadas para doses de condicionante e taxas de aplicação de sólidos mais elevadas e fissuras menores para doses de condicionante e taxas de aplicação de sólidos reduzidas. 
Em relação à influência das variações climáticas, foi possível observar que os ensaios E7, E8, E9, E10 e E11 tiveram as maiores temperaturas médias ao longo do período de secagem e todos chegaram a $20 \%$ de teor de sólidos antes de 15 dias.

Algumas fotos que ilustram o processo de secagem ocorrido durante o ensaio E10 estão no APENDICE 10 e uma foto da torta formada no E11, em um período de 31 dias de secagem para uma dose de polímero de $4 \mathrm{~g} / \mathrm{kgST}$ e taxa de aplicação de sólidos de 14,89 kgST $/ \mathrm{m}^{2}$.ciclo, é apresentada na Figura 83:

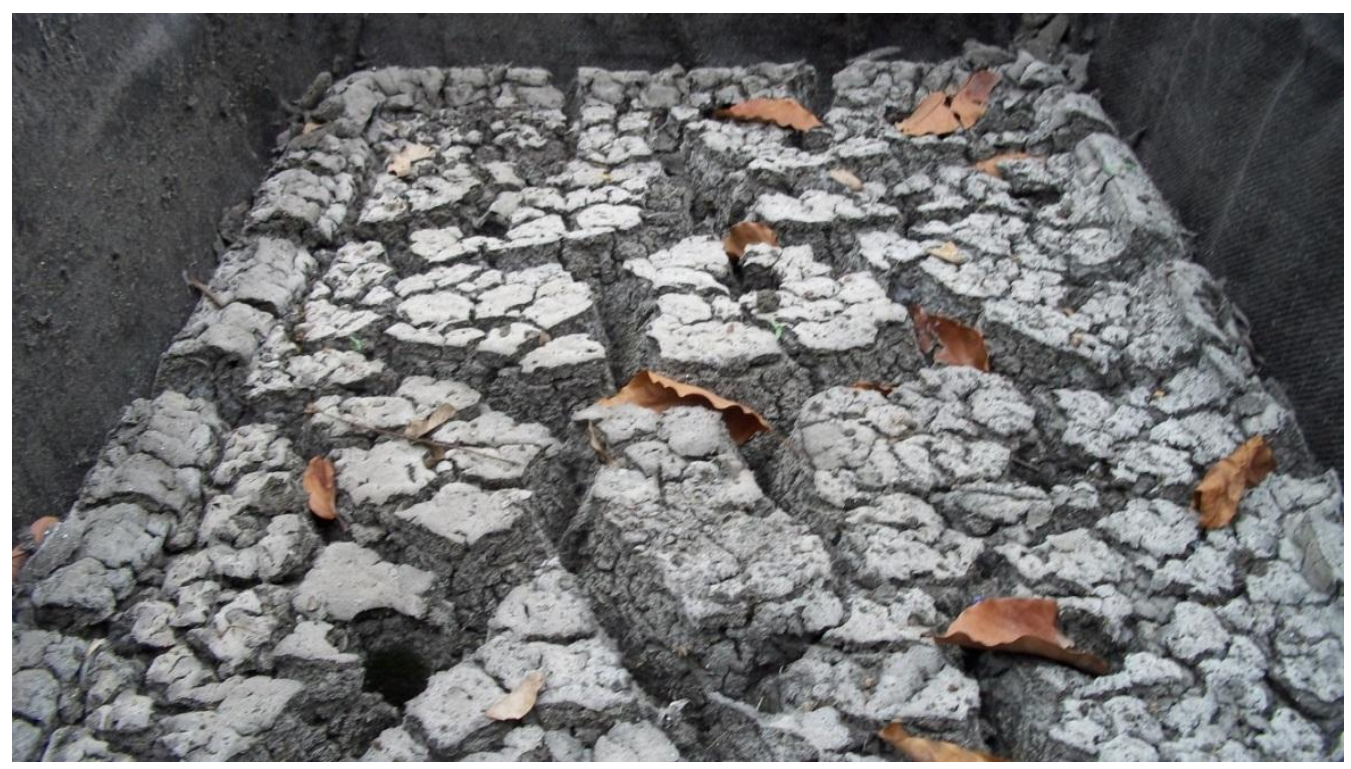

Figura 83 - Aspecto do leito de drenagem ao final do ciclo de secagem do E11 


\section{CONCLUSÕES E RECOMENDAÇÕES}

Os polímeros catiônicos testados proporcionaram significativa redução do tempo de drenagem nos Testes do Tempo de Drenagem (TTD) realizados em laboratório para dosagens iguais ou superiores a $1 \mathrm{~g}$ de polímero por $\mathrm{kg}$ de sólidos totais no lodo (peso seco).

As mantas geotêxteis mais indicadas para os leitos de drenagem são as tecidas por apresentarem maior facilidade de limpeza e sofrerem menor desgaste em operações sucessivas de remoção de lodo desaguado.

Nos ensaios em escala piloto verificou-se que o condicionamento do lodo com doses de polímero $\geq 2 \mathrm{~g} / \mathrm{kgST}$ aumentou significativamente a velocidade inicial de drenagem, porém, nenhuma dosagem alterou a evolução da remoção de umidade do lodo ao longo do período de secagem. Além disso, o condicionamento com doses de polímero $\geq 2 \mathrm{~g} / \mathrm{kgST}$ proporcionou maior facilidade na remoção da torta do leito de drenagem e na limpeza das mantas geotêxteis. Assim, a dose mais interessante que proporcionou melhorias na operação dos leitos de drenagem em escala piloto foi de $2 \mathrm{~g} / \mathrm{kgST}$.

As taxas de aplicação de sólidos devem ser mais estudadas, pois indicam que os leitos de drenagem mantém as velocidades de secagem mesmo com taxas superiores a $15 \mathrm{~kg}$ de sólidos totais por $\mathrm{m}^{2}$ de área de leito, por ciclo de secagem.

Em vista dos procedimentos de amostragem de lodo utilizados terem subavaliado os teores de sólidos nas tortas do leito de drenagem, e considerando as características do local onde foram montados os leitos de drenagem, considera-se que as evoluções dos teores de sólidos ao longo do período de secagem possam ser mais favoráveis do que as apresentadas neste trabalho. 


\section{REFERÊNCIAS}

ABRAMENTO, M. Durabilidade e comportamento de longo prazo de geossintéticos - Parte 1: Propriedades mecânicas e hidráulicas. 2० Simpósio brasileiro sobre a aplicação de geossintéticos. São Paulo. 1995.

ABU-ORF, M. M.; DENTEL, S. K. Rheology as a tool for polymer dose assessment and control. Journal of Environmental Engineering. 1999. 1133-1141.

ABU-ORF, M. M.; ÖRMECl, B. Measuring Sludge Network Strength Using Rheology and Relation to Dewaterability, Filtration, and Thickening Laboratory and Full-Scale Experiments. Journal of Environmental Engineering. 2005;131(8):1139.

ABU-ORF, M. M.; WALKER, C. A.; DENTEL, S. K. Centrate viscosity for continuous monitoring of polymer feed in dewatering applications. Advances in Environmental Research. 2003. 687-694.

ALEM SOBRINHO, P. Tratamento de Esgoto e Geração de Lodo. In: Biossólidos na agricultura. SABESP, Escola Politécnica da USP, ESALQ - USP/Nupegel e UNESP - Jaboticabal. São Paulo, 2001

AMERICAN SOCIETY FOR TESTING AND MATERIALS. ASTM D4491. Standard Test Methods for Water Permeability of Geotextiles by Permittivity. 2009.

ANDREOLLI, C. V. (Coordenador). Lodo de fossa e tanque séptico: caracterização, tecnologias de tratamento, gerenciamento e destino final. ABES, Projeto PROSAB. Rio de Janeiro, 2009. 388p.

ANDREOLLI, C.; FERNANDES, F.; VON SPERLING, M. Lodos de esgotos: tratamento e disposição final. Belo Horizonte/MG: DESA/UFMG, 2007.

APHA, AWWA \& WPCF. Standard Methods for examination of water and wastewater. $21^{\text {a }}$ ed. New York, 2005.

ASSOCIAÇÃO BRASILEIRA DE NORMAS TÉCNICAS. ABNT ISO 12.968: Geotextiles and Geotextiles-related products - Determination of Water Flow Capacity in their Plane. 1999. 
ASSOCIAÇÃO BRASILEIRA DE NORMAS TÉCNICAS. ABNT NBR 10.004: Resíduos sólidos - Classificação. 2004.

ASSOCIAÇÃO BRASILEIRA DE NORMAS TÉCNICAS. ABNT NBR 12.209: Projeto de estações de tratamento de esgotos sanitários. 1992

ASSOCIAÇÃO BRASILEIRA DE NORMAS TÉCNICAS. ABNT NBR 12.553: Geossintéticos - Terminologia. 2003.

ASSOCIAÇÃO BRASILEIRA DE NORMAS TÉCNICAS. ABNT NBR 12.568: Geossintéticos - Determinação da massa por unidade de área. 2003.

ASSOCIAÇÃO BRASILEIRA DE NORMAS TÉCNICAS. ABNT NBR 12.569: Geossintéticos - Determinação da espessura. 1992.

ASSOCIAÇÃO BRASILEIRA DE NORMAS TÉCNICAS. ABNT NBR 12824 Geotêxteis - Determinação da resistência à tração não-confinada - Ensaio de tração de faixa larga - Método de ensaio. 1993.

ASSOCIAÇÃO BRASILEIRA DE NORMAS TÉCNICAS. ABNT NBR 13359 Geotêxteis - Determinação da resistência ao puncionamento estático - Ensaio com pistão tipo CBR - Método de ensaio. 1995.

ASSOCIAÇÃO BRASILEIRA DE NORMAS TÉCNICAS. ABNT NBR 15.223: Geotêxteis e produtos correlatos - Determinação das características de permeabilidade hidráulica normal ao plano e sem confinamento. 2005.

ASSOCIAÇÃO BRASILEIRA DE NORMAS TÉCNICAS. ABNT NBR 15.229: Geotêxteis e produtos correlatos - Determinação da abertura de filtração característica. 2005.

BACHE, D. H.; PAPAVASILOPOULOS, E. N. Viscous behavior of sludges centrate in response to polymer dewatering. Water Research, v. 34, n. 1, p. 354358, 2000. Elsevier Science Ltd. Great Britain

BARROSO, Marcelo Melo. Influência das micro e macropropriedades dos lodos de estações de tratamento de águas no desaguamento por leito de drenagem. Tese (Doutorado) - Escola de Engenharia de São Carlos, Universidade de São Paulo, São Carlos, 2007. 
BAUDEZ J-C.; COUSSOT, P. Rheology of aging, concentrated, polymeric suspensions: Application to pasty sewage sludges. Journal of Rheology, 2001.

BAUDEZ, J-C.; AYOL, A.; COUSSOT, P. Practical determination of the rheological behavior of pasty biosolids. Journal of Environmental Management. 2004.

BRAGA, Wallace Marcelino. Utilização de parâmetros reológicos para verificar a aptidão ao desaguamento de lodos de uma estação de tratamento de esgotos do tipo UASB + BF's condicionados com polieletrólitos. Universidade Federal do Espirito Santo. Vitória - ES. 2003.

BRASIL. Lei 11.445. 5 janeiro de 2007. Plano Nacional de Saneamento Básico (PNSB).

BRASIL. Lei 12.305. 2 de agosto de 2010. Política Nacional de Resíduos Sólidos (PNRS).

BRASIL. Lei 9.605. 12 de fevereiro de 1998. Chamada de "Lei da Vida" ou dos "Crimes Ambientais".

CANTRÉ, S.; SAATHOFF, F. Design method for geotextile tubes considering strain - Formulation and verification by laboratory tests using photogrammetry. Geotextiles and Geomembranes, 2010.

CHEN, G.; YUE, P. L.; MUJUMDAR, A. S. Sludge dewatering and drying. Drying Technology. 2002.

CHERNICHARO, Carlos Augusto de Lemos. Reatores anaeróbios. Belo Horizonte: DESA/UFMG, 1997. 245 p.

CHRISTENSEN, J. R.; CHRISTENSEN, G. L.; HANSEN, J. A. Improved characterization of mixing for sludge conditioning. Journal of Environmental Engineering, v. 121, n. 3, p. 236-244, Mar. 1995.

CHRISTENSEN, J. R.; SORENSEN, P. B.; CHRISTENSEN, G. L.; HANSEN, J. A. Mechanisms for overdosing in sludge conditioning. Journal of Environmental Engineering, v. 119, n. 1, p. 159-171. 1993. 
CIBA, Ciba Specialty Chemicals. Ciba®ZETAG® 8165 Flocculant informations. 2006.

COFIE, O. O.; AGBOTTAH, S.; STRAUSS, M., et al. Solid-liquid separation of faecal sludge using drying beds in Ghana: implications for nutrient recycling in urban agriculture. Water Research, 2006.

COLIN, F.; GAZBAR S. Distribution of water in sludges in relation to their mechanical dewatering. Water Research, v. 29, n. 8, p. 2000-2005, Elsevier Science Ltd. Printed in Great Britain. 1995.

CONSELHO NACIONAL DO MEIO AMBIENTE (CONAMA). Resolução $n^{\circ} 375$, de 29 de agosto de 2006. Define critérios e procedimentos, para o uso agrícola de lodos de esgoto gerados em estações de tratamento de esgoto sanitário e seus produtos derivados, e dá outras providências. Brasília, DF, 2006.

CORDEIRO, J. S. Processamento de lodos de Estações de Tratamento de Água (ETA's). In: ANDREOLLI, C. V. (Coord.). Resíduos sólidos do saneamento: processamento, reciclagem e disposição final. Capítulo 9. Rio de Janeiro: ABES, 2001. 282 p. (Projeto PROSAB).

DENTEL, S. K.; DURSUN, D. Shear sensitivity of digested sludge: comparison of methods and application in conditioning and dewatering. Water research. 2009.

DHARMAPPA, H. B.; HASIA, A.; HAGARE, P. Water treatment plant residuals management. Water Science and Technology, Volume 35, Issue 8, 1997.

ELSHARIEF, A. M.; LOVELL, C. W. A probabilistic retention criterion for nonwoven geotextiles. Geotextiles and Geomembranes. 1996.

FONTANA, A. O. Informação pessoal, 2008.

FONTANA, A. O. Sistema de Leito de Drenagem e Sedimentador como Solução para Redução de Volume de Lodo de Decantadores e Reúso de Água de Lavagem de Filtros - Estudo de Caso ETA Cardoso. 2004. 161 p. Dissertação (Mestrado) - Universidade Federal de São Carlos, São Carlos, 2004.

FONTANA, A. O.; OLIVEIRA, A. C.; ARVATI NETO, O. A.; GRANELLO, E. C. A.; CORDEIRO, J. S. Redução de lodo digerido gerado em lagoas de estabilização 
com utilização de leito de drenagem. In: CONGRESSO BRASILEIRO DE ENGENHARIA SANITÁRIA E AMBIENTAL, 24. Belo Horizonte/MG, 2007.

FREITAS, R. A. S. Comportamento de geotêxteis como filtro de resíduos fosfogesso e lama vermelha. Dissertação de Mestrado. Universidade Federal do Rio de Janeiro - UFRJ. Rio de Janeiro. 2003.

GLENDINNING, S.; LAMONT-BLACK, J.; JONES, C. J. F. P. Treatment of sewage sludge using electrokinetic geosynthetics. Journal of Hazardous Materials. 2007.

GONÇALVES, R. F. (Coord.). Gerenciamento do lodo de lagoas de estabilização não mecanizadas. Rio de Janeiro: ABES, 1999. 64 p. (Projeto PROSAB).

GONÇALVES, R. F.; LUDUVICE, M.; LIMA, M. R. P.; RAMALDES, D. L. C.; FERREIRA, A. C. F.; TELES, C. R.; ANDREOLI, C. V. Desidratação de Lodo de Esgotos. In: ANDREOLLI, C. V. (Coord.). Resíduos sólidos do saneamento: processamento, reciclagem e disposição final. Capítulo 9. Rio de Janeiro: ABES, 2001. 282 p. (Projeto PROSAB).

GRANDIN, S.R. Desidratação de lodos produzidos nas estações de tratamento de água. 1992. Dissertação (Mestrado) - Escola Politécnica, Universidade de São Paulo. São Paulo, 1992.

HWANG, G. S.; HWU, B. L.; HSING, W. H.; LU, C.K. Manufacturing effects on the hydraulic properties of needlepunched nonwoven geotextiles. Geotextiles and Geomembranes, 16, (1998).

HWANG, Gin-Shing; HWU, Bao-Lin; HSING, Wen-Hao; LU Chiu-Kuang. Manufacturing effects on the hydraulic properties of needlepunched nonwoven geotextiles. Geotextiles and Geomembranes no. 16, 1998.

JACOMASSI, F. E. Estudo das micropropriedades de resíduos sólidos gerados nos decantadores de estações de tratamento de água. Dissertação de Mestrado. Universidade Federal de São Carlos, 2009.

KASSAKURA, T.; IMOT, Y.; MORI, T. Overview and system analysis of various sewage sludge drying processes. Drying Technology. 1993.

KOERNER, G. R.; KOERNER, R. M. Puncture resistance of polyester (PET) and polypropylene (PP) needle-punched nonwoven geotextiles. Geotextiles and Geomembranes. 2010. 
KOERNER, R. M. Designing with geosynthetics. $3^{\text {rd }}$ ed. Englewood Cliffs, N.J: Regents/Prentice Hall, 1994. 783 p.

KRISHNAMURTHY S.; VIRARAGHAVAN T. Chemical conditioning for dewatering municipal wastewater sludges. Energy Sources. 2005.

KUFFOUR, A. R.; AWUAH, E.; ANYEMEDU, F. O. K.; STRAUSS, M.; KONÉ, D.; COFIE, O. O. Effect of using different particle sizes of sand as filter media for dewatering faecal sludge. Desalination. 2009.

LAFLEUR, J. Selection of geotextiles to filterbroadly graded cohesionless soils, Geotextiles \& Geomembranes, 17, p.299-312. 1999.

LEITE, Leandro de Oliveira Barbosa. Determinação física e numérica de corridas de lama resultantes de ruptura de barreira retendo material viscoplástico. Dissertação (mestrado) - Universidade Estadual Paulista. Faculdade de Engenharia de Ilha Solteira. Ilha Solteira, 2009.

MARINETTI, M.; DENTEL, S. K.; MALPEI, F.; BONOMO, L. Assessment of rheological methods for a correlation to sludge filterability. Water Research. 2010.

MAYER, E. Sludge dewatering operations. In: Liquid filtration. Cheremisinoff, N. P. 2 Edição. Capítulo 7. Elsevier. 1998.

MELO, A. S. Contribuição para o dimensionamento de leitos de secagem de lodo. Dissertação de Mestrado. Universidade Federal de Campina Grande. Centro de Ciências e Tecnologia. Campina Grande, RN, 2006.

METCALF \& EDDY, INC. Wastewater Engineering: treatment, disposal and reuse. $4^{\text {th }}$ ed. Revisão de George Tchobanoglous e Franklin L. Burton. New York: McGraw-Hill, 2003.

METCALF, L.; EDDY, H. P. Wastewater Engineering: treatment, disposal and reuse. $3^{\text {rd }}$ ed. Revisão de George Tchobanoglous e Franklin L. Burton. New York: McGraw-Hill, 1991. 1334 p.

METCALF, Leonard; EDDY, Harrison P. American sewerage practice. New York: McGraw-Hill, 1935. 
MIKI, Marcelo Kenji. Utilização de polímeros para condicionamento de lodo de ETE para desidratação em filtro prensa de placas. 405 p., 2 v. Dissertação (Mestrado) - Escola Politécnica, Universidade de São Paulo. São Paulo, 1998.

MIKI, Marcelo Kenji. Informação pessoal. 2010.

MORI, M.; SEYSSIECQ, I.; ROCHE, N. Rheological measurements of sewage sludge for various solids concentrations and geometry. Process Biochemistry. 2006.

MUTHUKUMARAN, A.; ILAMPARUTHI, K. Laboratory studies on geotextile filters as used in geotextile tube dewatering. Geotextiles and Geomembranes. 2006.

NAGHETTINI, Mauro; PINTO, E. J. A. Hidrologia Estatística. CPRM - Serviço Geológico do Brasil. Belo Horizonte. 2007

NEBIKER, J. H. Drying of wastewater sludge in the open air. Journal of the Water Pollution Control Federation, v. 39, n. 4, p. 608, 1967.

NOVAK, J. T., O'BRIEN, J. H. Conditioning of chemical sludges. Journal Water Pollution Control Federation, V47, n.10, p.2397, Oct. 1975.

NOVAK, J. T.; BANDAK, N. Chemical conditioning and the resistance of sludges to shear. Journal Water Pollution Control Federation, v. 61, n. 3, p. 327-332, Mar. 1989.

NOVAK, J. T.; GOODMAN, G. L.; PARIDOO, A.; HUANG, J. The blinding of sludges during filtration. Journal Water Pollution Control Federation, v. 60, n. 2, feb. 1988

NOVAK, J. T.; HAUGAN, B. E. Chemical Conditioning of Activated Sludge. Journal of Environmental Engineering, v. 105, n. 5, p. 993-1008, Oct. 1979.

NOVAK, J. T.; HAUGAN, B. E. Mechanisms and methods for polymer conditioning of activated sludge. Journal Water Pollution Control Federation, v. 52, n. 10 , p. 2571-80, Oct. 1980. 
NOVAK, J. T.; NGUYEN, T. P.; HILAL, N.; HANKINS, N. P. Characterization of synthetic and activated sludge and conditioning with cationic polyelectrolytes. Desalination, v. 227, p. 103, 2008.

ÖRMECl, B. Optimization of a full-scale dewatering operation based on the rheological characteristics of wastewater sludge. Water Research. 2007.

ÖRMECI, B.; AHMAD, A. L. Measurement of additional shear during sludge conditioning and dewatering. Water Research. 2009.

OUTWATER, A. B. Reuse of sludge and minor wastewater. Boca Raton: Lewis Publishers, 1994.

PINTO, Carlos de Souza. Curso Básico de Mecânica dos solos em 16 aulas. Oficina de Textos. São Paulo. 2000.

RANDALL, C. W.; KOCH, C. T. Dewatering Characteristics of aerobically Digested Sludge. Journal of the Water Pollution Control Federation, v. 41, p 215, 1969.

REBHUN, M.; ZALL, J.; GALIL, N. Net sludge solids yield as an expression of filterability for conditioner optimization. Journal Water Pollution Control Federation, v.61, n.1, p.52-4, Jan. 1989.

SAMUDIO, Edgar Manuel Miranda. Critério racional para dimensionamento de leitos de secagem de lodo de ETE's convencionais e do reator UASB. 1993. 233 p. Dissertação (Mestrado) - Escola Politécnica, Universidade de São Paulo, São Paulo, 1993.

SÃO PAULO (ESTADO). Decreto Estadual 8.468, 8 de setembro de 1976.

SCHWOYER, W. L.K. Polyelectrolytes for Water and Wastewater Treatment. Boca Raton: CRC Press, Inc., 1981.

SEYSSIECQ, I. State-of-the-art: rheological characterization of wastewater treatment sludge. Biochemical Engineering Journal. 2003. 
SEYSSIECQ, I.; MARROT, B.; DJERROUD, D.; ROCHE, N. In situ triphasic rheological characterisation of activated sludge in an aerated bioreactor. Chemical Engineering Journal. 2008.

SLATTER, P. T. The rheological characterization of sludges. Water Science and Technology, Volume 38, Issue 11, 1997.

SOARES, S. R. A.; MATOS, Z. M. R.; BERNARDES, R. S. Modelagem do processo de desidratação de lodo anaeróbio em leitos de secagem simulados. Revista Brasileira de Engenharia Agrícola e Ambiental, v.5, n.2, p.313-319, 2001.

SPAVIER, L. C.; DA SILVA, A. L. B.; RAMALDES, D. L. C.; BRAGA, W. M.; GONÇALVES, R. F. Comparação da desidratabilidade por métodos mecânicos de lodos provenientes de UASB clássico e de UASB digerindo lodo aeróbio de descarte. 210 CONGRESSO BRASILEIRO DE ENGENHARIA SANITÁRIA E AMBIENTAL, João Pessoa - PB, Brasil. 2001.

SPAVIER, L. C.; VACCARI, K. P.; CASSINI, S. T. A.; GONÇALVES, R. F. Um método simplificado para avaliação da eficiência de processos de desaguamento. 1997.

SPELLMAN, Frank R. Dewatering biosolids. Lancaster, Pa: Technomic Pub., 1997. $276 \mathrm{p}$.

UNITED STATES ENVIRONMENTAL PROTECTION AGENCY (USEPA). Sludge treatment and disposal. Cincinnati, Ohio, 1978.

URASHIMA, D.; VIDAL, D. Dimensionamento por teoria probabilística de filtros em geotêxteis não tecidos. $2^{\circ}$ Simpósio Brasileiro sobre aplicação de geossintéticos. São Paulo. 1995.

van HAANDEL, A. C.; LETTINGA, G. Tratamento anaeróbio de esgotos: Um manual para regiões de clima quente. Campina Grande, PB, 1994.

van HAANDEL, A; MARAIS, G. O comportamento do sistema de lodo ativado: teoria e aplicações para projetos e operação. Campina Grande, Paraíba: Epgraf, 1999. $472 \mathrm{p}$.

VERTEMATTI, J. C. (Coordenador). Manual brasileiro de geossintéticos. São Paulo. Edgard Blücher. 2004. 
VESILIND, P.A. Capillary suction time as a fundamental measure of sludge dewaterability. Journal Water Pollution Control Federation, v.60, n.2, p.215-20, Feb.1988.

VESILIND, P.A. The role of water in sludge dewatering. Water Environment Research, v. 66, n. 1, p. 4-11, Jan./Feb. 1994.

VIDAL, D. (Org). Os Geossintéticos e suas principais aplicações. Módulos 1, 2, 3, 4 e 5. São José dos Campos. Instituto de Aeronáutica. Apostila disponível em http://www2.ita.br/ delma/cursos/dlcpaa.html (acessada em maio de 2008). 2002.

WANG, Y. Condicionamento de lodo de estação de tratamento de água: estudo de caso. 1996. 419 p., 2 v. Dissertação (Mestrado) - Escola Politécnica, Universidade de São Paulo. São Paulo, 1996.

WANG, Y. L.; DENTEL, S. K. The effect of high speed mixing and polymer dosing rates on the geometric and rheological characteristics of conditioned anaerobic digested sludge (ADS). Water Research. 2010.

WANKE, Renate. Drenagem natural de água livre de lodos de reator UASB condicionado com polieletrólitos em desaguador estático vertical com tela. Dissertação de mestrado. Universidade Federal do Espírito Santo. Vitória, ES, 2005.

WATER ENVIRONMENTAL FOUNDATION (WEF). Design of Municipal Wastewater Treatment Plants: Manual of Practice (Mop) 8 and ASCE Manual and Report on Engineering Practice Series, No 76. $4^{\text {th }}$ edition, 1998.

WATER POLLUTION CONTROL FEDERATION (WPCF). Innovative process assessment: sludge processing, disposal and reuse. WPCF Research Foundation: 1990.

WATER POLLUTION CONTROL FEDERATION (WPCF). Operation of municipal wastewater treatment plants, Alexandria, VA. Water Environment Federation, 1996. 3 v. Manual of Practice No. 11.

WATER POLLUTION CONTROL FEDERATION (WPCF). Sludge dewatering. Washington D.C., 1983. 164 p. (Manual of practice $n^{\circ} 20$ ). 
WERLE, C.P.; NOVAK, J.T.; KNOCKE, W.R.; SHERRARD, J.H. Mixing intensity and polymer sludge conditioning. Journal of Environmental Engineering, v.110, n.5, p.919-934, Oct. 1984.

WOLFF, E.; SCHWABE W. K.; LANDIM, A. B.; VITORINO, M. D. Caracterização do lodo gerado na Estação de Tratamento de Água da Cenibra. 23ํㅡㄴ Congresso Brasileiro de Engenharia Sanitária e Ambiental, Campo Grande/MS, 2005.

WORLEY, J. W.; BASS, T. M.; VENDRELL, P. F. Use of geotextile tubes with chemical amendments to dewater dairy lagoon solids. Bioresource technology. 2008.

YAMAOKA, M.; HATA, K. Improvements in drying beds for non-concentrated sludge. Advances in Environmental Research. 2003. 


\section{APÊNDICE 1 - Desenhos do sistema piloto}

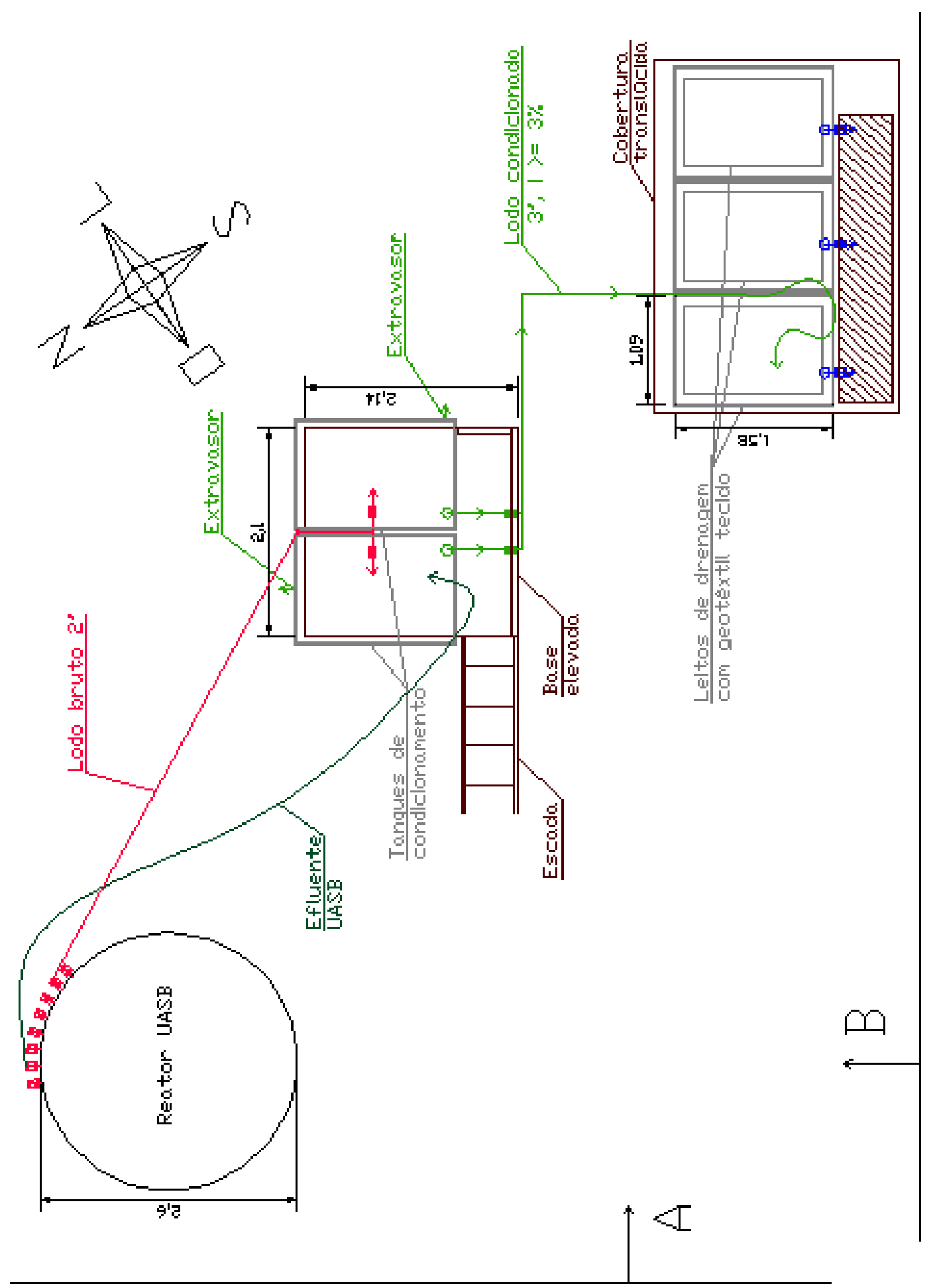

Figura 84 - Desenho em planta do sistema piloto de desaguamento 


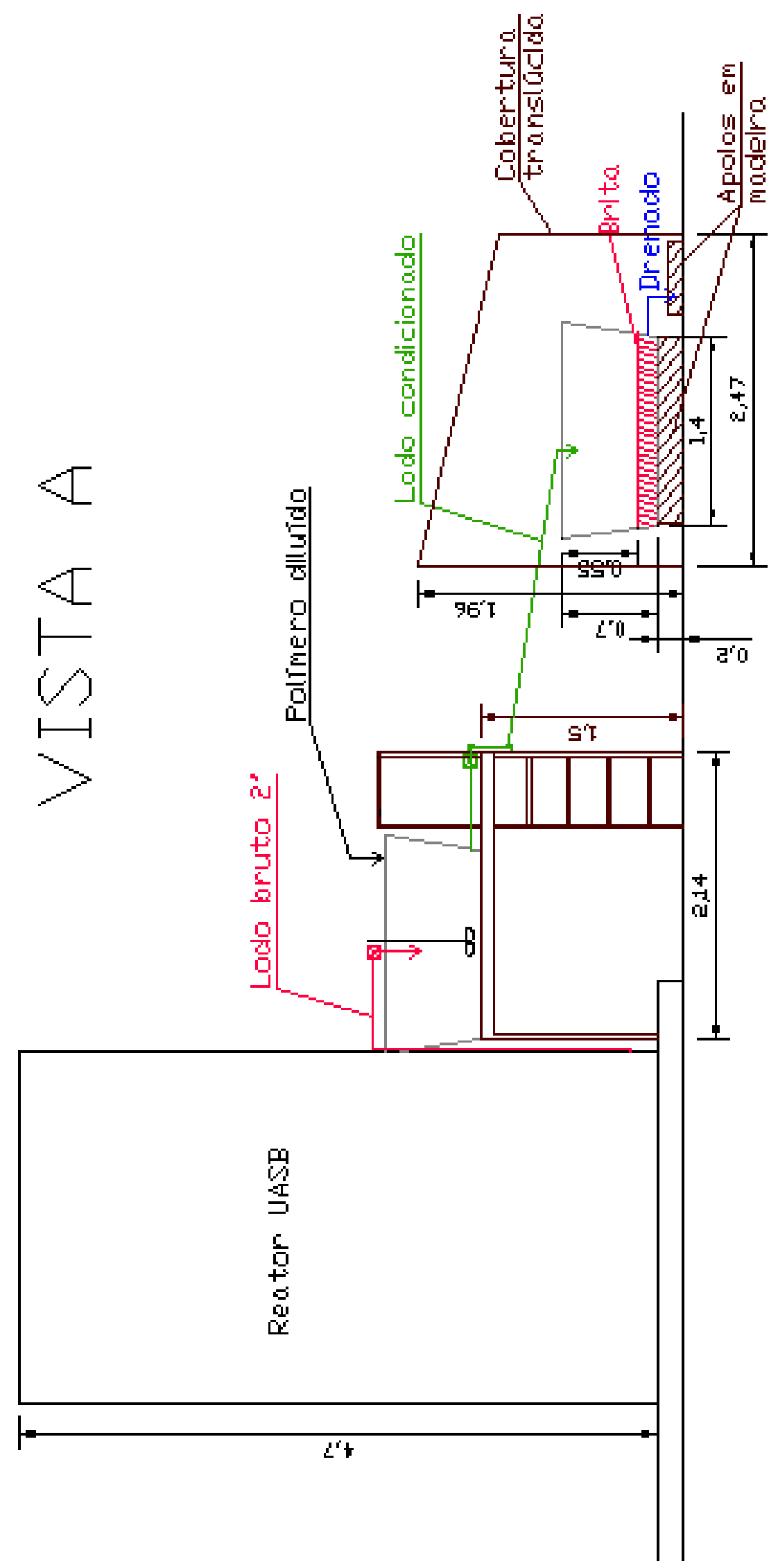

Figura 85 - Vista A do sistema piloto de desaguamento 


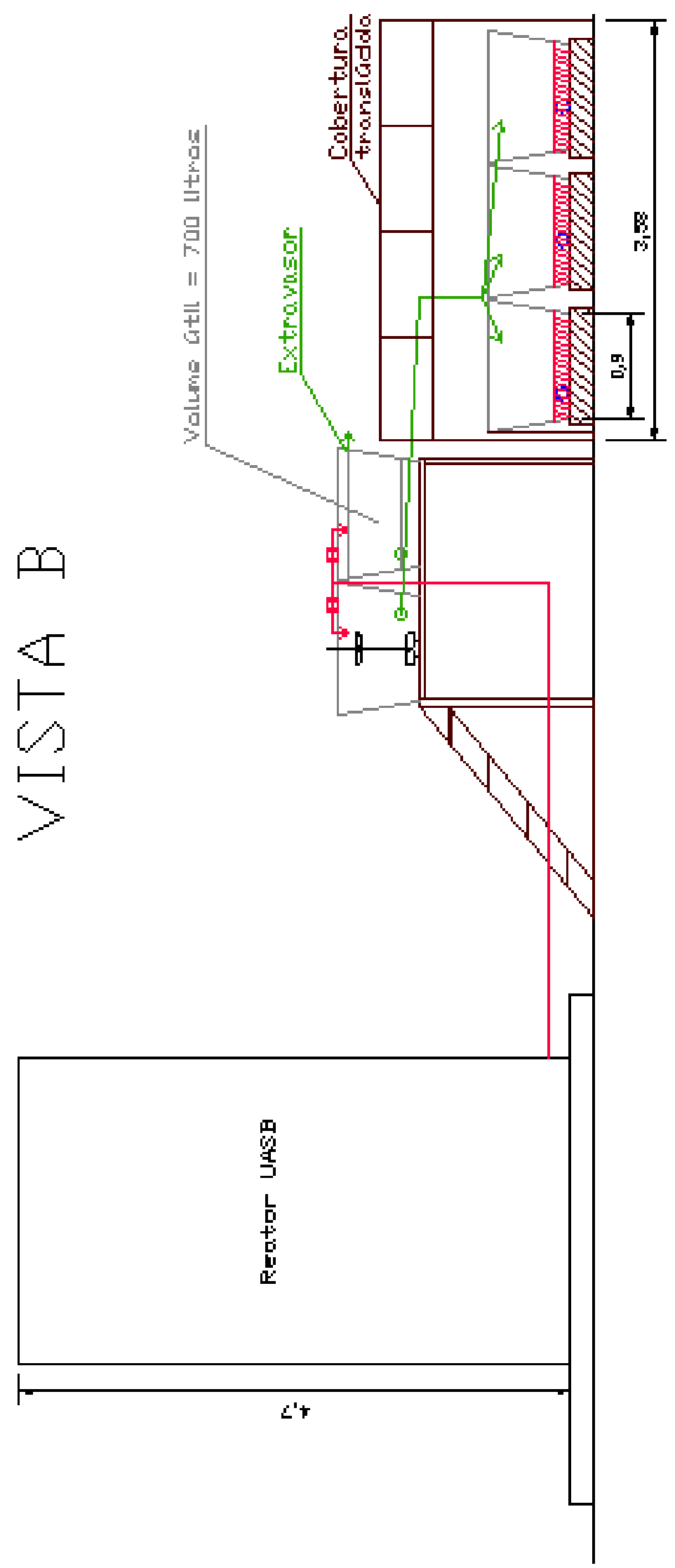

Figura 86 - Vista B do sistema piloto de desaguamento 


\section{APÊNDICE 2 - Resultados da primeira série de testes com o TTD}

Os ensaios preliminares foram realizados com todos os 18 polímeros recebidos. Depois de realizados mais de 180 testes de tempo de drenagem, iniciou-se uma etapa de repetição dos ensaios para que pudessem ser observadas as variações entre os resultados e médias mais confiáveis pudessem ser utilizadas como parâmetro para a sequência dos ensaios.

Porém, com o inicio das repetições, variações muito grandes nos tempos de drenagem para as mesmas doses foram observadas. Uma análise destas variações possibilitou identificar que estas não eram aleatórias em torno de uma média aritmética de uma dose de determinado polímero, mas que seguiam um padrão de deslocamento da curva inteira para a direita, como se o ponto ótimo de dosagem e toda a curva de concavidade negativa do TTD estivesse se deslocando.

Esta hipótese indicava que existia algum erro metodológico entre a análise de concentração de sólidos do lodo coletado na ETE e a dosagem de polímero durante o Teste do Tempo de Drenagem, que alterava a real dosagem testada. Com uma simples análise de concentração de sólidos de um dos recipientes de coleta em fase final de utilização (menos de 5 litros no galão de 20 litros) foi possível confirmar a hipótese: O teor de sólidos das amostras utilizadas para os testes variavam ao longo da retirada do material de dentro do recipiente de coleta, mesmo com agitação intensa e prolongada.

Portanto, os resultados da série preliminar de testes com o Teste do Tempo de Drenagem, que ocorreram entre agosto de 2008 e setembro de 2009 com lodo de Ribeirão Pires, serviram apenas para demonstrar que alguns polímeros com alta aptidão poderiam apresentar doses “ideais" próximas a 2 g/kg.

Com o reconhecimento do erro metodológico e uma avaliação apenas superficial de cada polímero, partiu-se para a definição de uma nova metodologia e iniciou-se a segunda série de TTD com diferentes doses de cada polímero. 
A nova metodologia difere apenas na realização de uma etapa intermediária entre a análise de concentração de sólidos no recipiente de 20 litros e a utilização do lodo nos TTD. Esta etapa consistiu em colocar 4 litros de lodo em um recipiente de 5 litros de volume e, neste recipiente, determinar a concentração de sólidos, sendo que a amostragem foi realizada durante mistura contínua, com a utilização de agitador magnético. Este procedimento tentou garantir uma menor variabilidade nos resultados em função da sedimentação de sólidos que ocorreu no recipiente de maior volume ao longo da série preliminar de testes.

Os procedimentos e resultados da nova metodologia estão apresentados ao longo do trabalho. Um exemplo do deslocamento que a curva do TTD sofreu na repetição do teste para as mesmas doses está apresentado na Figura 87:

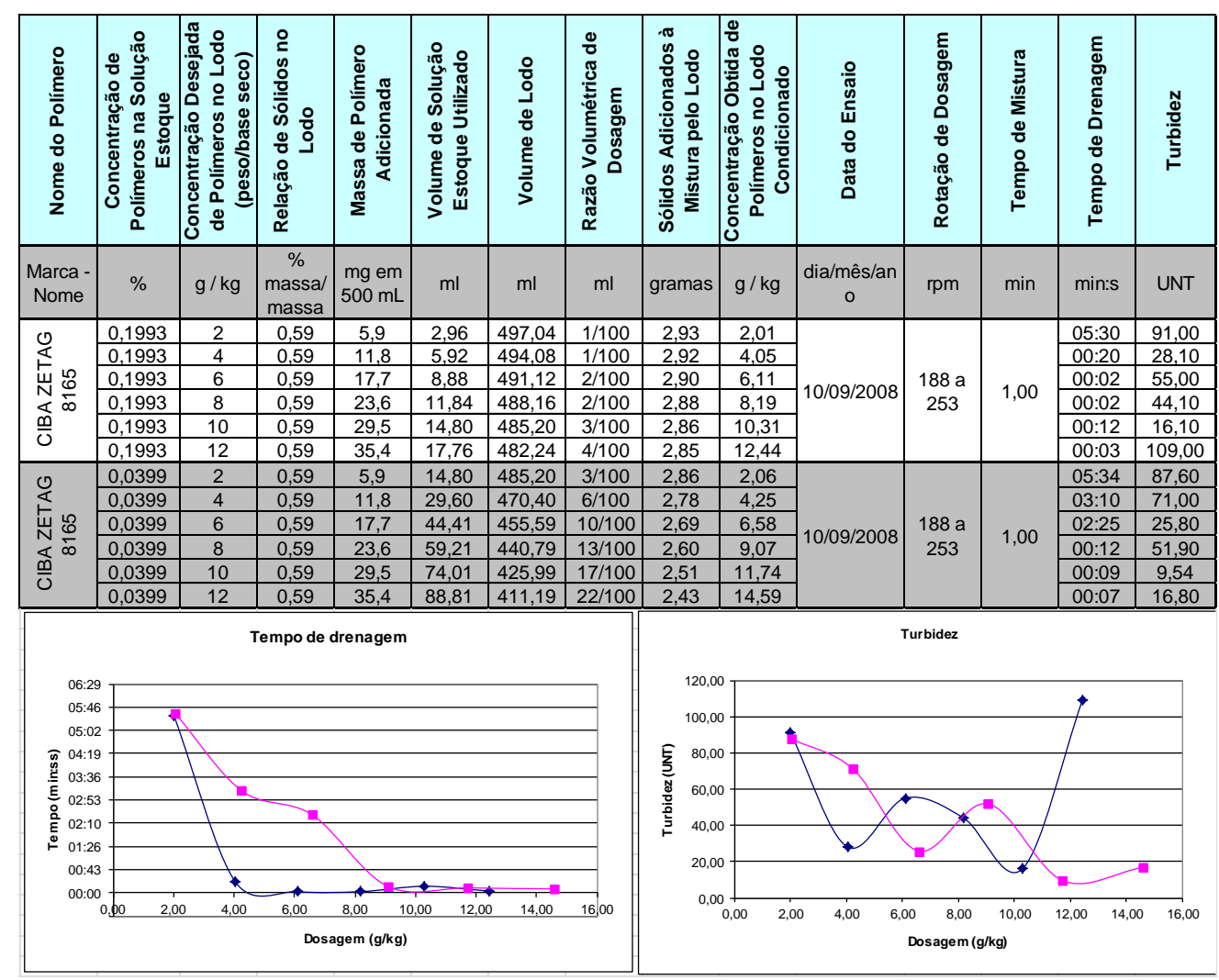

Figura 87 - TTD para o mesmo polímero e doses com erro na metodologia. 


\section{APÊNDICE 3 - Dados e resultados da segunda série de testes com o} TTD

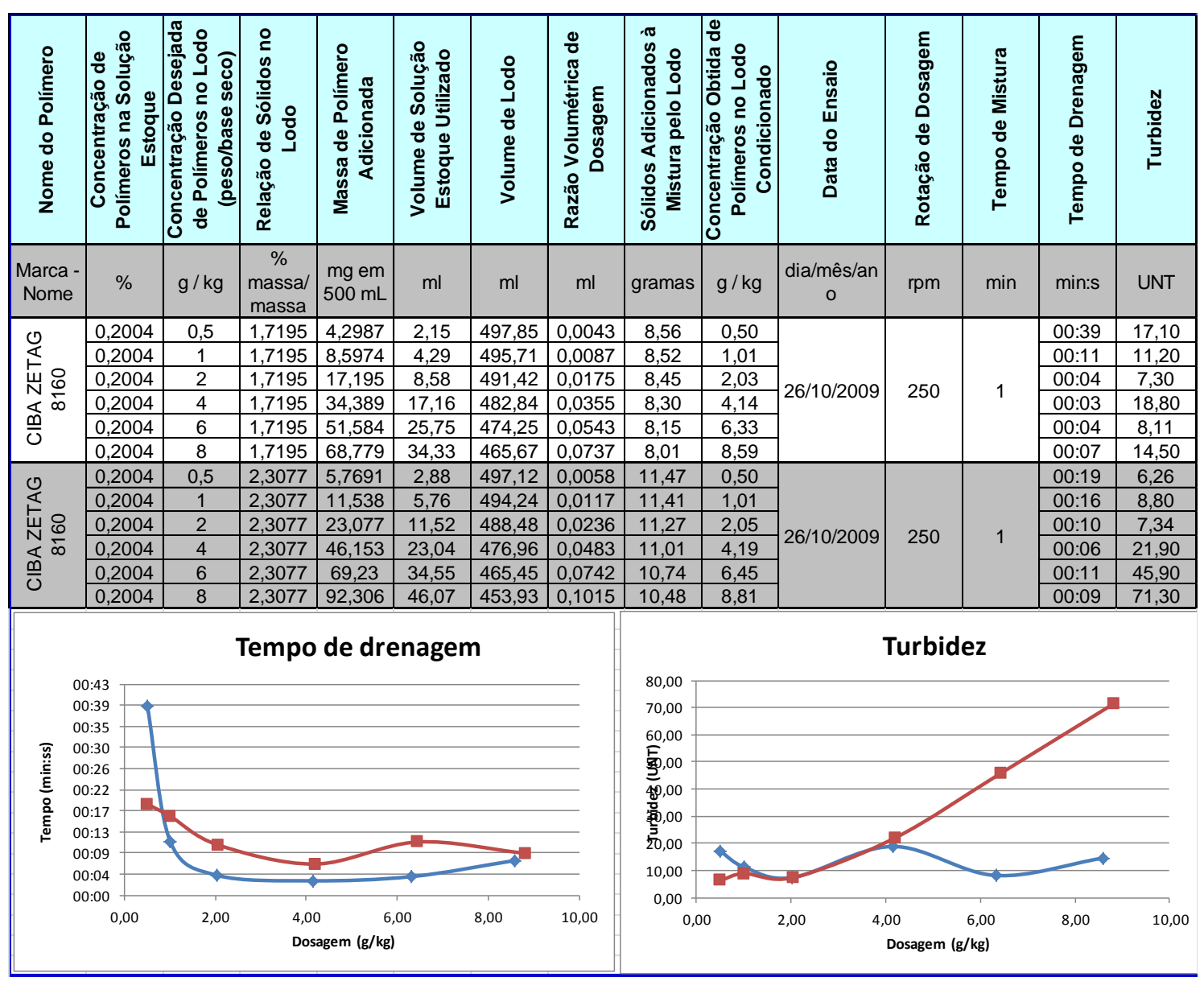

Figura 88 - Resultados do teste em duplicata para o polímero CIBA ZETAG 8160 


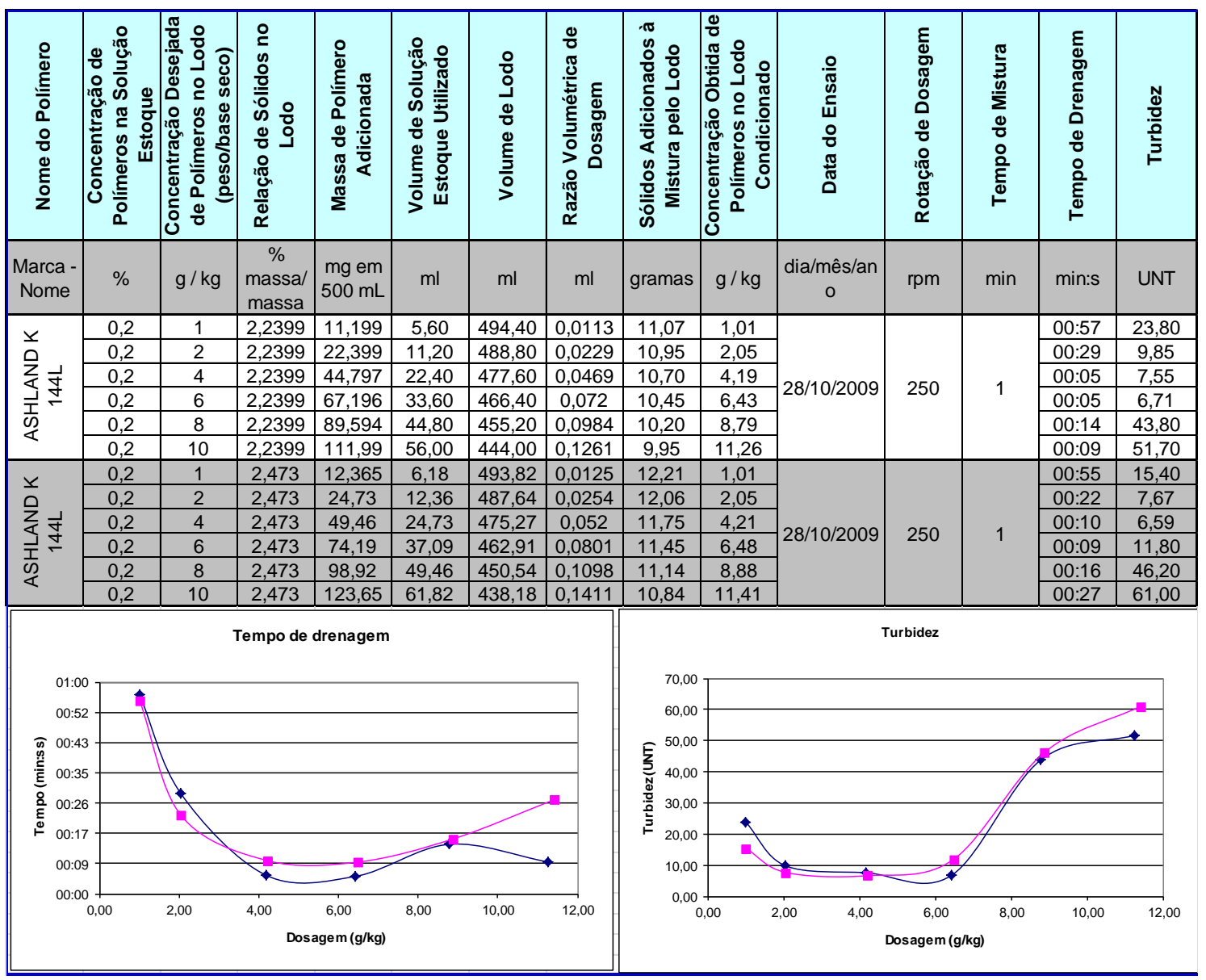

Figura 89 - Resultados do teste em duplicata para o polímero ASHLAND K 144L 


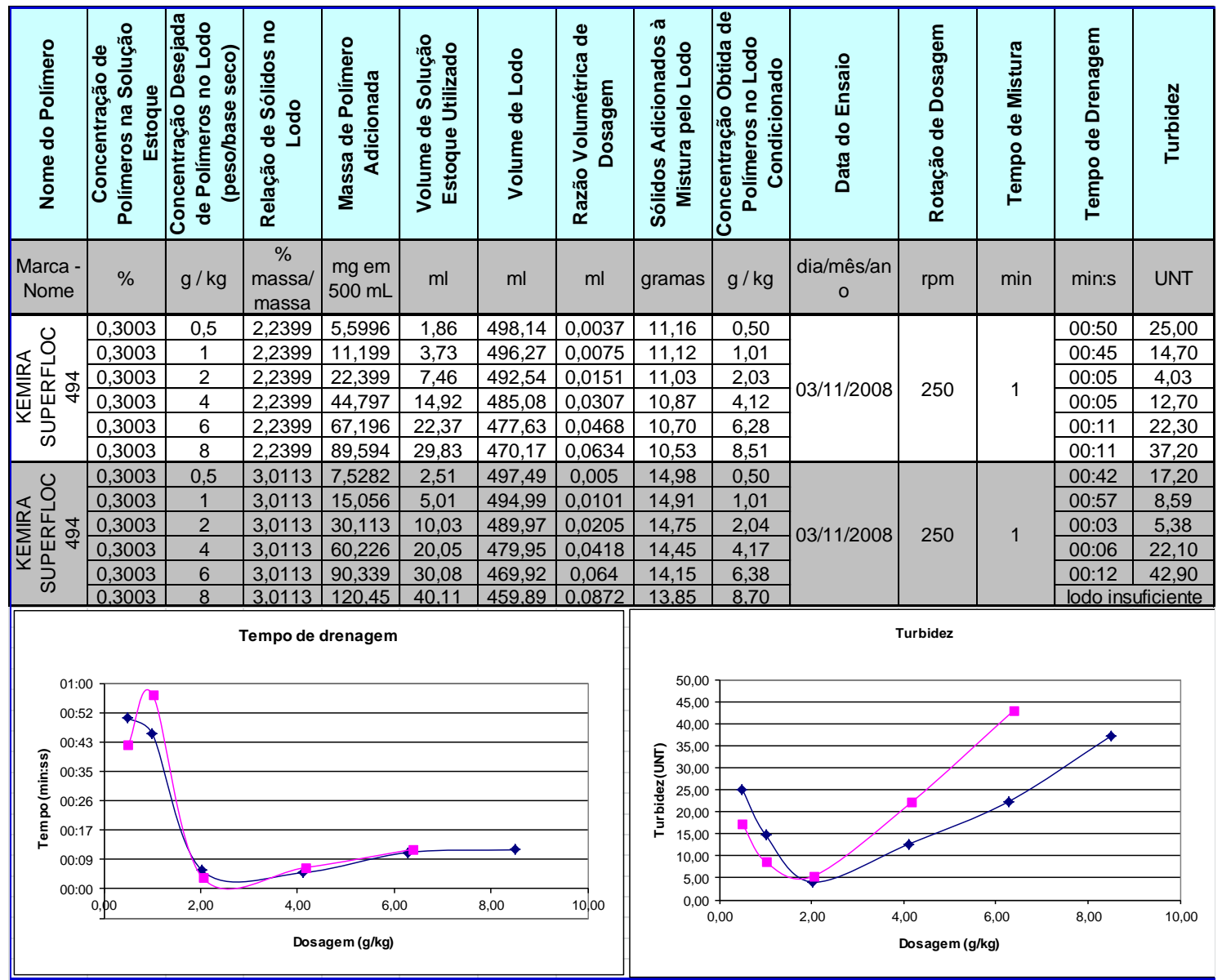

Figura 90 - Resultados do teste em duplicata para o polímero KEMIRA SUPERFLOC 494 


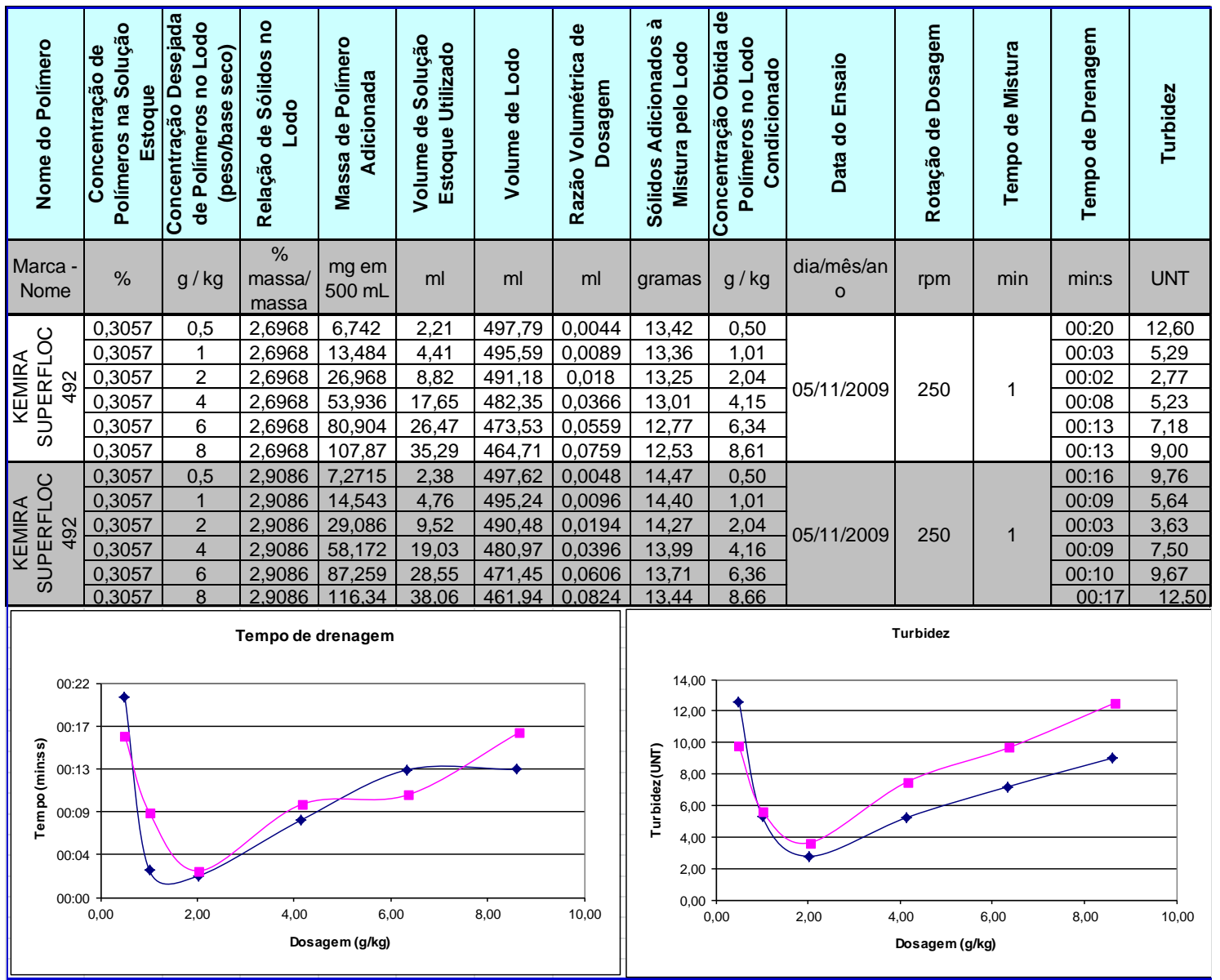

Figura 91 - Resultados do teste em duplicata para o polímero KEMIRA SUPERFLOC 492 


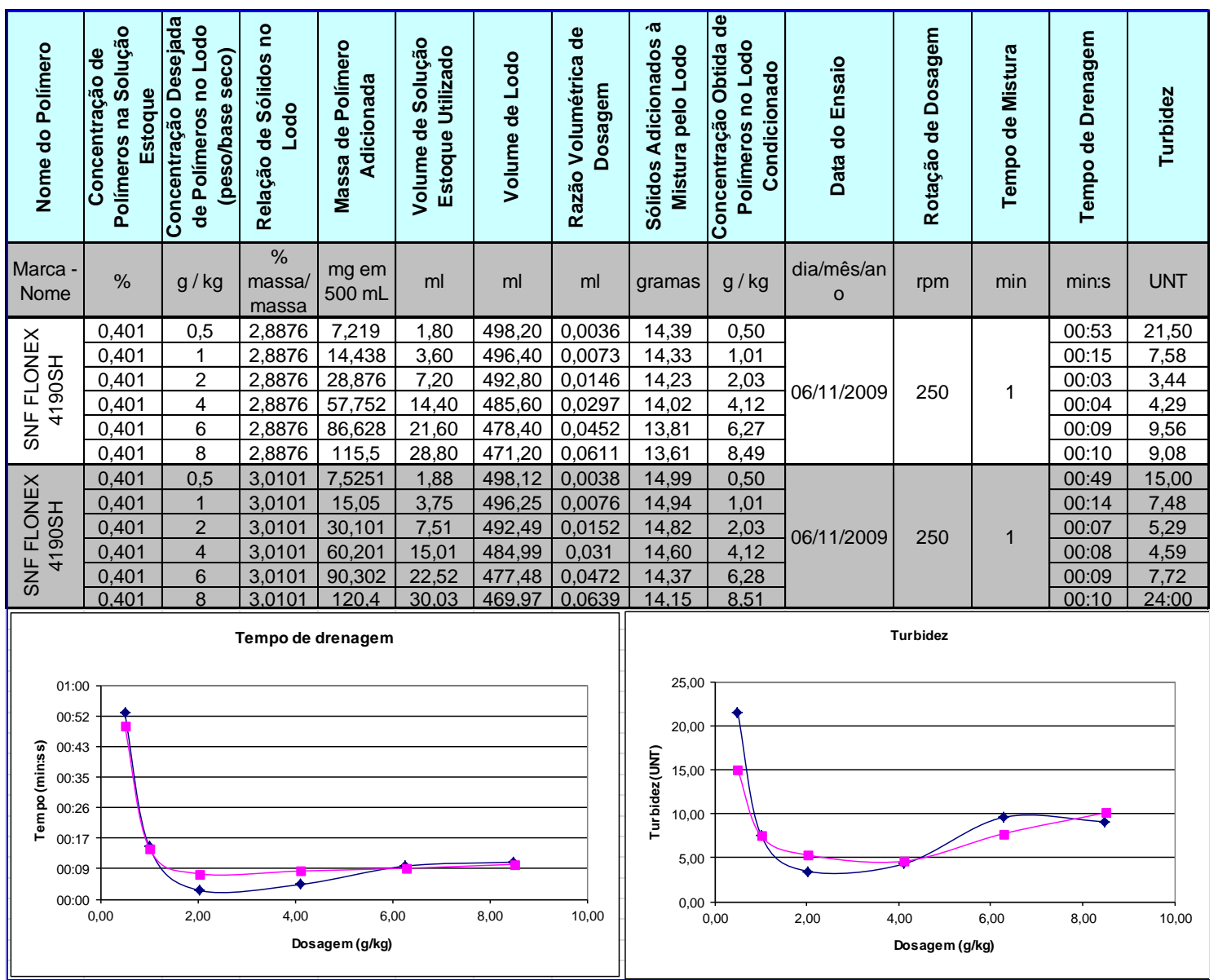

Figura 92 - Resultados do teste em duplicata para o polímero SNF FLONEX 4190SH 


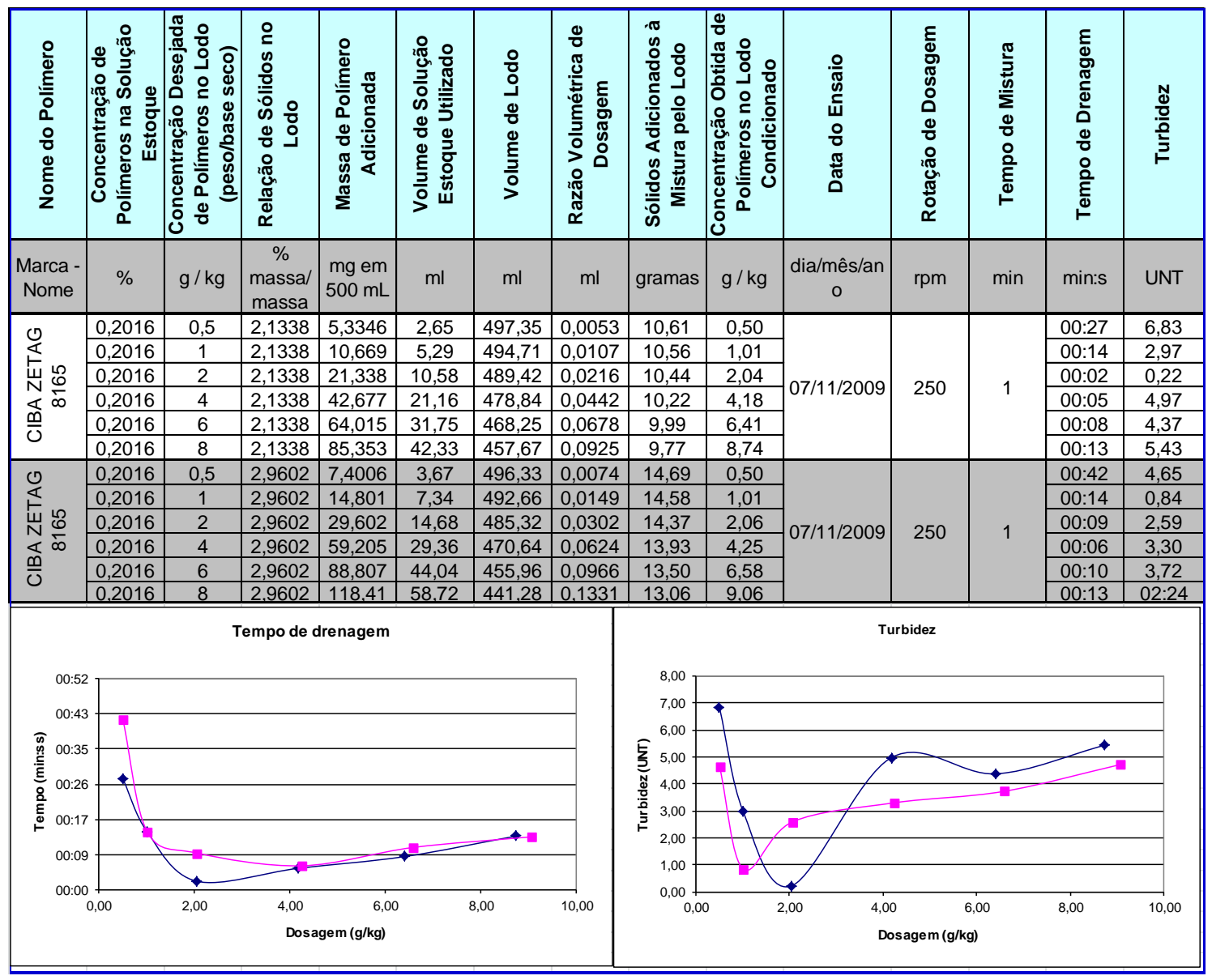

Figura 93 - Resultados do teste em duplicata para o polímero CIBA ZETAG 8165 


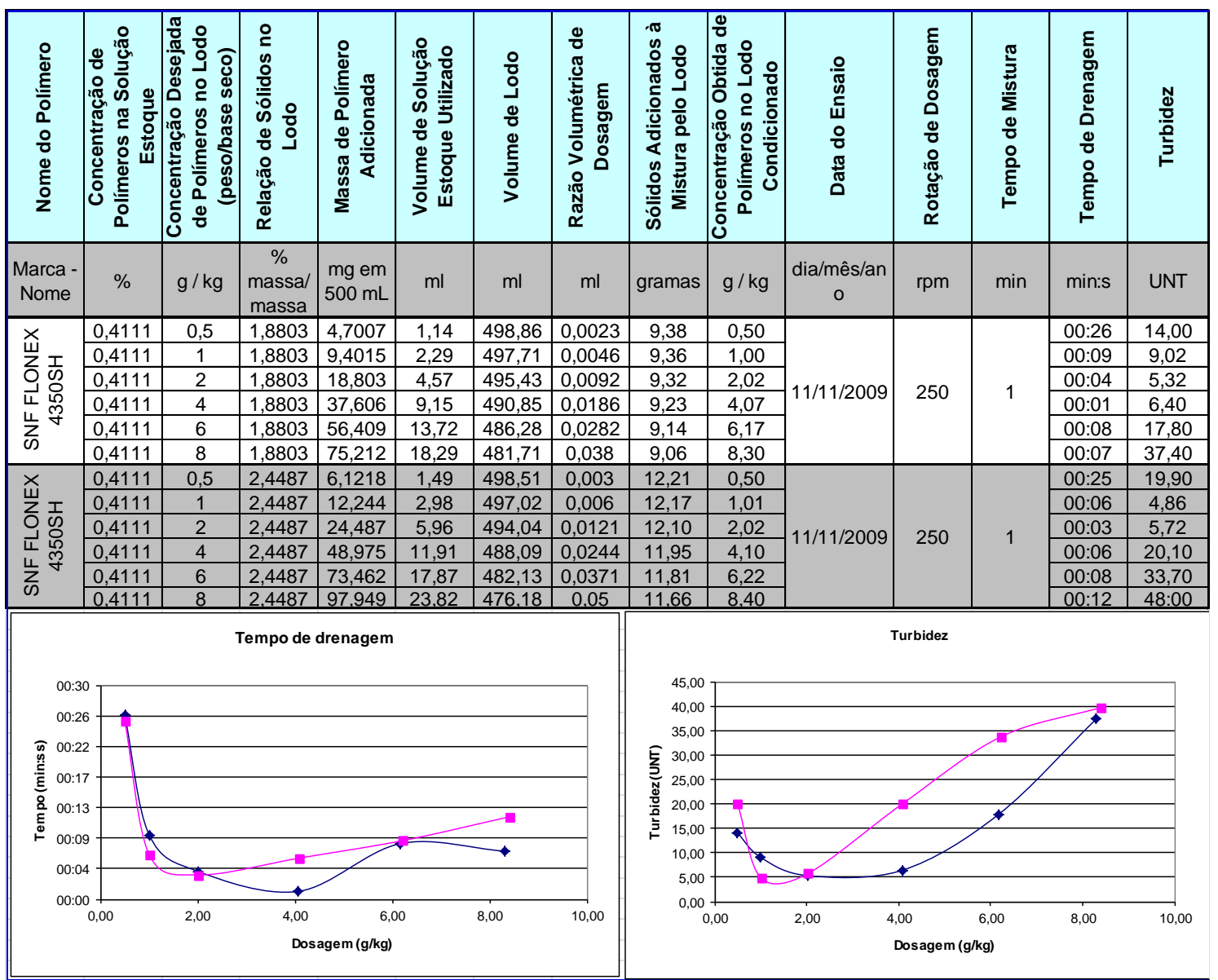

Figura 94 - Resultados do teste em duplicata para o polímero SNF FLONEX 5350SH 


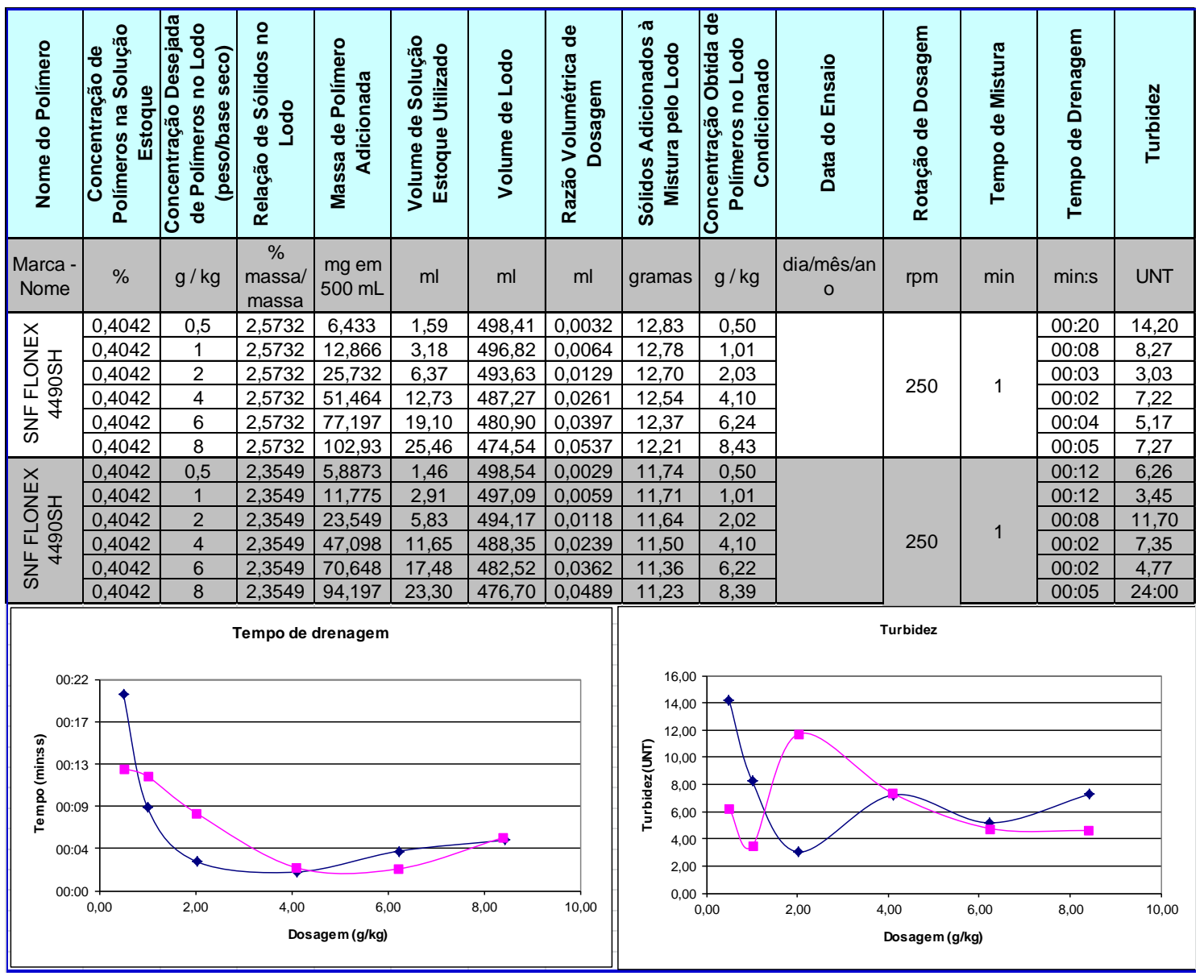

Figura 95 - Resultados do teste em duplicata para o polímero SNF FLONEX 4490SH 


\section{APÊNDICE 4 - Dados e resultados da terceira série de testes com o TTD}

Tabela 23 - Planilha dos testes da terceira série com polímeros sólidos

\begin{tabular}{|c|c|c|c|c|c|c|c|c|c|c|c|c|}
\hline zәp!qun! & 厹 & 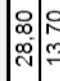 & 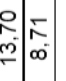 & & \begin{tabular}{l|l}
0 \\
\multirow{2}{*}{} \\
\hdashline \\
\hdashline
\end{tabular} & $\begin{array}{l}\bar{\sigma} \\
\bar{\sigma}\end{array}$ & & 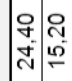 & $\mid \begin{array}{c}0 \\
N \\
N\end{array}$ & & 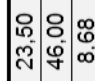 & \\
\hline 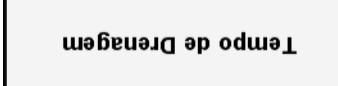 & : & $\mid \begin{array}{l}\hat{0} \\
\grave{\partial}\end{array}$ & 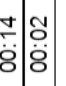 & & $\left|\begin{array}{c|c}\tilde{n} \\
\dot{\delta} \\
\dot{8}\end{array}\right|$ & : & & $\mid \begin{array}{c}\hat{m} \\
\ddot{8} \\
\ddot{8}\end{array}$ & 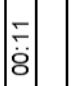 & & 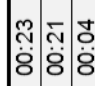 & \\
\hline 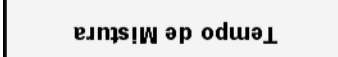 & $\frac{c}{E}$ & & - & & & - & & & - & & & - \\
\hline шә6еsog әр ов & $\underline{\underline{2}}$ & & 움 & & & 品 & & & 임 & & & 员 \\
\hline ореsuэ ор щер & 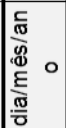 & & 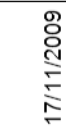 & & & 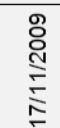 & & & 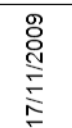 & & & 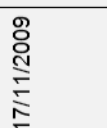 \\
\hline 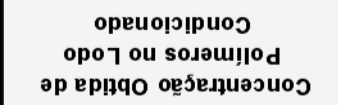 & $\frac{\stackrel{9}{\stackrel{9}{7}}}{0}$ & 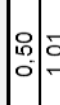 & 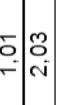 & & 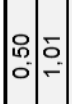 & $\mid$ & & $\left|\begin{array}{l}0 \\
0 \\
0 \\
\circ\end{array}\right|-$ & $\left|\begin{array}{l}+1 \\
0 \\
\text { ind }\end{array}\right|$ & & 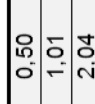 & $\begin{array}{l}\text { U } \\
\text { i }\end{array}$ \\
\hline $\begin{array}{c}\text { opo7 oped edmsı!w } \\
\text { e sopeuo!j!p } \forall \text { sop!lọs }\end{array}$ & 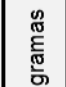 & 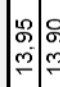 & 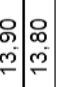 & & 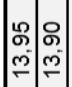 & $\begin{array}{l}0 \\
\infty \\
m \\
m\end{array}$ & & 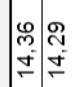 & $\mid$ & & 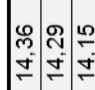 & a \\
\hline 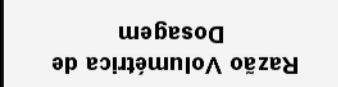 & $\bar{\varepsilon}$ & 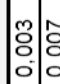 & \begin{tabular}{|l|l|l|} 
\\
\hdashline \\
0 \\
0 \\
0 \\
0
\end{tabular} & & $\mid \begin{array}{lll}0 & 0 \\
0 & 0 \\
0 & 0 \\
0 & 0 \\
0\end{array}$ & $\mid \begin{array}{l}0 \\
0 \\
0 \\
0\end{array}$ & & $\mid \begin{array}{ll}0 \\
0 \\
0\end{array}$ & $\mid \begin{array}{l}0 \\
0 \\
0 \\
0\end{array}$ & & \begin{tabular}{l|l|l} 
& 0 \\
0 & 0 & 0 \\
0 & 0 \\
0 & 0 & 0 \\
0
\end{tabular} & \\
\hline ороך әр әшијол & $\bar{\varepsilon}$ & 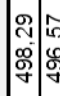 & 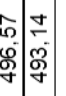 & & 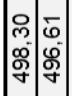 & \begin{tabular}{l}
$\bar{v}$ \\
\hdashline \\
\hdashline \\
\end{tabular} & & 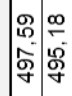 & 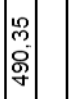 & & 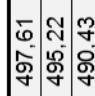 & \\
\hline 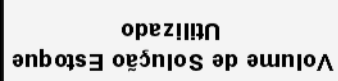 & $\bar{\varepsilon}$ & $\nwarrow \underbrace{\infty}_{0}$ & 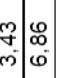 & & 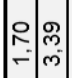 & $\left|\begin{array}{l}9 \\
9 \\
6\end{array}\right|$ & & 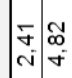 & $\mid$ & & 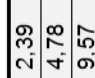 & \\
\hline 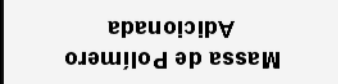 & के है & : & 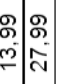 & & 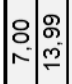 & 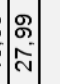 & & 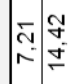 & 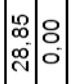 & : & 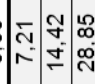 & \\
\hline ороך ou sop!lọ & 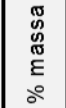 & 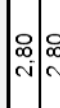 & 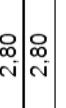 & & 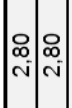 & $\mid \begin{array}{l}0 \\
0 \\
i \\
i\end{array}$ & & \begin{tabular}{l|l}
$\infty$ & $\infty$ \\
$\infty$ & $\infty$ \\
$\sim$ & $\infty$ \\
\end{tabular} & $\left|\begin{array}{c}\infty \\
\infty \\
\sim \\
\sim\end{array}\right|$ & & 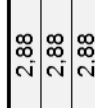 & \\
\hline 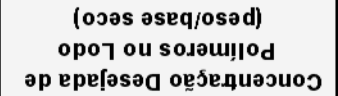 & 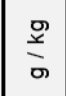 & - & $-N$ & $+\infty \infty_{\infty}$ & {$[0 \mid-$} & $n$ & $+\infty \infty$ & $\mid-$ & $n+$ & $\infty$ & $\mid-$ & $N+\infty \infty$ \\
\hline 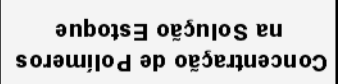 & $\therefore$ & 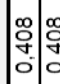 & 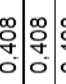 & 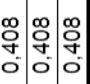 & 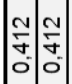 & $\mid$\begin{tabular}{c}
0 \\
\hdashline \\
\hdashline
\end{tabular} & 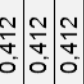 & 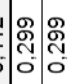 & 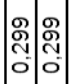 & : & 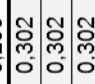 & ర్లి \\
\hline odau! & 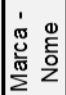 & & $\begin{array}{l}\mathrm{HSOS} \\
\mathrm{ANOT}\end{array}$ & $\begin{array}{l}s 9 t \\
\exists \pm N S\end{array}$ & & & $\begin{array}{l}t Z t \\
\exists I N S\end{array}$ & $30^{-}$ & 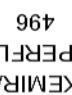 & dns & $\begin{array}{r}8 \\
\text { כ07t } \\
\forall d 1\end{array}$ & 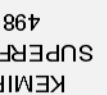 \\
\hline
\end{tabular}


Tabela 24 - Planilha dos testes da terceira série com polímeros sólidos

\begin{tabular}{|c|c|c|c|c|c|c|c|c|c|c|c|c|c|}
\hline 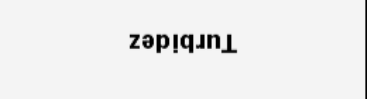 & 乬 & 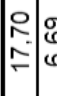 & \begin{tabular}{l|l}
8 \\
6 \\
0
\end{tabular} & & 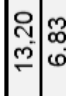 & \begin{tabular}{l|l|l|}
0 & 8 \\
0 & 0 \\
0 & 0 \\
\end{tabular} & & 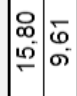 & 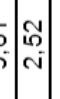 & & 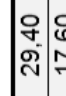 & 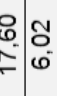 & \\
\hline шәбеиәда әр оdшә口 & 吕 & 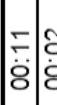 & 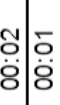 & & 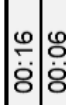 & : & & 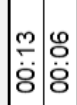 & $\mid$\begin{tabular}{l|l} 
\\
\\
\\
\end{tabular} & & 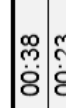 & 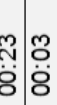 & \\
\hline e..nłs!W әp oduə। & $\frac{\complement c}{\varepsilon}$ & \multicolumn{3}{|c|}{-} & \multicolumn{3}{|c|}{-} & \multicolumn{3}{|c|}{-} & \multicolumn{3}{|c|}{-} \\
\hline шәбеsog әр овбероч & 흔 & \multicolumn{3}{|c|}{$\stackrel{\leftrightarrow}{\mathrm{O}}$} & \multicolumn{3}{|c|}{ 怘 } & \multicolumn{3}{|c|}{$\stackrel{\circ}{N}$} & \multicolumn{3}{|c|}{ 怘 } \\
\hline о!̣suヨ ор вұе & 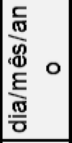 & \multicolumn{3}{|c|}{ 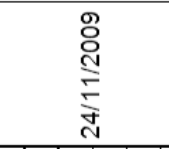 } & \multicolumn{3}{|c|}{ 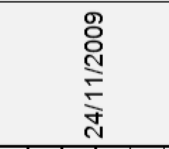 } & \multicolumn{3}{|c|}{ 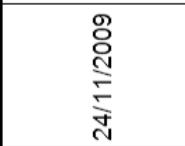 } & \multicolumn{3}{|c|}{ 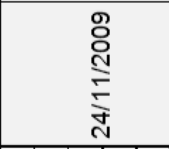 } \\
\hline 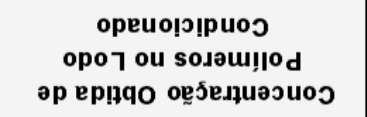 & $\frac{\stackrel{9}{9}}{0}$ & 落: & ס & & $\overline{5}$ & 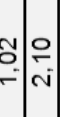 & & $i \begin{array}{l}\infty \\
0 \\
0\end{array}$ & $=$ & & {$\left[\begin{array}{l}\bar{n} \\
0 \\
0\end{array}\right]$} & $\begin{array}{l}\text { OS } \\
-i\end{array}$ & \\
\hline $\begin{array}{c}\text { opo7 opəd edm!s!w } \\
\text { e sopeuo!̣!p } \forall \text { sop!los }\end{array}$ & 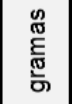 & 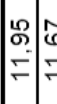 & 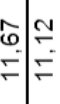 & & 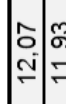 & 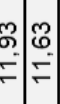 & & 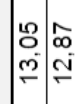 & ja. & & & 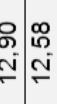 & \\
\hline 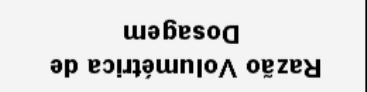 & $\bar{\varepsilon}$ & 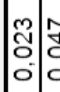 & 仑ิ & & 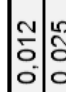 & 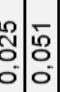 & & $\left|\begin{array}{l}m \\
\hdashline \\
0 \\
0\end{array}\right| \begin{array}{c}0 \\
0\end{array}$ & : & & & 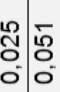 & \\
\hline ороך әр әшпю^ & $\bar{\varepsilon}$ & 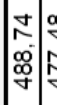 & 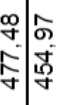 & & $\mid$\begin{tabular}{lll}
$\infty$ & $\infty$ \\
\hdashline & $\infty$ \\
\hdashline & $\infty$
\end{tabular} & 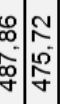 & & 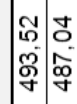 & 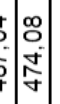 & & & 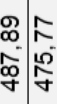 & \\
\hline 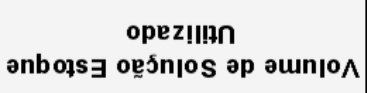 & $\overline{\mathrm{\varepsilon}}$ & 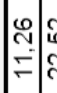 & 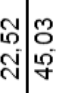 & & $\left|\begin{array}{c}7 \\
0 \\
0\end{array}\right|$ & 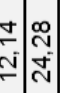 & & 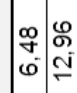 & 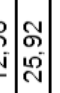 & & $\left.\mid \begin{array}{l}0 \\
0 \\
0\end{array}\right]$ & 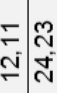 & \\
\hline 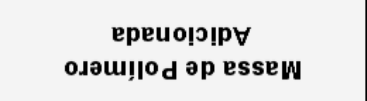 & जि & $=\frac{-}{6}$ & 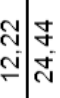 & & 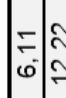 & 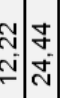 & & 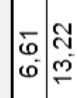 & 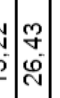 & & 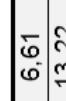 & 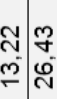 & \\
\hline ороך ou sop!Ios әр ов & 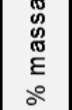 & $\begin{array}{c}\mathrm{i} \\
\mathrm{i} \\
\mathrm{i}\end{array}$ & \begin{tabular}{l|l}
$\mathrm{i}$ \\
$\mathrm{A}$
\end{tabular} & & \begin{tabular}{l|l}
4 \\
2 \\
\end{tabular} & \begin{tabular}{r|r|r|}
4 & 4 \\
& 2 \\
\end{tabular} & & 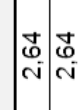 & 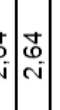 & & 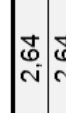 & 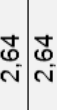 & \\
\hline 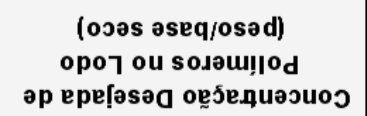 & $\frac{⿱ 亠 0}{\circ}$ & م. & $-v$ & & - & $-N$ & & $\mid$ & $-N$ & & - & $-N$ & \\
\hline 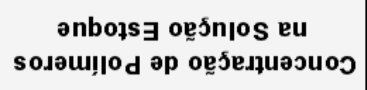 & ஃ & $\mid \begin{array}{l}\mid \\
0 \\
0 \\
0\end{array}$ & \begin{tabular}{l|l} 
\\
0 \\
0 \\
0
\end{tabular} & & 휭 & \begin{tabular}{l|l}
$\overline{0}$ & $\overline{-}$ \\
& 0 \\
0
\end{tabular} & & 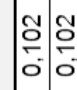 & $\frac{1}{0}$ & & : & $\frac{8}{\circ}$ & \\
\hline o.əu!! & 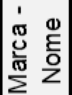 & & $\begin{array}{c}\dot{d} \perp 0 \\
\text { aN } \forall^{-}\end{array}$ & $\begin{array}{l}0 \subseteq 9 \\
\text { THS }\end{array}$ & & $\begin{array}{c}\text { כg } \\
\mathrm{aN} \forall 7\end{array}$ & $\begin{array}{l}\text { S8 } \\
-1 S \forall\end{array}$ & a & $\begin{array}{c}39 \varepsilon \\
\mathbb{N} \forall \text { 가 }\end{array}$ & 8 & & & $\begin{array}{l}\angle \mathrm{LS} 8 \\
\mathrm{HHSH}\end{array}$ \\
\hline
\end{tabular}


Tabela 25 - Planilha dos testes da terceira série com polímeros em emulsão

\begin{tabular}{|c|c|c|c|c|c|c|c|c|c|c|c|c|}
\hline 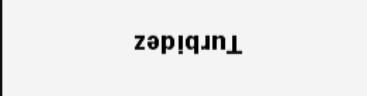 & 气 & 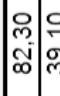 & & & 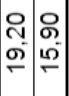 & & S:ll & & 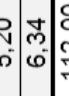 & 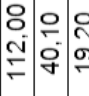 & 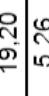 & \\
\hline шәбеиәла әр оduә & 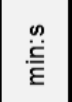 & পே: & \begin{tabular}{ll}
0 \\
\hdashline \\
\hdashline
\end{tabular} & 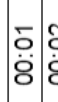 & 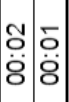 & $\underset{c}{c}$ & ஜே: & & s:|l: & 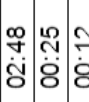 & \begin{tabular}{l}
$\frac{1}{2}$ \\
\hdashline \\
$\dot{\delta}$
\end{tabular} & 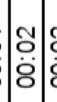 \\
\hline e.ms!W әp oduə」 & 듵 & & r & - & & & - & - & & & - & \\
\hline шә6еsog әр овбеңоу & 흔 & & & B & & & in & 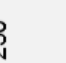 & & & 윰 & \\
\hline оำsuэ ор еұе & 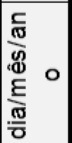 & & & 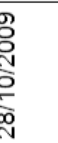 & & & 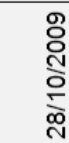 & & & & $\begin{array}{l}\text { Oे } \\
\frac{\mathrm{N}}{\mathrm{N}} \\
\frac{\mathrm{N}}{2}\end{array}$ & \\
\hline 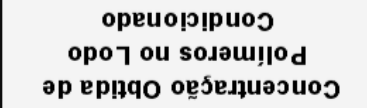 & 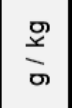 & $\left.\stackrel{-}{-}\right|_{0} ^{\infty}$ & & $\mid \begin{array}{lll}0 & 0 \\
0 & 0 \\
0 & 0 \\
0 & 0\end{array}$ & \begin{tabular}{|l|l|l|} 
& $:$ \\
$\infty$ & 0 \\
$\infty$ & 0 \\
\hdashline
\end{tabular} & & 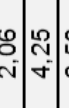 & & 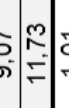 & 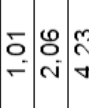 & & 임 \\
\hline $\begin{array}{c}\text { opo7 opəd e.m!s!W } \\
\text { e sopeuo!̣!p } \forall \text { sop!los }\end{array}$ & 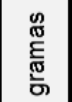 & 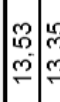 & 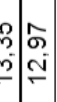 & 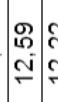 & 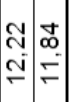 & 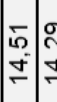 & 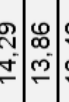 & & 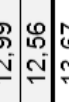 & 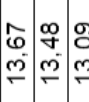 & & 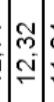 \\
\hline 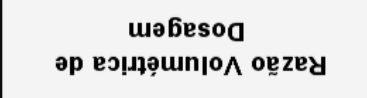 & $\bar{\varepsilon}$ & $\mid \begin{array}{l}0 \\
0 \\
0 \\
0 \\
0\end{array}$ & \begin{tabular}{l|l|l|}
$\infty$ & $\infty$ \\
& 0 \\
0 \\
0 \\
0 \\
0
\end{tabular} & $\begin{array}{l}8 \\
0 \\
0 \\
0\end{array}$ & 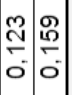 & مْ & 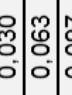 & 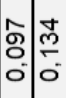 & 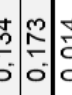 & 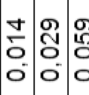 & סُ & $\mid$\begin{tabular}{l}
0 \\
\hdashline \\
0
\end{tabular} \\
\hline ороך әр әшијо & $\bar{\varepsilon}$ & 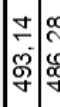 & 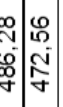 & 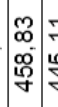 & 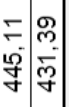 & 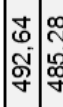 & 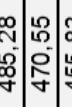 & 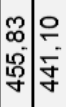 & 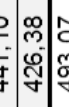 & 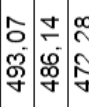 & 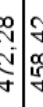 & \begin{tabular}{l}
0 \\
0 \\
0 \\
\hdashline
\end{tabular} \\
\hline 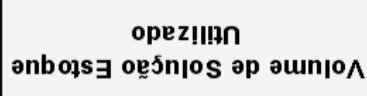 & $\bar{\varepsilon}$ & 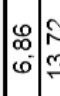 & 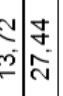 & $\underset{y}{z}=\frac{0}{2}$ & 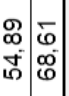 & 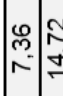 & 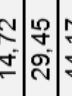 & & $\mid \begin{array}{lll}0 \\
0 \\
0\end{array}$ & 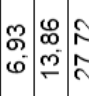 & & $\left|\begin{array}{lll} \\
3 \\
0 \\
0\end{array}\right|$ \\
\hline 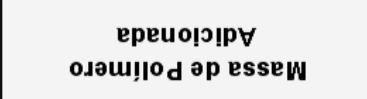 & 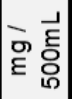 & 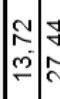 & 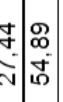 & 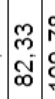 & 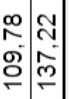 & 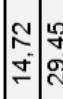 & 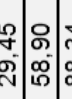 & & 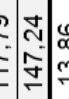 & 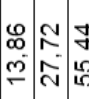 & 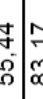 & : \\
\hline ороך ou sop!los әр op & 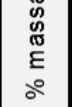 & ais & 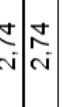 & $\mid \begin{array}{c}4 \\
4 \\
4\end{array}$ & 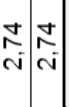 & 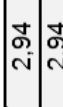 & 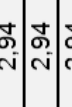 & 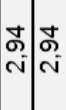 & $\begin{array}{c}\mathbf{u} \\
\mathbf{i} \\
\mathbf{n}\end{array}$ & 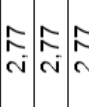 & \begin{tabular}{c|c}
$\hat{N}$ \\
$\mathrm{~N}$
\end{tabular} & $\hat{N}$ \\
\hline 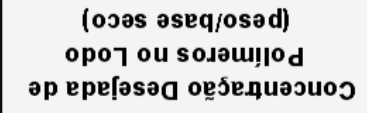 & 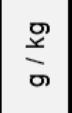 & $-n$ & $N+4$ & 0 & $\infty$ 으 & $-n$ & $N \rightarrow$ & $\omega \infty$ & ㅇㅇㅡ- & $-n \theta$ & $\nabla C$ & $\infty$ \\
\hline 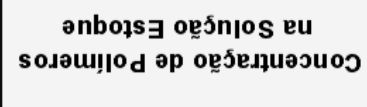 & $\therefore$ & 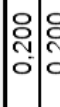 & 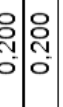 & 思 & \begin{tabular}{l|l|l|} 
& 0 \\
& 0 \\
$\vdots$ & 0 \\
0
\end{tabular} & 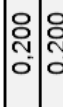 & 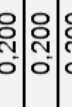 & 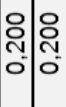 & : & 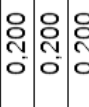 & 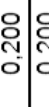 & : \\
\hline o.әu!ן do op әuоN & 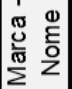 & & & $\begin{array}{l}\text { Lll } \\
\forall 7 \mathrm{HS}\end{array}$ & & & & 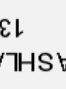 & & y an & & HS \\
\hline
\end{tabular}




\section{APÊNDICE 5 - Dados e resultados da quarta série de testes com o} TTD

Tabela 26 - Planilha com os dados dos testes da quarta série de ensaios

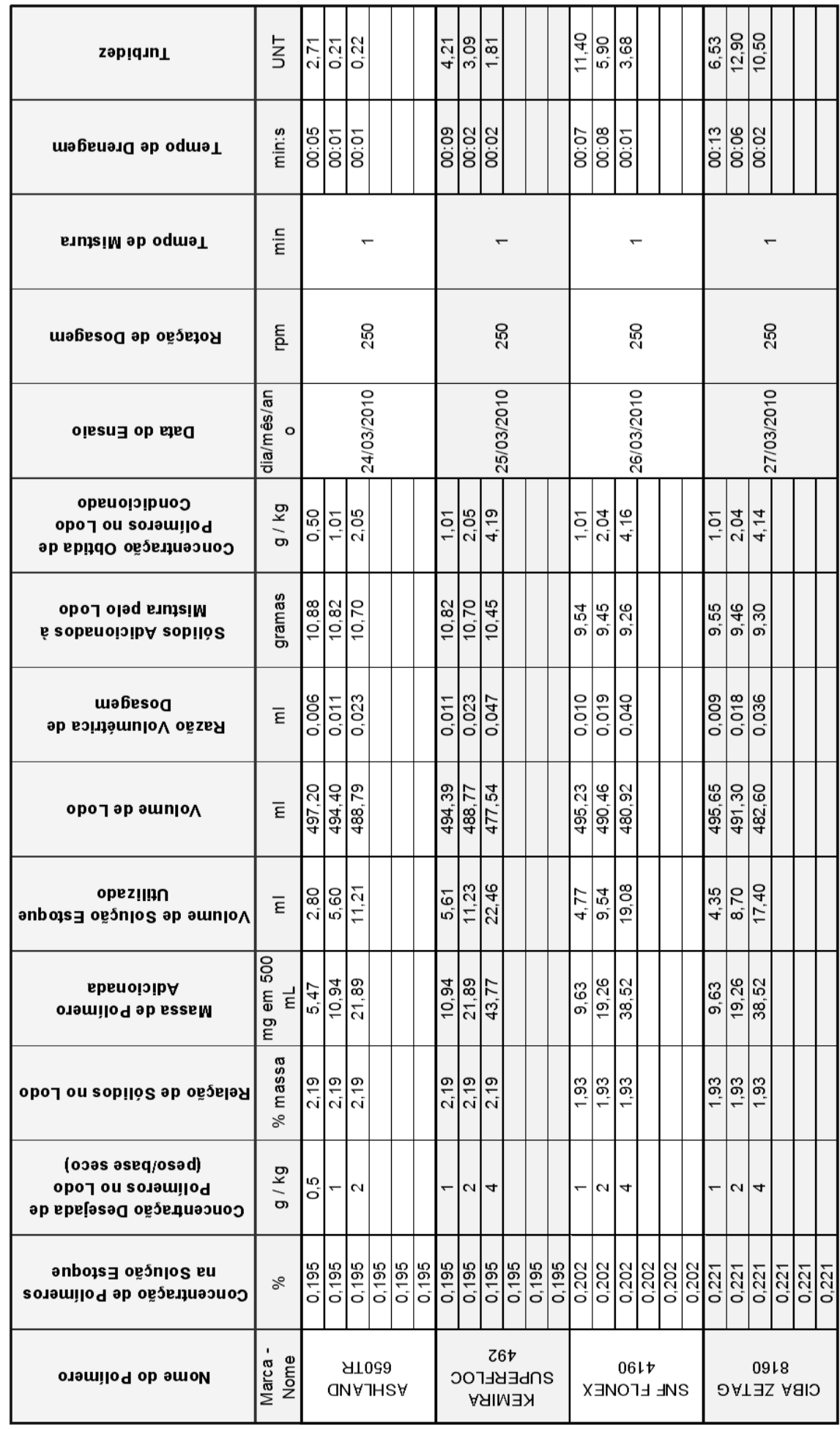




\section{APÊNDICE 6 - Dados e resultados da quinta série de testes com o TTD}

Tabela 27 - Planilha com os dados dos testes da quinta série de ensaios

\begin{tabular}{|c|c|c|c|c|c|c|c|c|c|c|c|c|c|c|c|}
\hline 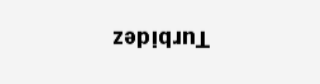 & 乬 & \begin{tabular}{r|rl}
$\hat{N}$ & $\infty$ \\
0 & 0 & 0 \\
0 & 0
\end{tabular} & \begin{tabular}{l|l|l|}
0 & 5 \\
0 & 0 \\
0
\end{tabular} & 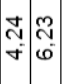 & & 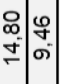 & $\begin{array}{l}0 \\
0 \\
5\end{array} \mid$ & 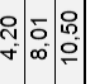 & 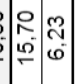 & 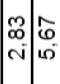 & 원 & 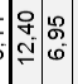 & ח & & $\frac{8}{7}$ \\
\hline แәбеиәла әр оdшә口 & : & (: & ș: & 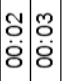 & & 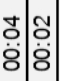 & (1) & 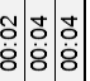 & 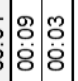 & 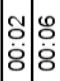 & $\div$ & 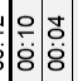 & סू & & 응 \\
\hline 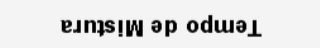 & 듵 & & - & & & & - & & & - & & & - & & \\
\hline 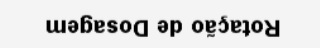 & 흔 & & : & & & & : ڤ్రి & & & 品 & & & 品 & & \\
\hline оำsuэ ор ереа & 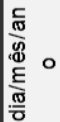 & & 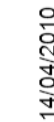 & & & & $\begin{array}{l}\text { 응 } \\
\text { N } \\
\text { d } \\
\text { d }\end{array}$ & & & $\begin{array}{l}\text { 웋 } \\
\text { N } \\
\text { 寸 } \\
\text { 寸 }\end{array}$ & & & 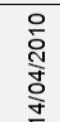 & & \\
\hline 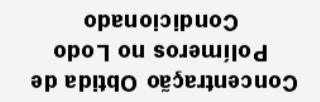 & $\frac{\stackrel{9}{9}}{\sigma}$ & : & $\tilde{r}$ & 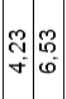 & & \begin{tabular}{l|l}
0 & 0 \\
0 & 0 \\
0 & -
\end{tabular} & : & 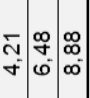 & $\mid$\begin{tabular}{l|l|l|}
0 & 0 \\
0 & 0 \\
\hdashline & - \\
\end{tabular} & 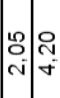 & $\mid \begin{array}{lll}\mid & \infty \\
0 & \infty & 0 \\
0 & \infty & 0\end{array}$ & & & & $\mid \begin{array}{l}\infty \\
\infty \\
\infty \\
\infty\end{array}$ \\
\hline $\begin{array}{c}\text { opo7 opəd eum!s!W } \\
\text { e sopeuo!o!p } \forall \text { sop!los }\end{array}$ & 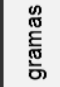 & 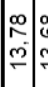 & 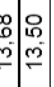 & 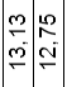 & & 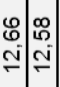 & 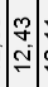 & 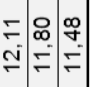 & 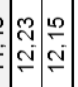 & 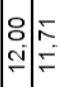 & 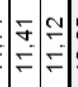 & 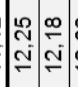 & & & 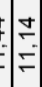 \\
\hline 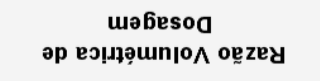 & $\bar{\varepsilon}$ & $\left|\begin{array}{ll}\hat{0} \\
0 \\
0\end{array}\right|$ & t. & \begin{tabular}{|l|l|l}
1 & $\infty$ \\
0 & 0 \\
0 & 0 \\
0 & 0 & 0 \\
0
\end{tabular} & & 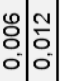 & $\mid \begin{array}{l}1 \\
0 \\
0\end{array}$ & \begin{tabular}{l|l|l|}
$\tilde{N}$ & 0 & 0 \\
\hdashline & 0 \\
0 & 0 & 0 \\
\hdashline & 0 \\
\end{tabular} & $\mid$\begin{tabular}{l|l|}
0 & 0 \\
0 & 0 \\
0 & 0 \\
0
\end{tabular} & 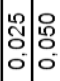 & $\mid$\begin{tabular}{ll|}
$\infty$ & 0 \\
$\vdots$ & 0 \\
0 & 0 \\
0 & 0 \\
0
\end{tabular} & $\left|\begin{array}{lll}0 & 0 \\
0 & 0 \\
0 & 0 \\
0\end{array}\right|$ & 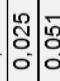 & & $\frac{1}{0}$ \\
\hline ороך әр әшп|ол & $\overline{\mathrm{E}}$ & 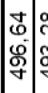 & 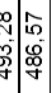 & 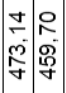 & $\begin{array}{c}\hat{N} \\
0 \\
0 \\
y\end{array}$ & 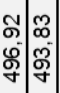 & $\mid \begin{array}{l}0 \\
0 \\
\infty \\
0 \\
y\end{array}$ & 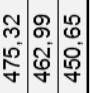 & \begin{tabular}{|l|l|} 
\\
\hdashline \\
\end{tabular} & 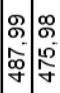 & 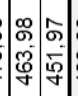 & 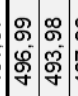 & 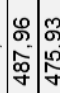 & & 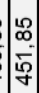 \\
\hline 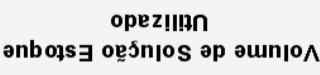 & $\bar{\varepsilon}$ & 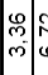 & 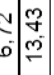 & 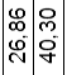 & & 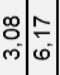 & 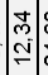 & 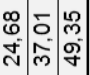 & \begin{tabular}{|l|l|l|l|} 
& 0 \\
& 0 & 0 \\
0
\end{tabular} & 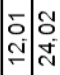 & 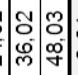 & & 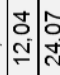 & & $=\frac{\infty}{0}$ \\
\hline $\begin{array}{c}\text { еpeuo!j’!p } \forall \\
\text { osəu!!lod әр essew }\end{array}$ & 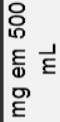 & : & 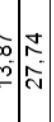 & 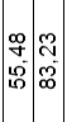 & & & : & 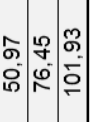 & 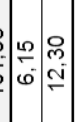 & 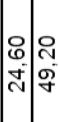 & & & 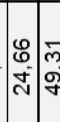 & 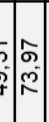 & ֻ \\
\hline 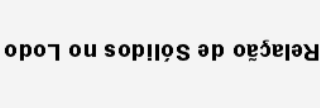 & 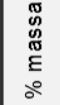 & Nis & 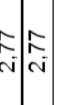 & $\begin{array}{lll}N & N \\
N & N\end{array}$ & & 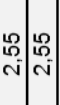 & : & 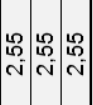 & \begin{tabular}{|ll}
0 \\
0 \\
\end{tabular} & 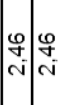 & 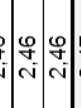 & 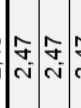 & $\hat{N}$ & $\hat{v}$ & $\hat{A}$ \\
\hline 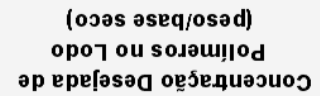 & $\frac{\stackrel{9}{\stackrel{9}{0}}}{0}$ & 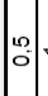 & $-N$ & $\nabla 0$ & & - & $N$ & $\nabla \omega$ & $\mid \begin{array}{lll}0 & 0 \\
0 & -1 & -1\end{array}$ & $N \theta$ & $\infty \infty$ & {$\left[\begin{array}{c}\infty \\
0\end{array} \mid-\right.$} & $N \sigma$ & & $\infty$ \\
\hline 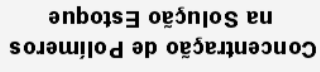 & $\therefore$ & 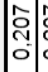 & 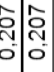 & 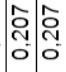 & î̀ & 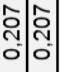 & $\left|\begin{array}{c}\hat{2} \\
0 \\
0\end{array}\right|$ & 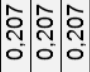 & 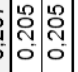 & | & 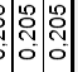 & 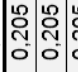 & $\begin{array}{lll}0 & 0 \\
& 0 \\
0 & 0 \\
0 & 0\end{array}$ & & : \\
\hline Oدau! & 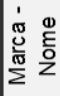 & & $\begin{array}{l}\text { VIIC } \\
\text { an } B\end{array}$ & $\begin{array}{l}0 \subseteq 9 \\
\mathrm{THSH}\end{array}$ & & & & IHS & כo7 & $\begin{array}{l}26 t \\
1 \pm y \exists \\
\text { dilw }\end{array}$ & Inns & & $\begin{array}{l}26 t \\
7 \exists y \exists \\
\text { fylW }\end{array}$ & $\begin{array}{l}\text { Bdns } \\
\text { By }\end{array}$ & \\
\hline
\end{tabular}




\section{APÊNDICE 7 - Planilhas do ensaio piloto}

Tabela 28 - Planilha do ensaio piloto E1

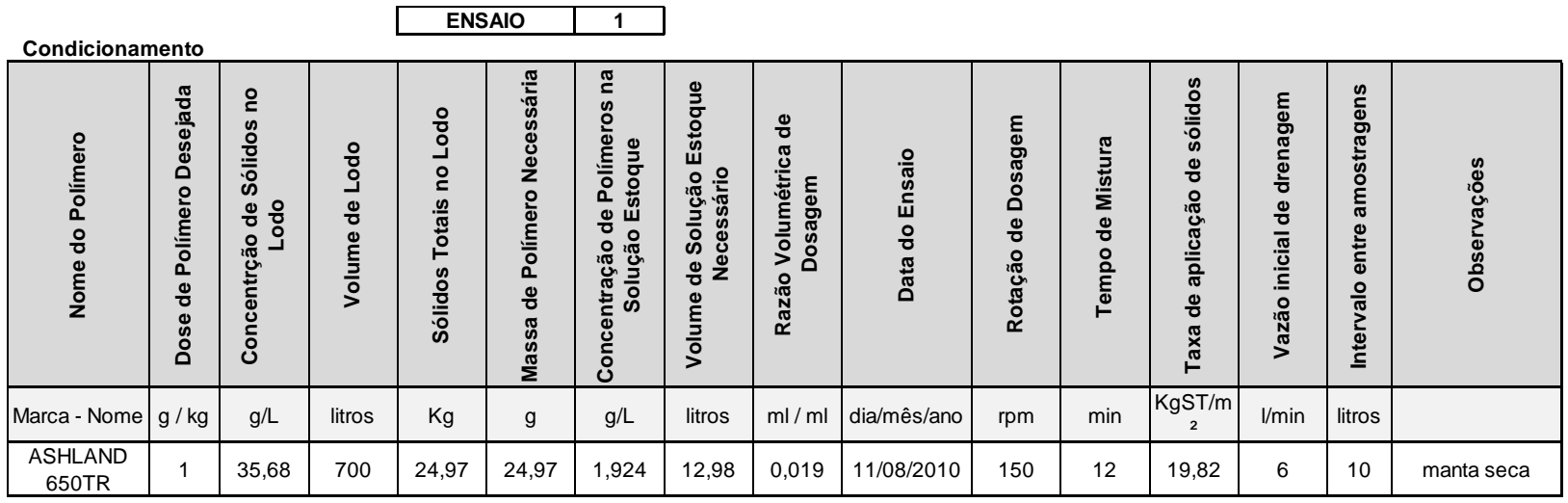

Análise do drenado

\begin{tabular}{|c|c|c|c|c|c|c|}
\hline & 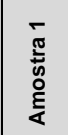 & 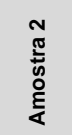 & 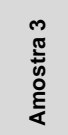 & 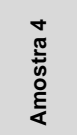 & 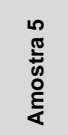 & 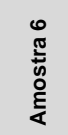 \\
\hline $\mathrm{DQO}(\mathrm{mg} / \mathrm{l})$ & 244,7 & 155,3 & 174,8 & 151,5 & 147,6 & 174,8 \\
\hline $\begin{array}{c}\text { Condutividad } \\
\text { e }(\mu \mathrm{S})\end{array}$ & 859,0 & 892,0 & 907,0 & 884,0 & 901,0 & 885,0 \\
\hline $\mathrm{pH}$ & 6,14 & 6,06 & 6,20 & 6,74 & 6,27 & 6,30 \\
\hline $\begin{array}{c}\text { Turbidez } \\
\text { (UNT) }\end{array}$ & 118,0 & 68,1 & 83,1 & 75,2 & 66,6 & 74,7 \\
\hline
\end{tabular}

Acompanhamento da torta

\begin{tabular}{|c|c|c|c|c|c|c|c|c|c|c|c|c|c|c|c|}
\hline & $\begin{array}{l}\frac{0}{0} \\
\frac{\pi}{5} \\
\frac{0}{0} \\
\frac{0}{\pi}\end{array}$ & 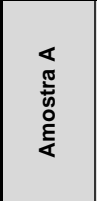 & 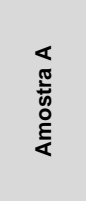 & 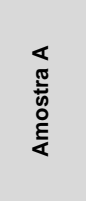 & 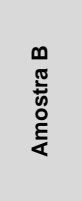 & 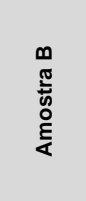 & 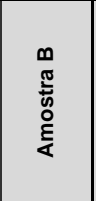 & 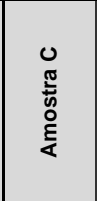 & 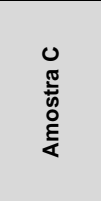 & 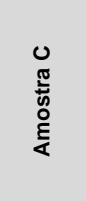 & 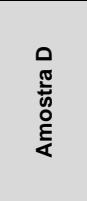 & 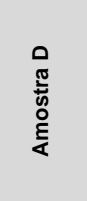 & 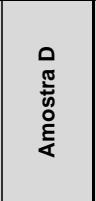 & 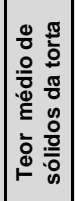 & 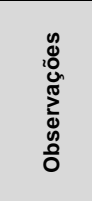 \\
\hline Dias corridos & $\mathrm{cm}$ & $\mathrm{P0}(\mathrm{g})$ & $\mathrm{P} 1(\mathrm{~g})$ & P2 (g) & P0 (g) & $\mathrm{P} 1(\mathrm{~g})$ & P2 (g) & P0 (g) & $\mathrm{P} 1(\mathrm{~g})$ & P2 (g) & P0 (g) & $\mathrm{P} 1(\mathrm{~g})$ & P2 (g) & TS & \\
\hline 0 & 45 & & & & & & & & & & & & & 3,57 & \\
\hline 1 & 25 & 107,404 & 117,44 & 108,66 & 98,71 & 109,65 & \begin{tabular}{|l|}
100,069 \\
\end{tabular} & & & & & & & 12,49 & \\
\hline 6 & 15 & 105,819 & 141,53 & 110,52 & 91,12 & 129,51 & \begin{tabular}{|l|}
96,230 \\
\end{tabular} & 110,794 & 158,607 & 117,11 & 107,11 & 135,07 & 110,947 & 13,32 & Choveu \\
\hline 9 & 14 & 92,590 & 142,55 & 99,56 & 102,91 & 148,41 & 109,344 & 103,706 & 149,456 & 110,02 & 102,98 & 144,54 & 108,576 & 13,85 & \\
\hline 11 & 13 & 103,854 & 157,95 & 112,24 & 107,1 & 174,19 & 116,882 & 110,781 & 175,584 & 120,06 & 106,51 & 173,43 & 119,860 & 16,13 & \\
\hline 13 & 13 & 103,706 & 186,47 & 116,66 & 91,11 & 151,46 & \begin{tabular}{|l|}
100,359 \\
\end{tabular} & 28,719 & 71,01 & 34,98 & 110,76 & 184,22 & 123,087 & 15,76 & \\
\hline 15 & 13 & 103,860 & 195,49 & 118,13 & 107,39 & 185,74 & 123,581 & 105,803 & 167,362 & 119,86 & 102,97 & 182,49 & 115,098 & 18,21 & \\
\hline 18 & 13 & 107,407 & 185,79 & 120,83 & 105,82 & 137,23 & 114,467 & 106,538 & 143,977 & 115,13 & 102,99 & 169,42 & 113,875 & 19,44 & \\
\hline 20 & 12 & 107,119 & 173,69 & 121,02 & 110,80 & 178,88 & 121,747 & 92,587 & 152,647 & 106,41 & 114,37 & 173,97 & 124,658 & 19,25 & \\
\hline 22 & 12 & 105,82 & 162,56 & 119,91 & 102,98 & 172,76 & 114,5 & 106,52 & 179,191 & 119,2 & 103,71 & 153,51 & 116,93 & 20,69 & \\
\hline 24 & 12 & 119,802 & 173,18 & 129,51 & 118,61 & 160,96 & 127,07 & 107,109 & 157,73 & 115,37 & 92,589 & 153,34 & 116,4 & 24,26 & \\
\hline 26 & 12 & \begin{tabular}{|l|}
107,4 \\
\end{tabular} & 169,99 & 123,69 & 105,82 & 169,87 & 117,75 & 106,52 & 177,963 & 122,29 & 103,87 & 161,15 & 113,94 & 21,17 & \\
\hline 28 & 12 & 108,413 & 194,52 & 123,28 & 110,80 & 204,64 & 126,26 & 107,118 & 191,09 & 124,8 & 119,86 & 190,69 & 136,54 & 19,33 & \\
\hline 30 & 12 & \begin{tabular}{|l|}
103,71 \\
\end{tabular} & 168,79 & 120,08 & 106,53 & 179,02 & 118,88 & 103,88 & 203,798 & 119,94 & 102,98 & 169,06 & 119,16 & 20,08 & \\
\hline 33 & 11 & 109,75 & 166,83 & 119,49 & 114,37 & 161,66 & 127,2 & 107,11 & 173,889 & 118,4 & 108,41 & 155,77 & 122,6 & 21,99 & \\
\hline
\end{tabular}


Tabela 29 - Planilha do ensaio piloto E2

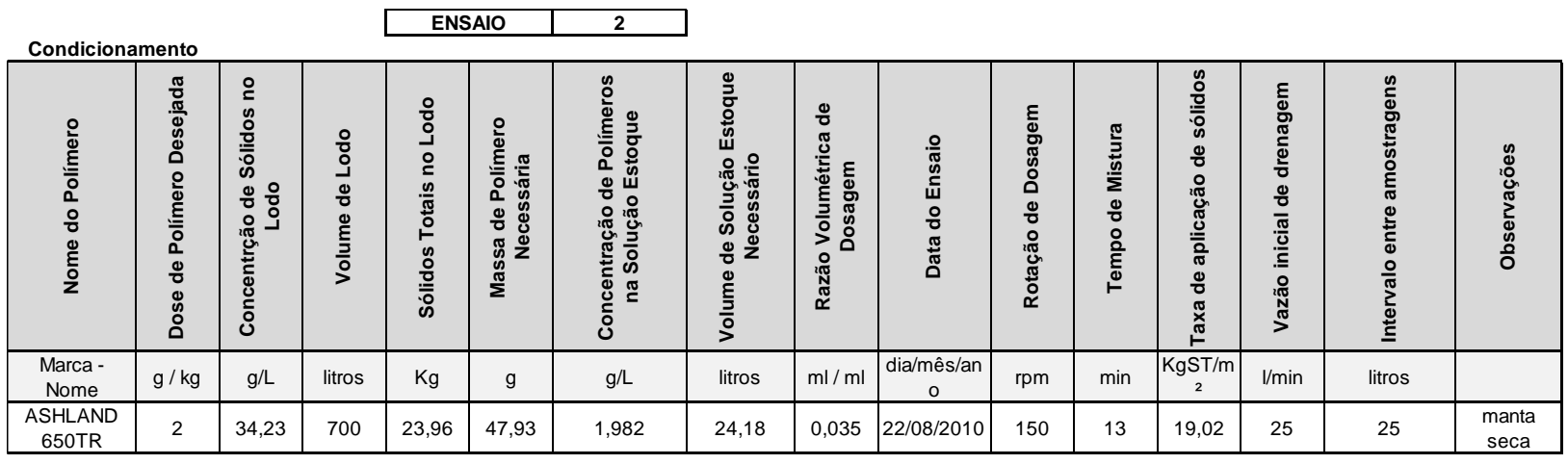

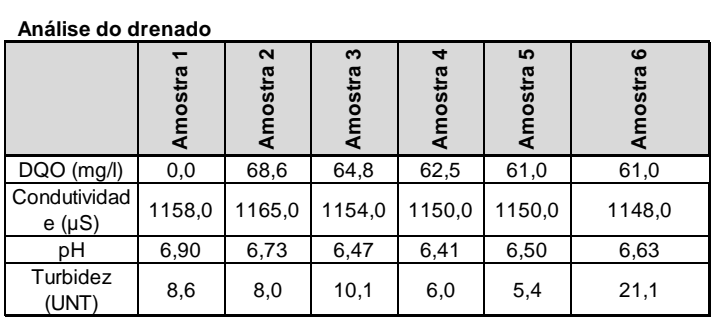

Acompanhamento

\begin{tabular}{|c|c|c|c|c|c|c|c|c|c|c|c|c|c|c|c|}
\hline & 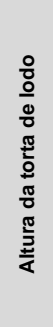 & 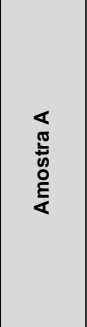 & 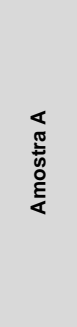 & 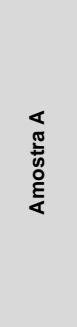 & 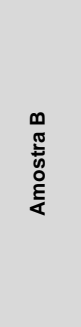 & 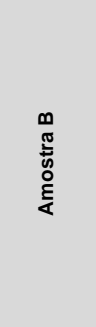 & 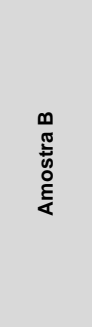 & 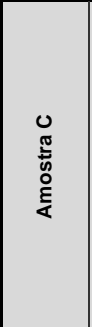 & 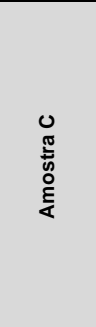 & 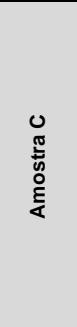 & 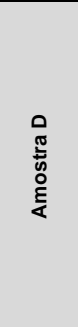 & 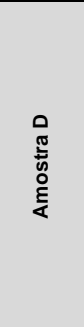 & 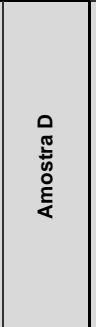 & 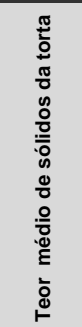 & 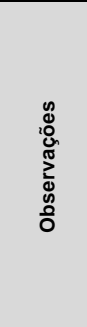 \\
\hline Dias corridos & $\mathrm{cm}$ & P0 (g) & $\mathrm{P} 1 \mathrm{~g}$ ) & P2 (g) & $\mathrm{PO}(\mathrm{g})$ & $\mathrm{P} 1 \mathrm{~g})$ & P2 (g) & PO (g) & $\mathrm{P} 1 \mathrm{~g})$ & P2 (g) & $\mathrm{PO}(\mathrm{g})$ & $\mathrm{P} 1 \mathrm{~g})$ & P2 (g) & TS (\%) & \\
\hline 0 & 45 & & & & & & & & & & & & & 3,42 & \\
\hline 1 & 17 & 106,500 & 146,66 & 112,85 & 92,59 & 138,28 & 99,465 & 105,826 & 154,48 & 113,08 & 102,98 & 130,65 & \begin{tabular}{|l|}
107,26 \\
\end{tabular} & 15,26 & \\
\hline 2 & 15 & 103,860 & 183,01 & 115,48 & 107,41 & 197,28 & 121,216 & 102,922 & 193,387 & 117,48 & 107,10 & 204,98 & 122,201 & 15,41 & Choveu \\
\hline 4 & 15 & 103,698 & 204,81 & 119,51 & 91,11 & 195,39 & 110,983 & 102,903 & 203,265 & 118,80 & 106,52 & 204,75 & 125,065 & 17,36 & \\
\hline 7 & 14 & \begin{tabular}{|l|}
91,124 \\
\end{tabular} & 148,95 & 100,61 & 103,72 & 141,468 & 111,190 & 102,952 & 139,886 & 118,87 & 103,9 & 150,24 & 113,385 & 23,68 & \\
\hline 9 & 14 & 118,609 & 174,28 & 127,59 & 119,80 & 154,17 & 126,206 & 108,402 & 164,47 & 119,77 & 109,75 & 158,26 & 118,312 & 18,15 & \\
\hline 11 & 14 & 91,122 & 128,23 & 97,02 & 102,91 & 141,91 & 109,377 & 103,874 & 152,083 & 114,42 & 107,41 & 170,00 & 120,240 & 19,12 & \\
\hline 13 & 14 & 114,370 & 188,15 & 126,82 & 108,40 & 141,71 & 119,091 & 109,749 & 195,307 & 123,55 & 110,80 & 157,31 & 125,283 & 21,51 & \\
\hline 15 & 13,5 & 102,909 & 172,27 & 115,99 & 91,11 & 141,73 & 101,637 & 103,706 & 149,161 & 114,28 & 102,98 & 147,21 & 110,849 & 20,05 & \\
\hline 17 & 13,5 & 92,599 & 131,17 & 98,675 & 114,4 & 174,062 & 125,755 & 109,79 & 142,813 & 116,99 & 118,62 & 164,1 & \begin{tabular}{|l|}
126,29 \\
\end{tabular} & 18,27 & \\
\hline 19 & 13,5 & 91,133 & 175,16 & 105,66 & 107,41 & 179,44 & 121,63 & 105,823 & 150,76 & 113,27 & 102,93 & 149 & \begin{tabular}{|l|}
113,39 \\
\end{tabular} & 18,88 & \\
\hline 22 & 13,5 & \begin{tabular}{|l|}
110,8 \\
\end{tabular} & 154,62 & 120,85 & 119,81 & 159,636 & 127,347 & 118,62 & 147,799 & 124 & 92,591 & 148,37 & 104,82 & 20,87 & \\
\hline 24 & 13,5 & 105,823 & 148,87 & 116,36 & 91,12 & 130,278 & 97,841 & 102,918 & 164,98 & 116,11 & 103,71 & 147,96 & 112,65 & 20,89 & \\
\hline 27 & 13,5 & \begin{tabular}{|l|}
108,4 \\
\end{tabular} & 144,04 & 117,45 & 105,82 & 148,196 & 114,051 & 91,118 & 142,167 & 102,94 & 103,71 & 158,61 & 114,28 & 21,56 & \\
\hline 29 & 13,5 & 102,98 & 172,31 & 117,73 & 107,41 & 150,133 & 115,653 & 107,11 & 148,707 & 115 & 106,53 & 136,35 & 121,58 & 25,04 & choveu \\
\hline
\end{tabular}


Tabela 30 - Planilha do ensaio piloto E3

\begin{tabular}{l|l|} 
ENSAIO & 3 \\
\hline
\end{tabular}

\begin{tabular}{|c|c|c|c|c|c|c|c|c|c|c|c|c|c|c|c|}
\hline 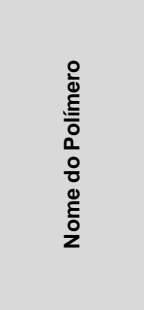 & $\begin{array}{l}\frac{\pi}{0} \\
\frac{\pi}{0} \\
0 \\
0 \\
0 \\
0 \\
0 \\
\frac{0}{0} \\
\frac{E}{0} \\
0 \\
0 \\
0 \\
0 \\
0 \\
0 \\
0\end{array}$ & $\begin{array}{l}\circ \\
\stackrel{0}{0} \\
0 \\
\circ \\
\frac{0}{0} \\
0 \\
0 \\
0 \\
0 \\
0 \\
0 \\
0 \\
0 \\
0 \\
0 \\
0 \\
0 \\
0 \\
0 \\
0 \\
0\end{array}$ & 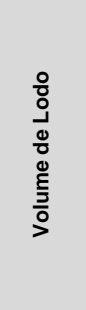 & $\begin{array}{l}\circ \\
0 \\
0 \\
0\end{array}$ & 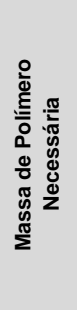 & 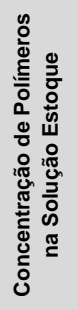 & 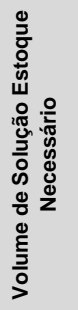 & 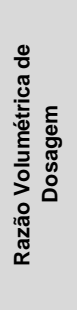 & 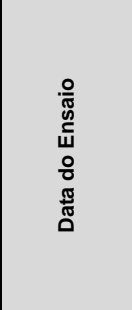 & 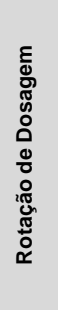 & 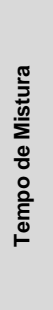 & 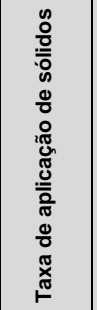 & 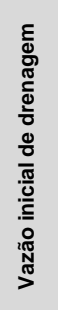 & 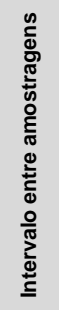 & 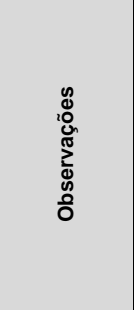 \\
\hline Marca - Nome & $\mathrm{g} / \mathrm{kg}$ & $g / L$ & litros & $\mathrm{Kg}$ & g & $g / L$ & litros & $\mathrm{ml} / \mathrm{ml}$ & dia/mês/ano & rpm & $\min$ & $\mathrm{KgST} / \mathrm{m}^{2}$ & $1 / \min$ & litros & \\
\hline $\begin{array}{c}\text { ASHLAND } \\
\text { 650TR }\end{array}$ & 3 & 26,46 & 700,00 & 18,52 & 55,56 & 2,001 & 27,77 & 0,040 & $17 / 09 / 2010$ & 150 & 11 & 14,70 & 50 & 40 & $\begin{array}{l}\text { manta úmida } \\
\text { com resíduos }\end{array}$ \\
\hline
\end{tabular}

\begin{tabular}{|c|c|c|c|c|c|c|}
\hline & 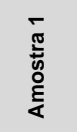 & 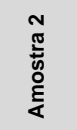 & 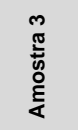 & 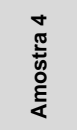 & 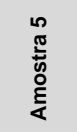 & 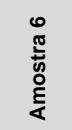 \\
\hline $\mathrm{DQO}(\mathrm{mg} / \mathrm{l})$ & 176,7 & 125,6 & 41,9 & 65,1 & 51,2 & 60,5 \\
\hline $\begin{array}{c}\text { Condutividade } \\
(\mu S)\end{array}$ & 1185,0 & 1160,0 & 1140,0 & 1138,0 & 1170,0 & 1172,0 \\
\hline $\mathrm{pH}$ & 6,97 & 6,75 & 6,57 & 6,51 & 6,53 & 6,53 \\
\hline Turbidez (UNT) & 5,2 & 4,7 & 5,1 & 4,2 & 4,0 & 3,8 \\
\hline
\end{tabular}

Acompanhamento da

\begin{tabular}{|c|c|c|c|c|c|c|c|c|c|c|c|c|c|c|c|}
\hline & 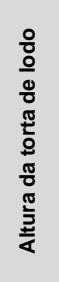 & 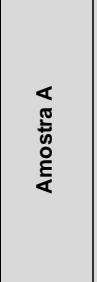 & 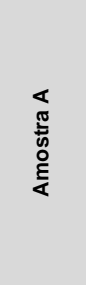 & 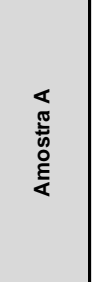 & 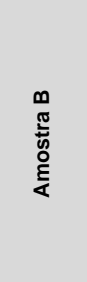 & 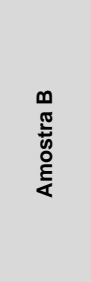 & 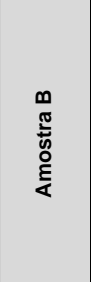 & 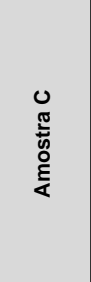 & 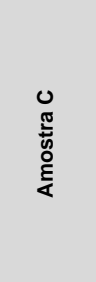 & $\begin{array}{l}0 \\
\frac{\pi}{2} \\
\text { के } \\
\stackrel{0}{<}\end{array}$ & 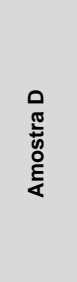 & 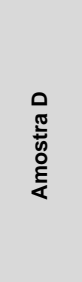 & 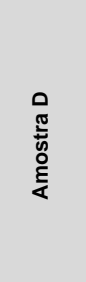 & 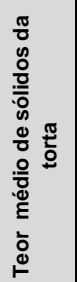 & 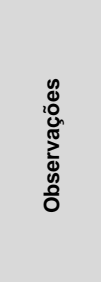 \\
\hline Dias corridos & $\mathrm{cm}$ & $\mathrm{PO}(\mathrm{g})$ & $\mathrm{P} 1(\mathrm{~g})$ & P2 (g) & $\mathrm{PO}(\mathrm{g})$ & $\mathrm{P} 1 \mathrm{~g})$ & P2 (g) & $\mathrm{PO}(\mathrm{g})$ & $P 1(\mathrm{~g})$ & P2 (g) & $\mathrm{PO}(\mathrm{g})$ & $P 1(g)$ & P2 (g) & TS (\%) & \\
\hline 0 & 45 & & & & & & & & & & & & & 2,65 & \\
\hline 1 & 11 & \begin{tabular}{|l|}
118,615 \\
\end{tabular} & 159,45 & 124,88 & 92,59 & 139,11 & 99,145 & 119,812 & 153,79 & 124,42 & 114,38 & 154,17 & 119,72 & 14,14 & \\
\hline 3 & 11 & \begin{tabular}{|l|}
102,934 \\
\end{tabular} & 178,94 & 113,37 & 109,75 & 198,51 & 123,783 & 103,874 & 203,541 & 117,68 & 110,80 & 200,29 & 124,463 & 14,67 & Choveu \\
\hline 5 & 11 & \begin{tabular}{|l|}
103,715 \\
\end{tabular} & 182,23 & 117,15 & 118,62 & 204,11 & 131,004 & 91,119 & 188,928 & 107,48 & 105,82 & 180,3 & 116,519 & 15,72 & \\
\hline 7 & 11 & \begin{tabular}{|l|}
102,928 \\
\end{tabular} & 179,17 & 116,72 & 106,52 & 185,523 & 118,247 & 107,412 & 160,428 & 117,65 & 102,99 & 185,51 & 115,694 & 16,66 & \\
\hline 10 & 11 & \begin{tabular}{|l|}
103,911 \\
\end{tabular} & 190,76 & 116,87 & 109,78 & 202,29 & 124,973 & 107,120 & 197,803 & 120,67 & 110,80 & 198,07 & 125,272 & 15,72 & \\
\hline 12 & 11 & \begin{tabular}{|l|}
109,786 \\
\end{tabular} & 183,91 & 122,30 & 118,62 & 195,44 & 130,383 & 103,907 & 198,781 & 119,58 & 120,02 & 196,42 & 131,802 & 16,05 & \\
\hline 14 & 10,5 & \begin{tabular}{|l|}
105,961 \\
\end{tabular} & 186,72 & 118,31 & 102,99 & 173,10 & 115,308 & 91,309 & 180,651 & 105,16 & & & & 16,04 & \\
\hline 15 & 10,5 & \begin{tabular}{|l|}
103,039 \\
\end{tabular} & 185,78 & 115,21 & 110,9 & 180,069 & 122,962 & 108,568 & 201,35 & 122,87 & 103,9 & 203,4 & 120,46 & 16,01 & \\
\hline 17 & 10,5 & 118,62 & 201,49 & 134,051 & 105,876 & 203,806 & 120,53 & 102,984 & 198,627 & 118,56 & 119,9 & 197,89 & 131,954 & 16,28 & \\
\hline 19 & 10,5 & 103,02 & 187,914 & 117,72 & 114,48 & 186,66 & 125,624 & 103,890 & 170,538 & 113,75 & 110,9 & 177,75 & 123,310 & 16,56 & \\
\hline 21 & 10 & 109,77 & 183,48 & 120,73 & 92,701 & 149,202 & 102,81 & 118,62 & 187,679 & 130,81 & 105,87 & 194,64 & 118,05 & 15,77 & \\
\hline 24 & 10 & 103,746 & 196,76 & 118,66 & 92,66 & 158,379 & 105,96 & 106,628 & 197,47 & 120,91 & 114,46 & 177,18 & 126,11 & 17,34 & \\
\hline 26 & 10 & 105,84 & 168,63 & 116,3 & 118,72 & 186,035 & 131,3 & 104,02 & 158,977 & 115,52 & 92,656 & 162,84 & 104,99 & 18,36 & cobertura \\
\hline 28 & 10 & 106,62 & 170,34 & 120,21 & 107,3 & 175,71 & 119,24 & 119,96 & 171,961 & 131,01 & 92,647 & 153,74 & 103,12 & 19,19 & \\
\hline 31 & 10 & 109,86 & 192,37 & 131,14 & 111,07 & 202,47 & 128,43 & 118,95 & 186,12 & 134,94 & 104,02 & 172,34 & 117 & 21,85 & \\
\hline
\end{tabular}


Tabela 31 - Planilha do ensaio piloto E4

\begin{tabular}{|l|l|} 
ENSAIO & 4 \\
\hline
\end{tabular}

\begin{tabular}{|c|c|c|c|c|c|c|c|c|c|c|c|c|c|c|c|}
\hline 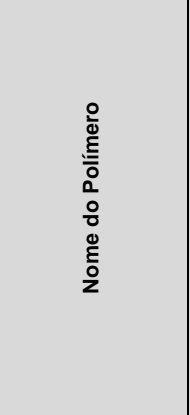 & 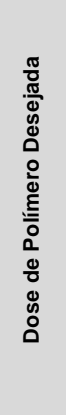 & 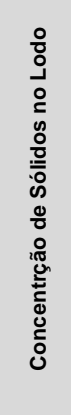 & 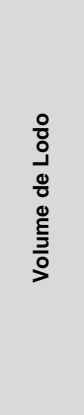 & 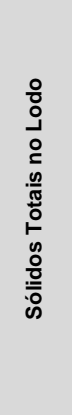 & 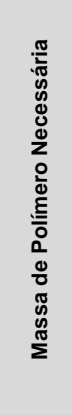 & 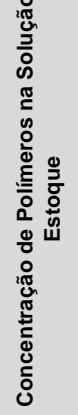 & 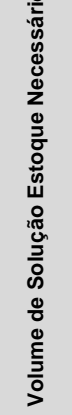 & 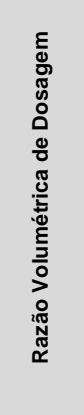 & 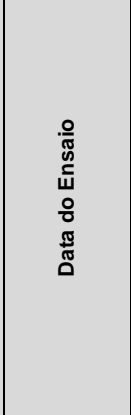 & 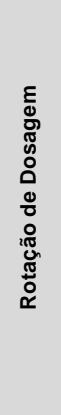 & 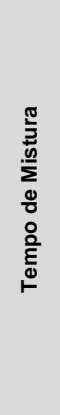 & 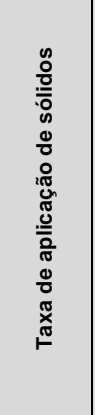 & 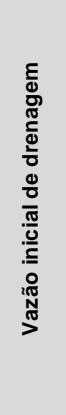 & 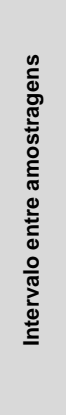 & 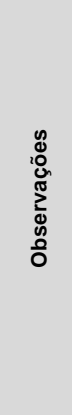 \\
\hline Marca - Nome & $\mathrm{g} / \mathrm{kg}$ & $g / L$ & litros & $\mathrm{Kg}$ & $\mathrm{g}$ & $\mathrm{g} / \mathrm{L}$ & litros & $\mathrm{ml} / \mathrm{ml}$ & dia/mês/ano & $\mathrm{rpm}$ & $\min$ & $\underset{2}{\mathrm{KgST} / \mathrm{m}}$ & $1 / \min$ & litros & \\
\hline ASHLAND 650TR & 4 & 26,83 & 700,00 & 18,78 & 75,14 & 2,059 & 36,50 & 0,052 & $01 / 10 / 2010$ & 150 & 14 & \begin{tabular}{|l|}
14,91 \\
\end{tabular} & 60 & 50 & manta \\
\hline
\end{tabular}

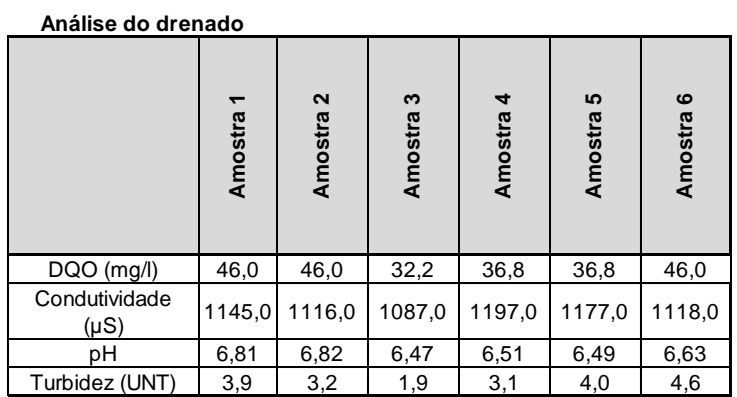

Acompanhamento da

torta

\begin{tabular}{|c|c|c|c|c|c|c|c|c|c|c|c|c|c|c|c|}
\hline & 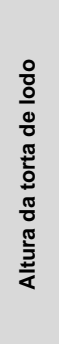 & 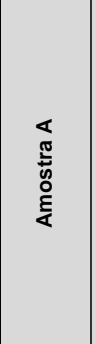 & 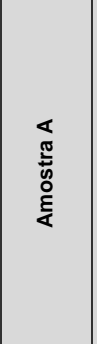 & 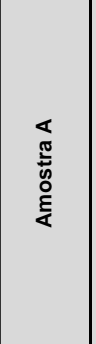 & 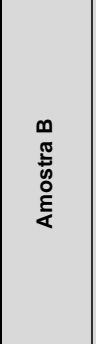 & 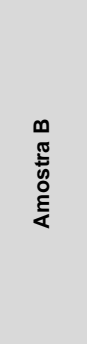 & 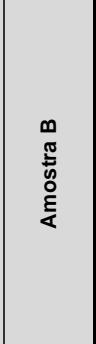 & 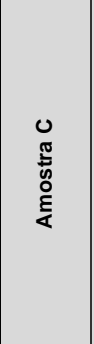 & 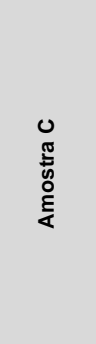 & 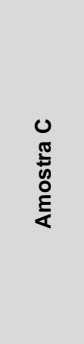 & 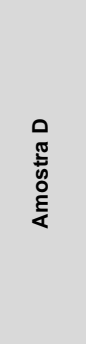 & 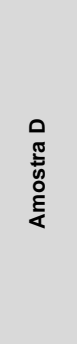 & 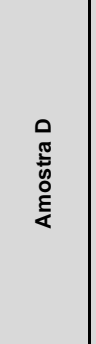 & 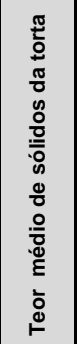 & 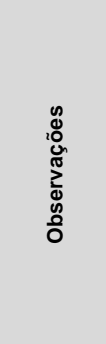 \\
\hline Dias corridos & $\mathrm{cm}$ & $\mathrm{PO}(\mathrm{g})$ & $\mathrm{P} 1$ (g) & P2 (g) & P0 (g) & P1 (g) & P2 (g) & PO (g) & P1 (g) & P2 (g) & PO (g) & P1 (g) & P2 (g) & TS (\%) & \\
\hline 0 & 45 & & & & & & & & & & & & & 2,68 & \\
\hline 1 & 11 & 107,58 & 203,88 & 121,894 & 107,199 & 196,78 & 119,96 & 106,692 & 193,96 & 119,69 & 114,52 & 185,24 & 124,493 & 14,56 & \\
\hline 3 & 10,5 & 109,76 & 188,11 & \begin{tabular}{|l|}
121,86 \\
\end{tabular} & \begin{tabular}{|l|}
92,693 \\
\end{tabular} & 176,92 & 104,61 & 91,201 & 163,243 & 102,02 & 103,91 & 196,34 & 117,35 & 14,76 & \\
\hline 5 & 10 & 108,52 & 177,430 & 118,73 & 107,19 & 167,82 & 117,956 & 107,553 & 186,075 & 119,30 & 108,65 & 171,68 & \begin{tabular}{|l|}
118,440 \\
\end{tabular} & 15,69 & \\
\hline 7 & 10 & \begin{tabular}{|l|}
91,177 \\
\end{tabular} & \begin{tabular}{|l|}
175,09 \\
\end{tabular} & 103,73 & 102,98 & 186,51 & 117,555 & 103,770 & 191,919 & 117,21 & 119,87 & 194,91 & \begin{tabular}{|l|}
133,620 \\
\end{tabular} & \begin{tabular}{|l|}
16,43 \\
\end{tabular} & \\
\hline 10 & 10 & \begin{tabular}{|l|}
108,491 \\
\end{tabular} & 193,33 & 122,18 & 102,99 & 166,99 & 116,297 & 110,847 & 197,946 & 124,47 & 105,85 & 174,02 & \begin{tabular}{|l|}
119,965 \\
\end{tabular} & 18,00 & \\
\hline 12 & 10 & \begin{tabular}{|l|}
91,977 \\
\end{tabular} & 177,21 & 118,54 & 103,08 & 200,00 & 119,106 & 109,899 & 188,684 & 125,79 & 103,75 & 166,36 & \begin{tabular}{|l|}
113,511 \\
\end{tabular} & 21,10 & cobertura \\
\hline 14 & 10 & \begin{tabular}{|l|}
107,642 \\
\end{tabular} & 184,17 & 123,51 & 108,48 & 180,52 & 120,644 & 114,454 & 186,578 & 129,65 & 104,00 & 191,54 & \begin{tabular}{|l|}
118,481 \\
\end{tabular} & 18,72 & \\
\hline 17 & 10 & \begin{tabular}{|l|}
119,973 \\
\end{tabular} & 201,5 & 135,13 & 107,30 & 189,54 & 126,172 & 106,611 & 172,576 & 120,77 & 103,97 & 177,18 & 116,563 & 20,06 & \\
\hline 19 & 10 & \begin{tabular}{|l|}
91,653 \\
\end{tabular} & 146,07 & 104,98 & 103,92 & 189,82 & 119,58 & 106,1 & 167,88 & 119,61 & 109,85 & 180,62 & 122,45 & 20,19 & \\
\hline 22 & 9 & \begin{tabular}{|l|}
104,039 \\
\end{tabular} & 163,97 & 116,16 & 118,86 & 172,88 & 133,82 & 111,001 & 177,54 & 123,99 & 106,67 & 165,13 & 122,58 & 23,42 & \\
\hline 24 & 9 & \begin{tabular}{|l|}
105,9 \\
\end{tabular} & 160,37 & 117,77 & 92,635 & 153,85 & 107,06 & 114,44 & 186,462 & 128,15 & 108,46 & 167,93 & 127,04 & 23,70 & \\
\hline 26 & 9 & \begin{tabular}{|l|}
103,067 \\
\end{tabular} & 173,48 & 118,00 & 109,83 & 169,46 & 128,6 & 107,180 & 158,29 & 117,85 & 104,03 & 152,32 & 122,61 & 27,43 & \\
\hline 28 & 9 & 110,99 & 171,1 & 125,51 & 106,65 & 133,2 & 120,89 & \begin{tabular}{ll|}
107,56 \\
\end{tabular} & 157,871 & 123,74 & 118,85 & 186,06 & 132,9 & 28,89 & \\
\hline 30 & 9 & 109,83 & 153,9 & 122,93 & 103,09 & 149,3 & 113,68 & 107,19 & 137,378 & 128,39 & 103,83 & 150,13 & 121,93 & 37,77 & \\
\hline
\end{tabular}


Tabela 32 - Planilha do ensaio piloto E5

\begin{tabular}{|c|c|c|c|c|c|c|c|c|c|c|c|c|c|c|c|}
\hline \multicolumn{16}{|c|}{ Condicionamento } \\
\hline 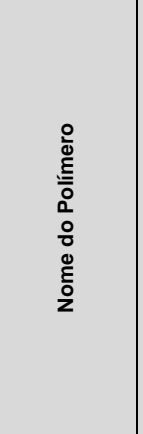 & 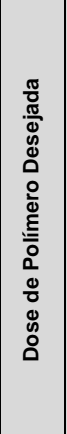 & 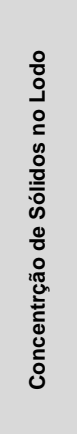 & 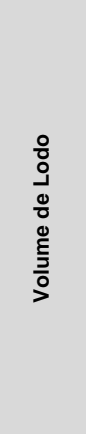 & 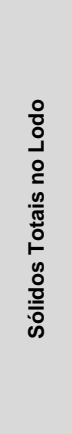 & 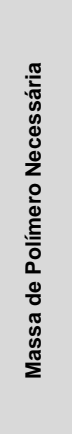 & 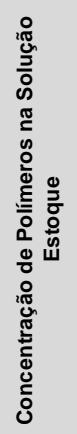 & 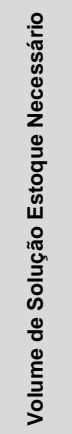 & 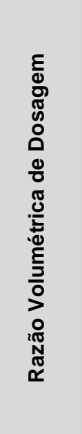 & 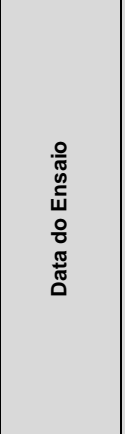 & 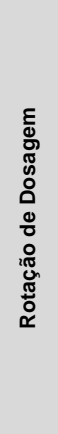 & 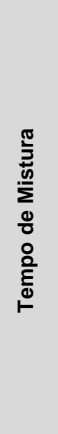 & 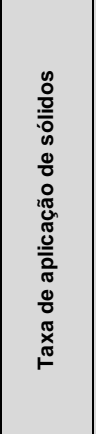 & 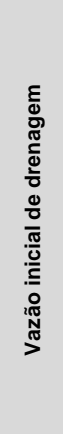 & 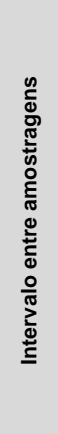 & 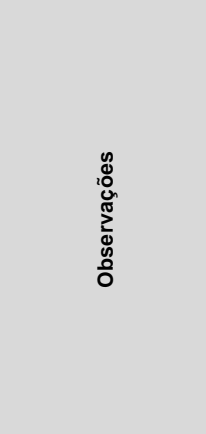 \\
\hline Marca - Nome & $\mathrm{g} / \mathrm{kg}$ & $g / L$ & litros & $\mathrm{Kg}$ & g & $g / L$ & litros & $\mathrm{ml} / \mathrm{ml}$ & $\begin{array}{c}\text { dia/mês/an } \\
\text { o }\end{array}$ & rpm & $\min$ & $\begin{array}{c}\mathrm{KgST} / \mathrm{m} \\
2\end{array}$ & $1 / \min$ & litros & \\
\hline $\begin{array}{l}\text { ASHLAND } \\
\text { 650TR }\end{array}$ & 5 & 27,90 & 700,00 & 19,53 & 97,64 & 1,992 & 49,02 & 0,070 & $19 / 10 / 2010$ & 100 & 14 & 15,50 & 60 & 50 & $\begin{array}{l}\text { manta umida e motor } \\
\text { novo }\end{array}$ \\
\hline
\end{tabular}

\begin{tabular}{|c|c|c|c|c|c|c|}
\hline \multicolumn{7}{|c|}{ Análise do } \\
\hline & 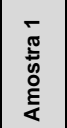 & 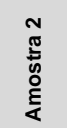 & 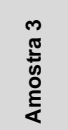 & 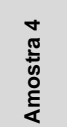 & 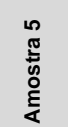 & 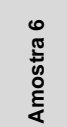 \\
\hline $\mathrm{DQO}(\mathrm{mg} / \mathrm{l})$ & 132,0 & 120,0 & 132,0 & 128,0 & 120,0 & 120,0 \\
\hline $\begin{array}{c}\text { Condutividad } \\
\text { e }(\mu \mathrm{S})\end{array}$ & 953,0 & 969,0 & 972,0 & 978,0 & 982,0 & 985,0 \\
\hline $\mathrm{pH}$ & 6,94 & 6,73 & 6,64 & 6,80 & 6,64 & 6,70 \\
\hline $\begin{array}{c}\text { Turbidez } \\
\text { (UNT) }\end{array}$ & 12,8 & 6,4 & 7,1 & 5,1 & 6,6 & 4,2 \\
\hline
\end{tabular}

Acompanhamento da torta

\begin{tabular}{|c|c|c|c|c|c|c|c|c|c|c|c|c|c|c|c|}
\hline & 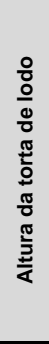 & 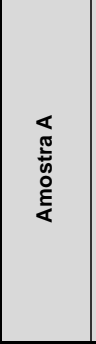 & 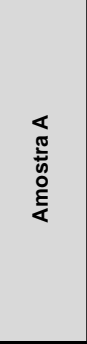 & 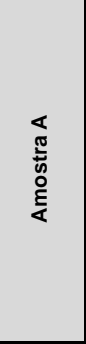 & 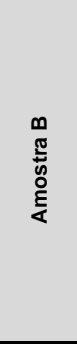 & 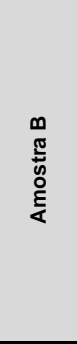 & 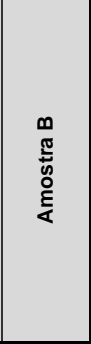 & 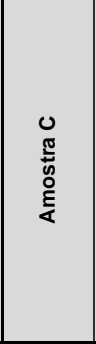 & 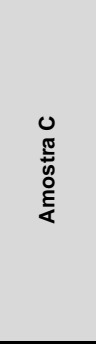 & 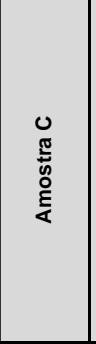 & 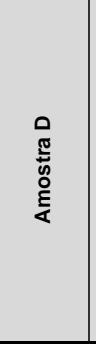 & 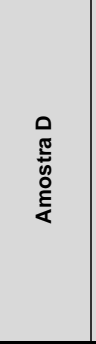 & 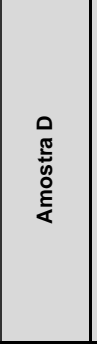 & 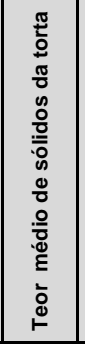 & 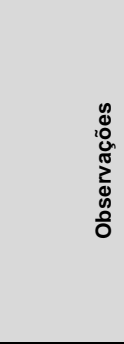 \\
\hline Dias corridos & $\mathrm{cm}$ & $\mathrm{PO}(\mathrm{g})$ & $\mathrm{P} 1$ (g) & P2 (g) & P0 (g) & $\mathrm{P} 1 \mathrm{~g})$ & P2 (g) & PO (g) & $\mathrm{P} 1$ (g) & P2 (g) & P0 (g) & $\mathrm{P} 1$ (g) & P2 (g) & TS (\%) & \\
\hline 0 & 45 & & & & & & & & & & & & & 2,79 & \\
\hline 1 & 15 & \begin{tabular}{|l|}
103,158 \\
\end{tabular} & 196,65 & 116,86 & 103,18 & 196,77 & 115,685 & 107,276 & 195,908 & \begin{tabular}{|l|}
120,062 \\
\end{tabular} & \begin{tabular}{|l|}
119,941 \\
\end{tabular} & \begin{tabular}{|l|}
200,196 \\
\end{tabular} & 130,760 & 14,00 & \\
\hline 4 & 15 & 114,434 & 190,9 & 125,44 & 92,66 & 197,75 & 110,653 & 107,578 & 200,746 & \begin{tabular}{|l|}
120,73 \\
\end{tabular} & \begin{tabular}{|l|}
108,46 \\
\end{tabular} & \begin{tabular}{|l|}
173,51 \\
\end{tabular} & 121,380 & 16,21 & \\
\hline 6 & 14 & 110,978 & 195,93 & 123,42 & 107,56 & 182,13 & 122,802 & 106,645 & 185,602 & 122,10 & 118,83 & 202,28 & 130,924 & 17,16 & \\
\hline 8 & 12 & 103,075 & 183,06 & 119,57 & 119,9 & 176,51 & 133,350 & 103,831 & 202,448 & 119,41 & 91,261 & 175,17 & \begin{tabular}{|l|}
104,467 \\
\end{tabular} & 18,40 & \\
\hline 10 & 12 & \begin{tabular}{|l|}
92,853 \\
\end{tabular} & 164,33 & 103,86 & 114,72 & 199,60 & 127,814 & 106,117 & 157,934 & 118,52 & 108,71 & 183,83 & 125,095 & 18,67 & \\
\hline 12 & 12 & 91,253 & 137,46 & 102,39 & 119,90 & 184,24 & 137,374 & 103,070 & 185,002 & 116,83 & 104,04 & 167,58 & 115,197 & 20,91 & \\
\hline 15 & 11 & 119,877 & 183,38 & 134,53 & 104,00 & 181,77 & 117,015 & 103,056 & 156,374 & 116,17 & 103,81 & 189,12 & 117,728 & 19,54 & \\
\hline 17 & 11 & 103,053 & 157,42 & 117,41 & 103,81 & 180,68 & 117,453 & 109,825 & 176,36 & 121,76 & 106,7 & 182,12 & 126,103 & 21,72 & \\
\hline 20 & 11 & 106,72 & 162,22 & 121,57 & 103,05 & 174,85 & 116,14 & 110,92 & 182,841 & 124,07 & 107,25 & 169,47 & 123,33 & 21,87 & \\
\hline 22 & 10 & 103,057 & 143,46 & 116,23 & 107,71 & 191,65 & 122,01 & 106,149 & 175,525 & 120,51 & 108,73 & 159,55 & 122,7 & 22,82 & \\
\hline 24 & 10 & 92,792 & 148,28 & 103,24 & 103,97 & 169,97 & 121,81 & 91,351 & 146,533 & 101,92 & 106,71 & 153,96 & 121,46 & 23,94 & \\
\hline 28 & 9 & 103,967 & 153,5 & 118,99 & 119,85 & 184,45 & 132,64 & 108,693 & 187,50 & 123,85 & 105,93 & 152,43 & 120,52 & 24,04 & \\
\hline 30 & 9 & 108,63 & 184,27 & 123,46 & 103,02 & 168,4 & 120,72 & 113,02 & 180,955 & 119,94 & 107,2 & 164,95 & 126,71 & 22,11 & \\
\hline 33 & 9 & 106,78 & 156,53 & 124,24 & 92,828 & 143,34 & 103,34 & 91,368 & 145,445 & 109,5 & 104,01 & 167,98 & \begin{tabular}{|l|}
117,74 \\
\end{tabular} & 27,41 & \\
\hline
\end{tabular}


Tabela 33 - Planilha do ensaio piloto E6

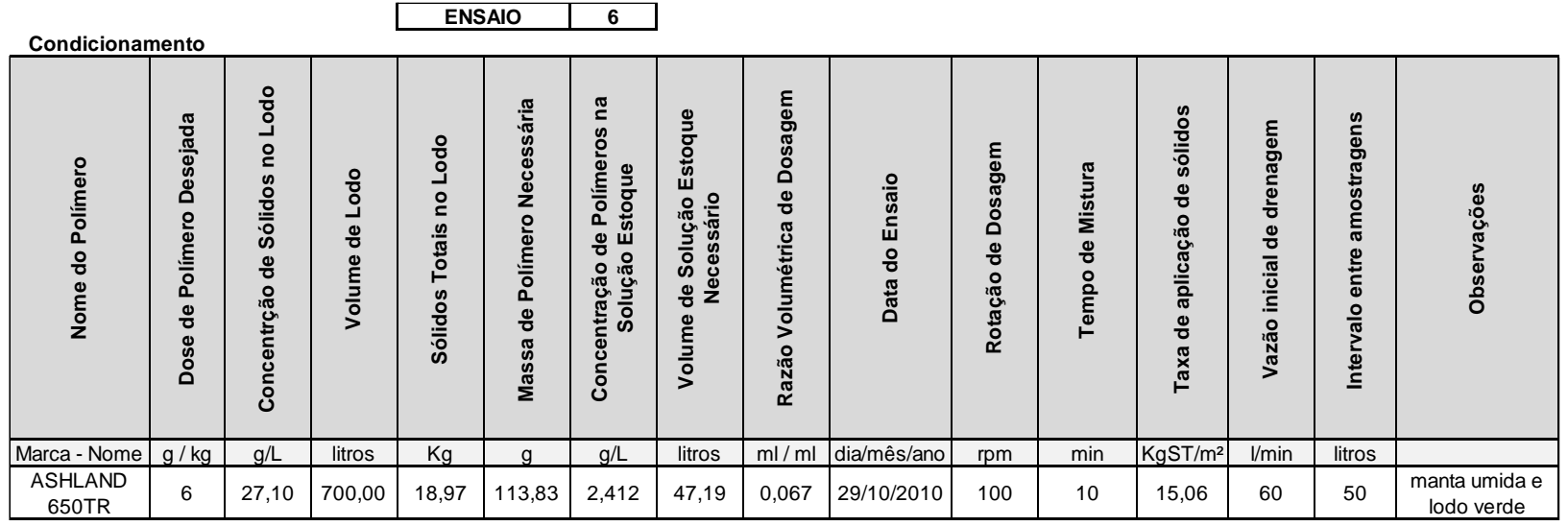

\begin{tabular}{|c|c|c|c|c|c|c|}
\hline & 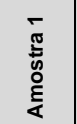 & 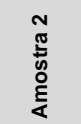 & 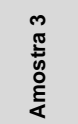 & 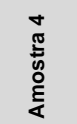 & 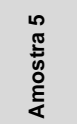 & 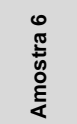 \\
\hline $\mathrm{DQO}(\mathrm{mg} / \mathrm{l})$ & 203,9 & 200,0 & 164,7 & 168,6 & 176,5 & 196,1 \\
\hline $\begin{array}{c}\text { Condutividade } \\
(\mu \mathrm{S})\end{array}$ & 1211,0 & 1266,0 & 1234,0 & 1195,0 & 1151,0 & 1111,0 \\
\hline $\mathrm{pH}$ & 6,14 & 6,34 & 6,23 & 6,16 & 6,16 & 6,15 \\
\hline $\begin{array}{l}\text { Turbidez } \\
\text { (UNT) }\end{array}$ & 20,3 & 24,6 & 14,8 & 18,7 & 15,1 & 14,2 \\
\hline
\end{tabular}

Acompanhamento da torta

\begin{tabular}{|c|c|c|c|c|c|c|c|c|c|c|c|c|c|c|c|}
\hline & $\begin{array}{l}\text { 융 } \\
\text { 응 } \\
\frac{0}{0} \\
\frac{\pi}{0} \\
\frac{0}{0} \\
\frac{0}{0} \\
\frac{\pi}{0} \\
\frac{\pi}{3} \\
\frac{3}{4}\end{array}$ & 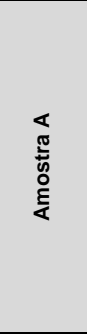 & 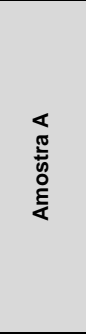 & 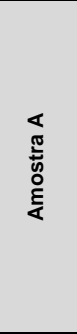 & 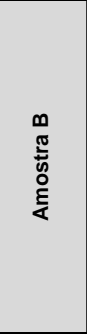 & 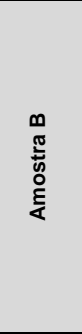 & 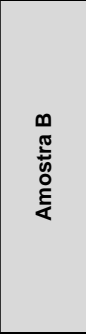 & $\begin{array}{l}0 \\
\frac{\pi}{2} \\
\text { के } \\
\stackrel{2}{\varepsilon}\end{array}$ & 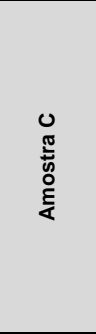 & 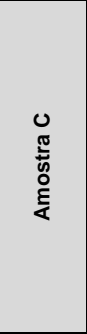 & 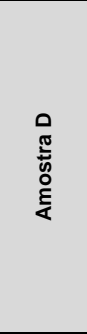 & 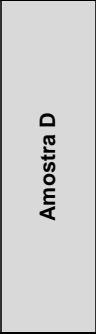 & 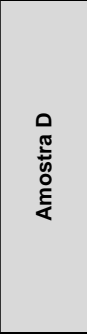 & 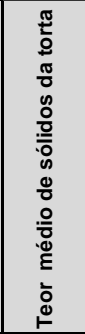 & 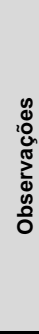 \\
\hline Dias corridos & $\mathrm{cm}$ & $P 0(g)$ & $P 1(g)$ & P2 (g) & $P 0(g)$ & $P 1(g)$ & P2 (g) & $P 0(g)$ & $P 1(g)$ & P2 (g) & $\mathrm{PO}(\mathrm{g})$ & $P 1(g)$ & P2 (g) & TS (\%) & \\
\hline 0 & 45 & & & & & & & & & & & & & 2,71 & \\
\hline 2 & 15 & 114,737 & 202,71 & 128,70 & 110,97 & 166,25 & 120,109 & 92,843 & 202,21 & 109,66 & 106,648 & 195,334 & 129,22 & 16,13 & \\
\hline 5 & 14 & 110,919 & 174,88 & 122,38 & 109,83 & 183,34 & 120,941 & \begin{tabular}{|l|}
114,520 \\
\end{tabular} & 187,075 & 127,81 & 92,69 & 176,17 & 105,523 & 16,59 & \\
\hline 7 & 14 & 92,679 & 164,18 & 108,23 & 103,98 & 197,36 & 118,084 & \begin{tabular}{|l|}
110,917 \\
\end{tabular} & 192,472 & 126,40 & 91,294 & 191,321 & 106,540 & 17,43 & \\
\hline 10 & 12 & 91,295 & 157 & 101,20 & 92,68 & 154,25 & 105,33 & \begin{tabular}{|l|}
103,996 \\
\end{tabular} & 194,02 & 118 & 103,114 & 188,437 & 120,23 & 17,73 & \\
\hline 12 & 11 & 119,016 & 175,9 & 116,23 & 114,47 & 171,57 & 127,095 & \begin{tabular}{|l|}
119,877 \\
\end{tabular} & 156,547 & 136,45 & 103,99 & 165,33 & 117,120 & 18,65 & \\
\hline 14 & 10 & 109,835 & 197,86 & 123,49 & 107,23 & 168,90 & 121,831 & 110,899 & 171,58 & 120,24 & 103,07 & 170,36 & 117,955 & 18,90 & \\
\hline 18 & 9 & 103,040 & 163,08 & 112,77 & 118,88 & 188,03 & 131,976 & \begin{tabular}{|l|}
114,431 \\
\end{tabular} & 187,199 & 126,75 & 107,62 & 178,29 & 124,051 & 18,92 & \\
\hline 20 & 9 & 107,604 & 170,73 & 118,67 & 110,87 & 158,09 & 122,918 & \begin{tabular}{|l|}
105,924 \\
\end{tabular} & 180,867 & 119,80 & 114,473 & 173,023 & 129,825 & 21,47 & \\
\hline 23 & 9 & 105,92 & 168,21 & 121,39 & 103,01 & 165,93 & 115,64 & \begin{tabular}{|l|}
107,2 \\
\end{tabular} & 167,46 & 125,91 & 114,429 & 196,383 & 130,62 & 23,56 & \\
\hline 26 & 9 & 106,732 & 141,29 & 117,38 & 92,80 & 163,52 & 106,45 & \begin{tabular}{|l|}
103,081 \\
\end{tabular} & 159,86 & 119,5 & 103,012 & 161,804 & 114,57 & 23,67 & \\
\hline 28 & 9 & 110,86 & 187,52 & 127,01 & 119,85 & 185,83 & 138,17 & \begin{tabular}{|l|}
107,19 \\
\end{tabular} & 157,612 & 117,69 & 114,422 & 145,899 & 124,54 & 24,53 & \\
\hline 31 & 9 & 108,557 & 151,59 & 125,35 & 109,85 & 186,76 & 126,46 & \begin{tabular}{|l|}
107,546 \\
\end{tabular} & 143,87 & 121,04 & 105,922 & 174,151 & 119,72 & 27,03 & \\
\hline
\end{tabular}


Tabela 34 - Planilha do ensaio piloto E7

\begin{tabular}{l|l|} 
ENSAIO & 7 \\
\hline
\end{tabular}

\begin{tabular}{|c|c|c|c|c|c|c|c|c|c|c|c|c|c|c|c|}
\hline 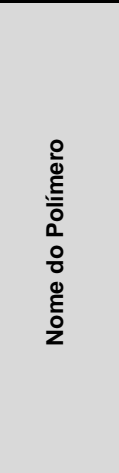 & 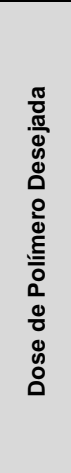 & 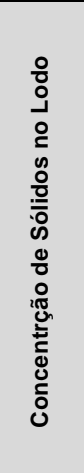 & 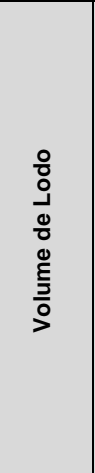 & 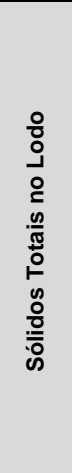 & 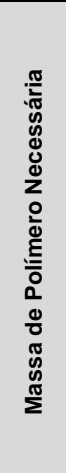 & 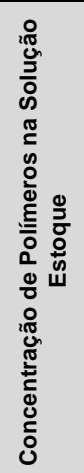 & 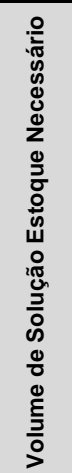 & 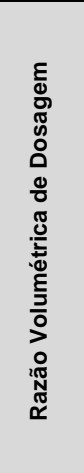 & 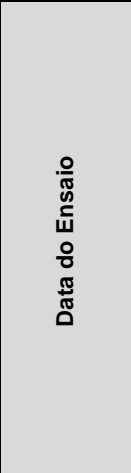 & 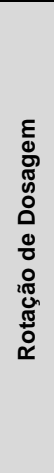 & 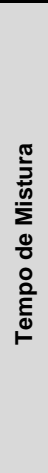 & 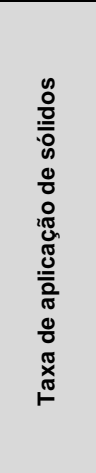 & 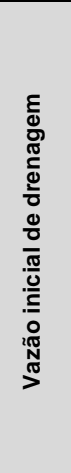 & 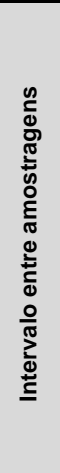 & 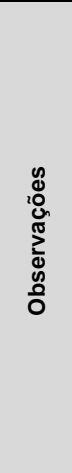 \\
\hline $\begin{array}{l}\text { Marca - } \\
\text { Nome }\end{array}$ & $\mathrm{g} / \mathrm{kg}$ & $\mathrm{g} / \mathrm{L}$ & litros & $\mathrm{Kg}$ & g & $\mathrm{g} / \mathrm{L}$ & litros & $\mathrm{ml} / \mathrm{ml}$ & $\begin{array}{c}\text { dia/mês/an } \\
\text { o }\end{array}$ & $\mathrm{rpm}$ & $\min$ & $\begin{array}{c}\mathrm{KgST} / \mathrm{m} \\
2\end{array}$ & $1 / \mathrm{min}$ & litros & \\
\hline $\begin{array}{l}\text { ASHLAND } \\
\text { 650TR }\end{array}$ & 0 & 27,63 & 700,00 & 19,34 & 0,00 & 0,000 & 0,00 & - & $04 / 11 / 2010$ & - & - & 15,35 & 6 & 10 & $\begin{array}{l}\text { manta } \\
\text { umida }\end{array}$ \\
\hline
\end{tabular}

\begin{tabular}{|c|c|c|c|c|c|c|}
\hline & 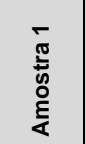 & 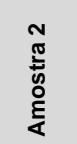 & 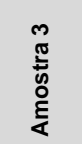 & 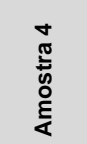 & 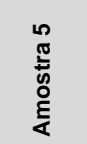 & 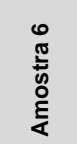 \\
\hline $\mathrm{DQO}(\mathrm{mg} / \mathrm{l})$ & 384,3 & 349,0 & 258,8 & 266,7 & 294,1 & 313,7 \\
\hline $\begin{array}{c}\text { Condutividad } \\
e(\mu \mathrm{S})\end{array}$ & 1102,0 & 960,0 & 1084,0 & 1137,0 & 1182,0 & 1203,0 \\
\hline $\mathrm{pH}$ & 6,84 & 6,67 & 7,26 & 6,94 & 6,79 & 6,61 \\
\hline $\begin{array}{c}\text { Turbidez } \\
\text { (UNT) }\end{array}$ & 441,0 & 116,0 & 80,4 & 68,3 & 78,3 & 68,9 \\
\hline
\end{tabular}

Acompanhamento

\begin{tabular}{|c|c|c|c|c|c|c|c|c|c|c|c|c|c|c|c|}
\hline & $\begin{array}{l}\circ \\
\frac{0}{0} \\
\frac{0}{0} \\
\frac{0}{0} \\
\frac{\pi}{5} \\
\frac{0}{0} \\
\frac{\pi}{8} \\
\frac{\pi}{5} \\
\frac{3}{4}\end{array}$ & 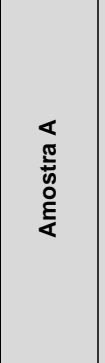 & 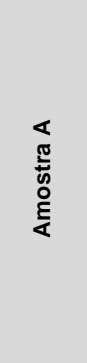 & $\begin{array}{l}\frac{1}{\pi} \\
\frac{\pi}{2} \\
\frac{1}{0} \\
\frac{E}{4}\end{array}$ & 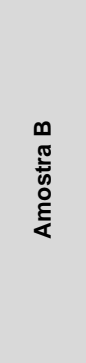 & 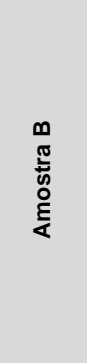 & 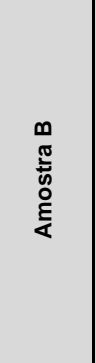 & 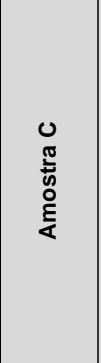 & 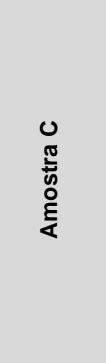 & 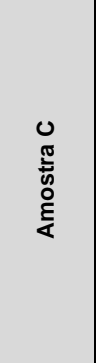 & 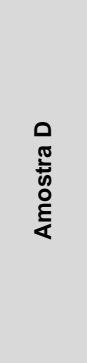 & 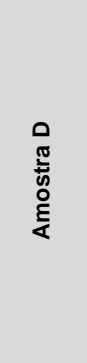 & 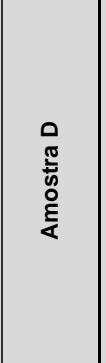 & 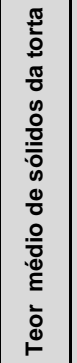 & 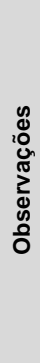 \\
\hline Dias corridos & $\mathrm{cm}$ & $\mathrm{PO}(\mathrm{g})$ & P1 (g) & P2 (g) & PO (g) & P1 (g) & P2 (g) & PO (g) & P1 (g) & P2 (g) & PO (g) & P1 (g) & P2 (g) & $\begin{array}{l}\text { TS } \\
(\%)\end{array}$ & \\
\hline 0 & 45 & & & & & & & & & & & & & 2,76 & \\
\hline 1 & 15 & 113,499 & 161,77 & 122,45 & 119,88 & 200,76 & 131,550 & \begin{tabular}{|l|}
103,875 \\
\end{tabular} & 185,21 & 115,03 & 107,27 & 184,12 & 118,42 & 15,97 & \\
\hline 4 & 14 & 103,840 & 184,22 & 115,85 & 109,83 & 199,79 & 125,057 & 119,922 & 193,907 & 131,76 & 114,50 & 182,08 & 125,594 & 16,09 & \\
\hline 6 & 14 & 107,244 & 187,86 & 121,10 & 110,90 & 196,35 & 122,048 & \begin{tabular}{|l|}
103,059 \\
\end{tabular} & 198,218 & 120,15 & 109,85 & 187,96 & 126,047 & 17,18 & \\
\hline 8 & 14 & 103,046 & 179,23 & 114,62 & 107,66 & 174,62 & 122,547 & 114,463 & 203,45 & 127,92 & 118,99 & 196,14 & 133,793 & 17,69 & \\
\hline 12 & 13 & 103,033 & 178,61 & 118,87 & 110,87 & 191,26 & 123,352 & 109,815 & 201,825 & 124,06 & 107,22 & 183,15 & 123,770 & 18,25 & \\
\hline 14 & 12 & 109,820 & 181,46 & 122,13 & 118,86 & 156,98 & 130,757 & \begin{tabular}{|l|}
119,851 \\
\end{tabular} & 192,877 & 131,64 & 103,96 & 179,07 & 121,708 & 20,84 & \\
\hline 17 & 12 & 119,861 & 198,47 & 137,42 & 110,87 & 201,55 & 132,333 & 118,814 & 195,239 & 135,75 & 103,96 & 186,23 & 122,706 & 22,77 & \\
\hline 20 & 11 & 105,920 & 185,08 & 120,90 & 107,58 & 166,13 & 125,486 & \begin{tabular}{|l|}
108,604 \\
\end{tabular} & 132,332 & 112,56 & 109,87 & 165,93 & 122,065 & 22,55 & \\
\hline 22 & 10 & 105,92 & 160,04 & 116,53 & 107,57 & 168,02 & 126,54 & 109,86 & 169,996 & 127,5 & 108,58 & 162,2 & 118,77 & 25,15 & \\
\hline 25 & 10 & 114,416 & 180,23 & 133,03 & 118,85 & 167,74 & 122,19 & 119,848 & 172,86 & 136,11 & 107,18 & 167,8 & 119,27 & 22,03 & \\
\hline 28 & 10 & 106,65 & 197,77 & 140,1 & 110,86 & 193,25 & 127,8 & 119,84 & 186,821 & 140,76 & 114,41 & 175,31 & 127,25 & 27,92 & \\
\hline 30 & 10 & 103,931 & 160,5 & 116,26 & 105,91 & 162,52 & 125,27 & 118,756 & 180,97 & 131,91 & 91,311 & 149,61 & 108,52 & 26,55 & \\
\hline 32 & 10 & 103 & 170,96 & 116,31 & 103,89 & 169,42 & 125,7 & 110,85 & 153,417 & 123,42 & 106,64 & 164,97 & 131,99 & 31,17 & \\
\hline
\end{tabular}


Tabela 35 - Planilha do ensaio piloto E8

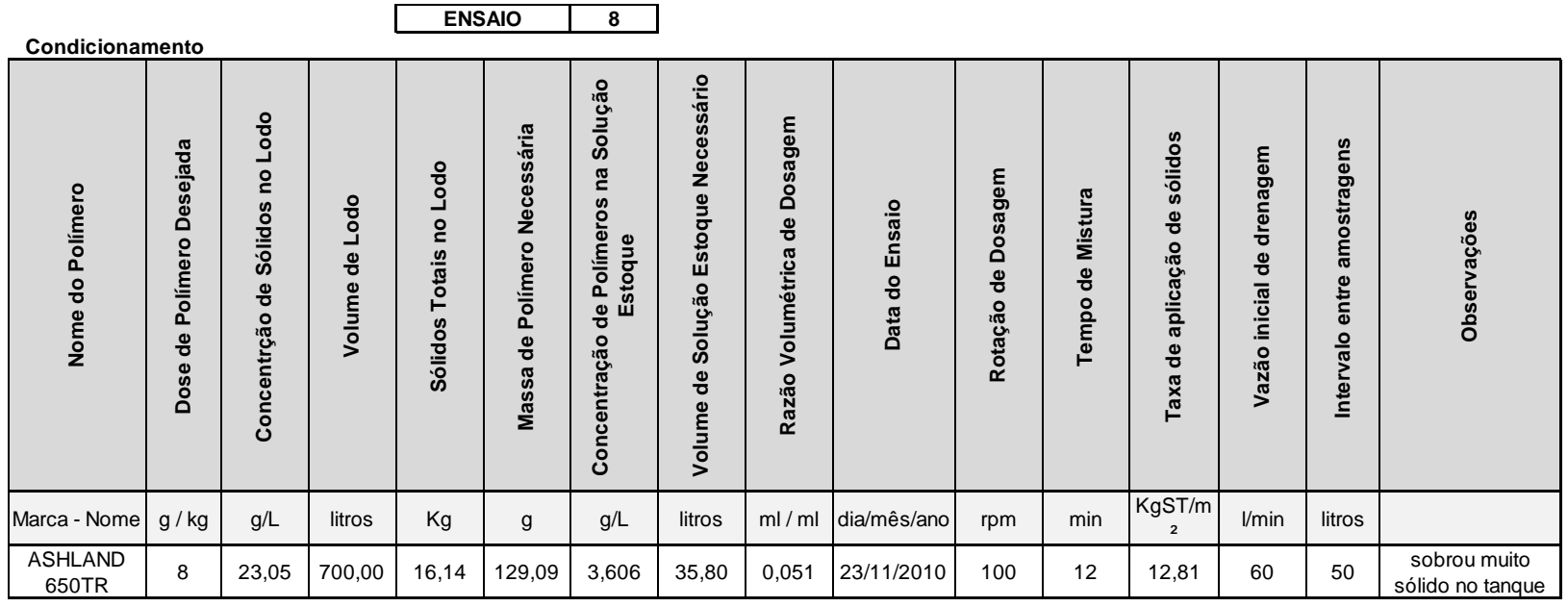

\begin{tabular}{|c|c|c|c|c|c|c|}
\hline \multicolumn{7}{|c|}{ Análise do drenado } \\
\hline & 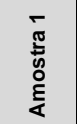 & 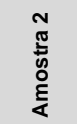 & 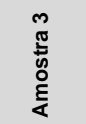 & 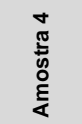 & 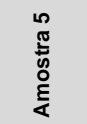 & 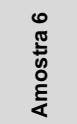 \\
\hline $\mathrm{DQO}(\mathrm{mg} / \mathrm{l})$ & 313,7 & 176,5 & 180,4 & 192,2 & 180,4 & 125,5 \\
\hline $\begin{array}{c}\text { Condutividad } \\
e(\mu \mathrm{S})\end{array}$ & 1071,0 & 1090,0 & 1099,0 & 1102,0 & 1103,0 & 1106,0 \\
\hline $\mathrm{pH}$ & 7,00 & 6,86 & 6,76 & 6,75 & 6,71 & 6,62 \\
\hline $\begin{array}{c}\text { Turbidez } \\
\text { (UNT) }\end{array}$ & 13,6 & 12,8 & 13,9 & 13,9 & 11,6 & 6,4 \\
\hline
\end{tabular}

Acompanhamento da torta

\begin{tabular}{|c|c|c|c|c|c|c|c|c|c|c|c|c|c|c|c|}
\hline & $\begin{array}{l}\text { 응 } \\
\text { 응 } \\
\frac{0}{0} \\
\frac{\pi}{4} \\
\frac{1}{0} \\
\frac{\pi}{0} \\
\frac{\pi}{2} \\
\frac{\pi}{2}\end{array}$ & 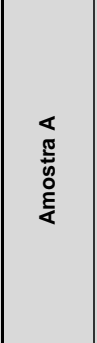 & 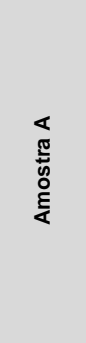 & 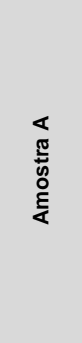 & $\begin{array}{l}m \\
\frac{\pi}{2} \\
\text { के } \\
\stackrel{2}{\varepsilon}\end{array}$ & 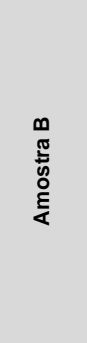 & 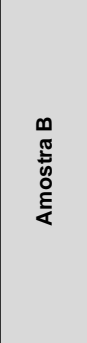 & 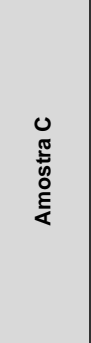 & 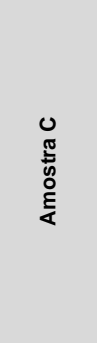 & 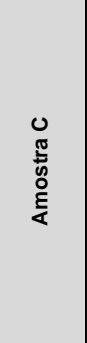 & 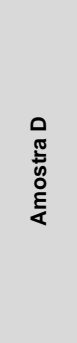 & 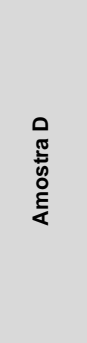 & $\begin{array}{l}0 \\
\frac{\pi}{2} \\
\text { के } \\
\stackrel{2}{\varepsilon}\end{array}$ & 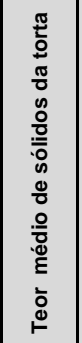 & 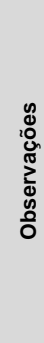 \\
\hline Dias corridos & $\mathrm{cm}$ & P0 (g) & $\mathrm{P} 1 \mathrm{~g})$ & P2 (g) & P0 (g) & $\mathrm{P} 1 \mathrm{~g}$ ) & P2 (g) & $\mathrm{PO}(\mathrm{g})$ & P1 (g) & P2 (g) & PO (g) & $\mathrm{P} 1$ (g) & P2 (g) & TS (\%) & \\
\hline 0 & 45 & & & & & & & & & & & & & 2,31 & \\
\hline 1 & 9 & \begin{tabular}{|l|}
114,424 \\
\end{tabular} & 182,65 & 124,21 & 107,19 & 180,81 & 116,038 & 119,864 & 186,67 & 129,61 & 110,86 & 182,52 & 120,48 & 13,14 & \\
\hline 3 & 8 & 103,006 & 157,96 & 111,39 & 92,77 & 143,07 & 100,839 & 106,717 & 156,198 & 114,16 & 103,07 & 148,53 & 111,109 & 15,95 & \\
\hline 6 & 7 & 106,667 & 155,88 & 115,87 & 103,01 & 159,62 & 111,740 & 92,751 & 119,176 & 96,75 & 103,06 & 153,85 & 113,060 & 17,45 & \\
\hline 9 & 6 & 102,998 & 147,26 & 110,58 & 103,05 & 144,48 & 112,691 & 107,178 & 147,273 & 116,82 & 103,9 & 135,26 & \begin{tabular}{|l|}
109,394 \\
\end{tabular} & 20,59 & \\
\hline 11 & 6 & 107,557 & 142,76 & 114,04 & 108,56 & 164,53 & 122,276 & 109,844 & 144,406 & 116,03 & 92,73 & 147,91 & 105,929 & 21,88 & \\
\hline 13 & 5 & 119,842 & 157,05 & 130,17 & 114,42 & 163,28 & 123,821 & 103,052 & 152,074 & 111,97 & 107,18 & 158,29 & 120,192 & 22,38 & \\
\hline 15 & 5 & 103,928 & 153,7 & 117,15 & 105,91 & 150,04 & 114,757 & 91,275 & 131,683 & 102,79 & 118,75 & 169,26 & 129,074 & 23,76 & \\
\hline 17 & 5 & 110,848 & 163,58 & 125,32 & 103,89 & 158,84 & 114,762 & 119,862 & 172,246 & 130,91 & 106,64 & 146,37 & 119,523 & 24,67 & \\
\hline 20 & 5 & \begin{tabular}{|l|}
105,91 \\
\end{tabular} & 144,07 & 121,39 & 118,74 & 150,09 & 126,47 & 103,94 & 152,609 & 119,3 & 92,715 & 152,36 & 105,07 & 28,63 & \\
\hline 22 & 5 & \begin{tabular}{|l|}
114,423 \\
\end{tabular} & 167,03 & 125,67 & 106,64 & 152,83 & 120,18 & 103,895 & 155,16 & 116,03 & 110,86 & 151,81 & 124,67 & 26,55 & \\
\hline 24 & 5 & \begin{tabular}{|l|}
107,57 \\
\end{tabular} & 155,95 & 118,23 & 109,85 & 156,79 & 125,2 & 92,704 & 150,923 & 103,1 & 103,93 & 149,46 & 115,92 & 24,31 & \\
\hline 28 & 5 & \begin{tabular}{|l|}
114,418 \\
\end{tabular} & 167,85 & 133,22 & 103,05 & 141,17 & 112,31 & 110,848 & 172,998 & 134,24 & 103,88 & 162,32 & 118,79 & 31,28 & \\
\hline 30 & 5 & \begin{tabular}{|l|}
109,84 \\
\end{tabular} & 151,25 & 122,79 & 103,93 & 166,71 & 116,9 & 91,269 & 130,079 & 116,65 & 107,55 & 156,18 & 122,93 & 34,80 & \\
\hline
\end{tabular}


Tabela 36 - Planilha do ensaio piloto E9

\begin{tabular}{|l|l|}
\hline ENSAIO & 9 \\
\hline
\end{tabular}

\begin{tabular}{|c|c|c|c|c|c|c|c|c|c|c|c|c|c|c|c|}
\hline 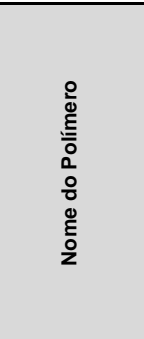 & 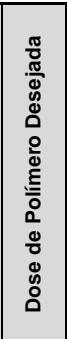 & 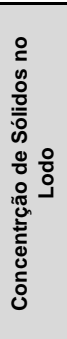 & 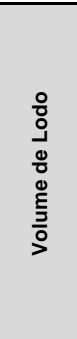 & 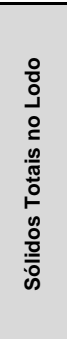 & 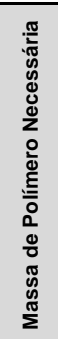 & 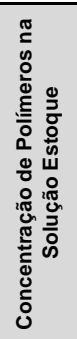 & 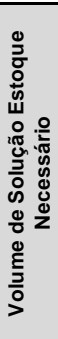 & 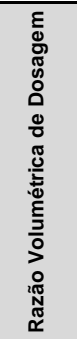 & 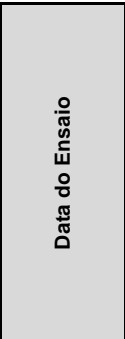 & 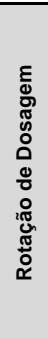 & 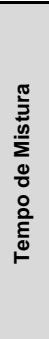 & 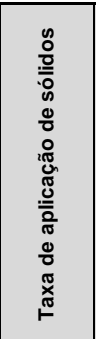 & 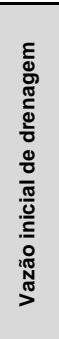 & 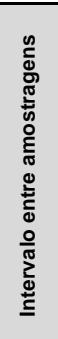 & 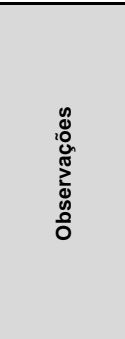 \\
\hline Marca - Nome & $\mathrm{g} / \mathrm{kg}$ & $g / L$ & litros & $\mathrm{Kg}$ & g & $g / L$ & litros & $\mathrm{ml} / \mathrm{ml}$ & dia/mês/ano & $\mathrm{rpm}$ & $\min$ & $\mathrm{KgST} / \mathrm{m}^{2}$ & $1 / \min$ & litros & \\
\hline $\begin{array}{c}\text { ASHLAND } \\
\text { 650TR }\end{array}$ & 0 & 24,46 & 700,00 & 17,12 & 0,00 & 0,000 & 0,00 & - & $01 / 02 / 2011$ & - & - & 13,59 & 8 & 25 & manta umida \\
\hline
\end{tabular}

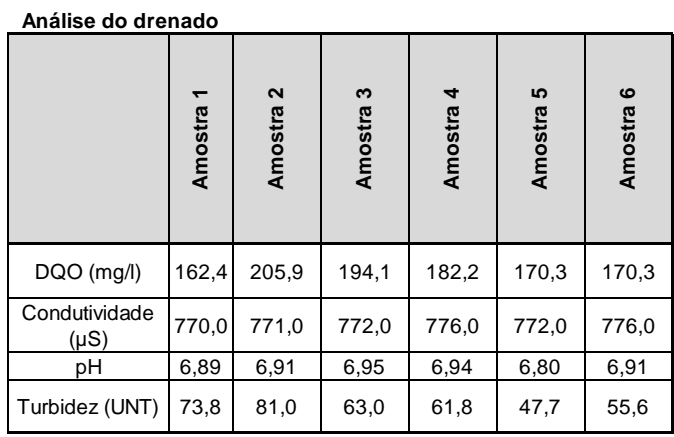

Acompanhamento da

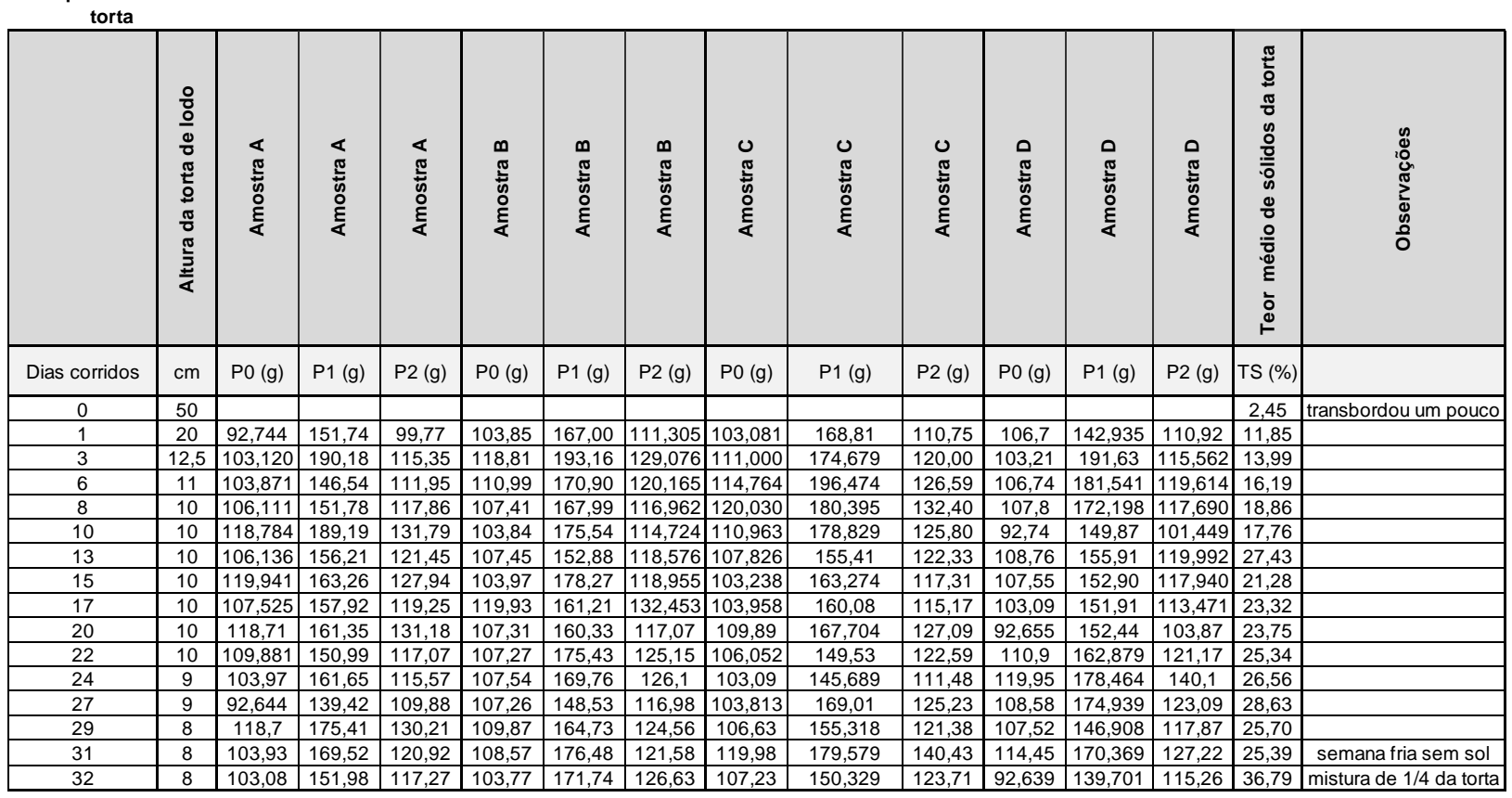


Tabela 37 - Planilha do ensaio piloto E10

\begin{tabular}{|l|l|} 
ENSAIO & 10 \\
\hline
\end{tabular}

\begin{tabular}{|c|c|c|c|c|c|c|c|c|c|c|c|c|c|c|c|}
\hline 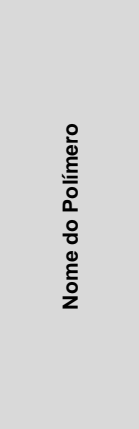 & 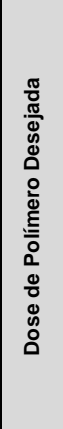 & 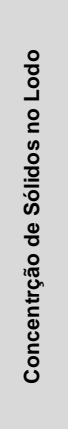 & 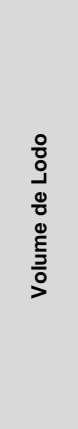 & 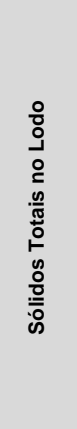 & 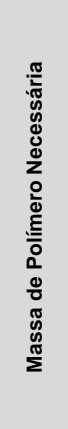 & 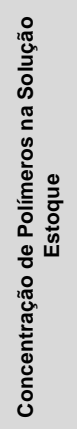 & 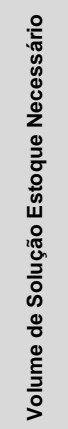 & 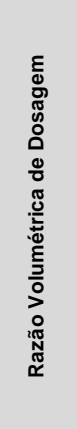 & 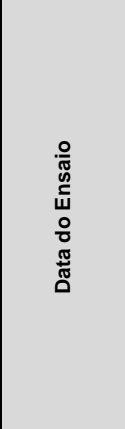 & 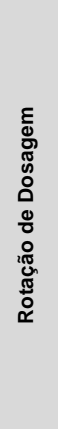 & 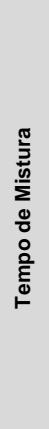 & 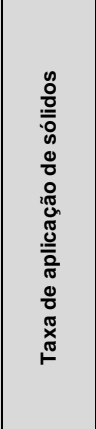 & 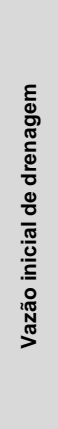 & 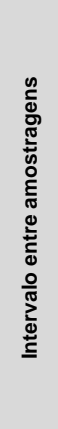 & 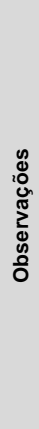 \\
\hline Marca - Nome & $\mathrm{g} / \mathrm{kg}$ & $g / L$ & litros & $\mathrm{Kg}$ & g & $g / L$ & litros & $\mathrm{ml} / \mathrm{ml}$ & dia/mês/ano & rpm & $\min$ & $\mathrm{KgST} / \mathrm{m}^{2}$ & $1 / \min$ & litros & \\
\hline $\begin{array}{l}\text { ASHLAND } \\
\text { 650TR }\end{array}$ & 2 & 26,23 & 700,00 & 18,36 & 36,73 & 1,750 & 21,00 & 0,030 & 03/02/2011 & 100 & 12 & 14,57 & 60 & 50 & \\
\hline
\end{tabular}

\begin{tabular}{|c|c|c|c|c|c|c|}
\hline & 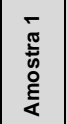 & 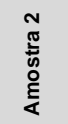 & 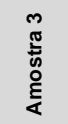 & 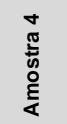 & 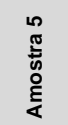 & 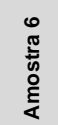 \\
\hline $\mathrm{DQO}(\mathrm{mg} / \mathrm{l})$ & 95,0 & 79,2 & 91,1 & 122,8 & 138,6 & 170,3 \\
\hline $\begin{array}{c}\text { Condutividade } \\
(\mu \mathrm{S})\end{array}$ & 570,0 & 596,0 & 617,0 & 639,0 & 660,0 & 676,0 \\
\hline $\mathrm{pH}$ & 6,60 & 6,65 & 6,66 & 6,69 & 6,73 & 6,74 \\
\hline Turbidez (UNT) & 10,3 & 10,7 & 9,0 & 7,5 & 11,8 & 8,8 \\
\hline
\end{tabular}

Acompanhamento da

\begin{tabular}{|c|c|c|c|c|c|c|c|c|c|c|c|c|c|c|c|}
\hline & $\begin{array}{l}\circ \\
\text { 은 } \\
\frac{0}{0} \\
0 \\
\frac{\pi}{0} \\
0 \\
\frac{\pi}{0} \\
\frac{\pi}{2} \\
\frac{\pi}{2}\end{array}$ & 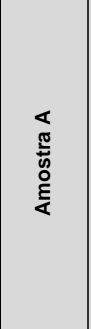 & 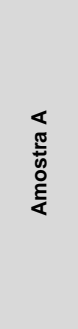 & 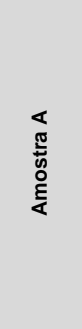 & 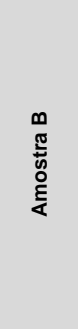 & 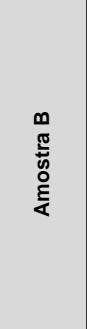 & 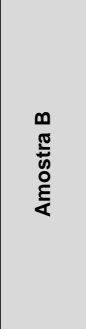 & 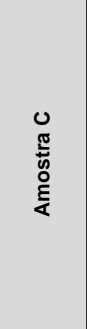 & 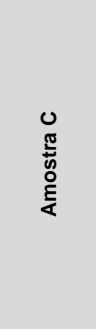 & 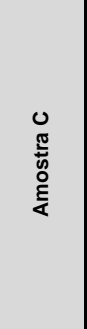 & 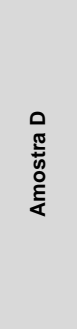 & 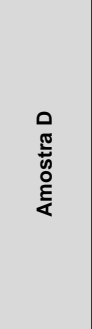 & 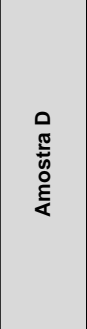 & 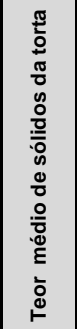 & 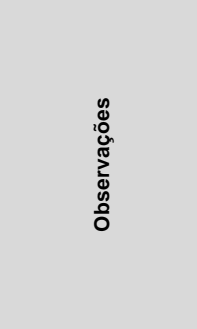 \\
\hline Dias corridos & $\mathrm{cm}$ & P0 (g) & $\mathrm{P} 1$ (g) & P2 (g) & P0 (g) & $\mathrm{P} 1$ (g) & P2 (g) & P0 (g) & $\mathrm{P} 1 \mathrm{~g})$ & P2 (g) & P0 (g) & $\mathrm{P} 1$ (g) & P2 (g) & TS (\%) & \\
\hline 0 & 45 & & & & & & & & & & & & & 2,62 & \\
\hline 1 & 12 & 114,683 & 196,11 & 125,89 & 92,75 & 199,81 & 107,361 & 106,723 & 184,21 & 117,36 & 103,89 & 204,651 & 117,48 & 13,69 & \\
\hline 4 & 11 & 118,770 & 189,07 & 131,06 & 103,13 & 166,81 & 113,002 & 103,176 & 184,001 & 115,54 & 92,76 & 154,06 & 102,022 & 15,86 & \\
\hline 6 & 11 & 104,044 & 197,12 & 119,35 & 91,35 & 181,75 & 105,060 & 109,967 & 203,06 & 127,77 & 108,67 & 198,729 & 122,885 & 16,65 & \\
\hline 8 & 10 & 103,107 & 181,3 & 115,34 & 114,67 & 178,15 & 126,380 & 103,191 & 199,5 & 117,99 & 106,7 & 193,503 & 124,114 & 17,29 & \\
\hline 11 & 10 & 110,004 & 176,15 & 125,54 & 104,16 & 142,92 & 110,694 & 120,081 & 179,26 & 133,05 & 91,40 & 164,95 & 103,354 & 19,78 & \\
\hline 13 & 10 & 108,625 & 180,64 & 120,30 & 91,26 & 152,96 & 105,626 & 106,026 & 169,328 & 120,33 & 103,88 & 174,937 & 116,918 & 19,91 & \\
\hline 15 & 10 & 91,239 & 174,41 & 105,77 & 106,00 & 148,49 & 116,823 & 103,843 & 177,438 & 116,97 & 108,62 & 178,14 & 125,214 & 20,49 & \\
\hline 18 & 10 & 108,602 & 172,27 & 127,32 & 103,84 & 177,80 & 117,263 & 114,605 & 187,595 & 133,04 & 106,68 & 161,30 & 116,451 & 22,75 & \\
\hline 20 & 10 & 103,15 & 173,01 & 117,01 & 114,49 & 170,6 & 130,71 & 92,645 & 159,503 & 111,84 & 105,95 & 167,669 & 118,6 & 24,33 & \\
\hline 22 & 10 & 114,460 & 158,68 & 127,40 & 109,87 & 185,2 & 125,65 & 106,628 & 184,74 & 127,48 & 103,13 & 180,575 & 118,52 & 23,62 & \\
\hline 25 & 9 & 105,93 & 169,46 & 131,93 & 103,06 & 167,57 & 118,32 & 103,12 & 156,127 & 121 & 119,92 & 187,85 & 135,6 & 30,05 & \\
\hline 27 & 9 & 114,207 & 188,86 & 135,49 & 115,77 & 177,41 & 127,69 & 107,483 & 157,68 & 127,62 & 94,452 & 144,48 & 107,67 & 28,14 & \\
\hline 29 & 9 & 103,1 & 170,03 & 125,26 & 110,88 & 179,87 & \begin{tabular}{|l|}
127,04 \\
\end{tabular} & 105,92 & 179,712 & 130,63 & 103,78 & 175,886 & 120,46 & 28,29 & semana \\
\hline 31 & 9 & 103,03 & 185,75 & 131,18 & 114,45 & 149,29 & 126,1 & 91,197 & 158,566 & 117,06 & 103,93 & 161,83 & 129,79 & 37,68 & mistura de $1 / 4 \mathrm{da}$ \\
\hline
\end{tabular}


Tabela 38 - Planilha do ensaio piloto E11

\begin{tabular}{l|l|} 
ENSAIO & 11 \\
\hline
\end{tabular}

\begin{tabular}{|c|c|c|c|c|c|c|c|c|c|c|c|c|c|c|c|}
\hline 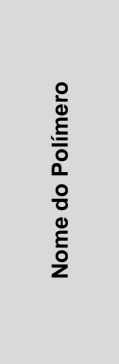 & 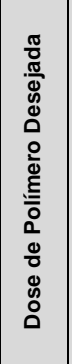 & 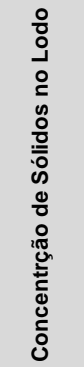 & 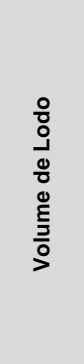 & 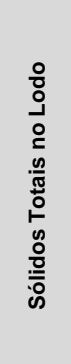 & 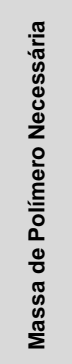 & 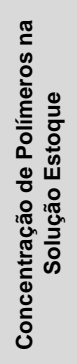 & 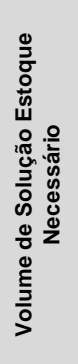 & 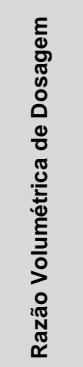 & 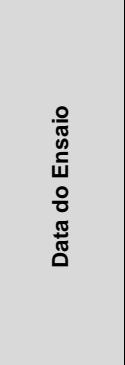 & 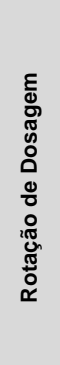 & 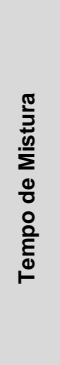 & 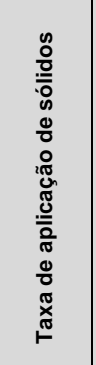 & 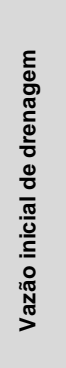 & 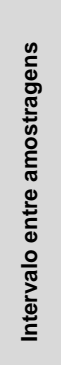 & 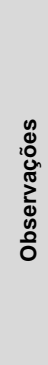 \\
\hline $\begin{array}{l}\text { Marca - } \\
\text { Nome }\end{array}$ & $\mathrm{g} / \mathrm{kg}$ & $\mathrm{g} / \mathrm{L}$ & litros & $\mathrm{Kg}$ & g & $\mathrm{g} / \mathrm{L}$ & litros & $\mathrm{ml} / \mathrm{ml}$ & \begin{tabular}{|c|} 
dia/mês/an \\
0
\end{tabular} & $\mathrm{rpm}$ & $\min$ & $\begin{array}{c}\mathrm{KgST} / \mathrm{m} \\
2\end{array}$ & $1 / \min$ & litros & \\
\hline $\begin{array}{l}\text { ASHLAND } \\
\text { 650TR }\end{array}$ & 4 & 26,80 & 700,00 & 18,76 & 75,04 & 1,750 & 42,87 & 0,061 & $15 / 02 / 2011$ & 100 & 12 & 14,89 & 60 & 50 & \\
\hline
\end{tabular}

\begin{tabular}{|c|c|c|c|c|c|c|}
\hline \multicolumn{7}{|c|}{ Análise do } \\
\hline & 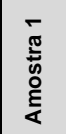 & 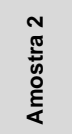 & 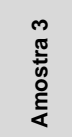 & 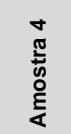 & 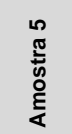 & 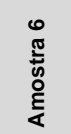 \\
\hline $\mathrm{DQO}(\mathrm{mg} / \mathrm{l})$ & 175,2 & 194,3 & 144,8 & 270,5 & 201,9 & 186,7 \\
\hline $\begin{array}{c}\text { Condutividad } \\
e(\mu S)\end{array}$ & 812,0 & 800,0 & 795,0 & 794,0 & 799,0 & 794,0 \\
\hline $\mathrm{pH}$ & 6,52 & 6,61 & 6,61 & 6,71 & 6,66 & 6,63 \\
\hline $\begin{array}{c}\text { Turbidez } \\
\text { (UNT) }\end{array}$ & 31,3 & 31,9 & 30,5 & 27,4 & 26,1 & 30,5 \\
\hline
\end{tabular}

Acompanhamento

\begin{tabular}{|c|c|c|c|c|c|c|c|c|c|c|c|c|c|c|c|}
\hline & 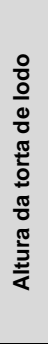 & 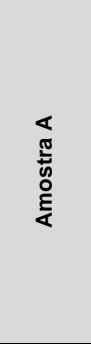 & 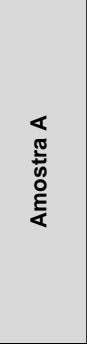 & 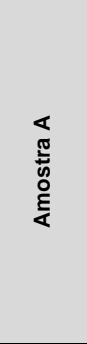 & 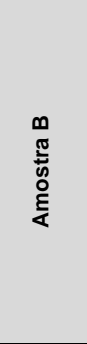 & 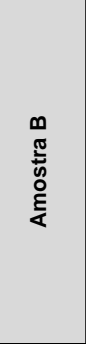 & 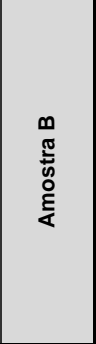 & 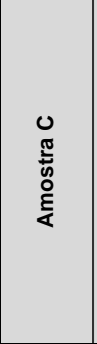 & 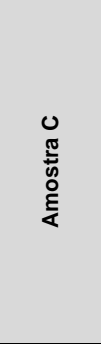 & 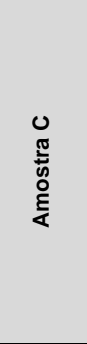 & 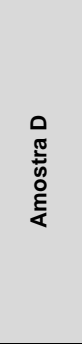 & 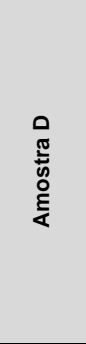 & 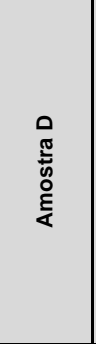 & 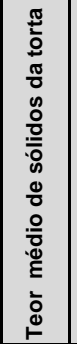 & 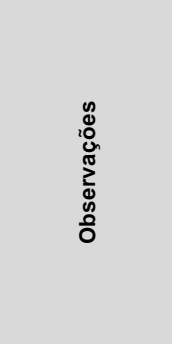 \\
\hline Dias corridos & $\mathrm{cm}$ & P0 (g) & P1 (g) & P2 (g) & P0 (g) & P1 (g) & P2 (g) & PO (g) & P1 (g) & P2 (g) & PO (g) & $\mathrm{P} 1$ (g) & P2 (g) & $\begin{array}{l}\text { TS } \\
\text { (\%) }\end{array}$ & \\
\hline 0 & 45 & & & & & & & & & & & & & 2,68 & \\
\hline 1 & 12 & 109,914 & 152,13 & 117,77 & 107,32 & 183,43 & 115,776 & 92,753 & 169,54 & 104,72 & 118,78 & 178,35 & 129,23 & 13,79 & \\
\hline 3 & 11 & 114,613 & 193,16 & 126,08 & 103,21 & 160,63 & 112,573 & \begin{tabular}{|l|}
110,952 \\
\end{tabular} & 200,91 & 124,88 & 106,70 & 196,49 & 122,031 & 15,86 & \\
\hline 6 & 11 & 91,239 & 164,99 & 104,01 & 105,99 & 188,26 & 119,276 & 103,214 & 167,759 & 117,36 & 110,96 & 184,2 & 122,354 & 17,56 & \\
\hline 8 & 11 & 108,595 & 178,2 & 122,93 & 103,82 & 172,75 & 114,818 & \begin{tabular}{|l|}
91,225 \\
\end{tabular} & 166,041 & 106,64 & 118,71 & 164,48 & 126,355 & 18,68 & \\
\hline 10 & 11 & 91,203 & 180,24 & 109,37 & 110,89 & 200,60 & 125,846 & \begin{tabular}{|l|}
110,691 \\
\end{tabular} & 183,434 & 131,62 & 105,93 & 176,15 & 117,628 & 20,44 & \\
\hline 13 & 11 & 110,883 & 197,78 & 128,74 & 91,20 & 188,64 & 108,289 & \begin{tabular}{|l|}
103,940 \\
\end{tabular} & 200,663 & 127,16 & 114,46 & 197,96 & 129,864 & 20,18 & \\
\hline 15 & 11 & 112,146 & 172,35 & 125,85 & 119,09 & 164,66 & 128,169 & 113,900 & 177,157 & 128,95 & 117,96 & 193,93 & 131,114 & 20,81 & \\
\hline 17 & 11 & 92,643 & 146,8 & 105,67 & 103,04 & 150,33 & 112,794 & \begin{tabular}{|l|}
91,209 \\
\end{tabular} & 155,212 & 105,37 & 107,27 & 190,8 & 122,379 & 20,91 & semana fria sem \\
\hline 22 & 10 & 108,55 & 175,22 & 121,32 & 110,87 & 172,28 & 125,53 & 105,93 & 202,71 & 127,81 & 119,89 & 204,51 & \begin{tabular}{|l|}
137,8 \\
\end{tabular} & 21,72 & \\
\hline 27 & 10 & 107,230 & 165,5 & 118,90 & 103,77 & 164,16 & 117,8 & 92,644 & 171,25 & 110,01 & 103,08 & 171,13 & \begin{tabular}{l|l|}
123,43 \\
\end{tabular} & 23,90 & \\
\hline 29 & 10 & 110,87 & 152,06 & 124,48 & 119,88 & 176,66 & 133,22 & 114,45 & 185,998 & 133,17 & 102,02 & 178,4 & 119,11 & 25,52 & \\
\hline 31 & 10 & 114,45 & 186,06 & 137,79 & 110,86 & 188,17 & 138,47 & 119,87 & 180,389 & 136,4 & 103,02 & 164,35 & 136,86 & 37,42 & \\
\hline
\end{tabular}


Tabela 39 - Planilha do ensaio piloto E12

\begin{tabular}{l|l|} 
ENSAIO & 12 \\
\hline
\end{tabular}

\begin{tabular}{|c|c|c|c|c|c|c|c|c|c|c|c|c|c|c|c|}
\hline Condiciona & mento & & & & & & & & & & & & & & \\
\hline 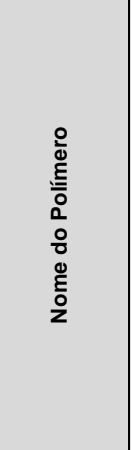 & 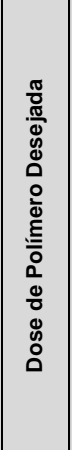 & 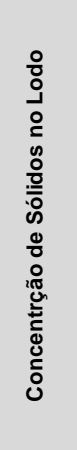 & 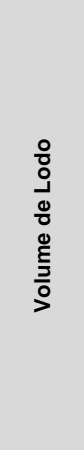 & 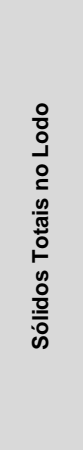 & 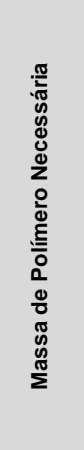 & 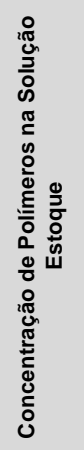 & 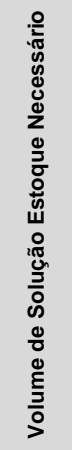 & 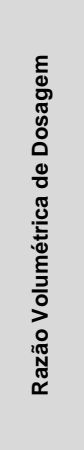 & 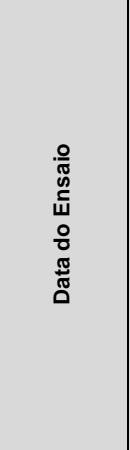 & 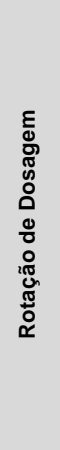 & 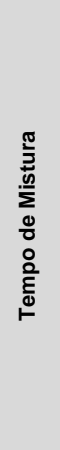 & 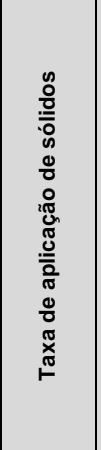 & 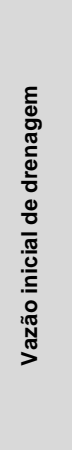 & 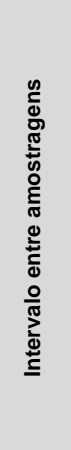 & 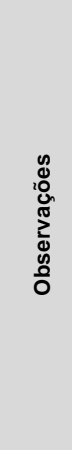 \\
\hline $\begin{array}{l}\text { Marca - } \\
\text { Nome }\end{array}$ & $\mathrm{g} / \mathrm{kg}$ & $g / L$ & litros & $\mathrm{Kg}$ & g & g/L & litros & $\mathrm{ml} / \mathrm{ml}$ & dia/mês/ano & rpm & $\min$ & $\underset{2}{\mathrm{KgST} / \mathrm{m}}$ & $1 / \min$ & litros & \\
\hline $\begin{array}{l}\text { ASHLAND } \\
\text { 650TR }\end{array}$ & 2 & 25,89 & 700,00 & 18,12 & 36,25 & 2,036 & 17,81 & 0,025 & 29/04/2011 & 100 & 8 & 14,38 & 60 & 50 & \\
\hline
\end{tabular}

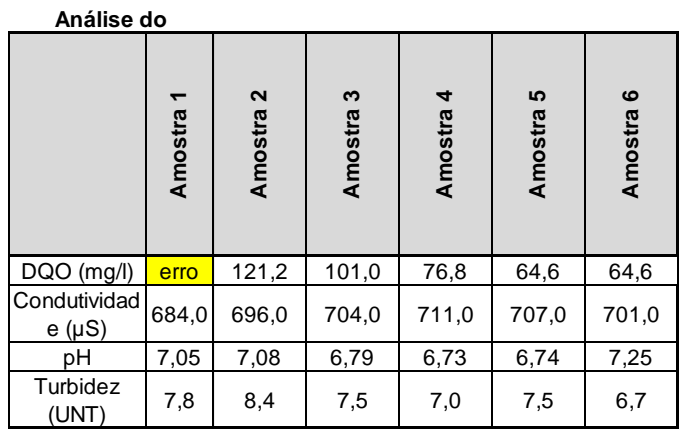

Acompanhamento

\begin{tabular}{|c|c|c|c|c|c|c|c|c|c|c|c|c|c|c|c|}
\hline & 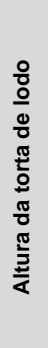 & 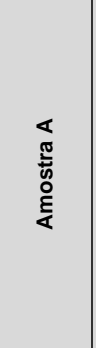 & 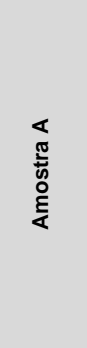 & 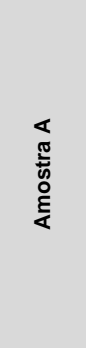 & 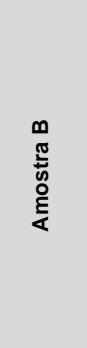 & 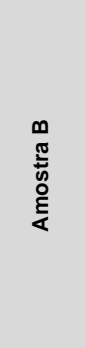 & 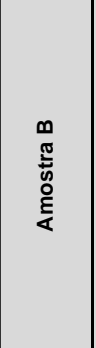 & 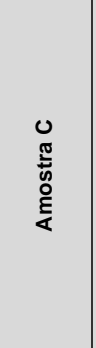 & 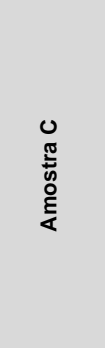 & 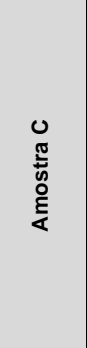 & 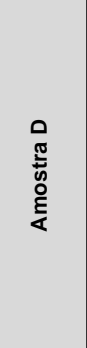 & 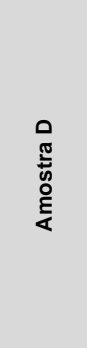 & 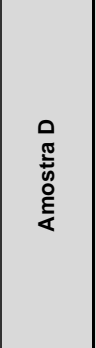 & 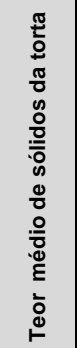 & 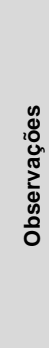 \\
\hline $\begin{array}{c}\text { Dias } \\
\text { corridos }\end{array}$ & $\mathrm{cm}$ & PO (g) & P1 (g) & P2 (g) & PO (g) & $\mathrm{P} 1$ (g) & P2 (g) & P0 (g) & P1 (g) & P2 (g) & P0 (g) & P1 (g) & P2 (g) & TS (\%) & \\
\hline 0 & 45 & & & & & & & & & & & & & 2,59 & \\
\hline 1 & 12 & 110,015 & 202,8 & 122,96 & 114,45 & 203,71 & 126,352 & 103,767 & 170,32 & 113,01 & 92,646 & 181,82 & 104,2 & 13,65 & \\
\hline 3 & 11 & 103,017 & 194,91 & 116,69 & 119,01 & 199,24 & \begin{tabular}{|l|}
129,980 \\
\end{tabular} & \begin{tabular}{|l|}
107,883 \\
\end{tabular} & 195,464 & 121,11 & 106,94 & 199,28 & \begin{tabular}{|l|}
120,527 \\
\end{tabular} & 14,62 & \\
\hline 6 & 10 & 106,138 & 193,11 & 120,47 & 120,16 & 202,11 & 132,776 & 110,005 & 176,451 & 121,58 & 110,87 & 190,89 & 122,563 & 15,92 & \\
\hline 11 & 10 & 106,150 & 185,28 & 118,92 & 103,09 & 198,57 & \begin{tabular}{|l|}
117,879 \\
\end{tabular} & \begin{tabular}{|l|}
110,887 \\
\end{tabular} & 168,076 & 120,07 & 114,45 & 180,97 & 124,623 & 15,73 & \\
\hline 14 & 10 & 107,344 & 203,91 & 123,05 & 106,18 & 199,97 & 123,785 & \begin{tabular}{|l|}
18,913 \\
\end{tabular} & 196,086 & 131,33 & 105,70 & 173,42 & 120,878 & 18,17 & \\
\hline 18 & 10 & 110,093 & 190,84 & 124,96 & 92,70 & 177,90 & 106,434 & 110,878 & 194,318 & 126,65 & 103,03 & 195,56 & 117,921 & 17,33 & \\
\hline 21 & 10 & 110,879 & 180,59 & 124,81 & 110,01 & 173,90 & \begin{tabular}{|l|}
121,257 \\
\end{tabular} & 103,052 & 165,105 & 115,36 & 92,65 & 171,35 & 106,554 & 18,73 & \\
\hline 24 & 10 & 110,858 & 189,55 & 124,95 & 110,00 & 173,47 & \begin{tabular}{|l|}
123,312 \\
\end{tabular} & \begin{tabular}{|l|}
103,011 \\
\end{tabular} & 185,59 & 118,18 & 92,643 & 164,65 & 108,705 & 19,76 & \\
\hline 28 & 9,5 & 108,67 & 161,01 & 118,91 & 107,21 & 175,84 & 123,24 & \begin{tabular}{|l|}
106,08 \\
\end{tabular} & 169,833 & 119,55 & 120,08 & 173,59 & 130,37 & 20,99 & \\
\hline 31 & 9 & 114,451 & 195,49 & 133,91 & 103,08 & 173,64 & \begin{tabular}{|l|}
117,55 \\
\end{tabular} & 109,991 & 182,74 & 124,88 & 104 & 168,16 & 115,67 & 20,97 & \\
\hline 35 & 9 & 103,767 & 188,4 & 121,01 & 103,96 & 164,67 & \begin{tabular}{|l|}
118,54 \\
\end{tabular} & \begin{tabular}{|l|}
107,215 \\
\end{tabular} & 188,97 & 125,27 & 108,62 & 162,66 & 124,94 & \begin{tabular}{|l|}
23,54 \\
\end{tabular} & \\
\hline
\end{tabular}


Tabela 40 - Planilha do ensaio piloto E13

\begin{tabular}{l|l|} 
ENSAIO & 13 \\
\hline
\end{tabular}

\begin{tabular}{|c|c|c|c|c|c|c|c|c|c|c|c|c|c|c|c|}
\hline 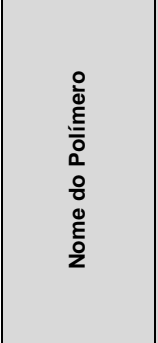 & 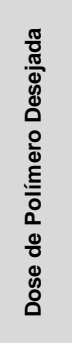 & 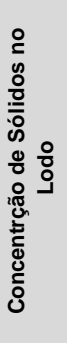 & 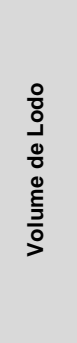 & 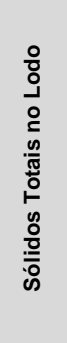 & 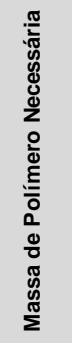 & 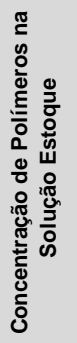 & 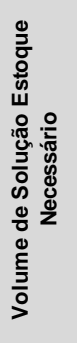 & 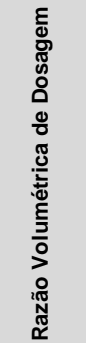 & 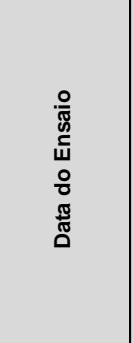 & 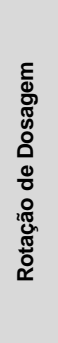 & 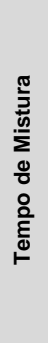 & 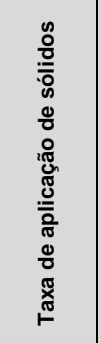 & 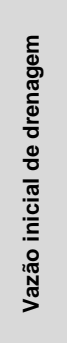 & 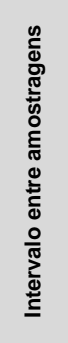 & 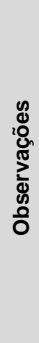 \\
\hline Marca - Nome & $\mathrm{g} / \mathrm{kg}$ & $\mathrm{g} / \mathrm{L}$ & litros & $\mathrm{Kg}$ & $\mathrm{g}$ & $g / L$ & litros & $\mathrm{ml} / \mathrm{ml}$ & dia/mês/ano & $\mathrm{rpm}$ & $\min$ & $\mathrm{KgST} / \mathrm{m}^{2}$ & $1 / \mathrm{min}$ & litros & \\
\hline $\begin{array}{c}\text { ASHLAND } \\
650 T R\end{array}$ & 2 & 38,23 & 700,00 & 26,76 & 53,52 & 1,981 & 27,02 & 0,039 & 04/05/2011 & 100 & 15 & 21,24 & 60 & & \\
\hline
\end{tabular}

\begin{tabular}{|c|c|c|c|c|c|c|}
\hline & 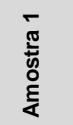 & 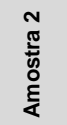 & 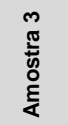 & 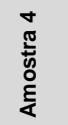 & 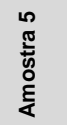 & 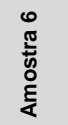 \\
\hline $\mathrm{DQO}(\mathrm{mg} / \mathrm{l})$ & 47,1 & 15,7 & 23,5 & 11,8 & 70,6 & 7,8 \\
\hline $\begin{array}{c}\text { Condutividade } \\
(\mu \mathrm{S})\end{array}$ & 542,0 & 513,0 & 511,0 & 509,0 & 506,0 & 503,0 \\
\hline $\mathrm{pH}$ & 6,70 & 6,52 & 6,47 & 6,45 & 6,42 & 6,42 \\
\hline $\begin{array}{l}\text { Turbidez } \\
\text { (UNT) }\end{array}$ & 12,8 & 8,2 & 7,6 & 6,6 & 6,8 & 7,0 \\
\hline
\end{tabular}

Acompanhamento da

\begin{tabular}{|c|c|c|c|c|c|c|c|c|c|c|c|c|c|c|c|}
\hline & 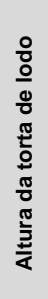 & 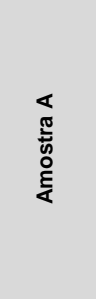 & 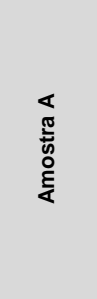 & 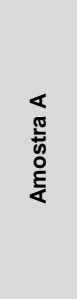 & 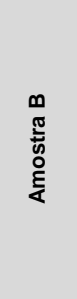 & 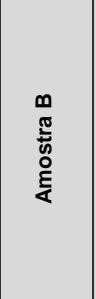 & 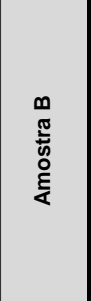 & 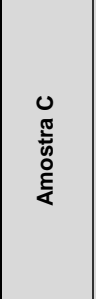 & 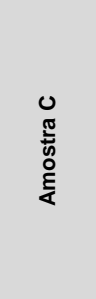 & 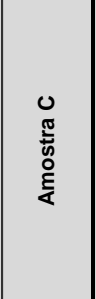 & 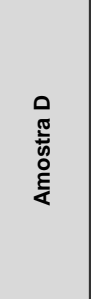 & 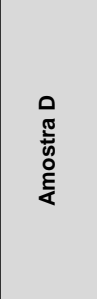 & 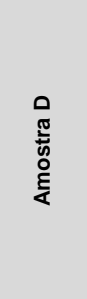 & 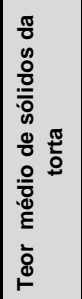 & 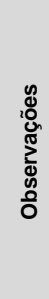 \\
\hline Dias corridos & $\mathrm{cm}$ & P0 (g) & P1 (g) & P2 (g) & P0 (g) & P1 (g) & P2 (g) & P0 (g) & P1 (g) & P2 (g) & PO (g) & P1 (g) & P2 (g) & TS (\%) & \\
\hline 0 & 45 & & & & & & & & & & & & & 3,82 & \\
\hline 1 & 17 & 114,438 & 188,48 & 126,21 & 103,00 & 195,34 & 117,271 & 103,760 & 163,70 & \begin{tabular}{|l|}
114,775 \\
\end{tabular} & 103,073 & 155,948 & 112,177 & 15,65 & \\
\hline 6 & 15 & 92,678 & 185,27 & 110,12 & 118,86 & 196,67 & 131,784 & 107,270 & 197,254 & \begin{tabular}{|l|}
121,85 \\
\end{tabular} & 108,64 & \begin{tabular}{|l|}
204,42 \\
\end{tabular} & 125,997 & 17,49 & \\
\hline 9 & 14 & 103,973 & 194,756 & 119,52 & 91,20 & 197,50 & 107,636 & 103,786 & 198,512 & 123,09 & 120,12 & 200,64 & 132,854 & 17,19 & \\
\hline 13 & 14 & 103,940 & 201,527 & 123,21 & 91,212 & \begin{tabular}{|l|}
194,417 \\
\end{tabular} & 107,936 & 103,777 & 182,442 & 120,38 & 120,168 & 202,344 & 134,927 & 18,63 & \\
\hline 16 & 14 & 103,970 & 195,776 & 119,08 & 91,22 & \begin{tabular}{|l|}
196,93 \\
\end{tabular} & 114,000 & 103,826 & 204,435 & 120,81 & 120,13 & \begin{tabular}{|l|}
196,65 \\
\end{tabular} & 137,312 & 19,23 & \\
\hline 19 & 14 & 103,994 & 204,82 & 122,86 & 91,18 & 172,27 & 108,215 & 103,789 & 199,366 & 122,55 & 120,12 & 199,25 & 137,965 & 20,33 & \\
\hline 23 & 14 & 103,969 & 200,1 & 124,83 & 118,82 & 194,99 & \begin{tabular}{|l|}
136,647 \\
\end{tabular} & 91,220 & 201,605 & 111,65 & 103,79 & 190,90 & 123,052 & 21,19 & \\
\hline 26 & 14 & 110,954 & 202,85 & 132,77 & 118,81 & 204,52 & 136,343 & 91,235 & 196,097 & 110,79 & 107,207 & 204,19 & 124,743 & 20,15 & \\
\hline 30 & 13 & 92,644 & 195,586 & 118,07 & 109,99 & 192,854 & \begin{tabular}{|l|}
126 \\
\end{tabular} & 120,017 & 203,538 & 140,1 & 110,87 & 197,482 & 127,842 & 22,05 & \\
\hline 33 & 13 & 103,064 & 191,312 & 124,86 & 114,48 & \begin{tabular}{|l|}
171,633 \\
\end{tabular} & 126,59 & 102,990 & 186,79 & \begin{tabular}{|l|}
119,765 \\
\end{tabular} & & & & 22,11 & \\
\hline 36 & 13 & 109,98 & 196,256 & 126,68 & 108,61 & 172,255 & \begin{tabular}{|l|}
123,57 \\
\end{tabular} & 103,946 & 169,313 & 119,845 & & & & 22,09 & \\
\hline
\end{tabular}


Tabela 41 - Planilha do ensaio piloto E14

\begin{tabular}{|l|l|}
\hline ENSAIO & 14 \\
\hline
\end{tabular}

\begin{tabular}{|c|c|c|c|c|c|c|c|c|c|c|c|c|c|c|c|}
\hline 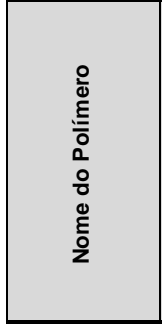 & 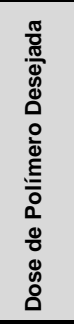 & 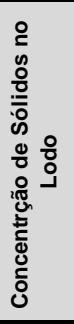 & 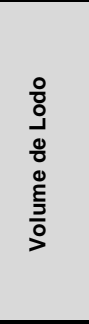 & 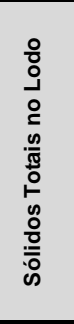 & 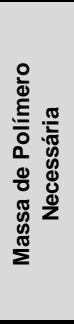 & 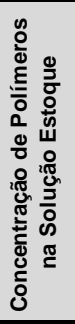 & 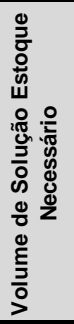 & 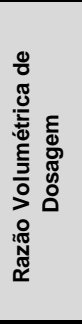 & 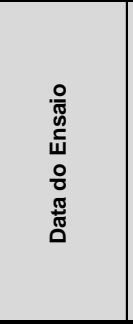 & 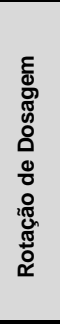 & 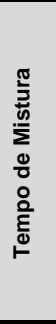 & 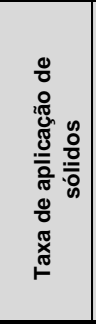 & 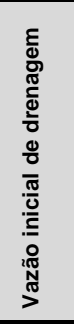 & 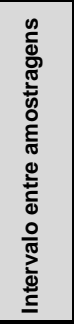 & 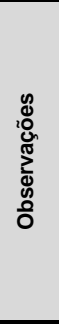 \\
\hline Marca - Nom & $\mathrm{g} / \mathrm{kg}$ & $g / L$ & litros & $\mathrm{Kg}$ & $\mathrm{g}$ & $g / L$ & litros & $\mathrm{ml} / \mathrm{ml}$ & dia/mês/ano & $\mathrm{rpm}$ & $\min$ & $\mathrm{gST} / \mathrm{m}^{2}$ & $1 / \mathrm{min}$ & litros & \\
\hline $\begin{array}{l}\text { ASHLAND } \\
650 T R\end{array}$ & 2 & 17,58 & 700,00 & 12,30 & 25,20 & 2,100 & 12,00 & 0,017 & 05/05/2011 & 100 & 8 & \begin{tabular}{|l|}
9,77 \\
\end{tabular} & 60 & & \\
\hline
\end{tabular}

\begin{tabular}{|c|c|c|c|c|c|c|}
\hline & 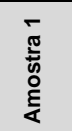 & 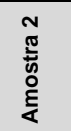 & 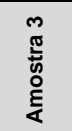 & 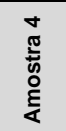 & 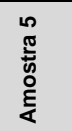 & 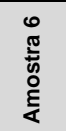 \\
\hline $\mathrm{DQO}(\mathrm{mg} / \mathrm{l})$ & 94,1 & 152,9 & 98,0 & 82,4 & 19,6 & 152,9 \\
\hline $\begin{array}{l}\text { Condutividade } \\
(\mu \mathrm{S})\end{array}$ & 604,0 & 615,0 & 628,0 & 632,0 & 630,0 & 632,0 \\
\hline $\mathrm{pH}$ & 7,66 & 7,22 & 7,46 & 7,22 & 7,47 & 7,18 \\
\hline $\begin{array}{c}\text { Turbidez } \\
\text { (UNT) }\end{array}$ & 3,0 & 3,1 & 3,6 & 4,1 & 3,3 & 3,6 \\
\hline
\end{tabular}

Acompanhamento da

\begin{tabular}{|c|c|c|c|c|c|c|c|c|c|c|c|c|c|c|c|}
\hline & 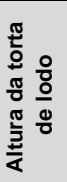 & 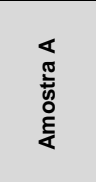 & 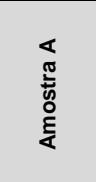 & 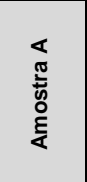 & 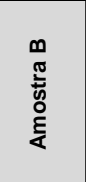 & 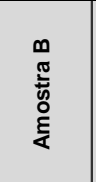 & 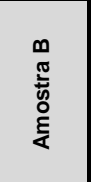 & 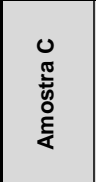 & 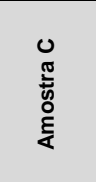 & 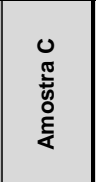 & 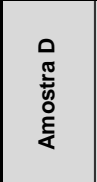 & 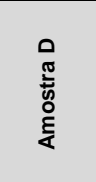 & 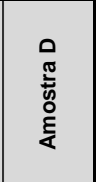 & 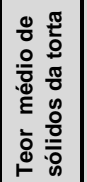 & 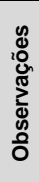 \\
\hline Dias corridos & $\mathrm{cm}$ & PO (g) & $\mathrm{P} 1$ (g) & P2 (g) & PO (g) & $\mathrm{P} 1$ (g) & P2 (g) & $\mathrm{PO}(\mathrm{g})$ & $P 1$ (g) & P2 (g) & PO (g) & $\mathrm{P} 1$ (g) & P2 (g) & TS (\%) & \\
\hline 0 & 47 & & & & & & & & & & & & & 1,76 & \\
\hline 1 & 8 & 103,767 & 175,9 & 113,65 & 110,01 & 179,49 & 119,604 & 120,131 & 196,32 & 131,245 & 103,003 & 165,347 & 112,242 & 13,75 & \\
\hline 5 & 7 & 103,929 & 162,303 & 112,51 & 91,20 & 156,83 & 100,749 & 107,636 & 183,083 & \begin{tabular}{|l|}
118,57 \\
\end{tabular} & 106,71 & 180,66 & 117,530 & 14,59 & \\
\hline 8 & 7 & 110,073 & 175,692 & 119,95 & 92,67 & 133,83 & 98,832 & 110,884 & 177,33 & 120,91 & 103,022 & 162,575 & 111,430 & 14,81 & \\
\hline 12 & 7 & 107,307 & 178,366 & caiu & 106,09 & 154,668 & 114,391 & 118,892 & 181,003 & 128,22 & 108,637 & 156,165 & 116,542 & 16,14 & \\
\hline 15 & 7 & 118,866 & 173,839 & 127,95 & 108,67 & 197,38 & 122,965 & 106,051 & 182,631 & 117,83 & 107,94 & 150,19 & 113,917 & 15,67 & \\
\hline 18 & 7 & 118,842 & 178,867 & 129,80 & 108,64 & 166,74 & 118,696 & 106,039 & 165,464 & 118,35 & 107,00 & 167,47 & 116,562 & 18,02 & \\
\hline 22 & 7 & 110,884 & 179,458 & 123,91 & 110,00 & 171,12 & 121,297 & 103,033 & 166,604 & 114,91 & 92,65 & 155,48 & 102,940 & 18,15 & \\
\hline 25 & 7 & 92,649 & 152,513 & 105,17 & 106,00 & 137,60 & 112,515 & 108,630 & 175,074 & 121,95 & 120,029 & 159,174 & 127,500 & 20,21 & \\
\hline 29 & 7 & 102,996 & 161,161 & 114,88 & 106,02 & 150,47 & 115,79 & 114,431 & 150,168 & \begin{tabular}{|l|}
121,262 \\
\end{tabular} & 103,066 & 183,734 & 119,191 & \begin{tabular}{|l|}
20,37 \\
\end{tabular} & \\
\hline 32 & 7 & 92,630 & 155,69 & 106,96 & 110,87 & 193,76 & 128,87 & 107,210 & 184,59 & \begin{tabular}{|l|}
124,771 \\
\end{tabular} & & & & 22,34 & \\
\hline 35 & 7 & 105,022 & 177,776 & 123,27 & 120,03 & 186,04 & 135,24 & 103,768 & 179,511 & 123,626 & & & & 24,85 & \\
\hline
\end{tabular}




\section{APÊNDICE 8 - Resultados da altura e teor de sólidos da torta dos ensaios piloto E1 a E8}

Para a comparação entre os diversos ensaios foram plotados 2 gráficos para a altura da torta no leito com os ensaios E1 a E8 (Figura 96) e 2 gráficos para a altura da torta no leito com os ensaios E9 a E11 (Figura 98) de modo a possibilitar uma avaliação visual do comportamento das tortas geradas. Assim como nos gráficos para comparação de polímeros, cada gráfico é repetido na sequência (na mesma figura) com uma alteração na escala do eixo das ordenadas, para facilitar as análises e comparações visuais.

Em relação à evolução do teor de sólidos ao longo do ciclo de secagem, também foram plotados 2 gráficos para os ensaios E1 a E8 (Figura 97) e 2 gráficos para o teor de sólidos na torta nos ensaios E9 a E11 (Figura 99) de modo a possibilitar uma avaliação visual do comportamento das tortas geradas. Assim como nos gráficos para comparação das alturas da torta ao longo do período de secagem, cada gráfico é repetido na sequência (na mesma figura) com uma alteração na escala do eixo das ordenadas, para facilitar as análises e comparações visuais. 

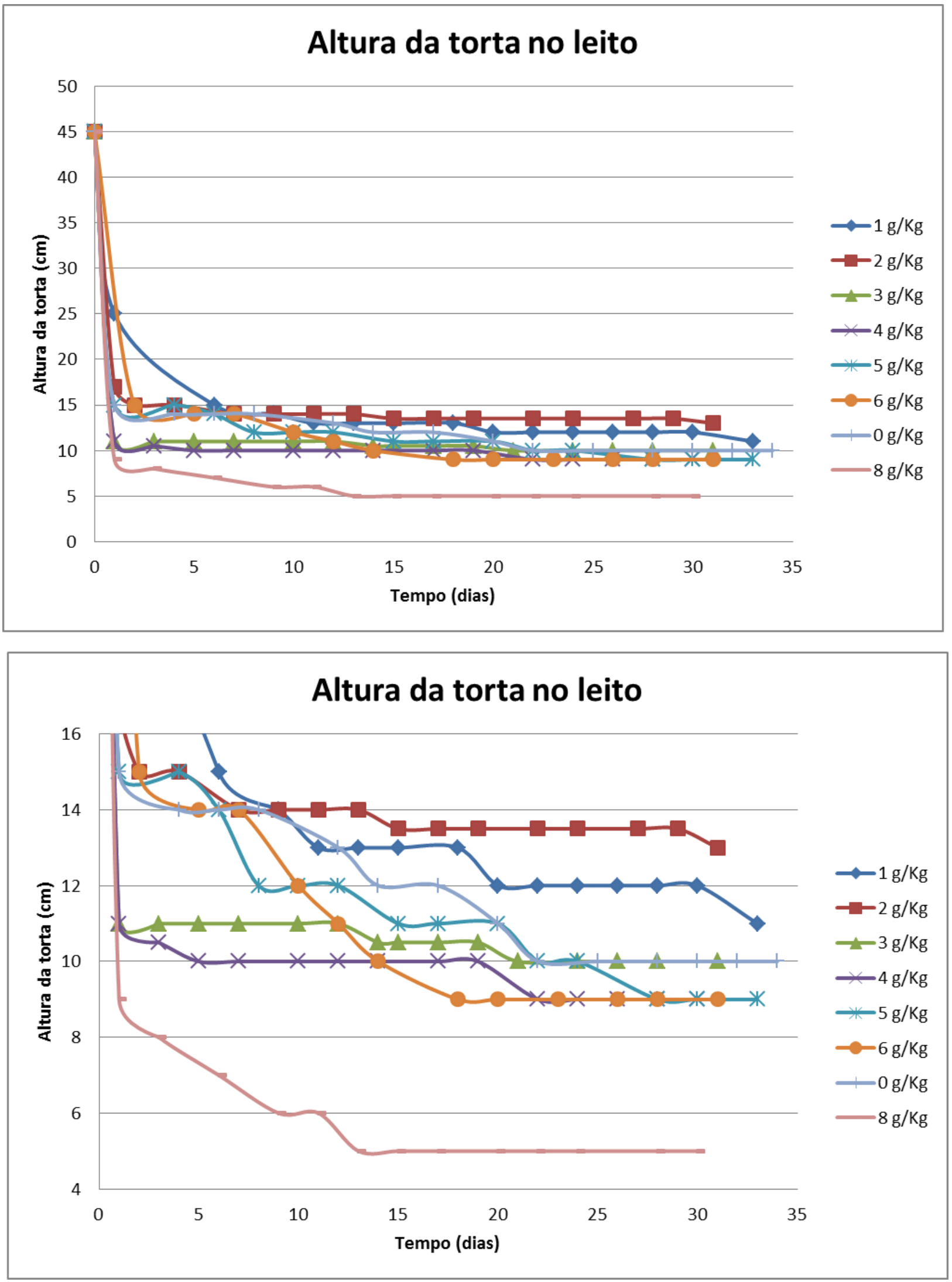

Figura 96 - Resultado da altura da torta nos ensaios E1 a E8 

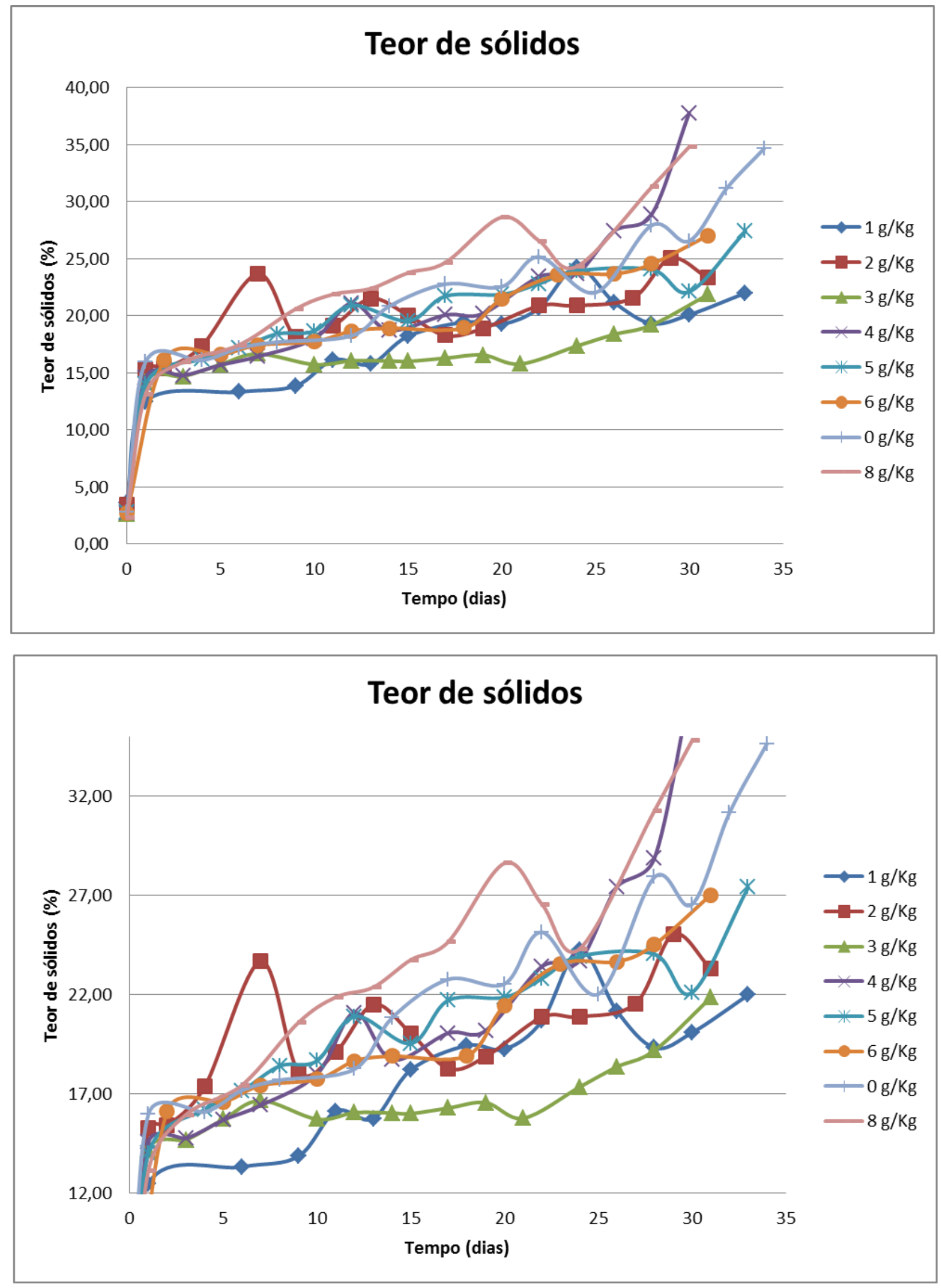

Figura 97 - Resultado do teor de sólidos nos ensaios E1 a E8 

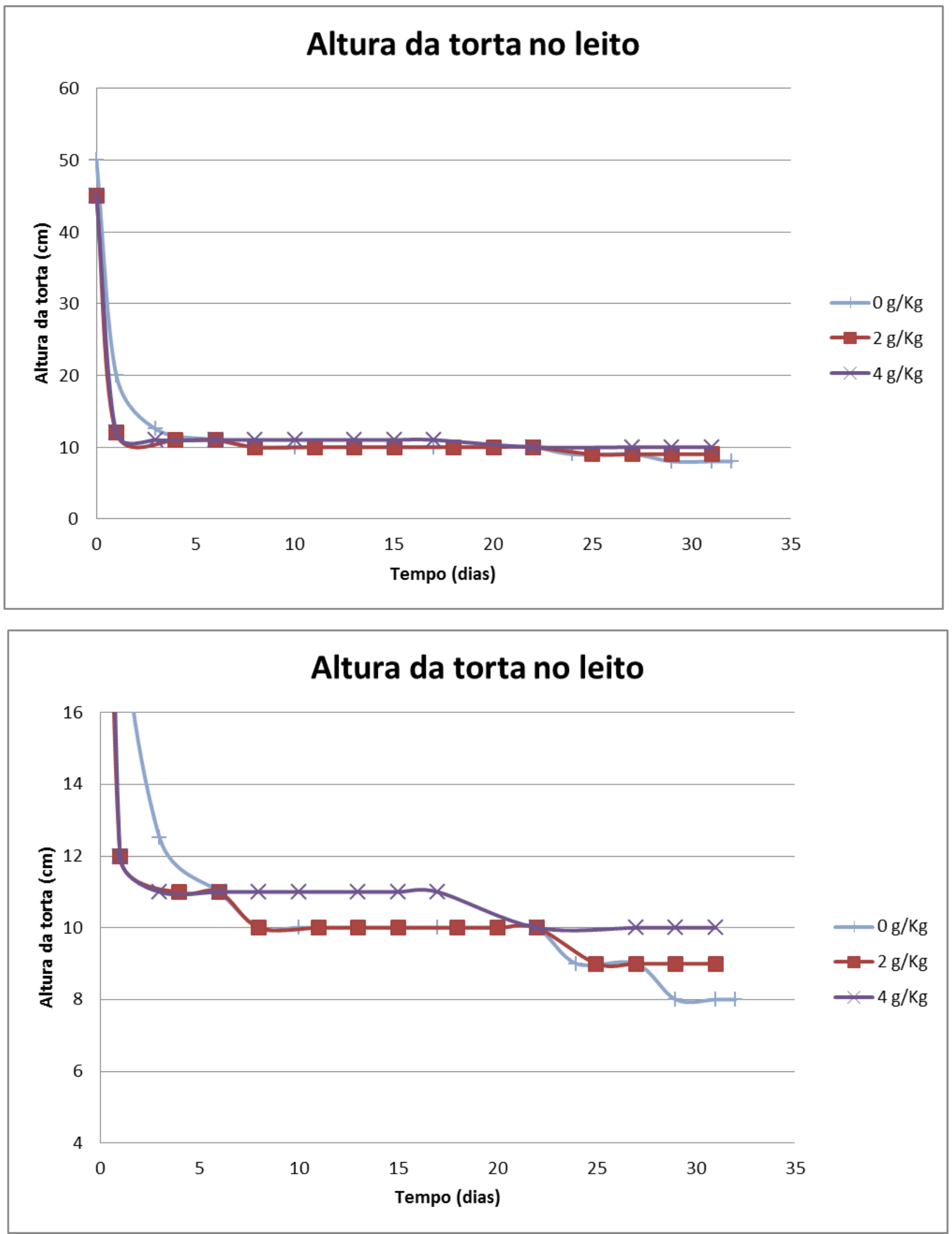

Figura 98 - Resultado da altura da torta nos ensaios E9 a E11 

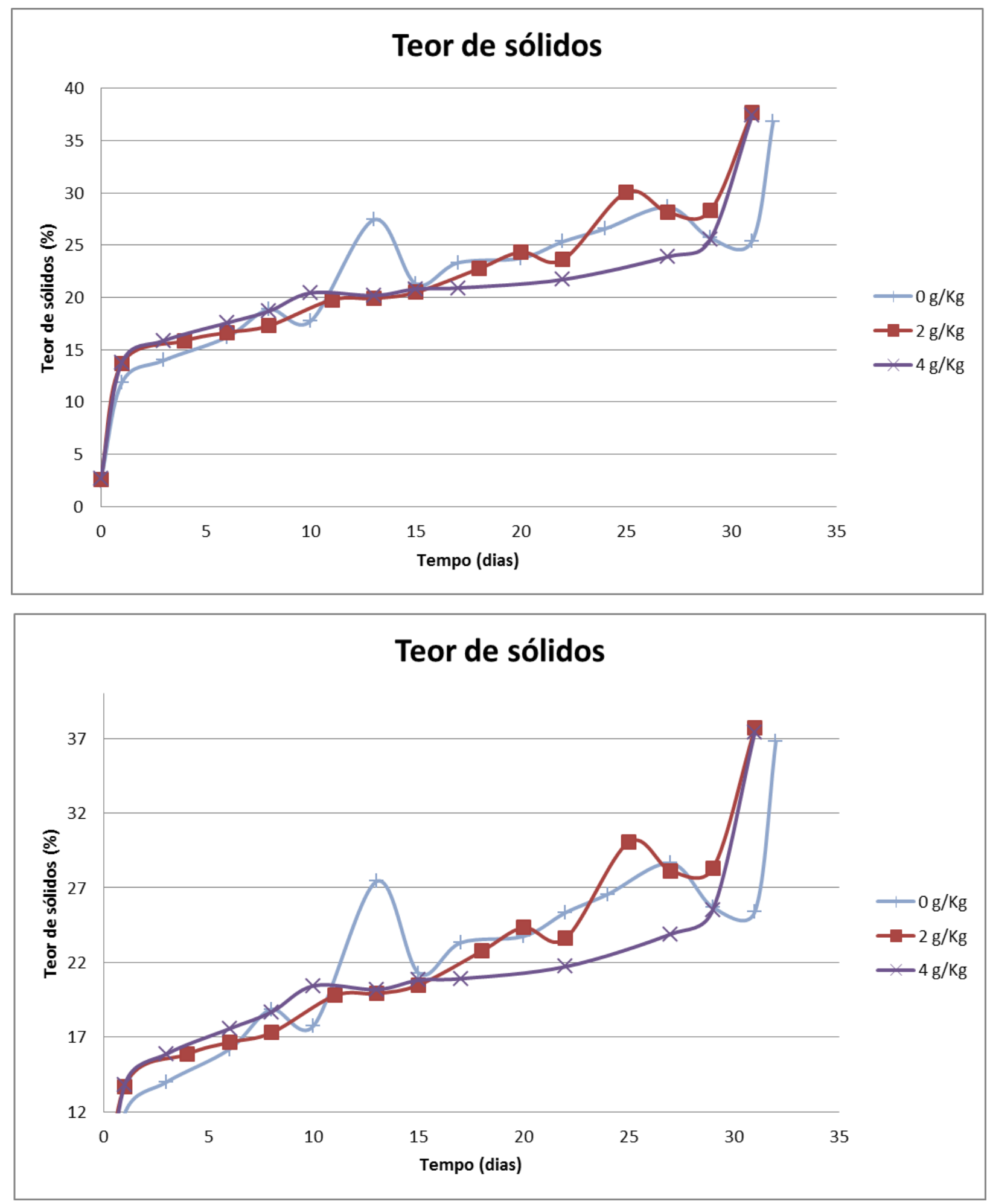

Figura 99 - Resultados do teor de sólidos nos ensaios E9 a E11 


\section{APÊNDICE 9 - Resultados das análises do drenado dos ensaios piloto}
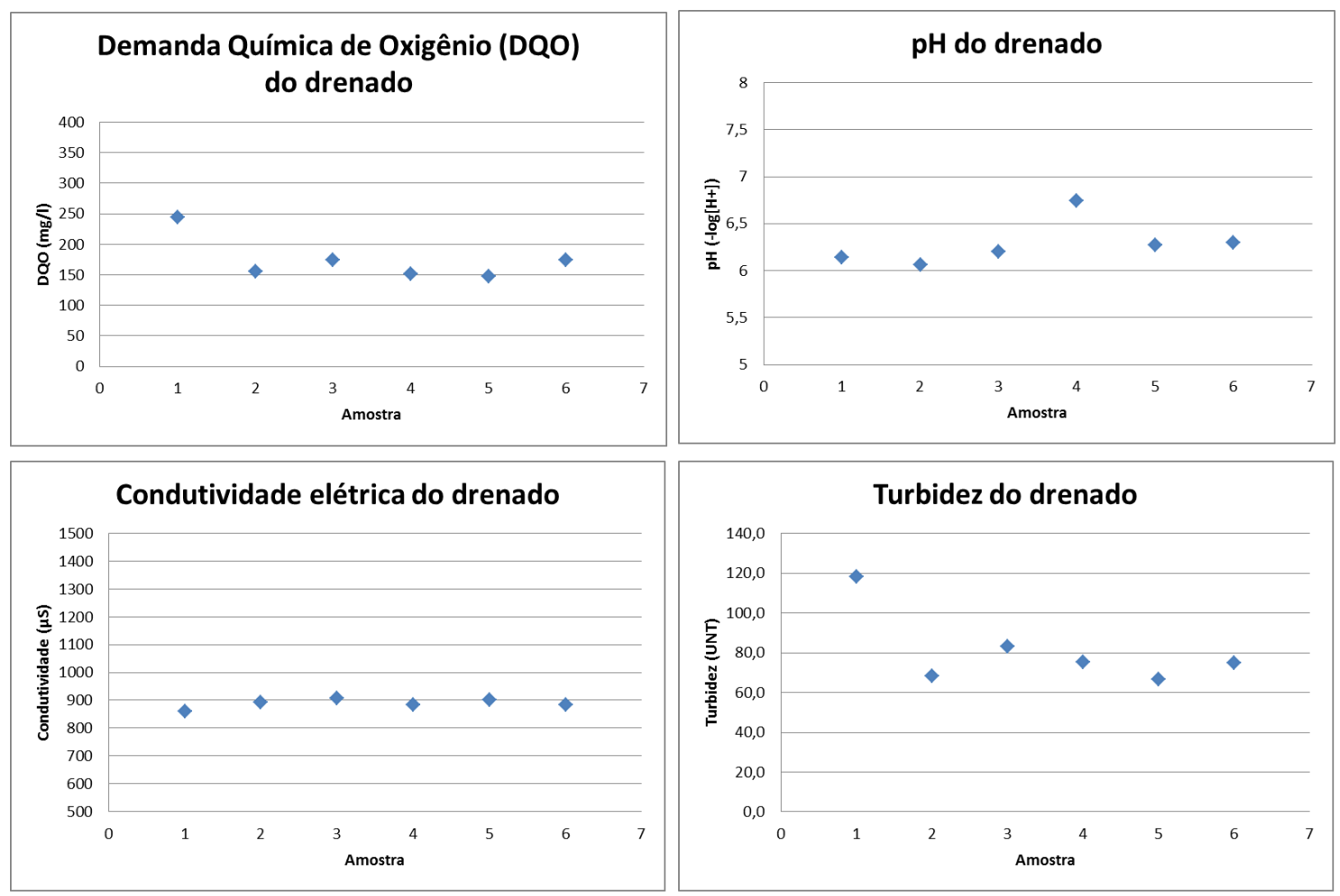

Figura 100 - Ensaio $1-\mathrm{Dc}=1 \mathrm{~g} / \mathrm{kgST}$ e $\mathrm{Ca}=19,82 \mathrm{kgST} / \mathrm{m}^{2}$.ciclo $-\mathrm{DQO}$, Condutividade, $\mathrm{pH}$ e turbidez do drenado 

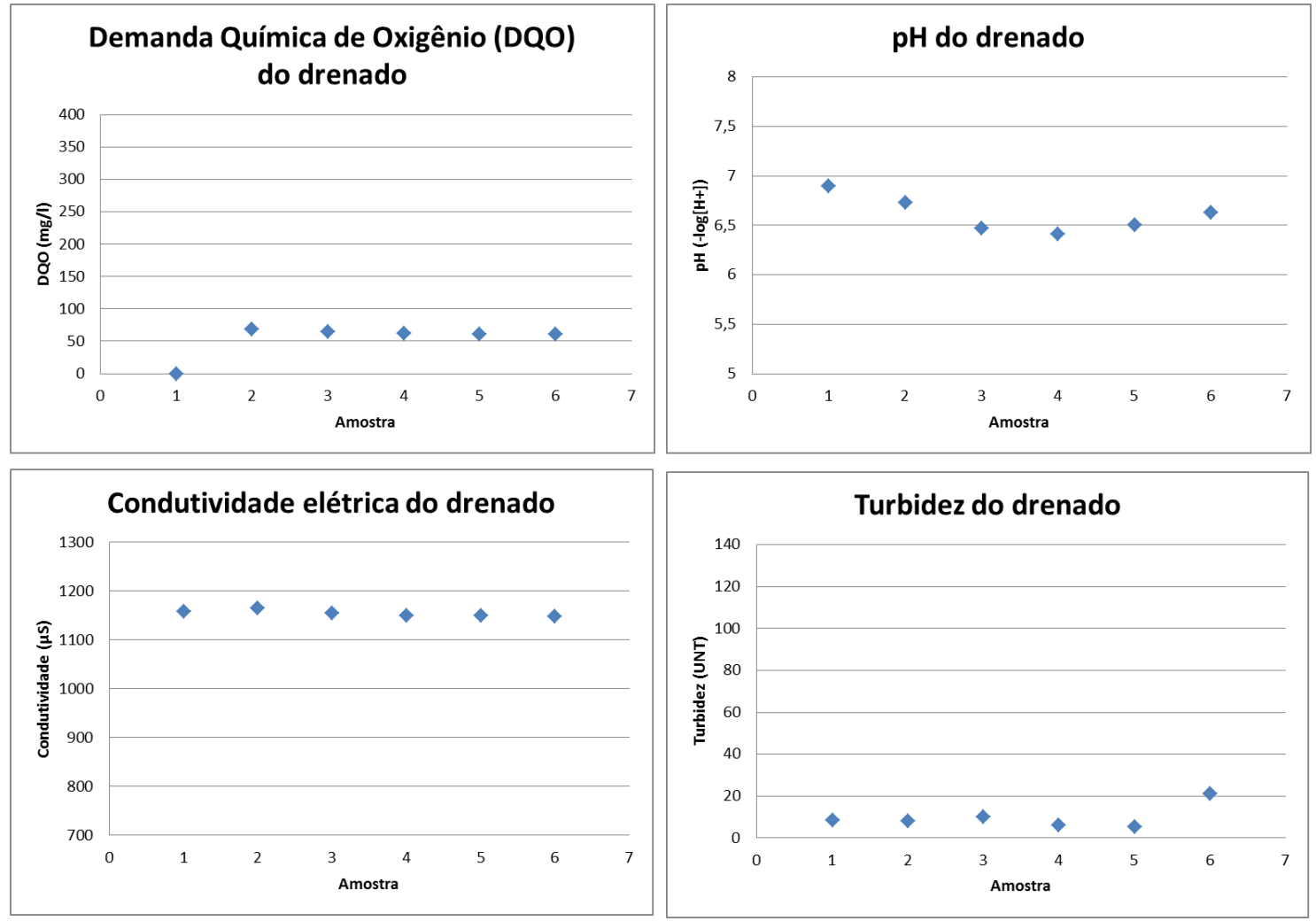

Figura 101 - Ensaio $2-\mathrm{Dc}=2 \mathrm{~g} / \mathrm{kgST}$ e $\mathrm{Ca}=19,02 \mathrm{kgST} / \mathrm{m}^{2}$.ciclo $-\mathrm{DQO}$, Condutividade, $\mathrm{pH}$ e turbidez do drenado
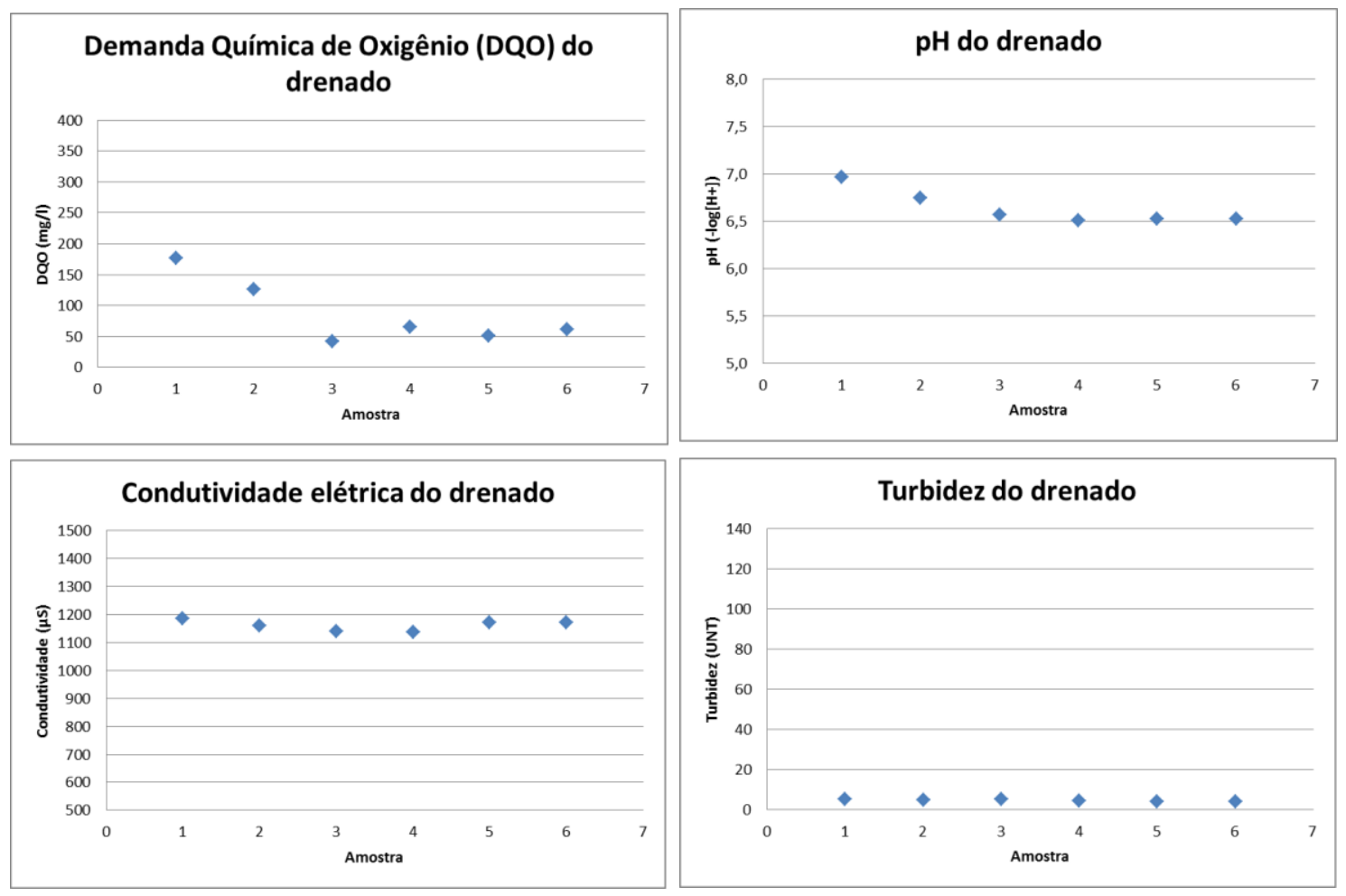

Figura 102 - Ensaio 3 - Dc = $3 \mathrm{~g} / \mathrm{kgST}$ e $\mathrm{Ca}=14,7 \mathrm{kgST} / \mathrm{m}^{2}$.ciclo - DQO, Condutividade, $\mathrm{pH}$ e turbidez do drenado 

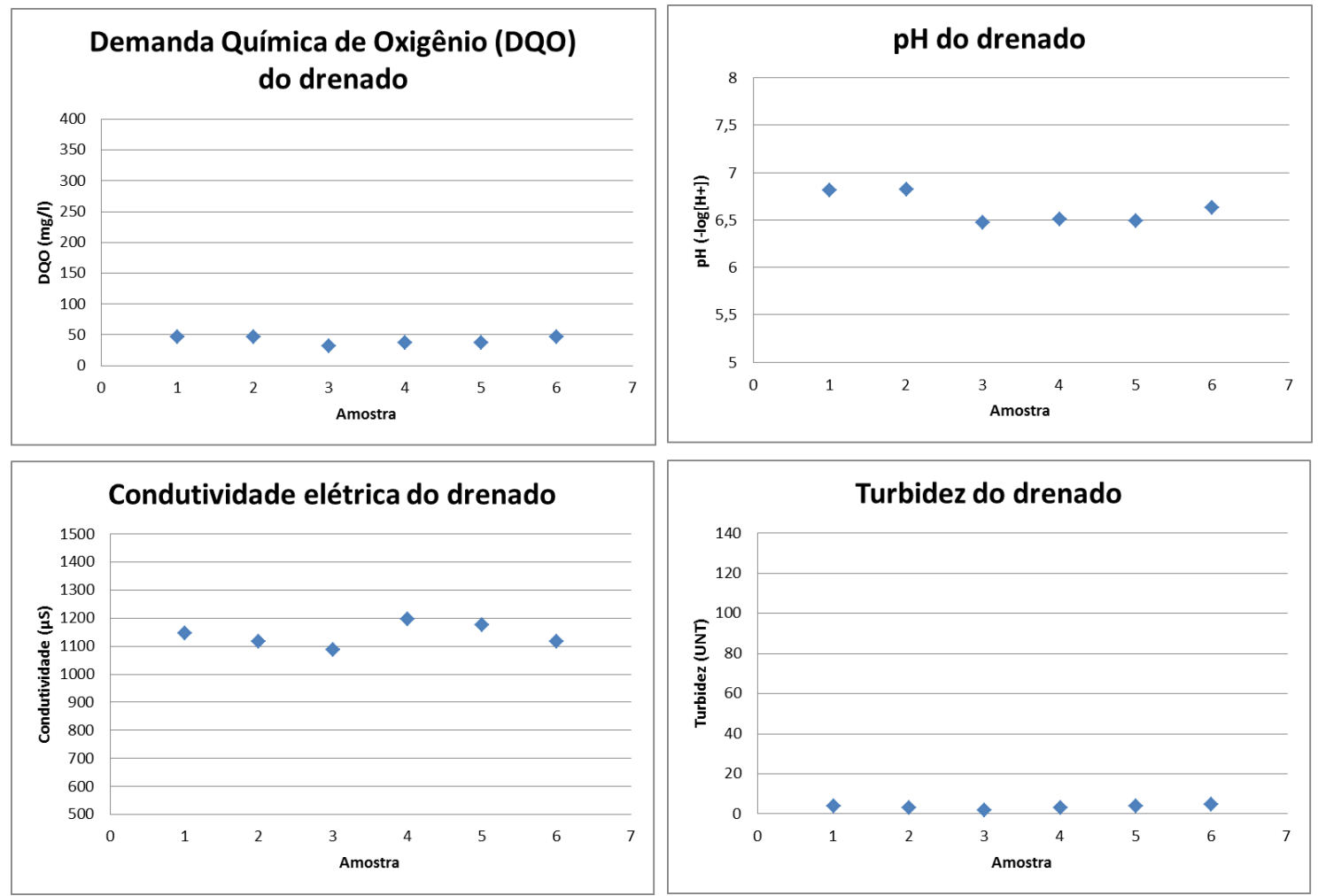

Figura 103 - Ensaio 4 - Dc = 4 g/kgST e $\mathrm{Ca}=14,31 \mathrm{kgST} / \mathrm{m}^{2}$.ciclo - DQO, Condutividade, $\mathrm{pH}$ e turbidez do drenado
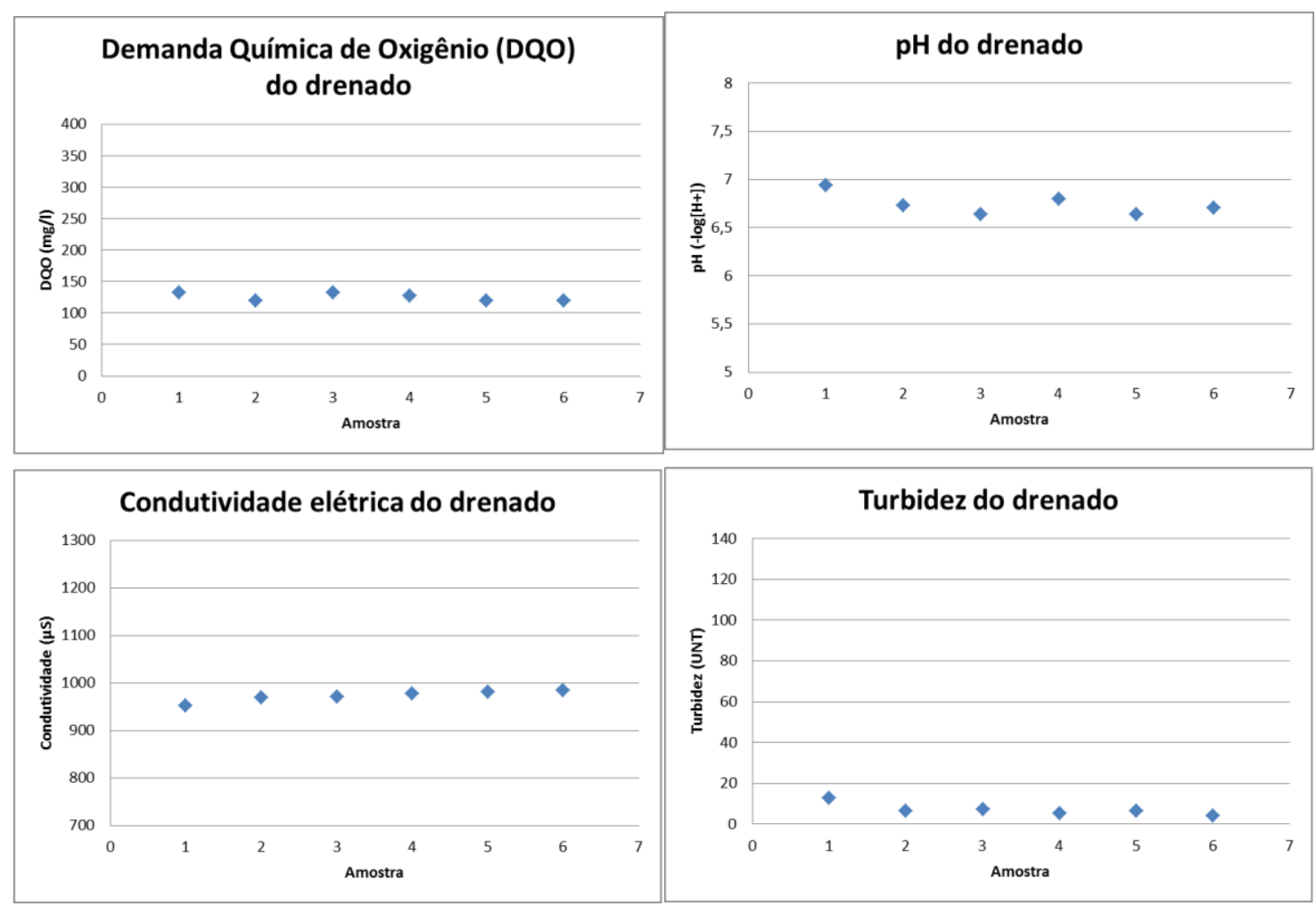

Figura 104 - Ensaio 5 - Dc = $5 \mathrm{~g} / \mathrm{kgST}$ e $\mathrm{Ca}=15,5 \mathrm{kgST} / \mathrm{m}^{2}$.ciclo - DQO, Condutividade, $\mathrm{pH}$ e turbidez do drenado 

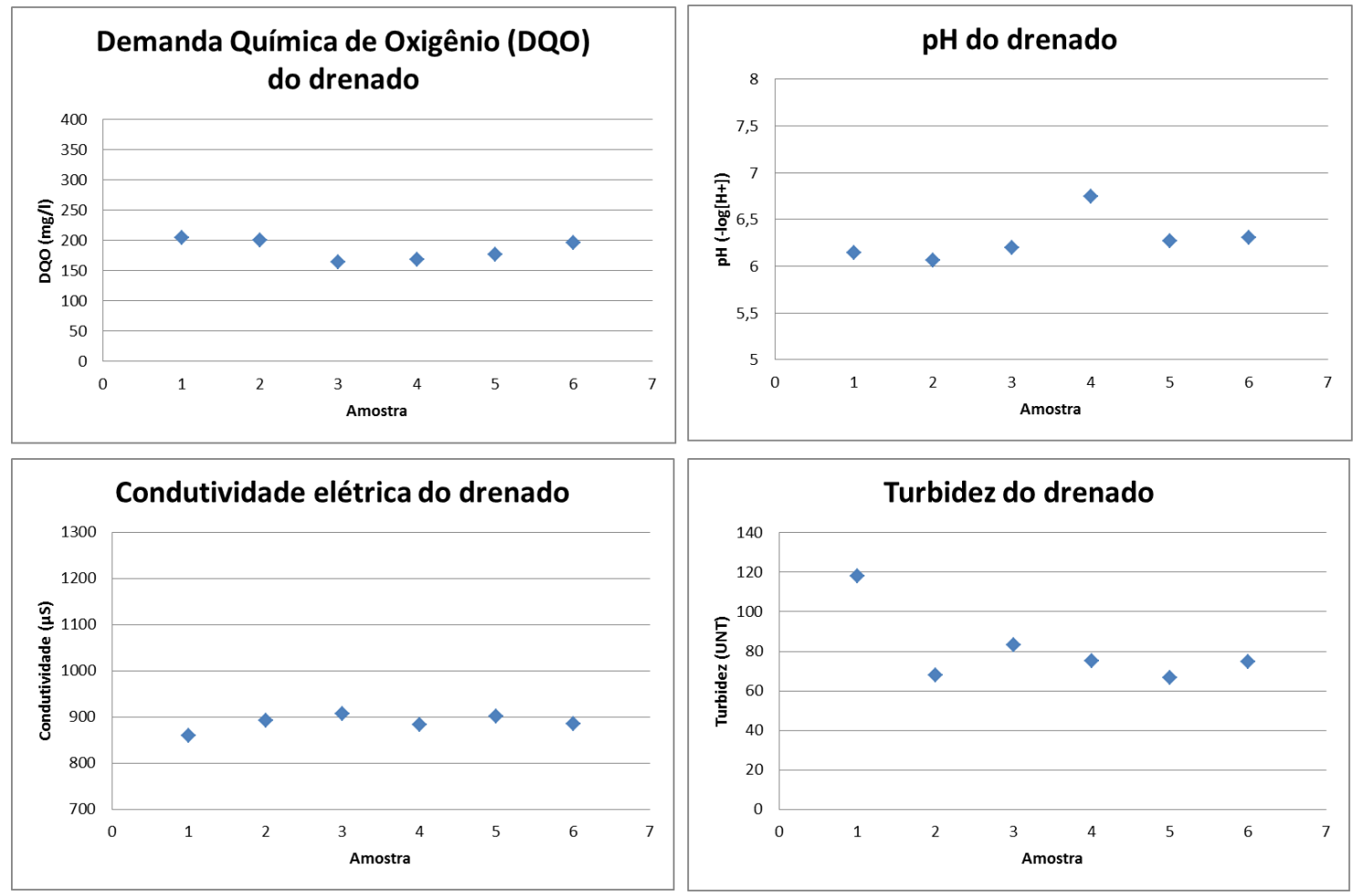

Figura 105 - Ensaio 6 - Dc = $6 \mathrm{~g} / \mathrm{kgST}$ e $\mathrm{Ca}=15,06 \mathrm{kgST} / \mathrm{m}^{2}$.ciclo - DQO, Condutividade, $\mathrm{pH}$ e turbidez do drenado
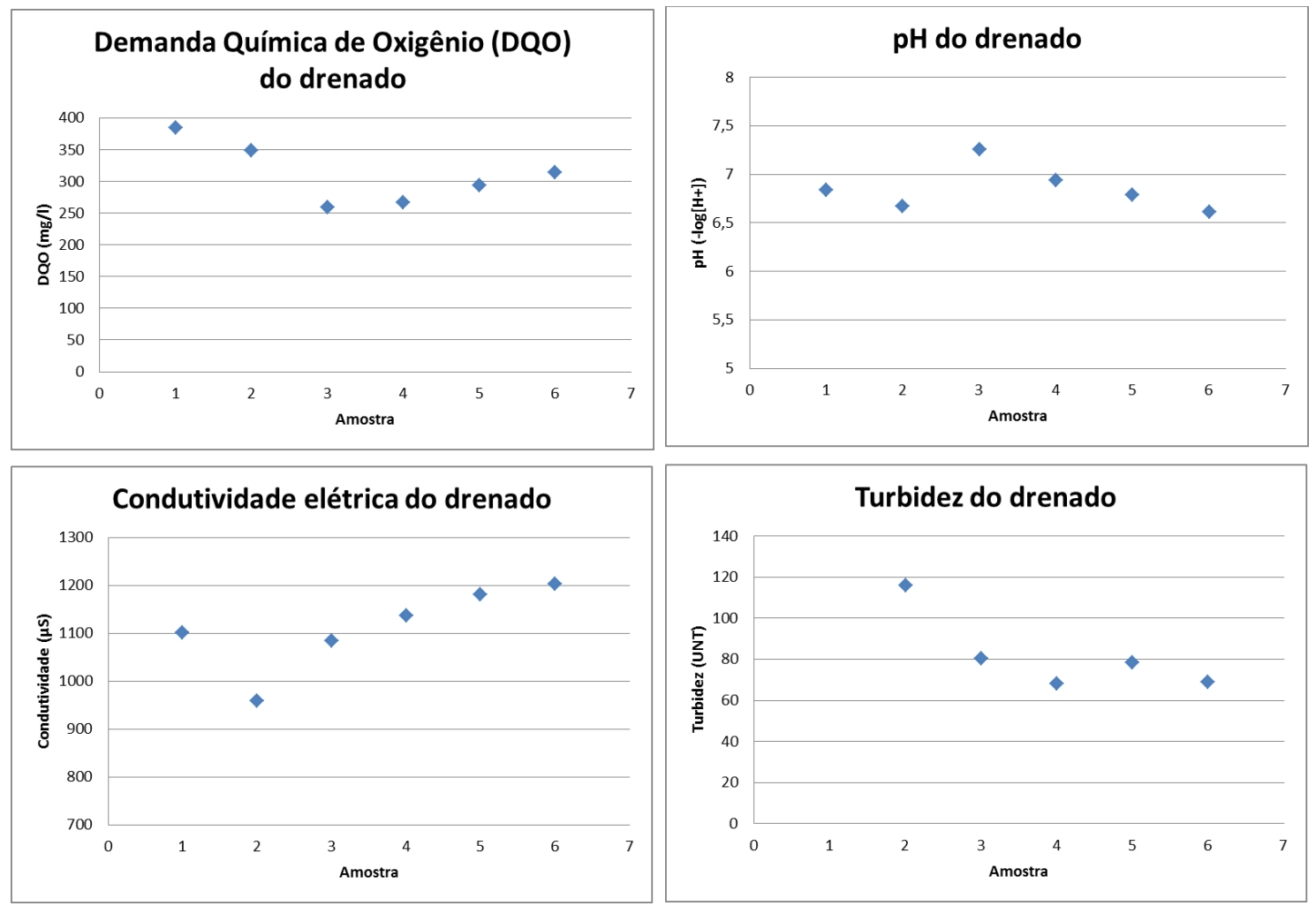

Figura 106 - Ensaio 7 - Dc = $0 \mathrm{~g} / \mathrm{kgST}$ e $\mathrm{Ca}=15,35 \mathrm{kgST} / \mathrm{m}^{2}$.ciclo - DQO, Condutividade, $\mathrm{pH}$ e turbidez do drenado 

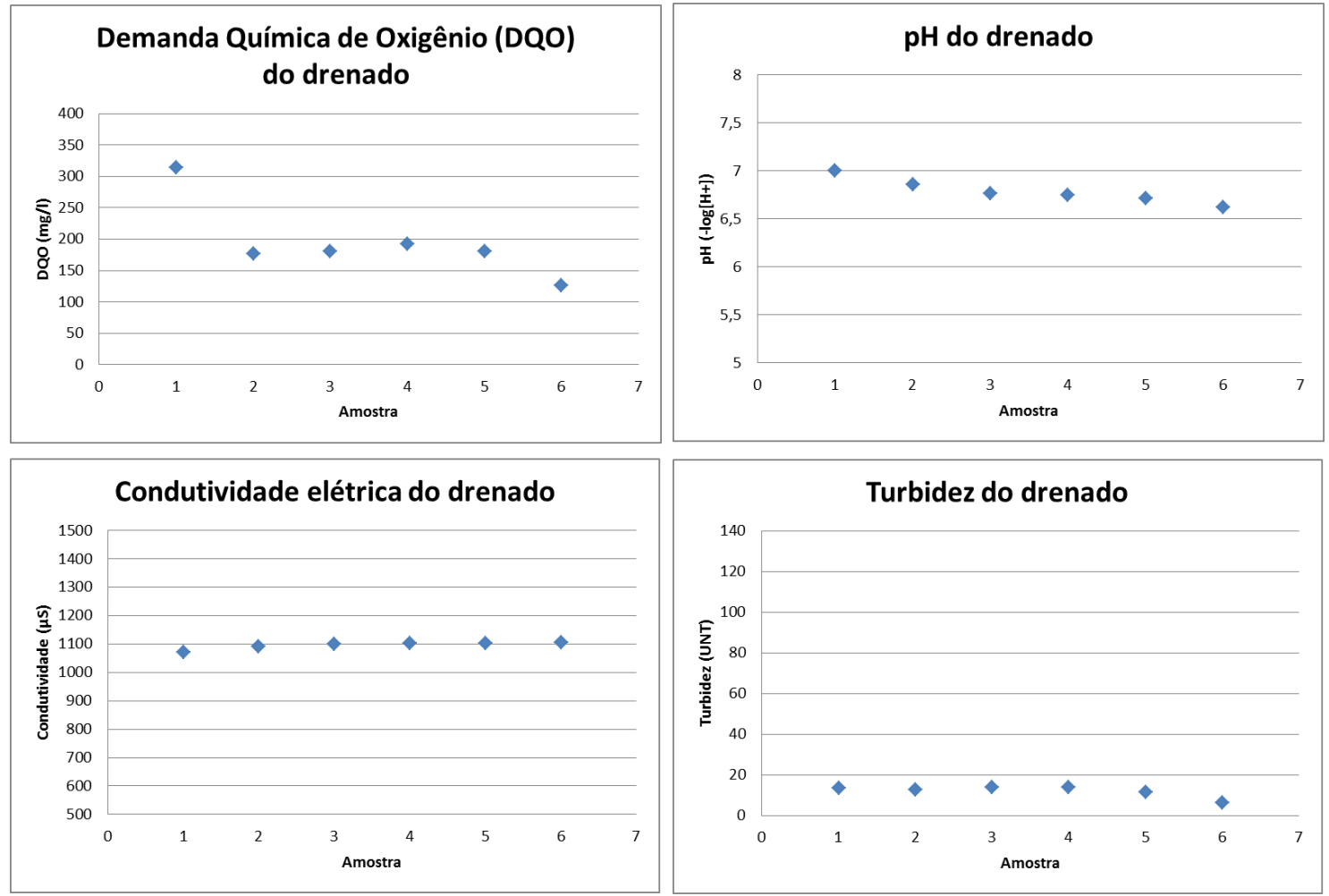

Figura 107 - Ensaio 8 - Dc = $8 \mathrm{~g} / \mathrm{kgST}$ e $\mathrm{Ca}=12,81 \mathrm{kgST} / \mathrm{m}^{2}$.ciclo - DQO, Condutividade, $\mathrm{pH}$ e turbidez do drenado
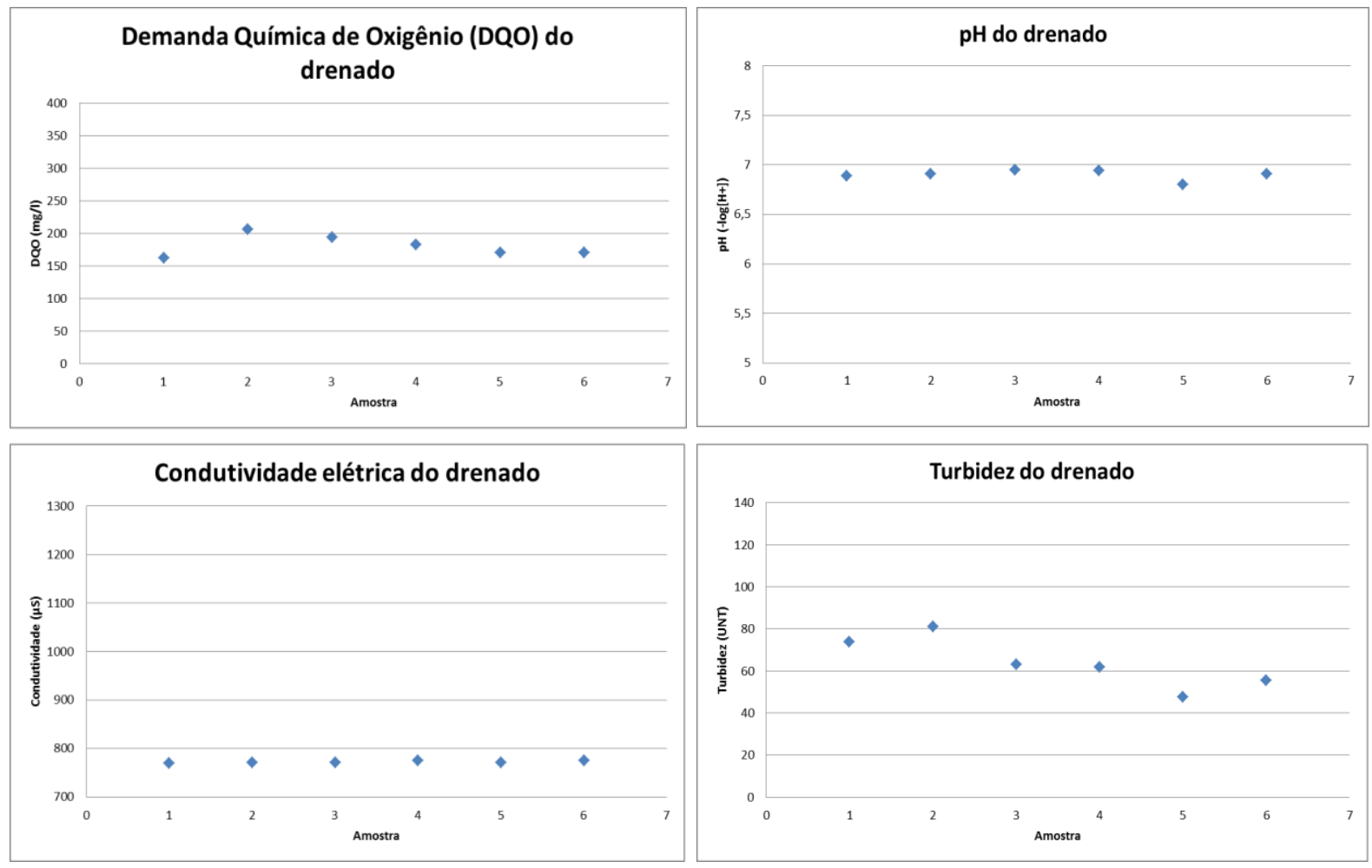

Figura 108 - Ensaio 9 - Dc = $0 \mathrm{~g} / \mathrm{kgST}$ e $\mathrm{Ca}=13,59 \mathrm{kgST} / \mathrm{m}^{2}$.ciclo $-\mathrm{DQO}$, Condutividade, $\mathrm{pH}$ e turbidez do drenado 

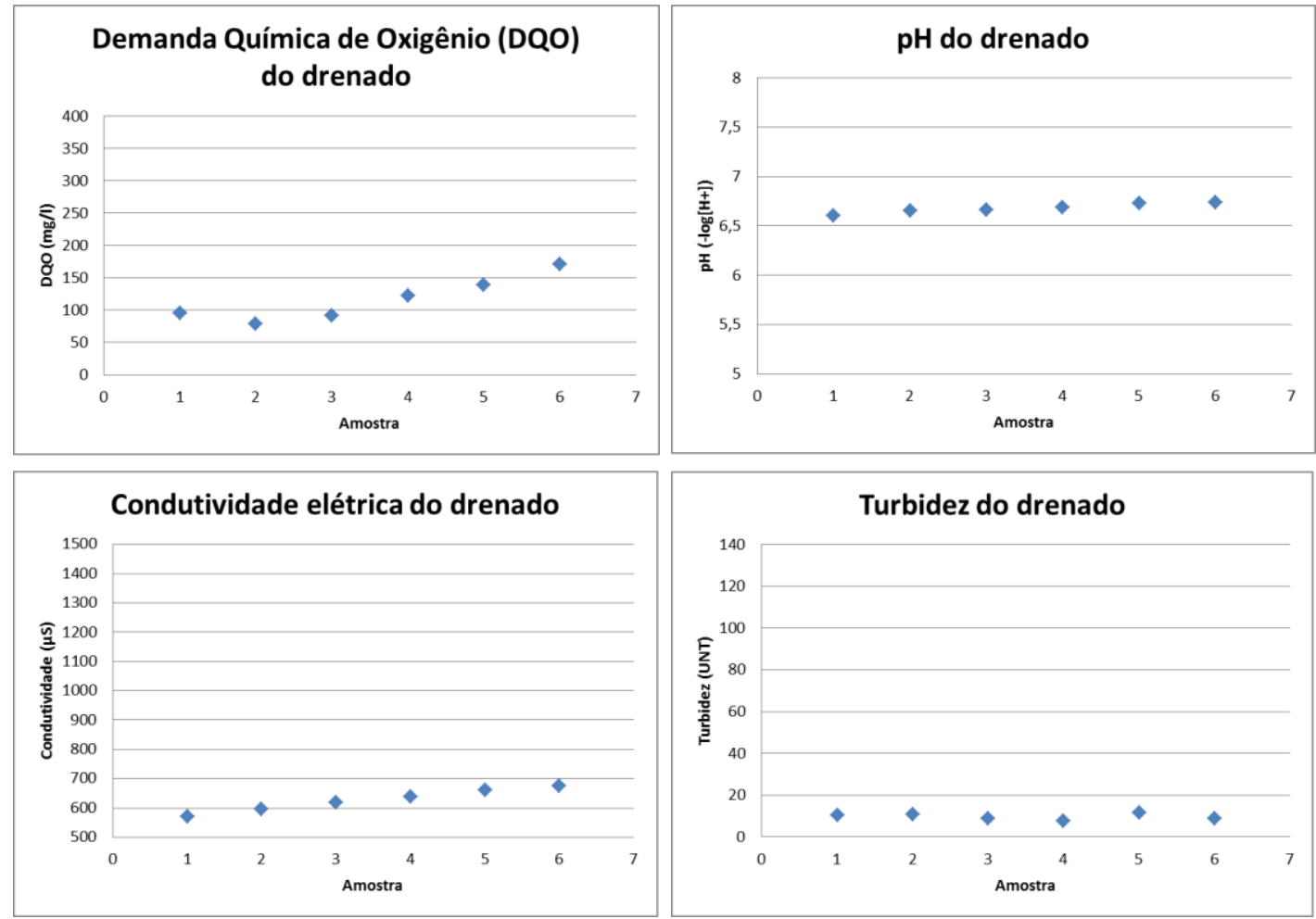

Figura 109 - Ensaio $10-\mathrm{Dc}=2 \mathrm{~g} / \mathrm{kgST}$ e $\mathrm{Ca}=14,57 \mathrm{kgST} / \mathrm{m}^{2}$. ciclo $-\mathrm{DQO}$, Condutividade, $\mathrm{pH}$ e turbidez do drenado
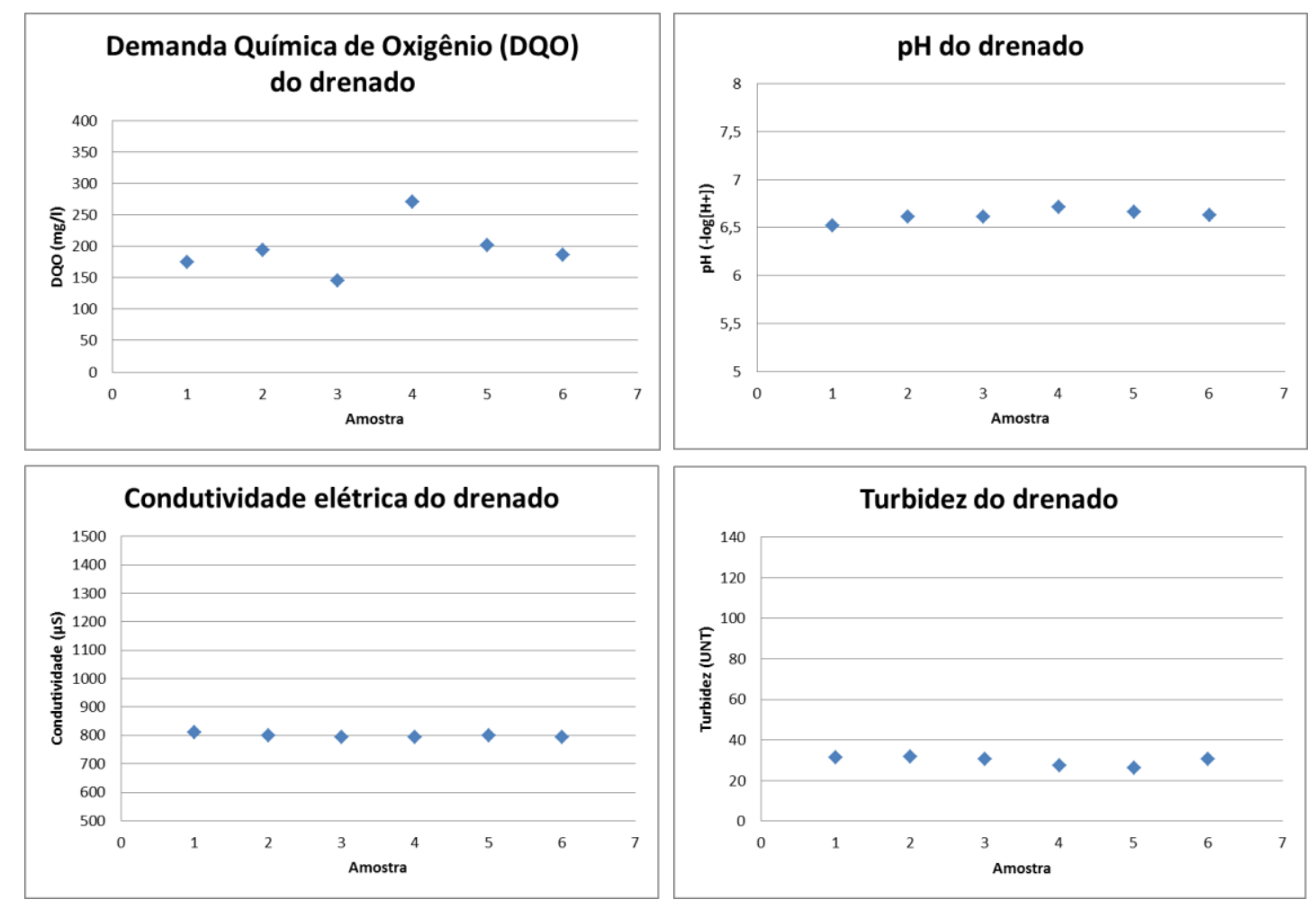

Figura 110 - Ensaio $11-\mathrm{Dc}=4 \mathrm{~g} / \mathrm{kgST}$ e $\mathrm{Ca}=14,89 \mathrm{kgST} / \mathrm{m}^{2}$. ciclo $-\mathrm{DQO}$, Condutividade, $\mathrm{pH}$ e turbidez do drenado 

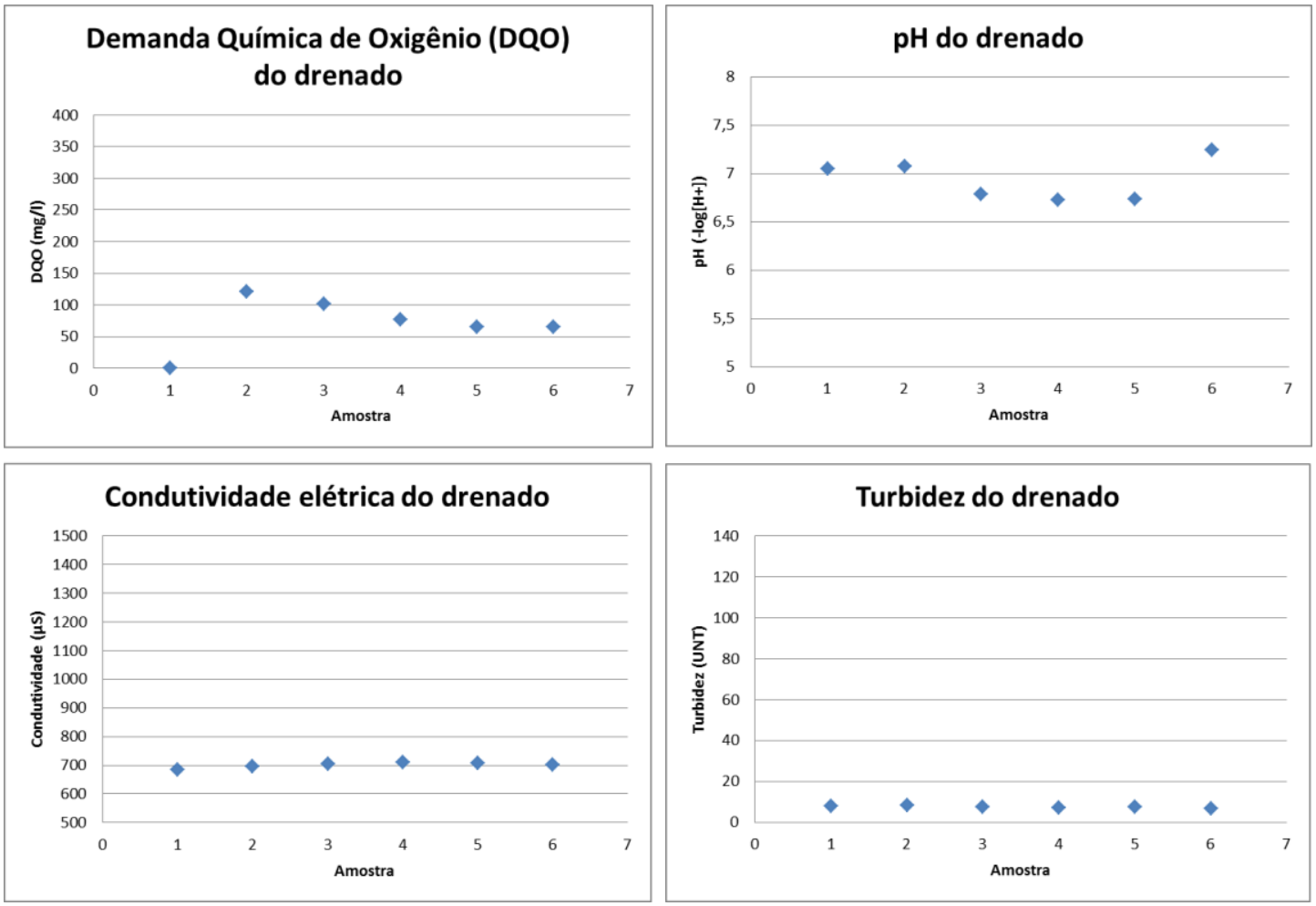

Figura 111 - Ensaio $12-\mathrm{Dc}=2 \mathrm{~g} / \mathrm{kgST}$ e $\mathrm{Ca}=14,38 \mathrm{kgST} / \mathrm{m}^{2}$.ciclo $-\mathrm{DQO}$, Condutividade, $\mathrm{pH}$ e turbidez do drenado
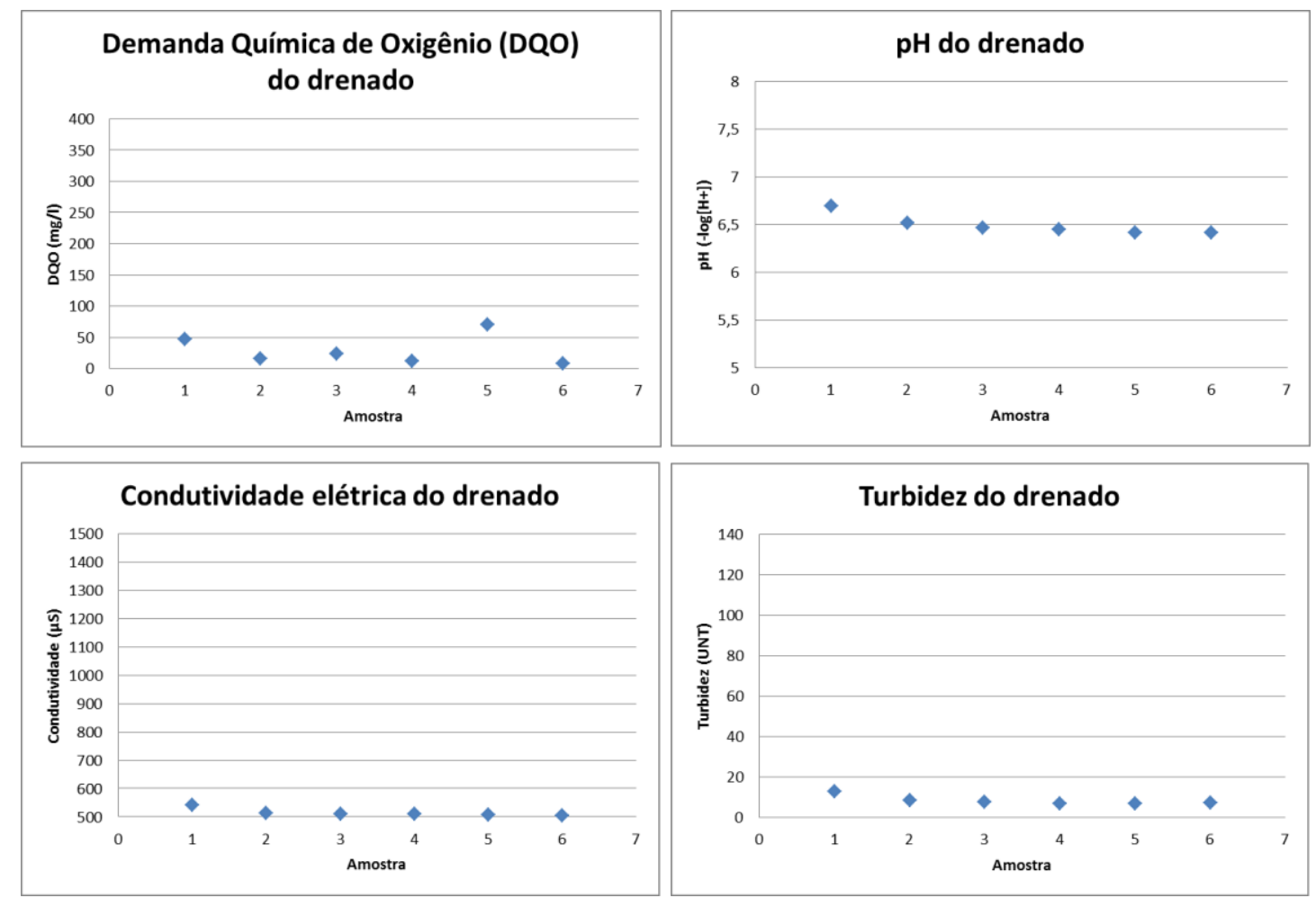

Figura 112 - Ensaio $13-\mathrm{Dc}=2 \mathrm{~g} / \mathrm{kgST}$ e $\mathrm{Ca}=21,24 \mathrm{kgST} / \mathrm{m}^{2}$.ciclo $-\mathrm{DQO}$, Condutividade, $\mathrm{pH}$ e turbidez do drenado 

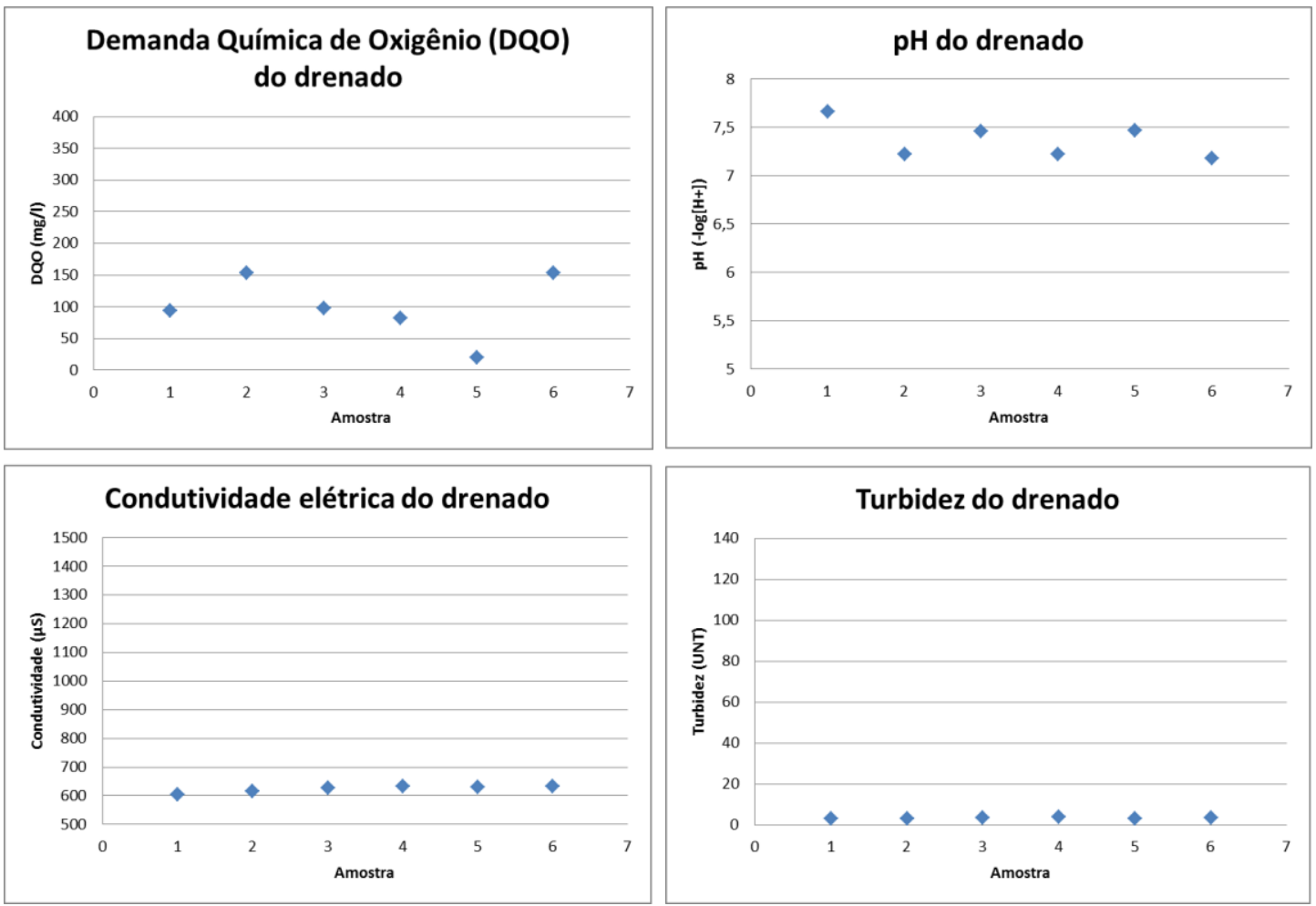

Figura 113 - Ensaio $14-\mathrm{Dc}=2 \mathrm{~g} / \mathrm{kgST}$ e $\mathrm{Ca}=9,77 \mathrm{kgST} / \mathrm{m}^{2}$.ciclo $-\mathrm{DQO}$, Condutividade, $\mathrm{pH}$ e turbidez do drenado 


\section{APÊNDICE 10 - Sequência de fotos ilustrativa do aspecto da torta} formada ao longo do ciclo de secagem do ensaio E10.
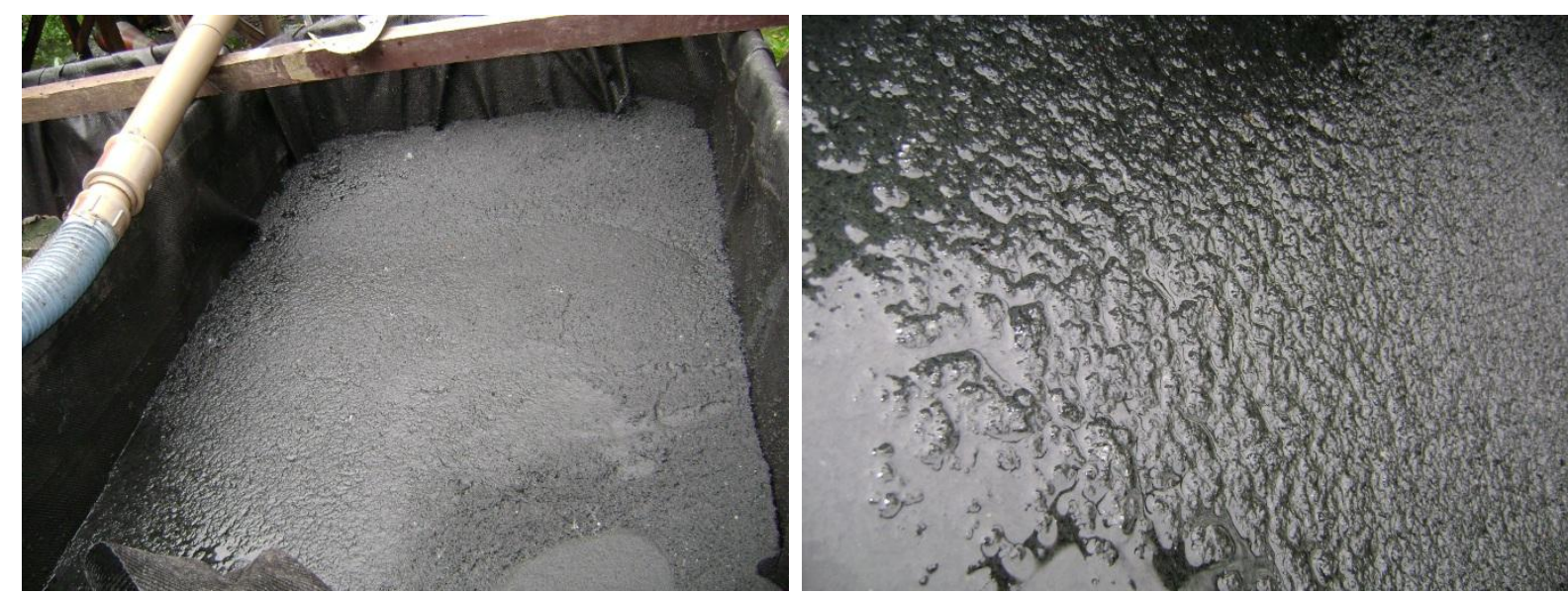

Figura 114 - Alimentação do leito de drenagem com lodo condicionado ( $\mathrm{Dc}=2 \mathrm{~g} / \mathrm{kgST}$ e Ca $=14,57$ $\left.\mathrm{kgST} / \mathrm{m}^{2}\right)$
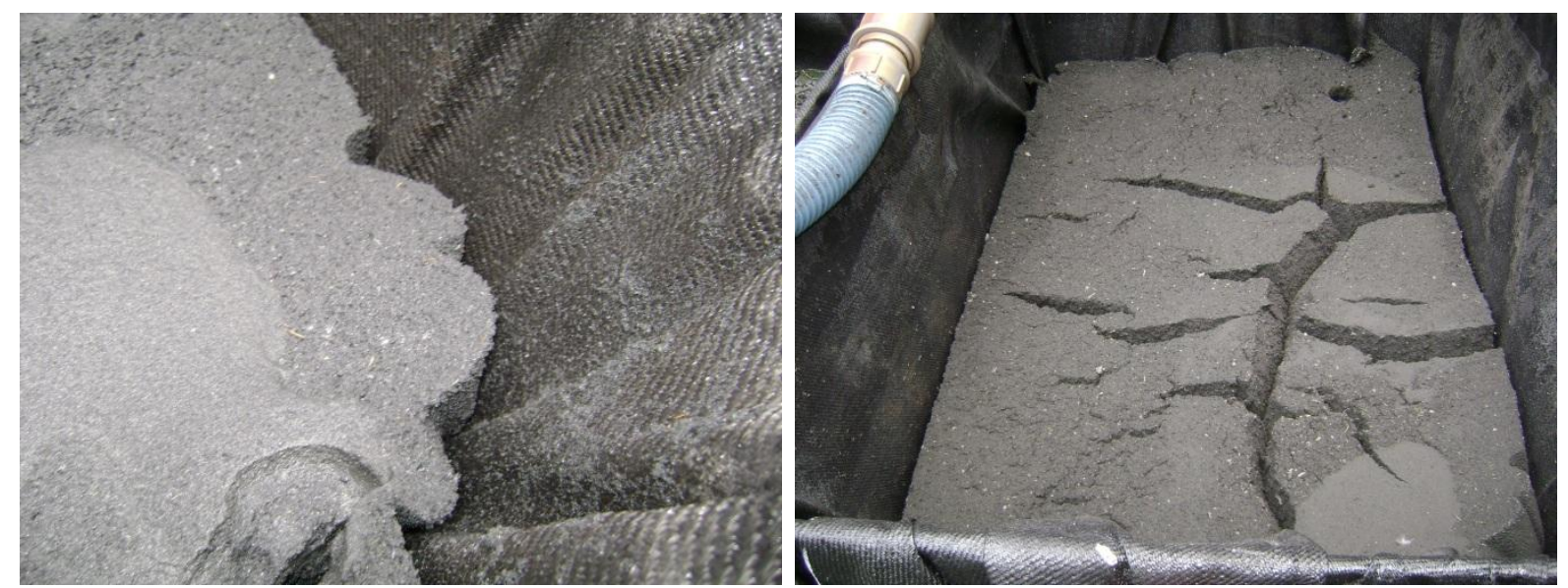

Figura 115 - Aspecto da torta com 4 dias de secagem 

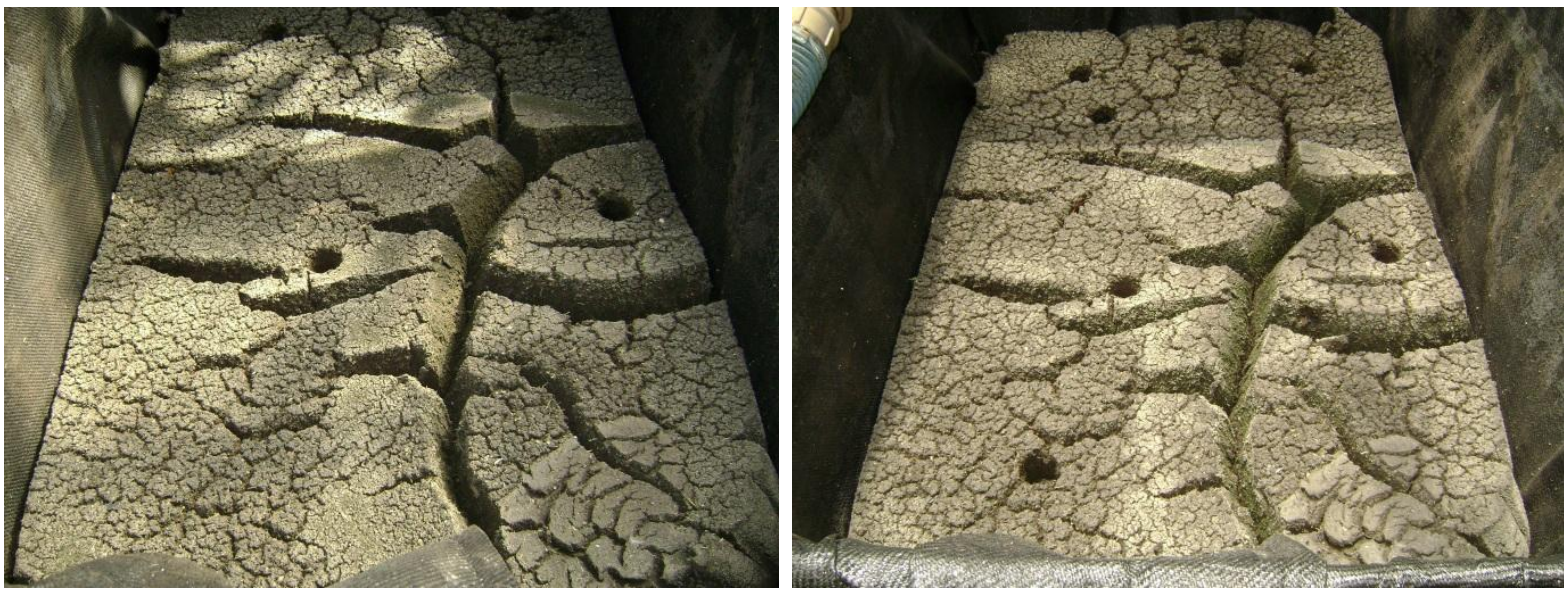

Figura 116 - Aspecto da torta com 8 (esquerda) e 13 (direita) dias de secagem
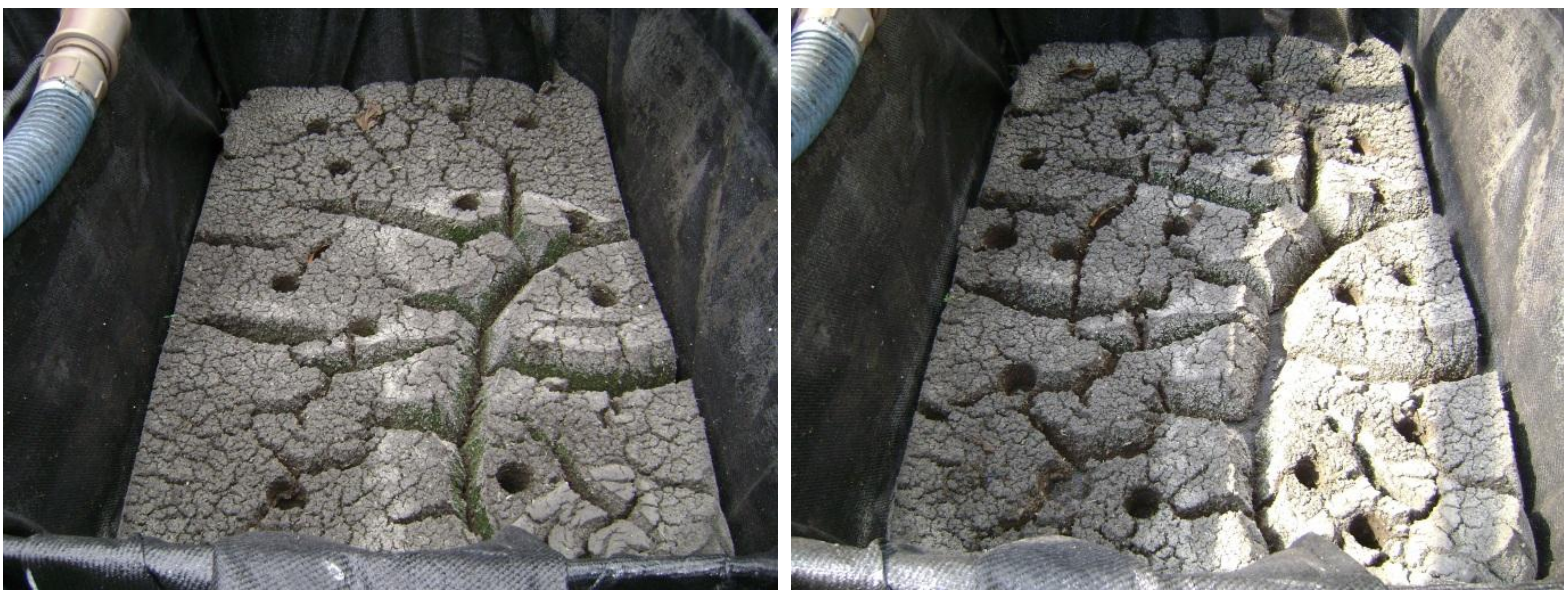

Figura 117 - Aspecto da torta com 18 (esquerda) e 25 (direita) dias de secagem
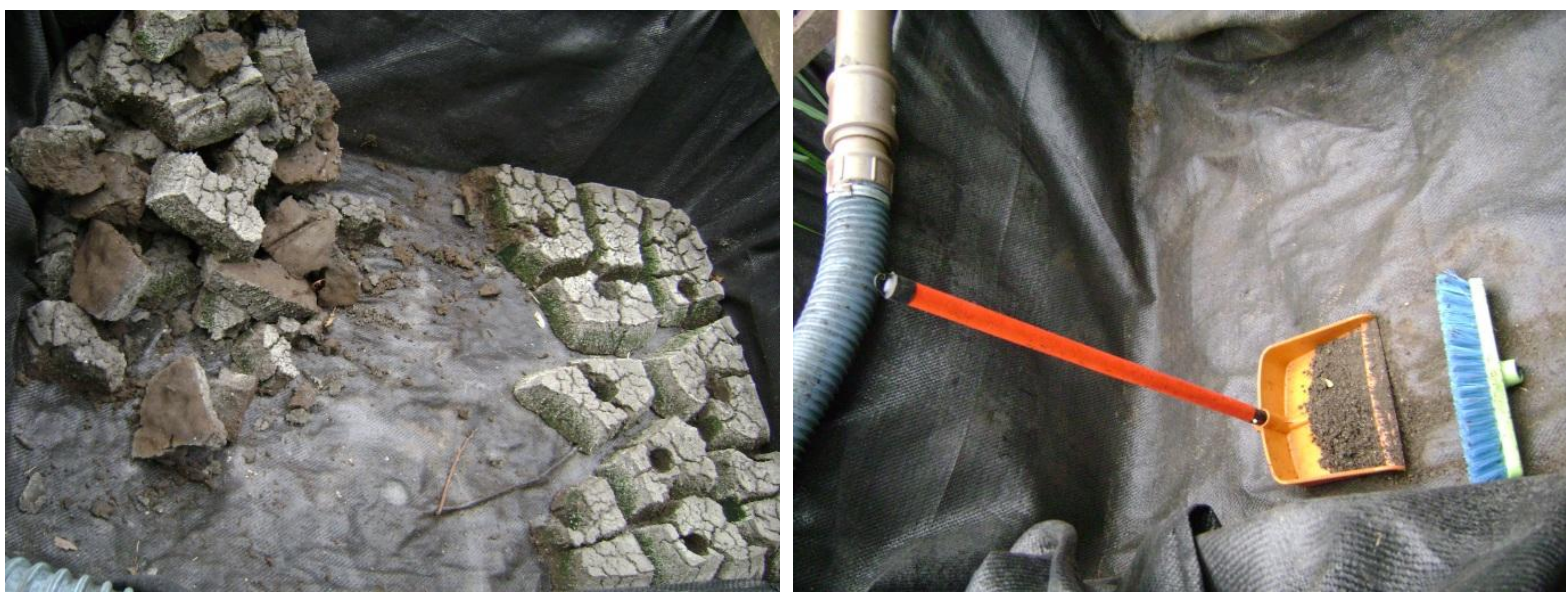

Figura 118 - Remoção da torta no $31^{\circ}$ dia de secagem 


\section{ANEXO A - Características dos polímeros}

Tabela 42 - Planilha com as características dos polímeros utilizados nos ensaios laboratoriais e em escala piloto

\begin{tabular}{|c|c|c|c|c|c|c|c|c|c|c|c|}
\hline \multicolumn{12}{|c|}{ Características dos polímeros } \\
\hline marca & produto & $\begin{array}{l}\text { forma } \\
\text { física }\end{array}$ & $\begin{array}{c}\text { peso } \\
\text { molecular }\end{array}$ & $\begin{array}{c}\text { densidade } \\
\text { da carga }\end{array}$ & $\begin{array}{l}\text { tipo da } \\
\text { carga }\end{array}$ & $\begin{array}{c}\text { concentração de } \\
\text { abertura de } \\
\text { cadeia (\%) }\end{array}$ & $\begin{array}{l}\text { tempo de } \\
\text { mistura } \\
\text { (min) }\end{array}$ & $\begin{array}{l}\text { rotação ou } \\
\text { gradiente } \\
\text { de mistura } \\
\quad(\mathrm{rpm})\end{array}$ & $\begin{array}{c}\text { validade } \\
\text { da } \\
\text { solução } \\
\text { estoque } \\
\text { (dias) } \\
\end{array}$ & $\begin{array}{l}\text { preço do } \\
\text { produto }\end{array}$ & $\begin{array}{c}\text { forma de } \\
\text { comercialização }\end{array}$ \\
\hline \multirow{7}{*}{$\begin{array}{l}\text { ASHLAND - } \\
\text { PRAESTOL }\end{array}$} & $\mathrm{K} 111 \mathrm{~L}$ & emulsão & & levemente & catiônico & 0,2 a 0,5 & 15 & $\begin{array}{c}\text { entre } 80 \text { e } \\
100 \text { rpm e } \\
\text { uniforme }\end{array}$ & 1 & $11 \mathrm{R} \$ / \mathrm{kg}$ & $\begin{array}{c}\text { bombona de } 50 \text { ou } \\
\text { conteiner de } 1000 \\
\mathrm{~kg}\end{array}$ \\
\hline & K144L & emulsão & & muito forte & catiônico & 0,2 a 0,5 & 15 & $\begin{array}{l}\text { entre } 80 \text { e } \\
100 \text { rpm e } \\
\text { uniforme }\end{array}$ & 1 & $13,2 \mathrm{R} \$ / \mathrm{kg}$ & \begin{tabular}{|c|}
$\begin{array}{c}\text { bombona de } 50 \text { ou } \\
\text { conteiner de } 1000 \\
\mathrm{~kg}\end{array}$ \\
\end{tabular} \\
\hline & K133L & emulsão & & fortemente & catiônico & 0,2 a 0,5 & 15 & $\begin{array}{c}\text { entre } 80 \text { e } \\
100 \text { rpm e } \\
\text { uniforme } \\
\end{array}$ & 1 & $\begin{array}{l}14,15 \\
\mathrm{R} \$ / \mathrm{kg}\end{array}$ & $\begin{array}{c}\text { bombona de } 50 \text { ou } \\
\text { conteiner de } 1000 \\
\mathrm{~kg}\end{array}$ \\
\hline & $650 \mathrm{TR}$ & pó & alto & media & catiônico & $<0,05$ & 60 & $\begin{array}{c}\text { entre } 80 \mathrm{e} \\
100 \mathrm{rpm} \text { e } \\
\text { suave }\end{array}$ & 2 & $\begin{array}{c}9,45 \\
\text { US\$/Kg }\end{array}$ & sacos de $25 \mathrm{~kg}$ \\
\hline & $851 B C$ & pó & muito alto & levemente & catiônico & 0,1 a 0,05 & 60 & $\begin{array}{c}\text { entre } 80 \text { e } \\
100 \text { rpm e } \\
\text { uniforme }\end{array}$ & 3 & $\begin{array}{c}8,7 \\
\text { US } \$ / K g\end{array}$ & sacos de $25 \mathrm{~kg}$ \\
\hline & $853 B C$ & pó & muito alto & levemente & catiônico & 0,1 a 0,05 & 60 & $\begin{array}{l}\text { entre } 80 \text { e } \\
100 \text { rpm e } \\
\text { uniforme }\end{array}$ & 3 & 9 US\$/Kg & sacos de $25 \mathrm{~kg}$ \\
\hline & 857BS & pó & muito alto & fortemente & catiônico & 0,1 & 60 & $\begin{array}{l}\text { entre } 80 \text { e } \\
100 \text { rpm e } \\
\text { uniforme }\end{array}$ & 3 & $\begin{array}{c}10,6 \\
\text { US\$/Kg }\end{array}$ & sacos de $25 \mathrm{~kg}$ \\
\hline \multirow{3}{*}{$\begin{array}{l}\text { CIBA - } \\
\text { ZETAG }\end{array}$} & 8160 & sólido & muito alto & media-alta & catiônico & 0,05 a 0,025 & & & & $\begin{array}{c}7,3 \\
\text { US } \$ / \mathrm{Kg}\end{array}$ & sacos de $25 \mathrm{~kg}$ \\
\hline & 8165 & sólido & alto & media-alta & catiônico & 0,05 a 0,2 & & & 1 a 3 & $\begin{array}{c}7,38 \\
\text { US\$/Kg }\end{array}$ & sacos de $25 \mathrm{~kg}$ \\
\hline & 8180 & sólido & alto & alta & catiônico & 0,05 a 0,2 & & & 1 a 3 & $\begin{array}{c}7,42 \\
\text { US\$/Kg }\end{array}$ & sacos de $25 \mathrm{~kg}$ \\
\hline \multirow{4}{*}{$\begin{array}{l}\text { KEMIRA - } \\
\text { SUPERFLOC }\end{array}$} & 492 & sólido & alto & confidencial & catiônico & 0,3 & 30 & 400 & & 7 US\$/Kg & sacos de $25 \mathrm{~kg}$ \\
\hline & 494 & sólido & alto & confidencial & catiônico & 0,3 & 30 & 400 & & $\begin{array}{c}7,6 \\
\text { US } \$ / \mathrm{Kg} \\
\end{array}$ & sacos de $25 \mathrm{~kg}$ \\
\hline & 496 & sólido & alto & confidencial & catiônico & 0,3 & 30 & 400 & & $\begin{array}{c}8,8 \\
\text { US } \$ / \mathrm{Kg}\end{array}$ & sacos de $25 \mathrm{~kg}$ \\
\hline & 498 & sólido & alto & confidencial & catiônico & 0,3 & 30 & 400 & & $\begin{array}{c}9,25 \\
\text { US } \$ / \mathrm{Kg}\end{array}$ & sacos de $25 \mathrm{~kg}$ \\
\hline \multirow{5}{*}{$\begin{array}{l}\text { SNF - } \\
\text { FLONEX }\end{array}$} & 4190SH & pó & muito alto & baixa & catiônico & $\begin{array}{c}1 \text { a } 0,4^{*}\left({ }^{*} \text { pode }\right. \\
\text { ser } 0,2)\end{array}$ & 60 & & 1 & $\begin{array}{c}R \$ \\
20,00 / \mathrm{kg} \\
\end{array}$ & sacos de $25 \mathrm{~kg}$ \\
\hline & $4240 \mathrm{SH}$ & pó & & & catiônico & & & & & $\begin{array}{c}\mathrm{R} \$ \\
20,00 / \mathrm{kg} \\
\end{array}$ & sacos de $25 \mathrm{~kg}$ \\
\hline & $4650 \mathrm{SH}$ & pó & muito alto & alta & catiônico & 1 a $0,4^{*}$ & 90 & & 1 & $\begin{array}{c}\mathrm{R} \$ \\
23,00 / \mathrm{kg}\end{array}$ & sacos de $25 \mathrm{~kg}$ \\
\hline & $4350 \mathrm{SH}$ & pó & muito alto & media & catiônico & 1 a $0,4^{*}$ & 90 & & 1 & $\begin{array}{c}\mathrm{R} \$ \\
23,00 / \mathrm{kg}\end{array}$ & sacos de $25 \mathrm{~kg}$ \\
\hline & $4490 \mathrm{SH}$ & pó & muito alto & media & catiônico & 1 a $0,4^{*}$ & 90 & & 1 & $\begin{array}{c}\mathrm{R} \$ \\
23,00 / \mathrm{kg}\end{array}$ & sacos de $25 \mathrm{~kg}$ \\
\hline
\end{tabular}


ANEXO B - Características dos geotêxteis

Tabela 43 - Planilha com as características de diversos geotêxteis do mercado

\begin{tabular}{|c|c|c|c|c|c|c|c|c|c|c|c|c|}
\hline \multirow{2}{*}{$\begin{array}{c}\text { Características } \\
\text { FÍS ICAS }\end{array}$} & \multirow[t]{2}{*}{ Unidade } & \multirow[t]{2}{*}{$\begin{array}{l}\text { Norma } \\
\text { aplicável }\end{array}$} & \multicolumn{4}{|c|}{$\begin{array}{l}\text { BIDIM: não-tecido, poliéster } \\
\text { estabilizado, filamentos contínuos } \\
\text { agulhados. }\end{array}$} & \multicolumn{4}{|c|}{$\begin{array}{l}\text { MACCAFERRI: não-tecido } \\
\text { agulhado em poliéster }\end{array}$} & \multicolumn{2}{|c|}{$\begin{array}{l}\text { MACCAFERRI: } \\
\text { não-tecido em } \\
\text { polietileno }\end{array}$} \\
\hline & & & RT 16 & RT 21 & RT 26 & RT 31 & $300 \mathrm{E}$ & $400 E$ & $500 \mathrm{E}$ & $600 E$ & 300P & 350P \\
\hline $\begin{array}{l}\text { Resistência ao } \\
\text { puncionamento }\end{array}$ & $\mathrm{N}$ & $\begin{array}{l}\text { ASTM D } \\
4833\end{array}$ & 550 & 700 & 850 & 1000 & 550 & 700 & 850 & 1000 & 489 & 660 \\
\hline $\begin{array}{c}\text { Resistência ao } \\
\text { puncionamento CBR }\end{array}$ & $\mathrm{KN}$ & $\begin{array}{c}\text { ABNT NBR } \\
13359\end{array}$ & 3,1 & 4,1 & 5,1 & 6 & 3,1 & 4,1 & 5,1 & 6 & - & - \\
\hline Resistência a tração $L$ & $\mathrm{~N}$ & $\begin{array}{l}\text { ASTM D } \\
4632\end{array}$ & 1150 & 1550 & 1960 & 2350 & 1150 & 1550 & 1960 & 2350 & 890 & 1060 \\
\hline Alongamento L & $\%$ & $\begin{array}{l}\text { ASTM D } \\
4633\end{array}$ & 60 & 60 & 60 & 60 & $>60$ & $>60$ & $>60$ & $>60$ & 50 & 70 \\
\hline Resistência a tração $T$ & $\mathrm{~N}$ & $\begin{array}{c}\text { ASTM D } \\
4634\end{array}$ & 980 & 1320 & 1650 & 1980 & 980 & 1320 & 1650 & 1980 & - & - \\
\hline Alongamento $T$ & $\%$ & $\begin{array}{l}\text { ASTM D } \\
4635\end{array}$ & 70 & 70 & 70 & 70 & $>70$ & $>70$ & $>70$ & $>70$ & - & - \\
\hline Resistência a tração $L$ & $\mathrm{KN} / \mathrm{m}$ & $\begin{array}{c}\text { ABNT NBR } \\
12824\end{array}$ & 16 & 21 & 26 & 31 & 16 & 21 & 26 & 31 & - & - \\
\hline Alongamento L & $\%$ & $\begin{array}{c}\text { ABNT NBR } \\
12825\end{array}$ & 50 a 65 & 50 a 65 & 50 a 65 & 50 a 65 & 50 a 65 & 50 a 65 & 50 a 65 & 50 a 65 & - & - \\
\hline Resistência a tração $T$ & $\mathrm{KN} / \mathrm{m}$ & $\begin{array}{c}\text { ABNT NBR } \\
12826\end{array}$ & 14 & 19 & 23 & 27 & 14 & 19 & 23 & 27 & - & - \\
\hline Alongamento $T$ & $\%$ & $\begin{array}{c}\text { ABNT NBR } \\
12827\end{array}$ & 60 a 75 & 60 a 75 & 60 a 75 & 60 a 75 & 60 a 75 & 60 a 75 & 60 a 75 & 60 a 75 & - & - \\
\hline $\begin{array}{l}\text { Resistência ao rasgo } \\
\text { trapezoidal - } L\end{array}$ & $\mathrm{~N}$ & $\begin{array}{l}\text { ASTM D } \\
4533\end{array}$ & 440 & 560 & 680 & 800 & 440 & 560 & 680 & 800 & 378 & 420 \\
\hline $\begin{array}{l}\text { Resistência ao rasgo } \\
\text { trapezoidal - T }\end{array}$ & $\mathrm{N}$ & $\begin{array}{l}\text { ASTM D } \\
4533\end{array}$ & 400 & 520 & 640 & 750 & 400 & 520 & 640 & 750 & - & - \\
\hline Gramatura & $\mathrm{g} / \mathrm{m}^{2}$ & $\begin{array}{c}\text { ASTM D } \\
\text { 4491 ABNT } \\
\text { NBR } 12568 \\
\end{array}$ & & 400 & & 600 & 300 & 400 & 500 & 600 & 237 & 271 \\
\hline $\begin{array}{c}\text { Resistência aos raios } \\
\text { UV }\end{array}$ & $\begin{array}{l}\text { Preservação das } \\
\text { caract.(\%)/t(h) }\end{array}$ & & & & & & & & & & $80 / 500$ & $80 / 500$ \\
\hline HIDRÁULICAS & & & RT 16 & RT 21 & RT 26 & RT 31 & $300 E$ & $400 E$ & $500 \mathrm{E}$ & $600 \mathrm{E}$ & 300P & 350P \\
\hline $\begin{array}{l}\text { Permeabilidade } \\
\text { Normal }\end{array}$ & $\mathrm{cm} / \mathrm{s}$ & $\begin{array}{l}\text { ASTM D } \\
4491\end{array}$ & 0,35 & 0,35 & 0,35 & 0,35 & 0,35 & 0,35 & 0,35 & 0,35 & 0,42 & 0,41 \\
\hline $\begin{array}{c}\text { Abertura Aparente } \\
\text { Mínima }\end{array}$ & $\mathrm{mm}$ & $\begin{array}{c}\text { ASTM D } \\
4751\end{array}$ & 0,11 & 0,09 & 0,07 & 0,06 & 0,11 & 0,09 & 0,07 & 0,06 & 0,212 & 0,18 \\
\hline $\begin{array}{l}\text { Abertura Aparente } \\
\text { Máxima }\end{array}$ & $\mathrm{mm}$ & $\begin{array}{c}\text { ASTM D } \\
4751\end{array}$ & 0,19 & 0,16 & 0,14 & 0,13 & 0,19 & 0,16 & 0,14 & 0,13 & 0,15 & 0,15 \\
\hline Permissividade & $\mathrm{s}^{\wedge}(-1)$ & $\begin{array}{c}\text { ASTM D } \\
4491\end{array}$ & 1,5 & 1,2 & 1 & 0,9 & 1,5 & 1,2 & 1 & 0,9 & 1,7 & 1,5 \\
\hline Fluxo de água & $1 / \mathrm{s} \cdot \mathrm{m}^{2}$ & $\begin{array}{c}\text { ASTM D } \\
4491\end{array}$ & 75 & 57 & 46 & 39 & 75 & 57 & 46 & 39 & 81,5 & 68 \\
\hline
\end{tabular}


Tabela 44 - Planilha com as características de diversos geotêxteis do mercado.

\begin{tabular}{|c|c|c|c|c|c|c|c|c|c|c|c|c|}
\hline Características & Unidade & $\begin{array}{l}\text { Norma } \\
\text { aplicável }\end{array}$ & $\begin{array}{r}\text { MACC } \\
\text { tecid } \\
\text { polipr }\end{array}$ & $\begin{array}{l}\text { AFERRI: } \\
\text { lo em } \\
\text { pileno }\end{array}$ & HUES K & R: tecid & m poli & ropileno & PROPE & $\mathrm{X}$ : tecido & m polipr & copileno \\
\hline FÍSICAS & & & $200 \mathrm{~T}$ & $300 \mathrm{~T}$ & $\begin{array}{l}\text { Hate } \\
25 / 25 \\
\end{array}$ & $\begin{array}{l}\text { Hate } \\
55 / 55\end{array}$ & $\begin{array}{l}\text { Hate } \\
80 / 80 \\
\end{array}$ & $\begin{array}{c}\text { Hate } \\
105 / 105 \\
\end{array}$ & $\begin{array}{l}\text { Propex } \\
25 X 25 \\
\end{array}$ & $\begin{array}{l}\text { Propex } \\
50 \times 35 \\
\end{array}$ & $\begin{array}{l}\text { Propex } \\
50 \times 42 \\
\end{array}$ & $\begin{array}{c}\text { Propex } \\
14000 \\
\end{array}$ \\
\hline $\begin{array}{l}\text { Resistência ao } \\
\text { puncionamento }\end{array}$ & $\mathrm{N}$ & $\begin{array}{c}\text { ASTM D } \\
4833\end{array}$ & 300 & 640 & & & & & & & & \\
\hline $\begin{array}{c}\text { Resistência ao } \\
\text { puncionamento CBR }\end{array}$ & KN & $\begin{array}{c}\text { ABNT NBR } \\
13359\end{array}$ & - & - & & & & & 3,4 & 5,8 & 5,9 & 3,1 \\
\hline Resistência a tração $L$ & $\mathrm{~N}$ & $\begin{array}{c}\text { ASTM D } \\
4632\end{array}$ & & & & & & & & & & \\
\hline Alongamento $\mathbf{L}$ & $\%$ & $\begin{array}{c}\text { ASTM D } \\
4633\end{array}$ & & & & & & & & & & \\
\hline Resistência a tração $T$ & $\mathrm{~N}$ & $\begin{array}{c}\text { ASTM D } \\
4634\end{array}$ & & & & & & & & & & \\
\hline Alongamento T & $\%$ & $\begin{array}{l}\text { ASTM D } \\
4635\end{array}$ & & & & & & & & & & \\
\hline Resistência a tração $L$ & $\mathrm{KN} / \mathrm{m}$ & $\begin{array}{c}\text { ABNT NBR } \\
12824\end{array}$ & 24 & 48 & 25 & 55 & 80 & 105 & 25 & 50 & 50 & 25 \\
\hline Alongamento $\mathbf{L}$ & $\%$ & $\begin{array}{c}\text { ABNT NBR } \\
12825\end{array}$ & 15 & 30 & 15 & 15 & 15 & 8 & 18 & 35 & 35 & 18 \\
\hline Resistência a tração $\mathbf{T}$ & $\mathrm{KN} / \mathrm{m}$ & $\begin{array}{c}\text { ABNT NBR } \\
12826\end{array}$ & 24 & 36 & 25 & 55 & 80 & 105 & 25 & 35 & 42 & 25 \\
\hline Alongamento T & $\%$ & $\begin{array}{c}\text { ABNT NBR } \\
12827\end{array}$ & 15 & 20 & 15 & 15 & 15 & 8 & 24 & 20 & 22 & 16 \\
\hline $\begin{array}{l}\text { Resistência ao rasgo } \\
\text { trapezoidal - L }\end{array}$ & $\mathrm{N}$ & $\begin{array}{l}\text { ASTM D } \\
4533\end{array}$ & & & & & & & 300 & 480 & 495 & 230 \\
\hline $\begin{array}{l}\text { Resistência ao rasgo } \\
\text { trapezoidal - } T\end{array}$ & $\mathrm{~N}$ & $\begin{array}{l}\text { ASTM D } \\
4533\end{array}$ & & & & & & & 310 & 590 & 730 & 305 \\
\hline Gramatura & $\mathrm{g} / \mathrm{m}^{2}$ & $\begin{array}{c}\text { ASTM D } \\
4491 \text { ABNT } \\
\text { NBR } 12568\end{array}$ & 140 & 225 & 129 & 289 & 390 & 486 & 133 & 222 & & 136 \\
\hline $\begin{array}{c}\text { Resistência aos raios } \\
\text { UV }\end{array}$ & $\begin{array}{l}\text { Preservação das } \\
\text { caract.(\%) / } \mathrm{t}(\mathrm{h})\end{array}$ & & $80 / 1000$ & $80 / 1000$ & & & & & & & & \\
\hline HIDRÁULICAS & & & 200 & 300 & $\begin{array}{l}\text { Hate } \\
25 / 25\end{array}$ & $\begin{array}{l}\text { Hate } \\
55 / 55\end{array}$ & $\begin{array}{l}\text { Hate } \\
80 / 80\end{array}$ & $\begin{array}{c}\text { Hate } \\
105 / 105\end{array}$ & $\begin{array}{l}\text { Propex } \\
25 \mathrm{X} 25\end{array}$ & $\begin{array}{c}\text { Propex } \\
50 \times 35\end{array}$ & $\begin{array}{l}\text { Propex } \\
50 \times 42\end{array}$ & $\begin{array}{c}\text { Propex } \\
14000\end{array}$ \\
\hline $\begin{array}{l}\text { Permeabilidade } \\
\text { Normal }\end{array}$ & $\mathrm{cm} / \mathrm{s}$ & $\begin{array}{c}\text { ASTM D } \\
4491\end{array}$ & 0,007 & 0,003 & & & & & & & & \\
\hline $\begin{array}{c}\text { Abertura Aparente } \\
\text { Mínima }\end{array}$ & $\mathrm{mm}$ & $\begin{array}{l}\text { ASTM D } \\
4751\end{array}$ & 0,9 & 0,2 & & & & & & & & \\
\hline $\begin{array}{c}\text { Abertura Aparente } \\
\text { Máxima }\end{array}$ & $\mathrm{mm}$ & $\begin{array}{c}\text { ASTM D } \\
4751\end{array}$ & 0,9 & 0,2 & $\begin{array}{l}\mathrm{O} 90 \\
0,25\end{array}$ & $\begin{array}{l}\mathrm{O} 90 \\
0,20\end{array}$ & $\begin{array}{l}\text { O90 } \\
0,20\end{array}$ & $\begin{array}{l}\mathrm{O} 90 \\
0,20\end{array}$ & $\begin{array}{l}\text { O95 } \\
0,24\end{array}$ & $\begin{array}{l}\mathrm{O} 95 \\
0,42\end{array}$ & $\begin{array}{l}\text { O95 } \\
0,23\end{array}$ & $\begin{array}{l}\mathrm{O} 95 \\
0,49\end{array}$ \\
\hline Permissividade & $s^{\wedge}(-1)$ & $\begin{array}{c}\text { ASTM D } \\
4491\end{array}$ & 0,17 & 0,05 & & & & & 0,06 & 0,04 & 0,04 & 0,42 \\
\hline Fluxo de água & $1 / \mathrm{s} \cdot \mathrm{m}^{2}$ & $\begin{array}{c}\text { ASTM D } \\
4491\end{array}$ & 10 & 3 & 20 & 15 & 15 & 15 & & & & \\
\hline
\end{tabular}




\section{ANEXO C - Dados climáticos da Estação Meteorológica do Instituto de Astronomia, Geofísica e Ciências Atmosféricas}

Tabela 45 - Dados climáticos de agosto 2010

\begin{tabular}{|c|c|c|c|c|c|c|}
\hline 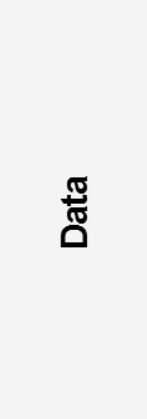 & 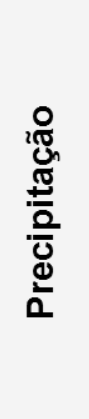 & 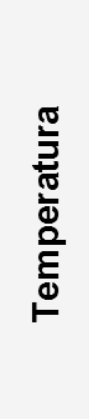 & $\begin{array}{l}\frac{1}{\pi} \\
0 \\
\frac{0}{0} \\
\frac{\pi}{2} \\
\frac{D}{\pi} \\
\frac{\pi}{0} \\
\frac{0}{0} \\
\frac{\pi}{0} \\
\frac{0}{E}\end{array}$ & 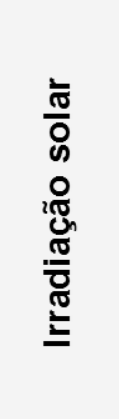 & 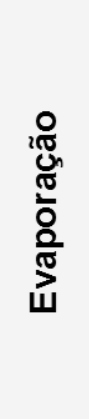 & 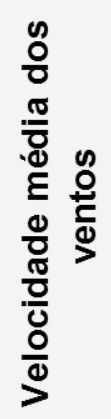 \\
\hline Unidade & $\mathrm{mm}$ & ${ }^{\circ} \mathrm{C}$ & $\%$ & $\mathrm{MJ} / \mathrm{m}^{2}$ & $\mathrm{~mm}$ & $\mathrm{Km} / \mathrm{h}$ \\
\hline 01/ago & 1,0 & 16,8 & 80,8 & 14,4 & 1,80 & 4,3 \\
\hline 02/ago & 0,2 & 14,9 & 93,7 & 3,1 & 0,50 & 4,8 \\
\hline 03/ago & 0,3 & 13,4 & 91,3 & 4,9 & 0,60 & 5,1 \\
\hline 04/ago & 0,4 & 11,9 & 94,6 & 4,5 & 0,50 & 4,4 \\
\hline 05/ago & 0,8 & 12,9 & 91,8 & 5,1 & 0,60 & 3,6 \\
\hline 06/ago & 0,1 & 12,3 & 84,0 & 11,2 & 1,25 & 4,1 \\
\hline 07/ago & 0,0 & 14,4 & 81,8 & 17,2 & 1,75 & 4,3 \\
\hline 08/ago & 0,0 & 16,7 & 74,6 & 17,9 & 3,20 & 3,3 \\
\hline 09/ago & 0,0 & 13,3 & 87,6 & 6,9 & 0,80 & 2,9 \\
\hline 10/ago & 0,0 & 14,5 & 86,6 & 7,8 & 0,95 & 5,1 \\
\hline 11/ago & 0,0 & 15,1 & 85,1 & 9,0 & 1,15 & 6,6 \\
\hline 12/ago & 0,0 & 18,7 & 68,3 & 16,2 & 3,20 & 7,8 \\
\hline 13/ago & 0,0 & 20,2 & 57,5 & 16,9 & 5,75 & 10,3 \\
\hline 14/ago & 0,0 & 11,8 & 87,3 & 4,5 & 0,95 & 4,0 \\
\hline 15/ago & 0,8 & 9,8 & 87,0 & 7,9 & 0,90 & 4,8 \\
\hline 16/ago & 0,0 & 11,8 & 77,5 & 18,6 & 2,05 & 7,0 \\
\hline 17/ago & 0,1 & 12,6 & 80,1 & 22,0 & 1,65 & 6,6 \\
\hline 18/ago & 0,0 & 13,0 & 75,5 & 20,6 & 2,30 & 5,3 \\
\hline 19/ago & 0,0 & 15,7 & 63,5 & 19,3 & 3,50 & 4,3 \\
\hline 20/ago & 0,0 & 16,9 & 66,2 & 18,2 & 3,55 & 2,5 \\
\hline 21/ago & 0,0 & 17,8 & 69,4 & 18,7 & 3,25 & 2,7 \\
\hline 22/ago & 0,0 & 18,6 & 61,2 & 18,7 & 4,40 & 3,9 \\
\hline 23/ago & 0,0 & 19,3 & 54,5 & 19,3 & 4,90 & 2,9 \\
\hline 24/ago & 0,0 & 19,9 & 55,5 & 20,3 & 5,40 & 3,4 \\
\hline 25/ago & 0,0 & 20,4 & 54,2 & 18,1 & 4,90 & 1,9 \\
\hline 26/ago & 0,0 & 20,4 & 52,9 & 19,2 & 5,10 & 2,3 \\
\hline 27/ago & 0,0 & 19,9 & 58,2 & 18,7 & 5,10 & 2,3 \\
\hline 28/ago & 0,0 & 17,2 & 79,0 & 18,2 & 2,30 & 2,8 \\
\hline 29/ago & 0,0 & 19,2 & 70,6 & 18,6 & 3,40 & 3,1 \\
\hline 30/ago & 0,0 & 16,6 & 81,7 & 15,7 & 1,70 & 4,7 \\
\hline
\end{tabular}


Tabela 46 - Dados climáticos de setembro 2010

\begin{tabular}{|c|c|c|c|c|c|c|}
\hline 丞 & 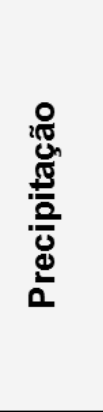 & 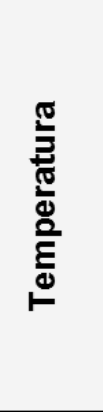 & 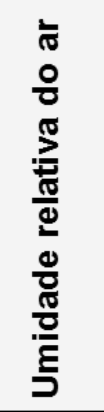 & 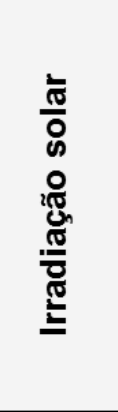 & 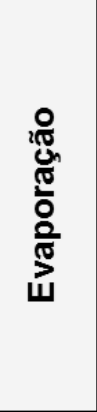 & 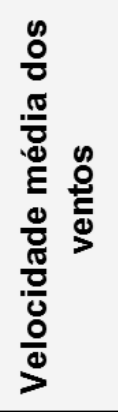 \\
\hline Unidade & $\mathrm{mm}$ & ${ }^{\circ} \mathrm{C}$ & $\%$ & $\mathrm{MJ} / \mathrm{m}^{2}$ & $\mathrm{~mm}$ & $\mathrm{Km} / \mathrm{h}$ \\
\hline $01 /$ set & 0,0 & 20,8 & 57,3 & 20,6 & 4,80 & 5,5 \\
\hline $02 /$ set & 0,0 & 21,2 & 55,4 & 20,1 & 5,00 & 2,6 \\
\hline $03 /$ set & 0,0 & 21,5 & 61,1 & 19,8 & 4,50 & 2,4 \\
\hline $04 /$ set & 0,1 & 22,7 & 50,4 & 20,7 & 6,70 & 5,6 \\
\hline $05 /$ set & 0,0 & 15,5 & 85,5 & 6,9 & 1,30 & 5,7 \\
\hline $06 /$ set & 0,0 & 14,1 & 90,1 & 5,1 & 0,80 & 6,2 \\
\hline $07 /$ set & 16,8 & 15,4 & 95,0 & 3,5 & 0,35 & 2,4 \\
\hline $08 /$ set & 0,6 & 15,0 & 90,3 & 11,4 & 0,85 & 5,3 \\
\hline 09/set & 0,1 & 16,2 & 81,1 & 17,5 & 1,95 & 7,0 \\
\hline $10 /$ set & 0,1 & 16,9 & 78,8 & 20,2 & 2,30 & 8,9 \\
\hline $11 /$ set & 0,0 & 19,6 & 61,6 & 23,0 & 4,60 & 7,5 \\
\hline $12 /$ set & 0,0 & 20,2 & 57,4 & 21,0 & 4,50 & 4,3 \\
\hline $13 /$ set & 0,0 & 22,9 & 40,6 & 22,4 & 7,30 & 6,1 \\
\hline $14 /$ set & 0,0 & 24,3 & 34,3 & 18,4 & 8,25 & 7,8 \\
\hline $15 /$ set & 0,0 & 17,7 & 80,5 & 5,2 & 1,95 & 4,6 \\
\hline $16 /$ set & 0,1 & 16,4 & 89,1 & 12,1 & 1,10 & 5,5 \\
\hline $17 /$ set & 0,2 & 19,7 & 78,8 & 18,6 & 2,70 & 6,2 \\
\hline $18 /$ set & 0,2 & 14,3 & 87,9 & 6,8 & 1,15 & 6,9 \\
\hline $19 /$ set & 0,2 & 14,5 & 85,9 & 9,4 & 1,25 & 7,8 \\
\hline $20 /$ set & 8,2 & 16,5 & 85,6 & 12,4 & 1,60 & 8,3 \\
\hline $21 /$ set & 0,8 & 19,0 & 81,3 & 18,1 & 2,20 & 4,5 \\
\hline $22 /$ set & 0,0 & 20,4 & 78,3 & 21,2 & 3,10 & 5,5 \\
\hline $23 /$ set & 0,0 & 20,7 & 79,7 & 17,7 & 2,10 & 2,8 \\
\hline $24 /$ set & 8,3 & 18,4 & 88,4 & 5,7 & 1,10 & 5,1 \\
\hline $25 /$ set & 0,2 & 17,0 & 85,1 & 14,6 & 1,20 & 5,3 \\
\hline $26 /$ set & 23,3 & 17,2 & 91,8 & 6,6 & 0,70 & 5,5 \\
\hline $27 /$ set & 30,0 & 18,5 & 89,8 & 7,1 & 0,80 & 4,9 \\
\hline $28 /$ set & 5,9 & 17,9 & 92,2 & 7,5 & 0,65 & 2,8 \\
\hline $29 /$ set & 1,5 & 19,7 & 86,7 & 9,1 & 1,15 & 2,2 \\
\hline $30 /$ set & 0,1 & 20,8 & 86,8 & 10,7 & 1,40 & 5,0 \\
\hline
\end{tabular}


Tabela 47 - Dados climáticos de outubro 2010

\begin{tabular}{|c|c|c|c|c|c|c|}
\hline $\begin{array}{l}\frac{\pi}{\pi} \\
\frac{\pi}{2}\end{array}$ & 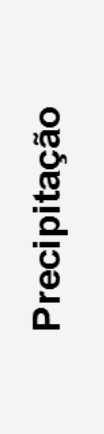 & 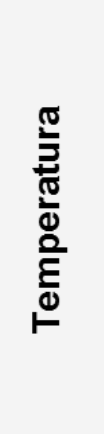 & 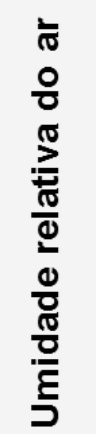 & 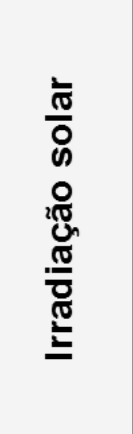 & 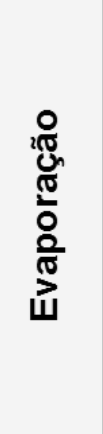 & 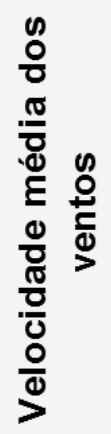 \\
\hline Unidade & $\mathrm{mm}$ & ${ }^{\circ} \mathrm{C}$ & $\%$ & $\mathrm{MJ} / \mathrm{m}^{2}$ & $\mathrm{~mm}$ & $\mathrm{Km} / \mathrm{h}$ \\
\hline 01/out & 1,9 & 20,0 & 92,0 & 6,1 & 1,05 & 2,9 \\
\hline 02/out & 3,5 & 18,7 & 89,3 & 9,0 & 1,75 & 6,9 \\
\hline 03/out & 2,1 & 14,2 & 93,8 & 6,7 & 0,70 & 6,3 \\
\hline 04/out & 0,1 & 15,6 & 91,0 & 5,6 & 1,45 & 5,0 \\
\hline 05/out & 0,0 & 16,8 & 89,7 & 11,5 & 2,25 & 5,1 \\
\hline 06/out & 0,0 & 18,4 & 82,6 & 22,9 & 4,25 & 5,3 \\
\hline 07/out & 21,2 & 20,5 & 81,0 & 12,7 & 5,00 & 11,4 \\
\hline 08/out & 0,0 & 19,5 & 64,3 & 24,7 & 9,45 & 12,1 \\
\hline 09/out & 3,3 & 14,6 & 88,9 & 14,5 & 0,30 & 6,8 \\
\hline 10/out & 0,1 & 14,0 & 83,7 & 13,0 & 2,30 & 6,0 \\
\hline 11/out & 0,0 & 13,0 & 85,9 & 7,8 & 1,75 & 5,6 \\
\hline 12/out & 0,1 & 13,3 & 75,1 & 21,7 & 4,20 & 6,2 \\
\hline 13/out & 0,0 & 14,8 & 76,4 & 25,0 & 4,80 & 7,1 \\
\hline 14/out & 0,0 & 18,1 & 79,7 & 19,7 & 4,70 & 7,1 \\
\hline 15/out & 2,8 & 20,1 & 83,7 & 11,8 & 3,30 & 5,2 \\
\hline 16/out & 1,3 & 22,5 & 78,5 & 21,0 & 5,00 & 5,3 \\
\hline 17/out & 0,2 & 19,8 & 84,7 & 19,7 & 3,50 & 4,5 \\
\hline 18/out & 5,9 & 16,7 & 90,5 & 11,4 & 0,60 & 5,8 \\
\hline 19/out & 0,5 & 15,7 & 77,3 & 24,7 & 4,25 & 5,8 \\
\hline 20/out & 0,1 & 15,9 & 74,1 & 29,6 & 5,20 & 5,0 \\
\hline 21/out & 0,1 & 16,6 & 80,5 & 25,1 & 3,90 & 5,5 \\
\hline 22/out & 0,0 & 18,7 & 83,9 & 22,4 & 4,35 & 6,1 \\
\hline 23/out & 0,1 & 21,1 & 79,4 & 10,8 & 4,15 & 7,0 \\
\hline 24/out & 0,3 & 18,5 & 88,9 & 9,5 & 1,70 & 4,9 \\
\hline 25 /out & 21,8 & 20,2 & 81,5 & 22,5 & 4,30 & 5,7 \\
\hline 26/out & 0,1 & 17,2 & 87,3 & 17,3 & 2,45 & 6,3 \\
\hline 27/out & 0,0 & 16,4 & 78,5 & 23,2 & 4,35 & 5,1 \\
\hline 28 /out & 0,0 & 17,9 & 75,5 & 28,3 & 5,55 & 4,9 \\
\hline 29/out & 0,1 & 20,5 & 74,8 & 27,3 & 6,05 & 4,9 \\
\hline 30/out & 10,9 & 18,9 & 85,2 & 7,3 & 1,10 & 6,6 \\
\hline 31/out & 0,1 & 20,3 & 81,3 & 18,9 & 3,75 & 3,8 \\
\hline
\end{tabular}


Tabela 48 - Dados climáticos de novembro 2010

\begin{tabular}{|c|c|c|c|c|c|c|}
\hline $\begin{array}{l}\frac{\pi}{\pi} \\
\text { Q }\end{array}$ & 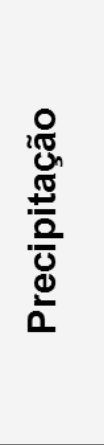 & 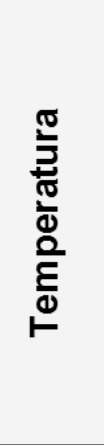 & 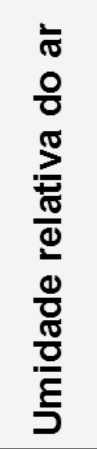 & 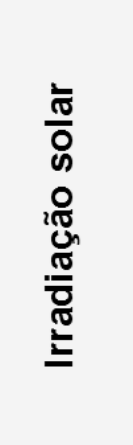 & 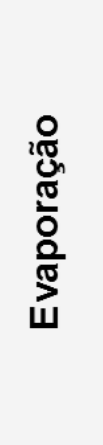 & 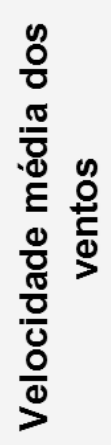 \\
\hline Unidade & $\mathrm{mm}$ & ${ }^{\circ} \mathrm{C}$ & $\%$ & $\mathrm{MJ} / \mathrm{m}^{2}$ & $\mathrm{~mm}$ & $\mathrm{Km} / \mathrm{h}$ \\
\hline $01 /$ nov & 0,0 & 18,5 & 80,7 & 12,3 & 1,70 & 3,9 \\
\hline $02 /$ nov & 0,0 & 18,6 & 77,0 & 27,7 & 2,45 & 4,5 \\
\hline $03 /$ nov & 0,1 & 18,9 & 78,7 & 26,6 & 2,50 & 5,2 \\
\hline $04 / \mathrm{nov}$ & 0,0 & 21,1 & 75,1 & 21,8 & 2,95 & 6,9 \\
\hline $05 /$ nov & 10,5 & 24,2 & 67,0 & 24,4 & 4,70 & 9,0 \\
\hline $06 /$ nov & 14,8 & 17,6 & 91,2 & 8,2 & 0,80 & 5,3 \\
\hline $07 /$ nov & 0,1 & 19,0 & 79,2 & 25,6 & 2,30 & 5,3 \\
\hline $08 / \mathrm{nov}$ & 0,0 & 22,7 & 74,4 & 24,6 & 3,15 & 7,0 \\
\hline $09 /$ nov & 15,3 & 25,5 & 63,5 & 28,0 & 5,20 & 7,8 \\
\hline $10 /$ nov & 4,1 & 19,2 & 88,5 & 14,4 & 1,30 & 7,3 \\
\hline $11 /$ nov & 1,6 & 14,9 & 90,0 & 9,3 & 0,85 & 7,0 \\
\hline $12 /$ nov & 0,3 & 15,3 & 90,8 & 7,1 & 0,80 & 7,0 \\
\hline $13 /$ nov & 0,3 & 14,9 & 90,3 & 7,2 & 0,70 & 7,3 \\
\hline $14 /$ nov & 0,0 & 17,1 & 86,6 & 13,3 & 1,30 & 5,2 \\
\hline $15 /$ nov & 0,0 & 18,9 & 78,3 & 24,1 & 2,30 & 5,5 \\
\hline $16 /$ nov & 25,5 & 17,6 & 93,5 & 6,3 & 0,55 & 5,7 \\
\hline 17/nov & 2,5 & 19,2 & 86,7 & 19,4 & 1,25 & 4,4 \\
\hline $18 /$ nov & 0,7 & 20,1 & 72,8 & 27,1 & 3,70 & 6,3 \\
\hline 19/nov & 0,0 & 21,0 & 67,1 & 30,2 & 4,50 & 4,6 \\
\hline $20 /$ nov & 0,0 & 21,6 & 74,9 & 19,2 & 2,60 & 3,5 \\
\hline $21 /$ nov & 0,0 & 23,3 & 69,6 & 23,0 & 3,55 & 4,3 \\
\hline $22 / \mathrm{nov}$ & 12,4 & 21,6 & 80,9 & 13,4 & 2,40 & 6,4 \\
\hline $23 /$ nov & 0,3 & 19,7 & 91,8 & 8,7 & 0,90 & 4,4 \\
\hline $24 /$ nov & 0,6 & 20,7 & 84,7 & 17,9 & 1,60 & 4,6 \\
\hline $25 /$ nov & 13,8 & 21,4 & 84,6 & 17,2 & 1,95 & 5,4 \\
\hline $26 /$ nov & 0,0 & 20,1 & 84,5 & 14,8 & 1,50 & 3,8 \\
\hline $27 /$ nov & 0,0 & 21,7 & 77,0 & 26,5 & 2,40 & 4,3 \\
\hline $28 / \mathrm{nov}$ & 0,0 & 22,5 & 72,6 & 29,2 & 3,50 & 6,3 \\
\hline $29 / \mathrm{nov}$ & 5,5 & 24,3 & 70,7 & 20,7 & 4,30 & 11,4 \\
\hline $30 /$ nov & 50,8 & 22,5 & 80,3 & 12,5 & 2,30 & 6,5 \\
\hline
\end{tabular}


Tabela 49 - Dados climáticos de dezembro 2010

\begin{tabular}{|c|c|c|c|c|c|c|}
\hline $\begin{array}{l}\frac{\pi}{\pi} \\
\frac{\pi}{\pi}\end{array}$ & 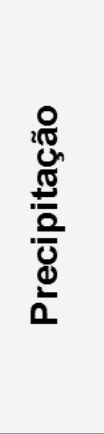 & 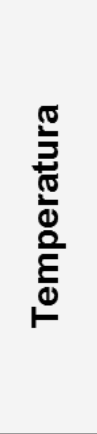 & 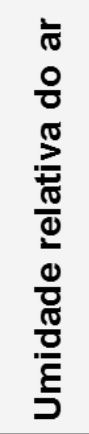 & 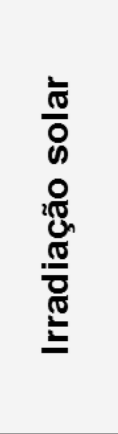 & 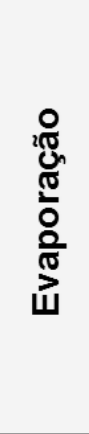 & 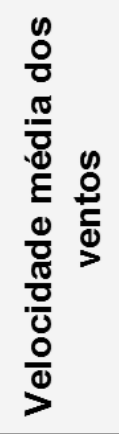 \\
\hline Unidade & $\mathrm{mm}$ & ${ }^{\circ} \mathrm{C}$ & $\%$ & $\mathrm{MJ} / \mathrm{m}^{2}$ & $\mathrm{~mm}$ & $\mathrm{Km} / \mathrm{h}$ \\
\hline $01 / \mathrm{dez}$ & 0,1 & 21,6 & 87,9 & 15,9 & 1,20 & 5,0 \\
\hline 02/dez & 0,8 & 23,6 & 82,2 & 20,6 & 2,40 & 5,7 \\
\hline 03/dez & 0,4 & 24,4 & 78,2 & 20,8 & 2,75 & 7,4 \\
\hline 04/dez & 0,1 & 22,8 & 85,2 & 20,5 & 1,75 & 4,9 \\
\hline 05/dez & 24,2 & 22,9 & 86,1 & 13,9 & 1,80 & 5,1 \\
\hline 06/dez & 1,5 & 21,5 & 87,5 & 14,2 & 1,40 & 5,0 \\
\hline 07/dez & 1,2 & 22,7 & 86,6 & 16,1 & 1,50 & 5,0 \\
\hline 08/dez & 18,8 & 24,9 & 73,1 & 21,6 & 3,60 & 6,9 \\
\hline 09/dez & 0,0 & 21,2 & 84,6 & 21,4 & 2,05 & 6,0 \\
\hline 10/dez & 0,0 & 21,2 & 80,9 & 23,8 & 1,95 & 5,6 \\
\hline 11/dez & 5,7 & 23,9 & 81,5 & 17,8 & 2,00 & 6,4 \\
\hline 12/dez & 9,9 & 26,2 & 72,2 & 25,5 & 4,20 & 7,6 \\
\hline 13/dez & 50,4 & 22,4 & 84,8 & 12,6 & 2,00 & 7,4 \\
\hline 14/dez & 43,4 & 17,4 & 95,4 & 6,1 & 0,45 & 5,6 \\
\hline 15/dez & 14,1 & 18,4 & 94,2 & 7,8 & 0,55 & 5,8 \\
\hline 16/dez & 35,2 & 20,4 & 93,3 & 13,5 & 0,70 & 4,3 \\
\hline 17/dez & 0,0 & 22,5 & 82,9 & 15,0 & 2,00 & 5,3 \\
\hline 18/dez & 1,2 & 21,8 & 83,7 & 13,4 & 1,50 & 5,6 \\
\hline 19/dez & 0,0 & 23,2 & 80,2 & 24,0 & 2,30 & 3,8 \\
\hline 20/dez & 21,1 & 24,3 & 81,5 & 22,3 & 2,40 & 5,3 \\
\hline $21 / \mathrm{dez}$ & 2,0 & 23,7 & 84,7 & 13,3 & 1,80 & 3,5 \\
\hline 22/dez & 0,3 & 22,8 & 84,0 & 15,2 & 1,65 & 4,1 \\
\hline 23/dez & 13,4 & 20,8 & 91,1 & 8,8 & 0,85 & 3,9 \\
\hline 24/dez & 0,0 & 22,0 & 83,6 & 19,4 & 1,80 & 4,8 \\
\hline 25/dez & 0,0 & 23,4 & 79,9 & 25,1 & 2,50 & 4,9 \\
\hline 26/dez & 34,7 & 22,1 & 86,5 & 13,1 & 1,40 & 3,3 \\
\hline 27/dez & 2,0 & 20,2 & 90,5 & 14,2 & 1,00 & 3,9 \\
\hline 28/dez & 0,1 & 19,4 & 83,6 & 21,0 & 1,80 & 4,1 \\
\hline 29/dez & 0,0 & 19,5 & 80,0 & 26,7 & 2,20 & 5,3 \\
\hline 30/dez & 0,0 & 20,1 & 81,0 & 20,8 & 2,00 & 6,2 \\
\hline $31 / \mathrm{dez}$ & 0,0 & 20,7 & 78,7 & 21,9 & 2,40 & 5,4 \\
\hline
\end{tabular}


Tabela 50 - Dados climáticos de janeiro 2011

\begin{tabular}{|c|c|c|c|c|c|c|}
\hline$\frac{\pi}{\pi / 7}$ & 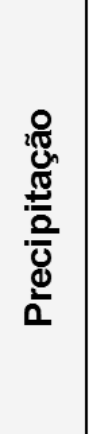 & 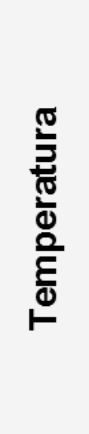 & 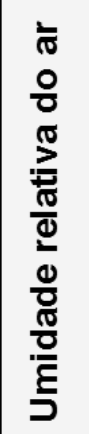 & 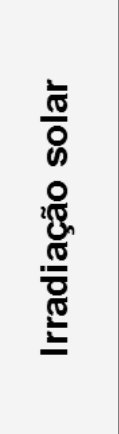 & 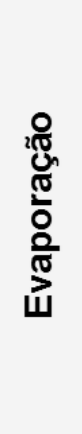 & 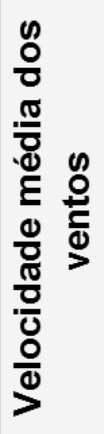 \\
\hline Unidade & $\mathrm{mm}$ & ${ }^{\circ} \mathrm{C}$ & $\%$ & $\mathrm{MJ} / \mathrm{m}^{2}$ & $\mathrm{~mm}$ & $\mathrm{Km} / \mathrm{h}$ \\
\hline 01/jan & 0,3 & 21,0 & 84,3 & 12,4 & 2,9 & 5,7 \\
\hline 02/jan & 37 & 20,1 & 95,0 & 6,1 & 0,1 & 2,5 \\
\hline 03/jan & 21 & 20,5 & 94,4 & 8,0 & 0,4 & 4,0 \\
\hline 04/jan & 12 & 21,7 & 92,9 & 12,3 & 1,5 & 4,9 \\
\hline 05/jan & 33 & 23,8 & 81,6 & 22,7 & 5,4 & 8,3 \\
\hline 06/jan & 6,9 & 23,4 & 80,5 & 21,3 & 5 & 8,3 \\
\hline 07/jan & 9,8 & 22,5 & 86,1 & 12,3 & 2,9 & 4,9 \\
\hline 08/jan & 25 & 22,3 & 88,7 & 13,5 & 2 & 3,2 \\
\hline 09/jan & 40 & 24,2 & 77,5 & 25,6 & 6,5 & 6,1 \\
\hline 10/jan & 51 & 24,0 & 80,4 & 18,5 & 5,1 & 6,5 \\
\hline 11/jan & 4,1 & 22,3 & 86,6 & 16,1 & 3 & 5,6 \\
\hline 12/jan & 4,3 & 23,4 & 83,8 & 15,1 & 3 & 7,5 \\
\hline 13/jan & 23 & 22,7 & 86,7 & 12,4 & 2,7 & 6,8 \\
\hline 14/jan & 98 & 21,9 & 91,3 & 11,0 & 0,3 & 4,3 \\
\hline 15/jan & 0 & 22,3 & 84,8 & 21,2 & 3,3 & 4,1 \\
\hline 16/jan & 0 & 23,3 & 81,3 & 19,1 & 4,3 & 5,4 \\
\hline 17/jan & 3,2 & 22,3 & 83,0 & 14,5 & 2,2 & 7,2 \\
\hline 18/jan & 15 & 23,5 & 82,4 & 19,2 & 3,5 & 4,3 \\
\hline 19/jan & 0,3 & 23,7 & 81,2 & 18,8 & 4,3 & 5,1 \\
\hline 20/jan & 18 & 22,6 & 86,1 & 13,1 & 2,5 & 4,7 \\
\hline 21/jan & 21 & 23,2 & 87,3 & 15,3 & 1,3 & 5,5 \\
\hline 22/jan & 0 & 24,0 & 81,4 & 22,9 & 3,8 & 4,5 \\
\hline 23/jan & 12 & 24,4 & 80,5 & 21,4 & 4,7 & 5,2 \\
\hline 24/jan & 0 & 23,8 & 81,2 & 23,7 & 4,4 & 3,7 \\
\hline 25/jan & 0 & 23,9 & 81,1 & 18,0 & 3,9 & 4,1 \\
\hline 26/jan & 0,8 & 23,6 & 83,1 & 19,5 & 3,8 & 4,1 \\
\hline 27/jan & 20 & 25,5 & 71,5 & 27,4 & 8,6 & 6,4 \\
\hline 28/jan & 0,1 & 25,1 & 71,5 & 23,3 & 7,5 & 3,6 \\
\hline 29/jan & 1,1 & 24,6 & 78,8 & 15,5 & 3,9 & 3,0 \\
\hline 30/jan & 0,2 & 24,9 & 79,3 & 22,9 & 4,5 & 3,3 \\
\hline 31/jan & 10 & 23,6 & 81,0 & 15,8 & 2,5 & 3,3 \\
\hline
\end{tabular}


Tabela 51 - Dados climáticos de fevereiro 2011

\begin{tabular}{|c|c|c|c|c|c|c|}
\hline 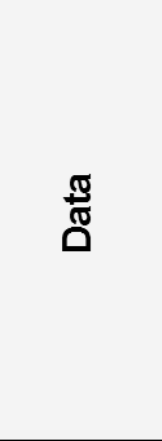 & 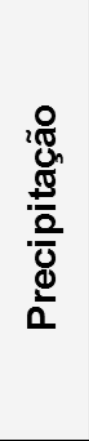 & $\begin{array}{l}\frac{\pi}{2} \\
\frac{\pi}{\pi} \\
\frac{\pi}{\Phi} \\
\frac{0}{E} \\
\stackrel{\Xi}{0}\end{array}$ & 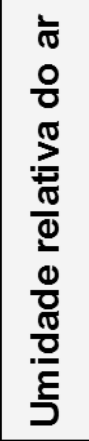 & 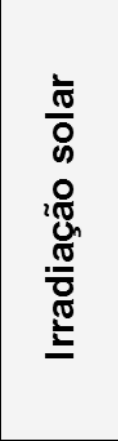 & 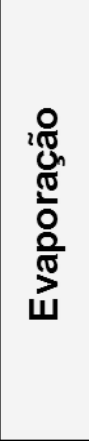 & 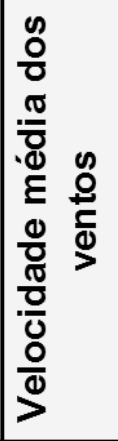 \\
\hline Unidade & $\mathrm{mm}$ & ${ }^{\circ} \mathrm{C}$ & $\%$ & $\mathrm{MJ} / \mathrm{m}^{2}$ & $\mathrm{~mm}$ & $\mathrm{Km} / \mathrm{h}$ \\
\hline $01 /$ fev & 0 & 23,9 & 69,7 & 18,6 & 3,3 & 6,7 \\
\hline $02 /$ fev & 17 & 22,3 & 89,3 & 9,4 & 1,2 & 3,0 \\
\hline $03 /$ fev & 4,4 & 21,7 & 88,8 & 10,1 & 1,1 & 4,3 \\
\hline $04 / \mathrm{fev}$ & 0,7 & 22,8 & 81,3 & 14,2 & 1,8 & 3,8 \\
\hline $05 / \mathrm{fev}$ & 0 & 25,3 & 73,8 & 25,4 & 3,6 & 4,5 \\
\hline $06 /$ fev & 0 & 25,9 & 71,7 & 24,3 & 3,9 & 4,9 \\
\hline $07 / \mathrm{fev}$ & 37 & 23,2 & 83,0 & 15,3 & 2,1 & 5,5 \\
\hline $08 / \mathrm{feV}$ & 0,1 & 24,1 & 76,8 & 21,4 & 2,9 & 4,8 \\
\hline $09 /$ fev & 0 & 25,9 & 66,9 & 26,0 & 4,6 & 5,7 \\
\hline $10 /$ fev & 0 & 25,5 & 70,4 & 21,1 & 3,1 & 5,0 \\
\hline $11 /$ fev & 25 & 23,4 & 78,2 & 12,6 & 2,5 & 4,7 \\
\hline $12 / \mathrm{fev}$ & 16 & 23,6 & 76,3 & 20,4 & 3,1 & 5,3 \\
\hline $13 / \mathrm{feV}$ & 0 & 24,6 & 73,8 & 19,4 & 3,3 & 3,4 \\
\hline $14 /$ fev & 6,9 & 23,5 & 81,6 & 13,9 & 1,9 & 4,1 \\
\hline $15 / \mathrm{fev}$ & 50 & 21,8 & 91,6 & 7,7 & 0,8 & 3,1 \\
\hline $16 /$ fev & 39 & 22,2 & 84,0 & 14,8 & 1,4 & 5,6 \\
\hline $17 /$ fev & 0,1 & 22,4 & 80,0 & 20,2 & 2,3 & 4,0 \\
\hline $18 /$ fev & 1 & 22,5 & 83,1 & 18,8 & 1,9 & 4,3 \\
\hline $19 /$ fev & 0 & 23,4 & 80,0 & 19,1 & 2,3 & 4,3 \\
\hline $20 /$ fev & 22 & 22,9 & 82,3 & 21,3 & 2,2 & 4,0 \\
\hline $21 /$ fev & 41 & 22,3 & 85,6 & 16,8 & 1,7 & 3,4 \\
\hline $22 / \mathrm{fev}$ & 9 & 24,2 & 76,1 & 23,7 & 3,3 & 5,5 \\
\hline $23 / \mathrm{fev}$ & 8 & 22,6 & 85,6 & 18,0 & 1,3 & 4,0 \\
\hline $24 /$ fev & 15 & 22,7 & 85,6 & 16,2 & 1,6 & 3,5 \\
\hline $25 / \mathrm{fev}$ & 0 & 23,5 & 81,7 & 21,9 & 2,3 & 5,9 \\
\hline $26 /$ fev & 0 & 23,7 & 81,1 & 21,1 & 2,4 & 4,8 \\
\hline $27 /$ fev & 7,4 & 22,0 & 89,5 & 11,5 & 1,2 & 3,8 \\
\hline $28 / \mathrm{feV}$ & 29 & 21,2 & 92,7 & 8,4 & 0,8 & 3,8 \\
\hline
\end{tabular}


Tabela 52 - Dados climáticos de março 2011

\begin{tabular}{|c|c|c|c|c|c|c|}
\hline$\frac{\pi}{\pi}$ & 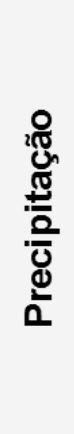 & 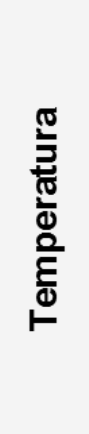 & 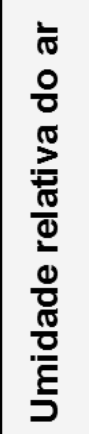 & 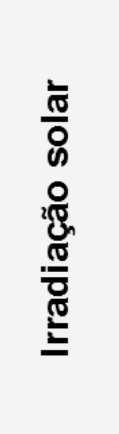 & 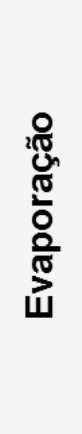 & 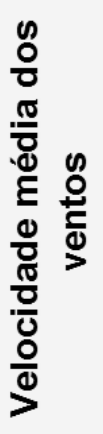 \\
\hline Unidade & $\mathrm{mm}$ & ${ }^{\circ} \mathrm{C}$ & $\%$ & $\mathrm{MJ} / \mathrm{m}^{2}$ & $\mathrm{~mm}$ & $\mathrm{Km} / \mathrm{h}$ \\
\hline $01 / \mathrm{mar}$ & 12 & 20,4 & 92,9 & 10,4 & 0,6 & 4,8 \\
\hline $02 / \mathrm{mar}$ & 17 & 18,8 & 93,6 & 6,8 & 0,6 & 6,1 \\
\hline 03/mar & 6,3 & 18,2 & 91,4 & 8,2 & 0,8 & 4,9 \\
\hline 04/mar & 3,5 & 19,3 & 89,8 & 10,1 & 1 & 5,6 \\
\hline 05/mar & 1,3 & 18,9 & 88,6 & 9,2 & 1,1 & 6,0 \\
\hline 06/mar & 0,4 & 19,5 & 86,5 & 13,1 & 1,3 & 6,3 \\
\hline 07/mar & 0 & 19,3 & 85,9 & 9,6 & 1,3 & 5,5 \\
\hline 08/mar & 7,6 & 19,9 & 89,9 & 11,8 & 0,9 & 3,2 \\
\hline 09/mar & 0 & 21,4 & 85,4 & 17,5 & 1,6 & 5,2 \\
\hline 10/mar & 0 & 22,3 & 82,2 & 19,8 & 2,1 & 7,4 \\
\hline 11/mar & 0 & 22,9 & 81,2 & 15,7 & 2,3 & 8,0 \\
\hline $12 / \mathrm{mar}$ & 1,3 & 21,4 & 90,6 & 8,2 & 0,8 & 2,8 \\
\hline $13 /$ mar & 16 & 22,3 & 87,8 & 14,0 & 1,3 & 2,9 \\
\hline 14/mar & 1,2 & 21,8 & 87,9 & 15,4 & 1,5 & 5,2 \\
\hline $15 /$ mar & 1,6 & 20,3 & 92,3 & 14,6 & 1 & 8,9 \\
\hline $16 /$ mar & 0,5 & 18,6 & 88,8 & 11,1 & 0,9 & 6,3 \\
\hline 17/mar & 0 & 20,7 & 87,8 & 13,9 & 1,2 & 5,2 \\
\hline $18 / \mathrm{mar}$ & 3,8 & 22,8 & 83,8 & 14,4 & 1,8 & 4,3 \\
\hline 19/mar & 1,9 & 19,8 & 93,7 & 6,0 & 0,7 & 6,0 \\
\hline $20 /$ mar & 1,2 & 18,7 & 92,3 & 8,9 & 0,8 & 7,6 \\
\hline $21 / \mathrm{mar}$ & 0,2 & 19,8 & 88,1 & 10,9 & 1,2 & 7,1 \\
\hline $22 /$ mar & 0 & 20,8 & 81,8 & 14,5 & 1,8 & 6,3 \\
\hline $23 /$ mar & 0,3 & 22,3 & 78,5 & 13,6 & 2,3 & 6,2 \\
\hline $24 /$ mar & 12 & 22,9 & 80,5 & 16,8 & 2,3 & 4,9 \\
\hline $25 /$ mar & 0,1 & 22,7 & 84,8 & 13,7 & 1,7 & 3,4 \\
\hline 26/mar & 0 & 24,1 & 78,8 & 18,6 & 2,6 & 3,3 \\
\hline $27 / \mathrm{mar}$ & 1,6 & 23,8 & 82,2 & 15,7 & 2,1 & 4,3 \\
\hline $28 /$ mar & 0 & 24,3 & 79,7 & 16,7 & 2,4 & 5,3 \\
\hline 29/mar & 0,6 & 22,0 & 88,0 & 13,2 & 1,4 & 4,9 \\
\hline $30 / \mathrm{mar}$ & 2,1 & 20,0 & 92,0 & 9,5 & 0,8 & 5,3 \\
\hline $31 / \mathrm{mar}$ & 0,1 & 20,4 & 86,8 & 13,2 & 1,4 & 5,3 \\
\hline
\end{tabular}


Tabela 53 - Dados climáticos de abril 2011

\begin{tabular}{|c|c|c|c|c|c|c|}
\hline 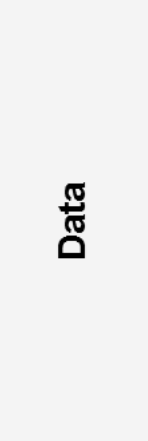 & 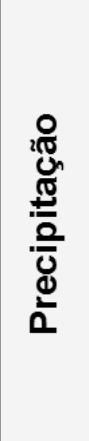 & 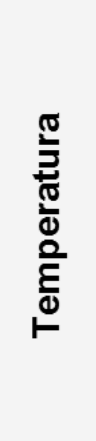 & 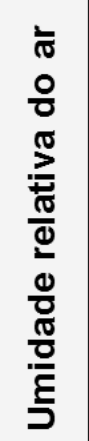 & 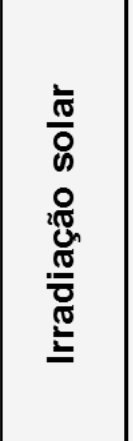 & 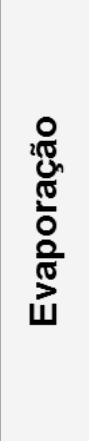 & 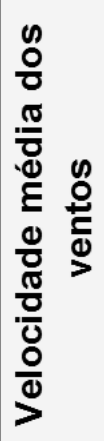 \\
\hline Unidade & $\mathrm{mm}$ & ${ }^{\circ} \mathrm{C}$ & $\%$ & $\mathrm{MJ} / \mathrm{m}^{2}$ & $\mathrm{~mm}$ & $\mathrm{Km} / \mathrm{h}$ \\
\hline 01/abr & 0 & 21,7 & 82,1 & 19,6 & 2,1 & 5,8 \\
\hline 02/abr & 18 & 22,2 & 83,5 & 14,6 & 1,8 & 5,9 \\
\hline 03/abr & 11 & 19,2 & 93,4 & 5,8 & 0,6 & 2,9 \\
\hline 04/abr & 2,3 & 19,8 & 92,0 & 9,1 & 0,7 & 3,7 \\
\hline 05/abr & 9,3 & 20,1 & 88,0 & 13,8 & 1,2 & 3,4 \\
\hline 06/abr & 0 & 19,9 & 80,0 & 20,8 & 2,1 & 3,9 \\
\hline 07/abr & 0 & 20,0 & 81,1 & 17,5 & 2 & 5,0 \\
\hline 08/abr & 0 & 20,3 & 81,1 & 16,8 & 2 & 4,8 \\
\hline 09/abr & 0 & 18,8 & 80,8 & 15,6 & 1,9 & 5,4 \\
\hline 10/abr & 4,5 & 18,7 & 83,8 & 16,5 & 1,7 & 6,0 \\
\hline 11/abr & 2,8 & 20,4 & 79,1 & 17,5 & 2,5 & 5,0 \\
\hline 12/abr & 28 & 21,9 & 80,7 & 17,0 & 2,4 & 5,6 \\
\hline 13/abr & 2,7 & 20,4 & 80,2 & 13,3 & 2,2 & 8,0 \\
\hline 14/abr & 0 & 22,3 & 77,7 & 18,7 & 2,6 & 2,6 \\
\hline 15/abr & 0 & 23,2 & 78,2 & 18,8 & 2,7 & 4,5 \\
\hline 16/abr & 0 & 23,9 & 78,6 & 17,6 & 2,3 & 4,5 \\
\hline 17/abr & 0 & 22,5 & 81,3 & 17,1 & 2,1 & 4,6 \\
\hline 18/abr & 0 & 23,1 & 80,4 & 16,2 & 2,2 & 4,7 \\
\hline 19/abr & 1,2 & 21,3 & 84,9 & 12,4 & 1,5 & 4,5 \\
\hline $20 / a b r$ & 0 & 21,8 & 80,9 & 16,4 & 2 & 4,7 \\
\hline $21 / a b r$ & 0 & 22,8 & 72,7 & 18,4 & 3,3 & 5,9 \\
\hline $22 / a b r$ & 0 & 23,5 & 73,8 & 17,0 & 3,1 & 4,3 \\
\hline 23/abr & 0 & 23,5 & 71,7 & 17,4 & 3,3 & 4,9 \\
\hline 24/abr & 2,1 & 19,2 & 90,0 & 6,3 & 1 & 5,4 \\
\hline 25/abr & 1,1 & 19,5 & 86,0 & 13,8 & 1,4 & 5,8 \\
\hline 26/abr & 0 & 17,4 & 83,0 & 6,9 & 1,6 & 6,8 \\
\hline $27 / a b r$ & 1,1 & 17,1 & 77,8 & 10,2 & 1,9 & 6,5 \\
\hline $28 / a b r$ & 18 & 15,9 & 92,1 & 4,4 & 0,5 & 2,5 \\
\hline 29/abr & 0,1 & 19,3 & 86,0 & 15,5 & 1,3 & 4,2 \\
\hline 30/abr & 0 & 20,4 & 71,4 & 18,1 & 3,2 & 4,8 \\
\hline
\end{tabular}


Tabela 54 - Dados climáticos de maio 2011

\begin{tabular}{|c|c|c|c|c|c|c|}
\hline $\begin{array}{l}\stackrel{\pi}{\mathbb{N}} \\
\text { Q }\end{array}$ & 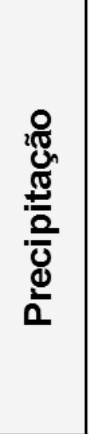 & 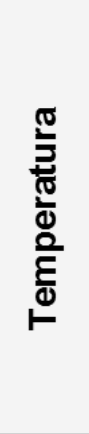 & 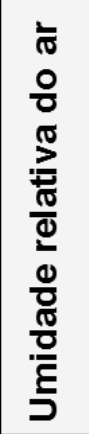 & 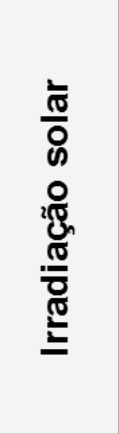 & 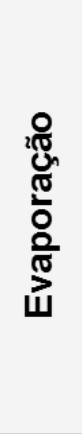 & 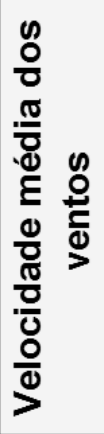 \\
\hline Unidade & $\mathrm{mm}$ & ${ }^{\circ} \mathrm{C}$ & $\%$ & $\mathrm{MJ} / \mathrm{m}^{2}$ & $\mathrm{~mm}$ & $\mathrm{Km} / \mathrm{h}$ \\
\hline 01/mai & 3 & 18,5 & 82,1 & 10,3 & 1,8 & 5,3 \\
\hline 02/mai & 1,2 & 18,1 & 90,2 & 6,7 & 0,9 & 5,5 \\
\hline 03/mai & 0 & 15,6 & 79,3 & 15,3 & 1,8 & 4,8 \\
\hline 04/mai & 0 & 16,4 & 82,9 & 15,8 & 1,6 & 3,2 \\
\hline 05/mai & 0 & 19,1 & 71,5 & 18,6 & 3,2 & 4,1 \\
\hline 06/mai & 0 & 19,0 & 74,2 & 14,9 & 2,7 & 2,7 \\
\hline 07/mai & 0 & 17,9 & 83,9 & 12,8 & 1,5 & 3,6 \\
\hline 08/mai & 0 & 19,5 & 77,8 & 16,9 & 2,4 & 4,6 \\
\hline 09/mai & 0,2 & 17,4 & 91,1 & 7,4 & 0,7 & 3,9 \\
\hline 10/mai & 0 & 18,7 & 86,2 & 10,4 & 1,4 & 5,8 \\
\hline 11/mai & 0 & 20,4 & 80,9 & 15,2 & 2,1 & 5,7 \\
\hline 12/mai & 0 & 19,3 & 84,6 & 12,6 & 1,6 & 3,6 \\
\hline 13/mai & 1,4 & 17,2 & 90,1 & 6,6 & 0,8 & 4,4 \\
\hline 14/mai & 0,1 & 16,0 & 83,4 & 11,7 & 1,3 & 4,5 \\
\hline $15 /$ mai & 12 & 16,0 & 86,9 & 11,0 & 1,3 & 6,5 \\
\hline 16/mai & 2,6 & 14,8 & 88,5 & 10,6 & 1,1 & 5,8 \\
\hline 17/mai & 0,4 & 13,7 & 85,7 & 7,2 & 1 & 5,0 \\
\hline 18/mai & 0,3 & 14,5 & 84,2 & 10,8 & 1,4 & 5,2 \\
\hline 19/mai & 0 & 15,5 & 83,3 & 11,6 & 1,5 & 5,5 \\
\hline 20/mai & 0 & 15,8 & 84,0 & 13,6 & 1,5 & 5,7 \\
\hline $21 /$ mai & 0 & 16,4 & 83,6 & 15,6 & 1,8 & 5,2 \\
\hline 22/mai & 0 & 17,2 & 76,9 & 16,8 & 2,4 & 6,6 \\
\hline 23/mai & 0 & 16,9 & 72,1 & 17,7 & 3,1 & 4,5 \\
\hline 24/mai & 0 & 18,0 & 79,8 & 13,8 & 2,1 & 3,2 \\
\hline 25/mai & 0 & 18,5 & 74,4 & 15,5 & 2,6 & 4,3 \\
\hline 26/mai & 0 & 18,3 & 78,9 & 8,9 & 1,8 & 3,5 \\
\hline 27/mai & 1,6 & 15,9 & 87,0 & 7,7 & 1,1 & 4,7 \\
\hline 28/mai & 0,7 & 13,3 & 90,1 & 7,8 & 0,7 & 5,2 \\
\hline 29/mai & 0 & 12,4 & 80,0 & 14,7 & 1,6 & 3,9 \\
\hline 30/mai & 0 & 13,6 & 85,1 & 12,5 & 1,2 & 3,9 \\
\hline 31/mai & 0 & 14,7 & 83,8 & 11,7 & 1,4 & 4,9 \\
\hline
\end{tabular}

